$=29$

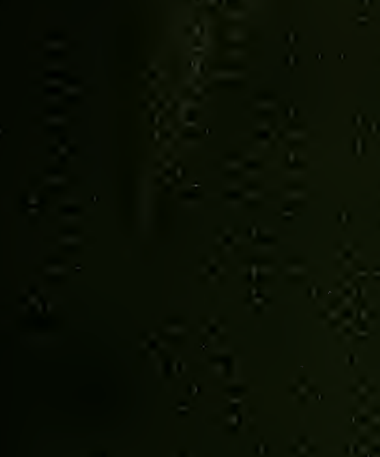

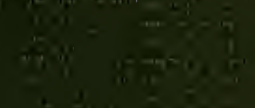

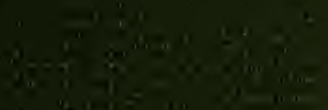




$$
\text { ช }
$$











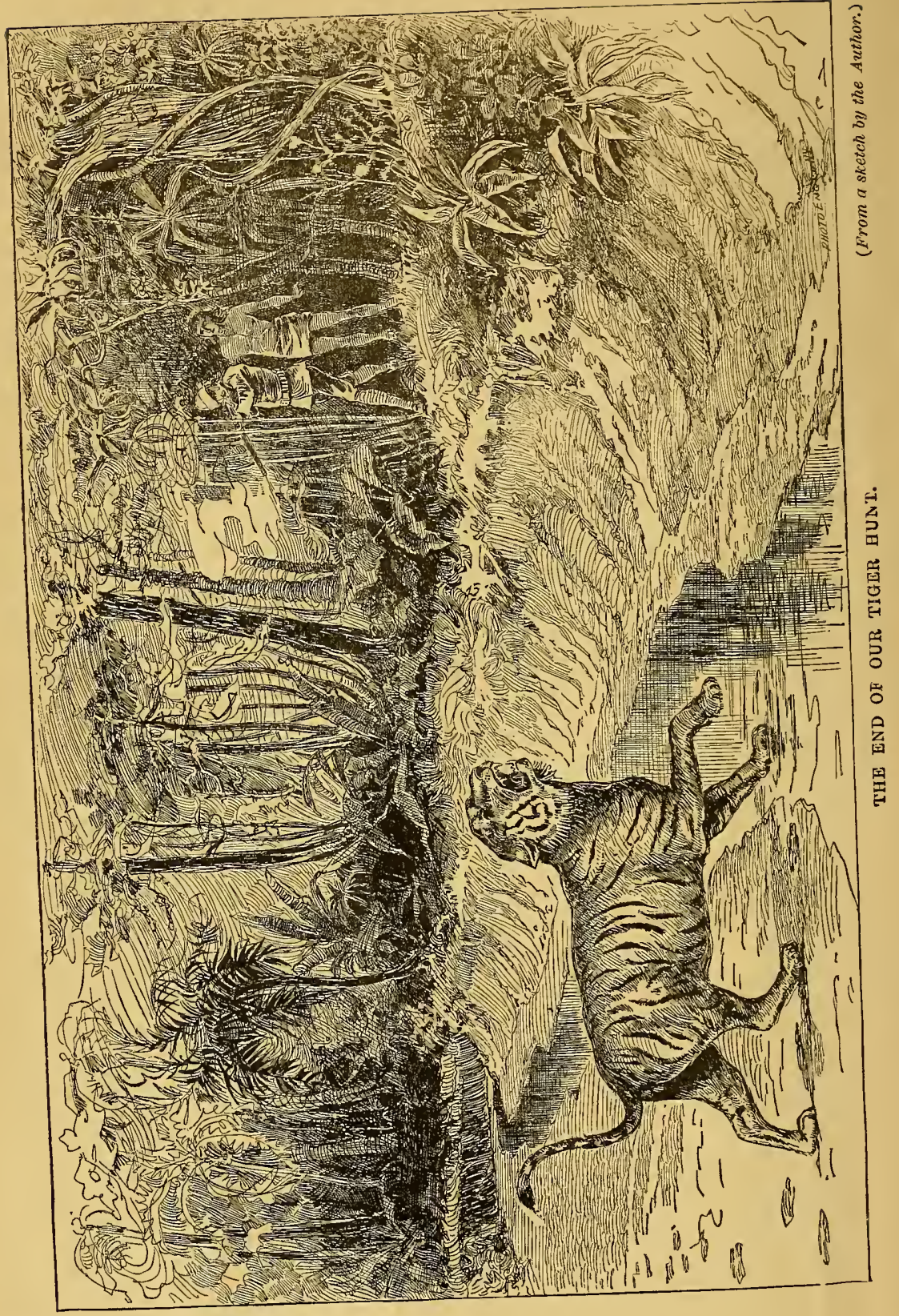




\section{LIST OF ILLUSTRATION}

The ENd of our Tiger Hunt, . . . . . - Frontispiece. The Manis, Rolled UP, . . . . . . . . To face page xxi

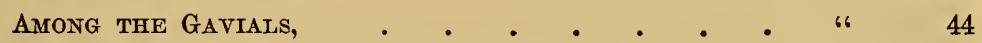
BIRD-NestiNG ON THe JUMNA, . • • • • • " 61 The Neilgherries, aNd a Part of OOtaCamund, - " " 96

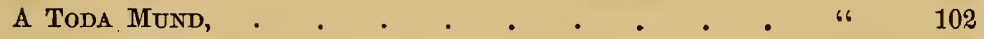
GROUND-PLAN OF A TODA HUT, . . . . . . Mr. Theobald AND his Forest BUngalow, - • " " 123 Pera Vera, . . . . . . . . . . . " My Camp at Tellicul, . . . . . . . . . Section of an Elephant's SkUli, etc., • • • " " 135 Charge of a Female Elephant, • • • • • " 141 Tiger-hunting on ELEPHANT-BACK, • • • • "

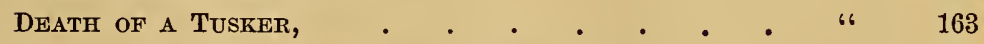
HERd OF AXIS DEER IN BAMBoo Forest, • • - 6 167 The Neilgherry Goat, ANd the MUNTJAC, • • " " 172 The Indian Bison, or Gadr, . . • • • • c " c 188

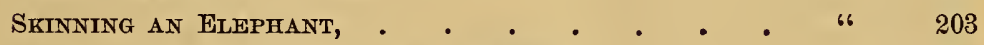
A Koomeriah Elephant, and a Meerga, - • • " " 226 COLOMBO FROM THE ClOCK TOWER, LOOKING SOUTHWEST, . " " 238 Rhamphobatis ancylostomus, . . . . . . " 257 Good Collecting Ground, Mullaitive, - • • " " 267 Catching a Crocodme with Hook and Line, - • " 306 The Jumping Fish._(Periophthalmus Schlosserii), • " 309 A JACOON HOUSE, . . . . . . . . . . . " 319 Vertical Section of a Cave In Selangore, • • " " 327 Malat Houses on the Sarawak Rrver, • • • 66338

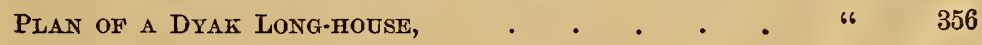


Exterior of a Sea Dyak Long-hodse, To face page 356

INTERTOR OF A SEA DYAK LONG-HOUSE, 357 WADING AFTER A WOUNDED ORANG-UTAN, • . . " 361 Female ORANG-Utan, Infant and Nest, . . . . " “ 368 A Fight IN THE TREe-TOPs, • • • • • “ “ 375 HEAD OF Cynogale Bennetiii, • • • • • “ 380 EMBRyo OF Crocodilus porosus, • • . • . “ “ 380 THE "OLD MAN," . . • • . • • • • “ 381 The Thread Fish, . • • • • . . • “ " 386 Stegostoma tigrinum, . . . . . . . “ “ 387 Luciocephalus pulcher, • . . . . . “ 387

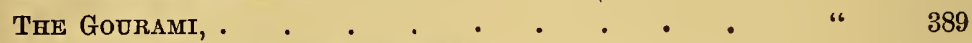
Portratt of a Proboscis Monkex, • • • . “ “ 395 The Gibbon's Modes of Progression, • • • " “ 415 The TARSIER.—(Tarsius spectrum), • • • • “ " 420 Buttresses of a Tapang Tree, . . . . . . “ “ 428 DYAK WEAPONS, UTENSILS, ETC., • • • • • “ “ 443 KYAN WARRIOR, . . . . . . . . “ " 447

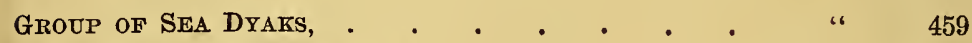
A SEA DYAK. (SERIbas Clan), • • • • • “ A Sea Drak Belie, . • • • • • “ " 461 DYAK HARP, . . . • • c • • • “ 4469 DYAKS USING THE BILIONG, OR AXE-ADZ, • • • “ 484

\section{MAPS.}

BRITISH INDIA, - . . . . . . . At end of volume. Borneo, EthNographic AND General, . . . Opposite page 333 


\section{TWO YEARS IN THE JUNGLE}

THE EXPERIENCES OF A HUNTER

AND NATURALIST

IN INDIA, CEYLON, THE MALAY PENINSULA AND BORNEO

BI

WILJIAM T. HORNADAY

CHIEF TAXIDERMIST, U. \$. NATIONAL MUSEUM

IATE OULECTOR FOR WARD'S NATURAL SCLENCE ESTABLISHMFANT

WITH MAPS AND ILLUSTRATTONS

"There is a pleasure in the pathless woods,

There is a rapture in the lonely shore." - Byron

SEVENTH EDITION

NEW YORK:

CHARLES SCRIBNER'S SONS, 1901 


$$
\text { 1) } \frac{15^{-50^{-1}}}{45^{4}}
$$

CoprrighT, 1885, BI

CHARLES SCRIBNER'S SOYS

$$
\begin{gathered}
5.108 \\
.04
\end{gathered}
$$

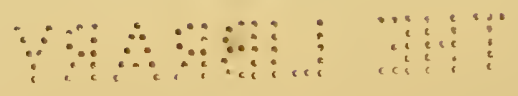


To

MY GOOD WIFE

JOSEPHINE

WHOSE PRESENCE BOTH WHEN SEEN AND UNSEE

HAS EVER BEEN THE SUNSHINE OF MT LIFE

THIS BOOK

IS AFFECTIONATELY DEDICATED 



\section{PREFA CE.}

As a matter of simple justice to myself, I must inform the reader that the journey of which this book is a record was one of action rather than observation, and opportunities for study were few and far between. Owing to the circumstances under which the trip was carried out, all my waking hours were occupied in a ceaseless warfare for specimens, and my only regret comes when I think what " it might have been," for me at least, had I not been obliged to shoot, preserve, care for and pack up nearly every specimen with my own hands. From first to last I had no other assistance than such as could be rendered by ignorant and maladroit native servants. Even in the preparation of these pages the demon of Work has still pursued me, and the task has been accomplished only by the aid of "midnight oil," when wearied by the labors of the day.

What follows is offered merely as a faithful pen-picture of what may be seen and done by almost any healthy young man in two years of ups and downs in the East Indies.

$\mathrm{He}$, at least, who loves the green woods and rippling waters, and has felt the mystic spell of life in "a vast wilderness," will appreciate the record of my experiences. I love nature and all her works, but one day in an East Indian jungle, among strange men and beasts, is worth more to me than a year among dry and musty "study specimens." The green forest, the airy mountain, the plain, the river, and the sea-shore are to me a perpetual delight, and the pursuit, for a good purpose, of the living creatures that inhabit them adds an element of buoyant excitement to the enjoyment of natural scenery, which at best can be but feebly portrayed in words. 
In the belief that the average reader is more interested in facts of a general nature than in minutiæ, I have avoided going into natural history details, but have endeavored instead to indicate the most striking features of the countries visited, and the more noteworthy animals and men encountered in their homes.

As the pages which follow will presently reveal, this is in every sense a personal-I might even say a first-personal-narrative, in which the reader is taken as a friend into the author's conifidence while they make the trip together. The writer addresses,' not the public, in general, but The Reader, individually. To him I would say, confidentially of course, that as a duty to him, in the preparation of these pages I have labored earnestly to avoid all forms of exaggeration, and to represent everything with photographic accuracy as to facts and figures. It is easy to overestimate and color too highly, and I have fought hard to keep out of my story every elephant and monkey who had no right to a place in it.

I consider it the highest duty of a traveller to avoid carelessness in the statement of facts. A narrative of a journey is not a novel, in which the writer may put down as seen any thing that "might have been seen."

To a great many kind friends in the East Indies my thanks are due for aid, comfort, and advice; but I will not consign their names and the acknowledgment of my gratitude to the obscurity of a preface, and each will be found in its own place in the story. But for the friends I made as I went along, and the kindly interest they manifested in my welfare and happiness, I would have felt like a rogue elephant-solitary, uncared for, and even spurned by the other members of the social herd.

Curiously enough, nearly all my East Indian friends were English, and to my American reader I would say, when you meet an English traveller treat him kindly for my sake.

W. T. H.

Washington, D. C. 


\title{
CONTENTS.
}

\author{
$P A R T I$.
}

INDIA.

\section{CHAPTER I.}

\section{THE JOURNEY TO INDIA.}

Objects of the Trip.-Boycotted in Ireland.-The Challenger Collections. -The Liverpool Museum.-The British Museum.-From Paris to Rome.-Art versus Nature.-Collecting at Naples.-The Zoological Station.-Alexandria.-The Nile Delta.-Cairo.-A Picnic to the Petrified Forest - The Author rides a Camel.-Egyptian Fossils. - Through the Suez Canal._A Day at Jeddah.-Pilgrims and Strangers. -The Tomb of Eve.-The Red Sea.-A Pleasant Voyage.-Bombay......................

\section{CHAPTER II.}

\section{BOMBAY.}

Duty on Outfit.-A Model (!) Consul. - The Servant Question.-The Grand Market. - Flowers. - Fruit. - Fish. - Live Birds.-The First Specimen. - Street Cars. - An Interesting Crowd.-Vehicles. -The Bullock Hackery.-The Homeliest Animal Alive.-The Victoria and Albert Museum. - Soft-hearted Hindoos.-The Hospital for Animals. - A Strange Sight. -A Good Servant.-Departure for Allahabad..............................

\section{CHAPTER III.}

\section{FROM BOMBAY TO ETAWAH.}

Physical Aspect of the Country.-Scarcity of Animal Life.-A Barren Region.-Major Ross.-A Boat Trip up the Jumna.-A Mile of 
Bathers. - Dead Hindoo. - Plenty of Birds but no Gavials. - Return and go to Etawah.-The Dak Bungalow.-Two Specimens the First Day.-My Boat and Crew.-A Day in the Bazaar.-An

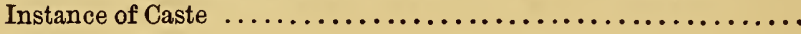

\section{CHAPTER IV.}

\section{GAVIAL SHOOTING ON THE JUMNA.}

Afloat on the Jumna.-Character of the River.-Diffoulties of Crocodile Shooting. - The Fatal Spot-_Prospects. - The Fun Begins. Defeat through Poor Shooting and Native Timidity.-An Harangue.-Swimming after a Wounded Gavial.-Death of "Number One."-Another still Larger.-How to Skeletonize a Gavial._Mode of Skinning Described.-Birds of Prey._Crowds of Spectators.-Gavial Eggs.-A Model Crew.-Plucky Encounter with a Wounded Gavial._A Struggle at Close Quarters._Our Plan of Operations.-A Good Rifle.-Killing Gavials at Long Range....

\section{CHAPTER V.}

\section{THE GANGETIC CROCODILE.}

A Jolly Life. - Native Tenderness for the Gavial.--Eating the Flesh.The Jumna swarming with Gavials.-A "Mass Meeting."-Loss of an Enormous Specimen.-Maximum size Attained.-The Gavial's Place in Nature.-Habits and Characters of the Species. -General Observations on the Crocodilians. - Number of Eggs Deposited.-The Gavial not a Man-eater. - A Ticklish Reptile.

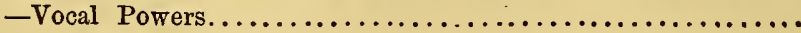

\section{CHAPTER VI.}

\section{ANIMAL LIFE ALONG THE JUMNA.}

Boating on the Jumna.-A Long Prayer.-The Saras Crane.--Queer Antics.-The Jabiru.-Nests of the Scavenger Vulture.-Peacocks. - A Jungle Cat Surprised. - The Jackals' Serenade.-Turtles.-The Gangetic Porpoise.-Native Villages. - The People.Female Ugliness.-Friends and Foes.-A Native Funeral.-Cremation a mere For'm. - An Adjutant Shot._Goodbye to the River.

\section{CHAPTER VII.}

\section{RAVINE DEER AND BLACK BUCK HUNTING.}

An Invitation. - Aspect of the Country. - Major Ross's Camp.-A Luxurious Establishment. - The Jumna Ravines. - The "Ravine 
Deer."-A Day's Sport. - Fifteen Gazelles and a Nil-Gai.-The PAGE Sasin Antelope or "Black Buck."-Animal Pests - Another Hunt with Major Ross.-Interesting Sport.-A Narrow Escape.-A Stern Chase at Mid-day.-Eight Antelopes Gathered in.-A Holiday at Agra. - The Taj Mehal, of course. - Taj-struck Travellers. -

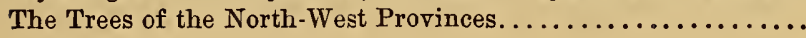

\section{CHAPTER VIII.}

\section{BENARES, CALCUTTA, AND MADRAS.}

The Monkey Temple. - Sacred Animals. - The Fakir.-The Hindoos as Beast Worshippers. - A Beastial Religion.-From Benares to Calcutta.-The Hot Season.-_"Punkahs and Tatties."-Departure for Madras.-The Hoogly River.-Sailor Anatomists.-The Hoogly Channel. - Madras. -A Seaport without a Harbor.-Two Years of Drought. -A Famine-stricken City.-A Paternal Government.-The Madras Museum.-Another Language and another

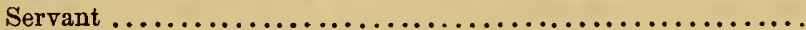

\section{CHAPTER IX.}

\section{THE NEILGHERRY HILLS.}

The "Blue Mountains."-A Natural Eden.-Physical Aspect.-The Coonoor Pass. - Beauty and Grandeur._Climbing up to Paradise. -Ootacamund.-Products of the Hills.-The Worst Hotel in India.-A Hunt in the "Delectable Mountains."-Above the Clouds. -The Todas._A Remarkable People.-Their Negative Qualities. - Phenomenal Laziness. - The "Paulaul" and the "Paulchi."-Physique of the Todas.-Dress.-Polyandry, or Plurality of Husbands. - Betrothal, Marriage, and Divorce.-Infanticide.-The Toda Hut.-The Mund.-The Toda Buffalo.Little Game but Splendid Scenery.-A Cloud Scene.-An Empty

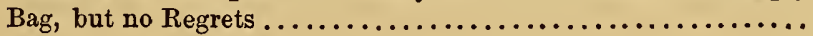

\section{CHAPTER $\mathrm{X}$.}

\section{THE WAINAAD FOREST.}

A Hunting Trip to Mudumallay.-Monkey Shooting.-The Karkhana. -The Meanest Natives in India._Obstacles._An Old Hypocrite. -Record of One Day's Hunting.-Expert Trackers.-Bison.-A Long Chase.-Death of a Sambur Stag.-A Herd of Wild Elephants.-An Attack by an Amateur, on Foot and Alone-Close Quarters.-Failure.-Lost in the Jungle.-A Sambur Killed by a 
Tiger.-A Bad Predicament.-Deliverance by a Lucky Guess.The Author's Status as a Shikaree.-Death of a Bull Bison.Skinning Under Difficulties.-Instinct of Self-preservation in Monkeys.-Jungle Fever.-Native Cussedness again.-Return to Ooty.-A Good Samaritan.-A Model (!) Physician.-Mr. and Mrs. Dawson. - Departure........................

\section{CHAPTER XI.}

\section{THE ANIMALLAI HILLS.}

A Hunter's Paradise.-Getting there.-The Bullock Bandy and its Driver.-His Discourse.-Physical Aspect of the Animallais.Toonacadavon.-A Glorious Prospect. - Mr. Theobald:-An Efficient Officer and Faithful Friend.-Character of the Forest.-Seasons.-Protection of the Elephants.-A Permit Obtained.-My Mulcer Hunting Gang. - The Karders.-More Ornamental than Useful . . ..................................

\section{CHAPTER XII.}

\section{ELEPHANT HUNTING.}

"A Lodge in a Vast Wilderness."-Hut-building with Bamboos.Elysian at Last.-Character of Elephant Hunting.-Grand but Dangerous Sport.-Indian versus African Methods.-The Skull. -Difficulty of Hitting the Brain.-Cranial Fracture Impossible. -The Fatal Shots. - Physique of the Elephant.-Tracking up a Herd. - Welcome Sounds. - Surrounded by Giants. - The Attack. - Stampede and Flight of the Herd.-Great Abundance of Large Game.-The Charge of a Dangerous Animal.-Fooling around a Baby Elephant.-Charge of an Infuriated Female.-A Grand but "Scarey" Sight. - Repelling the Charge................

\section{CHAPTER XIII.}

\section{MONKEYS, BEARS, AND ELEPHANTS.}

The Black Langur.-IIonkey Shooting.-A Startling Cry.-Absurd Encounter with Three Bears.-A Stern Chase.-Death of Number Two.-A Woful "Slip 'twixt cup and lip."-_Surprise Number Two.-The Old Bear Dies.-Habits of the Species.-A Typical Elephant Hunt.-Hunters Hunted.-Wonderful Manœuvring of the Elephants.--A Stealthy Retreat.-A Double-barrelled Attack. -"Shavoogan!"-Panic-stricken Hunters.-Failures, Fever,

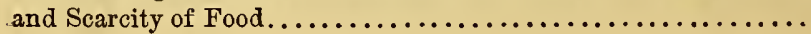




\section{CHAPTER XIV.}

\section{A TIGER HUNT.}

Tigers. - The Game-killer. — The Cattle-lifter. - The Man-eater.Reign of Terror. - Eight Hundred Victims Annually. -Modes of Tiger-hunting.-Howdah Shooting. - Machan Shooting. - Shooting on Foot. - An Impromptu Tiger-hunt. - The Trail.-A Light "Battery."-The Game Overhauled.-A Good Shot.-Death of a Superb "Game-killer."-Dimensions and Weight.-A Proud Moment.-Struggle to Preserve the Skin.................

\section{CHAPTER XV.}

\section{SKELETONIZING AN ELEPHANT.}

Mischievous Elephants. - Chase of a Large Herd._Death of a Tusker. -Forbidden Ground.-A Secret. - The Mulcer's Oath.-A Change of Base.-Skeletonizing an Elephant in Sixteen Hours._Cacheing the Bones. - The Traces of our Guilt.-Moral Aspect of the Affair. -The Spotted Deer.-A Pretty Picture.-The Indian Elk or Sambur. - Bad Case of Protective Coloring.- Serenaded by Sambur. The "Brain-fever bird."-Tree Rats. - The Muntjac.-Delicious Venison.-The Neilgherry Goat. —Wild Hogs............ 161-173

\section{CHAPTER XVI.}

\section{THE SECOND YEAR OF THE MADRAS FAMINE.}

Sickness in the Jungle.-Temporary Absence from the Hills.-A Starving Waif.- The Spectre of Famine.-Famine-stricken Natives.-Cause and Effects of the Famine.-The Relief Camp at Animallai.-A Review of the Hungry.-The Government and the Famine._" Money Doles."-Mortality._" Be ye Warmed and Fed! "-End of the Drought.......................

\section{CHAPTER XVII.}

\section{THE POETRY OF FOREST LIFE.-BISON SHOOTING.}

Return to the Hills.-Benighted in the Jungle.-Native Meanness. Doraysawmy, the "Gentleman's God."-A Jewel of a Servant. Prospects.-Fever again.-Bass' Pale Ale._Glorious Weather. -Fine Forest. - The Poetry of Life in the Forest. - Our Mode of Hunting.-A Bison Hunt.-Death of a Solitary Bull.-A Noble Animal.-Characters and Habits of the Species.-Another Hunt. 
-Four Bison in Five Shots. - The Bison as an Antagonist. - Mr.

Morgan's Encounter with a Wonnded Bull.-A Close Shave.-A Typical English Sportsman and his Pattery.-How to Preserve a

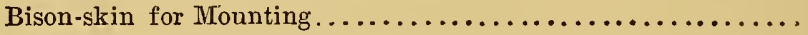

\section{CHAPTER XVIII.}

\section{A MEMORABLE ELEPHANT HUNT.}

A Run of Ill luck. -The Climax.-Strained Relation with an Official. - The Turn of the Tide.-My Last Card. - An Official Favor.Permission to Kill a Tusker.-More to Sungam.-A Memorable Elephant Hunt.-A Bad Shot.-Dangerous Ground.-A Bold Advance and a Disorderly Retreat. - Mulcer Philosophy.-A Long and Tiresome Chase.-Desperate Character of the Jungle.-Luck at Last.-The Attack. - An Anxious Moment.-Victory.-The Dead Tnsker.-A Sell on the Mulcers.-Skinning a Nine-anda-half Foot Elephant. - The Modns Operandi._Camp on the Field of Battle.--Surrounded by Wild Beasts._Getting up a Scare.Burning Bamboo.-A Tiger about.-An Accident.-Back to Sungam.-A Mulcer Row._Fever again.-Mutiny in Camp.......

\section{CHAPTER XIX.}

\section{END OF THE ANIMALLAI CAMPAIGN.}

Balky Mulcers.-Work on the Elephant again.-Wild Beast versus Tramp and Burglar.-My Mulcers go on a Strike.-Playing a Lone Hand.-Bringing the Men to Terms.-A Bloodless but Complete Victory.-Another Tiger about.-Treatment of the Elephant Skin.-The March ont to Sungam. - The Season.-The Last of my Hunting Gang.-Descent from the Hills in a Storm.-Paradise Lost. -Fever Again. - Good-by to the Animallais. - My Collection

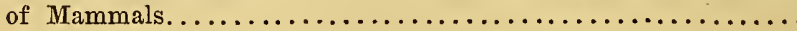

\section{CHAPTER XX.}

\section{THE INDIAN ELEPHANT.}

Geographical Distribution.-Indian and African Species Compared.The Ceylon Elephant. - The Capture of Wild Elephants.-Breeding in Captivity.-Gestation of the Elephant.-Duration of Life. - Growth and Height. - Size of Tusks. - Classes of Elephants. Uses.-Table of Valnes.-Intellectual Capacity and Temper.Elephants at Work in a Timber Forest. - Feeding Elephants. - Cost of Keeping.- "Must," or Temporary Insanity-"Rogue" Elephants.-How an Elephant Kills a Man.-Swimming Power of

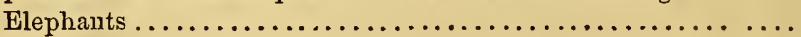




\section{$P A R T I I$.}

\section{CEYLON.}

\section{CHAPTER XXI.}

\section{COLOMBO.}

Madras to Colombo.-Farewell to Jungle Fever.-The Queen of the Tropics. - The Singhalese. - The Native Shops. - Exorbitant Duty on Methylated Spirits._An Appeal, and its Result.-Public Opinion.-A Protest-Legislation for the "Odd Man."-The Sea View Hotel.-Natives as Collectors.-A Morning's Work.How to Clean and Preserve Echini.-The Gatherings of one Day. -The Fish Market.-The Colombo Museum and its Director.Native Taxidermists. - Need of European Preparateurs in the

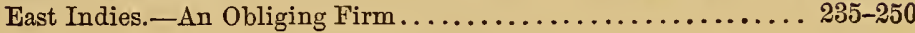

\section{CHAPTER XXII.}

\section{THE NORTHERN PROVINCE.}

Trip to Jaffna. - The Paumben Passage._-Jaffna._Coral Gathering.The Beauties of Living Coral.-Shallow Waters.-A Harvest of Cartilaginous Fishes.-Rhinobati.-Large Rays. - A Handsome Shark.-A Rare and Curious Fish.-Rhamphobatis ancylostomus Described.-Sea Turtles.-Questionable Value of Native Help.Start for Mrullaitivu. - Jaffna to Point Pedro. - The most Northern Point of Ceylon. - Native Cussedness again. --The Slowest SailingCraft on Record........................... 251-262

\section{CHAPTER XXIII.}

\section{MULLAITIVU.}

An Unwholesome Village Site. - Dirt and Diseomfort. - Crocodile Hunting.-Cannibalism and Leprosy among Crocodiles.-Flying Foxes. - A Big Haul.-A Heronry.-Hot Jungle.-Death of Mr. Leys by Sunstroke.-Mammals.-A Live Manis and its Doings. On Short Rations.-Exasperating Failure to Receive Supplies. Tropical Hunger.-A Gloomy Proposition Strangely Refuted.-A Delicious Beverage.-Journal of a Trip into the Interior.-Monkey-shooting.-Character of the Jungle.-Joseph Emerson.Elephant Skeletons. - Self-buried Frogs.-Two Hundred Monkeys in Four Hours. - Their Fleetuess in the Tree-tops. - Deer. Overland Journey to Jaffna.-Elephant Pass.-Return to Co-

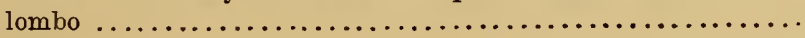




\section{CHAPTER XXIV.}

\section{KANDY AND POINT DE GALLE.}

The Interior of Ceylon.-A Run up to Kandy.-Native Plows and Plowing. - The Mountains. -Kandy.-An Overpraised Town.Summary of Ceylon Collections. - The Royal Mail Coach.-Gorernmental Eccentricities. - The Ride to Galle.-Charming Coast Scenery.-A Church Episode.-Bentotte.-Point de Galle.-Neptune's Garden.-Ceylon Gems. -Classification of Dealers. - Study of a Scoundrel, in Black and White.-Diamond cut Diamond.Farewell to Ceylon.............................

THE MALAY PENINSULA.

\section{CHAPTER XXV.}

\section{SINGAPORE.}

New Harbor. - A Back-door Entrance.-Mangrove Swamps and Malay Houses._Street Scenes.-The Sailors' Quarter.-Well-planned City. - Chinese Shops and Houses.-Populace.-Social Life.The Curse of the East Indies. -The American Consul.-Two American Travellers. -A Model Millionaire.-The Climate of Singapore.-Market for Live Animals.-A Visit to Mr. Whampoa's Villa.-Curios. - A Tigerish Orang-Utan._Curiosities in Garden-

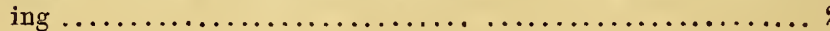

\section{CHAPTER XXVI.}

\section{ON THE SELANGORE SEA-COAST.}

Malacca.-Selangore.-Klang River and Town.-A Kindred Spirit. Visit to Jerom on the Sea-coast to Collect.-Bamboo Creek.-A Filthy Chinese Village.-A Foul Stream.-Crocodiles.-Catching a Twelve-foot Crocodile with Hook and Line.-The "Alir." - A Harvest of Saurians again.-Crocodiles in the Sea.-Birds.Shrimp-eating Monkeys-An Iguana-The Slowest Race on Record. -Remarkable Fishes. -Catching Periophthalmi.-An Adventure in Mud.-Various Vertebrates.-Centipedes and their Doings.-Doctoring a Ray-stung Fisherman.-Malay Character.

-Return to Klang.............................. 301-313 


\section{CHAPTER XXVII.}

\section{HUNTING IN THE INTERIOR OF SELANGORE.}

PAGE

A Trip to the Interior.-Road to Kwala Lumpor.-The Town."The Captain Cheena."-A Bonanza in Champagne.-Sungei Batu.-A Foolish Feat.-Our House.-Feasting on Durians.-A Jacoon House and Family.-Resemblance to the Dyaks.-An Impromptu Elephant Hunt.-Attack in a Swamp.-Death of a Young Tusker.-Plague of Flies.-Another Elephant Hunt.-A Close Shave and a Ludicrous Performance.-Discovery and Exploration of Three Fine Caves.-Cathedral Cave.-Mammals.Visit to a Tin Mine.-Chinese versus Malays.-Political Condition of Selangore.-Statistics.--Snakes.-Good-by to Klang.-Mr.

Robert Campbell, my Good Genius.................. 314-332

\section{$P A R T I V$.}

BORNEO.

\section{CHAPTER XXVIII.}

\section{SARAWAK, PAST AND PRESENT.}

Geographical Position and Area of Borneo.-Explorations.-From Singapore to Sarawak.-The Finest City in Borneo.-Historical Sketch of Sarawak Territory.-Sir James Brooke.-Anarchy and Oppression.-Cession of the Territory.-Order out of Chaos.Evolution of a Model Government.-A Wise and Good Rajah.Justice in Sarawak and the United States.-Present Prosperity. A Lesson for Political Economists. . . . . . . . . . . . . . . . . 333-346

\section{CHAPTER XXIX.}

\section{FROM SARAWAK TO THE SADONG.}

Hunting near Kuching.-Crocodiles in the Sarawak.-A Dangerous Pest.-War of Extermination. - From Sarawak to the Sadong.The Simujan Village.-A Hunt for an Orang-utan.-In the Swamp.-On the Mountain.-Valuable Information at Last..... 347-353 


\section{CHAPTER XXX.}

\section{AMONG THE ORANG-UTANS.}

Start up the Simujan.-Boat-roofs.-Among the Head-hunters. - A PAGE Dyak Long-house.-Monkeys. - Fire-flies. - A Night on a Tropical River.-Mias' Nests._" Mias, Tuan."-Death of the First Mias. -Another Killed._Screw Pines._- "Three Mias in one Day ! "Laborious Work.-Swamp Wading.-Padang Lake.-Cordial Reception at a Dyak House....................... 354-365

\section{CHAPTER XXXI.}

\section{DOINGS IN THE ORANG-UTAN COUNTRY.}

Preparation of Orang Skins and Skeletons.-Return down the Simujan.-Three Orangs Killed. -A Troublesome Infant. - Accessions from Native Hunters. - Seven Orangs in One Day.-Miscellaneous Gatherings. - A Battle-scarred Hero.-The Bore in the Sadong.Another Trip up the Simujan.-Doctoring an Injured Hunter.The Dyak at his Worst. -Death of a Huge Orang, " the Rajah." -Dimensions. $\rightarrow$ A Rival Specimen.-Two Captives

\section{CHAPTER XXXII.}

\section{COLLECTING AROUND SIMUJAN.}

Native Hunters.-Two Orangs Killed at Simujan.-Nest-making by an Orang.-A Harvest of Mammals.-A Deputation of Dyaks from the Sibuyau.-An Inviting Invitation.-The Rise and Progress of the Baby Orang.-An Interesting Pet.-Humanlike Habits and Emotions.-A Tuba-fishing Picnic.-Third Journey up the Simujan.-Snake Curry. - A Voyage in the Dark....... 378-389

\section{CHAPTER XXXIII.}

\section{COLLECTING AT PADANG LAKE.}

A Hunt on Gunong Popook.-A Lost Hunter.-A Handsome Dyak.A Reception by Torchlight.-More Orang-utans.-How an Orang Sleeps.-Proboscis Monkeys.-Living versus Stuffed Specimens.A Remarkable Nose.-Luckless Gibbon-hunting. -Luckless Wildhog Hunting.-Mud and Thorns.-Picturesque Vegetation.Fresh-water Turtles and Fishes.-Return to the Sadong....... 390-397 


\section{CHAPTER XXXIV.}

\section{FACTS ABOUT THE ORANG-UTAN.}

Distribution of the Orang-utan.-Its Affinities.-External Appearance. - Remarkable Facial Ornament (?).-Color of Skin.-Hair.Eyes.-Mode of Fighting.-Pugnacity.—Food.-Unsocial Habits. - Young at Birth.-Nesting Habits.-Locomotive Powers.-Inability to Walk or Stand Erect.-Height of Adults.-General Measurements.-Two Species Recognized.-Characters of Simia, Wurmbii and Satyrus.-Individual Peculiarities............

\section{CHAPTER XXXV.}

\section{A MONTH WITH THE DYAKS.}

Journey to the Sibuyau.--The River.-A Malodorous Village.- Barriers.-Proboscis Monkeys and Flying Lemurs.-Head of Canoe Navigation.-Swamp-wading.-Our Journey's End.-A Lodge in a Vast Wilderness. - Fine Hunting-grounds. - Source of the River.-Hunting Gibbons.-Lively Sport.-Gibbons' Remarkable Mode of Progress.-A Mias.-A Snccessful Hunt.Affection and Courage of a Male Gibbon.-Helplessness of the Baby Orang in Water.-A Live Tarsier.-More Gibbons Shot. -Argus Pheasants.-Dyak Mode of Snaring.-A Deadly Pigtrap. - A Shiftless Village.-A Magnificent Bird.-Curious Rodent. - Visit to Lanchang.-A Village of Head-hunters.-Trophies of the Chase. -A Fine Dyak Specimen .................. 409-425

\section{CHAPTER XXXVI.}

\section{A MONTH WITH THE DYAKS-Concluded.}

Leeches.-Model Making.-Poor Shooting-Boots.-Bad Ammunition. -A Big Buttress.-Wild Honey.-Human-like Emotions of the Baby Orang. - My Guides go on a Strike._Flying Gibbons._Boils and Butterflies.-Bear and Muntjac.-Delicious Venison.-Lee Tiac's Omen Bird.-Dyak Shiftlessness in Trade.-Gatheriug Gutta.-Lee Tiac Climbs a Tapong Tree.-A Perilous Feat.-Ah Kee gets Lost.-A Torch-light Search in the Swamp.-Another Bear.-Retiurn to the Sadong.-The Last Orang.- The Nipa Palm. - A dangerous Squall. - Nesting Habits of the Crocodile.-

Farewell to the Sadong......................... 426-442 


\section{CHAPTER XXXVII.}

\section{THE ABORIGINES OF BORNEO.}

Civilization an Exterminator of Savage Races.-Stability of the Dyaks. -The Survival of the Fittest. - The Typical Dyak.-Four Great Tribes.-The Kyans. - Their Strength and Distribution.-Tribe Misnamed Milanau.-General Characteristics.-Mechanical Skill. -Modes of Warfare.-Aggressiveness.-Cannibalism of certain Sub-tribes. - Tattooing. - Ideas of a Future State. - Human Sacrifices.-Houses. - The Hill Dyaks. -Distribution. - Takers of Head Trophies. - Fighting Qualities. - Physique. - Dress and Ornaments. - A Curious Corset. - Weapons. - Houses.-The Pangah.-Social Life.-Strict Morality without Religion.-Prohibition of Consanguineous Marriages.-Marriage Ceremony.-Honesty.-Disposal of the Dead.--A Relic of Hindooism.-Ideas of a Supreme Being and Future State._The Mongol Dyaks. - Remains of Former Chinese Influence.-An Advanced Tribe.-Position.Physique.-Dress. - Houses. - Skill in Agriculture.-Implements of Husbandry.-Independent but Peaceful. - The Muruts. - Dress and Ornaments.-Houses. - The Kadyans. - Comparative Estimate

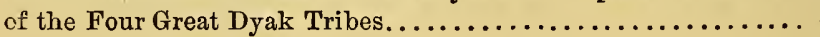

\section{CHAPTER XXXVIII.}

THE SEA DYAKS.

Habitat. - Number. - Sub-tribes. - Their Physique. - Sea Dyak Women.- Their Dress and Ornaments. - The Men. - Their Weapons.-War Boats.-Fighting Qualities.-Head-taking and Head-hunting.-A Mania for Murder.-Houses and House-life of the Sea Dyaks. - Communal Harmony. - Daily Occupations. Amusements.-Music-making. - Feasts. - Gentlemanly Drunkenness.-High Social Position of Women.-The Doctrine of Fair Play. - Strict Observance of the Rights of Property.-A Race of Debt-Payers.-Morality without Religion.-Infrequency of Crime. -Dyak Diseases. - Mode of Burial. - The Future of the Race.-

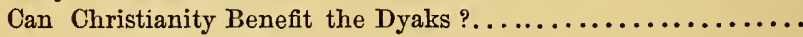

\section{CHAPTER XXXIX.}

\section{A PLEASURE TRIP UP THE SARAWAK.}

The Firefly.-Mr. A. H. Everett.-The Chinese Gold-washings at Bau.-Caves and Crevices near Paku.-Walk to Tegora.-The Cinnabar Mines of the Borneo Company.-Romantic Boat Ride 
down the Staat. - Trip to Serambo Mountain.-Dyak Bridges.-

PAGE

Village of Peninjau. - The Rajah's Cottage.-Magnificent View. -

Return to Kuching.--Farewell to Borneo.-Singapore once more.

-End of the Expedition.-Retrospect.-Conclusion

\section{APPENDIX.}

Outfit for a Collector.................................... 491

Recipe for Making Arsenical Soap ....................... 492

How to Skin a Quadruped, and Prepare the Skin for Mounting..... 492

Loss of Life in British India by Wild Beasts and Serpents......... 493

Statistical Tables of Human Lives, Cattle, and Dangerous Animals

Destroyed ................................... 494

Measurements of some Indian Mammals. . ................. 495

INDEX 




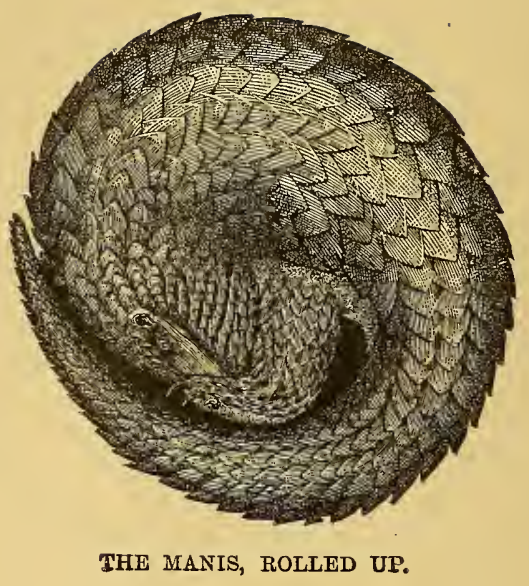




\title{
TWO YEARS IN THE JUNGLE
}

\author{
WITH RIFLE AND KNIFE.
}

\section{$P A R T$ I.-INDIA.}

\section{CHAPTER I.}

THE JOURNEY TO INDIA.

Objects of the Trip. -Boycotted in Ireland.-The Challenger Collections. -The Liverpool Museum.-The British Museum.-From Paris to Rome.-Art versus Nature.-Collecting at Naples.-The Zoological Station.-Alexandria - The Nile Delta.-Cairo._A Picnic to the Petrified Forest.-The Author rides a Camel -Egyptian Fossils. - Through the Suez Canal.-A Day at Jeddah._-Pilgrims and Strangers. -The Tomb of Eve.-The Red Sea.-A Pleasant Voyage.-Bombay.

I sHaLl always believe I was born under a lucky star as a compensation for not having been born rich. My greatest piece of good luck came to me in 1876, when I was equipped for field work in natural history and sent to the East Indies on a two years' hunting and collecting tour. True, I had spent two years in Professor Ward's famous establishment at Rochester, hard at work learning the art of taxidermy, and all the methods employed in zoological collecting. I had also made two trial trips as a collector in tropical America, so that taking all together, I had served a regular apprenticeship under skilled instructors.

Of course my trial trips were considered successful, else would $I$ have been elected thereafter to remain at home in quiet comfort. As it was, fortune smiled upon me, very broadly I thought, and in 
October, just two months after the plan was first proposed, I started eastward to India.

Was it by some institution of learning or scientific society that I was sent out? No, indeed; there is not one in this country or any other that ever had the enterprise to set on foot such an undertaking and back it up to the bitter end with the necessary hard cash. A private individual then, was it? It was, and who else than Henry A. Ward would have had the pluck to send a collector on a tour around the world, to furnish him ample funds for expenses during nearly three years' work, and pay him a good salary besides?

Yet this lavish expenditure proved a good investment, and yielded more museum materiæ, in a better state of preservation, than could be purchased with three times the amount of money expended on the trip. This novel expedition was rendered necessary by the demands of various scientific museums upon Professor Ward's establishment, for East Indian forms which were not to be obtained without sending a collector to gather them in the field.

Behold me, then, on board the steamship Bolivia, steaming swiftly, but not too swiftly, I confess, across the Atlantic, in company with Professor Ward himself, whose companionship I was to enjoy as far as the Red Sea. My outfit of fire-arms and ammunition, knives, tools, preservatives, collecting cases, and camp equipage was both complete and compact, and I considered it very nearly perfect. My instructions were anything but rigid, and I had really a roving commission to visit India, Ceylon, the Malay Peninsula, and Borneo, in quest of mammals in particular, and vertebrates of all kinds in general. It was particularly to my liking that quadrupeds of all species, from the elephant downward, were needed most of all, and that my natural preference for the chase and study of mammals in their haunts was to be indulged almost without limit. I was directed especially to secure skins and skeletons of elephants, Indian bison and elk, orang-utans, gibbons, monkeys of all species, two or three tigers if practicable, and every species of crocodile procurable. The avifauna of that region was then being very thoroughly studied by A. O. Hume, Esq., and his co-laborers, and I could well afford to leave the birds to him and his army of collectors.

In due time we landed at Londonderry, and to me was assigned the pleasant task of visiting the Giant's Causeway, near Port Rush, to procure several of its kasalt columns for Professor Ward's cabinet. This great geological wonder is the most interesting feature 
of the picturesque north coast of Ireland, and to my mind it really is, as the local guides assure the visitor again and again, "wan uv the foremust sights uv the known wurruld." After securing and shipping five large columns, I went to Belfast, and from thence about twenty miles farther, to the head of Loch Neagh, where $I$ skeletonized four old donkeys, and very nearly had my scalp taken by a mob of wild Irishmen, who came at me with long-handled spades. They objected to the proceedings on the ground that the "pore bastes had been jist murthered fur me, so they had," and in the tenderness of their hearts they were spoiling for an excuse to pound me and my two butcher boys to a jelly. I was boycotted for an entire day in a cabin, by a mob of nearly a hundred men, women, females, and children, who like

\section{"A legion of foul fiends \\ Environed me, and howl'd in mine ears,"}

while I exercised all the arts of diplomacy I knew to keep the crowd on a peace footing until the arrival of British reinforcements from a police station. I wish I could narrate the whole episode, to show what the festive Home Ruler is capable of on his native bog; but it is too long a story, and a rehearsal of what I endured from those howling bog-trotters would make me lose my temper entirely. I am happy to say I came off with whole bones-mine, I mean, not the donkeys'-for they were a complete wreck-after an adventure ten times more dangerous than any $I$ experienced with the head-hunters of Borneo, or any other East Indian natives.

After joining Professor Ward at Glasgow we went to Edinburgh, where we visited the collections of the Challenger expedition, or as much of them as were stored at No. 1 Park Place. Aside from the marine invertebrates, the amount collected seems small almost to insignificance, in comparison with the cost, the equipment and personnel of the expedition, and the distance it traversed. The higher forms of animal life received but scant attention, and the results obtained are interesting to a few scientific specialists only. Aside from the deep-sea sounding and dredging, I, for one, am puzzled to know how such an expedition could go so far and accomplish so little. The collections of vertebrates would be no great credit, eren if shown as the work of a private individual, to say nothing of such an expedition sent out by a great nation.

At Manchester we visited the Owens College Museum, whence I went on to Sheffield and had made to order, after my own patterns, 
two dozen skinning knives of various sizes. They were made of the best shear steel by E. Blaydes \& Co., and proved a valuable invest. ment.

At Liverpool we visited the Derby Museum, which is my ideal of what a public museum ought to be. It is readily seen that no effort has been spared to make it perfect in quality of both specimens and fixtures, and one only regrets that Dr. Moore has not unlimited funds at his disposal for the indefinite increase of the quantity. The methods of installation happily combine attractiveness of display with economy of space.

After that came London and its museums of all kinds. The city is but a vast, inhospitable wilderness of brick, gloomy but not grand, ancient but not attractive, redeemed from utter loneliness only by its wonderful museums and galleries of art, and its gardens of zoology and botany. Not even in the jungles of India, with only half a dozen native followers, did I feel so utterly lonely as in the heart of London's immensity, surrounded by nearly four million human beings speaking my own language.

The British Museum is undoubtedly the most complete of any of its kind in existence, and always will be. It outranks all other museums just as the Great Eastern surpasses in size and carrying capacity all other ships. There is not now, and there never will be, even in boastful, progressive America, another museum which can even be compared with it as to size and scientific completeness. Englishmen have a pride in this institution which reaches to the bottom of their pockets, and this, with the dispersal of Englishmen all over the world, has made it what it is. British consuls are paid good salaries, from which they can and do afford to gather valuable collections in foreign lands for the British Museum. So long as our consuls are limited to the paltry salaries they now receive, for a year at a time, by the grace of Congress, they would be very foolish to spend a dollar for the benefit of any American museum; though they might, at a trifling expense, send collections to the Smithsonian Institution which would make a magnificent museum in a year. More than this, the British Museum is allowed to buy what it wants and cannot get by presentation, but the wisdom of our Congress fails to provide for the purchase of a single specimen by the National Museum. What a glorious scheme for building up a national institution!

To a stranger, the extent and completeness of the British Museum's scientific collections are truly astonishing. Unless he is a 
scientific sharp, the chances are he cannot name a living species of any except the lowest forms of animal life which cannot be found represented there in some form. It may be a skin, a mounted specimen, a skeleton, a skull, a preparation in alcohol, or perhaps only a pair of horns ; anyhow, it will be there, somewhere, although it may not be on exhibition by any means. Of many species there are dozens of specimens of various ages, from various localities, all valuable as showing the variations in size, color, and texture of covering. The best of it all is, that this wonderful storehouse of science is open on equal terms to all, and, be you ever so humble a student, an assistant is always at your service to hunt up and show you at once the specimens you desire to examine. Even before I had intimated a desire for a closer examination of the tortoises on exhibition, a vigilant attendant noticed my interest in the group and immediately came forward, with an offer to uulock the cases and take out any specimens I wished to examine closely. When I protested that I did not wish to give him so much trouble, he replied that he was there for that very purpose. No introduction, no unwinding of red tape was necessary; that I had been found studying those specimens as well as I could through the glass was enough. Again, when I wished to see a particular crocodile skull described by Gray as Molinia Americana, Dr. Guntlier immediately sent an assistant with me, who went into the basement with a lantern and found it directly. When I wished to see Seba's figure and description of "the American crocodile," published so many years ago, the distinguished keeper of zoology sent another assistant to the library, who found the volume and the plate for me at once. This, and much more, was done to assist the inquiries of a mere nobody.

It is in this great institution that the naturalist will find the type specimens of so many thousand species, and the array of objects from which those extremely valuable but far too costly contributions to science, known as the British Museum Catalogues, have been made up. Each catalogue is in reality a handbook of classification, but the trouble is, the volumes are so expensive as to be beyond the reach of the average impecunious student who would gladly inform himself from them. What a boon to poor naturalists it would be if these catalogues and monographs were published and issued upon the same generous plan as that pursued by the Government of the United States in the issue of similar works. We have not as yet a British Museum, but we have a Government 
which bountifully provides for the publication and free distribution of complete and systematic information bearing upon all branches of American natural history. The reports of the Geological Survey, the Bureau of Ethnology, the Miscellaneous Publications, the reports of the Commissioner of Fish and Fisheries, the Bulletins of the National Museum, and nearly all the publications of the Smithsonian Institution are all sent free as air and postage paid to deserving applicants. This liberality on the part of the Government, umparalleled in the history of nations, has given to science in America such an impetus as could not have been acquired in less than a century by any other means.

After six weeks of London, Paris came and went like a beautiful dream, leaving confused memories of clean buildings, pretty parks and gardens full of nude marble figures, monumental columns and arches; acres of fine paintings by masters old and new ; gorgeously gilded and frescoed ceilings; rooms full of artistically mounted bones, "stuffed animals," and beautiful birds ; long rows of human skeletons; naked Hottentots in wax; and museums of everything under the sun.

On Christmas day we crossed the Alps into "sunny Italy," and landed in the lap of winter at Turin. "Sunny Italy" indeed, with a foot of snow on the ground! Together, Professor Ward and I did the natural history museums of Turin, Milan, Florence, Pisa, and Rome, and, surreptitiously, I did the art galleries alone.

Rome is a paradise for art, but a desert for natural history. The Eternal City turus out paintings by the square mile, and regiments of women and men in marble, but she cannot stuff an animal so that it is fit to be seen. She has the Vatican and St. Peter's, but she has not the least idea about cleaning and mounting skeletons properly. There is one scientific man in Rome, the professor of natural history who has charge of the University Museum ; but I am sure he must feel very lonesome there. The naturalist is too heavily handicapped in Rome. It requires the untrammelled genius of the western world to produce a real mermaid, a Cardiff giant, gorillas eight feet high, made of buffalo skins, and a forty-foot whale made of bull hides sewn together. Rome ought certainly to produce the most artistic taxidermists in the world, consiclering how much artistic talent there is running to seed all over Italy; but Rome does not care a whit for nature unless it is reproduced in paint or marble.

At Naples we spent eight delightful days, in spite of beggars 
and bad smells, in the course of which we made two excursions to Vesuvius and collected a ton of lava specimens, and also visited Pompeii to see the place, and scoop up a bagful of the fine pumicestone which still covers a large portion of the city. Men are just as great fools as other animals. There are half a dozen populous villages nearer to the treacherous old volcano than this which was buried out of sight, and human memory too, in a few hours' time; and the vineyards reach as far up the mountain as the lava will allow. Familiarity has bred contempt, and the people take it for granted that the great ash-pile will never again get up such high jinks with pumice-stone, sand, ashes, and hot water, as broke up the circus that fine day in Pompeii, in the year 79.

While in Naples we spent several days among the oyster-stalls on the quay, buying quantities of shells, star-fishes, and echinoderms of many species from the Mediterranean. It really seems as if the Italians eat every living animal they can catch in the sea excepting the corals and sponges. In addition to the common edible fishes, the poor people devour sharks, rays, octopods, echinoderms, squids, crustaceans, and shell-fish of all sorts. By way of experiment, we tried a few of the outré dishes which are daily cooked and served up in the oyster-stalls. Fried shark was very good, and so was shellfish soup, but the festive echinoderm was rather tasteless and delusive. We tried to eat some stewed octopus, but it was tough as india-rubber and salt as the ocean, and after five minutes' steady chewing we gave it back to the caterer to be sold again for the benefit of the poor.

Naples has no public market, but there is a certain wide street in which, as in Albany, fish, flesh, and fowl are gathered together every morning, and every man with aught to sell stands up and howls at the top of his voice until whatever he has is sold. The infernal din, the dirt and bad smells, were enough to appall sensitive nerves; but every morning we used to go in and take our chances amid the motley rabble of buyers and beggars. In this way we secured many fine specimens of Octopus vulgaris, and various cuttle-fishes, murænas, lobsters, crabs, shell-fish, etc., which we preserved in spirits.

Of course we visited the famous zoological station, founded and conducted by Dr. Dohrn, for the systematic study of marine invertebrate life under the best possible advantages. The basement story of the pretty building, which stands at one end of a grassy esplanade, close to the shore, is devoted to an aquarium for the 
benefit of the general public, and is bountifully filled with interest. ing marine animals of many kinds, such as cephalopods, medusæ in all their delicate and filmy beauty, live corals, sponges, sharks, rays, crabs, lobsters, fishes, and turtles in great variety and profusion. A walk through the aquarium is like taking a stroll under the sea and becoming personally acquainted with its inhabitants. The water supply comes directly from the bay, and the denizens of the commodious tanks seem quite at home in the pretty bits of sea-bottom that have been transferred hither for them.

The upper story of the station is, to the gaping crowd, a sealed book, and "shall fools rush in where angels fear to tread?" By no means; hence I did not attempt to penetrate the inner temple where Dr. Dohrn and his investigators have their "tables," and prosecute their divings after the unfathomable, and graspings for the unknowable.

But all too soon the time came for us to move on; and, in obedience to the summons, we shipped home sixteen cases of specimens and sailed for Egypt.

At sunrise of the fifth day out, a long, low stretch of barren sand all along the south betokened our approach to the land of deserts. At eight o'clock Pompey's pillar loomed up from its hilltop behind the city, graceful, prominent, and sharply outlined against the clear eastern sky, and we steamed around the end of the breakwater into the harbor of Alexandria. This city is the gateway to all Egypt, and we found its harbor filled with the ships of many nations, among which we counted nineteen large steamers.

To my mind, there is absolutely nothing attractive about Alexandria, and but for the European quarter, the Place des Consuls, the city would be intolerable, even for a day. The only good things that ean be said about it are, that the city is of great commercial importance to Egypt, and is the starting-point for Cairo. We visited Pompey's pillar and the Khedive's gardens, but to reach them we had to drive through such filthy streets, and past so many dens of wretchedness, that the charm of sight-seeing was utterly lost. We saw sights we had in no wise bargained for. It seems to me that Alexandria is the dirtiest city I ever saw, and it certainly smells worse than Naples. No wonder that fevers are prevalent, or that the plague always breaks out here prior to its appearance in any other part of Egypt.

The ride from Alexandria to Cairo, one hundred and thirty-one miles by rail, is full of interest. Leaving behind us the slums of 
the city, we sped quietly along the eastern shore of Lake Mareotis for several miles, then turned off to cross the flat and fertile delta of the Nile. Although it was mid-winter, the fields were green with young crops of wheat, save those which had been newly ploughed; and for a great part of the journey, the landscapes reminded me strongly of the level green prairies of Northern Illinois near the southern shore of Lake Michigan.

For a number of miles the railway runs along the bank of an irrigation canal, the space between the two being used as a public highway. As the railway traveller flies along, he is treated to an endless moving panorama of turbaned men, women, and children, riding donkeys or plodding along on foot; groups of laborers, idlers, beggars, and strings of laden camels. And so we rattled on, past the green fields; across muddy canals ; across the iron viaduct over the Rosetta branch of the Nile; past mud villages, with their miserable peasant inhabitants squatting on the sunny side of their huts, fighting the flies ; past ruined villages-mere round hillocks of mud-across the splendid iron tubular bridge at Benha, over the Damietta branch of the Nile; across bits of desert, wider or narrower; in sight of the Pyramids ; in sight of Cairo; through clouds of sand and dust, and at last into the grand old city itself.

We took up quarters at the Grand New Hotel, and immediately began to gather in specimens. But it wouldn't do, and we might have known it before going there. The high-toned guests of the hotel wondered too much and looked too much scandalized when we began to buy ibex skulls, stuffed mastigures, polypterus, and other queer animals, and carry them upstairs to our rooms. A naturalist who intends to accomplish anything has no business to stop at a grand hotel, where he must stand upon ceremony and do nothing remarkable. He must put up at the small hotels, where, being a guest who pays cash for everything, the landlord will be his warmest friend and abettor in whatever he undertakes, will give him every accommodation the house affords, and allow him to turn its best room into a taxidermist's shop if necessary. Being compelled to realize this, we moved to the Hôtel de l'Europe, where the landlord gave us all the rooms on the lower floor, and in those we bargained with natives, sorted and packed specimens, sawed and hammered at our boxes, and were happy.

In this day of modern improvements and European innovations upon the ways and means of the oriental races, there are two Cairos, the old and the new. The latter is the foreign-or, more properly, 
European-quarter, and is characterized by broad streets, fine, airy buildings, parks and gardens, grand hotels and a theatre, stylish carriages and gas-lamps, in all of which it is eminently Parisian. All this is agreeable, but uninteresting, and we turn back to the wonders and delights of the old city. Here, at least, the nineteenth century has wrought no change, and we take pleasure in thinking that the city is to-day very like what it was when the Pyramids were new, when England was inhabited by savages, and America was unknown. It may not be so, but still we like to believe that these are the same cramped and crooked streets, the same latticed windows and overhanging upper stories, the same bazaars and work-shops and wells that were here when the brethren of Joseph came down, as envoys extraordinary, to practise the arts of diplomacy in the court of Pharaoh.

Of course we saw the sights as we went along, the beautiful mosque of Mehemet Ali, built of oriental alabaster-the prettiest building material in the world; the mosque of Sultan Hassan; the citadel, and the place where the Mamaluke leaped his horse over the wall ; Joseph's well, cut 260 feet deep through solid rockwhich is much better for the posterity of "Joseph" (the Sultan Saladin!) than a bronze equestrian statue or a monument could possibly be. The Turkish bazaar is very like a church fair, inasmuch as you get less there for your money than anywhere else, but it is worth a visit all the same. The Museum of Egyptian Antiquities at Boulac was full of interest and mummies, but I fear the Egyptian collection in the British Museum surpasses it. The Khedive has lately put a stop to the exportation of antiquities from Egypt, and now not a single article can be shipped without an order from him.

Our pleasantest excursion from Cairo was to the Petrified Forest, south of the city, for specimens of petrified wood and other fossils. Cook does not take his tourists out that way, and for once we were not harassed by crowds of beggars for "backsheesh," or sellers of Brummagem antiquities.

Having made all preparations the previous day, we mounted our donkeys very early one morning and set out. Our cavalcade consisted of Professor Ward, Mr. Farman, the U. S. Consul General, myself, our dragoman, Mr. Farman's chuprassie, all upon donkeys, and three brown-skinned, barefooted little Arabs, clad in long blue drilling shifts, to whip up. The sun was just rising as we rode out at the famous Bab-el-Nasr gate, and there, near the 
tents of the Bedouins, was an old Arab with a camel waiting to join us. We had engaged them the day before, but were nevertheless surprised at finding them both there and ready to start. The plan was for me to ride the camel out to the Forest, where we would load it with specimens of petrified wood to be brought back; so I dismounted from my donkey and prepared to embark upon the ship of the desert.

The Bedouin made him kneel, which he did under protest, with much guttural swearing; not loud but deep; but when I prepared to mount, he bawled aloud in remonstrance against a "Christian infidel dog" getting upon his back, which was sacred to the followers of the Prophet. But his objections were overruled by the court; the stirrup-straps were adjusted over the front horn of the sawbuck I was to ride upon, and I mounted.

"Now look out," said Mr. Farman.

Immediately the camel began to heave up behind and sink earthward in front, just like an Arab when he prostrates himself and touches the ground with his forehead while saying his prayers. It seemed as though my camel was going to stand on his head, and but for the timely warning I should have pitched gracefully over his bows into the sand. ButI clung to the rack, and presently the ship began to right itself. The next thing I knew, the affair was high in the air, with its leg-joints partially straightened out; the Bedouin took hold of the halter and we were off.

How strange and romantic the scene. How soft and pure and balmy the fresh morning air. How pleasing the landscape ; and yet how barren. Not a single green thing in sight, yet somehow it seems more like a freshly ploughed field than a desert. Here and there are the same umbrella-like Bedouin tents that we have seen pictured in the geography on the page opposite the map of Africa, ever since we began to remember, and close to each tent is the very same camel. The wandering Arabs pitch their tents just outside the gates of the city, and feel quite at home, for the desert comes quite up to the walls.

Over to the left there stand a number of low, dome-like structures, and we do not need to be told that they are the tombs of the caliphs who have-mercy! A trotting camel is enough to stampede the reflections of a mirror. The donkeys walk faster than our camel, so we have fallen behind, and must trot to catch up. While we walked, camel-riding went well enough, for the old fellow went very easily and softly forward, and it is not 
so very disagreeable to be heaved forward with a jerk, stopped suddenly, and thus bent nearly double at every step. One's stomach soon learns to accommodate itself to the circumstances, and after half an hour or so one's lumbar vertebræ get into pretty good working order. But when we fall far behind, which we do quite often, then the Arab begins to run, the camel starts to trot, and I drop all side issues to devote all my energies to the task of holding myself together.

We passed the limestone cliffs and quarries of the Mokattem Hills, wound along up a little valley for several miles, and finally turned off eastward into the desert. The surface was very uneven, and thickly strewn with black and porous fragmentary limestone, which very closely resembled the pieces of lava we collected upon the sides of Vesuvius. About ten o'clock we reached the Petrified Forest-a hilly, sandy desert, strewn with petrified tree-trunks and countless fragments of wood. In many places we found trunks twenty, thirty, and even forty feet in length, and often a foot and a half in diameter. The large trunks were always broken in a number of places, squarely, as if they had been sawn. A few stood perpendicularly in the sand, with only their upper ends visible. Fragments of all sizes lay scattered thickly all about, showing petrified knots, bark, decayed places, small branches, and roots.

What a grand picnic that was! We gathered up petrified wood, found a great number of fossil oyster-shells, similar to $\mathrm{O}_{3-}$ trea deltoidea, wandered about, and enjoyed ourselves generally. It was a glorious day, and for once in Egypt we enjoyed peace, balmy peace. It was free and roomy and quiet out there, for we had a whole desert all to ourselves. At noon we sat down upon a little sand hill, just at the edge of a great sandy basin that was once a lake, to rest and enjoy our luncheon. A cloth was spread upon the clean brown sand, and from the lunch-basket Mahomet produced two bottles of claret and one of water, oranges, dates, sandwiches, and other substantials.

Why do not more artists paint such glorious pictures as the one that lay before us then, instead of the tame and hackneyed scenes of lakelet, meadow, hill and dale so universally depicted? On either hand the view was bounded by lofty sand ridges, or limestone cliffs, but before us stretched the warm brown desert in gently rolling hills of sand, sloping gradually down toward the Nile. Cairo lay half hidden behind the Mokattem Hills, its grace- 
ful minarets and mosque-domes shining brightly in the morning sun. Above the city, where there were no hills to hide it from our view, we could see the sluggish Nile, and trace its winding course through the narrow, level valley of fertile fields that stretched like a ribbon of green velvet between the two great deserts. Beyond Cairo, at the edge of the green valley, the Pyramids loomed up far above the horizon, mysterious and majestic mountains of stone, while far beyond them stretched a vast but lifeless oceana sea of desolate sand, reaching from the Nile to the far-off shore of the Atlantic.

On our way home from the Petrified Forest with a camel-load of specimens, we stopped at the limestone quarry a mile from the city, to look for fossils in the piles of rock that had recently been quarried from the cliff. In a couple of hours' vigorous scrambling and hammering, we secured a fine assortment of fossils, including about thirty good specimens of a pretty little fossil crab, bearing, as none but a stone crab could, the appalling name of Lobocarcinus Paulo-Wurtemburgensis, a number of large Nautili, and several species of Voluta, Turritella and Cerithium. The most interesting find was a rib of a Sirenian.

Egypt is one of the grandest countries in the world for an antiquarian, but one of the poorest for a naturalist. The Polypterus (a ganoid fish valuable to science because of its close resemblance to Osteolepis, a fossil fish of the Devonian) is found in the Nile, but it is exceedingly rare. Crocodiles (C. vulgaris) are also found in the Nile, but so far above Cairo that we decided not to hunt them. A trip up the Nile by rail, four hundred and fifty-seven miles to the mummy pits at Manfalout, revealed the fact that the pits had been fairly gleaned of the mummied crocodiles, ibises, cats, and human beings they once contained. The result of this tedious three day's trip was but two mummied crocodiles, a skull, and an armful of mummied arms, legs, and heads of ancient Egrptians.

An Arab brought us an earthen jar, said to contain a mummied ibis, for which he asked the modest sum of $£ 1$. The mouth of the jar was tightly closed with cement, and the Arab would not allow us to open it, so Professor Ward, who had seen Arabs before, declined it with thanks. We met an old Bedouin who had just come across the desert from the peninsula of Sinai, and had carried on one of his camels, all that weary distance, seven heads of Egyptian ibex (Capra Nubiana), all of which were quickly added to our collection 
at a price highly satisfactory to both parties. The skin remained upon each skull, dry and hard, and had perfectly protected all parts of the bony structure from injury. Not a bad idea for the preparation of small skulls that are destined to be banged about on camel-back.

We procured specimens of the polypterus ( $P$. bichir), the spinytailed mastigure of the desert (Uromastix spinipes), one specimen of the Egyptian wild-cat (Felis chaus), and about three camel-loads of petrified wood, fossils of many kinds, blocks of Egyptian granite and oriental alabaster to be sawed up into cabinet specimens. Near the beautiful mosque of Mehemet Ali lay a number of blocks of alabaster like those of which the mosque has been built, "stones which the builders rejected." After the exercise of considerable diplomacy, General Stone, the Khedive's Chief-of-Staff, to whom Prof. Ward had letters, obtained the vice-regal permission for us to cart through the gates of the citadel one slab of alabaster for ourselves, and another which he consigned to the care of Prof. Ward for the Smithsonian Institution. General Stone also obtained the Khedive's permission for our two mummy coffins and their contents to be exported from the country without let or hindrance.

Even at the Pyramids, last of all suitable places for a naturalist, we found specimens valuable to science. The Pyramids are built entirely of nummulitic limestone blocks, and the passages are lined with limestone brought from the Mokattem Hills east of Cairo, eight miles away. This limestone is full of nummulites, little flat echinoderms, which, as the blocks upon the surface slowly disintegrate through exposure, are set free and roll down to the base of the Pyramids, where they are picked up by the Arabs and sold to travellers.

Another interesting fossil which we also obtained at the Pyramids was a larger echinoderm, Clypeaster Ghizaensis, from the limestone (a lower strata than the nummulitic), which is the foundation upon which the Pyramids rest. The Arabs dig these fossils out of deep holes in the sand.

As a sort of penance for two delightful weeks in Cairo and ricinity, I was exiled to Port Said for a ferv days to look after our heavy luggage, which had been shipped there, and to watch for an outward steamer.

Port Said (pronounced Side), named after Said Pasha, under whose patronage the Suez Canal was commenced in 1859, is the 
port at the Mediterranean entrance of the canal, a very important, but very dreary, dirty, and uninviting modern town, built upon the sand and infested by Arabs and fleas. But deliverance came at last. I embarked one night upon the Austrian-Lloyd steamer $M e m f i$, and when I awoke at sunrise the next morning, Port Said lay far behind us and we were steaming slowly through the great canal. Some one had told me that this passage was an "uninteresting and monotonous voyage through a big ditch," but I do not believe he ever saw the canal. After leaving Port Said, the channel is cut through Lake Menzaleh, a vast but shallow lagoon, swarming with wild fowl. From that, a cutting through a low, sandy plain leads into another lagoon, called Ballah Lake, which is also traversed by the canal. From Ballah Lake to Lake Timsah the canal is cut through the plateau of $\mathrm{El} \mathrm{Guisr,} \mathrm{the} \mathrm{highest} \mathrm{ground} \mathrm{on} \mathrm{the}$ route. The banks grow higher and higher, and the channel narrower, until we suddenly emerge upon Lake Timsah (Crocodile Lake), nearly midway between the two seas. On the western bank of the lake stands Ismailia, a pretty little town, a garden in the desert, with substantial houses, fine streets, shady avenues, green gardens, and all the institutions of business and religion pertaining to a modern town.

Crossing the lake, we entered another cutting several miles in length, full of curves and gares, or sidings where ships can meet and pass each other. After steaming slowly all the afternoon through the desert, we anchored just before sunset in the deepest part of the Great Bitter Lake. What an odd sensation it is to cross a desert in a steamship! Never have I seen water look so smiling and delicious as do these clear blue lakes in the midst of a scorching and lifeless expanse of brown sand. As the sun set, the full moon rose, lighting up a broad, golden track across the glassy surface of the lake, the stars came out until we had one shining firmament above and another in the lake below, the evening air was balmy and pure, and, as if to crown all these delights, the bell rang for supper.

The Suez Canal is 86 miles in entire length, 21 of which are through the three larger lakes. It is 26 feet deep in mid-channel, and the bed is 72 feet wide. At the surface, the width varies from 350 to 196 feet, according to the books, but in the narrowest cuttings, the surface width looked more like 96 than 196 feet. Vessels are not to steam faster than five and one-third miles per hour in the canal. The toll charged by the company is thirteen francs per foot 
of draught for laden vessels, ten francs per foot when in ballast. The total cost of the canal was eighteen and a quarter million pounds sterling, to say nothing of the millions of pounds worth of "forced labor"-or, in plain English, slave labor of the most deadly sort-supplied by Ismail Pasha.

The next morning we ran the gauntlet of buoys and beacons which mark the channel across the Bitter Lakes, and continued our winding course througl the desert. The canal makes a great many very sharp curves, and it is a delicate task to take a large steamer through without a mistake. About noon, we saw, across the desert, a number of ships; the desert gradually sank away into the sea, and at one o'clock P.M., just thirty-one hours from Port Said, we anchored in the harbor of Suez. Professor Ward came on board directly, with nearly a bushel of fresh echinoderms, and after a stay of two hours, we weighed anchor and started down the Gulf of Suez.

Half way down the Red Sea, on the Arabian shore, lies Jeddah, the nearest port to Mecca, and therefore the landing place for the throng of Mohammedan pilgrims constantly coming from all parts of Northern Africa and Southern Asia to visit the tomb of the Prophet. We were to call there for a deck-load of returning pilgrims bound to Bombay, and just forty-eight hours from Suez, the town lay before us, compact, angular and gray, bounded on three sides by the desolate barrenness characteristic of the Arabian peninsula. Taking a position with as much precision as a man going to leap over a bar, we slowly and cautiously threaded our way through a break in the coral barrier reef which forms the harbor.

It was close nipping sometimes, and once or twice we had to stop and go astern before we could pass the end of a reef ; but the swarthy Arab pilot we had brought from Suez took our ship through without accident. How large sailing ships manage to get through is more than a landsman can see, but they do it somehow, for we saw several riding at anchor inside the reefs, which is the only harbor there is at Jeddah. There were in port a dozen or more large steamers like our own, and a whole fleet of sailing vessels, most of which had come laden with pilgrims, and were waiting to bear back their living freight.

We had a day to spend on shore, and made the most of it. Upon landing we found that the substantial portion of the town is built of fossil coral and coralline limestone. Great masses of brain coral, Meandrince and Astreoporce, have been quarried from the 
raised beaches, trimmed up as ordinary building stone, and used in the construction of houses. Blocks of limestone full of very perfect Madrepora were common, and sometimes we found four or five species of coral in a single wall. Owing to the purely coralline nature of the building material, the houses of Jeddah are of dazzling whiteness when fairly viewed. In the suburbs, the houses are mere huts of reeds and brushwood.

Taken altogether, Jeddah is a fine little city. The houses are built quite solidly, in a peculiar style of architecture, half Moorish, half Saracenic, which is both unique and beautiful. Each upper window is a square latticed casement of brown wood, projecting from one to two feet beyond the wall. The city is entirely surrounded, on the landward side, by a high wall, and, owing to its close proximity to Mecca, and the presence of so many pilgrims, it is a perfect little hot-bed of fanaticism, ready for a religious (!) disturbance upon very short notice. One occurred in 1858, during which the meek and lowly followers of the Prophet massacred all the white Christians in the place, including the British and French consuls. In return for this, the British Government, with its usual promptness, taught them the gospel of peace by bombarding the place. That lesson has had its effect, and until it is forgotten, every white man in Jeddah will be safe. And yet I fancy it must be very much like living in a powder magazine to hold a consulship there.

In the cemetery, a quarter of a mile northeast of the city, is the celebrated tomb of Eve. Whether the dust of the great mother of mankind really reposes there or not, no man can say: but all true Mohammedans believe that such is the case, and reverence the spot accordingly. In fact, they hold it as very sacred indeed, but the guardian angels of the tomb are not proof against the seductive power of backsheesh, and for about fifteen piastres each, we were cheerfully admitted to all the rights and privileges of the place.

If Eve was, when living, as long as this tomb, then she was indeed a woman fit to start a world with. Her tomb is about two hundred and twenty feet long, but very narrow, enclosed by a whitewashed stone wall. Across the centre stands a small building, in which is a shrine, and under this is supposed to lie the dust of Adam's wife, the first woman, who came direct from the hand of the Creator. It gives one's head a turn to think of it.

There is one thing about the tomb, which is both strange and pitiful. At the southern end of the enclosure is a sort of tower, 
low and square, in each side of which is a large window. To the iron bars of these windows were tied hundreds, perhaps even thousands, of small strips of cotton cloth, one upon another, so that not an atom of iron was visible in either of the three windows.

Each of those little ragged strips,-none of them large enough to tie up a cut finger, - - had been tied there by some barren Mohammedan woman who had made a pilgrimage to the shrine, and performed this act of faith, praying and believing that the great first Mother would have pity for her distress, and render her fruitful. Think of the years of wretched longing for maternity that were represented by those fluttering bits of cloth.

Jeddah has only three gates, except those facing the sea, and having gone out at the northern gate to reach the cemetery, we concluded to keep on around the wall, and so make a complete circuit of the city.

At the eastern side of the town we came to the famous Mecca gate, through which one hundred and twenty thousand pilgrims pass every year on their way to Mecca, the Mohammedan Jerusalem, sixty-two miles inland. It used to be death for a Christian to pass through this gate, just as it would even now be death for a Christian to attempt to enter Mecca. Only two Englishmen have ever been inside the walls of that city. Captain Burton was the first, and he went with a large party of pilgrims, so thoroughly disguised in feature, speech and habit, that his true character was not suspected. The other was Hadji Brown, of Bombay, who professed full conversion to the Mohammedan faith, and made the pilgrimage in 1876. In my opinion, getting into Mecca and safely out again is a mere question of backsheesh. The man who bids high enough will be granted the freedom of the city, and it is a wonder that Cook is not even now paying an annual subsidy to the Pasha, and taking his tourists there. The Mecca gate (at Jeddah), is open to all comers now, and we passed inside just for the sake of enjoying what used to be a forbidden privilege.

Professor Ward had arranged to stop at Jeddah, and did so, having in early life formed the habit of doing what he sets out to do. He spent a few days there, then took the Egyptian steamer to Suakin and Massowah, busily collecting at every opportunity, and shortly returned to Europe and home to America with a goodly lot of Red Sea invertebrates and fishes. And so I was left to go on alone to the East Indies, and work out my own salvation with fear and trembling. The Memfi took aboard one hundred and 
eleven pilgrims-Hadjis-as deck passengers for Bombay, and the next morning we continued our course down the Red Sea.

There were only three saloon passengers besides myself, an officer of the Indian army with his wife and child, returning from furlough to their station at Kohat, in the Punjab, close to the Khyber Pass. In Colonel-then Captain-Ross of the 1st Sikh Infantry, I met a man whose mind was a store-house, full of valuable information, who patiently endured a tedious amount of questioning, and whose friendship and advice afterward proved of great service to me. He entered heartily into the details of my plans for India, and even condescended to teach me enough Hindostanee to enable me to inquire whether there were "any large gavials near here?"- "how far away?"- "who can take me in a boat?"-and so on. My meeting with Colonel Ross was indeed most fortunate, as events proved, and as I look back wpon it, I do not see how I could possibly have accomplished what I did, without his assistance.

In the course of many delightful conversations with Mrs. Ross, each of which was to me a mental treat, she rendered me an important and lasting service. She diagnosed so cleverly a malady which had often attacked me-" the blues"-and prescribed a remedy so skilfully that I never have suffered from it since that day. For the benefit of fellow-sufferers I will state both. Diagnosis :"The blues" are caused by envy and selfishness. Remedy:When attacked, go to work vigorously to promote the happiness of those around you, and thereby forget yourself.

The third day after leaving Jeddah we passed through the strait of Bab-el-Mandeb, which is the Arabic for "gate of tears," a name applied to these straits on account of the many wrecks that have occurred here of vessels trying to get in or out of the Red Sea. At the point where the strait is narrowest the island of Perim stands mir-way between Arabia and Africa, a sentry-box with a British soldier in it. Of course England occupies Perim and holds the key to the Red Sea, just as she holds the keys to all the important points between Downing Street and Canton. This little bit of barrenness was made, like Gibraltar, Aden, and Hong Kong, especially for England. At the narrowest point, the strait of Bab-elMandeb is but fifteen miles wide, and the navigable channel on either side of Perim is near the island and very narrow. The Arabian coast, which is in sight all day, is mountainous, rocky, and entirely barren, save for an occasional palm-tree along the shore.

After getting through the strait, we called at Aden. The 
Mohammedans believe that this burnt-up place was once the Garden of Eden, but we know that it is about sixty degrees $\mathbf{F}$. from that now. It has been very truly spoken of as a cinder, for it is composed of rugged black mountains of lava, piled high up, without a single tree, bush, or blade of grass visible to the naked eye. It was once a cluster of volcanoes that poured lava down their steep sides into the sea, but now they are extinct, and the town of Aden is located in the crater of the largest. It is surrounded by high walls and ridges of lava, and has but two outlets, the road to the west, and a tunnel, a mile and a quarter long, to the north. Aden is said to be the hottest place in the world, and yet it boasts 21,500 inhabitants.

The first Parsee (fire-worshipper) I ever saw was a wealthy and apparently respectable merchant, but when the chance offered he could not resist the temptation to tell me a lie and cheat me out of a rupee, just as a hackman would do. At Steamer Point I stepped into the store of Messrs. Swindlejee \& Co., and after making a little purchase, handed a sovereign in payment. I asked how much a sovereign was worth in rupees, and he assured me only ten. Trusting to his honor as a respectable merchant I made no further inquiry, and he gave me my change on the basis of ten rupees. As soon as I left the place I was fairly beset by a mob of ragged little Arab money changers who had got wind of the transaction and wanted to give me ten and a half rupees for all the sovereigns I had. During the day I had occasion to change several, for each of which I received eleven rupees without any trouble. I shall never forget my introduction to the Parsees.

I obtained a fine lot of ostrich eggs, and a few fine feathers also which had been brought across the Gulf of Aden from the African coast, but, finding nothing else there worth taking, the Memfi weighed anchor and proceeded on her course across the Arabian Sea.

Taken altogether, I think that voyage from Port Said to Bombay was the most agreeable I ever made. It was the poetry of life at sea, a sort of lotus-eaters' voyage. The sea was smooth, the weather was clear and balmy, the officers were as kind and courteous as officers could possibly be, and my fellow-passengers in the cabin seemed to have been selected especially for me. The ship was clean, roomy, and comfortable, and the devotions of the deck-load of Hadjis afforded a pleasing diversion. But it had to end at last.

We sighted the Bombay light just before midnight of January 16th, and three hours after were at anchor in the harbor. 


\title{
CHAPTER II.
}

\author{
BOMBAY.
}

Duty on Outfit.-A Model (!) Consul.-The Servant Question.-The Grand Market.-Flowers._Fruit.-Fish.-Live Birds.-The First Specimen.Street Cars.-An Interesting Crowd.--Vehicles. - The Bullock Hackery. -The Homeliest Animal Alive.-The Victoria and Albert Museum. - Softhearted Hindoos. - The Hospital for Animals. - A Strange Sight.--A Good Servant.-Departure for Allahabad.

AND now we have come to India, the land of princes and paupers, of creeds and castes, of savage men and still more savage beasts. The sun rose upon what was, to me, a new world, full of strange sights, and sounds, and people. We were at anchor in the middle of a bay several miles long, on one side of which lay the flat city, stretching far along the shore ; in the distant east the sun was just rising above the high brown hills of the Western Ghauts, while to the south lay a perfect archipelago of mountainous islands, large and small. A single look over the ship's side into the murky water, told me that I need not expect to find any shells, corals, or starfishes at Bombay, for they do not live upon a muddy bottom.

The bay was fairly alive with small native boats, in one of which I immediately went ashore to look for suitable lodgings. Almost in the shadow of Watson's Hotel, a splendid iron structure of five stories, the finest hotel between Cairo and San Francisco, I found Doughtey's Hotel, a little nest of a place that would hardly have made a kitchen for Watson's ; but I found in it what no one can in a big, stylish hotel-freedom, the privilege of taking " mine ease in mine inn."

When I went to the steamer to bring away my baggage, I found that the custom-house officers had swooped down upon us and that ten per cent. duty was demanded on most of my outfit. Feeling that I was, in every sense, a traveller, merely passing through India with all my personal effects, and that my belongings were designed for scientific work, I thought that a proper representa- 
tion to the collector of customs would secure the passage of my outfit free of duty. A naturalist, unless he is a millionaire or has one at his back, cannot afford to look lightly upon a matter involving forty to fifty rupees. So I went to the United States Consul, and asked that he make a statement of the facts in the case to the collector of customs. Mr. Farnham may be of more use to the Uuited States than a wooden man would be, but he certainly wasn't to me. He simply declined to trouble himself about the matter in the least and, with not more than a dozen words; went back to his "long-sleeved" chair and his newspaper. I was so completely snubbed that I determined to give our consuls a wide berth thereafter, and meekly paid the duty clemanded.*

In the Jard of the custom-house I saw about three hundred elephant tusks lying in a pile, arvaiting shipment to England. I was greatly surprised at the shortness of them all.

Knowing that I could remain but a comparatively short time in India, I realized that I could not afford to spend time in learning the languages of the different Presidencies. I resolved therefore to depend entirely upon interpreters; and my first care was to find a servant who could speak a little English. I wanted some one who would act as my shadow every time I went out, and who could also assist me at whatever work I should undertake. The Hindoo servant is a nuisance, for he can only eat in a certain way, at a certain time, and do but one kind of work; and the Mohammedan is not easily induced to travel. I wanted a man who would be willing to do any kind of work that I myself would do, and I found a little fellow from Goa who proved to be the very man. He was a native Christian, and therefore not hampered by caste prejudice; he dressed neatly in European style, wore a nobby, high black hat, a moustache and side whiskers, and was as black as night. He did not know more than fifty words of English, but he was quick to understand and prompt to execute my wishes. I took him at first on trial, with the understanding that if we suited each other, I would take him to Northern India with me.

With my new servant, Carlo, at my heels, I started out to visit the market, which is always good collecting ground in a new locality. Bombay is the only city in the East Indies blessed with street cars, and being well managed and liberally patronized by all classes, they

* In justice to the service I should add that I soon reconsidered this determination, for I found our consuls at Calcutta, Columbo, and Singapore, ex tremely obliging and serviceable. 
are a complete success. The distances would seem very great without them. Taking a car at Watson's Hotel, we rolled smoothly along a broad, shady street at the side of a spacious esplanade, at the farther end of which stand the splendid new buildings of the University, High Court, Secretariat, and Post Office. A ride of about a mile and a half brought us to the Grand Market, which was to me the most interesting sight of the city. Standing so as to form a triangle, are three buildings, long and wide, with roofs of corrugated iron supported upon iron pillars, and in the centre of the triangle is a fine fountain with flowering shrubs and trees. The best American housewife cannot show a pantry cleaner or more perfectly arranged than this vast market. Fifty-six thousand square feet of space are divided into sections for the sale of flowers, fruits, vegetables, grains, spices, fish, and meats, and these are subdivided into hundreds of stalls where native men and women squat upon the sloping platform and serve the passers-by.

In the flower market was a scene that would have made the reputation of any artist who could fairly depict it. Seated upon the raised platform, and surrounded by great heaps of fresh-blown roses, marigolds, jessamines, and brilliant tropical flowers of many kinds, was a group of dark-skinned Hindoo men and women tying the blossoms up into bouquets and long garlands while they laughed and chatted. The huge, snow-white turbans and loose jackets of the men, the raven-black hair of the women, the massive silver ornaments around their arms, ankles, and toes, and their gaudily colored robes in the midst of such brilliant flowers, made up a picture which, if seen once, could never be forgotten. The air was heavy with sweet perfume.

The vast space occupied by the fruits and vegetables seemed more like the display at an agricultural fair than a simple market for the sale of daily food. There were piles of oranges, bananas, grapes-both purple and white-pomegranates, pummeloes, and many other kinds entirely new to me.

But what interested me most was the fish market. Besides a fine assortment of common edible species, such as are most abundant in the Arabian Sea, there were a number of sharks, shark-rays (Rhinobati), and skates, which were of special interest. My first visit occurred so late in the morning that the kinds I wanted had all been chopped up, and I found that, in order to eatch large rays or rhynobates before they were cut up, I would have to be on hand before daybreak. 
To a Hindoo, beef is an abomination, and the ever-patient au. thorities have located the beef market in a building off at one side, the doors of which are shut by screens, so that good Brahmins may not be offended by even the sight of holy heifers which have been sacrificed to the wants of Englishmen and Mohammedans. In the garden adjoining the market are men who have live birds for salecranes, quails, pheasants, mainahs, jays, doves, etc.

Eager to secure at least one valuable specimen the first day, "for luck," I found that the crane-seller had a dead saras (Grus antigone) in his possession, and upon finding it to be a specimen both large and old, I bought it of him, after a good deal of haggling, for two rupees. Its plumage was soiled and ragged, but it made a fine skeleton.

How strange it seems to ride upon a modern street-car as it rolls on its way through the narrow, crooked, and crowded streets of the native bazaar. It seems like the true car of Progress, pushing its way through the throng of caste prejudices, ancient customs, and silly traditions, inviting all to meet upon a common level. This nineteenth century street-car looks as strangely out of place here in the narrow streets of the native town as would a train of camels plodding along Broadway. The driver whistles and shouts and the crowd quickly opens a passage for us.

And what a strange, fantastic crowd it is, to be sure! Most noticeable of all are the Parsees (from Persia), tall, lank, and intellectual in appearance, clad in long black satin ulsters and oil-skin hats that always remind one of the cone and crater of Vesuvius. I am sure I never saw a Parsee on the street who did not carry from one to half a dozen books. There were Portuguese half-castes neatly dressed in white; long-bearded Jews in red fezzes and long robes; Catholic priests; Arabs; tall Mohammedans under huge turbans of white or green; fierce-looking Mahrattas in turbans of red; and Hindoos of a hundred types and castes with shaven heads and caste-marks on their foreheads. The low-caste Hindoo women are gorgeously attired in short jackets and mysterious windingsheets of red, white, black, green, and yellow; while nearly every shining black arm and ankle boasts from one to half a dozen silver bangles or bracelets. There are rings and rivets of gold, brass, or silver through their noses and ears, huge silver rings upon their toes, and betel-nut in every mouth. There are children in the crowd, too, mostly Parsee boys, cunningly bedecked in little jackets, trowsers, and caps of silk and satin of the most gorgeous 
colors, and glistening with gold and silver embroidery. Each gaudy little chap carries himself with the air of a peacock or a prince, and were we small boys once more, we should turn green with envy of their splendid clothes.

In the broader streets, vehicles of various kinds go rattling by us, carrying passengers usually, for the coolies carry most of the freight. Here we meet for the first time the gharry, which prevails throughout all the large cities of the East Indies. This necessary evil consists of a small, closed carriage with shutters in the sides, a double roof, four wheels-no two of which are of the same diameter, a miserable pony, and a most rascally driver. There must be something pernicious in the society of a horse and a fourwheeled carriage. Either gharry-driving will corrupt the morals of the best native, or else none but the most rascally take to it, for they are all as grasping and unscrupulous as the hackmen of New York City, or Niagara Falls. There seems to be a sort of freemasonry of meanness among all the hack-drivers in the world, for, as a class, I do not know of any other public servants who are such extortionate liars and professional bullies. If the gharry-wallah of India only had the pluck to be a bully, he would be ten times worse than he is, and life would indeed be a burden to a stranger in Inlia.

But the oddest rehicle is the bullock-hackery. This is a light cart, or rather a high platform, enclosed at the back and sides, with a roof so low that it can only accommodate a man sitting cross-lecged, like a Turk. Four big, fat, and sleek Hindoo merchants will crowd into this go-cart, the semi-naked driver doubles himself up on the tongue in front, the little bullocks strike into a sharp trot or gallop which they can keep up comfortably for a mile or two, and away they go. The way they get over the ground is surprising, not in the least resembling the slow, creeping gait of our ponderous American oxen, one of which could easily drag off backery, bullocks and all. These bullocks, which are used throughout Inclia and Ceylon instead of draught-horses, are the sacred cattle of India, tle zebus (Bos Indicus), with straight horns, humped shoulders, and almost invariably either wholly white or black. They are light, leet, and hardy, and easily perform work which in this Indian climate would quickly kill the best horses in the world.

The Indian boffalo (Bos butalus) is also used in Northern India for heavy work, and in my opinion it is the homeliest quadruped that ever breathed. It is simply a huge skeleton covered with a 
bluish-black, and almost hairless india-rubber-like skin; the hipbones stand up high and sharp like obelisks, and the feet are huge, clumsy, and wide-spreading. The buffalo loves mud and moist ground, and nature has provided these broad splay feet to prevent the animal from sinking too deeply in the mire. He carries his head precisely like a camel, low down, with nose thrust far forward; and his horns, which join his skull exactly on a level with his eye, sweep downward and backward as they diverge, until they reach back to the shoulders and beyond. The horns are broad, flat, wrinkled, and jet black, and to look at the whole head one would say that the beast was created with especial reference to running rapidly through very thick brush. This animal so interested me that I went to the market at four o'clock in the morning, just when the butcher-train came in from Bandora, bought fire large heads, and after breakfast, Carlo and I cleaned them with our knives in the back-yard of the hotel. Two of them afterward went to English museums-like coals carried to Newcastle.

I visited the Victoria and Albert Museum, in the Victoria Gardens, expecting to find there a collection illustrating the fauna of the Bombay Presidency, from which I could learn where to ${ }_{3}$ o or send for certain animals which I clesired to obtain. The Museum consists of a very fine building containing an admirable statue of the Prince Consort and another of the Queen, two stuffed animals, half a dozen skulls, some minerals and.seeds, and that is about all. The Museum seems to have been built for the statues, rather than the statues for the Museum. I had been joyfully anticirating the sight of the splendid tigers I would find there in various shapes, but I was not prepared for the sight whicl really awaited me. It was a huge tiger made of papier-mâché and gorgeously painted, in the act of rending a native to death. The man lay unler the tiger holding a long knife in the brute's stomach, perfectly unconcerned, while his eyes were fixed upon the visitor with a realy jolly "what do-you-think-of-that?" expression.

Why Bombay, the largest city in India, should taize so much less interest in scientific matters than cities in the otler Presidencies, I do not know, unless it is that she is wholly absorbed in cotton. It is certainly a poor place for a naturalist, and tll the time I felt lonesome and out of place.

At the hotel I met one day an educated native who spoke English perfectly, and whom I immediately proceeded to question about the localities where I might find certair animals, particularly 
crocodiles, since he was acquainted with Kurrachee and the sacred crocodiles of Mugger Peer. He was talking at a great rate, and I was busily jotting down notes, when he suddenly stopped and asked, "Sir, why do you require to know about these animals?" "Why, I wish to find them." "Why do you require to find them ? Do you wish to shoot them, to kill them?" "Exactly, for their" skins and skeletons." "Ah," said he, dropping my map, "then I cannot inform you where any animals are ; I do not wish any thing to be killed, and if I tell you where you can find any animals I shall do a great wrong."

"Did you never kill an animal ?" said I. me."

"Never sir, never; not purposely, it would be a great sin for

He then went on to tell me of a certain caste of Hindoos, the members of which are so conscientious about taking the life of any living thing that they always eat before sunset to avoid making a light which might be the death of some moth or guat. They do not kill even mosquitoes, fleas, or lice, and if a man finds a louse upon himself, he either allows it to feed comfortably, or else he puts it carefully upon his next neighbor. What a paradise for insects their homes must be!

This morbid Hindoo prejudice against taking life has developed in the Jain sect into an institution which is perhaps the only one of its kind in existence. I refer to the hospital for animals, not far from the Mombadevi Temple. In a spacious enclosure, divided into yards, sheds, stables, kennels, cages, etc., are gathered together hundreds of diseased, worn out or starving horses, bullocks, cows, sheep, cats, and monkeys; cranes, crows, chickens, ducks, and parrots-in short, a perfect zoological garden of the most woebegone description. Domestic animals that have been turned out by heartless owners to perish miserably of starvation and disease; wild birds whose wings or legs have been broken by sportsmen; kittens, "left in the road," to die of starvation, just as tenderhearted Christian people serve them in America, are all gathered up by the agents of this Jain institution, and cared for in every possible way. Many animals, whose festering sores, broken legs, and incurable diseases make life a burden to them, need far more to have their miseries encled by a speedy, painless cleath, than to have their sufferings prolonged a single day, even with the best intentions. As I looked at some of those miserable animals which were slowly dying by inches and suffering intensely, I thought of 
the railway engineer I once saw, who, caught and crushed beneath his wrecked locomotive, with the scalding water pouring in a stream over his wretched body, screamed in agony and implored his friends to shoot him through the head. But no; spades were procured, he was dug out, lingered for hours, and the papers calmly stated that he died in great agony! Alas! humanity has not yet been educated up to the point which teaches that it is as great an act of duty and kindness to end the miseries of a hopelessly burned, boiled, or mangled man by a speedy and painless death, as it is to mercifully put an end to the sufferings of a dumb brute. Were my best friend to implore me to end his hopeless sufferings, I would do it and take the consequences. And I believe the time will come when mankind, as a class, will be as merciful to man as the more humane of us are to lower animals.

There are few marine animals to be found in the vicinity of Bombay, except the fishes in the Grand Market, and thither I made a pilgrimage every morning. The most interesting specimen I procured there was a large blue ray (Trygon sephen), weighing 80 pounds, with a body measuring 2 feet 8 inches in length, by 4 feet 2 inches in width, of which I prepared the skeleton. Rhinobati are common, but it is a difficult matter to secure one entire, for the moment one of these, or a shark, is landed in a market-stall, its fins and tail are cut off to be dried and shipped to China, where the Chinese eat them in soups and consider them a great delicacy. By dint of perseverance I secured one fine specimen (R. djeddensis), 5 feet 6 inches in length, the skin of which I preserved dry with salt.

By the end of a week I had proved to my satisfaction that Bombay was no place for me, and determined to go to Allahabad for gavials and other things. My new servant was in doubt about the advisability of going so far away, until one day he caught sight of my guns, ammunition, and camp-outfit, when he suddenly anwounced, "I no care, sir, I go Allahabad. I like see new country, I like go shoot. I no care how I come back Bomba5." I had told him that I could not pay his way back to Bormbay after only two months on the Jumna, but that I would take him to Calcutta with me if he would go. He suddenly became possessed of a desire for travel and adventure (it overcomes the best of men sometimes), and we quickly concluded a bargain. I agreed to pay his expenses and give him 15 rupees per month, for which he was to interpret, cook, skin crocodiles, and do anything that might need to be done. I had found in the bazaars that he was as shrewd as 
any native at a bargain, and had not the least modesty to hamper him when clealing with a tricky or exorbitant huckster. Natives usually make it a rule to charge a white man from fifty to a hundred per cent. more than any one else, and but for vigorous bullying on the part of Carlo, I could seldom have got an article at its proper price. Luckily for me, Carlo, being a native Christian, felt no sympathy whatever with Hindoos or Mohammedans, and I very often had hard work to repress my laughter when he would start in to brow-beat a bazaar man and bring down his prices to what they ought to be.

I trusted Carlo with an advance of 9 rupees for his outfit, in spite of advice to the contrary from the very man who recommended him to me, who feared he would "jump the bounty;" but the little fellow was honest, and very grateful to me for trusting him against advice. He afterward repaid me for it in many ways.

Before I left Bombay, Colonel Ross very kindly gave me two letters of introduction, one to a brother, a barrister, in Allahabad, and the other to another brother, Major* J. C. Ross, of the Royal Engineers, quartered at Etawah, in an excellent hunting district. These letters proved to be of the greatest service to me, although I have since wondered how Colonel Ross dared give them to a stranger. Excepting those two letters, I landed in India without a single scrap of introductory paper to anybody, save a letter of credit, and I prided myself upon my independence. I said I had money, and would not need any letters of introduction. Before long I found that every such letter is worth a thousand times its weight in gold.

After a week in Bombay we shipped a large case of specimens to Calcutta, and bought our tickets for Allahabad. By going third class I did what an independent white man rarely does in India, and astonished both Europeans and natives. I am not sure that I would do it again, but for once the experience was worth the discomfort. The charges upon excess baggage are very high, and mine cost 44 rupees. Two Englishmen, travelling by the same train toward Lahore, paid 128 rupees for excess luggage. But think of riding from Bombay to Allahabad, 845 miles, for 16 rupees 13 annas, or about $\$ 7.50$ !

* Then Captain. 


\section{CHAPTER III.}

\section{FROM BOMBAY TO ETAWAH.}

Physical Aspect of the Country.-Scarcity of Animal Life.-A Barren Region. -Major Ross. - A Boat Trip up the Jumna.-A Mile of Bathers.-Dead Hindoo.-Plenty of Birds, but no Gavials. - Return and go to Etawah.The Dak Bungalow.-Two Specimens the First Day.--My Boat and Crew. -A Day in the Bazaar. - An Instance of Caste.

The sun was just setting as our long train crossed the bridge from Bombay island to the mainland, and began toiling up the Western Ghauts. These are the Andes of India, and extend close along the coast from Cape Comorin to Bombay and vanish in the Central Desert. We crossed that chain during the night, the next day we crept over the Satpura Range at a snail's pace, and were then fairly upon the great Indian plateau which extends north to the Rajpootana desert and east to Calcutta. But where are the luxuriant tropical forests, the waving palms, and the crowds of people one naturally expects to see? Not here, certainly. Where the country is not cut up by ravines, it stretches out on every side, level as a billiard-table, dry, parched, and thirsty-looking, and, except in the vicinity of Kundwah, utterly destitute of any thing like forests or jungle. There the dry, hot plains are covered with a scattering growth of scrubby trees, and it was quite a surprise to learn that this brushy tract is dignified by the title of forest and duly officered by the Government. North of this are the famous tiger districts of Indore, Bhopal, and Gwalior.

There are no fences, no houses, nor villages worth mentioning, no swamps, lagoons, nor ponds in this region, and the only living objects are a few herds of buffalo and zebu. Except for the scattered fields of young wheat and a few straggling trees, the landscape is gray and monotonous in the extreme. But it is the dry season now, there are no rains, and we see the country at its worst. With the burst of the southwest monsoon in May, these parched and barren plains will blossom like a garden, and the intense dry 
heat will be replaced by the Turkish-bath atmosphere of the wet season.

During the first day's ride we saw not a single wild animal, nor even a bird of any size, but in one district we saw many " machans" -platforms of poles erected in the fields, upon which the owners sit to scare away the deer and wild pigs which come to feed upon the growing crops.

In the same compartment of the railway carriage as myself were three old Hindoo merchants, gray-bearded, dignified, and respectable, who evidently were natives of the better sort. Breakfast time came, we were still many hot and dusty miles from a refreshment station, and from the depths of some of their bundles, the old gentlemen, who had evidently travelled before, evolved a supply of cooled food. It consisted simply of a large bowl of "dal," like stiff peasoup, and a pile of "chapatties," small, leathery, unleavened pancakes, made of flour. With my usual indifference as to the wants of my inner man, I had neglected to provide myself with a luncheon to fall back upon, and while I was busily thinking of the nice warm breakfast I should have in two or three hours more, one of the old native gentlemen suddenly thrust his fingers into the bowl of cooked "dal" (they had no spoons, forks, or knives), scooped up a good, generous handful, plastered it over a little pile of "chapatties," and, with a benevolent beam over his spectacles, handed it to me. I was completely taken aback for an instant, for the old gentleman's hands were as grimy as my own, but I accepted the food with my politest bow and ate it down with every appearance of gratitude. I would have eaten it had it been ten times as dirty as it undoubtedly was. It was an act as friendly as any man could perform, and I was pleased to find such a feeling of pure charity and benevolence in a native.

About noon we stopped at Khundwa for breakfast. There was a clean and commodious wash-room, a table well filled with choice eatables, ice-water in abundance, and plenty of time. What a comfort a sharp appetite is upon such an occasion!

Nearly every station upon the line of the G. I. P. Railway has its beds of flowers, and vines running up its walls, and occasionally a switch-tender has trained flowering vines over his little house until it has become a perfect bower, fit for a fairy queen.

As we approach the Ganges the plain becomes green and fertile and dotted over with trees and villages. There are ponds and pools of water along the railway, in which herons, storks, and ibises are 
cautiously wading, and the earth no longer has that dry and parched appearance observed from Bombay to near Jubbulpore. After riding through two cold nights and one hot and dusty day, the morning of the second day finds us crossing the great iron viar duct over the Jumna into Allahabad. This is a grand structure, 2,870 feet long, with the bottoms of its piers sixty feet below the bottom of the river. English, every inch of it, or, in other words, built to stand forever.

Allahabad, the "city of God," also called by the irreverent, "Fakirabad," or " city of beggars," stands at the confluence of the Ganges and the Jumna, both of which rivers rise in the Himalayas in the same latitude and flow southeastward, almost parallel to each other, to their point of meeting here. The gavial, or Gangetic crocodile (Gaviaiis Gangeticus), inhabits both these rivers and their tributaries, and my task was to find where they were most plentiful and grew to the largest size. Professor Ward had tried in vain to buy skins and skeletons of this crocodile, had made most tempting offers to Indian naturalists without success, and at last decided that I should go to the Ganges, spend about six weeks time, and get about twenty-five specimens. At last, after a journey of 10,500 miles, nearly half-way round the world, I found myself in the gavial region, and ready to begin collecting in earnest. Sight-seeing was at an end, and what remained was hard work.

Upon presenting my letter to Mr. Ross, I was fortunate enough to meet Major Ross also, who had come down from Etaivah for a few days, both of whom received me with the utmost cordiality, and we three sat down directly to a council of war in reference to my movements. It was decided that the Jumna was a better river for gavials than the Ganges, and that I should try in the former above the city. If that venture failed me, i.e., if $I$ found no large gavials, which was all I asked, then I should pack up and go on to Etawah, a civil and military station 206 miles up the Jumna, near which Major Ross had for some time been engaged in surveying upon the Ganges Canal and its branches.

When a naturalist goes hunting for any particular and important animal, he is quite in the hands of those who undertake to give him reliable information. A long series of disappointments growing out of exaggerated information, has taught me how to gauge the value of a friend's advice as accurately as a hydrometer marks the strength of aicohol. The universal tendency of people in the game districts of both North and South America is to exaggerate 
fearfully. One man told me, "If you go to New River, you will get any quantity of birds, a whole boat-load of birds' heggs, and 'gators (alligators) by the million!" I went, and found a great many alligators, that was all. In Trinidad, a wealthy and respectable English merchant soberly informed me that "at Punta Piedra, twenty miles above Bolivar, in the Orinoco, you will find manatee in millions, sir ; get all you want in one day!" "Lord, how this world is given to lying" about wild animals. As a rule, game grows plentiful directly as the distance from it increases, and vice versa. A collector in search of a certain animal must be guided by the information that is given him, and it was a blessed relief to find a man who gave as careful estimates and opinions as Major Ross. I felt from the first that he never exaggerated or overestimated in the least, that his information was always strictly accurate, and there was an abundance of it. He informed me that large gavials were numerous immediately below Etawah, that ravine deer were plentiful in the ravines, and black buck upon the uplands, and that, if I shot reasonably well, I could probably kill every day one or two specimens of either species I chose to follow up.

Keeping this fine prospect in reserve, I engaged a small boat and three boatmen, laid in a stock of provisions, and the next morning we were off. Starting from the railway bridge, the boatmen poled our little craft along the shore, which was crowded with natives, in the water and out, busily bathing or washing their clothes-a whole mile of bathers. Cleanliness, or rather, bathing, is the only feature of a Hindoo's religion which is not objectionable. It makes an excellent plank in any religious platform, especially in a hot climate, and I have often wished that the negroes of the West Indies, who have enough of religion and to spare, had made the bathing obligation an article in their creed. Just think what a grand thing it would be for white folks if a Barbadoes or Demerara negro's religion could beguile him into washing himself once a day.

We passed a number of clumsy river boats moored to the shore, and one man in the water, who was neither washing himself nor his clothes. He was dead. He floated there upon the water, naked, bloated, and hideous, with only a few patches of his brown Hindoo epidermis remaining upon his body, which was otherwise perfectly white. Men and women were bathing within ten yards of this disgusting object, perfectly indifferent, and one man was actually fishing within two yards of it. I asked one of the boatmen : 
"Is this water good to drink?"

He replied :

"Yes, sir ; see, the people drink it," and he pointed to a woman who was filling an earthen jar. Perched upon the edge of the high bank was a huge vulture (Otogyps calvus), with his eyes fixed upon the corpse in the water, but the bathers were so near it he did not venture farther just then. When I first saw the bird from below, I decided to have him for a specimen, but when I found what he had been feeding upon, and was waiting to feed upon again, I concluded my collection would be complete without him.

After getting clear of the bathers and the boats, two long and light grass lines were made fast to the top of our stumpy little mast, and two of the boatmen went ahead along the bank, towing us canal-boat fashion, while the third man steered. The boat was short, but broad, heavy, and clumsy, and could not be rowed against a strong current. It had. a roomy deck, with a thatch roof over it, and was altogether a very comfortable little craft. As the men slowly towed the boat along, we cooked, ate, skinned birds, and loaded cartridges under the awning, while the boatmen kept a sharp lookout ahead for any thing which needed to be shot.

This little trip was full of interest and enjoyment, but so far as gavials were concerned it was a failure. We went five days' journey up the river, found no gavials at all, save very small ones, not worth the trouble of shooting, and when the natives told us there were no gavials "two miles farther up," we knew the case was hopeless. We collected a number of large birds, however, among which were specimens of the black vulture (Otogyps calvus), brown vulture (Gyps Bengalensis), the sea eagle (Halioetus albicilla), the black-backed goose (Sarkidiornis melanonotus), bar-headed goose (Anser Indicus), the Casarca rutila, and several fine specimens of the curious Indian skimmer (Rhynchops albicollis). At our farthest point, where the river is full of huge boulders, I shot an otter that was resting upon the top of a large rock out in the stream. The animal rolled off the rock into the water, was quickly borne away by the swift current, and before we could get near it had sunk out of sight. By digging rifle-pits in the sand, and lying in them until I was almost roasted, I managed to kill two small gavials; but it was unprofitable work, and after having given the place a fair trial, we returned to Allahabad.

Leaving all our specimens and a portion of our heavy luggage at the hotel, we lost no time in starting for Etawah. It is the rule 
in India to make all railway journeys in the night, if possible, to avoid the oppressive heat of the day. Leaving Allahabad at 11 P.м., we rolled up in our double blanket and slept comfortably until we reached Cawnpore, at 5 A.M.

As we neared our destination, we watched the landscape with greedy interest, and the prospect was perfectly satisfactory. The country was a dead level, dry and baked hard, covered with fields of wheat, barley, and dal, with here and there thorny acacias, and little mud villages nestling in clumps of green and shady mango or banyan trees. We saw eight pairs of saras cranes stalking majestically over the open fields, large numbers of ibises, small cranes, herons, and plovers wading in the pools of water along the railway, and a small fox (Vulpes Bengalensis), standing a hundred yards away, looking at the rushing train with a stare of curiosity.

At half-past eight we reached Etawah, an insignificant civil station, with a population of twenty-seven thousand natives (a town of that size is nothing in India), and eight Europeans, the headquarters of the Lower Ganges Canal Department, containing, besides a dak bungalow, a church, school, jail, and a court presided over by a single assistant magistrate, who is the sole representative of English power that is allotted to this host of natives. Major Ross and his wife were then twenty miles east of Etawah, tenting and surveying the line of a new irrigation canal, so I took up quarters at the dak bungalow, until I could get a boat ready upon the river.

The dak bungalow is a government institution, common through out India and Ceylon, which is simply indispensable to the very existence of European travellers. In Southern India it is called a traveller's bungalow, and in Ceylon it becomes a rest house, but its plans and purposes are just the same. A traveller in India cannot start out boldly across the country as we do in America, travel until nightfall, and then demand shelter, food, and fire for a consideration at any farm-house or settler's cabin he may happen upon. Ninety-nine out of a hundred Indian natives would see a white man perish by the roadside before they would take him into any of their houses, even for a night, simply because he has no caste, and therefore is not quite so good as a dog. The traveller across country, in India, must reach a dak bungalow or camp in the open fields, for only the largest cities have hotels.

The dak bungalow is a house built and kept in repair by the Government, usually containing two suites of rooms-dining, bed, 
and bath-room-furnished with floor matting, plain but substantial chairs and tables, and a bedstead upon which the traveller spreads his bed, for every one in India carries with him his thick cotton rizai, or comforter, blankets, and pillow. Attached to every dak bungalow upon the important lines of travel, is a cook-house, a complete set of table furniture, and an old gray-bearded Mohammedan, who has charge of the whole establishment, and who will supply the traveller with meals, if required. Each traveller pays one rupee per day for occupying the bungalow, and "the old man" will supply the provender by private contract at from two to three rupees per day. The rule is that any European traveller is entitled to shelter in the dak bungalow for at least twenty-four hours, and if no other traveller demands his place, he is at liberty to remain three days. The Etawah bungalow is clean, airy, and cool, standing in a thick grove of mangos, a perfect haven of rest for a dusty, heated, and hungry wayfarer.

I had barely finished bathing and breakfasting, when Mr. Fraser, the assistant magistrate, dropped in to help me get acquainted with the place and to offer whatever assistance I might require. In the afternoon $I$ went over to his bungalow, where we sat on the verandah and shot small birds in the trees near by, until the midday heat was over, when we took a rifle and started down to the Jumna prospecting. The river is two miles from the European cantonment, but a fine metalled road winds down from the level plateau into the ravines, and through them to the bridge of boats. Near the river I had a snap shot at a jackal, but missed him. Just opposite the point where we first reached the river bank were two saras cranes, stalking along the river margin, at the farther side of a sand-bar one hundred and fifty yards in width. Mr. Fraser knelt down in the wheat and knocked one of them over very neatly, with a bullet through its breast. It proved to be the male bird and a very fine specimen. Farther up we saw three large gavials lying on a sand-bar in the middle of the river, but could not succeed in getting a shot at them. Above the bridge of boats we found a five-foot gavial lying upon another sand-bar, which Mr. Fraser shot through the shoulders and killed instantly. This made two valuable specimens for the first day, which was enough to bring good luck. A party of native boys carried the crane and the gavial up to the dak bungalow, and I skinned them both the next morning.

I saw that I had found good collecting ground at last, and lost 
not a moment in getting ready for a long cruise on the river. Boats were exceedingly scarce, and but for my friends I should have had serious trouble in hiring a suitable craft. Major Ross very kindly relieved me of all trouble on that score by obtaining for my use, as long as I should want it, and free of charge, a large boat belonging to a wealthy old native gentleman, Mumtaz Ali Khan, who had the government contract for the bridges of boats in that district. It was a very large and unwieldly craft, flat-bottomed and square-ended, sloping far up from the water, 35 feet long, 12 wide, and 2 deep, a perfect model of the old-fashioned ferry-boats to be seen upon many of our Western rivers. We built a deck across amidships, and erected an awning of grass thatch over a portion of this to protect us from the rays of the sun, for there was not a drop of rain to fear. Our craft was provided with a mast, a sail, lines to tow it, poles to push it, oars to row it, and five able-bodied men to work all these appliances. We tried hard to hire a small and light row-boat to take along, but without success, for there was not one available on the river. Should I go there again to collect, I would take with me a small boat of some kind.

Two days after we reached Etawah (March 13th), our boat was ready. We loaded our traps into a buffalo cart and drove through the bazaar to lay in a stock of provisions sufficient for three weeks. We bought rice, bread, flour, sugar, onions, butter, and ghee, in the purchase of which last an amusing incident occurred.

The sun was pouring down upon us at high noon and I became very thirsty. Carlo bought a clean new chattie, an earthen pot, worth about one cent, and when we came to a well where people were drawing water he had it filled for me. I took a long draught and handed the chattie back to Carlo, who threw the water out, wiped it dry, and, going to a ghee-seller close by, asked to have it filled with that immortal stuff. Ghee is clarified butter, and is used in India instead of lard, ordinary butter, and other animal fats. To our amazement the ghee-seller flatly refused to sell us any, for the reason, as Carlo explained, that the gentle Hindoo had seen me put the chattie to my mouth, which defiled it to such an extent that he could not take it into his hands. I was strongly tempted to knock his ghee-pots about his ears, take thirty rupees worth of satisfaction out of his royal highness, and then go up to court and pay my fine. But Carlo was equal to the occasion; he raised his voice to its regular commanding pitch, bullied the man of caste, and threatened him with arrest, until he gave in and pro- 
ceeded to sell us the ghee. But he would not touch that chattie with his hands! Not he. He handled it with two sticks as though it were the dead carcass of some foul animal ; and all because I drank water from it once.

After three hours' work in the crowded, hot, and dusty bazaar, we drove down to where the boat lay at the bathing ghaut, the boatmen quickly carried our cargo aboard, and with a feeling of profound relief we let go our moorings and drifted down the stream. 


\section{CHAPTER IV.}

\section{GAVIAL SHOOTING ON THE JUMNA.}

Afloat on the Jumna. - Character of the River. - Difficulties of Crocodile Shooting.-The Fatal Spot.-Prospects.-The Fun Begins.-Defeat through Poor Shooting and Native Timidity.-An Harangue.-Swimming after a Wounded Gavial. - Death of " Number One." - Another still Larger. - - How to Skeletonize a Gavial._Mode of Skinning Described.-Birds of Prey.Crowds of Spectators. - Gavial Eggs.-A Model Crew.-Plucky, Encounter with a Wounded Gavial.-A Struggle at Close Quarters.-Our Plan of Operations.-A Good Rifle.-Killing Gavials at Long Range.

As we floated down the river, I began to realize that the task which lay before me, to be accomplished regardless of circumstances, was no light one. The Jumna is a very crooked, muddy, swift, and deep river, full of treacherous eddies and under-currents, but fortunately only about two hundred yards in average width at that season. Usually the banks are low and covered with fields of wheat and grain, to which every foot of fertile land is devoted, but in many places the stream is hemmed in by perpendicular cliffs of hard clay, behind which are barren and rugged ravines. At each bend in the river there was a wide sand-bar, often many acres in extent.

Previous experience had taught me the uselessness of shooting crocodiles in the water, for a dead crocodile or alligator sinks to the bottom like a stone, and is lost in a moment. If the water is still, your victim will be found floating belly up at the end of two days, but the skin will be a total loss, for the scales will slip off in spite of all that can be done. In rivers that are swift, deep, and very muddy, like the Jumna at that season, it is simply impossible to shoot crocodiles and get them unless they are lying out upon the banks. Even then they must be hit hard in a vital spot, and either killed stone-dead upon the instant, or stunned so effectually that they will not be able to recover and crawl into the water before the hunter or an attendant has time to rush forward and 
seize them by the tail. When a crocodile leaves the water to take his daily sun-bath upon the bank, he does not go rambling about over the country, to be suddenly set upon and killed by almost any one before he has time to reach the water. Far from it. He cautiously lays himself down to sleep within a yard of the water's edge, head toward the stream, ready to plunge forward out of sight at the slightest alarm. He usually sleeps with one eye open, too, and however fast asleep he may appear to be, you have only to show yourself within easy rifle shot, and adios! he is off to the bottom of the river.

I have found by a long series of experiments, that the only sure way to stop a large crocodile or alligator is to shoot him in the neck or at the shoulders, so as to strike the vertebral column. It is easy enough to kill small specimens by shooting them in the head, but a crocodile with the top of its head blown off is useless either for its skin or skeleton, while one shot through the heart or lungs will get into the water much faster than one not shot at all. The brain of a twelve-foot gavial is so small that it would hardly fill an eggcup, and it is surrounded by such a huge mass of solid bone that it offers no mark at all to fire at. The sides of the neck and the shoulders, however, are wholly unprotected by bony plates, and when a bullet strikes the vertebral column, the whole nervous system receives such a terrible shock that the animal is instantly paralyzed, at least for a time, and rendered powerless to move a single yard. When the spinal column is struck by a bullet, the crocodile's jaws fly wide open, as if the bullet had touched a spring, the legs draw up and quiver convulsively, and the reptile lies still for further treatment.

I soon found that if we captured any gavials, I should have to shoot them at long range and do much better shooting than I had ever done before. At first I feared that my little rifle and I had undertaken more than we could accomplish under so many disadvantages. The river was very swift owing to the recent freshets in the lower Himalayas, and our boat was so much like an old clumsy raft that shooting from it was simply out of the question. The cover along the banks was so pitifully thin, and the sand-banks were so wide I saw I should often have to shoot across the river, or else just as far across the sand-banks, in order to kill a gavial at all.

Just below Etawah we stopped at a wide sand-bar and I spent some time in firing at targets from one hundred to three hundred yards, until I got the peep-sight of my Maynard rifle graduated 
very carefully. I also spent some time in learning to estimate distances accurately, which now became a matter of the first importance.

The next day the fun began. As we rounded a bend in the river, we saw far down the stream seven gavials, large and small, lying at the lower end of a long, narrow sand-bar, which joined the shore by a narrow strip at the upper end. We brought the boat to the shore and moored it, then made a detour into the wheat field to aroid being seen by our game. Just at the upper end of the sand-bar I posted Carlo and three of the boatmen, telling them that when I fired they were to run down the peninsula, seize by the tail the 'ghariyal' I would shoot, and prevent it from getting into the water. I told them that if they could catch the tail and hang on, the reptile could not bite them and I would soon come up and finish it. They promised to obey, but I saw they were nervous, and I had my doubts as to the result. I went down through the wheat field, keeping well out of sight until I arrived opposite the largest gavial, and then crept softly up to the top of the bank. The largest gavial was about ten feet in length, lying at the water's edge broadside on, a beautiful specimen. Aiming to hit the vertebral column I fired at the neck, but the gavial plunged into the river and I gave it up for lost. I signalled the men to stay where they were, and waited for the gavials to come out again. And then happened the strangest thing I ever saw in crocodile hunting. The large gavial I fired at suddenly appeared at the top of the water and actually rushed out upon the bank. He clanked his bony jaws together and flung his head from side to side as if in great agony. When he reached the bank I fired a second time, and again he took to the water, but soon appeared with his head held high up, snapping and struggling as though in the agonies of death. He pushed up into the shallow water and groaned three or four times, like a strong man in distress. It was the first time I ever heard such a pure vocal tone from a crocodile. I fired a third shot, which seemed to strike the right spot, for the gavial's jaws flew open and it lay quite still. The men now came running down, but before they reached the scene of action the crocodile began to slowly drag itself into the shallow water. They arrived in ample time to stop it, but they stood in a shrinking group within three feet of the huge reptile's tail, cowering back and afraid to touch it. As the gavial slowly crept away I shouted to the men to encourage them, offering a reward of two rupees if they would stop it, and I fairly stormed 
at them as the animal reached the water. Twice they plucked up the courage to take hold of the long, scaly tail, but as it gave a slight twitch they dropped it. I fired another shot, but my rifle seemed quite bewitched, and that splendid reptile crawled slowly away before my eyes, in spite of all I could do or say. One man could easily have stopped it, but I did not care to swim across the strip of water that lay between the end of the sand-bar and the bank. As the gavial reached deeper water it turned belly up, kicked its legs feebly in the air, and slowly drifted down to where no one dared follow. The water was so murky we could not see an object three inches below the surface.

And so we lost that fine ten-foot gavial. I was disgusted with myself for my miserably poor shooting, and vexed with the men for their timidity, which lost the game. In a few words I shamed them for their cowardice, and pointed out how the reptile was too nearly dead to bite any one. I told them that if any one of them should ever be bitten by a gavial, I would send him to the hospital and pay him double wages until he should get well, and that if any one should be drowned while trying to catch one for me, I would give his widow a hundred rupees. This harangue had a wonderful effect upon them.

The next morning we all began to do better work. We found a large gavial lying upon an isolated sand-bar out almost in the middle of the river, and from the top of the bank I put a bullet into its back-bone just at the shoulders. Its jaws flew wide open and its legs drew up, but otherwise it lay perfectly still. To my great surprise three of the boatmen immediately sprang into the water and started to swim across to the sand-bar. There was no telling how many gavials lay right under them, but I quickly made up my mind I could risk it as well as they, and taking only my hunting knife in my belt, swam after them.

The gavial was powerless to move, but as we approached, it snapped viciously from side to side in a manner which warned us to be careful. We immediately seized it by the tail, and reaching from behind I stabbed it to the heart with my hunting-knife, which soon ended its struggles. This specimen measured exactly eleven feet. The boat was brought down, and we hauled aboard the carcass of "Number One."

We had still better luck that day. A mile below our first capture we found seven fine gavials lying at the edge of a broad sand-bank, which extended along the shore. I posted the men 
as near as it was prudent to go, then crept along the bank through a field of dal, until I arrived opposite the group. The distance was only about ninety yards, for a wonder, and my first shot stopped the largest reptile. In a moment the men rushed across the sand and seized him. He kicked and struggled and snapped vigorously, but the men held him fast until I ran down and broke his neck with another bullet, which killed him instantly. This one measured eleven feet eight inches, and having two large specimens, we decided to stop and dissect them without delay. The boat was brought down to where our last victim lay, moored to the bank, and dragging our specimens out upon the level sandbar, Carlo and I rolled up our sleeves, sharpened our knives and began work.

We prepared the skeleton of the first gavial, an operation which was accomplished as follows: After having measured the animal, the skin was slit open along the under side, from the throat to the tip of the tail, and removed from the body in the most expeditious manner. The forelegs were detached from the body at the shoulders, the hind legs at the hips, and the flesh carefully cut off the bones of each leg and foot. The head was detached from the body at the first cervical vertebra and the tail cut off close up to the pelvis. Thus the animal was divided into seven parts. From each of these all the flesh was cut away piece by piece until only the bones remained, which were always left united by their ligaments. The vital organs were removed from the trunk, the flesh carefully cut from between the ribs, from the pelvis, from the vertebræ of the tail, and from the head. After the flesh had been carefully cut away so that only small fragments remained, each part of the entire skeleton was rubbed thoroughly with strong arsenical soap* to preserve all the remaining flesh and the ligaments from decay, and protect the bones from being attacked by rats and Dermestes. When the bones were thoroughly anointed, the skull, the tail, and the legs were carefully packed into the cavity of the thorax and the bundle tightly bound up with strong twine. In a few days the skeleton becomes perfectly dry and hard, is free from all bad odors, and can be packed without loss of space. Such is the character of a "rough skeleton." It is about five hours' work for one man who understands the process to prepare the skeleton of a ten-foot gavial in this manner. 
It is quite a task to skin a ten-foot saurian properly, and to pre. serve the skin so successfully that none of the scales will slip off when the time comes for the skin to be softened and stuffed. My method, which I have practised successfully with the skins of eleven species of crocodiles and alligators, is as follows: For the sake of science in general and the taxidermist in particular, measure the crocodile carefully and record the dimensions. Divide the skin along the under side, following the median line from the throat to the tip of the tail, in one long straight cut. Beginning at the end of each middle toe, divide the skin along the bottom of the foot and the under side of the leg up to the point where the leg joins the body, but no farther. Then begin at the edges of the first cut, and skin as far down the sides of the body as possible. When the legs are reached, detach them from the body at hip and shoulder without cutting the skin, and continue on around the body until the back-bone is reached and the skin entirely detached. Sever the head from the neck at the first cervical vertebra without cutting the skin. Skin out the tongue and remove the flesh from the palatal apertures and various cavities of the head. Skin each leg by turning the skin wrong side out until the toes are reached. Leave all the bones of each leg attached to each other and to the skin itself at the toes, but cut away the flesh carefully, the same as in skeletonizing. Remove from the skin as much as possible of the flesh which will be found adhering to it. When the skin is thoroughly clean, immerse it in a strong bath of salt and water and allow it to remain twenty-four to thirty hours. Then take it out, rub the inside and the leg-bones thoroughly with strong arsenical soap, after which apply powdered alum liberally over the inner surface, so that not a single spot is missed. Then hang the skin up by the head (no danger of stretching in this case), and allow it to dry in the wind and shade. When almost hard and stiff take it down and fold it up as carefully as if it were a Sunday coat, so that it can be packed in a box of ordinary dimensions.

When Carlo and I began our work upon the dead gavials, the birds of prey began to gather round us from all directions. Dozens of huge, ungainly vultures (Otogyps calvus), came and settled down upon the sand within twenty yards of us, looking on with greedy eyes. A little farther away a huge flock of crows kept up an incessant cawing as they watched their opportunity. A pair of white scavenger vultures (Neophron percnopterus), stood off some distance, while a score of hawks and kites swooped and circled above us. 


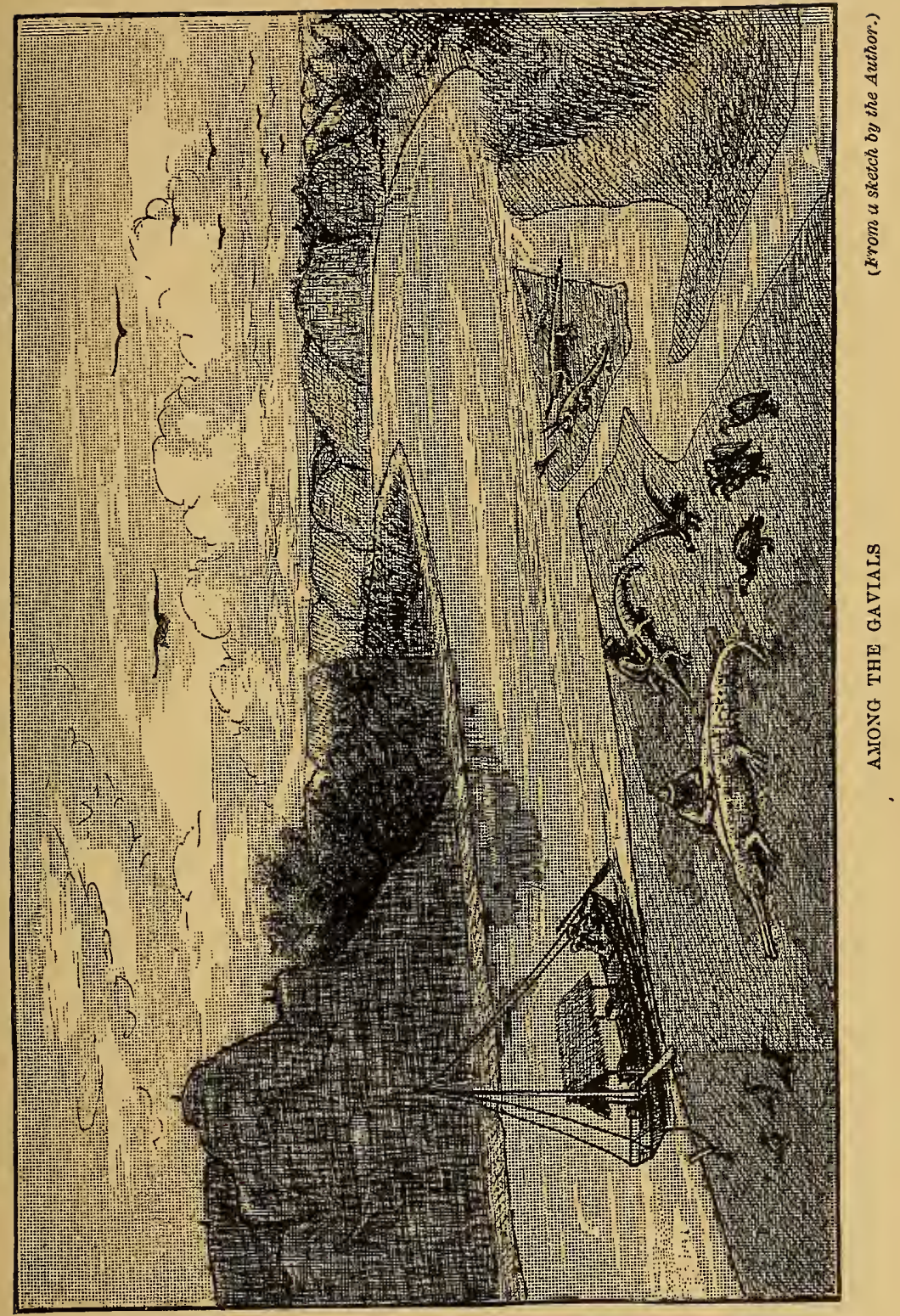



We had fine sport in feeding the birds. We threw large pieces of meat toward the vultures, upon which eight or ten of the foremost would rush forward, seize it with their beaks, and then such a tumult! Each one would try to swallow the meat before the others, and their huge, horny beaks actually clanked together as they struggled for the coveted flesh. Wings, legs, beaks, and talons were all brought into use, and such flopping, pulling, and hauling I never saw before. Once a large old vulture seized a long piece of meat and started off, swallowing as he ran. Half a dozen others immediately gave chase, overhauled him when the meat was three-fourths swallowed, and, fastening their beaks into the end which was exposed, they pulled and hauled at it until they yanked the precious morsel out of that poor vulture's throat and greedily devoured it themselves. I never saw a more disgusted looking bird, and he seemed utterly discouraged, too, for he gave his feathers a contemptuous shake and walked off by himself.

The crows would caw and peck at the meat thrown to them until a party of greedy vultures would gallop over and gobble up everything. We tossed small pieces of meat high up in the air, and every time a hawk would eome swooping down and clutch it with a "spat" in his talons. They never missed their aim nor allowed a piece of meat to descend to the earth again. Once a vulture started to fly away with a piece of meat in his beak, but a hawk was down upon him in an instant. They flew nearly a hundred yards, fighting in mid-air, and at last both fell upon the sand struggling fiercely and losing many feathers. The hawk whipped the vulture, but by the time he had accomplished it the vulture had stallowed the meat, leaving to his conqueror only the empty honor of victory.

While we were at work, dozens of natives came to watch us, and at one time there were about forty brown men and boys, naked except their loin cloths, sitting upon their heels in a close group near us, solemnly looking on. They talked very little and scarcely asked us a question, which was a blessed relief. They did not ask all about my private affairs, nor did they get up afterwards and mob us, as that crowd of Irish yahoos did at the south end of Loch Neagh when we were skeletonizing donkeys.

Both of our gavials were females. From the ovary of one we took forty-one eggs, and forty-four from the other, which were so fully developed that I blew them out successfully. In the stomach of one we found three half-digested fishes of very good size, in the 
other two, and four small, flat bits of broken earthen-ware. Even as we worked there, several gavials came out upon a sand-bank not more than a hundred and fifty yards below us.

From that time forward we followed up very systematically the plan of hunting we had inaugurated so successfully on the second day among the gavials. My boatmen proved to be capital fellows every way. They belonged to a hereditary boatman caste, and knew all about navigating the Jumna. They were, without exception, the best watermen I ever had, always willing to do precisely as they were asked, without any questioning or advice, and they never tried to thwart my plans, as most boatmen are prone to do. They were always ready to " go on," "go back," or "go across," without a word, and I believe they would have scuttled the old craft and sent her to the bottom if I had directed them to do so. They soon found that there was no great danger in seizing a wounded gavial by the tail, and by a judicious bestowal of praises and rewards I managed to infuse into them a real esprit de corps, which increased up to the last. In hunting gavials they ceased to be "gentle Hindoos," and became active, plucky men, as the following incident will show :

We came one day to an isolated sand-bar out in the middle of the river, near which there was absolutely no cover on either bank, only wide sand-banks. But this isolated bar was frequented by two or three large gavials, and in order to get a shot, $I \cdot d u g$ a riflepit and threw up a little embankment at the nearest point on the shore. The men were posted as near as possible, while I took up my position in the rifle pit and waited. It was about mid-day, just when the sun was hottest. Its rays beat fiercely down upon me as I lay there in the hot sand, and soon heated my rifle barrel so that I could not hold it unless I filled my hand with freshly dug sand. I wore a solar topee given me by Major Ross, of which the pith was a good inch in thickness, and which extended far down my back. Without its protection I would probably have received a sunstroke in less than an hour.

But, fortunately, we are not condemned to endure that baking process more thau an hour. At last we see a black line, with an eye at one end of it, lying upon the water out in the middle of the stream. The eye looks about for a moment, and the black line quietly sinks out of sight. Fifteen minutes later the same black line comes up close to the sand-bar, and we see that it is the upper surface of a gavial's head. The old fellow looks about a moment, 
gathers confidence, and allows his body to float up to the top of the water. His back and tail are now-visible, and we carefully estimate his length to within six inches. While we are thinking about it, he gives a gentle sweep sidewise with his tail, and floats forward till his snout touches the sand. Slowly and deliberately he puts his best foot forward, raises the end of his snout, and lazily slides up the sand until he is fairly out of the. water, then he slides slowly round to the left until he lies broadside to us. If he is a little suspicious, he turns until his head is toward the water again and only a yard from it. He does not stand up on his feet and walk; he simply slides along in the laziest possible way. As he settles down, he gives his tail a flirt to one side, draws his feet close up to his body, and is soon sound asleep, though in appearance only, and dreaming of young calves, big fish, and dead Hindoos.

Just as my intended victim cleared the water and showed me his side, my rifle spoke, and his jaws flew open. Instantly four of the boatmen rushed across the sand, jumped into the river, and started to swim to the sand-bar. The gavial saw them coming, mustered up his strength, and began to struggle toward the water. I fired at him again but missed the vital spot, and the gavial redoubled his efforts to reach the water. I shouted to the men and promised them four annas each (twelve cents, or two days' wages), if they stopped that "ghariyal." They struggled through the water faster than ever, but just as they touched bottom the gavial reached the water. As he slid out of sight I yelled to the men that I would give "eight annas!" They rushed across the sand-bar, and reached the further side just as the end of the gavial's tail disappeared, and I gave it up for lost. But they were not to be beaten so easily. Two men jumped into the water above their knees, made a grab for the gavial's tail, caught it and held on, and in a twinkling they dragged the huge reptile out of his native element and to the middle of the sand-bar. The gavial was now fairly recovered and thoroughly roused, and I never saw a crocodile try so viciously to bite his assailants. He was a large one too (measuring 11 feet 6 inches), and the men had a fierce struggle to hold him, and to keep from being bitten. I cheered them lustily, but could do no more, for my last cartridge had been expended. Fortunately, one of the men had carried over with him a rope, and another had taken a stout little bamboo, for just such an emergency. At last the rope was slipped round one of the gavial's hind legs and made fast to the bamboo, which was stuck in the sand, and the 
question was settled. As soon as possible the boat was brought down to ferry me across, and a pistol shot in the neck ended the troublesome reptile.

But for the almost perfect accuracy of my little Maynard rifle up to three hundred yards, my gavial hunt would have been almost a total failure, for in only two or three instances did I succeed in getting a shot at a less distance than one hundred yards. I loaded my cartridges with the most scrupulous care, kept my rifle thoroughly clean, and did my shooting as if I were firing at a target for a prize. It often happened that my only chance to kill a gavial was to fire across the river, from the high bank. to the opposite sandbar. Under such circumstances I would leave three men on the same side as the crocodile, and from my post on the opposite side direct them by various signals where to take up a position. Then at the signal they would sit down upon the hot sand and wait patiently, hours if necessary, for further developments. I would then take up my position, and with my field-glass carefully examine the position of the crocodiles, and decide upon the exact spot to fire at. After carefully estimating the distance, the direction of the wind, and the amount of "windage" to allow the bullet, I would adjust my peep-sight, lie flat upon the ground, and rest my rifle upon the leather-case of my field-glass, or the top of my solar topee. It was firing to hit a gray, horizontal line, the actual mark to be struck being smaller than a man's arm. A long, careful aim, a holding of the breath, a firm grip, a steady pull and a sharp "bang," would be the climax of perhaps two or three hours mancuvring in the scorching sun. If all the gavials upon the opposite shore skurried into the river and plunged out of sight in a twinkling, I made no further demonstration; but if the jaws of the largest one flew wide open, I would spring to my feet, wave my solar topee in a circle, and the men would jump up and rush across the sand-bar to our victim. On one occasion I killed a gavial, measuring 11 feet 6 inches, a large specimen, with my peep-sight elevated for 225 yards, and the largest one I secured during my hunt on the Jumna measured just 12 feet, and was killed at 200 yards, across the river. From first to last I killed eight gavials by firing across the river at long range and hitting their spinal column. Once I was so far from my game that when I fired and overshot the mark the gavials did not even take the water. I fired again, and undershot, and still they did not take alarm, but having now got the exact range, a third shot struck one of the gavials and cut.its spinal cord 
squarely in two. That was the best shooting I have ever done with a rifle, and it was a surprise even to myself. My success was due mainly to the admirable qualities of my Maynard rifle, which was always to be depended upon in time of greatest need.

The air was perfectly clear, for one thing, the light was usually good, and my nerves were reasonably steady. 


\section{CHAPTER V. \\ THE GANGETIC CROCODILE.}

A Jolly Life._Native Tenderness for the Gavial._Eating the Flesh.—The Jumna swarming with Gavials.-A "Mass Meeting."-Loss of an Enormous Specimen.-Maximum size Attained.-The Gavial's Place in Nature.Habits and Characters of the Species.-General Observations on the Crocodilians. - Number of Eggs Deposited.-The Gavial not a Man-eater.-A Ticklish Reptile.--Vocal Powers.

As I look back upon it through the rose-tinted vista of memory, it really seems that $I$ never in my life spent another month of such unalloyed happiness as that upon the Jumna. I was steadily gathering in a bountiful harvest of gavials, birds, and mammals ; I had glorious sport with both rifle and fowling-piece upon new and interesting animals, and my surroundings were strange, romantic, and agreeable. The weather was perfect. The nights were breezy and cool, so that we needed to wrap up in our blankets as we slept soundly under the awning of our boat, and there was not a single mosquito, gnat, or sand-fly to annoy us. The mornings were soft and balmy, the days were cloudless and hot, and there was not a drop of rain to fear. Although my boat was the clumsiest I ever had, it was also the most comfortable and convenient. Under the awning we had our boxes of provisions, preservatives, and tools, ammunition, clothes, etc., all conveniently arranged, while along one side hung the fire-arms, always loaded, and the indispensable field-glass ready at hand. Under one side of the awning we piled up gavial skeletons and skins, tied into compact bundles, and hung up rough skeletons of birds. Down in the forward part of the boat stood a large barrel of brine in which we soaked gavial skins, and beside it was the little mud fire-place, where Carlo did a very moderate amount of cooking for himself and me. He was fond of shooting, and nearly every day would take one of my shot-guns and wander off along the banks until he succeeded in shooting two 
or three doves or partridges for my dinner. I had roast dove or partridge on toast nearly every day, and we had no other meat during the trip than such as we shot. We killed geese, ducks, and peacocks, which made excellent roasts and curries, and once I shot a gazelle ("ravine deer"), upon a brushy sand-flat, the flesh of which was very acceptable to us all.

There was ample room on the deck of the boat for us to work at our specimens, and we skinned and skeletonized many a gavial and large bird as we floated quietly along. We could not hang our crocodile skins under any shade, and so we tried hanging them on the mast. By taking the skins down during the hottest part of the day we managed to dry them very successfully, and as soon as they were dry we folded them up. One day as we went floating down the river with an eleven foot gavial skin suspended by the head from the top of the mast, its legs held straight out by sticks, and the jaws gaping wide open to allow a free circulation of air, we saw some distance ahead of us three large gavials lying upon the bank. Just beyond them were some natives washing at the riverside. We began to lay our plans for making a kill, but suddenly two of the natives caught sight of us, and guessing our purpose from the emblem at the mast-head, they ran toward the gavials and drove them into the water. We shouted angrily at them, and by way of reply they threw stones at the gavials until their heads entirely disappeared under the water, and were thus beyond our reach. This was the only time $I$ ever saw the natives show any sympathy for the crocodiles. In some portions of India, however, crocodiles are held sacred, and it would be safer to shoot a native than one of those scaly reptiles. At Mugger Peer, eight miles from Kurrachee, there is a large tank full of huge and ugly muggers (Crocodilus bombifrons), which are regularly fed by priests and held sacred.

Twice while we were on the Jumna, low-caste natives came to us for the flesh of young gavials, which they declared they wanted to eat. I have eaten roast crocodile in South America, where they feed only upon fish, and the flesh was white, tender, free from all disagreeable musky odors, and toothsome as the nicest roast veal.

For about fifteen miles below Etawah the Jumna fairly swarms with gavials, many of which are of monstrous size. Unlike all the other saurians I ever hunted, they come out upon the sand-bars very early in the morning, and are to be found there at all hours 
of the day until almost sunset.* Individuals have their favorite haunts, and unless disturbed the same crocodile will return day after day to the same sand-bank, as I have plainly seen by observing those which were peculiarly marked. Several times I have seen gavials swimming leisurely up and down the river over the same course for an hour at a time, apparently enjoying a promenade. Generally we found them upon the shore in groups of four to sir, but of course many solitary individuals were seen. As a rule they were very shy, but several times after missing a certain animal of a group, I have seen it take to the water at the sound of the rifle, but almost immediately come out again, if we remained quietly hidden. As an instance of their great numbers, $I$ find it recorded in my note-book that in six hours we once counted twenty-four gavials lying upon the sand-banks. Once, while hidden behind a small bush at the base of a clay cliff, with my rifle and field-glass in my hand, I saw twelve gavials (not one of which was under ten feet in length) crawl slowly out of the water, one after another, upon a little isolated sand-bar which was no larger than a good-sized croquet-ground. Such a mass-meeting of saurians I never saw before nor since. But here let me caution the next hunter, or naturalist, who may visit this locality, that in a few years' time conditions may become so changed that not a dozen gavials will be found in that particular spot, where in March, 1877, they existed in scores. And furthermore, during the wet season when the river is high and wide, it may be almost impossible to find gavials upon the banks in such situations that they can be secured. $\dagger$

Although the largest of the twenty-six gavials I shot and secured measured only twelve feet, we saw three or four individuals which

* I attribute this to the coldness of the water, which is due to its snowy sources, and also to its swiftness and strong undercurreuts, which combine to render life beneath its surface not entirely agreeable to a lazy, heat loving animal.

† In order to give an idea of the seasons in which gavials may be successfully hunted on the Ganges and Jumna, the following facts concerning the rise and fall of the river may be useful. About May 1st, the snow water begins to swell the river. The volume of this gradually increases until June 15th, when most of the sand-banks are covered. From the latter date until October 1st, the river is frequently in high flood, shooting is practically impossible, and navigation is dangerous. After this the water falls steadily until January 1st, and from this date until May, there is a minimum of water in the river, except during slight freshets caused by light rains in the lower Himalayas. From April 15th to October 1st the heat is dangerous to European constitutions 
must have been from fifteen to eighteen feet in length, or even more. To my chagrin and disappointment I found after two or three trials that a single bullet from my little Maynard rifle (calibre .40, larger calibres are made now), had not weight and force enough to shatter the spinal-column of a seventeen-foot crocodile at one hundred and fifty yards. Had I possessed a heavy rifle of the same accuracy as my Maynard, we should have accounted for two or three of them at least.

Once I found an old monster, beside which a ten-foot gavial seemed entirely insignificant, sunning himself upon an isolated bar in the middle of the river. I offered my men a rupee each if we secured him, and fired at his neck. At the first shot his jaws flew open, he lay quite still, and my men instantly plunged into the river. I quickly reloaded and fired two more shots to make matters more sure, but in my eagerness and haste they must have missed the vital spot, for when the old monster saw my boatmen surging madly through the water straight toward him, he put forth all his strength, slid slowly down the sand into the river and disappeared. It was a bitter disappointment to us all, for we knew we should never see him again. Although during that trip we shot a number of gavials which must have died in the water, not one of them ever came to the surface afterward. One small one, however, did deliberately come out upon a bank and die there, the only instance of the kind I ever saw.

Pliny states that if turmeric be fired into a crocodile's body he will come out upon the sand to die, so Major Ross sent me his express rifle, and some turmeric, for me to make the experiment. I filled some explosive bullets with it instead of detonating powder and fired them at gavials, but none of them ever came out of the water after they had once got into it. I have heard of parties of mighty hunters shooting "one hundred and twenty-eight alligators a week in the St. Johns," and even of a hundred "shot" in a day; but be it remembered that these alligators were only shot at. There is a world of difference between shooting (at) a crocodile and securing it, and when your mighty hunter boasts of the great number he "shot," ask him how many he got.

In the museum at Allahabad is a fine skeleton of a male gavial which measures 17 feet in length as it stands. If we allow for the shortening of the skeleton which has undoubtedly taken place in mounting and drying, I think we may safely say that the animal when alive was 17 feet, 8 inches in length. In the Jardin 
des Plantes, Paris, there is a stuffed Gavialis Gangeticus, 20 feet, I inches long, but that animal when alive was apparently an exceptionally slender one. The largest specimen in the British Museum measures only 14 feet, 9 inches.

My chief disappointment at failing to secure one of the three monster gavials that we saw, was owing to the fact that these individuals were the only ones that possessed the strange bony knob at the end of the snout, which is peculiar to the largest specimens of this species. I particularly desired to examine it upon a living specimen, for the manner of its growth, and its uses, are as yet a puzzle to naturalists. It is the development of the inner edge of the premaxillary bones into a lofty double knob of smooth bone, nearly surrounding the external nostril. For my part, I believe it to be a purely sexual characteristic, possessed only by those males which have attained their full growth, and reached an advanced age. In my collection of twenty-six gavials, there were both males and females of various sizes up to twelve feet, not one of which showed the least sign of any unusual development of the premaxillaries. A skull which was kindly presented me by Mr. Palmer, of Etawah, and which according to my calculations, belonged to an animal thirteen feet in length, also showed no signs of the "boss" upon the snout.

The gavial, or "ghariyal" of the Hindoos (Gavialis Gangeticus, Geoff.), stands at the head of the order Sauria (Crocodilians), which includes the gavials of India and Borneo, the crocodiles of both the old world and the new, the alligators and caimans of America only. Grenerally speaking, the main points of difference between crocodiles and alligators are as follows: a crocodile (of any species) is distinguished by a triangular head, of which the snout is the apex, a narrow muzzle, and canine teeth in the lower jaw which pass freely upward in the notches in the side of the upper; whereas an alligator (also caiman or jacare) has a broad flat muzzle, and the canine teeth of the lower jaw fit into sockets in the under surface of the upper jaw.

The gavial has very slender and elongated jaws, with an expanded end, quite like the handle of a frying-pan, smooth and compact, set with twenty-seven teeth in each side of the upper jaw and twenty-five in the lower. The lower large front teeth pass upward entirely through two holes at the extremity of the snout, but all the remaining teeth are wholly free upon the sides, slanting well outward, and in young specimens they are so prominent and sharp that it is unpleasant to grasp the muzzle in the naked hand. 
From the gavial, which has the narrowest muzzle of all the crocodilians, all the known species of crocodiles, caimans, and jacares, can be arranged in a regular series according to the width of their muzzles, leading by regular gradations down to the alligator, which has the broadest muzzle of all, inasmuch as the sides are nearly parallel from the angle of the jaw to the canine teeth.

The Indian gavial inhabits all the large rivers of Northern India, the Ganges up to Hurdwar, nine hundred and eighty-three feet above the sea, the Jumna, Sárdáh, Indus, Brahmapootra and their tributaries, but does not occur anywhere in Southern India, nor Burmah. Another species of gavial, called by Dr. Gray, Tomistoma schlegellii, is found in Borneo, but nowhere else so far as we know at present. The mugger (Crocodilus bombifrons), inhabits all India from the foot of the Himalayas where the water is often frozen,* almost to Cape Comorin. I saw only one small specimen of this species in the Jumna, and as it lay upon a sand-bar close beside some gavials, the points of difference between the two were very striking. I observed it long and carefully with a powerful fieldglass, and fully satisfied myself as to its identity. The gavial looked smooth and yellow, whereas the little mugger had a very rugose appearance, and in color was of a dirty gray. When he left the water he deliberately walked out upon the sand, and when I finally fired at him he sprang up on his feet, and ran across the bar into the water, in doing which he more nearly resembled a huge iguana than a crocodile. I examined the spot directly afterward, and besides the tracks left by his feet there was only a broken mark where the tip of his tail had touched the sand as he ran. Out of perhaps four hundred and fifty to five hundred gavials, crocodiles, and alligators which I have watched getting from the land into the water, only four have stood up on their legs and run. This mugger was one, and another was a Mississippi alligator, which I afterward killed, and found to be in a very emaciated condition, owing to the fact that nearly half of its upper jaw had been bitten off, and it had apparently experienced great difficulty in capturing its prey.

Gavials are the smoothest of all the large crocodilians it has been my privilege to handle as living specimens, i.e., all the American species save one, and three in the East Indies. They are also the brightest in color. Lying upon the sand at a distance of two hundred yards, their bodies often seem to be of a uniform dull 
chrome yellow, but in reality the entire upper surface of the animal, from snout to tail, is of a uniform olive green, mottled with the former color. Of course the older individuals lose the original brightness of their coloring with advancing age. The under surfaces are all pale yellow, the iris is green frosted with black, while the pupil is a very narrow, perpendicular black line.

It would appear probable from the examination of some of our specimens, that the number of eggs deposited by a female gavial depends upon her size. One of our specimens, 9 feet in length, contained 15 eggs almost ready to be deposited, another measuring 10 feet contained 30 eggs, while two measuring between 11 and 12 feet contained 41 and 44 eggs respectively. As nearly as I could estimate, all these eggs would have been ready for the sand by about April 1st. As with the eggs of all saurians, these were subcylindrical, and pure white.

Evidently gavials are not man-eaters, or rather man-catchers, else they would certainly have carried off some of my boatmen. Upon many occasions they swam the river as fearlessly as though not a saurian existed in it, whereas they actually swarmed there. The natives who live along the river also assured me the ghariyals never caught men. The stomachs of all those I dissected contained only the remains of fishes, and I looked in vain for pieces of dead Hindoos. Still, it is not improbable that gavials devour the bodies of defunct natives who are thrown into the river after undergoing a mock cremation, such as I shall describe further on.

Although the skin of a large gavial is very thick, and the entire back is covered with bony plates nearly a quarter of an inch thick, it is still as sensitive to touch as the bottom of a man's foot. Often when watching gavials that lay apparently sound asleep upon the sand, I have seen them suddenly reach a leg backward or forward to kick off a fly that had alighted upon them. A 9-foot female which I captured was exceedingly ticklish upon the back and sides. Although my shot had broken her neck and she lay apparently dead, the lightest scratch with the finger-nail upon her sides or dorsal scales caused her to flinch and squirm violently. Even the tip of a crow's feather drawn lightly along between the rows of dorsal scales, or across the thin skin of the flanks was attended with the same result.

Wounded gavials often bawl aloud like calves, when seized by their captors, a thing $I$ have never known any other crocodiles to do. One of our largest specimens, a female 11 feet 6 inches long, 
made the most determined resistance of any, and bawled aloud more than a dozen times while struggling with her assailants. It has been asserted that crocodiles are voiceless, but this is certainly not the case with Gavialis Gangeticus. Nor is it true of the Orinoco crocodile (Crocodilus intermedius), as I know by a personal encounter with an old male nearly 12 feet in length, who turned upon me with a deep guttural snarl like a dog as I attempted to seize him by the tail. 


\section{CHAPTER VI.}

\section{ANIMAL LIFE ALONG THE JUMNA.}

Boating on the Jumna.-A Long Prayer.-The Saras Crane.-Queer Antics.The Jabiru. - Nests of the Scavenger Vulture.-Peacocks.-A Jungle, Cat Surprised.--The Jackals' Serenade.—Turtles. -The Gangetic Porpoise.Native Villages.-The People.-Female Ugliness._Friends and Foes.-A Native Funeral. - Cremation a mere Form.-An Adjutant Shot.-Goodbye to the River.

We worked on down the Jumna until we reached the mouth of the river Chumbul, which flows into it from the south. Here the banks began to grow muddy, and almost destitute of both gavials and birds, so we decided to work back up toward Etawah. Coming down the river is a very easy matter, for it is only necessary to steer the boats, but going up, the boatmen have to tow them against a current running from two to three miles per hour. We often mot large boats laden with wheat floating rapidly down, steered with long sweeps, like lumber rafts. Many others passed up the river empty, some of which required ten to twenty men to tow them. It was a strange sight to see one of those huge, clumsy crafts coming round a bend in the river with fifteen to twenty long, slender grass lines radiating from the top of the mast, like a beam of light falling far ahead upon a long line of nearly naked Hindoos toiling slowly along the bank.

One night we tied up to the shore near one of these grain-boats, and in the still small hours of the morning, we heard a Hindoo say his prayers. It was one of the boatmen, lying comfortably stretched out on the bags of the wheat, who was perhaps wakeful toward morning and took occasion to indulge in a season of prayer. Shortly after three o'clock we were awakened from a sound sleep by this boatman's singing out "Sita-Ram-a-Sita-Ram-aSita-Ram-a-Sita-Ram-a-Sita-Ram," which was kept up with slight variations until morning. There was a kind of sameness to this 
however, so at the end of about every fifteen minutes he would dash off into a variation of "Ram-Ram-Ram-Ram-Ram," which always afforded us quite a rest, prior to the next instalment of "SitaRam." Sleep was out of the question so long as that performance continued. I could not count the fellow's prayers, but I timed him and ciphered out the number in that way. He began to pray at twenty minutes past three o'clock and kept it up until ten minutes to five; and during that time he uttered the name of Rama and his consort at least once every second, which made sixty prayers to the minute, or altogether about five thousand four hundred prayers that morning before breakfast. All very well in its way; but after that we took care not to tie up near any other boat, lest another boatman should be taken with Sita-Ram in the middle of the night.

On the way up the river we devoted much of our time to collecting large birds, which frequented the river in greater variety and greater numbers than $I$ ever saw in any one locality.

Saras cranes fed in pairs in the fields, along the banks, or stalked majestically over the sand-bars in flocks of six to thirty. Excepting the large snow-white whooping crane of America (Grus Americanus) the saras crane (Grus antigone) is the largest and handsomest of the genus. The saras stands over four feet high, and is of a pale bluish color, except the head and nape, which are almost bare and of a dark crimson tinge. On the uplands they nearly always go in pairs, and although their cry sounds at first like the note of one bird, it is in reality a double cry made up of a low short note from the female, immediately taken up and improved upon by the male. The second cry always follows the first instantly, and it requires sharp watching for a stranger to detect the true manner in which it is made. It is, as a whole, very loud and clear, and would be noted musically about as follows :

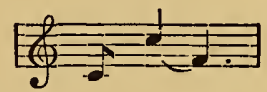

with the interval of the fifth much slurred.

These cranes sometimes cut some of the queerest antics ever indulged in by sober and dignified birds. Several times I have seen a whole flock indulge in a regular dance upon a level sandbank. While the birds are idly stepping about, one suddenly flaps his long wings several times in succession, another jumps straight into the air, and, with one accord, they throw off their dig- 
nity for the time being and the fun begins. Some stand still and flap their wings, others jump straight up and down-one jump after another-as high as they can go, often springing three feet from the ground; others run about, bowing and bobbing to each other, courtesying with half-opened wings, their breasts low down and tails high in the air, cutting the most ridiculous figures imaginable.

The saras, like most of the large cranes and herons, fights desperately when wounded, and is not to be approached with impunity. I once winged a large male bird, and when my boatmen ran forward to seize him he struck out so dangerously with his long, sharp bill and unwounded wing that he actually kept the men at bay, until I ran up from behind, seized him by the head, and quickly thrust a slender knife-blade through the occiput into the brain, which instantly ended the life of the noble bird. Usually I was obliged to shoot the saras at one hundred yards, with my rifle, but upon finding that they suffered the natives to approach them much nearer than me, I killed several with my. shot-gun by getting behind the boatmen as they went slowly forward along the bank in towing the boat. Once or twice we found the saras and the small common crane (Grus cinerea) flocking sociably together.

We saw two pairs of jabiru (Mycteria Australis), but they were exceedingly wary at this season, never alighting near the slightest cover of any kind, and never allowing me to approach within less than two hundred yards. One of these birds surprised us one day by deliberately sitting down upon his tarsi to take a rest. I tried to bring one down with the rifle, but failed. We found the black ibis (Geronticus papillosus), probing in the sand along the water's edge, also an occasional stork (Ciconia alba), and large egret (Herodias alba).

Birds of prey were abundant, among which was the white scavenger vulture (Neophron percnopterus). This bird happened to be nesting at that time (April 10th), and although Jerdon informs us it usually builds in trees, we here found its nests in the most inaccessible places it could possibly select. Invariably, indeed, we found its nest placed upon a narrow ledge against the side of a perpendicular bluff, usually just about midway from top to bottom, and not to be reached at all without the aid of a rope. As was the case with seizing the wounded gavial by the tail, my boatmen needed first to be shown how to reach a nest by means of a rope. 



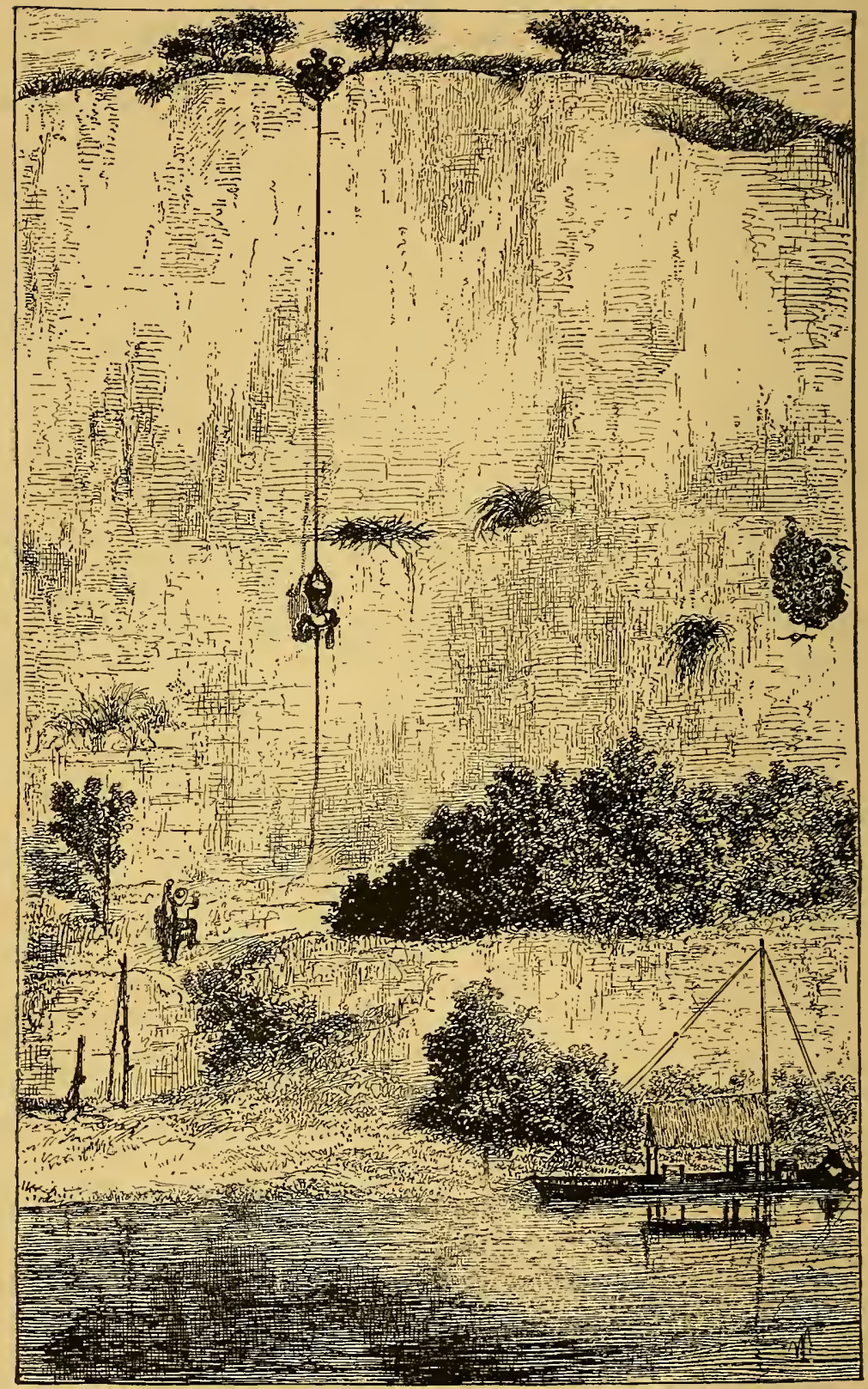

BIRD-NESTING ON THE JUMNA.

(From a sketch by the Author.) 
We found the first nest against the side of a cliff, about forty feet from the ground and thirty from the top, killed the old bird upon the nest, and then we wanted the eggs. As I expected, my men were each afraid to be let down from above, so I went myself. When I had put one leg through a loop tied firmly at the end of our strongest rope, four of my men lowered me over the top of the bank and slowly paid out the rope, until I reached the nest and stood safely on the narrow ledge, upon which it was built. It contained two eggs of a dirty gray color, minutely dotted over with dull brownish red. One of them measured 2.65 inches by 1.90.

The nest was a remarkable conglomeration of materials. The groundwork was an armful of twigs from the thorny acacia, some of great size considering the smallness of the bird, and upon this was laid a bunch of long, black Hindoo hair (cut from the head of some man going into mourning), a square foot of dried goat-skin, a human humerus, buffalo and goat's hair, cotton in small quantities, a dorsal plate, two metacarpal bones, and eight inches of caudal vertebræ from some of our gavials, the back of a sheep's skull, an assorted lot of rope fragments, and rags of every color and degree of dirtiness. No wonder the builder of such a nest is called the scavenger vulture.

The next time we found a nest, the boatmen let down the rope from the top of the cliff to the bottom, and one who was drawn from below up to the nest, put the eggs into the empty case belonging to my field-glass, and lowered them down safely. This stout leathern case made an excellent receptacle for bird's eggs when hung over the shoulders of a man hanging against the face of the cliff.

A few yards from the vulture's nest, stuck against the cliff like a huge honey-comb of mud, was a cluster of about thirty nests of the Indian cliff swallow (Lagenoplastes fluvicola). The proprietors of the place were at home, and in their breeding season. By the aid of the rope we soon reached the colony of retort-shaped, tubemouthed nests, and secured a goodly number of eggs. The number of eggs in a nest was usually three, although four were found together more than once, all pure white.

Wherever the deep and barren ravines came down to the river, peacocks were numerous, and we often heard their piercing cry of "pee-goo-ee" ringing from the tops of the barren ridges. Late in the evening they would appear upon the tops of the cliffs, poise upon the edge, and launching off one by one, fly across the river 
into the low wheat fields upon the opposite side to feed unmolested until morning. At sunrise they would fly back again and disappear in the ravines. We shot several for their skeletons and two splendid males for their skins, expecting trouble with the natives almost any day on this account, for the peacock is a sacred bird among the Hindoos. It is not worshipped as a god, but it serves as a throne for the god Rama, and is thus held sacred.

The peacock is a bone of contention between the English soldiers in the North-West Province and the Hindoos. The soldiers go out hunting and shoot peacocks, for which the natives attempt to mob them, and it is said that they seldom go out shooting without getting into a row and perhaps shooting a native. Carlo found where a flock of peacocks roosted in a large banyan tree, and killed several. At last the natives came down to us and humbly begged, as a personal favor to themselves, that we would not kill " any more of those poor fellows that never did anything bad, but only ate a little wheat;" and so we promised to desist.

One day we found a pair of rose-winged paroquets (Palceornis torquatus), which occupied a hole in a bank similar to the nest of a lingfisher. One bird came out of the burrow and alighted upon a small bush near the mouth beside its mate. We shot both of them for speicmens and then climbed up to look for eggs. The hole extended horizontally into the bank in nearly a straight line, two inches in diameter, and we thrust in a stout stick eight feet long without reaching the end. This was the longest stick we could procure, and we decided not to attempt to follow up the burrow by digging. Up to that time, I never heard of this bird burrowing in a bank like a king-fisher, for they almost invariably nest in holes in trees.

Besides twenty-eight important species of birds, we also found some small mammals along the banks of the Jumna. As I sat under the awning, skinning a saras crane while the boatmen towed us up stream, Carlo pointed out a small wild animal trotting along the opposite bank of the river. I could not make out what it was without the glass, but determined to take a shot at it for luck. Putting my peep-sight up to one hundred and seventy-five yards, I got down in the bottom of the boat, rested my rifle firmly upon the edge, and without stopping the boat, blazed away. To the astonishment of us all, especially myself, the little beast on the opposite side fell down, rolling over and over, kicking and growling furiously. A native on the other bank ran to seize it, and held it 
cautiously until we crossed over. It proved to be a jungle cat (Felis chaus). Height at shoulders 14 inches, length of head and body 26 inches, tail 9 inches.

Jackals (Canis aureus), were numerous in the ravines along the river, and some of the night concerts with which they favored us were highly entertaining, to say the least. Twice in particular, I remember that as the sun went down, and darkness closed in rapidly, the jackals all around us broke out into a perfect concert of agonized yelping and yaw-yawing, so ludicrous that we all laughed outright. The cry of a jackal is an abominable chopped-up yell, half howl, half bark.

Upon opening my eyes one morning I saw a saucy and inquisitive jackal sitting coolly upon the top of the bank, looking down into our boat, apparently studying the internal economy of our old floating slaughter-house. As I reached for my rifle he gracefully retired, and I stole quickly but quietly up the bank. Reaching the top I failed to see him, and sat down to pull various thorns out of the bottoms of my feet. While thus engaged I espied a dark gray object across a little ravine, sitting quietly upon a little mound, watching me with the greatest curiosity. It was my morning. caller. It was hardly light enough to see my sight, but I fired at him from where I sat. He fell down, but jumped up with a profane growl, remarking that that was a pretty way to treat a visitor, and disappeared in the ravines. An hour later one of my men found him lying dead under a bush, shot through the liver. Carlo watched one night near the carcass of a gavial, and killed another specimen with my No. 10 shotgun.

Two species of turtle, Batagur thurgii and Trionyx Gangeticus, were abundant in the river, especially the latter. Above Allahabad we saw this large, soft-shelled variety in great numbers, and of very large size, lying upon the sand at the water's edge, with their long; skinny necks stretched high in air. Below Etawah, also, we saw them frequently, and several times I tried to break their necks with a bullet, but without success. A good net would have been more useful than fire-arms. One day we were fortunate enough to find a large female Batagur thurgii out in the middle of a sand-bar, whither she had crawled to deposit her eggs. We cut off her retreat toward the water and she fell an easy prey. She weighed thirty-two pounds, and from her ovary we took twenty-five fully developed eggs.

There was another animal in the river which I desired above 
everything else, but of which I was unable to obtain a single speci. men. It was the Platanista Gangetica, or fresh-water porpoise, numerous in the Ganges, Jumna, Gogra, and Brahmapootra, but exceedingly rare in museums on account of the difficulty of capturing it. Professor Ward wished me to capture specimens, if it could possibly be accomplished during the time we had allotted to that region, but without a long net and a light boat it was impossible. Had I but known the situation, I would have brought a stout net a hundred and fifty feet long, and ropes and harpoons in plenty, by the aid of which we could have captured Platanista enough for all the great museums of America and Europe. As matters stand at present, the scientists of Calcutta vainly offer the fishermen of the Ganges £5 each for specimens. We saw dozens of them in the Jumna below Etawah, passing up and down, appearing at the surface every forty or fifty yards as they swam along, rising for a second only to instantly disappear. It would have been folly to fire at them, for after a long series of trials on the coast of Florida and in the Orinoco I am convinced that porpoise shooting is a delusion and a snare. No animal that I ever hunted has baffled me like the fresh-water porpoise (Inia) of the Orinoco, and the Platanista. With experienced Venezuelan fishermen to help me, I have tried time after time to harpoon and to shoot Inia, but without success. They do not stupidly play around the bows of one's boat as marine porpoises do, inviting harpoons into their vitals; they simply rise for a moment, now here, now yonder, anywhere except just where you expect them. When I go to the Jumna again I will take a net, stretch it across the river according to a certain plan, and then have my revenge.

Villages were numerous along the river, and, in the course of our bird-hunting, we had occasion to visit or pass through a number of them, usually to procure a drink of water. We were always received very civilly by the natives, and some one would be deputed to bring us a clean brass chattie full of fresh water.

But woe unto us had we had the ignorance or the audacity to put one of their vessels to our lips. It would have been worse defiled than if a hog had stuck his snout into it, and no matter whether the vessel were of cheap earthenware or brass of high value, it would have to have been broken in pieces, thrown into the river, or melted down. Ordinarily the Christian traveller bends down, puts both hands to his mouth so as to form a trough into which the water is poured from the chattie held aloft, and so the 
stream is conducted into the mouth. I always kept a clean compartment in my leather cartridge-bag which, when filled with water, served me as well as a drinking-cup.

The villages were built of mud and thatched with straw, the houses huddled closely together in a higgledy-piggledy way, windowless, often doorless, and with mother earth for a floor. At midday they are hot as ovens. How wretchedly filthy they must be during the rainy season, when all this dust is turned into liquid mud, and rain drips through every roof.

In one of these river villages, at the foot of a tree which seemed to be used as a shrine, I came suddenly upon a sculptured stone image which almost took my breath away. Like Mark Twain in the Jardin Mabille, I covered my face with my hands-but I looked between my fingers. It was about two feet long, very neatly sculptured, but the subject was the most obscene that could be imagined. And this emblem of purity (?) the villagers reverence, I suppose. Verily the Hindoos have queer tastes.

The native men were, as a rule, very good looking, and their features were as regular, symmetrical, and finely cut as those of Europeans. If they were white they would mako handsome Italians. Physically they are, as a rule, lean, lank, and poorly muscled, which is due to their living a life of perpetual hunger. No wonder they are naturally timid and cowardly, or that one vigorous, beef-eating white man can overawe a multitude. In civil life this is actually the case, for we behold 130,886 English men and women occupying the country and ruling 191,307,070 nativesonly one white person to every 1,461 natives, every one of whom would gladly see the English thrust out of India, but they do not clare say so. The natives have a saying that if every native in India would throw only a handful of dust upon the nearest Englishman, every one of them would be buried.

Whenever I chanced to meet a woman in any of those villages, she invariably pulled a corner of her mantle across her face and turned her head aside, as if she were ashamed for such ugliness to be seen. It was certainly very considerate of them, for they were almost as homely as buffaloes. Somehow it seemed that all the women were old, wrinkled, and skinny, and all the females who were not, were the little girls.

The natives were kind to us, after a fashion, in occasionally bringing us milk, for which they refused all pay. I would gladly believe they did this out of pure friendliness, but we must give 
the devil his due. Those who brought us milk were herdsmen, Brahmins who worship kine, and they believe that by making gifts of milk (with a deposit of black dirt at the bottom) to strangers, they will call down blessings upon their flocks and herds. Major Ross had so little faith in the dealings of the natives with a stranger unused to their ways and unsupported by any shadow of authority, that he sent one of his private peons to keep me company on the river, remarking that a brass plate with the Government stamp upon it often possessed great virtue in bringing surly natives to terms. He referred to the badge worn by all Government peons (messengers or guards), a brass plate engraved with the name of the department and worn upon the front of a colored sash. We were not long in finding out the virtues of the brass plate. I sent Carlo and Wazir, the peon, up to a village bazaar one day to buy some flour. They found where it was for sale and asked for a certain quantity, but with an earthen pot full of flour standing in plain view, the gentle Hindoo stoutly declared he had none to sell at any price. My men pointed to the flour and said they had just seen him sell some of it to a woman and take the money, but he sulkily refused to sell any to them. He had probably heard of my shooting peacocks and saras cranes (also sacred to the Hindoos), and he thought to have a little revenge. But the brass plate brought him around very soon. We always procured our drinking water from the village wells, and Wazir always accompanied the water jar to make sure of getting it filled. Once the villagers demanded pay for the water, a most unheard of proceeding, but the peon caused them to withdraw their claim almost as soon as it was made.

We noticed several human skulls bleaching upon the sand-bars in the river, and just below Etawah we witnessed a Hindoo funeral. The procession came filing along the bank, about twenty low-caste men, four of whom bore the corpse on a litter on their shoulders. They wore their ordinary business suits, simple waistcloths only, some carried straw, one carried an armful of wood, and all chanted a monotonous dirge. They reached a spot close to a ruined temple where the bank almost overhung the water, and the current was both deep and swift. There were bare, black spots upon the edge of the bank, as if the same ceremony for which they had come had often been performed there before.

A bed of straw was spread close to the edge of the bank and the corpse laid upon it. The body was wrapped from head to foot 
in a red cotton cloth. Then more straw was piled upon the body" and a very little wood upon that, after which one of the relatives touched a lighted match to the straw. The mourners sat down upon their heels in a group to windward of the pile, and chatted sociably while they watched it burn. The wind was strong and it burned fiercely for about three minutes, then very moderately for about ten more, by the end of which time the fuel was all consumed. Then the mourners arose, dipped water from the river and drowned out the fire; the corpse lay there almost intact, and we all saw that it was a woman. The limbs were drawn up and the face contorted, the hair was burned away, and the entire remains were black and hideous, yet only the skin and hair were burned. Presently one mourner put a stout stick under the neck, another put another stick under the hips, and at the word the carcass was tumbled over the edge of the bank and fell into the water with a loud splash. A few yards further down it reappeared at the surface for a moment; upon which one of the cremators reached out with his stick and pushed it under, after which we saw it no more. Not more than ten yards below that we saw the heads of two large gavials that floated at the surface, watching the proceedings with evident interest.

All the ashes and bits of wood were thrown into the river and the spot washed clean, after which the mourners took their departure. The Jumna never seemed so filthy and repulsive as at that moment, and I was glad I never drank from it.

That body-burning was a mere shallow pretence, and might just as well have been dispensed with, for all it amounted to in reality. But religion is religion, and the form, at least, must be carried out.*

In some portions of India, where fuel is exceedingly scarce and dear, the poorest of the low-caste natives fulfil the letter of their religion by simply putting a live coal upon the tongue of the corpse, and they call this "burning." After all, is not that as sensible and complete a "burning," as a few drops of water sprinkled upon one's head is a "baptism," or "burial" with Christ? To my mind one is no less absurd than the other.

Upon reaching Etawah again we stopped at the wide sand-bar opposite the bathing-ghaut, and while at work with our specimens,

* Natives who are sufficiently wealthy provide fuel enough to entirely consume the body, so that nothing remains after cremation except a few pieces of calcined bone. 
a fine adjutant (Leptoptilus argala) came winging his heary flight across the river and alighted upon the sand within a hundred and fifty yards of us. Standing upon that barren level he seemed of colossal size, and his legs were as white as if they had recently been white-washed. I had with me a boy named Jungi, whom Major Ross had sent to shoot birds for me, who was a very good shot. Knowing that the adjutant would never suffer me to approach him nearer than one hundred yards or so, I prepared to shoot him with my rifle, but Jungi asked me to leave the bird to him. He took his gun and walked deliberately across the sand, as if he would pass the adjutant within about fifty yards. The old bird saw a native coming, but did not dream of a trick, and stood still until Jungi reached the point nearest him, threw up his gun, and dropped him dead in his tracks. Upon skinning and dissecting this specimen we found an entire dog in its crop, a small animal of course, but still as large as a full-sized domestic cat, weighing perhaps five pounds. The lower mandibles of the adjutant are thin and springy, and evidently capable of spreading widely when necessary. No wonder these birds are such efficient scavengers, or that in Calcutta they are protected by law.

But at last we were done with the Jumna. In three weeks we had killed 26 gavials, for which we had to show 15 skins, 7 skeletons, and 4 skulls, besides many skins and rough skeletons of large birds. My experience on the river had been simply delightful, and I turned away from it with a feeling of sincere regret. 


\section{CHAPTER VII.}

\section{RAVINE DEER AND BLACK BUCK HUNTING.}

An Invitation. - Aspect of the Country. - Major Ross's Camp. -A Luxurious Establishment. -The Jumna Ravines. -The "Ravine Deer."-A Day's Sport. -Fifteen Gazelles and a Nil-Gai._The Sasin Antelope or "Black Buck." Animal Pests - Another Hunt with Major Ross.-Interesting Sport.-A Narrow Escape. - A Stern Chase at Mid-day.-Eight Antelopes Gathered in. -A Holiday at Agra. --The Taj Mehal, of course.-Taj-struck Travellers. The Trees of the North-West Provinces.

HAvING completed my work on the river, I received a very cordial invitation from Major and Mrs. Ross to visit them at their camp, thirty-five miles below Etawah, and spend a week in hunting the Indian gazelle, which quite abounded in the neighboring ravines. Accordingly, Carlo and I packed up my rifle and ammunition, a bag of powdered alum, a pot of arsenical soap, and a few tools, and went by rail down the line to Paphoond station. Spending the night in the road bungalow, we chartered an ekka (an antediluvian species of passenger cart) to take us to Major Ross's camp, twelve miles south. For two hours and a half we rattled along a splendid "metalled" (i. e., macadamized) road as fine in every way as any in Great Britain, so far as I have seen-another evidence of British rule in India. The milestones are marked in English and Hindustanee, which gives the natives to understand that the English have come to stay. The road is provided with good bridges, road bungalows and police stations, and is a type of the great arterial lines of road communication which have been constructed throughout India since the Mutiny in 1857. The GangesJumna Dooab, i.e., the country lying between these two waters, is also being rapidly traversed by a system of irrigation canals, which will render famine in this district forever impossible.

Mud villages were almost as thick as farm-houses in Iowa, and before long I found that it required good shooting to fire a rifle on the level without hitting a native. And no wonder. Compared 
with very many portions of India, Etawah is very thinly settled; but, upon an area of 1,631 square miles, of which quite twenty per cent. is unculturable ravines or reh-stricken plains, there are 1,591 villages and 668,581 people-nearly one village and quite 408 people to every square mile, fertile or barren. No wonder the fieids along the roadside were little garden-plots of one to two acres, or that there was no ground to spare for fences, and nothing to make them of. Each tiny field was bounded by a little ridge of earth, and fences, hedges, and ditches were alike unknown. The landscape was only redeemed from utter barrenness (for the winter crops had just been harvested), by the scattering mangos, acacias, and occasional banyan trees, which dotted the plain at long distances apart.

After two hours and a half of cramped limbs and aching backs, we alighted from our antiquated jaunting-car at Major Ross's camp. If the ride was cramped and shaky, it was also cheap, for the twelve miles cost us only one rupee.

Mrs. Ross led me at once to a mango tree near the tents, and pointed out a strange-looking animal which had taken refuge in it the night before, and been fairly "treed" ever since. A charge of shot soon brought it to the ground, and it proved to be a tree-cat

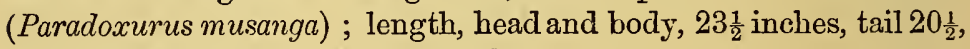
color, dark gray washed with black.

I was surprised at the elegance and completeness of my friend's camping establishment, which was simply luxurious as compared with all the camping-out I had ever seen before, and it was managed with military precision. There was a main wall-tent, large and roomy, with a double roof and verandah all around, and divided into an office, dining-room, and bath-room. Major and Mrs. Ross had a sleeping-tent, the khansama (cook) had a kitchen-tent, and there was another for me. Contrary to the ordinary rule of camp-hife there was an abundance of furniture, but it was all made to fold up and pack snugly away. There were five gharrys (bullock-carts) to transport the equipage, and three excellent saddle-horses for the "Sahib" and the "Memsahib." Counting cooks, sweepers, gunbearers, horse-keepers, and gharry-drivers, there were just twentyfour servants of various castes attached to the camp. The morning after my arrival, the camp was struck as soon as we had breakfasted, and moved off to a village nearer the ravines. Major and Mrs. Ross and I went shooting along the way, and when we reached Jeytpore, late in the evening, we found the tents pitched in a green grove of mango trees, the ground cleanly swept, the lamps lighted, and 
the table set with snowy linen and glistening silver. Fifteen minutes later we were discussing the various courses of soup, roast mutton, fowls, vegetables, and the finest dish of curry and rice I ate anywhere in the East Indies. The table was set out in the open air, under the stars, and it seemed that such a roving, out-door life as my friends led in the dry and pleasant winter months was simply a continuous picnic, more enjoyable than life in the best town-house that ever was built.

Mrs. Ross was the life of the camp, and her sparkling vivacity imparted to it a charm as refreshing as a mountain breeze. Under her energetic management the camp was always a model of neatness and comfort, and I was surprised to find that a lady in camp could be so great a blessing. Mrs. Ross rode, walked, and played lawn tennis daily with astonishing energy, considering the climate. She often accompanied us in our shorter hunting excursions, and we literally laid the spoils of the chase at her feet, proudly or otherwise, according to our luck.

Major Ross was my Encyclopædia Indica, and like the model British officer that he is, there was scarcely a subject that his information did not cover. A traveller meets a great many persons who are willing to answer his questions, and he soon learns to judge by the ring of the metal whether it is pure or not. The friendship of a man whose facts are always to be depended upon is something to be prized, and in this world of falsehoods and exaggeration it is like a glimpse of heaven to meet a man who never exaggerates. Such a man is Major Ross, and his brothers are like him.

The ravines that border the Jumna for half its entire length are very interesting from a geological point of view. Once these uplands extended in a high and fertile level plain quite down to the river, where they ended abruptly in a long continuous bluff. The water which fell upon this table-land along the river sought the lower level of the stream by pouring over the edge of the bluff, until first little gulleys and then deep ravines were cut down through the plain, and their beds became almost as low as the water in the river. The steep sides of these long ravines were in their turn furrowed and cut through by the little streasns which poured down them during the heavy rains of the wet season, and the fertile soil of the plain was washed into the ravines and swept away. Beneath this was a continuous stratum of hard, unweathered clay, which does not readily grow grass, etc., and thus collect regetable mould, and which has stubbornly resisted the 
disintegrating action of moisture; so that now, instead of the rich alluvial tracts of low " bottom-land," between the river and the uplands, which we would see had this clay been soft and friable, like that along the banks of our western rivers, we see the desolate "ravines." Between the fertile uplands and the river lies a broad belt of rugged and barren clay peaks, divided by ragged hollows, the tops of the highest just on a level with the uplands, and their steep sides sprinkled with a scraggy growth of low bushes which seem to put forth thorns instead of leaves. Here and there are miniature table-mountains forty to sixty feet high, their flat tops marking the level of the former plain. Every rainy season the ravines eat farther and farther into the fertile plain, and one field after another is abandoned as the mould and disintegrated soil is washed into the ravines, leaving only the hard and barren clay. Upon the top of one little table-mountain, half a mile from the present head of the ravines, we saw the ruins of a village that was once surrounded by fertile fields. A bird's-eye view of the Jumna ravines reveals a "gray and melancholy waste," apparently desolate and lifeless; yet these miniature mountains, this labyrinth of hills and hollows affords shelter for the gazelle, nil-gai, jackal, wolf, hare, wild-hog, panther, and even the leopard.

The Indian gazelle (Gazella Bennetti) is commonly called by Indian sportsmen the "ravine deer," because it is generally found in the dry and barren ravines along the Jumna, and in similar portions of Bundelkund, Rewah, the Central Provinces, and Gwalior. It is also found in the Punjab and Rajpootana, but does not occur south of the Godavery River.

This graceful little animal is of a pale, reddish-brown color, varying in the females, the entire under parts from chin to tail being white, while the tail itself is black. My largest buck measured 26 inches in height at shoulders, length of head and body, 3 feet 5 inches, tail 8 inches, and horns 13 inches. The horns of the male are almost perfectly straight, except that the points are tipped slightly forward, and are encircled with rings varying in number from eighteen to twenty-three, from the base to within two inches of the point. The horns never exceed $14 \frac{1}{3}$ inches in length, and only one pair out of a hundred exceeds 14.

Unlike all other autelopes, the female gazelle possesses horns, although they are short, very slender, and seldom systematically curved. They are usually 4 to 5 inches in length, sometimes 6 , but during my hunt with Major Ross I was fortunate enough to 
shoot an old female whose horns measured $8 \frac{1}{4}$ inches, the longest by two inches yet recorded. They were very slender, tapering gradually from the base to the tip.

Although the gazelle is rather dull in both hearing and smelling, as we proved many times, its sight is keen and restless, and it furnishes very interesting sport, especially if the little creatures are unusually wary and wild from previous acquaintance with firearms. They usually go in droves of five to eight, but we once encountered a splendid herd of thirty-seven gazelles and four sasin antelopes, feeding in a stubble field in the early morning. On that same ground two English sportsmen once made a famous "bag" at Christmas time, the net results of the day's shooting being two gazelles, one gazelle's ear, one horn, and one horse and his keeper peppered with bird-shot.

An account of our busiest day's sport in the ravines, and our best bag of specimens-for from first to last I took either skin or skeleton of every adult animal-will suffice to illustrate one phase of zoological collecting. The following is from my journal :

"Kiuntra, April 2d.-Major Ross awoke me at half-past three, and after a hasty toilet, two hard-boiled eggs and a cup of coffee, we mounted our horses and were off. Our rifles had gone on an hour before with Wazir and Jungi, the two horse-keepers, and men who went to carry the game home. As we cantered across the fields toward the ravines, daylight appeared in the east, and the cool morning air resounded on every side with the cooing of a hundred doves, blended into one continuous, trembling note rolling close along the earth.

"At the head of the ravines we planned out our respective courses and separated, so as to shoot over as much ground as possible, and also because we had found that a sportsman does better work alone when hunting 'small deer.' Wazir was to keep me company, and two game-carriers followed us at some distance. This was the place where we expected to find nil-gai (Portax pictus).

"We caught a glimpse of a fine wild boar crossing a little ridge as he was returning from his nightly raid upon the fields to his lair in the ravines, and tried to follow him up and get a shot, but failed to see him a second time. Walking down the level bed of a ravine we turned a corner suddenly, and came plump upon five gazelles walking leisurely toward us, when-whish! - there was a dash of tiny hoofs and the agile little creatures bounded out of sight like a flash. We bestirred ourselves to cut them off, but when we next saw them 
call a halt they were fully 300 yards away. I attempted to make a brilliant shot at that distance, aiming at a fine buck, but my bullet struck the bank about three inches above the top of his shoulders. Away they went again, and from a hill-top we marked their course until they disappeared entirely. Then we started for them, keeping well in the bottom of the ravines until we thought we were near them. Getting upon the top of a ridge we went cautiously forward, and very soon saw my identical buck climbing out of a ravine about ninety yards in advance of us. Feeling sure he would pause a moment at the top of the ridge to look for us, I dropped quietly upon one knee, and covered him with my rifle. Sure enough, as he reached the level he saw us and turned to look for a second or two, when my bullet struck him full in the chest and dropped him dead. It is the almost invariable habit of the gazelle, unless startled suddenly at close range, to stare at the hunter for two or three seconds before turning to run away, and that instant of rest is the hunter's time to fire. As soon as the buck fell, Wazir, who was a devout Mohammedan, ran forward with a knife and cut its throat, exclaiming 'Bismillah!' (in the name of God) while the animal was still alive, which rendered the flesh eligible for the cooking-pots of all true Moslems. This operation is called ' ballal karna,' and no Mohammedan can eat the flesh of any animal which has not been properly 'hallaled' before life became extinct, by some true follower of the Prophet. During our first two days' shooting, it somehow happened that not a single animal was 'ballaled,' and so, although the camp-followers had an abundance of fresh meat for which the souls of Mohammedans yearned and their mouths watered, not one of them touched a morsel.

"Shortly after the death of the buck, we saw a fine nil-gai or 'blue bull,' on the top of a little table-land nearly half a mile away, and we took a good look at him through the glass for fear we might never see him again. As he stood upon the summit of that high ground, his dark body sharply outlined against the sky, he seemed as large as our American moose, and he instantly reminded me of that long-legged and ungainly animal. Yet this great lumbering animal, perhaps four and a half feet high at the shoulders, with eight-inch horns and tail nearly two feet long, is an antelope, one of the largest of the antelope family.

"As the nil-gai disappeared in the ravines, I started across the succession of hills and hollows that lay between us, and in an incredibly short time reached the place where we last saw him. But 
the animal was not to be seen, and after a long search $f^{\prime}, \mathrm{r}$ him we had to give up beaten. It was utterly impossible to track him over that hard and barren clay. We heard two shots from Major Ross, and on looking in his direction saw two nil-gai climb out of the ravines and go galloping off across the uplands. They went at a heavy, lumbering pace, inore like the running of cows than antelopes. The Hindoos, with a total disregard for natural classification, assert that this animal is a 'cow' and not an antelope, and therefore a very sacred animal. They will not touch the nil-gai, but will eat all other antelopes.

" It had been our rule to return to camp about ten o'clock every morning, and rest quietly during the midday heat, which in the ravines was intense; but in the hope of finding nil-gai we pushed on and on in a wide circuit far into the ravines. While walking quietly down the bed of a ravine we espied two gazelles browsing upon the scanty leaves of an acacia. Both were does, and I fired at the nearest one. They wheeled and bounded out of sight, and upon running forward we found the grass bespattered with arterial blood which had gushed out from a mortal wound. We started at once on the bloody trail and soon found the doe lying gasping under a bush. (This was the female which possessed unusually long horns, mentioned in a former paragraph.) Within twenty minutes from the time we saw her browsing quietly under the acacia, her skin was hanging across Wazir's rifle and the vultures were tearing at her flesh. Then I turned my face toward camp. Passing through a village we rested, drank quantities of water and ate some roasted gram, which is about as good as parched corn. Within a mile of camp we met a horse coming for me, and a lively gallop soon brought me to the tents. Major Ross had shot a fine buck gazelle and a cow nil-gai, which were soon brought in upon a cart. The intense heat of the sun had quite roasted the skin on the side that was uppermost, so that its elasticity was gone forever. This animal was of an iron-gray color, without horns, and about the size of the female wapiti (Cervus Canadensis). After coming in from a hunt, we always took a bath the first thing and drained all the jars of drinking-water. 'Give us this day our daily bath,' is the universal cry in India.

" 'Tiffin ' over (two o'clock dinner), Carlo and I fell to work on our specimens, and before night the 'bag' received an addition of one saras crane, three spoonbills (Platalea leucorodia), and three black-backed geese (Sarcidiornis melanonotus), shot by my friends." 
The next day, in the evening, we rode to a bit of lowland between the ravines and the river. On the way we surprised a large wolf (Canis pallipes), making for the ravines with a black kid in his mouth. As bad luck would have it, we were both without our rifles, having sent them ahead with the bearers. We gave chase at once, but the wolf entered the ravines where we could not follow on horseback. These brutes are very destructive to small animals of all kinds, killing goats, sheep, and calves, and running down gazelle and antelope. The Indian Government pays a reward for the killing of wolves, and in 1876, five thousand nine hundred and seventy-six of these miserable brutes were destroyed.

On reaching our destination, we found several gazelles feeding out in the open plain with a scattered herd of cattle, and I brought down a buck at one hundred and thirty yards. Major Ross shot a hare (Lepus ruficaudatus) for me. It jumped out of a bush almost at our feet and went bounding off, when the Major made a brilliant shot with his rifle, striking the hare with an explosive express bullet which blew it all to pieces. The head lay in one place, the legs were scattered about in various directions, and the tail hung up in the top of a little bush like a signal of distress.

At the end of seven days' shooting we had accounted for fifteen gazelle and one nil-gai, not counting smaller specimens; and, sending my lot of skins and skeletons across country by bullockcart, I returned to Etawah by rail.

The sasin antelope, or "black buck" of sportsmen (Antelope bezoartica), is another animal which is found in great numbers in the Ganges-Jumna Dooab, as well as many other portions of India from the Punjab to Tutucorin, very nearly to Cape Comorin. In some districts they are found in immense herds of several thousand individuals, and, wherever they are, they do great damage to crops. It is the universal custom, or rather the necessity, of the natives who live in the game-infested districts, to build small elevated platforms of poles out in their fields, on which they patiently sit all night, beating tom-toms and shouting to keep away the deer and wild pigs. As a rule, the common people of India are not allowed to possess fire-arms of any description, or rather no one is allowed to supply them, and hence the country, notwithstanding the density of its population and the perpetual hunger of its people, is quite overrun with game, some kinds of which devour the crops of the agriculturists, while others prey upon domestic animals and the people themselves. The British 
Government does not, however, object to the employment of professional native hunters, or "shikarees," for thinning out the game, and all such persons are duly licensed by the magistrates.

The sasin antelope stands from 32 to 34 inches in shoulder height, length of body and head about 46 to 48 inches, and tail $6 \frac{1}{2}$ inches. The does and all the young bucks are of the same color, a pale yellowish fawn color above, with all the under parts white. As the bucks grow older they begin to acquire a dark streak from the knees straight up to the shoulder, which gradually extends backward along the sides and deepens in color with increasing age, until at last, when the animal has come to full majority, the vertical shoulder stripe is almost black and the sides of the body, neck, and head are of a rich dark brown. The female has no horns, and those of the young light-colored bucks are of course short and comparatively insignificant, but the old black buck is crowned by a royal pair, twenty to twenty-five inches long. They are black, spirally twisted in four or five turns, strongly ringed from the base up to the last curve, and diverge into a perfect $V$. The old male is, in every respect, a very handsome animal.

A few days after our gazelle hunt, my friends completed the survey of their canal and came to Etawah. Wishing now to obtain a specimen of the sasin antelope, Major Ross and I collected our forces once more and went to Shekoabad, a railway station thirtyfour miles above Etarvah. Here antelopes were very numerous within easy reach of the station, and, putting up at the dak bungalow, we sallied out morning and evening. An account of our first morning's work will serve to illustrate the character of blackbuck shooting and the habits of the animal.

Starting out at daybreak, we found a small herd within half a mile of the station, but it contained no good buck, and on firing at two hundred yards we each missed a doe and went on. The level plain is so thickly dotted with villages that we saw we could only fire with extreme caution. Fortunately the crops had been gathered and the people were threshing, else we would scarcely have dared to shoot at all. The crops here are watered by irrigation, and every four or five acres has its well and a sloping embankment of earth beside it, thrown up so as to form an inclined plane, down which the bullocks are driven as they haul up the skins full of water. These wells are never covered or enclosed, and before the day was out I nearly came to grief in one of them.

We found a herd of about forty antelopes, including one fine old 
buck, feeding quietly near one of these wells, and we easily stalked it under cover of the embankment. As usual, Major Ross gave me the first shot, and scrambling up to the top of the embankment I made a brilliant miss at the old buck, distance one hundred and fifty yards. Major Ross fired and brought down a young buck, and the herd bolted. Instead of running directly from us, they swung round for nearly a quarter of a circle, in a straggling line, the old buck bringing up the rear as a sort of whipper-in; we paid our respects to him as he came by but missed, and the herd, now thoroughly alarmed, sprang away at race-horse speed. As they passed us, several old does bounded high in the air as though they were leaping over four-foot hurdles, and as they dashed off down the plain, we saw first one and then another spring high in the air, clear above the backs of the others, come down with stiffened legs, and be lost to view in the flying herd. It was an astonishing sight. This strange demonstration in the face of danger is peculiar to the antelope, and whenever observed it betokens thorough alarm, and is a sort of defiant adieu to the sportsman, with the information that he need not trouble himself to follow.

In watching the herd as it disappeared, I walked backward a few paces, reloading my rifle at the same time, until, happening to look down I saw that I was standing upon the brink of the open well. In the excitement of the moment I had forgotten its existence, and had I taken just one more backward step, I would have gone down head first about sixty feet. What an aggravating, ignominious, and disgusting death it would have been. Hindoo women often commit suicide by jumping into the village well.

About ten o'clock we found another herd of antelope, many of which were lying down for their midday siesta. There was no cover near them, so we had to trust to their unwariness. With our guns in readiness we walked slowly forward, apparently without noticing the animals, and made as though we would saunter past them at a distance of one hundred and forty yards. There was a beautiful buck in the herd, quietly lying down chewing his cud. He rose as we approached but stood quite still, and just as we reached the nearest point I slowly raised my rifle and fired at him. My solid bullet passed throngh the muscles of his fore-arm and he fell to his knees, but recovered himself as I ran forward, and staggered away. Major Ross fired at him without effect, and the herd dashed away, leaving the wounded buck to his fate. We followed him as fast as possible, but the farther he went, the farther he seemed able to go. $\mathrm{He}$ 
passed within fifty yards of some natives tramping out wheat with bullocks, and stopped in an adjoining field. Stealing up behind the nearest cover I fired at him again, when he started up and slowly trotted off. Major Ross halted under a banyan tree, for the sun was now beginning to tell upon us, but I kept on. Disgusted with my unusually poor shooting, I determined to follow that buck and bring him down by main strength if necessary. He trotted slowly along and I hurried after him to keep him in sight. The hot winds were blowing from the northwest, the heat was intense, and it was risking a sun-stroke to go on, for the buck kept leading directly from the station, now five miles away. At intervals he would stop, but he watched me constantly, and whenever I came within two hundred yards of him he would start on again. The perspiration poured off me like rain, and such exertion was beginning to tell upon my nerves.

After a time I stalked him successfully a third time and got a shot, but perspiration half blinded me, and my arms were so unsteady that I could scarcely hope to hit. However, I heard the bullet strike with a dull thud upon his hide, and on we went as before. I was determined to measure that buck's horns before turning back. About noon he halted again in an open field, evidently much distressed, and getting him in line with an acacia I made a very creditable stalk, wiped the perspiration out of my eyes, and fired again. This time the buck failed to run away. He stood still, began to gasp violently, staggered, fell over, and the chase was ended. One bullet had gone through his fore-arm, another through his sternum, a third through his withers, breaking one of the vertebral processes, and the last went through his liver. I had shot all around the vital parts. His horns measured twenty inches and he was in every way a beauty; but the manner of his death left me nothing to be proud of.

Jungi arrived in search of me while I was cutting out the entrails of the buck to lessen his weight, and two natives who came up to see the quarry, were easily persuaded to sling it under a pole and carry it to the station for a consideration. We were six miles from home, and it was noon; but the buck was dead, and what cared we if the plain was like the floor of an oven and the air like the breath of a furnace?

During my chase, Major Ross killed another buck almost as black as mine. Two hours later, a cold bath, dry clothes, and a good tiffin had set us completely to rights. During the two days we 
spent at Shekoabad, eight antelopes, four bucks, and four does were called upon to yield up their skins and skeletons. There is really very little sport in hunting the sasin antelope, because of the unwariness of the animal and the ease with which they are approached. Any one who is a moderately accurate rifle-shot at one hundred and fifty yards can usually kill from two to five in a day, and if the hunter is really bloodthirsty be may bring down a good many more than that, but as far as real sport is concerned, it is tame. There is no excellent sport without great labor on the part of some one.

Upon returning to Etawah, I packed up my collection and shipped it to Calcutta, then took a little holiday trip up to Agra to see the famous Taj Mehal. Ever since the days of Heber, travellers have lavished adjectives and similes upon this pretty tomb, some because they were sincere, and all the rest because it is the fashion to do so. In my opinion, no other structure in the world has been so greatly over-praised. I can only account for it by the infrequency of really fine and well-finished specimens of architecture in India. The abundance of mud-huts and characteristic Hindoo temples make this really beautiful structure seem to be the most ravishingly beautiful one on the face of the earth. Hence the incoherent ravings, and the constant strain upon the English language on account of the Taj. I do not believe half the travellers who have written about it were really sincere in such a superlative degree of admiration and rapture as they have expressed. It is like the ravings over the expression of the Sphinx-a face with the eyes, nose, and lips hammered into one unsightly blur, which looks as if some wild animal had been tearing it. Look at the photographs of it, if you cannot get the object itself.

What are the elements which make up this "dream in marble," this "psalm in stone," this "essence of architectural beauty," this Taj in fact? It has not size certainly, for its width covers only one hundred and fifty feet each way. Its dome is a huge marble "chattie" turned bottom uppermost, with bulging sides and contracted base, an exact model of the useful vessel the gentle Hindoo boils his rice in. The building is square, except that the corners are cut off, and the upper half of the walls are set with huge, empty niches, as though they were prepared for statues that were never put in place.

The minarets on the corners of the terrace are low, dumpy, and plain, and in shape and size are as much like some of the light-houses on our Atlantic sea-board as one billiard ball is like another. But the Taj (as well as the minarets) is built of white marble, which 
Las never been discolored by smoke and soot; and I suspect its very cleanliness, purity, and lack of Hindoo paint is what renders it so all-powerful that ninety-nine travellers out of a hundred fall down before it, Taj-struck, and the hundredth who survives is set down as a dull, soulless, and ignorant fault-finder, destitute of taste and appreciation. Would the Taj be esteemed so exquisitely beautiful and so perfect in plan if it were built of brick or limestone, instead of white marble? The inside of the structure is wonderfully pretty, with its lotuses and lilies of precious stones. The cost of the Taj is entirely satisfactory, and as a monument to Love it is immense; but to my mind there are many buildings more grand, graceful, and imposing than this, and hundreds which seem more sacred.

The North-West Provinces offer but a barren field for the botanist or entomologist, at least in the dry season. I did not see a single serpent or lizard, nor any insects worth mentioning during my stay there. As for the flora of the country I could tell practically nothing, for, owing to the total lack of rain during the winter and spring months, vegetation is only conspicuous by its scantiness.

The tree which figures most conspicuously on the plains of the Dooab is the mango (Hindoo, "aam," Mangifera Indica), whose thick and ample green top affords most grateful shade. These trees are grown from cuttings planted by the Hindoos, who never think of cutting down a tree of any kind, or even cutting off long branches, and refuse to learn pruning and forestry. They encourage the planting of these excellent shade-trees, and the land occupied by the mango-groves is exempt from taxation.

The thorny acacia, or "bubool" (Acacia Arabica), is the commonest tree in the North-West Provinces, but owing to the fact that the natives feed their goats on its leaves and seed-pods, and the natural scantiness of its foliage, this tree, which is a very small one, always has a stunted, bare, and scraggy appearance. This is the tree which furnishes the gum arabic of commerce. It grows in the driest districts, apparently in defiance of drought, and is common in the "jungles" of Northern India along with Butea frondosa, which possesses a gorgeous, though odorless, scarlet flower. We found it in bloom at Auraiya, on April 1st, its branches loaded with flowers.

The "neem" (Azadirachta Indica), is found here and there, a small tree of which every part seems to possess some valuable medicinal property. The bruised leaves are used in healing sores, 
swellings, and rheumatism, and also some diseases of the skin; the bark is sometimes used as a substitute for quinine, and also as a tonic; a dye is manufactured from the fruit, and the seeds are used as an insect poison; the root is used as a vermifuge, and a gum exudes from the bark. Its wood is very bitter and is never attacked by white ants.

Here and there are seen solitary trees of large size, most of which have been planted by past generations in certain sacred spots or near villages, so that the inhabitants can sit in their grateful shade and discuss parish matters. There are four large trees belonging to this class, which figure conspicuously in the landscapes of Northern India. They are the sacred fig-tree, or "peepul" (Ficus religiosa), the banyan, Hindoo "burgud" (Ficus Indica), the tamarind, "imli" (Tamarindus Indica), and the "goolur," which latter is used to bottom wells that have walls of masonry.

From Agra I started for Calcutta, and the Neilgherry Hills in Southern India, having spent eight very busy and profitable weeks in the North-West Provinces. 


\title{
CHAPTER VIII.
}

\author{
BENARES, CALCUTTA, AND MADRAS.
}

The Monkey Temple. - Sacred Animals. - The Fakir. - The Hindoos as Beast Worshippers. - A Beastial Religion. - From Benares to Calcutta. - The Hot Season.-_"Punkahs and Tatties."-Departure for Madras.-The Hoogly River.-Sailor Anatomists.-The Hoogly Channel.-Madras.-A Seaport without a Harbor.-Two Years of Drought. - A Famine-stricken City.-A Paternal Government.-The Madras Museum.-Another Language and another Servant.

On the way to Calcutta I stopped for a day at the holy city of Benares, the Hindoo Mecca and the headquarters of Brahminism. Crossing the Ganges by the bridge of boats, I soon found a baboo who spoke English and was willing to be my guide for a consideration. We drove to the Golden Temple, to the minarets, and to the bathing ghauts, and finally to the place I came particularly to see, the Doorga Khond, or Monkey Temple, situated just outside the native town. Along the road leading to the temple there were monkeys chasing each other up and down, sitting on the stone walls and climbing about in the trees, their numbers increasing until we reached the temple itself. So far as its architecture is concerned, this temple amounts to almost nothing. In the centre of a paved yard stands a small stone pagoda no larger than a sentry-box, in which is a stone image of a hideous black goddess (Doorga), hung with wreaths of marigolds, beside which a stuffed monkey would seem divinely beautiful. Surrounding this open yard is a high stone wall like the walls of a house, furnished all around with shelves and niches for the accommodation of the monkeys. Adjoining this enclosure is a fine tank; a wide-spreading banyan overshadows the place, and that is all there is of this divine monkey-house.

Buying half a gallon of gram from a priest at the entrance, we stepped within the enclosure, and then another priest who was with us cried out, "Ah! Ah! Ah!" Directly there was a grand rush 
through the doorways, over the walls, and from the top of the banyan, as about a hundred and fifty monkeys of all ages, sizes, and degrees of fatness came crowding around us to be fed. Some impudent rascals snatched handfuls of gram and scampered off, cramming it into their cheeks as they ran; some took the food timidly and with suspicion, but when we threw handfuls of it on the floor there ensued a vigorous game of "grab-and-snatch-it." So long as the gram held out we were the centre of attraction, and each pair of watchful brown eyes was fixed upon us. Some fat old fellows sat and gravely looked at us, others made wry faces, some winked, and some grinned from ear to ear. A few were quarrelsome, and there was continuous biting and squealing, while, after the feeding was over, others busied themselves in examining each other's heads for vermin, just as I remember seeing people do in the streets of Naples more than once.

What a fine lot of monkey skins and skeletons are here running to waste! Here are specimens with a vengeance, but one might better risk shooting a native than one of these sacred pets. These monkeys are very sacred, next to the Brahmin bull in fact, because they are descendants of Hunuman, the famous monkey-god of Southern India, "who aided Rama in the conquest of Ceylon by forming a bridge of rocks opposite Manaar. The figure of the monkey who thus greatly distinguished himself is often found in Hindoo temples in the guise of a man, with a black monkey-face and a long tail." *

The species which infests this temple is the grayish-brown, short-tailed Inuus rhesus, which has conspicuous red callosities and is the common monkey of all Northern India. In this region, one must know the temper of the natives pretty well before venturing to shoot a monkey, for although this charming animal is not worshipped, he is greatly reverenced in many districts, and to kill one would precipitate a row with the natives, the net results of which would be highly uncertain. Some Anglo-Indians have assured me that at Benares any one killing a monkey would be almost torn in pieces by the natives. But Benares is the headquarters of fanaticism.

In the bazaar we met a big Brahmin bull stalking along the narrow street, crowding the people right and left, and sticking his nose into one basket of grain after another as freely as if he owned 
the whole city. And is he not monarch of all he surveys? These brutes become so accustomed to servile reverence that they are bold and insolent, and whoever does not make way for them will very likely get trampled upon, if not knocked down. The most daring European never ventures to strike a Brahmin bull in this city, nor even to swear at him if the natives know it. Any Hindoo would rather kill ten Christians than one Brahmin bull, and it would no doubt be safer for a Christian to kill ten natives than one of these brutes, provided he escaped the British authorities.

This reminds me of another sacred animal, some specimens of which I saw in Allahabad, and here again in Benares. I refer to the fakirs. Allahabad was full of them. I shall never forget an apparition that I encountered suddenly one day in the bazaar of that city while Carlo and I were out on a shopping expedition. We were standing at a grain stall buying some rice, when there suddenly appeared at my elbow a man (in external form at least) entirely naked, except a very small and very dirty rag around his loins, and a staff in his hand. He was tall, lank, and bony, his beard was tangled, full of dirt, and came far down his hairy breast. His long, matted hair hung around his shoulders like a bundle of untwisted hemp ropes. His body was mangy and caked with dirt of a year's standing, apparently, his claws were long and dirty, and he was certainly the most disgusting object I ever saw in human form.

"Carlo," said I, "what kind of an animal is this?"

"That Hindoo holy-man, sir. He never wash he-self; all same one pig."

The fakir was going around collecting money of the shop-keepers. He said never a word to any of them, but walked around and held out a piece of cocoanut shell, into which the bazaar-men dropped their " pice" without a word. He went about it quite like a landlord collecting his rent. And this was one of the fakirs, those holy men (there are nearly ninety thousand of them, it is said) whose feet and garments are kissed by men and women, and who are, in popular estimation, saints !

The Hindoos are essentially beast-worshippers. They reverence the Brahmin bull, the monkey, peacock, crocodile, cobra and other serpents-and these are the least objectionable of all their gods. We can forgive them for worshipping all these, because they are cleanly and respectable animals ; but for their reverence of such degraded, filthy, naked, and unclean beasts as these fakirs, there is 
simply no excuse. Indeed, I believe the animals mentioned above are the only decent objects of worship the Hindoos recognize. A scaly old mugger is a worthy god in comparison with the most common object of worship in all India, the name of which is not to be written. Their gods and goddesses are bloodthirsty and cruel monsters, guilty of adultery and incest, and some of the rites by which they are worshipped are so obscene that they can never be recorded. If there is a religion in existence which is destitute of even one redeeming quality, Hindooism is the one. If there is one which is wholly "earthly, sensual, devilish," it is this. It is a religion of frauds, cruelties, and horrors.

Leaving the Holy (?) City at eleven o'clock in the morning, we rode all that day over the same hot, dusty, and seemingly barren plain which we have been crossing nearly ever since we left Bombay. By daylight the next morning the scene had changed, and the plain was dotted over with groves of palms. What a blessed relief from that wide, level, thirsty-looking expanse, without forest or thickets, hills or valleys, to relieve the eye or excite the interest. As we sped rapidly along, the green palm-groves gradually grew denser and thicker, and finally blended into one continuous jungle. This is the India we have been longing to see-thick jungle with shady lanes running through it, thatched huts nestling among the cocoanut groves, banana-trees reaching their broad green leaves over the garden fences, tanks with villages beside them, and tropical moisture and luxuriance. Presently we reached Howrah, the busy terminus of the railway and the Brooklyn of Calcutta, crossed the Hoogly on the fine, new pontoon bridge, one of the finest of its kind ever constructed, and were in Calcutta, the City of Palaces. "But where are the Palaces?" is the natural query of every traveller. It is a conundrum, and I give it up. The palace of the exling of Oudh is the only one I saw or heard of, and that is an hour's drive from the city.

As might be expected, the European quarter of Calcutta is perfectly satisfactory-fine Government buildings, wide and regular streets, a spacious esplanade called the Maidan, a pleasure garden, the Eden, and the customary statues in each. The Imperial Museum has just taken possession of a huge rectangular pile, built expressly for it, but its collections are by no means what a naturalist has a right to expect. In some departments the collection is even poor, some of the most important Asiatic forms being conspicuous only by their absence. The collection of East Indian Che- 
lonia is very complete and the specimens are beautifully prepared. I had expected to devote a week or more to studying the fishes and reptiles which I should find here, but the absence of classified specimens rendered it impossible.* I had, however, the pleasure of meeting Dr. Anderson, the eminent Director of the Museum.

In Calcutta I began to realize very keenly that the hot season had set in, and hastened my preparations to depart for Southern India. The thermometer steadily stood at $98^{\circ}$ to $100^{\circ}$ in the shade, and the nights were almost as hot as the days. There are different qualities of heat, just as there are different degrees. At home, we work out in the fields when the thermometer stands at $102^{\circ}$ in the shade, with only a thin straw hat for a head-covering, whereas if a white man should attempt anything of the kind here with the same temperature, he would soon be hors de combat. Here, every office is provided with its long swinging fans called "punkahs," which hang from the ceiling over the desks and are pulled vigorously to and fro all day long by coolies kept constantly employed for that purpose. Every dinner-table has its punkah, and nearly every European has one over his bed and a coolie crouched down outside his door, pulling steadily all night long, fanning the "Sahib" while he sleeps, or until the coolie himself falls asleep, and the Sahib goes into a nightmare and awakes drenched with perspiration and gasping for breath. Instead of storm-doors such as we have to keep out the piercing cold, here we see the very same idea followed out in an opposite way. The doors of many houses and English shops are provided with open screens of grass, or "cuscus," upon which water is constantly thrown by the coolies, so that the air in passing through them will be cooled and charged with moisture, and render life less of a burden to those within. These are the "tatties" so indispensable to the existence of Europeans in Northern India during the hot season, and especially during the prevalence of the dreaded "hot winds."

Having carefully packed up my collection, and shipped it aboard a ressel bound for New York, on the morning of May 6th I embarked on the French Messageries steamer Meinam, for Madras. The broad and deep Hoogly River forms the harbor of Calcutta, and below the pontoon bridge the sailing vessels are moored close together along the eastern shore by strong chain cables, while the steamers lie at the jetties which have been built here and there on

* It must be borne in mind that the above was written in $187 \%$. 
the same side, but farther down the stream. As we steamed slowly down the Hoogly and left the "City of Palaces" (sic) behind us, the palm-groves and cocoanut gardens gradually disappeared, until there remained only a low and flat alluvial plain, dotted here and there with patches of low jungle, straggling native huts, grain stacks, and herds of grazing cattle.

The delta is, of course, green and fertile, but we are entirely disappointed of the lofty trees and luxuriant tangle of vegetation which we have had indelibly pictured in our mind ever since we first heard of India. And yet, away over on our left lie the Sunderbunds, a vast labyrinth of channels, creeks, and bayous, and islands clad with low, scrubby jungle, that really does afford shelter for wild hogs, spotted deer, jackals, crocodiles, and an occasional tiger and rhinoceros. I had intended to make a hunting trip to this famous game district, but upon questioning those who had been there I found that I could not be certain of finding anything except wild pigs and deer, which was not a satisfactory prospect.

How rudely a little travel lays in ruins some of our most cherished ideas, impressions which have been honestly acquired, too. Here have we travelled over sixteen hundred miles in India, without seeing a tropical forest, or even a tropical landscape, until reaching the delta of the Ganges. Judging from the tales of certain travellers and sea-captains, I expected to see the Hoogly below Calcutta almost covered with the bodies of dead Hindoos, whereas we saw never a one. Neither were there any swarms of native craft. I was surprised at the scarcity of birds along the river, for we saw only half a dozen small egrets (Herodias egrettoides), feeding in a salt marsh, and two gulls ( $L$. rudibunda) flying overhead.

At sunset we anchored in the river at Diamond Harbor, for we were yet many miles from the mouth, and no vessel dares to navigate this treacherous river after nightfall. Even in the daytime it is difficult enough to steer clear of its shifting quicksands.

While we lay at anchor, some of the sailors (French) went fishing over the bows and caught a shark about four feet long. Directly it was landed upon the deck, they procured a lantern and a knife and went to work to dissect their specimen as scientifically as they knew how. For half an hour those big, rough fellows worked over that animal, studying its anatomy with as much interest as a party of savants. I wondered if American sailors would have felt as much interest in a common shark, and whether an American mate would not have ordered the men to "heave that overboard" for 
fear of soiling the deck. The first shark I ever caught was at Nassau, B. I., from the deck of the steamer City of New York, and while I was gone below for a knife, Captain Deakin ordered a sailor to "heave that overboard before he makes a mess of it." But Captain Deakin despised second-class passengers on principle, and never lost an opportunity to do them a mean turn; in which he was like nearly all the other American and English steamship officers I ever met.

The banks of the Hoogly sink by such a gentle gradient into the Bay of Bengal that the mouth of the river is really miles at sea - quite out of sight of land in fact-and the navigation of the river is both difficult and dangerous. A long, winding line of buoys marks the channel out to the light-ship and pilot-brig at the Sandheads, without which no large vessel could ever reach Calcutta, for the banks are of fine sand and the channel is constantly shifting. The Calcutta Pilot Service very judiciously consists of Englishmen, so that in the event of war no hostile fleet could by any human possibility find its way up to Calcutta. The Sandheads are visible only upon the captain's chart now, but in due course of time there will be villages and rice-fields where is now smooth water.

The fourth morning from Calcutta we reached Madras. From north to south stretched a low, sandy coast, fringed with white breakers, without a sign of bay, harbor, or sheltering river-mouth, or even a break in the surf. Ships anchor in the open sea, exposed to the full fury of the storms, and during the cyclones which frequently visit Madras, vessels are often swept upon the beach and dashed to pieces. Those that are able usually slip their cables and put to sea, preferring to brave the fury of the storm in deep water, with plenty of sea-room.

Until the construction of the long iron pier which extends out into the sea, far beyond the surf, all communication with the shore was carried on by means of the famous masulah boats common to the Coromandel coast, which are built for the express purpose of going through the breakers. They are very deep and wide in proportion to their length, built of a light, tough, and pliant Ceylon wood called "hallmillia" (Berrya amonilla), and the planks are sewed together instead of nailed, so that when a sea strikes the side of a boat the planks yield sufficiently to deaden the force of the shock. But the fault of the masulah boat is that it will go to pieces by the ripping of its seams just when it ought not. Scarcely a week goes by but the daily papers mention how "Masulah boat No. 
so-and-so, returning from such-a-ship laden with rice, went to pieces in the surf and the cargo was lost. The crew escaped by swimming."

Looking shoreward from the ship, we see a long row of squarebuilt, flat-roofed warehouses, stores, and banks extending along the shore within a stone's throw of the surf. To the south of this there is a tall light-house, a fort (St. George), and behind these a wide esplanade, beyond which the city spreads out indefinitely. There is nothing prominent about Madras, no lofty buildings looming up above the smaller one, no domes, nor church-spires, nor even a palm-tree.

In good weather there is not the least difficulty or danger in going through the surf, and a masulah boat soon landed us high and dry upon the sand. Perhaps Madras never appeared to worse advantage than it did then, in May, 1877. The second year of drought and famine had filled the city with an immense crowd of half-starved, and four-fifths naked wretches, men, women, and children, who fairly swarmed in every street and alleyway. The trees were almost leafless, the ground was baked and bare, and from morning till night the sultry air was full of blinding red dust which covered everything, even penetrating the closed sleeping-rooms and coating the furniture and bed-curtains. The city had taken on a dull, reddish-brown color, instead of its traditional yellow.

For half a mile the beach was covered with masulah boats, and bags of rice stacked up eight feet high, at which a swarm of coolies worked like a huge colony of black ants, unloading boats and carrying rice-bags up to the level of the street. The streets near the beach were crowded with carts, which, when laden with rice were dragged away to the railway station by coolies instead of bullocks.

Women and children with baskets followed the laden carts, and whenever a rice-bag sprung a leak and a little grain was spilled in the dust, the dirt was swept up and carried away to be sifted for the few grains of rice it contained. Emaciated beggars swarmed about the hotel doors, begging with the piteous pantomime of hunger, or with the long-drawn wail of "Sawme___e !" In the streets, boys ran along beside the open gharry, holding out their hands and crying "Sahib!" at every rod; and no matter where the carriage stopped, there was always a living skeleton at hand to rise up, pat its hollow stomach with one hand and hold out the other for alms.

At first I thought the Madrasees were four or five shades blacker than the natives of Northern India, but their seeming so was only 
because they were so very nude. At first so much semi-nudity was very repulsive, but one soon becomes accustomed to it. What a mercy it is that these poor famine-stricken wretches do not have to contend with cold as well as hunger, and that under this blazing sun no one can suffer much from lack of clothes.

No government ever tried harder to mitigate the horrors of famine than the administration of the so-called Benighted Presidency. In the distressed districts there were relief works, relief camps, and hospitals, without which the wretched natives would have died by thousands. The railways were taxed to the utmost of their resources to remove the grain from Madras to the famine districts fast enough to keep the people from absolute starvation. But for the railways, it is probable that three-fifths of the people in the Madras Presidency would have died. The natives look upon the British occupancy of their country as a punishment inflicted upon them by the gods for past misdeeds, and they believe that the expiation of their sins will in time be completed and the punishment removed. They had better pray for their gods to punish them some more in that way. Lucky it is for them that Englishmen have built roads and railways for them, and that in time of famine England still acknowledges every wretch of them as a British subject, to be fed and doctored at any cost.

The Madras Government Museum is an institution of which the "Benighted Presidency" may well be proud. It approaches my ideal of a museum for the people, and to judge from the crowds of natives which throng its galleries, the people appreciate it. The collection of stuffed fishes is the finest I have ever seen, not only as to the number of genera (local forms are best represented, of course), but also as to the beautiful manner in which the specimens have been prepared. Fortunately for the taxidermist, Mr. P. Anthony Pillay, he receives nearly all his specimens fresh from the ocean, and fortunately for them, he prepares them with remarkable skill. The collection of mammals peculiar to Southern India is very instructive, and that of invertebrates from the Indian Ocean even more so. The Herbarium contains an immense number of botanical specimens. During my visits to the Museum I frequently had the pleasure of meeting its director, Dr. Bidie, who kindly gave me much information and useful advice concerning my intended work in Southern India.

At Madras I encountered another native language (Tamil), and was of course obliged to have another servant to speak it for me. 
The custom with Europeans in India is to have three or four servants to do the work of one man, and had I followed the ordinary rule, I should have hired one man as a cook, another as "bearer," another as general assistant, and a fourth loafer to boss the other three. Instead of that I engaged a man whose caste could not possibly stand in the way of his doing any kind of work, who spoke English very tolerably, and was an impudent rascal. I told him I would require him to do the work of two ordinary servants, for which I would pay him double wages, the most satisfactory arrangement a traveller can make.

I had come to Madras to collect mammals of all sizes, and in order to escape the heat of the plains during the hottest months, and also to find good collecting ground at the same time, I decided to visit the Neilgherry Hills. Accordingly, three days after reaching Madras, I packed up and started by rail for the foot of the Hills, accompanied by my new servant Appoo, as great a fraud as I could have found in a month. 


\section{CHAPTER IX.}

THE NEILGHERRY HILLS.

The "Blue Mountains."-A Natural Eden.-Physical Aspect.-The Coonoor Pass. - Beauty and Grandeur. - Climbing up to Paradise.-Ootacamund.Products of the Hills. - The Worst Hotel in India.-A Hunt in the "Delectable Mountains."-Above the Clouds.-The Todas - A Remarkable People.-Their Negative Qualities._Phenomenal Laziness. - The "Paulaul" and the "Paulchi."-Physique of the Todas. -Dress.-Polyandry, or Plurality of Husbands. - Betrothal, Marriage, and Divorce. - Infanticide.

-The Toda Hut.-The Mund.-The Toda Buffalo.-Little Game but Splendid Scenery.-A Cloud scene.-An Empty Bag, but no Regrets.

A RIDE of three hundred miles in a southwesterly direction over a hot and dusty level plain almost as barren as a brick-yard, and in places of a brick-red color, brought us to Coimbatore, from whence a branch line leads up north twenty-five miles to the village of Mettapollium, near the foot of the Neilgherries. Between Mettapollium and the foot of the Hills, lies the Bhowani River and a level belt of luxuriant tropical forest six miles wide, a dense, shady jungle of bamboos, palms, ferns, and forest trees. Reaching the end of this delightful road, we leave the carriage and start to ride on horseback up the Coonoor Pass, while our light luggage is carried by coolies.*

The Neilgherry Hills (or "blue mountains"-all mountains are called "hills" in India) rise very abruptly from the low, level plain of Southern India, into a lofty, triangular table-land of an average height of about seven thousand feet above the level of the sea. Except on the north, where a narrow, elevated ridge joins it to the Western Ghauts and the table-land of Mysore, this lofty plateau is completely isolated-a green and smiling garden in a parched and thirsty plain. In general shape it is a right-angled triangle of which the base is to the north, facing Mysore ; the perpendicular extends from north to south and faces the Malabar Dis-

* There is now a mountain railway up to Coonoor. 
trict; the hypothenuse extends northeast and southwest, and the apex reaches down to Coimbatore and Palghaut.

The base of the Neilgherries is encircled by a wide belt of dense and unhealthful forest, which affords abundant cover for elephants, tigers, bears, hyænas, elk, and small deer, and has long been famous as a hunting ground for large game. The sides of the hills are either perpendicular granite cliffs of great height, or very steep wooded slopes scored by deep ravines and rocky gorges. Upon the summit we see a wide expanse of smooth, rolling hills and ridges, which rise up on the northeast and southwest into three separate ranges of lofty peaks, one of which, Dodabetta, eight thousand seven hundred and sixty feet high, is the second highest peak south of the Himalayas. Five other peaks exceed eight thousand feet in height, and the town of Ootacamund, in the centre of the plateau, is seven thousand three hundred feet above the level of the sea.*

There are no forests upon these hills, nor continuous jungle of any kind ; but here and there, upon wet hillsides or in moist hollows, are small patches of dense, leafy jungle, called "sholas," which afford cover for sambur deer, muntjac, foxes, jackals, porcupines, black monkeys, and even tigers.

The climate upon the Neilgherry range is truly delightful. Owing to its elevation, it strikes the happy medium between the extremes of heat and cold, and of drought and flood, so that here there is at all seasons the "ethereal mildness" of perpetual spring. Even during the great drought and consequent famine of 1876-77, which prevailed upon the plains, the clouds which rolled up from the southwest laden with moisture from the Indian Ocean, encountering the cool peaks of the Blue Mountains, were compelled to "drop down the dew." The average annual rainfall at Ootacamund is fifty-five inches, and even in 1876, the first year of the famine, there were seventy-six rainy days, and the total rainfall was 25.16 inches. The average annual temperature at the same place is 55.83 degrees. In 1876 , the mean temperature for July was sixtyone degrees. The air upon the Hills is pure, cool, and invigorating, and the nights are decidedly cold. Naturally enough, this is the sanitarium for Southern India, whither come enervated civil and military officers, soldiers, and civilians of all classes, from the

* The Neilgherries are composed almost wholly of porphyritic granite, cov ered by a deep layer of rich, black, and fertile soil. 
plains to spend the hot months and repair constitutional damagesmost of which may be traced to the curse of the East Indies"brandy-and-soda."

The Coonoor Pass winds up one side of a deep, rocky gorge which is furrowed straight down the steep mountain side from top to bottom, widening and deepening as it goes. On one hand the steep side of the ravine rises up beside us almost like a wall, while on the other it descends precipitously from the roadside far down to the bottom of the gorge where the Karteri River, a mountain torrent, goes dashing downward over its rocky bed. All the way up, the road is shaded by forest trees which everywhere cover that side of the ravine with a dense green mantle, and from time to time we cross cool and shady little glens of the most romantic description, where little mountain streams, whose moist banks are covered with exquisite ferns, go tumbling downward over gnarled roots and mossy stones.

Every now and then a turn in the road gives us a clear view across the gorge to where a lofty precipice looms up a thousand feet or more, and looking backward we see the hot plain we have just quitted stretching out far below us like a vast, unruffled sea of brown and green. The higher we ascend, the cooler becomes the air, and vegetation takes on a rank and luxuriant freshness which contrasts so strongly with the region we have just quitted, that we seem to have climbed up out of a fiery hell into a cool, shady, and well-watered paradise.

But every rose has its thorns. The "pony" I rode (which was furnished by the Madras Carrying Co. at an exorbitant price) was a wretched, half-starved, and wholly worn-out beast which it seemed a sin to ride. At every step it threatened to collapse, like the famous "One-Hoss Shay." It was the first time I ever bestrode a skeleton, and tried to make it walk. The experiment was not a success, for about every two rods my pony skeleton insisted upon stopping, and, at the end of the second mile, I dismounted and walked on, leaving my fiery, untamed steed standing in the middle of the road with his head down, a prey to his own gloomy thoughts.

Two miles farther up a "fresh (!) pony" awaited me. It was a slight improvement upon the first one, having been fed only a week previously; but the fault of this noble animal was that he wanted to stop, and would stop every few minutes, to look at the scenery. After three miles I abandoned him also as a derelict, and finished the ascent on foot. The pass is nine miles long, and at the top we 
reached the picturesque little village of Coonoor, at an elevation of five thousand nine hundred and fifty-four feet.

Twelve miles from Coonoor, in the centre of the Neilgherry plateau, is Ootacamund, the capital of the Hill district, the fashionable resort of Southern India, and the headquarters of all the sportsmen who visit the hills. It is the least like a town of any I ever saw or heard of, for it is so effectually scattered, over so many hills, that as a town it has no individuality whatever. But it is a highly pretentious one nevertheless, with its hotels, club, pack of hounds, shops, and an assortment of Government institutions. A network of fine metalled roads run around and over the hills, and a goodly number of pretty cottages and fine bungalows perch around on the hill-sides, each with its spacious "compound" of an acre or more laid out in shady, gravelled walks, and terraces of flowers.

As to climate and natural scenery, the Neilgherries surpass any mountain region I have ever seen, neither cold nor hot at any season, always green and fresh, and always either softly beautiful or precipitously grand. The soil is very rich, and produces the finest fruits and vegetables to be found in Southern India, among which are mangos, bananas (or plantains, as they are universally called here), mandarin oranges, pineapples, and even pears, although I am bound to say the last-named tasted more like raw turnips than pear's. The common vegetables are potatoes, cabbages, and cauliflowers of good size and quality, celery, onions, sweet potatoes, turnips, beets, carrots, radishes, peas, lettuce, etc. Tea and coffee are grown in vast quantities, tobacco is grown very successfully, and also large quantities of cinchona bark, from which the priceless quinine is manufactured.

The British Government knows how to do some very admirable things now and then out of pure charity. For instance, it owns and manages a vast cinchona plantation upon the hills, from which it manufactures quinine in great quantities, and while this great fever specific is selling in the extortionate English apothecary shops for from fifteen to twenty rupees per ounce, the poor fever-stricken native, or European either, for that matter, can go to the Government Court-House and procure it for one and a half rupee per ounce. What a boon is this to suffering humanity!

In our glorious republic, we have, until very recently, managed this matter rather differently. We have charged a snug little thirty per cent. import duty upon quinine, which prevented its importation and sale at a low price, and protected a single firm of chem- 


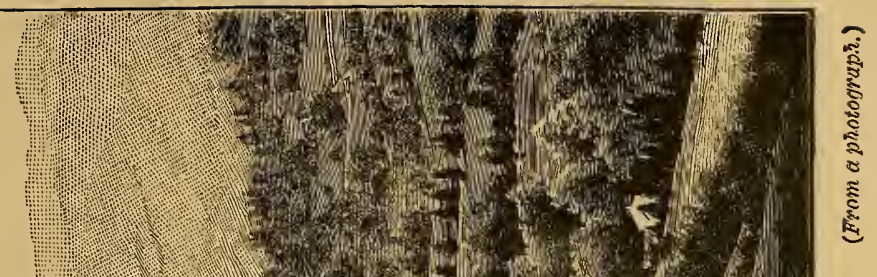

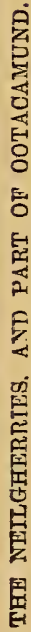

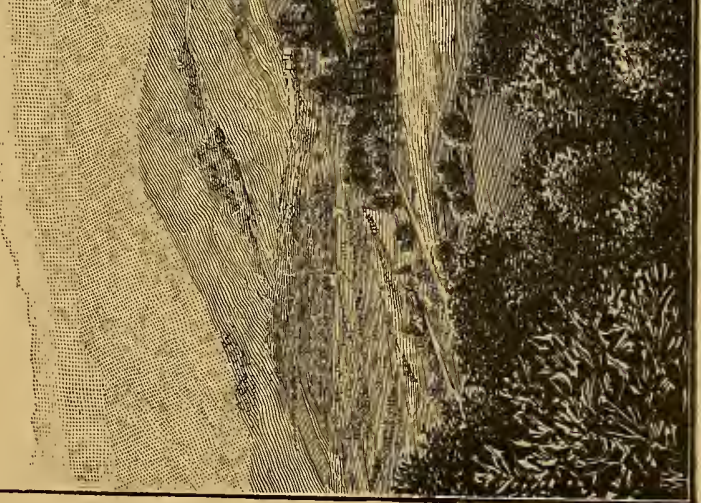



ists while it rolled up a princely fortune at the expense of the poor "fever-and-ager" victims in the back settlements and the Western river bottoms.

During my stay at Ootacamund (called Ooty, for short), I lived at Leigh's Alexandra Hotel, where, for four rupees a day, I had the poorest fare and the worst attendance I ever put up with in a hotel or boarding-house of any kind, or at any price. Although the fare was poor it had one redeeming feature-there was never very much of it, for mine hostess and her myrmidons seemed to be experimenting upon me to see how little a man could live upon. But it was the best I could do under the circumstances. In hotels like that, the traveller who does not spend nearly as much money in brandy, soda, and cigars as his board amounts to, is an unwelcome guest, and from mine host to the water-carrier he is treated accordingly. The servants of the Alexandra recognized one set of travellers as "big gentlemen," who were entitled to their attention, and the "small gentlemen" (such as I) were left to shift for themselves.

Soon after reaching Ootacamund I met a very enthusiastic young sportsman, with whom I planned a short trip to the Neddimullahs, a range to the west, to hunt sambur deer (Rusa aristotelis), and the Neilgherry goat (Hemitragus hylocrius), which is here (in sport, I suppose) called the "ibex." We took with us a native "shikaree" to be our guide, and a party of coolies who carried upon their heads the baskets laden with our camp-outfit, ammunition, and provisions for five days.

A brisk walk of about twelve miles over the hills and through the hollows, brought us to the range of peaks, and at a lovely spot, known as Betmund, we made our camp beside two little Toda huts, which sheltered us at night. Never have I seen a lovelier landscape than that which stretched before us then. Looking back toward Ootacamund we saw an endless succession of rolling hills and rounded ridges covered with bright green grass, relieved here and there by dense sholas of a darker hue. The hills looked as if they had just been gone over with a lawn-mower, they were so smooth and clean. Near our camp was a clear, cold mountain stream, while on three sides of us the hills rose into lofty peaks, still smooth in outline and covered with short grass. We were really among the "delectable mountains."

At daybreak the next morning we saw four wild goats feeding near the summit of one of the tallest peaks, at the base of which we were encamped. To the naked eye they were the merest dark 
specks, but with the glass we easily made them out. Dressing hastily, we were soon on our way up the steep side, and after an hour's steady and laborious climbing we reached the summit, made a careful stalk over, and found-nothing. All that day and the next also we climbed up and down those peaks, hunted along dangerous precipices and rocky ridges, but found no animals. We were so high that clouds enveloped us more than half the time and greatly retarded our progress. They enabled us to realize what a wet, cold, and disagreeable thing a cloud is, when one is in it, however beautiful it may look from below.

On the third day we moved six miles to the northeast, and pitched our tent in the edge of a fine shola at the mouth of a small cave in the rocks, low down beside a clear running brook, where we were quite sheltered from the wind. A hundred yards away, up the grassy slope, was a typical Toda village, or " mund," called Muddimund, and I was glad of so good an opportunity to make the acquaintance of these strange people. After all, the Todas are the most interesting amimals on the Neilgherries, and before them wild goats and sambur sink into insignificance.

The Todas of the mund regarded our camping so near them as a sort of invasion of their premises, and their suspicion of us rose to positive dislike when, on the second day, they discovered our coolies had stolen a couple of dry rails from their cattle-pen and cut them up for fire-wood. Of course it was a perfectly lawless act, and I quite admired the spirit of one of the men who came down to inform us of the fact, and threaten to have our men up for theft if the offence was repeated. As he stood upon a bare rock above our camp, with a long staff in his hand, clad only in a loin cloth and a cloudy cotton sheet worn sornewhat like a toga, with bare arms and legs, and a mass of long, jet-black hair falling in apostolic fashion over his shoulders, he seemed like another "John the Baptist preaching in the wilderness." He soon convinced us of the error of our ways, and a couple of rupees not only acted like oil upon the troubled waters, but rendered him both friendly and communicative.

The Todas are certainly a remarkable tribe, but their qualities are all of a negative character. Their history-which is really a history of nothing-goes to show that the natural laws which govern the progress of all other races and tribes of mankind do not affect them in the least. Man is a progressive being; whose gradual ascent in the scale of intelligence and refinement depends largely 
upon the nature of his environment, or whether his surroundings are favorable or unfavorable for his advancement. He reaches his highest level in a temperate climate, and on good soil, where life is not a continual struggle for bare existence.

With the exception of a few changes which have been forced upon them by the Government, as the cessation of infanticide, for example, the Todas are to-day precisely as they were when, in 1814, Mr. Sullivan discovered them on the Neilgherry plateau. They belong to the Dravidian race, but are the least cultivated of all its tribes. Although inhabiting this magnificent plateau from time immemorial, a very Eden in itself, living in a mild and salubrious climate, on bountifully fertile soil, and amid scenery that ought to inspire a mummy, they have never tilled the soil, nor planted fruit-trees, nor built cities, towns, or villages, or even comfortable dwellings. They have no domestic animals save buffaloes and eats, whereas they might easily have flocks upon flocks of sheep, goats, and fowls, and ponies and bullocks by the score.

With time enough for anything, they manufacture absolutely nothing, not even weapons; build nothing except the flimsy huts they live in, and like the lazy, indolent brutes they are, subsist wholly upon the milk from their buffaloes, and what grain they can beg of the Badagas, a neighboring tribe which pays an uncertain tribute to the Todas as the original possessors of all the land on the Neilgherries. The drove of buffaloes belonging to the mund is herded by the small boys, and milked by the dairyman only, the "paulaul." The only occupation of the men, aside from the milkman, is visiting the neighboring villages of Badagas and begging for tribute.

In a country teeming with game, and also with a natural appetite for flesh, the Todas are absolutely without weapons, or even spear's of the simplest sort, either for defence or capture. They make no traps for game, set no snares, dig no pitfalls, nor capture game in any way whatever. And yet they said they were fond of sambur flesh, and two of the men we questioned informed us, with the pricle of men who recall a banquet, that they once had all they could eat of a sambur killed by Morgan Doray. They have no caste prejudices to prevent them killing and eating game, as have many Indian natives, and nothing keeps them from the chase but sublime laziness. What total depravity!

Having learned the above, I was quite prepared for the information that the Todas have no written language, no songs, no history, 
writteñ or unwritten, no historical monuments nor compositions of any kind; in fact, nothing but buffaloes. I believe, however, they have some religious notions and ceremonies, but I did not succeed in getting anything like a clear idea of their nature, and so prefer to omit all mention of them. This much I learned to a certainty, however, that the milkman, the "paulaul," is regarded as a sacred character, a god in fact, and is never touched by any human being unless it be another sacred milkman of equal rank. The dairy, or "paulchi," is a sacred place, which may not be entered under any circumstances by any one but the paulaul. If there is any surplus milk after the wants of the mund are supplied, it is made into ghee, which, if not also used, he sells or trades to neighboring tribes for rice, millet, wheat, sugar, salt, or tobacco.

Even in India, with its many tribes and castes, the Todas are people of remarkably fine appearance. To judge by their form and features, one would suppose them capable of any degree of progress in the social scale. The men are tall and very erect, large-framed, broad-chested, and finely built every way, many being quite muscular. Their color is a blackish brown. The features are well-moulded every way, with Jewish nose, full lips, massive but not prominent cheek-bones, large eyes, and low forehead, but otherwise the head is well shaped.

Their hair is very abundant, wavy, jet-black, and rather coarse, and the thick, bushy beard is also black. I never saw men whose bodies were so densely hairy, especially on the breast and arms, as are these Todas generally. Every man is an Esau.

In height the women are, on an average, about six inches shorter than the men. There was one comely face at Muddimund, but the remainder of the women were not nearly so good-looking as the men. Both men and women part their hair in the middle, and the latter wear theirs either in curls or in a wavy mass hanging well down their backs.

The Toda garment is a sort of mantle of coarse cotton stuff of native manufacture, with a figured border, and when new is white. It is thrown over the left shoulder, brought forward under the right arm, and the corner is again flung over the left shoulder, which leaves the right arm entirely bare and free. The female robe is of the same size and material, but it is worn like a mantle over both shoulders. The priestly milkman usually wears nothing except the loin cloth, and neither men nor women ever wear any kind of head covering. 
The most remarkable fact about the Todas is that they practise polyandry-the marriage of several brothers or near relatives to one woman. This state of society presupposes a scarcity of women, which is indeed the case with the Todas, and has been from their earliest history. This condition of the population was brought about by infanticide, whereby a large proportion of the female children born to the tribe were killed at their birth.

Formerly the males of the tribe outnumbered the females two to one, but since the Madras Government has suppressed infanticide, the proportion has risen until now there are three-fourths as many females as males.

The regulations of these people in regard to marriage are very simple, and result in a perfectly tranquil and harmonious state of society. If my informants knew how to reckon time properly, a girl's marriage to her first husband takes place when she is fifteen years of age, by her own consent and choice only, and her husband receives from her father a dowry of several buffaloes. After that her husband's brothers may also marry her and unite their herds with his, thus forming a joint-stock company and one common herd. The women of the tribe never own or inherit property, and the men are therefore bound to support them.

Although the social laws of the Todas regarding betrothal, marriage, remarriage, and divorce are so extremely elastic they are actually shocking, they bear a resemblance to the customs of the Bible patriarchs, in many respects so close as to be positively alarming.

With the Todas, marriage seems to be quite a go-as-you-please institution, except that women are so scarce no man is allowed to have more than one wife at a time. Like many of the prominent characters in the Old Testament, who indulged in polygamy and polyandry, their complete social history would not make good family reading.

The practice of polyandry was brought about by infanticide, and the killing of female children was due to the phenomenal laziness of the Toda, who shrank from the task of supporting a whole woman and four or five children all by himself. But for that, this tribe of physically fine men and women might have expanded and founded upon the Neilgherries a magnificent principality.

As it is, there were in 1881 only six hundred and seventy-five of them, not so many by about forty as in 1870 , and they wander about from one grazing ground to another like the good-for-nothing heathens they are. 
By many observers they are thought to be directly descended from one of the tribes of Israel-which belief is based on their facial resemblance, their semi-nomadic habits, and their customs regarding marriage and divorce. To my mind, there is something so decidedly Israelitish in their hereditary and violent abhorrence of tilling the soil, horticulture, and all other manual labor, that I am constrained to believe the suspicion is well founded.

The habitation of the Toda is precisely what one would expect of such an animal. It is of the smallest possible size, close and hot, dark as a dungeon, destitute of furniture, and full of fleas. It is more like a rustic dog-kennel than the habitation of a human being. It looks like an overgrown dog-kennel in every line, and whoever enters it can only do so by going on all-fours. It has no window whatever, no chimney or smoke-hole, and the only opening is a door in one end of the hut.

The typical hut is eight feet square, and about the same in height to the angle of the Gothic roof. The ends are boarded up tightly with rough boards, the cracks being filled with sun-baked clay. There is but one door, a rectangular hole three feet high by two wide, at the middle of one end, next to the ground. There are no side walls, for the roof reaches quite to the ground on either side, and the rafters even run into the earth.

The roof is thatched with lemon-grass lashed to the bamboo rafters with split rattan. The huts built as above are quite substantial, but sometimes one is put up in more flimsy fashion, of smaller size, with angular peak, flat-sided roof, and low side walls. It was a hut of this kind that sheltered us from the rain at Bet-

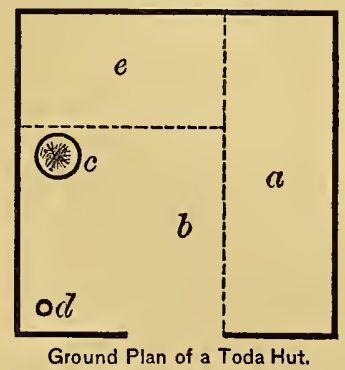
mund, and almost smothered us, too, until we kicked out one of the ends and secured a supply of fresh air.

In spite of the darkness and fleas I entered one of the huts at Muddimund and examined it carefully. The accompanying diagram will explain the interior better than any description, $a$ being a slightly elevated bed of clay, on which the adults of the family slept, $b$ a vacant space in the middle of the floor where the children slept, $c$ the fireplace, $d$ the stone mortar, and $e$ a place set apart for the culinary utensils, bags of grain, etc. To me, this place was like a veritable Black Hole, and how three adults and 


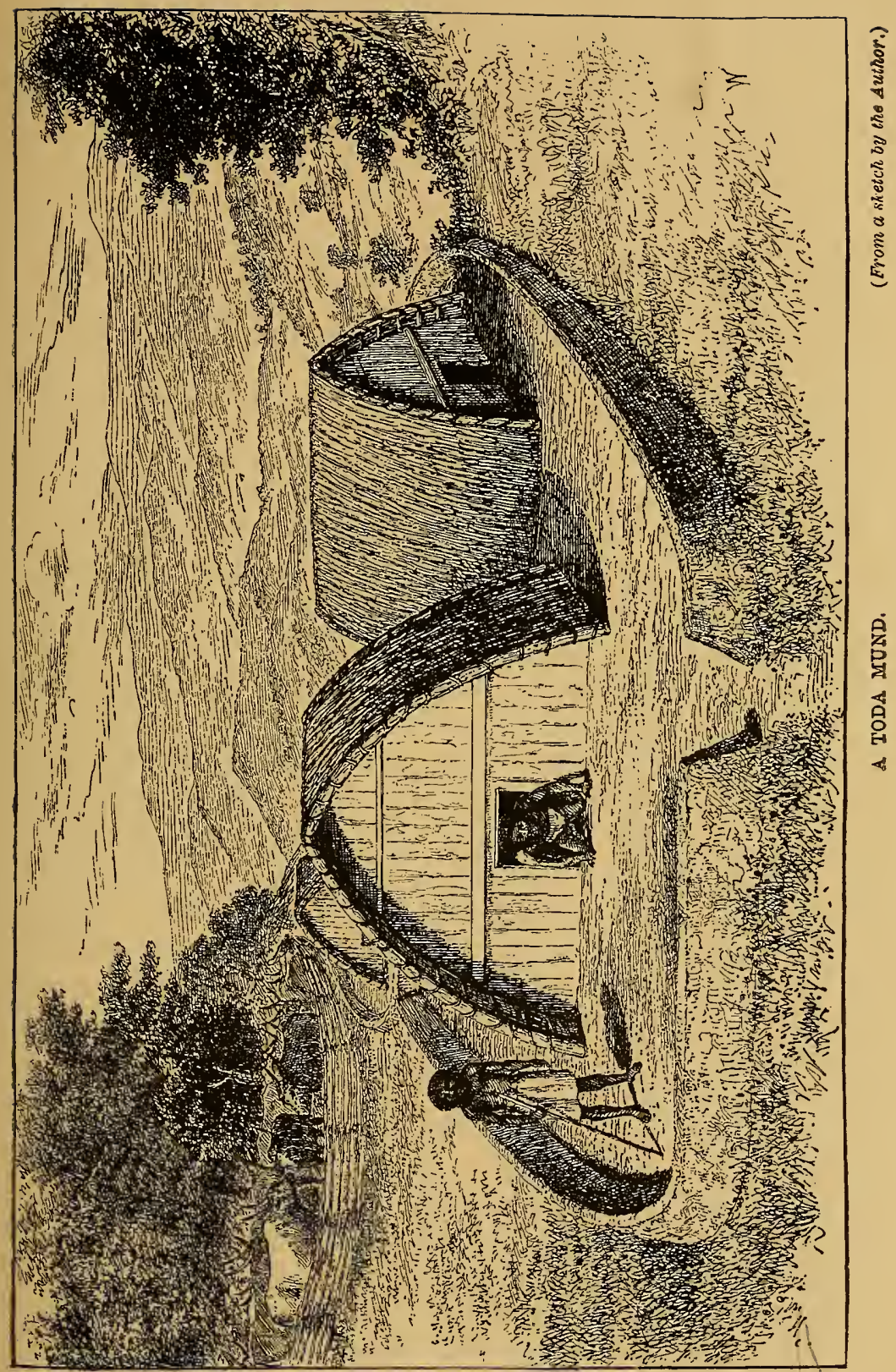



four children managed to sleep in such a den, with the door tightly closed, was a inystery.

Three such huts as the above standing close together, and the dairy a little distance away, all enclosed by a low wall of earth about three feet high, constituted Muddimund. Fifty yards away was the buffalo pen, built of small saplings twelve feet long; like an ordinary rail fence.

The Toda buffalo is a distinct breed from the domestic buffalo of India generally, being of a lighter build, more active habit, and having horns with much greater elevation, length, curvature, and divergence. He has more flesh on his bones and some hair on his blue hide, but for all that, he, too, is a very ugly specimen of the bovine tribe. He is "scarey" and sometimes even dangerous in the presence of white men, and the Todas say the herd is always able to defend itself against the tigers and leopards of the Hills. The buffaloes form a regular line of battle, with the largest bulls and best fighters nearest the enemy, and the corrs and calves take shelter in the rear of the fighting column. The buffaloes have even been known to rally to the protection of the children herding them.

For three days we hunted up and down the hills and through the sholas, but with no success. Late one evening we espied a stag sambur feeding near the edge of a dense shola, but just when we were getting fairly within range of him a dense white cloud came sweeping along and hid him completely from our view. Under the obscurity of this we hurried up nearer, and when it cleared away at last, we saw, through the driving mist, only the antlers and head of the stag as he stood behind a hill looking over the top, straight toward us. It was our only chance for a shot, for it was almost night, and aiming for the throat, we fired together. As we expected, the stag wheeled around, dashed into the shola and was gone.

All that the hills lacked in the matter of game and specimens they made up in scenery. Every day our hunting led us along the very edge of the Neilgherry plateau, where the hills end abruptly in a precipitous descent of 4,000 feet to a lower and more level plateau. From one spot in particular the view was sublime. Standing at the end of a lofty ridge, we looked down upon a plain which lay spread out before us like a map, surrounded on three sides by the encircling Neilgherries, and stretching away in front for a good forty miles. Nearest us it was dotted over with tiny houses and cultivated fields, and crossed here and there by a road, 
but in the distance there was discernible only a sea of green forest, broken here and there by grassy glades. My companion pointed out the location of the Government Reserved Forest at Mudumallay, where Indian bison (Bos gaurus), and sambur deer were numerous, and we planned a trip there forthwith.

The last day we visited our favorite point of observation we beheld a cloud-scene which was remarkably beautiful. From our lofty height we looked down upon a sea of billowy white clouds as white as the whitest pearls, which so completely obscured the plain below that there was no visible evidence of its existence. Above the expanse of clouds the air was clear, the sun shone brightly, and the grim, gray precipices and lofty peaks which loomed up round it and girt it in, were not more motionless than this sea of clouds. As a rule, it is folly for a traveller to describe a cloud-scene, and I mention this only to call attention to the surpassing beauty of a mass of clouds when seen in sunshine from above and surrounded by grim and sombre outlines.

At the end of five days' very laborious hunting over the hills we returned to Oocatamund. So far as specimens were concerned the hunt had been a total failure, for we had not a single one ; but any man who could regret such a trip as that on such grounds deserves to be shut up in a work-shop all his life, and see nothing of nature except musty skins and skeietons. 


\section{CHAPTER $\mathrm{X}$.}

\section{THE WAINAAD FOREST.}

A Hnnting Trip to Mudumallay.-Monkey Shooting.-The Karkhana. - The Meanest Natives in India.-Obstacles.-An Old Hypocrite.-Record of One Day's Hunting. - Expert Trackers. -Bison._A Long Chase.-Death of a Sambur Stag.-A Herd of Wild Elephants. - An Attack by an Amateur, on Foot and Alone.-Close Quarters.-Failure.-Lost in the Jungle.-A Sambur Killed by a Tiger. - A Bad Predicament.-Deliverance by a Lucky Guess.-The Author's Status as a Shikaree.-Death of a Bull Bison.Skinning Under Difficulties.-Instinct of Self-preservation in Monkeys. -Jungle Fever.-Native Cussedness again.-Return to Ooty.-A Good Samaritan.-A Model (!) Physician.-Mr. and Mrs. Dawson.-Departure.

Upos the Neilgherries, wild animals of all kinds are now so scarce that they cannot be hunted with any degree of certainty, and the best that either sportsman or naturalist can do is to make Ootacamund his headquarters and hunt in the forests about the base of the hills. Occasionally (three to five times a year), a tiger is met and killed upon the hills, and an enthusiastic sportsman who is a good shot may kill a wild goat or a stag sambur every week he is out; but to a collector who shoots for skins and skeletons this is ruinously slow work.

A few miles to the northwest of the Neilgherry plateau, and 4,000 feet lower, lies the great Wainaad Forest, like a vast preserve, teeming with large game of many kinds and famous as a hunting ground. My sporting friend had visited a certain portion of it known as the Mudumallay Reserved Forest, and he gave me such glowing accounts of the Indian bison and deer to be found there, that, after taking his report at a discount of fifty per cent., I decided to go there for a fortnight's shooting under his advice and guidance.

We hired four pack-ponies, loaded them with our outfit and provisions, and at two o' clock in the afternoon we were all ready to start. All except my friend's chief servant and right hand man. He had been given an advance of four rupees wherewith to buy his 
provisions for the trip, and had been gradually getting drunk ever since early morning. At the last moment he gave us the slip altogether, and hid away in the bazaar. My friend spent an hour in searching for him, with a native policeman and a stout cane, but he was not to be found, and we started without him.

We took the road leading north from Ooty to the Segor ghaut and Mysore, and as soon as we were well out of the town it began to rain. For nearly two hours we plodded along through a steady down-pour that completely drenched everything save my two packs, which I had covered with my waterproof blankets. Just at dark we reached the Kulhutty bungalow, wet, cold, tired, and hungry, and only eight miles from Ootacamund. But we soon had a good fire blazing on the hearth, a steaming pot of clocolate on the table, and dry clothes on ourselves.

As if to atone for our miserable drenching, the next morning broke clear and sunny, and we lost no time in starting on our way down the pass. Four miles from the Kulhutty bungalow we reached the Segor bungalow, a mere hovel at the foot of the ghaut, elevation twenty-seven hundred and ninety feet. From thence the road lay through a generally level country, thinly covered with low bushes and short, scrubby trees. Quartz rocks were quite abundant along the road, and in one ledge I found a bed of Muscovite mica, which furnished several fine specimens. Six miles from Segor we reached the village of Musnigoorie, which stands on a smooth bed of reddish porphyrite, through which run long, narrow, vertical veins of quartz, several of which extend lengthwise along the middle of the street.

After leaving Musnigoorie the jungle grows denser and higher, until it soon becomes a genuine forest, and the road is both hilly and rocky. Late in the evening we crossed the Moyar River and halted for the night at the Tippecadu traveller's bungalow, twentytwo miles from Ooty. The next morning the ponies, which had been turned out to graze, were missing, and it was not until 4 P.M. that they were found. To occupy the time, I took my rifle and strolled out into the forest along the river, which $I$ found in places to be composed chiefly of the common bamboo (Bambusa arundinacea), which here grows in scattering clumps to a height of forty to sixty feet. While I was walking along, lost in admiration of the first bamboo forest $I$ had ever seen, a large animal suddenly leaped to the ground from a tree a few paces in front of me, flourished a long tail in mid-air, and rushed away through the grass. From the 
length of its tail I thought it was a young leopard, and immediately gave chase, when the animal ran up a tree, and in another moment my rifle brought down a fine old gray monkey, the Madras langur (Semnopithecus leucoprymus). The report started a whole troop of the same species which had been feeding quietly in an adjoining tree, and away they went at a great rate, galloping through the tree-tops a little faster than I could run on the ground below. But one of the monkeys could not resist the temptation to stop and have a look at me, a very common habit with monkeys generally, and a moment later he, too, was tumbling to the ground. The largest monkey of this species which I obtained in the Wainaad measured as follows : length of head and body 23 inches, tail 37 . I also shot a Malabar squirrel ( $S$. Malabaricus), one of the handsomest of all the Sciuridoe, and also one of the largest.*

By the time I had prepared the skins of my three specimens the ponies arrived and we started for the Mudumallay Karkhana, or headquarters of the forest officers, six miles from Tippecadu. The village, which consists of about twenty huts, built of mud or of split bamboos woven together, stands upon the bank of a filthy, stagnant pond or "tank," a genuine cholera generator in fact, for it furnishes the sole water-supply of the village. The year before our visit the village had been nearly depopulated by cholera and fever, many dying, while the rest fled for their lives. There is a good bungalow here belonging to the forest department, quite vacant when we arrived, but owing to ignorance on my part, and lack of management on that of my companion, we had not obtained at Ooty permission to occupy it during our stay, and so we were obliged to go farther, and fare worse. Having come to hunt bison, we went on two and a half miles beyond the Karkhana to the very centre of the best game district, and camped near the house of a well-to-do old native, named Courti Chetty.

The natives inhabiting the Mudumallay forest, forest officers, and all, are certainly the meanest and most disobliging lot I met anywhere in the East Indies. As soon as they found we had come among them without any "backing" from the government authorities, or without any kind of tangible power over them, they became most insolent and disobliging. First of all we saw the hand of the government writer, Ramasawmy, in charge of the Karkhana and its affairs. While we were making our camp, a forest peon

* See Table of Measurements of S. I. Mammals, Appendix. 
came along and demanded to know who gave us permission to camp in that forest. We politely informed him that we had no permission and needed none. A little later, when we tried to engage trackers and game-carriers from among the natives living near us, they told us Ramasawmy had ordered them not to go with us, and they dared not go at any price. Here was a pretty fix. I at once wrote a letter to the most excellent Ramasawmy, threaten. ing to instantly report him to his superior at Ooty, Major Jago, if he hindered our movements or caused us further trouble of any kind. He at once countermanded his obnoxious "order," and became the cringing, fawning native who fears authority, even though it be ever so shadowy.

Then came old Courti Chetty, who had under his immediate control all the natives near our camp. We gave him various presents to start with, but these only served to whet his appetite to an alarming extent. He thought he was doing us a great favor when he furnished us trackers at a rupee each per day (three times their actual value), and pocketed half their wages. The Kurumbers themselves, even when hired, would do nothing unless they felt inclined, and what nearly ruined us was that they seemed to be indifferent to the power of the rupee.

Old Courti Chetty visited our camp very frequently, always wanting something, generally arrack or brandy. He had built for himself quite an elaborate family temple in one corner of his yard, and was a very devout old Hindoo, extremely careful of his "caste." One morning his son took my gun and shot a muntjac (Cervulus aureus), near our camp, of which I wanted the skin. The little animal was brought up and skinned by the old man's son under my instructions, but I was not allowed to touch the animal lest I should defile it! When they had carried away the carcase and all the flesh, I was at liberty to take up the skin. An hour later, when Courti Chetty came down and asked for a drink of brandy, I ordered Appoo to pour it out in my drinking-cup, that I might make a trial of the venerable Hindoo's principles. It was done. As usual, the old man declined to receive the cup from the hand of either of us, but had it placed upon the ground in front of him. Without another word he took up my cup, which had been at my lips a thousand times, and drank off the contents as though it had been mother's milk. The old hypocrite!

My friend had brought with him from Ooty a strong, healthy. looking coolie to serve as a gun-bearer, but the day after we 
reached our destination he stole nearly all the rice belonging to my cook, and refused to do any work about the camp. His master discharged him at once, and after eating an enormous quantity of rice he started back to Ooty. At the Karkhana he was attacked by cholera, and died in a few hours.

During the first three days my friend and I hunted together, and were completely unsuccessful, whereupon we decided to go out separately. The second day that I went out alone proved to be a very eventful one, and a record of its incidents will give a fair idea of our doings in that locality. The following is from my diary :

"June 3, 1877.-Started out very early, accompanied by a single old Kurumber, because no other trackers could be procured. The old man carried my rifle and game-bag, which latter contained my breakfast and luncheon. I carried my No. 10 gun, and cartridges all loaded with single round balls and six drachms. Throughout the day the character of the forest remained the same as usual bere-rolling hills covered with grass waist high, and a very open, scattering growth of low, scrubby trees; ground hard and dry, and no swamps.

"About nine o'clock found a very fresh bison trail, and started upon it at once. The way the Kurumbers and Chetties of these parts take up a bison trail through long, thin grass and over hard ground is surprising. They glide rapidly but almost noiselessly along, their eyes fixed upon the ground, but raised every now and then for a quick, piercing glance ahead to sight the herd. The old Kurumber lifted the trail very rapidly, and I followed close at his heels. On we went, up hill and down dale, over hard ground and soft ground, the trail freshening very rapidly. Sometimes it led down moist banks, and then the ground would be quite ploughed up by the hoofs of the herd. At last we were pretty well blown, and sat down beside the trail, under a bush on a bit of rising ground, to rest and refresh a little. I was getting deeply interested in a cold roast chicken, when suddenly we heard a rush and a trampling of feet, and the next instant a whole herd of bison hove in sight, coming toward us over the brow of the hill.

“" Kahtee, sahib! Kahtee!' said my old tracker, in an excited whisper.

“I snatched up my heavy gun and made ready.

"The herd came on at a brisk trot, suddenly turned off to the right when a hundred yards away, and swept along before us like a cavalry squadron under review. It was a grand sight, although 
but a momentary vision of massive heads and huge white horns, high humps, sides of chestnut brown, and about thirty pairs of legs, all white from the knee down. They were too far away for my smooth-bore to hit with certainty, but aiming as well as I could, I fired at the largest bull one barrel after another-and missed with both. The bison dropped their heads lower, humped their backs higher, redoubled their speed, and swept out of sight like a whirlwind.

"We were instantly up and after them, and in about twenty minutes saw them walking quietly along a quarter of a mile ahead of us, for the forest was very open. I undertook to stalk the herd, and was doing very well, when the old man touched me upon the arm and pointed to a fine stag sambur that was standing, heal erect and antlers thrown back, motionless as a bronze statue, looking full at us, and only fifty yards away. My policy is, 'one bird in the hand is worth two dozen in the bush,' and regardless of the bison in sight of us, I fired my rifle at the sambur's neck. He dropped instantly, and died almost without a kick. We cut his throat, blazed a tree on three sides to mark the spot, and hurried on after the bison.

"Apparently bison do not run far after being shot at, or hearing fire-arms, for half a mile from our dead sambur we came upon the herd again, and stalked up to within seventy yards of it. This time I fired my rifle at the heart-region of a large cow that stood nearest me, 'broadside on,' knowing that with that weapon I would hit my mark. To my chagrin the entire herd went tearing off, and I saw that my little rifle was too small for such large game, or at least too small to stop a bison. We followed on after the herd, which finally led us up a ligh, conical hill, and twice completely around it. Twice we came upon the bison where the grass was as high as our heads, but each time they saw us first and dashed away. After two hours of such chasing, we reluctantly abandoned the trail, and started back to find the sambur we had shot. The old man took his bearings, and we walked, and walked, and walked, but could not find it. It afterward proved that we went directly away from camp and the object of our search.

"I soon saw that my guide had lost his reckoning, and simply could not find our dead game. But he tried his best, I followed without grumbling, and again we walked and walked. It grew monotonous, but there was no help for it. And we could not talk a word except by signs, which made matters so much worse. 
"Late in the afternoon we came upon the first herd of wild elephants I ever saw. They were moving quietly along through the forest, a quarter of a mile from us, and after watching them for a while at a distance, we went our way without disturbing them. Half an hour later we came upon the same herd, this time where there was better cover from which to observe them. The herd consisted of one fine old tusker, one young tusker, five females, and two babies. They were feeding upon the grass, pulling up long bunches and jerking it from side to side to shake the dirt from the roots, then winding it up to their mouths. Some threw quantities of dry dirt over their backs, others fanned themselves with leafy branches. I wanted that old tusker for his skin and skeleton, but I had no right to shoot him there, or even attempt it, without laying myself liable to a heavy fine, and so we again left the herd and went our way.

"We walked on another half-hour, and came upon the herd for a third time. This was too much for human endurance. Twice had we resisted temptation, but here it was once more. I determined to kill that largest tusker then and there, if possible, and take the consequences. The highest possible fine would be five hundred rupees, and he would be worth that as a specimen. When my companion saw my intention he retired a quarter of a mile, and climbed a tree. I loaded my No. 10 with hardened balls and six drachms, quite enough for any elephant, I thought, and took up my position in advance of the herd. The old tusker was behind the rest, sauntering slowly along, feeding as he went. I crept up through the grass, keeping a tree-trunk all the time exactly between his eye and me, and stole from one tree to another, until at last I got within thirty feet of him. But unfortunately he kept his forehead from me, and I only knew about the front head shot. He passed on and I had to stalk him again. I stalked him at least six different times, but somehow his forehead was always away from me, and I would not fire at any other part.

"The elephant is certainly the most stupid animal I ever tried to approach. He is as easily stalked as an old sitting-hen. Evidently his hearing, sight, and scent are alike dull, or I would have been discovered. At one time the whole herd was feeding around me in a semi-circle, in a space not larger than could be covered by an ordinary circus-tent, and it seemed as if the elephants were in a menagerie, they were so near and so quiet.

"At last I had a reasonably fair chance at the tusker at twenty 
yards and fired both barrels, aiming to strike the brain through the nasal cavity, at the base of the trunk. My shot was a total failure. The elephants ran off a hundred yards, and to my great surprise stopped and began feeding again, all except the tusker, who stood quite still. I stalked him again and this time fired at his temple, but failed to bring him down, and gave up in shame and disgust. The elephants now made off, trumpeting as they went, and leaving a trail which looked as if a hundred men had marched along in Indian file. Then I regretted my folly in firing at the elephant and wounding a noble animal to no purpose, and likewise rendering myself liable to a fine whether I killed him or not. But the temptation was too great to be resisted.

"I found my old Kurumber, and we started home, abandoning the search for the dead sambur. In going through a patch of high grass we came suddenly upon a spot where a tiger had pulled down and devoured a sambur about four days previously. The grass was trampled all about, and it seemed the carcass had been dragged some distance. We saw a number of freshly picked leg-bones, and we might have found the skull and antlers by looking about a little, but I, for one, felt a trifle nervous in that dense high grass, considering who had just been there before us, and we left the spot without any unnecessary delay.

"We walked on until almost sunset, and then the old man told me by signs that we were lost, would have to sleep (!) in the jungle, and that we might as well prepare for it as best we could before dark. Here was a pretty fix. We had been rained upon several times and were wet to the skin, had no blankets, matches, nor food, nor even a chopper wherewith to build a hut. A night under such conditions, in that wet grass, would surely finish one of us for some time to come, even should the tigers let us alone, and to sit all night in the fork of a tree was not much better as a prospect. I said we must get back to camp, and the old tracker said (by signs all this) 'Well, I am lost. You may show the way home.'

"I replied, 'Very good, I will. Let us go in that direction,' and pointed across a little valley to a certain low hill. It was simply a hap-hazard ' guess' at the way out of our difficulty, although I felt, without in the least knowing why, that the Karkhana and our camp lay in that direction. Without a word of objection the old man waded on through the tall grass in the direction I had indicated, and just at sunset we climbed the little hill I had pointed out -and came suddenly upon a well-travelled road! Then we knew 
we could reach some shelter before midnight, at all events. Fifteen minutes later it was pitch-dark, and I can scarcely remember a night of more intense darkness. I could not see my companion two paces in front of me. Fortunately the road passed near our camp, which we succeeded in reaching about ten o'clock, to the surprise of every one, for we had long since been given up for lost, and the people were speculating calmly on our probable fate."

The next day we went back and found our sambur untouched, and I removed and preserved the skin, while the Kurumbers eagerly appropriated the flesh. Very soon after this my friend and his gunbearer, Dena, succeeded in killing a fine bull bison, and as they wanted only the skin, I was allowed to take the skeleton, all except the skull, which the "Leftenant" proposed to keep as a trophy. But he was a thrifty lad, and afterward sold me the skull for four rupees, which made my specimen complete. Having come wretchedly provisioned and equipped for such a trip, he soon abandoned his enterprise, which was to shoot bison for their skins and heads, and returned to Ooty, leaving me alone. I was not sorry when I found, immediately after his departure, that the chief reason why the Kurumbers were so backward about assisting us was, because my friend had neglected to pay a number of them for services rendered during a previous visit. He was a queer character, to say the least. One day he said to me, "I believe you have been having a war over in the United States, between the North and South. Is it over now?" "Yes." "Well, which side whipped?" This question from a man who had but a short time previously held a commission as a "Leftenant in the - th Lancers," was rather a stunner to me.

I find that, in nearly all cases, I have to see a new animal two or three times and get somewhat acquainted with it before $I$ can be at all sure of bringing it down. Especially is this the case with large game, and with very strange species I am not discouraged if I make two or three flat failures before bringing down a single specimen. After I succeed in killing my first one of any kind, I ask no odds of the rest. Should my reader be an old sportsman, I beg him to remember all along that these are but the adventures of a "griffin," who, until coming to India to hunt elephants, tigers, and bison, had never shot even an elk or buffalo; and his fire-arms, for large game, were such as no genuine "old shikaree" would accept as a gift.

The death of my first bison occurred as follows :

"Jume 6, 1877. - Went out this morning accompanied by 8 
three Chetties, one of whom is the keenest tracker I have yet seen. About 2 P.M., we struck the fresh trail of a solitary bull bison, worthy game for the most fastidious sportsman. Followed the trail rapidly for some time, when suddenly, with a loud snort and a crash, the old bull started up and went tearing off through the jungle. Instantly we were after him, swiftly but silently, half running and half walking. If one man lost the trail, another found it again in less than a minute, and on we went. We crossed a little ravine and clambered up the opposite bank, every one keenly on the alert. On gaining the top of the hill, the foremost Chetty suddenly crouched down, moved back a little, and motioned me to the front. I humied to his side, and there, about eighty yards distant, was our old bison, quietly walking away from us at a slight angle. It was a desperate chance, but I dared not lose it. Waiting a moment until he turned a trifle to pass a certain clump of bushes, I aimed at his flank so that my ball would range forward into his heart-region, and fired my No. 10. He sank upon his knees, but got up directly, ran straight on, and disappeared in a thicket. Reloading as I ran, we were soon at the spot where he was struck and saw his blood upon the grass. I hurried along his trail, but before I had gone a hundred yards he rushed out of a bamboo thicket and ran before me along the edge of a deep ravine. As he dashed along I fired a ball into his shoulders. He staggered, lost his balance, and fell, crashing and tearing down through the young bamboos, rolled completely over, and with a mighty bellow landed on his back, with legs in air, at the very bottom of the nullah. Finding that he was breathing freely, I fired a bullet from my Maynard quite into his heart, which saved the noble animal at least some minutes of suffering."

But what a time we had measuring and skinning him! He could not possibly have fallen in a worse situation than upon his back in the bottom of that narrow ravine. Although not of the largest size, he was still a very fine bison, his vertical height at the shoulders being five feet eight and one-half inches, while his horns were sixteen inches in circumference at the base. As this was but the beginning of my experience with the Indian bison, I will defer all observations upon the animal and its habits until we have had a more extended acquaintance with it upon the Animallai Hills.

Two days later I shot another bull bison, and some Chetties shot for me a fine brown flying-squirrel (Pteromys petaurista), and another langur (Semnopithecus). While out hunting that day we 
had a fine illustration of how the protective instinct varies in animals according to surrounding circumstances. We surprised a couple of gray langurs, feeding in a small grove of low trees in the midst of a very thin and very low forest, which was overgrown with tall grass. When the monkeys saw us they tried to hide in the tree-tops, but finding it impossible to escape in that way, they ran. We chased them through the grove without getting a shot, but at last, when they reached the farther side we felt that we were sure of them. In those low trees they would fall an easy prey to any of our weapons. Who ever heard of a monkey coming down from his native tree-top to escape a hunter?

When the monkeys saw that the trees no longer afforded them shelter and concealment, they leaped to the ground and started off at a tearing gallop through the tall grass. We ran after them as hard as we could go, but so long as the monkeys remained upon the ground they were completely hidden from us. Very soon one of them leaped upon a white-ant hill, and looked back to see where we were. The instant my gun touched my shoulder he was down and away again, with the most astonishing bounds, and flourishes of his long tail.

We renewed the chase at our best speed, and once more a monkey leaped up to see where we were. Four times this mancuvre was repeated, the animals gaining ground each time, until at last we gave up beaten. This was the only way in which they could escape us, and they knew it much better than we.

After sixteen days in the jungle, I decided to return to Ooty without delay, but soon found I had stayed a day too long. The night before we were to start back it rained nearly all night, and with a chill, a splitting headache, and a high fever, the grim Phantom of the jungle marked me for his own. In spite of my iron constitution and strictly temperate by-laws, the jungle-fever had fastened upon me, although it was no more than I could expect. But it is not such a terrible ailment after all-in fact it is half good -for, owing to its regular intermittence, it gives its victim a chance to rest and recuperate a little between spells.

We made ready to return to Ooty at once, and Ramasawmy promised to engage a bullock bandy (cart) for us. Instead of doing so, he did nothing at all about it, and went off shooting in the forest. We lost a day's time through relying on his word, our camp equipage got soaking wet in a rain-storm, and with the junglefever to help matters, my patience underwent a severe strain. When 
we asked one of Ramasawmy's peons to find a bandy-man for us, he flatly told us to find him ourselves, for he would not, which in the end we were obliged to do as best we could. It is a source of consolation to me now to know that cholera prevails at Mudumallay, and that in time it will eatch all those wretches.

When we were starting off from our miserable camping-place, old Courti Chetty made a last raid upon us, wanting arrack, powder, shot, my "cumbley" (double blanket), and some money to spend in redecorating(!) his family temple, all of which I took great pleasure in flatly refusing. He also begged me to write out a petition to the Forest authorities at Ooty, praying for the removal of Ramasawmy, which petition he and the other Chetties would sign and present. He complained most bitterly of the way the government writer lorded it over them, compelling them to do this or that without so much as saying "by your leave." He forgot that in the same manner he and his relatives lorded it over the poor Kurumbers and Puniyahs, and that they all had, with one accord, used me about as meanly as they could. To me there was a sweet consolation in the thought that

\footnotetext{
"So, naturalists observe, a flea

Has smaller fleas that on him prey ;

And these have smaller still to bite 'em, And so proceed ad infinitum."
}

And I left the Chetties to fight their own battles with Ramasawmy.

We hastened our return to the hills, and the first day travelled from the Karkhana to the foot of the Segor ghaut, when the bullocks could go no farther. I at once set out and walked up to the Kulhutty bungalow, where I spent a wretched night of fever and nightmare. The next day, finding that the bandy did not put in an appearance, and feeling that I must reach Ooty before night, I hired a pony at the toll-gate and tried to ride it bare-back. It balked, bucked, and kicked viciously, and I. could not get it a hundred yards beyond its owner's hut, so I gave up in despair and lay down by the road-side upon my blanket to enjoy my fever in peace and comfort. Just then, along came a good Samaritan (otherwise known as Captain E. A. Campbell, of Ooty), who at once dismounted from the fine bay horse he was riding, made me mount in bis place, and, walking by my side, brought me to the hotel at Ooty. Then I gave up entirely, and in a few hours was quite out of my head, so that for a time my miserable surroundings at the hotel and total lack of attention did not trouble me at all. 
My servant Appoo also came down with fever, was worse than useless, and begged me to send him back to Madras or he would die. I had before determined to discharge him, and forthwith gave him money enough to take him back to Madras, which so completely overwhelmed him that he actually fell upon his knees to express his thanks. I record this as the only instance I ever knew of a Hindoo thanking any one for a kindness, but I doubt if any Anglo-Indian will believe that it really occurred.

As soon as I was able to think, I sent for a doctor. After a long delay he came, but to me he seemed only an excuse for a doctor, for all the qualities a good physician should have seemed to be lacking in him. His first step was to find fault because I had not sent him a note instead of a verbal message. I was in a beautiful condition for the composition of a stylish note just then. Then he sniffed the damp, unsavory, and poisonous air of my room, looked dubiously at the chaos surrounding me, and remarked that I "ought to get cleaned up a little." Just my own opinion, but who was going to do it when my servant had gone home sick, and the landlord was good for nothing in looking after the comfort of his "small gentlemen" guests? The doctor felt my pulse, scribbled a worthless prescription, said he would not need to come again, he thought, pocketed his ten rupees, and went away.

In about a fortnight I was on my feet again, thanks to my own quinine, and able to skin the big black monkeys (S. cucullatus), which were brought me by the native shikarees. This was the only mammal they were able to obtain for me, except the blacknaped hare (Lepus nigricollis).

During my last fortnight upon the Hills I became acquainted with Mr. G. A. R. Dawson and his excellent lady, both of whom did all in their power to break the social monotony of my life. Mr. Dawson is an excellent artist and taxidermist, and was then engaged upon the text of an illustrated work entitled "Neilgherry Sporting Reminiscences," which has since been published by Higginbotham \& Co., Madras.

The illustrations, coming as they do from the hand of an artist as well as a naturalist and sportsman, are truly beautiful and valuable. Mrs. Dawson is a musician of rare ability, who, at eight years of age, travelled in the United States with Mrs. Bostwick's ccncert troupe, playing solos upon the concertina. Until meeting her in her charming Neilgherry home, I never for a moment suspected what delighful music the concertina can be made to yield in 
good hands, and so long as I remember India I shall recall with pleasure the evenings I spent at Grasmere.

For some weeks I had been corresponding with Mr. A. G. R. Theobald, a forest officer on the Animallai Hills, and he depicted such a splendid prospect for elephants, bison, and other large game, that I determined to visit his locality for six or eight weeks at least. Accordingly, as soon as I felt strong enough, I packed up my specimens and sent them to Madras, while I bade adieu to the Neilgherries and started south.

So far as specimens were concerned, my Neilgherry trip was not a complete success, and on that score I felt somewhat disappointed. I had the fever in my system, also, as I plainly felt. True, I had escaped the fierce heat of the plains during the hottest months, May and June, and, had I desired, I could not sooner have gone to the Animallais, because there were no rains and therefore no water upon those hills, until the burst of the southwest mon. soon late in June. 


\section{CHAPTER XI.}

\section{THE ANIMALLAI HILLS.}

A Hunter's Paradise. - Getting there. - The Bullock Bandy and its Driver. - His Discourse.-Physical Aspect of the Animallais.-Toonacadavon.-A Glorious Prospect.-Mr. Theobald. -An Efficient Officer and Faithful Friend.Character of the Forest. - Seasons. -Protection of the Elephants.-A Permit Obtained.-My Mulcer Hunting Gang.-The Karders.-More Ornamental than Useful.

THE Animallai Hills! How my nerves tingle and my pulse quickens as I write the name! It seems to have charged my pen with electricity, and no wonder. Let any young sportsman, young naturalist, or " griffin " of any description have a Hunter's Paradise for a four months' inheritance, with nothing to do but chase wild animals and preserve their skins and skeletons; let him have the keenest trackers in the East Indies, and a faithful friend within reach to help him over the rougher difficulties, and we will see if he does not afterward write and speak of his experiences with enthusiasm. India is the greatest game country in the world except South Africa, and the Animallai Hills are, beyond all question, the finest hunting grounds in all India. No other locality in all the East Indies can boast of possessing such splendid open forests for hunting, and such a genial climate, combined with such a variety and abundance of large game.

The lordly elephant has given his name to this range of mountains. In Tamil, Tellegu, and Canarese, his name is " ani," "arni," and " anay," respectively (which accounts for the variety of ways of writing the name of the hills), and "mallai" or "mullay," signify hills or mountains ; hence we have "Animallai," Elephant Mountains, a very appropriate name for a range which is the home of so many vast herds of elephants, bison, axis deer, and wild hog. Besides these, there is the sambur, or Indian elk, the wild goat or "ibex," of sportsmen, the muntjac or rib-faced deer, all in goodly numbers, while the hunter meets an occasional tiger, leopard, and 
bear, many squirrels, and black monkeys by the hundred. A glance at my list of Indian mammals * will enable the reader to gauge the accuracy of the above statements.

The Animallai Hills belong to the great range known as the Western Ghauts, and extend generally east and west along the south side of the great break known as the Coimbatore gap. Through this wide pass runs the Madras and Calicut railway, with the Neilgherries looming up close along the north and the Animallais from twenty to thirty miles farther south. The city of Coimbatore is the point of departure for the latter range, which must be reached by travelling across country. My friend in the hills, Mr. Theobald, had advised me to bring a full stock of provisions, since nothing was obtainable in or near the jungles, except the flesh of wild animals. Accordingly, when I and my new servant, Michael, reached Coimbatore on our way from the Neilgherries, we spent a very busy day in the erowded, hot, and dusty bazaar, buying provisions for our campaign in the jungles.

Our purchases were about as follows: For my native hunting gang, 2 bags of coarse rice, sundry bottles of arrack (native liquor of the fiery sort), several bundles of tobacco, salt, and chillies (red pepper). For myself, 20 loaves of fresh bread, flour, English jams and jellies, sausage, herrings, sardines, butter, and "biscuits" (crackers)—all in tins ; rice, potatoes, "curry stuff," cocoanuts, and brandy ; and for preserving skins of large animals, $96 \mathrm{lbs}$. salt and $96 \mathrm{lbs}$. alum; also, a new lantern, candles, cocoanut-oil, rope, nails, etc. We expected to remain in the jungles not less than two months, to prepare one large elephant skin and two skeletons, several ditto of bison, and every other species of mammal we could secure. We fully expected to have jungle-fever, for no stranger, white or black, can escape it long in the Animallais, so we took a good supply of quinine and chlorodine, the two great remedies of India, and other medicines for cholera and dysentery, the twin curses of jungle life, worse dreaded by Europeans than any number of savage animals.

Travelling in India is usually done at night, in order to go faster and farther, and to avoid the oppressive heat of the day. The commonest means of conveyance is the covered bandy (cart) drawn by two white bullocks. This ancient vehicle is simply a broad platform on very high wheels, completely covered with mats which

* See page 216. 
are supposed to be rain-proof. The driver sits astride the tongue of the cart, within easy reach of his bullocks' hind-quarters, and it is interesting to study the various methods he employs to start his cattle and keep them going. A foreigner could no more drive them than he could fly, until he has fully learned the Madras bullock-driver's language. It consists of a complicated system of "boh-boh-boh-ing!" chirrups, "tock-tocks," and other indescribable ejaculations, combined with slapping, tail-twisting, toe-poking, and ordinary goading and lashing. Two or three times I have seen my bandy-man save the heavily loaded bandy from sticking permanently in a muddy nullah by biting his bullock's tail in a most fiendish manner. It seems that a bullock has no idea what he can do until his tail is bitten. Their drivers talk to them a great deal, always aspersing the reputation of their female relatives when angry, especially their mothers and sisters-a common custom with Indian natives when quarrelling-and praising them when their horned steeds are doing well. The following was the drift of one driver's discourse to his bullocks as translated by an "Anglo-Indian journalist."

"You, Punniah, you a byle?* Not you;-your father must have been a donkey, and your mother a pig; no respectable cow would own so lazy a son. As to you, Moreeah, I believe your father was a Feringhee, and your mother a Pariah. You are the most abominable of all brutes, and how you came to have horns and a tail is quite a mystery to me. Some fine day I shall saw off your horns and sell them to a Mochee, and instead of coloring your long tail with goolal, I shall eut it off and sell it to some rascally English dragoon, to stick in his helmet and bring him bad luck, for he is sure to be killed in the first battle he goes in afterward. I wish they were all killed, but never mind, they soon will be, and then won't we have jolly times? Ah! now, you behave something like respectable animals : that's the way to get over the ground. You, Punniah, are my father and mother, and you, Moreeah, all the rest of my relations, except my wife. I'll give you both a fine feed of sugar-cane tops when we come to any, but not if you are lazytock-tock! tor-rr-ee-ee-ooh-ah!” †

* Bullock.

$\dagger$ I have often been surprised at the speed and endurance of the little white bullocks (zebus) which take the place of horses in India. It is no uncommon occurrence for a good pair of bullocks to make $3 \frac{1}{2}$ miles per hour for several hours, with a light bandy and proper encouragement. With two or three re. lays of bullocks one can easily travel 30 miles in 10 to 12 hours. 
About 4 P.M. of the day after we reached Coimbatore, we loaded one bandy with our outfit and provisions, filled the bottom of another with straw for ourselves, settled our dues at the traveller's bungalow, and with the little bullocks at a sharp trot, started south for the Animallais. The road was very good, and it literally swarmed with people travelling along. When night came I spread my blanket on the straw and then had my boy arrange boxes and bundles all around me, so that when the cart tilted sideways I would not roll about. The cart wheels are so large that a very small stone causes a terrible tilt and a fearful jolt, so that such riding is very wearisome. All night long we went jolting on, stopping only at midnight for the bullocks to feed and rest, and at daybreak the next morning the steep blue sides and serrated crest of the Animallai range loomed up all along the south. At last we reached the little village of Animallai, ten miles from the foot of the hills, a sort of half-way house between the heart of the jungles and Coimbatore. This is the winter headquarters of the Forest Ranger in charge of the Animallais, and for his use there is a good bungalow, in which all wandering white men are allowed to take shelter as a matter of charity. In the course of my goings and comings I afterward occupied the place many times, sometimes a week at a time, and it is not strange that I conceived quite an affection for this "snug harbor."

As soon as we arrived, the Government writer, with the appalling name of Venkateramiah, came and offered his services in helping us along. We halted at the bungalow until the next day, when early in the morning the writer mustered a gang of about twenty-five coolies to carry my luggage up the steep pass, and we drove on to the "foot of the ghaut."

On the northern or Coimbatore side, the Animallais rise very steeply up from the plains to a height of from two thousand to five thousand feet, so that it is a steep, steady climb from the level plain up to the summit of the range. Once the summit is reached, the hills slope very gradually down into Cochin and Travancore, draining nearly all the water in that direction; so that, while the Coimbatore district may be dry and parched by drought, the native states on the opposite side will be well watered, green, and fertile.

Upon reaching the foot of the Ardivarum ghaut we dismissed the carts, and the coolies took my luggage upon their shoulders. A horse was waiting there for me, sent down by the friend I had not yet seen, and leaving my servant to accompany the luggage, I 


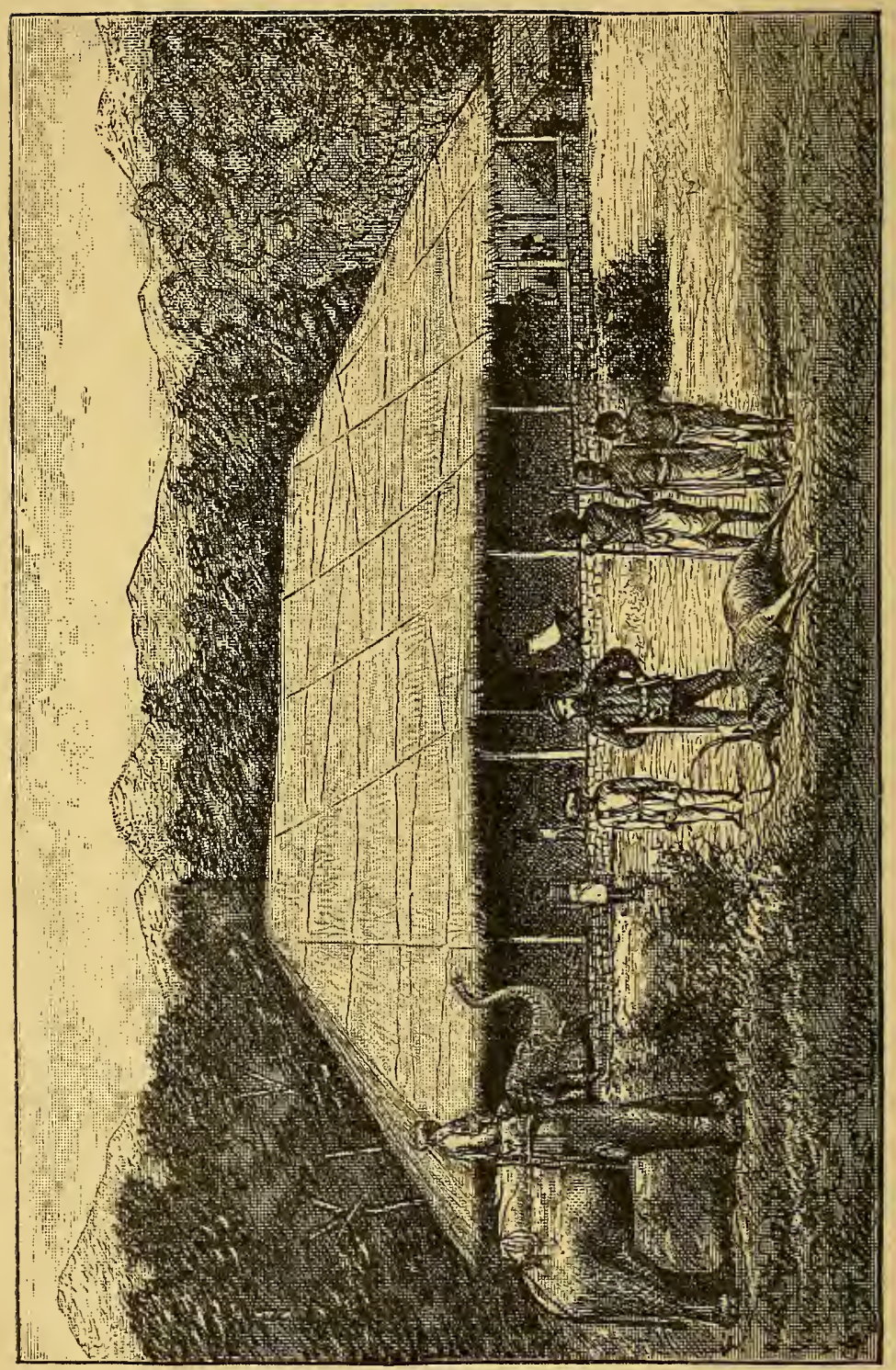

ङे

定 
mounted and rode on alone. After a long, hard climb up the steep and rocky pass, we reached the summit at an elevation of about two thousand feet, and began to descend the gentle slope. Then the road led through lofty bamboo and teak forests, across rocky ravines and mountain torrents, up hill and down, until at last, at the very end of a long ridge, seven miles from the top of the pass, we emerged from the thick forest, and the forest camp, called Too-na-cad-a-voo, lay before us. At the very point of the ridge stood a dozen bamboo huts and a comfortable thatched bungalow; a little river swept past them on the left and tumbled down a precipice, just beyond which rose a lofty cliff of smooth gray rock, with a fringe of feathery bamboos all along its base by the riverside. On the right rose a conical mountain-peak. Between the two mountains we looked over the camp and far across an unbroken sea of green forest, which in the distance was bounded by a lofty mountain-range. What a spot for a camp! A moment later I rode down to the door of the bungalow, and received a most cordial welcome from the officer in charge of the forest, Mr. Albert G. R. Theobald.

Now and then we meet a man whose looks and tones and words strike the cord of our sympathies so forcibly that we feel instinctively a kinship and confidence, and we say to ourselves "I shall like him." Such was my experience with Mr. Theobald, and at the end of an hour I felt that I knew him as an old friend and comrade in arms rather than an untried stranger. From the first moment we became fast friends, which feeling only deepened with time and further acquaintance. I found in him one of nature's noblemen, as frank, free-hearted, and steadfast as ever breathed.

In the course of time I discovered that he was a real genius, of the type so generously credited to the "Yankee." Besides possessing a very considerable fund of medical information and surgical skill, he was a good gunsmith and watchmaker, a first-rate photographer and taxidermist, and a very keen sportsman and naturalist. What an invaluable man he would be in an African exploring expedition! His natural ability as an experienced forester, and his varied accomplishments, entitle him to a higher position in the Forest Department than he now holds; but he is still a young man.

During my entire stay upon the Hills, Mr. Theobald never wearied in his efforts to assist me, in every possible way. $\mathrm{He}$ doctored me when I was ill; he divided his provisions with me 
several times when I was off in the jungles and nearly starved out; he lent me his elephant-gun, and taught me how to use it on elephants; and when my cook ran away he immediately sent me his. He also lent me one of his private peons when I was crowded with work upon elephants, and, in short, he helped me with more useful articles than I care to mention altogether. A traveller cannot afford to carry with him all the comforts and conveniences proper for a stationary camp-life, and his assistance was, therefore, invaluable. He knew the natives, the wild beasts, and the forests as intimately as a farmer knows his barnyard and its inhabitants, and the interesting incidents of jungle life he related to me would fill a volume.*

His bungalow was quite a museum in itself, stocked with a magnificent array of trophies of the chase which proclaimed the genuine "old shikaree." There were tusks and tails of more than one lordly elephant that had fallen before my friend's smooth-bore. Well-mounted heads of bison, sambur, muntjac, sasin antelope, axis deer and wild boar hung on the walls until they were crowded. Perched up on a book-case sat a very fine and rare monkey, the wanderoo (Silenus veter), along with a small crocodile, shot at an elevation of fifteen hundred feet, and stuffed birds both great and small. On the floor were spread, in the most indifferent way, skins of bear, hyæna, leopard, and deer, but of the half-dozen tigers killed by mine host only the skulls and claws remained. In out-ofthe-way corners of the bungalow I presently turned up divers and sundry skulls of bison, antlers of sambur, and about fifty black monkey skins. There were chests full of the best-made Indian bird-skins I ever saw, drawers full of eggs and nests, and piles of original scientific "Rough Notes" of all kinds. A well-stocked zoological library was the crowning feature of this interesting collection of trophies and scientific specimens, and I did not need to be told that this hunter-naturalist had joined the Forest Department to indulge his love of nature.

* Since my visit to India, Mr. Theobald encountered and killed on the Ponnasy Hills (Collegal Taluq), a famous rogue elephant, who began his career by killing nineteen other captive elephants, and making his escape. Since that time he killed three natives and several head of cattle, besides destroying large quantities of standing crops and terrorizing the district for several years. He was a giant in size, and for the gallant exploit which ended his career the Madras government voted Mr Theobald a reward of two hundred rupees, with permission to retain the tusks. The latter were fifty-eight inches long, and weighed together seventy-five pounds-a very large pair. 
I soon found that I had reached a perfect hunter's paradise, the ideal "happy hunting ground" which is the heaven of our NorthAmerican Indians, where all good braves go when they die, where game is ever abundant, and there are no white settlers nor Indian agents. The slope of the Animallais is a succession of high hills and deep ravines, lofty peaks or ridges, and broad valleys, everywhere covered with lofty virgin forest. Some portions of the range, those commonly termed the "higher ranges," which lay along the boundary between the Coimbatore District and Travancore, are very lofty. The highest peak has an elevation of eight thousand eight hundred and thirty-seren feet, and is the highest land in India south of the Himalayas. Around Toonacadavoo there were high, rocky precipices for the wild goats, thick bamboo jungle and marshes for the elephants, grassy glades and fine open forests for deer and bison, rugged, rocky hill-sides for bears, and dense patches of underbrush for the sounders of wild hog. The tiger needs no particular kind of jungle, for where other game is, there will you be sure to find him also. Thus are we able to account for the presence of so many large animals in the same locality.

The forest camp is situated very nearly in the centre of the Government Leased Forest, which is composed mainly of mighty teak trees (Tectona grandis), blackwood (Dalbergia latifolia), the "vella, naga" (Conocarpus latifolius), "ven-gi" (Pterocarpus marsupium), and the common bamboo (Bambusa arundinacea). Near the foot of the hills, I noticed a tree (Salvadora Indica) which somewhat resembles the weeping willow, and also the Euphorbia antiquorum.

There are two strongly marked seasons upon the Animallais, the wet and the dry. The former is during the monsoon rains, from June or July to November or December, when the streams and marshes are full of water, grass is abundant, and the forest has taken on the growth and freshness of spring. During this season the force of the Forest Service is engaged in cutting down teak trees, hewing out their trunks, hauling and "slipping" them down the mountain side, to be floated down to Calicut, and there taken charge of by H. M.'s Navy to be used in ship-building. Teak is impervious to the attacks of the white ant and the ship-morm, which, with other good qualities, renders it a very valuable timber.

The dry season begins at the end of the northeast monsoon, usually about January 1st, and continues six months. Then the leaves fall in the deciduous forest, which becomes open and bare, the streams dry up, and the forest is usually swept by fire. The 
elephants and bison seek the streams near the base of the kills, the members of the Forest Department return to the low lands to escape the fever, and the forest is then inhabited only by wild beasts. At the time of my visit, July 4th, the members of the Forest Department had come only the previous week from the plains; the elephants were beginning to come down from the higher ranges to feed upon the young bamboo shoots, and the whole forest appeared at its best.

In India, the elephant is a very useful and valuable animal when trained to service, and large numbers are caught annually by Government officers appointed for this work in the Coimbatore District, at Collegal, in Mysore, and in Chittagong. Formerly wild elephants were so numerous in many parts of India that they were regarded as a nuisance and a Government reward of $£ 7$ per head was paid for killing them. Through the efforts of sportsmen and native shikarees their numbers were reduced to the proper limit, whereupon the reward was discontinued and a fine imposed to prevent their destruction. At present, elephants are rigidly protected by law all over India, although it is very evident that their numbers will soon increase so much as to render further elephant shooting positively necessary.

In 1873 an act was passed to "prevent the indiscriminate destruction of wild elephants upon waste or forest land," not only in the Madras Presidency, but any of the "native territories for the time being subject to that government." The penalty for shooting a female elephant was for the first offence a fine not exceeding five hundred rupees, or three months' imprisonment, and for the second convictiou the penalty was double the first. Shooting wild male elephants was also prohibited under the same penalty as fixed for the killing of females, except it be done under a proper authorization. The act provides that any zemindar or native proprietor of land may shoot male elephants on his own land, and may also authorize others to do the same. Of course, any person is authorized to shoot any elephant in defence of himself or any other person, or to save his crop from destruction. Any native prince owning territory frequented by elephants may, if he choose, grant permission for male elephants to be shot, and the law provides that each District Collector shall have the same discretionary power, conditionally, although up to the time of my visit, the latter officers had always refused to give any such permission.

Before I came to the Animallais my friend Theobald had offered 
to obtain permission for me to kill two elephants in a tract of forest on the hills belonging to an old native prince, the Rajah of Kulungud, which adjoined the Government Leased Forest. $\mathrm{Mr}$. T. had done the old Rajah many a good turn in preventing the stealing of timber from his land, and after a good deal of talking and much diplomacy on the part of my friend, the matter was finally arranged, and I was given a written permit to kill two tusker elephants in the Kulungud Forest.

The day after I reached Toonacadavoo I formed a regular hunting gang of five picked men to serve me in the jungles as trackers, guides, game-carriers, porters, and general assistants. 1 was fortunate in finding there a hill-tribe, the Mulcers, of which every man is willing to work hard when well fed, is skilled in woodcraft, and is not in the least afflicted with caste prejudice, which is the most important point of all. The Mulcers are really agriculturists, but they will do any kind of work that pays, and live right boside it. They are, by preference, carnivorous in their habits, being very fond of flesh of all kinds, save that of the tiger, and, possessing no fire-arms themselves, they hail the visit of a sportsman with delight. When

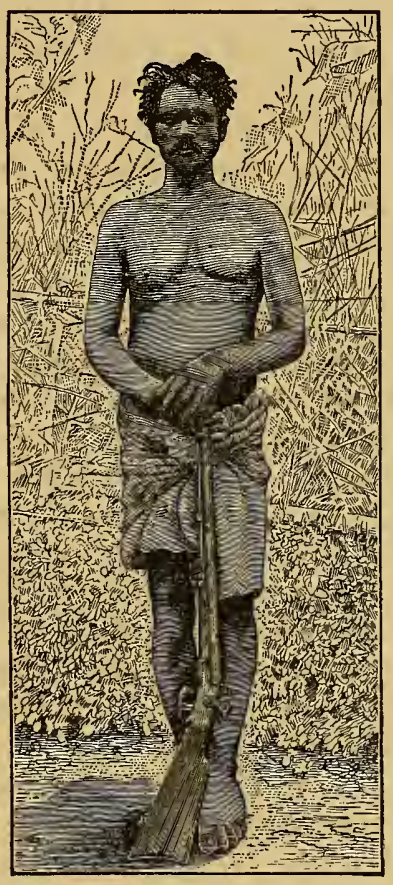

Pera Vera.

(A Mulcer Bunter.) well fed, the men are very strong and capable of great physical endurance. Two of my men once carried a dead wild boar, weighing $230 \mathrm{lbs}$, three miles through the jungle, up and down hill, halting only twice to rest.

The Mulcer men are of medium stature, well proportioned, very dark-skinned, with rather thick lips and slightly flattened noses, after the African type, wearing no ornaments whatever as a rule, and no other clothing than the loin-cloth. Ordinarily, their 
long, matted, jet-black hair is simply drawn back and tied in a coil at the back of the head, while they have no beard at all save now and then a few short black, kinky hairs. The women seem to be old and wrinkled from their youth up, and, without exception, are very ugly and unprepossessing.

Three of the men who formed my hunting-gang, Arndee, Pera Vera, and Channah, were the most expert trackers I ever saw, and I soon had reason to know that all were likewise brave and spirited men. When it came to the supreme danger of tracking up a tiger on foot and attacking him fairly and squarely in open ground, with only one little insignificant rifle, the two men who happened to be with me were fully equal to the occasion, and "game" to the last.

It was famine time, work was scarce, and food exceedingly dear, and the five Mulcers were glad to take service with me. I agreed to pay the head-man of the gang five annas per day in cash (fifteen cents), and each of the others four annas per day, besides which each received one quart of rice, and two leaves of tobacco per day, with salt and chillies ad libitum. This was much more than they could obtain elsewhere, and was amply sufficient for the support of themselves and their families, who would always accompany them. Being, as they were, passionately fond of fresh meat and receiving good wages, it is not surprising that I had a gang of faithful men always ready to undertake the hardest kind of work.

Besides the Mulcers, there are two other hill-tribes upon the Animallais, the Paliars and the Karders. The former are chiefly merchants and herdsmen, and it happened that I saw nothing of them. The Karders, however, were somewhat numerous. To a hunter they are entirely useless, for, owing to their caste prejudices they will not touch a dead elephant, bison, bear, or deer of any kind at any price. They are purely herbivorous in their habits, never touching flesh, but subsisting upon roots dug in the jungle, fruits, rice, etc. They collect honey and beeswax, cardamoms (Elettaria cardamomum), white dammer, a resin from the Vateria Indica, black dammer from Canarium strictum, and another gum resin called "mutty pal" from Ailantus Malabaricus, also wild ginger, turmeric, rattans (Calamus rotang), horns of deer, and "cheeakai" (the buds of Acacia concinna), largely used by the natives for bathing purposes instead of soap. These products of the jungle they exchange for rice, tobacco, salt, chillies, etc. In physique and physiognomy they very closely resemble the Mulcers, but they dress more elaborately, and wear many ornaments. They all file their front teeth 
to sharp points as a marriage ceremony, and the women wear an enormous coil of springy wood, or a strip from the leaf of the palmyra palm (Borassus flabelliformis), coiled up like a clock-spring in the lobe of each ear, which causes the flesh to expand into a thin ring two or three inches in diameter, which sometimes hangs nearly to the shoulder. The women also wear beads and necklaces of various kinds, but no other covering above the waist. The old women are always hideously ugly, and, as is also the case with the Mulcers, the men are handsomer than the women. Formerly the Karders would perform no menial labor at all, and, while consenting to carry a load of baggage or a gun, they would be deeply offended if they were called coolies. 


\title{
CHAPTER XII.
}

\author{
ELEPHANT HUNTING.
}

"A Lodge in a Vast Wilderness."-Hut-building with Bamboos.-Elysian at Last. - Character of Elephant Hunting.-Grand but Dangerous Sport.Indian versus African Methods.-The Skull.-Difficulty of Hitting the Brain.-Cranial Fracture Impossible. - The Fatal Shots. - Physique of the Elephant.-Tracking up a Herd.-Welcome Sounds. - Surrounded by Giants.-The Attack. - Stampede and Flight of the Herd.-Great Abundance of Large Game.-The Charge of a Dangerous Animal.-Fooling around a Baby Elephant.-Charge of an Infuriated Female.-A Grand but "Scarey" Sight.-Repelling the Charge.

ALtнобgн there was really an abundance of game around Toonacadavoo, such as bison, sambur, wild goat, muntjac and monkeys, there were no elephants, nor would there be any in that immediate vicinity until very late in the season. Moreover, had there been ever so many, we could not have killed one there. About a day's march farther into the very heart of the forest, they were quite numerous, and I soon decided to go out and camp where game of all kinds was most abundant. Accordingly, when the elephant permit came to hand from the old Rajah, we packed up provisions, preservatives and ammunition, pots, pans, and camp furniture, and took up the line of march for Tellicul, a mere vacant spot in the heart of the forest. And there, at the confluence of two little rivers, the Toonacadavoo and the Teckadee, where the teak-trees and the bamboos were the tallest, where the forest was silent, sombre, and shadowy, where big game was thick all about us and no white man ever came, my men cut down big bamboos and built huts for us all.

To me this hut-building is an interesting operation. First a skeleton hut is built of large bamboo stems set upright in the ground, and a ridge-pole, plate and rafters lashed firmly to them with green bark. Then large bamboo stems are cut in lengths corresponding to the length and width of the hut, and split irregularly all over. Finally each stem is split quite open on one side, and the 


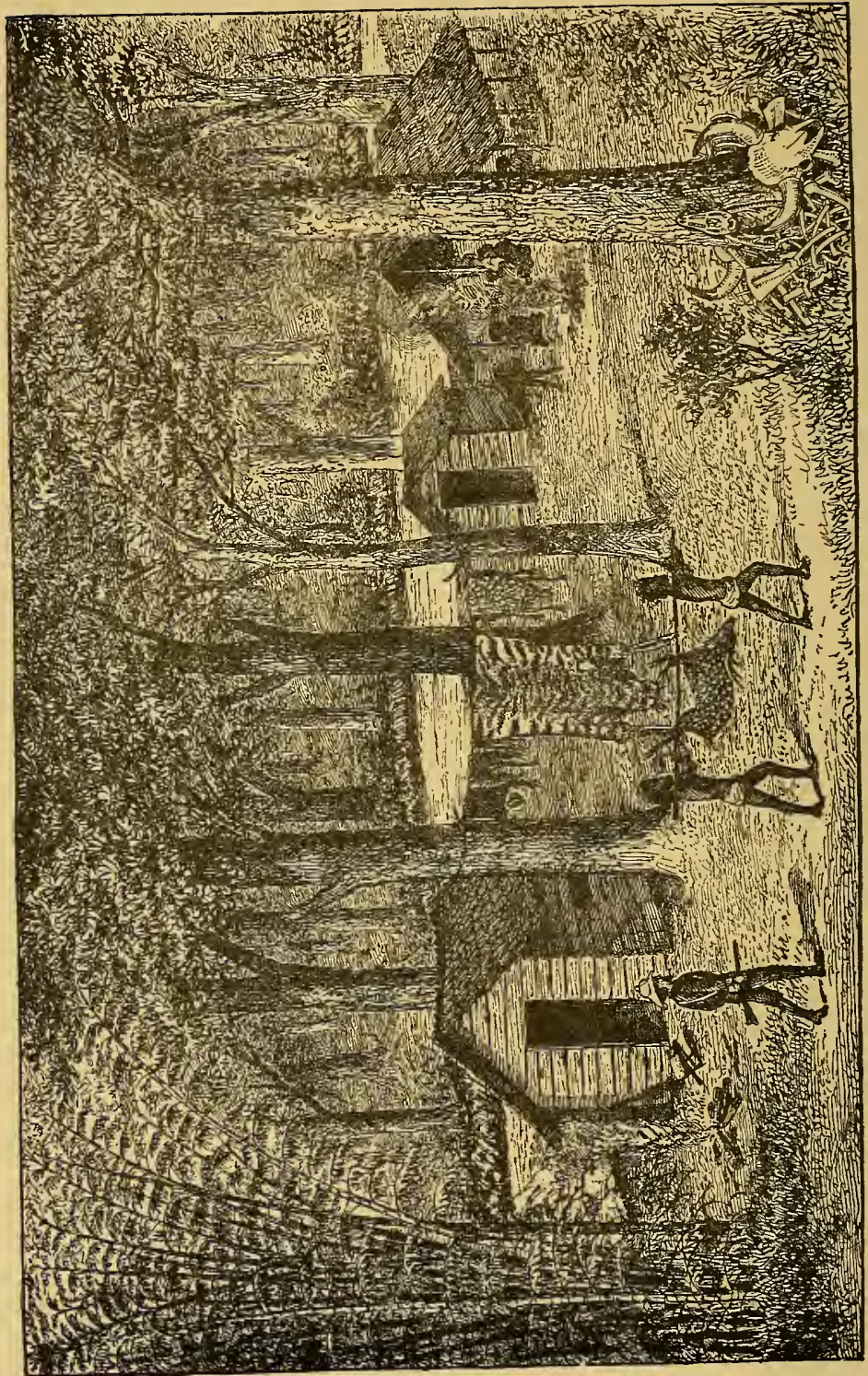

हैं

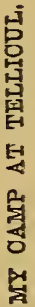


former cylinder now flattens out into a broad slab, twelve to eighteen inches wide. These bamboo slabs are then lashed with strips of bark to the upright posts of a hut and form the walls. Bamboos similarly treated were made into beds, tables, and doors, and it also served as an excellent flooring. My wash-basin was a joint of bamboo made into a trough, and my pail was a four-foot bamboo stem with all the joints broken out except the lowest one, which served as a bottom.

The roof of the hut is nothing but young teak-Jeaves laid on like slates and held by their own petioles, being partly split and hooked over the cross pieces. Besides a good comfortable hut for me, the men built another to serve as a cook-house and servants' quarters, while for themselves, their wives, children, and mothers-in-law, they built simply a huge, low shed and covered the ground beneath it with bamboo slabs.

No man ever experienced half the keen pleasure and delightful anticipation in taking possession of a mansion that I did in unpacking and arranging my guns, ammunition, and camp equipage in that rude little hut. Before the door stood a large clump of bamboos, an immense bouquet of ornamental grass sixty feet high, the long, green, feathery stems nodding and bending as gracefully as ostrich plumes. Far above us the tops of the giant forest trees met and shut out all but one little patch of blue sky, and the sun's rays never reached our camp until high noon. The shade was so dense that there was no undergrowth, and usually we could walk through that grand old forest as freely as though it were a meadow. I felt that at last I had reached the "happy hunting grounds" I had so often been disappointed of before, and subsequent events proved that I was not mistaken.

And now a word in regard to elephant hunting. I consider it the grandest and most exciting of all field sports, and by several of the greatest sportsmen living it is also considered the most dangerous. The elephant is the true king of beasts, both as regards size and strength, mental capacity, and natural dignity of character. As he marches majestically through the forest, monarch of all he surveys, or rushes like a living avalanche upon his foe, he seems the vital impersonation of au Irresistible Force. I have a greater fear of the elephant and a greater respect for him, than any other wild beast $I$ ever saw, either in the forest or in captivity, and this feeling has only increased with protracted acquaintance.

Elephant bunting is bound to bring into play all those qual- 
ities of endurance, perseverance, coolness, good judgment, and knowledge of an animal's habits, which go to make up a successful sportsman. There is a subtle charm about tracking up an elephant which I am sure is never found in any other pursuit. The trail is usually broad and plain, leading rapidly up hill and down, over mountain and through valley, across marsh and river, through dense forest and over grassy plain, mile after mile, growing fresher every hour, but often taxing the skill of the trackers to the utmost. At last the clear, resonant trumpet note, or the cracking and crashing of green branches, or a tall gray back above the bushes, tells the pigmy he is in the presence of the giant. It is a fair and square encounter every time, and the hunter backs his skill and nerve with his life against the great mountain of physical strength and impregnability. The game does not skulk in the bushes and wait to be driven out at random by a grand army of beaters; nor can the hunter climb into a tree-top and from thence shoot him with as much safety as though he were at home in his little bed; neither can the elephant be killed at long range. The hunter must boldly walk up in front of him to within twenty paces or less, fire away, and take his chances. While doing so he knows very well that if any accident or miscalculation places him within the power of that terrible trunk, those huge fore-feet or knees will immediately be upon his chest crushing him, like a miserable reptile, out of all human shape. Hunters frequently escape alive and recover from the jaws and claws of the lion, tiger, leopard, and bear, but I never yet heard of a man falling into the power of an infuriated wild elephant and living to tell the story.

Just before I began my elephant hunting, I came across the following encouraging (!) paragraph from the pen of Colonel Shakspere, a high authority on Indian sports :

"That elephant shooting requires much practice is certain from the fact that young hands at it, though very good shots, are rarely successful. Indeed, that famous sportsman, Captain Garrow, who probably at his death had killed more elephants than any man in India, and if you count only tusk elephants, perhaps more than any man who had ever shot, assured me that for the first two years he did not bag even one. I have known other sportsmen, who turned out very well afterward, to shoot at elephants for a couple of years, knock them over, but never able to persuade them to remain." *

* Wild Sports of India, p. 163. 
In the jungles of the East Indies an elephant must be shot through the brain, and thus killed at the first fire, or he is very apt to get away. Should the ball not touch the brain, the elephant is only stunned for an instant and is almost certain to move off at a high rate of speed. The latest writer on elephant hunting in India * says, in "Thirteen Years Among the Wild Beasts of India," "I have never recovered any elephant that has left the spot with a head shot," and my own experience has been the same. True, even in India an elephant may be shot in the shoulder and partially disabled, to be followed up and re-attacked time after time until he falls; but this practice is dangerous, unsportsmanlike, and undeserving of success. It is, perhaps, a surer way of bagging an elephant, but there can be no glory in it, nor even satisfaction, it seems to me. Although, by force of circumstances, I have to shoot all game animals regardless of age, sex, or condition, I yet have pride enough to be above shooting an elephant in the shoulder or anywhere else than in the brain. At the very outset I resolved to bag each of my elephants with a single ball through the brain, in a sportsmanlike manner, or else hire a sportsman to do it for me.

On the plains of South Africa the famous wild-animal slayer, Gordon Cumming, used to shoot elephants in the shoulder, and then gallop alongside them for miles, loading and firing until the weight of lead would compel the wretched beasts to fall. He relates how he once had to fire forty two-ounce balls into a single elephant before bringing him down. In India no such barbaric modes of hunting are practised, nor are they even possible.

In examining a section of an elephant's skull we find that while the skull is of great size in order to afford an extensive surface for the attachment of the powerful muscles of the trunk and jaws, the brain itself is very small indeed, situated far back, and surrounded by such a huge, irregular mass of bone and flesh, that its exact position in the living animal is very hard for the novice to determine. The skull is really of great thickness, but it is composed of long, narrow cells perpendicular to the surface of the skull, some three to six inches in length, others small, irregular, and honey-comb like. The skull has really an outer and an inner wall of considerable thickness, between which lie these bony cells, separated from each other by walls of bone as thin as pasteboard. These cells all communicate with each other, and through the frontal sinuses with

* G. P. Sanderson. 
the nasal cavity, so that they are filled with air only, and thus, while the skull is of great size, it is very light and buoyant in proportion to its bulk.

In the elephant we see an animal which very strikingly illustrates the perfect manner in which nature always adapts means to ends to secure the survival of the fittest, even under the most trying circumstances. $\mathrm{He}$ is possessed of a colossal body and head, joined by a neck so extremely short and thick that the head is almost a fixture upon the body. He cannot reach down to graze or drink, as all long-necked animals do, and so nature has provided him with a wonderful flexible proboscis six feet long, which is at once a powerful arm and hand, a drinking-cup, and a movable nose. The eye is very small indeed, placed far back upon the side of the head, and owing to the shortness of the neck and general unwieldiness of the head, the visual organ is almost a fixture upon his head, and its range of vision exceedingly circumscribed. His hearing is by no means acute, his sense of smell is also very deficient, and, taken altogether, he is easily approached in the forest. The most unskilful hunter can easily steal up to within ten feet of an elephant when he is feeding, provided there are no others near to discover him, and were the animal's brain enclosed in the same kind of a skull as that of every other terrestrial mammal, the most bungling hunter-or naturalist-could easily kill half a dozen elephants in a day.

But nature has not left this noble animal at the mercy of unskilful hunters. Instead of the thin, solid cranium wall which we see in the skulls of nearly all other land quadrupeds, a cranium which can be fractured by a blow or a bullet, thus producing death, a bullet may go crashing through those thin, bony cells, within two inches of the brain itself, and only cause the animal to run away much faster and farther than he otherwise would do. If the ball passes very close to the brain, the elephant may be stunned or knocked down by the concussion, but if he receives no further treatment he will quickly recover, regain his feet, and adios!-he is off, to recover entirely in a short time and live to a ripe old age, barring more serious accidents. The Ceylon Observer once gave an account of the death of a fine old male elephant near Trincomalee, whose skull showed the marks of twenty-three bullets, which had from year to year been fired into it by British naval officers hunting in that ricinity while their ships lay in the harbor. And yet the old fellow's serenity had not been disturbed sufficiently to 
. 


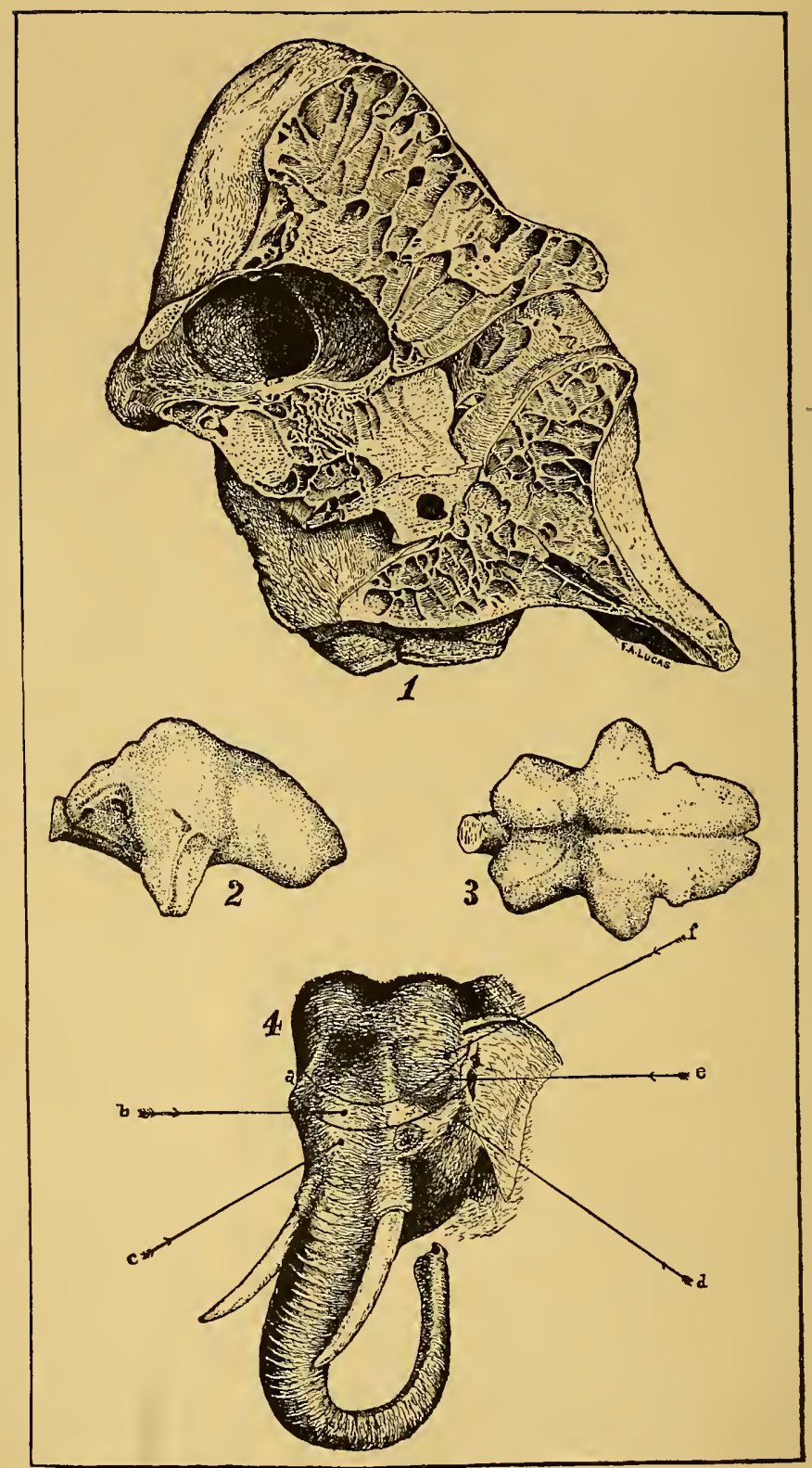

VIEW OF AN ELEPHANT'S SKULL AND BRANN.

1. Section of an Elephant's Skull.-2. Sice View of Brain.-3. Top View of Brain.4. How to Hit an Elephant's Brain. $a, a$, Horizontal plane of the brain; $b$, Front 4. below; $e$, Temple shot from level of brain ; $f$, Temple shot from above. 
frighten him away from his old haunts, for he frequented the same locality for several years. At last, however, a sportsman stole out one fine night in pajamas and slippers, found the battle-scarred veteran feeding close to the traveller's bungalow, and sent a ball into his brain, which ended his career.

Much has been written about the vulnerable points of an elephant's skull, and they are usually reckoned at two or three, but the fact of the matter is simply this : with a proper weapon, properly loaded, it is possible, nay easy, to reach the brain of an elephant from any quarter, side, or front, provided the animal is not charging you, and is not more than twenty yards away. When a gun will send a ball entirely through an elephant's head and out on the other side, even when fired through the thickest part of the skull, it stands to reason that one part of the skull will be as vulnerable as any other, and it makes no difference whether you fire at the forehead, temple, or ear, from above, below, or behind, so long as it is possible to get a fair, unobstructed shot. When an elephant is charging, the head is held high, the trunk tightly curled and thrown forward, so that the bullet must be sent through nearly two feet of trunk before even reaching the skull, a task almost impossible to accomplish with certainty and precision. The hunter must be perfectly familiar with the anatomy of the elephant's skull. Then, and then only, will he know at what point to aim in order to reach the brain. When on a level with his elephant's head the vulnerable point will be somewhere on a horizontal line drawn around the head from the ear-opening, three inches above the eye, and to the very centre of the bump in the middle of the face, which is really the base of the trunk and the nasal opening. When one is above the elephant, the vulnerable point will be above that line according to the height of the hunter's position, and when he is below him, it will be a proportionate distance below.

The brain of a full-grown Indian elephant is of very irregular, and almost indescribable shape, its greatest width being $10 \frac{1}{2}$ inches and extreme length 11. From the side, it is at best a difficuit mark to hit; even when seen, and infinitely more so when hidden away in a mass of bone and flesh.

We encountered a herd of elephants the very day after we camped at Tellicul. We started out about noon to find elephants, if possible, and whatever else we could find in the way of mammals. We had not gone far when up jumped a fine stag sambur, a half-grown fawn, and a doe. The first two dashed away with the 
speed of the wind before I could even raise my rifle, but the doe stopped short forty yards away, and for a full minute stood stockstill, staring at me in dull surprise and curiosity. I could easily have brought her down, but she would have been worthless as a specimen, and so we all stood there quietly and had a staring match with the doe, until she turned around and trotted off. The stag carried a fine pair of antlers, and we set upon his trail at once, hoping to come up with him in half an hour, at most. As we were hurrying along, we came to where that trail led across another of a very different description, and the trackers stopped short, pointed to it with broad smiles, and in low tones exclaimed, "Ani, sahib! ani !" or in other words, "Elephants, sir! elephants!" After examining the trail very carefully they declared that it was only four hours' old, and had been made by a herd of at least ten elephants. Without another word we turned off upon the elephant trail and followed it as fast as we could walk.

When travelling through the forest, going from one good feeding ground to another, elephants usually follow one another in Indian file, so that a whole herd leaves only a single trail ; but that is a broad, well-tramped path, as plain and well-beaten as if a regiment of men had marched along in the same order. When it leads through tall grass there is a clear lane a foot and a half wide.

The trail soon led us into a marsh of mud, water, and tall, rank grass as high as our heads, and there the herd had scattered somewhat. The soft mud was tramped full of great, deep holes where their huge feet had sunk down, and they had fairly mown down the high grass, as they went along, leaving the marsh cut up into a labyrinth of lanes. A green hunter acquires a very wholesome respect for an animal which leaves a track sixteen inches in diameter and eighteen inches deep! But we crossed the marsh and entered the forest again.

The trail freshened rapidly from the first, and we had followed it for about an hour at a good pace, when suddenly we heard a clear, resonant trumpet note, coming from the forest on our right.

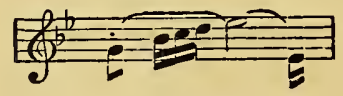

Tal-loo-ee!

It created a profound sensation, and instantly we turned off the trail and started in a bee-line for the old fellow who was doing the 
trumpeting. He repeated it at intervals, as if to guide us, and we made the most of it. Soon we were near enough to hear the welcome "crack! crack! crr-rr-rash!" of the young bamboo shoots upon which the herd was evidently feeding. No sound can be more welcome to the ears of the elephant hunter. There was not a breath of air stirring to betray us, and a moment later we were crouching behind a huge teak-tree, in sight of half a dozen tall, arching, gray backs that loomed up above the bushes.

I now told four of the men to stay were they were, while Arndee and I pushed carefully forward. The weapon upon which I depended was a Westley Richards double muzzle-loading, smoothbore No. 8 gun, weighing $9 \frac{8}{4} \mathrm{lbs}$., belonging to my friend Theobald. Each barrel was loaded with six drachms of powder and a No. 10 round ball of pure zinc. Arndee carried my No. 10 gun loaded with hardened balls, and I rather flattered myself I could floor an elephant with that old gun if need be. At first my tracker led the way, and almost before we knew it we were in the midst of the scattered herd.

The herd contained about sixteen elephants, three of which were young tuskers, but there was one old patriarch who carried a splendid pair of ivories, and I instantly marked him as my own. Being wholly unused to such work, I was all impatience to make the attack at once, for fear the game would discover us and make off. But Arndee had seen a good many elephants killed, and he forcibly prevented my bringing matters to a crisis at once, telling me by signs and looks to "keep cool and take my time." I obeyed him, and for fully half an hour we skulked around and through that herd, trying to get a sure thing on that old tusker.

The forest was quite open, with only a little underbrush here and there, and we could easily see an elephant a hundred yards away. Often we were within thirty yards of an elephant, and sereral times we crouched down in plain view of two or three. I was amazed at their neither seeing nor scenting us. They were feeding quietly on a hill-side, wandering all about, utterly unsuspicious of danger.

Now stand here with me and watch that lordly old tusker who is coming this way. See how lazily and leisurely he saunters along, swinging his huge trunk from side to side, until he comes to a thick clump of bamboos. He surveys the clump for a moment with his queer little brown eye, and sees in the very centre of it a soft and juicy young shoot, which looks very much like a huge stalk of aspar- 
agus, twenty feet high. Slowly and deliberately he forces his way right into the clump, and reaches inward and upward with his trunk until he gets a turn of it around the coveted young shoot. Now he quietly backs off a few steps, and the twenty-foot stem totters, cracks, and comes down with a tearing crash. Quietly placing his huge fore-feet upon the prostrate stem he crushes it into fragments, winds a soft, juicy piece of it up to his mouth, and begins a measured "champ! champ! champ!" which tells us he is wholly unsuspicious of our presence.

At last the elephants began to move off, quietly browsing as they went, and I saw that I must bring matters to a crisis at once. Four of them started off down the hill, the old tusker in the rear, crossed a nullah and entered a thick bamboo jungle on the other side. I sneaked along behind my old tusker within twenty feet of his tail, until at last the leading elephant turned off to the right, and I saw that they were all going to pass quite close to an unusually large clump of bamboos. I quickly made a detour to the right, almost crawling upon hands and knees, and was soon crouching motionless behind it. When the third elephant had sauntered past me I quietly took my position at the further side of the clump and waited for my old tusker. 'Slowly he pushed past the thorny tangle and came into view. I knelt there with the old smooth-bore at my shoulder, in plain view of the old fellow and only fifteen feet away, but I never moved a muscle and he did not twig me! I never felt more certain of killing a robin than I did of flooring him the next moment. Taking a steady, careful aim at his ear-opening, I fired, and sprang behind the bamboos to be out of his way when he fell. Horrors! Instead of coming down with a grand crash, as I expected, he threw his trunk aloft, gave a thrilling shriek and rushed off through the forest, trumpeting as he went. My shot had been a failure and a glorious chance was lost. But why? Or how? I could not understand it, and could scarcely believe it was a fact.

Of course my shot alarmed the entire herd and set the elephants running in all directions at first, during which time I executed a series of lively dodges to keep from being seen, and also to keep from impeding the progress of any elephant who might be running away. A hunter who is quite surrounded by elephants, and alarms them all by a shot, is often in great danger of being run over accidentally when the herd makes its first startled rush. In a moment or two the elephants all got together and started off, after which the forest was still as death. We followed them until nearly night, without 
success, of course, and returned home in disappointment, wondering why my shot had failed to hit the brain. I see now, that on account of my kneeling as I did, my bullet passed quite above the mark. Had I aimed ten inches lower, it would have done its work.

The next morning at daybreak we set out fully equipped for cutting up an elephant, and took up the trail where we abandoned it the evening before.

While following it up, we started quantities of game, but dared not fire, not knowing how soon we might come up with the elephants. We saw troop after troop of black monkeys, seventeen gangs in all that day, and a number of great horn-bills (Buceros bicornis) flying overhead. Out of a patch of low underbrush we started a sounder of wild hog; and farther on, a solitary old bull bison feeding upon a hill-side, saw us, gave a snort like a steamengine, and dashed heavily away. Later in the day we came upon a herd of axis deer feeding at the edge of a glade, and I could not resist the temptation to fire at a buck. I crept up to within sixty yards of him, rested my rifle upon a log, fired at him as he stood broadside-and never touched him! He did not even jump. Before I could recover from my astonishment and reload my rifle the herd quietly trotted off. Verily

\section{"All hits are history, All misses mystery,"}

but this new humiliation was very discouraging.

We followed the elephant trail until it crossed the Teckadee River and entered the Government Leased Forest, where we had no right to follow it, and then went home in disgust. On the way home we saw a sambur, but could not get a shot at it, and thus ended a day of disappointments.

For the next four days I had fever. My cook and interpreter, Michael, also came down with it, and declared that unless sent home at once he would die. I doctored both him and myself with quinine so successfully that in a few days the ferer was broken, and we were once more able to work. Every day it rained from two to four hours, and the forest was very dark and damp.

Eight days after the above fiasco, I had another experience of rather a different nature, and was considerably scared by an old cow elephant who took it into her head to run me down. The moment of danger in hunting a dangerous animal is when it "charges" the hunter, as the saying is, at which time nothing but the hunter's 
steadiness and presence of mind can save his life. It is enough to make any man shudder and turn pale to see an infuriated bear, bison, tiger, or wild elephant rushing down upon him to tear him in pieces or crush him to a jelly. Then the rifle must not miss fire nor the bullet fail to do its work in time. The charge must be stopped, or the hunter goes down. It is a very difficult matter to kill an elephant when in the act of charging, but a well-planted shot will turn him aside and make him glad to run away.

On that particular day my gang and I tramped about five hours through a drizzling rain, and finally overtook a herd of elephants, which we found to our disappointment contained no tusker at all, only females and young males. One of the females, however, had a cute little calf at her side, in which I soon became deeply interested. He was a cunning little rascal, only about three feet high, as demure and consequential as any pigmy could well be, and, hiding safely behind a large tree, I watched his movements for some time. His hide was smooth, shiny, and of a dark brown color, almost black it seemed at first. He wandered all around his colossal old mother who caressed him occasionally with her trunk, and occasionally he stood directly under her body, swinging his little trunk and tail from side to side just as naturally as the older elephants. A wild elephant is never still a moment when awake, swinging first one foot and then another, and both trunk and tail almost constantly. I never saw a more demure and cute looking animal than that absurd little elephant, and I fairly ached to steal up and grab hold of his trunk, and have a tussle with him.

I knew very well that, like most wild animals, the female elephant is very suspicious and dangerous when she has a young one to protect, but in watching that little calf for a good half-hour at a distance of only forty paces, I must have grown rather careless. The herd was huddled together in a thick clump of small trees, and my men were hiding near me, waiting patiently for the sahib to see all he wanted to see. At length the little baby elephant wandered off to the other side of the herd from me, and I determined to work round to that side also. Immediately around the clump of trees which sheltered the elephants, the ground was level and the cover very thin indeed. I saw that to reach the other side of the herd I would have to cross a small patch of open ground; but I thought the elephants would not notice me if I crouched low and went very slowly. Moving back a few paces I started to make the circuit, crouching almost to the ground, but keeping a careful eye 


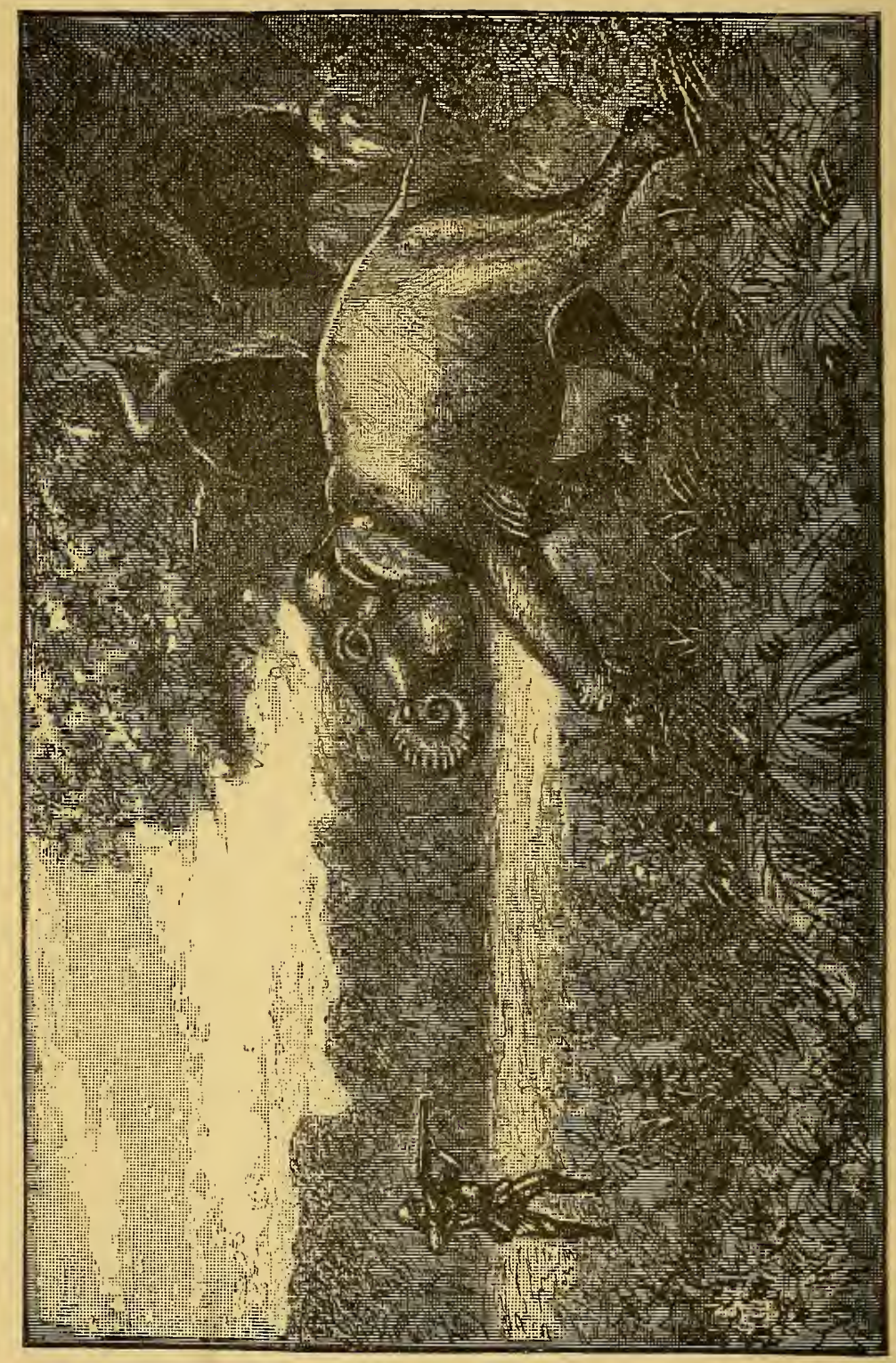

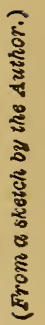


upon the herd. Just as I reached the middle of that small open space, I heard a profound rustling among the thick branches that screened the herd; in another instant the branches parted suddenly, and a luge old female came rushing down upon me.

She had sufficient distance to get under full headway, and although my breath stopped and my heart stood still with sheer fright, I yet realized she was the grandest living object I ever sawand the most terrible. Her head was held high and her trunk curled up under her mouth to be uncoiled when within reach of me, I suppose; her ears seemed to stand straight out from her head with the tips curled forward, and the strides of her massive legs were perfectly enormous. Luckily she came on in dead silence, or I should have been frightened out of my wits. As it was, I felt as if I was going to be run over by a locomotive. I knew it was useless folly to run, for in a few strides she would have been upon me. When I saw her coming I stood up quickly and faced her, threw my gun up to my shoulder and fired both barrels, at the base of her coiled-up trunk in the direction of the brain. She was within fifteen paces of me when I fired, but the thundering report, the smoke, and two zinc balls crashing into her skull close to her brain, stopped her charge, for she sheered off suddenly and rushed into the forest, trumpeting shrilly once or twice. Directly there was a grand crash and a rush in the thicket as the herd broke away and started off, and that was the last we saw or cared to see of it.

Then I had time to reflect upon what "it might have been" had my caps failed to explode, or my powder been damp. Once when walking on a railway track in a snow-storm, I was very nearly run over by a locomotive coming down a grade in muffled silence, and my sensations then were precisely the same as when that old female elephant came charging down that grassy slope. The approach of the powerful machine and the living monster seemed exactly alike. 


\title{
CHAPTER XIII.
}

\author{
MONKEYS, BEARS, AND ELEPHANTS.
}

Tho Black Langur. - Monkey Shooting. -A Startling Cry. - Absurd Encounter with Three Bears.-A Stern Chase.-Death of Number Two.-A Woful "Slip 'twixt cup and lip."-Surprise Number Two - The Old Bear Dies. -Habits of the Species. - A Typical Elephant Hunt.-Hunters Hunted.Wonderful Manœuvring of the Elephants.-A Stealthy Retreat.-A Double-barrelled Attack._"Shavoogan!"-Panic-stricken Hunters, Failures, Fever, and Scarcity of Food.

From the day we entered the forest we began to collect specimens of the black langur (Semnopithecus cucullatus), which actually swarmed in the tree-tops wherever we went. We often saw more than a hundred and fifty in a day, and had we desired, might easily have killed fifty every week. They are usually found in troops of five to ten individuals, and are very noisy, uttering a most diabolical cry which can be heard a mile in the densest forest. Often when out hunting with my gang, stalking like silent shadows through the forest, every eye and ear keenly on the alert to detect the presence of large game, we would be suddenly startled by hearing exploded thirty feet above our heads, a terrific guttural "wah! wah!! wah!!!" followed by a loud "a-hoo-oo-hoo-oohoo-oo," making the forest ring. On looking up we would see a jet-black face encircled by a ring of long, white hair, grinning and making faces at us from the fork of a tree. The moment we raise a gun the whole troop starts up, and the branches are alive with leaping and climbing black forms, each of which tries to make the quickest time on record in getting out of range. Once fairly started, they go galloping off through the tree-tops so fast that we have hard work to keep in sight of them, and mark down the largest one when he stops. But after about two hundred yards or less the flying column calls a halt to rest, count noses, and see how we below are getting on. 
As we hurry up, rifle in hand, my swiftest-footed Mulcer stands there with a long, bare, black arm, pointing upward into the top of a hundred-and-twenty-foot blackwood tree, and we begin to peer and dodge about to catch a glimpse of the largest monkey in the troop. All the men gather round the tree and peer and point, and try to show me just where he is. At last we see his head, and a pair of black eyes staring stealthily down at us. The rifle is up in a second, and we are about to pull the trigger when adios!-the monkeys are up and off again, and the chase begins anew.

The very same performance is repeated again, and perhaps two or three times more, the monkey running away just as I catch sight of him and raise my rifle. But at last he waits a little too long, the rifle cracks, the monkey starts up violently, clutches desperately at the branches around him, loses his balance, and with outstretched legs and arms, the big, black body comes flying down through space without touching a single limb to break his fall, and strikes with a terrific thud upon the earth. We naturally think such a fearful fall has broken every large bone in his body, but we find only a humerus, or perhaps a femur snapped in two. If he is not dead, or likely to die quickly, I take from my shot-bag a knife with a very slender blade, thrust its sharp point into his occiput, give it a slight turn and presto! he is dead. Then the Mulcers peel a long strip of bark from a tree near by and tie together the legs of Semnopithecus cucullatus, sling him under the pole with the deer or other small game and we start on.

It would seem that this black langur utters his diabolical cry at any animal of which he is particularly afraid, and it is well known that a troop of them will sometimes follow a tiger for some distance, hooting and swearing at him just as they did at us. The whereabouts of a tiger has often been discovered in this way, for instead of running from him they follow him up. After the explosive "wah! wah!" the remainder of the cry is continuous, every alternate syllable being produced by drawing in the breath, so that the sound is very much like that made by sawing an empty barrel in two. Many times the startling cry above our heads, and so very near, has caused us all to jump and involuntarily grasp our weapons, causing much amusement afterwards. At such times it always seemed to me that the monkeys were swearing at us, and the fiendish expression of their faces strengthened the belief.

From first to last I shot about forty.five langurs, out of which I got twenty skeletons and eight skins. The tree-tops were so lofty 
I was obliged to shoot them all with my rifle, and in order to get a skeleton having no broken bones, I had to shoot one monkey through the head and take its body and legs, and shoot another of the same size through the body for the sake of its skull. The Mulcers ate the flesh of every one I killed, and had it not been that deer were plentiful I should have been tempted to try it myself.

The black langur is a very handsome monkey. The fur is fine and glossy, black throughout, except that the head and nape are gray or grayish brown, the face is encircled by a ring of long gray hairs, and in old individuals there is a large gray patch on the rump. The largest of my specimens measured, head and body, 29 inches, tail 37 inches. But this was a giant in comparison with all the others, a good sized one being, head and body 23 inches, tail 35, and weight 23 pounds, which should be set down as the average size of this species.

One morning when out looking for elephants, we had a rather amusing adventure with a party of bears. We had tracked down and killed a sambur, but unfortunately it was too young to furnish either skin, skeleton, or skull, and so the game fell a prey to the Mulcers, who joyfully cut it up and loaded themselves with the flesh, while I looked on in disgust. On the way home we were strolling stupidly along in Indian file, utterly listless and inattentive, when, happening to cast my eyes to the left, I was amazed at seeing three black bears loping slowly along, one behind the other, and only thirty yards away. They were going to cross our path, and had we all been a trifle more stupid, we would have actually come into collision. The bears were wholly unaware of our presence and so were all my men of theirs' until I awoke the whole crowd by throwing up my rifle and firing at the largest bear.

Directly there was a terrible uproar. The bear fell to the ground, howling and bawling with all her might, while the other two pitched right upon her, snapping and snarling viciously, and all three yelling in concert. I had a rubber blanket tied around my shoulders to keep off the rain and the fever, and owing to my encumbrance and sudden excitement, I made most awkward work in getting reloaded. The wounded bear tried her best to charge us, although I saw her spine was broken, and as quickly as possible I gave her another bullet through the shoulders, which seemed to satisfy her rather better. By the time I had again reloaded, the two unwounded bears had taken in the situation and started up the hill as hard as they could go. A hundred yards away they 
ctopped, and one stood up on his haunches to have a good look at us. I fired at the yellow crescent on his breast, but missed, and on they went again.

Telling Arndee to come on, I started after them, throwing away my hat and rubber blanket as I ran. We could see the low bushes shake a hundred yards in advance of us, and occasionally we caught a glimpse of a black form, but could not get a shot. We crossed the top of the ridge, ran down the other side and found the bears were gaining on us. We crossed the ravine at the foot of the hill and started up the other side, which was very steep and in places thickly overgrown with brush and clumps of bamboo. Near the top of the hill we came to an unusually thick patch of underbrush, in which we heard the two bears grumbling and swearing as they paused to rest a little. Keeping a sharp lookout, we soon sighted a glossy black form, at which I fired.

Evidently the shot took effect, for directly one of the bears set up a terrible bawling, and came rolling end over end down the steep slope, clawing right and left, and yelling "bloody murder" at every tumble. He rolled down to within twenty feet of where we stood and finally lodged in a clump of bamboos, where he remained motionless and quiet. Arndee exclaimed that "he was dead ;" I thought so too, and so we started on after bear number three.

We found his trail at the top of the hill and followed it a little way, when I discovered that my head was aching and throbbing terrifically, so we abandoned the pursuit and went back to bear number two. We reached the spot, but lo and behold! we beheld not the bear. He had evidently concluded, on thinking the matter over, that he was not quite dead enough to skin, so he had picked himself up and gone off about his business. He left a ferw "foot-prints on the sands of time," and a drop of blood here and there, but that was all. We followed his trail for a mile or so, abandoned it finally in disgust, and went back to the scene of our first encounter.

We expected to find the dead bear, four Mulcers, and my castoff garments all there together, but to our utter amazement we found none of them! The whole affair began to look like a dream, but while I was trying to study it out, Arndee found where the old bear had gone off, dragging her hind-quarters,-and my gang had loafed off home. Vowing vengeance on those heedless rascals we started to follow up the broad and bloody trail left by our wounded quarry. 
Going up a brushy hillside close by, we came suddenly upon her, and were within twenty feet of her before we knew it. She saw us first, wheeled around and came charging at us, dragging her hindquarters, jaws wide set and eyes glistening, while her angry growls told us she was desperate and meant mischief. Arndee shouted a warning and vanished, but I stood still until she got within ten feet of me, then fired at the centre of the yellow crescent on her breast, which shot finished her.

This specimen was an old female (Ursus labiatus), no doubt the mother of the two smaller bears ; but, unfortunately for science, she had been living in a rocky cavern which had a very low front door, for the hair was worn off her back until the skin was quite bare. She furnished a fine skeleton, however.

The Indian black bear inhabits all India south of the Ganges, and also Ceylon. It lives chiefly in rocky caverns and fissures and feeds upon ants, both black and white, the larvæ of certain longicorn beetles which it forcibly sucks out of the ground, and various fruits, especially that of the mohwa tree (Bassia latifolia). Like our American bear, this Indian species is very fond of honey. During my hunting on the Animallais I never came upon any other bears than those mentioned above, but $\mathrm{Mr}$. Theobald has killed a good many there. Ursus labiatus is found in many other parts of the Madras Presidency, viz. : the Neilgherries, the Shervaroy Hills, Pulneys, the Wainaad, and also in Mysore.

In due time another herd of elephants visited our forest, and we lost no time in hunting it down. The trail led us a merry-goround of between twenty-five and thirty miles before we came to the end of it: Taking it up in our forest, it led out of that across the Teckadee River into the Government Leased Forest, made an immense circuit in that and recrossed the river again. Presently it led once more out of our forest, across another river, and this time entered the native territory of Cochin. We hoped the herd would recross the river higher up, and once more enter our huntinggrounds, so we took off our clothes for the third time that day, waded the river and kept on. Up hill and down the trail led us, through wet marshes, open glades, and dense forest, the signs growing fresher every mile, but still it went farther and farther into Cochin. At last, as it led us up a very steep and very siippery mountain-side which fairly took our breath away, I vowed we had. fairly and squarely earned one of those elephants, and we were going to have it, too! The fine for shooting an elephant in Cochin 
was even greater than for the same offense in the Coimbatore District, but we wanted an elephant terribly. We started our game in our own forest, and being thoroughly excited by the chase, we determined to kill an elephant out of that herd if possible, and risk the consequences.

We gained the top of the mountain at last, and then Arndee declared that the elephants were a great way off yet, it was a long way back to camp, and we had better abandon the chase. I said "No," very decidedly. The men started on, grumbling as they went, and in less than ten minutes more we sighted the herd! There was a very fine tusker in it, but he was feeding in a bit of open forest, and it was impossible to stalk him successfully.

Baiore we were aware of it, Arndee and I had walked into dangerous proximity to a group which included three female elephants and two calves. Out of a thick patch of underbrush, forty yards from us, there came up the end of a huge trunk with the tip bent in our direction. Then another trunk came up, and sniffed the air suspiciously, first in one direction and then another. Presently a movement was made in our direction, and two of the elephants emerged from the brush and stopped short, scenting the air in every direction. Arndee and I shrunk our bodies up as small as possible and cowered closely behind the foot of a tree, while I cocked both barrels of my gun and made ready to meet a charge.

For fully four minutes-a very long time under such circumstances-those two elephants stood there within twenty-five paces of us, listening intently, watching every object, and scenting the air very suspiciously, actually trying to discover where we were. They knew we were somewhere near them, and they deliberately searched for us to attack us. Every moment we expected to be discovered and charged by both the elephants, which would have been disagreeable, if not fatal. At last, one of the pair started straight in the direction of the other men, who had climbed trees, fifty yards off. When the elephants started for them, Arndee made a frantic signal with his arm, and the Mulcers went on up like squirrels. The old scout walked directly under them, then turned and came back, and during this diversion Arndee and I lost no time in beating a safe retreat. In returning, he came directly to the spot where we had been concealed, paused, and stood motionless as a statue for about two minutes, then quickly but noiselessiy vanished in the thicket, and all was silent.

We moved up again and waited to see what the herd was going to 
do next. Not a sound was heard for some minutes, not a movement seen. At last we stole up cautiously, and to my utter amazement I found that the entire herd had taken the alarm and stolen off through the thick undergrowth, without making a single sound that we could hear at a distance of fifty yards! Not a rustle, not a broken twig, nor a noisy footfall.

I was really amazed at this exhibition of sagacity and almost military mancuvring. We saw them deliberately

1. Reconnoitre dangerous ground by sending out scouts and spies.

2. Communicate intelligence by signs, or sign language.

3. Retreat in orderly silence from a lurking danger; and

4. March off in single file, like the jungle tribes of men.

How different was this stealthy, noiseless retreat from the wild stampede which follows an open attack, in which the crashing and tearing through the jungle is at first appalling. This time the foe was still in ambush when discovered, and the order signalled was, "Retreat in silence and good order."

And yet there are intelligent people who believe that none of the lower animals are capable of reasoning.

I have often been led to admire the perfect silence in which the elephant goes through the densest jungle, particularly when fleeing from an enemy. The sambur goes tearing through the forest when alarmed, smashing dry twigs and galloping over the ground with so much noise that he can be heard more than a quarter of a mile away; a herd of bison makes the earth fairly tremble during its first burst; but the lordly elephant, largest of all terrestrial mammals, glides away like a gray shadow, without breaking a twig, or scraping against a bough. His foot is like a buge, india-rubber car-spring, and is literally shod with silence.

Upon finding the elephants had decamped, we immediately made after them, and in half an hour came suddenly upon them, feeding quietly in thick underbrush. By great good luck the old tusker was nearest us, and facing in our direction. Without a moment's delay, I crept up in front of him, hid behind a tree considerably smaller than my body, and at a distance of trrelve paces waited in anxious suspense for him to face me a trifle more fully. Presently he swung around just right, and presented as beautiful a front head-shot as any hunter could possibly ask or obtain. I fired instantly, both barrels of my No. 10 with twelve drachms, aiming at the base of the trunk in the centre of the face. The gun kicked 
fearfully, nearly knocking me over, and I thought it had killed both the elephant and myself, but to my disgust I found it had done neither. The elephant wheeled around, and in doing so fell upon his knees, but while I was recovering from the stunning effects of my shot, he regained his feet and made off slowly and in silence.

Wiping the tears from my eyes and the blood from my nose, I started after him as fast as I could run, reloading as I went. At every new turn I expected to come upon him lying dead, but somehow I didn't. We were sure of having him down within an hour, and as we went puffing up that steep mountain-side, I planned just how we would skin and skeletonize him and get his remains to the nearest road. We were pushing along at our best speed, all excitement and eagerness, determined to bring down that elephant before we stopped, no matter whether he ran one mile or twenty, when suddenly we heard, "Hi-yoh-ho!" shouted out loud and clear a quarter of a mile directly ahead of us.

At this clap of thunder from a clear sky, we stopped dead short and looked at each other. "Hi-yoh-ho!" Again and much nearer! The men turned almost pale with fear, and with one voice exclaimed in a most tragic stage-whisper, "Shavoogan!"

It was the only time I ever saw those rascals really terrified. Without another word, they wheeled about, turned off the trail and fled down the mountain at full speed; of course I followed to see that they all got safely back to camp. We went down the steep slope about six feet at every step, fleeing in dead silence from that terrible "Shavoogan," whatever that was. We went as though the great dragon was close behind us, and never paused a moment, nor uttered a word, until we were at least three miles from that awful "Shavoogan." Then we enjoyed a laugh at our own expense over the sudden and ludicrous manner in which the tables were turned upon us.

I need scarcely add that that elephant escaped, or that we did also, and that I added another word to my Tamil vocabulary. "Shavoogan," is the Tamil word for "watchman" or "peon," and the one we heard belonged to the service of the Rajah of Cochin.

To my dying day, I shall never understand how I failed to kill that elephant in his tracks. I had a fair shot, had done my very best and failed, and was therefore at my wit's end. Such failures as that and my first one are, of all others, the most disappointing and discouraging. I had done all I knew how to do, and what 
could I do more? Those were the bitterest failures I ever made in hunting.

During my first six weeks in the hills, all circumstances seemed to combine against me. Several times we found the fresh tracks of elephants, and followed them diligently for several hours, only to find where the trail crossed over into the Government Forest, where we had no right to follow. It seemed at last as if the elephants knew that when we got after them, they had only to cross the Teckadee River to get beyond our reach, and fnally we almost despaired of ever coming up with elephants in our forest.

During all this time I devoted myself almost exclusively to elephants, killing no other game of any consequence, save enough deer and sambur to supply the camp with meat. Indeed, I fired as few shots as possible to avoid frightening away the larger kinds of game, particularly the elephants. I had had two glorious chances, and each time failed to kill, although $I$ had done my best. In fact, I was trying to shoot an elephant according to the recipe given me by my friend Theobald, and it was uphill work. Every week or ten days I had an attack of jungle fever, but it was always of the mild, intermittent type, and after about three days I would have it broken up with quinine, so that I could go hunting every day again until it returned. Several times the fever came on me when out hunting, several miles from camp, and I would have to crawl back as best I could, with my head throbbing like a steam-engine. My remedy for the fever was ten grains of quinine dissolved in half a wine-glassful of clear brandy, taken two or three hours before the fever was expected, then the same dose morning, noon, and night, until once more able to travel.

My provisions became exhausted all too soon, and I came down to plain bread, rice, and venison, with a potato now and then, by way of luxury. My cook was a failure at making curry, that "dish fit for the gods," without which India would be uninhabitable for either natives or Europeans. Being heavily handicapped on curry, I had to live upon deer and sambur tongues, with venison steaks and roasts by way of variety, and dry boiled rice. Once a week Mr. Theobald and I sent a coolie to Coimbatore (50 miles), for a basket of bread, but by the time the loaves reached me, they were always mouldy. A dozen bananas or potatoes were a positive treat, so scarce were fruit and vegetables during that long period of semistarvation. After a while, there came upon me an intense craving for vegetables, which could only be satisfied by Crosse \& Black. 
well's mixed pickles. But I cared very little about my inner man during those days; and, as nearly as could be possible, he was left to take care of himself.

After my second failure at shooting elephants, I determined to hunt smaller game for a time, and give that persecuted animal, as well as myself, a rest. Very soon after this my luck took a turn for the better, which now makes it necessary for me to say something about tiger-hunting. 


\section{CHAPTER XIV.}

\section{A TIGER HUNT.}

Tigers. - The Game-killer. - The Cattle-lifter. -The Man-eater. - Reign of Ter ror.-Eight Hundred Victims Annually.-Modes of Tiger-hunting.-Howdah Shooting. - Machan Shooting.-Shooting on Foot.-An Impromptu Tiger-hunt.-The Trail.-A Light " Battery."-The.Game Overhauled.A Good Shot.-Death of a Superb "Game-killer."-Dimensions and Weight.-A Proud Moment.-Struggle to Preserve the Skin.

Accondivg to their habits in procuring their food, tigers are divided by the people of India into three classes.

The least harmful is the "game-killer," who lives in the hills and dense forests where wild game is abundant, and leads the life of a bold, honest hunter. He feeds chiefly upon deer and wild hog, and so long as he remains a game-killer he is a real blessing to the poor ryots, who have hard work to protect their crops from the droves of deer and wild hog which sally forth from the jungle at nightfall to depredate upon them. But the trouble is, there is no knowing when this striped sportsman will take it into his head to try his teeth and claws on cattle or men : in fact, he is not to be trusted for a moment.

The "cattle-lifter" is a big, fat, lazy thief, too indolent to pull down fleet-footed wild animals, who prowls around the villages after nightfall, or the edge of the jungle where the cattle are herded, and kills a bullock every four or five days. The annual loss to the cattle owners whose herds are thus preyed upon by the cattle-lifter, is very great for poor natives to bear, since each tiger destroys in a year, cattle worth at least four hundred dollars.

But even the most greedy cattle-lifter sinks into insignificance in the presence of the fierce "man-eater," the scourge and terror of the timid and defenceless natives. Until a tiger has once had his fangs in human flesh, he has an instinctive fear of man, and unless attacked and brought to bay will nearly always retreat from his presence. But with his first taste of human blood that fear 
vanishes forever. His nature changes, and he becomes a maneater.

Tigers who prey upon human beings are usually ex-cattle-lifters, who, from long acquaintance with man have ceased to fear him, and find him the easiest prey to overcome and carry off. A large proportion of the man-eaters are mangy, superannuated, old tigers or tigresses, whose teeth and claws have become blunt with long use, and who find it too great an exertion to kill and drag off bullocks.

The presence of a man-eater causes a perfect reign of terror in the district which he frequents, which lasts until he is slain. It is almost invariably the case that the brute confines his operations to a few square miles of territory, and perhaps a dozen villages, so that each one becomes a walking scourge whose form, habits, and foot-prints become thoroughly known to the terrified villagers. At first, perhaps, he carries off a herdsman instead of a bullock, by way of experiment, and soon after an unlucky woodcutter at the edge of the jungle shares a similar fate. Finding that he can easily and with perfect safety kill men, he gradually becomes bolder, until finally he enters the villages after nightfall and seizes men, women, and children from off their own door-steps. No one is safe save when in his house with the door shut and barred. The herder no longer dares to take his hungry herd to graze in the jungle, and for the woodcutter to go forth to his task in the forest, would be to literally walk into the jaws of death.

The man-eater may be seen in the evening near a certain village, and before morning carry off a man from another five miles away. No one can say that he will not be the next victim. When the people go to sleep at night the last thing they think of is the maneater, and he is first in their thoughts when they awake in the morning. It is a horrible feeling to live in constant fear of being suddenly pounced upon by a big, hungry, wild beast that can carry you off in his jaws and eat you up clean at one meal.

But, thanks to English sportsmen, improved fire-arms and the liberal rewards offered by the Government, man-eating tigers are now rare compared with what their numbers once were. It is not now possible for a single tigress to cause the desertion of thirteen villages, and throw out of cultivation fifteen square miles of territory, as once occurred in Central India ; nor for another to kill one hundred and twenty-seven persons before being laid low. And yet, in spite of breech-loading rifles and zealous British sportsmen, 
poison, and pitfalls, the man-eaters still devour over eight hundred human beings in India every year.

The tiger inhabits all India from the Himalayas to Cape Comorin, and is hunted in three different ways.

The first, the best, and most interesting plan, is howdah-shooting. In this, the hunter is perched on an elephant's back, high up out of harm's way, in a comfortable square box called a howdah, with his weapons and ammunition placed conveniently around him. Of course the elephant is managed by a mahout, who sits astride his neck with an iron goad in his hand, a very exposed position, in fact. When it is possible, a large number of elephants are mustered for the hunt, to assist in stirring up the tigers. Now and then a grand party is made up of four or five.English sportsmen, and twenty or thirty elephants ; and perhaps five or six tigers and much other game may be killed in a week. But this is a very expensive method, and cannot be practised except by the wealthy or the influential few. This is an eminently safe method, too, the greatest danger attending it being the running away of one's elephant and the wreck of the howdah. Ladies often attend hunts of this kind, which tends to place this once noble sport upon a level with lawn tennis and badminton.

Tiger hunting with elephants is most extensively practiced in Central India where the jungle is in low, scrubby patches with bare ground between, and in the Terai, a wide stretch of grassy halfforest skirting the base of the Himalayas. In Southern India there is little chance to employ elephants in this way, because of the wide tracts of dense jungle * and forest in which no tiger can be effectually marked down and "flushed." Elephants can be used to great advantage, however, in following up a wounded tiger, a pursuit too dangerous for even the most reckless sportsman to prosecute safely on foot.

The second and most general plan of tiger hunting, is called " machan-shooting." A machan is a platform of poles, fifteen to twenty feet high, erected in the daytime near a recently killed bullock, a live bait, or a pool of water. Usually it is placed in the top of the treo nearest the spot or object the tiger is expected to visit.

In Central India where the jungles can be beaten for tigers, the

* In the East Indies the term "jungle" is applied to all kinds of arboreal growth lying in large tracts, whether it be composed of heary forest, low brush-wood, or a scattering growth of scrubby trees in tall grass. 


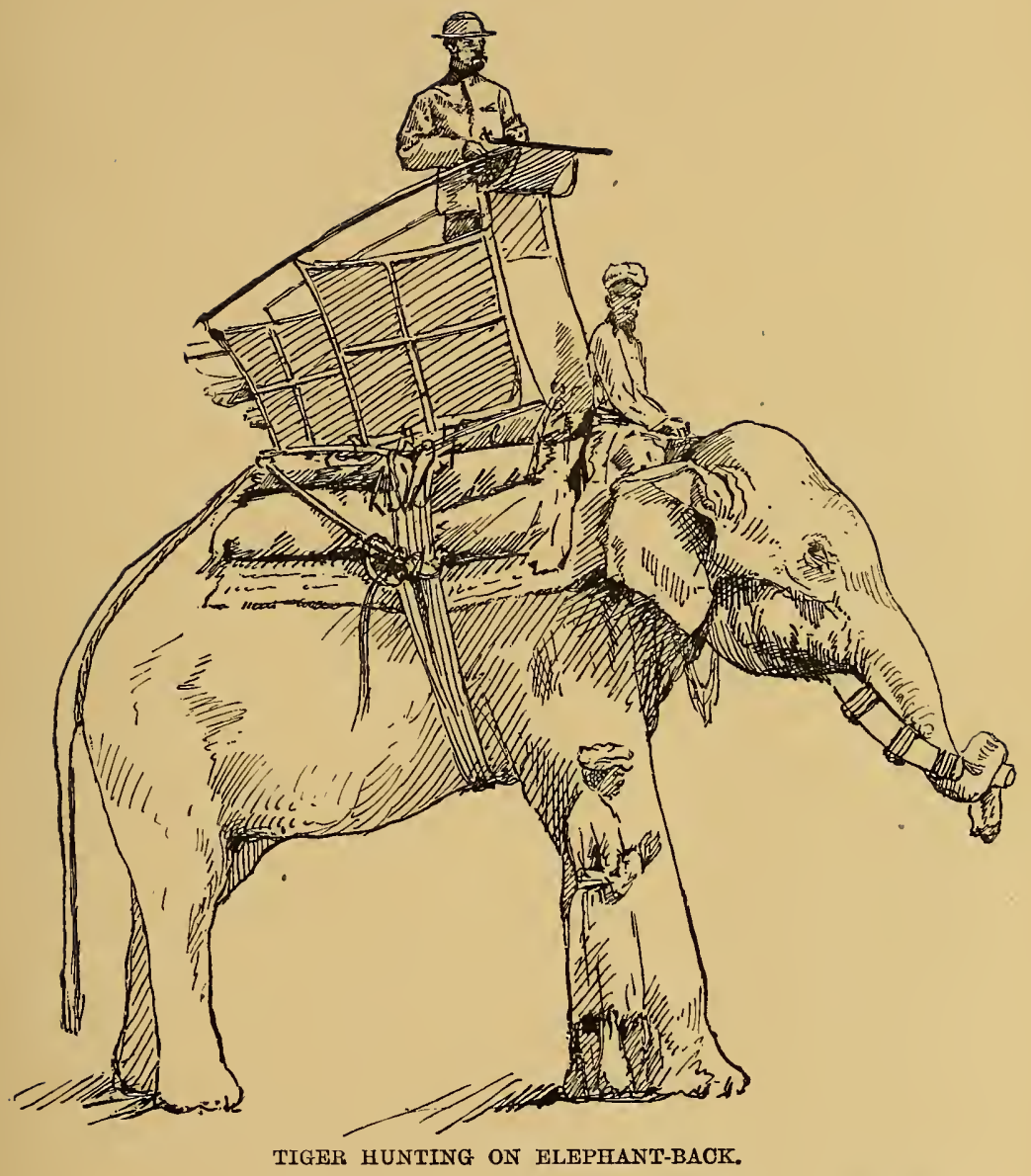

(From a photograph by A. G. R. Theobald.) 

sportsman builds his machan in the most favorable position, takes his place upon it, and waits while the tigers are actually driven toward him by a grand army of beaters-from fifty to three hundred native men blowing horns, beating tom-toms, firing guns and shouting, and then, when the tiger's come running past his position, he kills them-if he can. When a tiger lills a bullock, the hunter quietly builds a machan in the top of the nearest tree, takes up his position in the afternoon, and waits patiently until the tiger returns to his feast at nightfall; then he shoots him, or at least shoots at him, in the dark.

It is very seldom that accidents occur in hunting tigers by either of the above methods, for usually the sportsman is not in the least danger.

Shooting on foot is the third method of tiger hunting, but it is so dangerous that it is not regularly practised except as a last resort, and the most reckless hunter never dares follow it up for any length of time. Nine-tenths of all the tiger "accidents," as they are called in India, occur to sportsmen who are shooting on foot. The Collector of the Coimbatore District acknowledges the superior dangers and risks of this method by paying a reward of one hundred rupees for a tiger shot on foot, whereas he grants only the minimum reward, thirty-five rupees, for a tiger shot from a machan or poisoned. When a hunter attacks the tiger in open ground, he must shoot the animal in the brain or else break his spinal column, for nothing else is sure to stop his furious charge. A tiger is but a gigantic cat, endowed with the traditional nine lives, and even though shot through the heart, the lungs, body, neck or shoulders, he often has strength enough to spring upon the hunter and give him a terrible mauling or a mortal wound before falling dead. Tigers often become so enraged by the pain of their wounds that they attack the hunting elephants with the greatest fury.

The Animallai slope was one vast, unbroken forest, with such endless cover that successful beating for game was simply out of the question. There was such an abundance of it that no men or cattle were ever killed by tigers, and hence our only chance for finding them at all was to track them up on foot, or trust to meeting them by chance. Either plan was risky, but I had enough faith in the accuracy of my little Maynard rifle, and my own steadiness, to believe that between us we could floor a tiger if we ever got a fair chance. In tramping through the forest I often wished I could come face to face with a tiger and get just one fair shot. 
I thought I would like to be a little above him, if possible, so as to get a better view of his face, and be more certain of hitting the brain. I spun my theories very finely, and all I asked was a chance to give them a trial.

We often tried to follow up the "pugs" we found in the forest, and it was in this way I finally made the acquaintance of " $m y$ first tiger." It was during one of my fever-spells, too, when I was feeling rather low-spirited. I had been seven weeks in the hills, hunting constantly when not down with the fever, but had killed neither elephant nor tiger, and was beginning to think I never would. I had shot nothing for several days, and consequently there was no meat in camp. The old women grumbled, the little children cried for it, and, in fact, I wanted some fresh venison myself.

On that particular day, I had an attack of fever due at 2 P.M., but I thought I could stroll out and shoot an axis deer before it came on. It happened that three of my men had been sent away on various errands, and there remained in camp only Pera Vera, my second tracker, afterwards my head man, Nangen, a very quiet but courageous young fellow, and a small boy. I took along these three for general purposes, my little Maynard rifle for the deer, and my No. 16 shot-gun, loaded with bird-shot, for jungle fowl. Not a very heavy "battery," certainly, when compared with the formidable array of double rifles from the 4-bore, throwing a 4ounce ball, down to the double .577 Express rifle as the least deadly weapon which every genuine English sportsman in India possesses and carries with him when after big game. It takes twenty-nine of my Maynard bullets (calibre .40), to make a pound.

We hunted all the forenoon, and found a herd of axis deer feeding in a glade, but I had not enough energy to make a successful stalk, and so that chance was lost. In fact, I did not care much whether school kept or not.

We strolled through the Government Forest until nearly noon, when, just as we were about returning to camp, we heard a fearful growling and roaring a few hundred yards in advance, which set us instantly on the qui-vive. We hurried in the direction of the sound, which continued at intervals for some minutes. I said, "Tiger, Vera?" and he replied: "No, sahib, panther. Shall we go for it?" "Of course," and on we went.

Presently we heard trumpeting and branch-breaking half a mile beyond us, and then Vera said the low roaring, or growling, noise had been made by the elephants. On our way toward the ele- 
phants, to have a quiet look at them, we came to a little nullah,* and there, in the level, sandy bed of the stream, was the trail of a large tiger.

The men carefully examined the huge tracks in the wet sand, compared notes a moment, and declared the trail was fresh. Then I examined it for myself, looked wise, and said; "Oh, yes, it is ; very fresh, indeed." Vera looked anxiously about a moment, examined the bore of my rifle doubtfully, tried to measure it with the end of his little finger, and finally asked me very seriously whether I would dare to fire at a big tiger with that small rifle. I said, "Yes, certainly ; just show me one and see." I did not for a moment allow myself to hope for such good luck as a meeting with the animal that made those huge tracks, and a shot at him. But without a moment's delay we started to follow up the trail.

The little creek ran through perfectly level and very open forest. Its bed was about eight feet below the level, forty feet wide, and almost dry. The tiger had gone loafing leisurely along down the bed of the stream, walking in the shallow water every now and then, crossing from side to side, and occasionally sticking his claws into the bank, as if to keep them in practice. Vera led the way as usual, I followed close at his heels, and we stole along as silently as shadows.

We had followed the trail about a mile, when we came to a clump of bamboos growing in a sharp bend in the stream. Vera stopped short, grasped me by the arm, and pointed through the clump. He had the habit of grasping my arm with one hand, and pointing with the other whenever he discovered any game, and I could always tell the size and ferocity of the animal by the strength of his grasp. This time he gave my arm such a fierce grip I knew he must have found a tiger.

Sure enough, there was Old Stripes in all his glory, and only thirty yards arvay! The midday sun shone full upon him, and a more splendid object I never saw in a forest. His long, jet-black stripes seemed to stand out in relief, like bands of black velvet, while the black and white markings upon his head were most beautiful. In size and height he seemed perfectly immense, and my first thought was, "Great Cæsar! He is as big as an ox!"

* "“Nullah' is an Indian term of the most comprehensive signification, used in speaking of any channel or water-course, and applied alike to a small river or deep ravine, to the sandy bed of a dried-up stream, or a wet gutter." -A. C. McMaster. 
When we first saw him, he was walking from us, going across the bed of the stream. Knowing precisely what I wanted to do, I took a spare cartridge between my teeth, raised my rifle and waited. He reached the other bank, sniffed it a moment, then turned and paced slowly back. Just as he reached the middle of the stream, he scented us, stopped short, raised his head and looked in our direction with a suspicious, angry snarl. Now was my time to fire. Taking a steady, careful aim at his left eye, I blazed away, and without stopping to see the effect of my shot, reloaded my rifle with all haste. I half expected to see the great brute come bounding round that clump of bamboos and upon one of us ; but I thought it might not be I he would attack, and before he could kill one of my men I could send a bullet into his brain.

Vera kept an eye upon him every moment, and when I was again ready I asked him with my eyebrows, "Where is he?" $\mathrm{He}$ quickly nodded, "He's there still." I looked again, and sure enough, he was in the same spot, but turning slowly around and around, with his head held to one side, as if there was something the matter with his left eye! When he came around and presented his neck fairly I fired again, aiming to hit his neck-bone. At that shot he instantly dropped upon the sand. I quickly shoved in a fresh cartridge, and with rifle at full cock and the tiger carefully covered, we went toward him, slowly and respectfully. We were not sure but that he would even then get up and come at us. But he was done for, and lay there gasping, kicking, and foaming at the mouth, and in three minutes more my first tiger lay dead at our feet. He died without making a sound.

To a hunter, the moment of triumph is when he first lays his hand upon his game. What exquisite and indescribable pleasure it is to handle the cruel teeth and knife-like claws which were so dangerous but one brief moment before; to pull open the heavy eyelid ; to examine the glazing eye which so lately glared fiercely and fearlessly upon every foe; to stroke the powerful limbs and glossy sides while they are still warm, and to handle the feet which made the huge tracks that you have been following in doubt and danger.

How shall I express the pride I felt at that moment! Such a feeling can come but once in a hunter's life, and when it does come it makes up for oceans of ill-luck. The conditions were all exactly right. I was almost alone and entirely unsupported, and had not even one "proper" weapon for tiger-hunting. We met the tiger fairly, on foot, and in four minutes from the time we first saw him 
he was ours. Furthermore, he was the first tiger I ever saw loose in the jungle, and we had outwitted him. I admired my men quite as much as I did myself! They were totally unarmed, and they had seen me miss spotted deer at sixty yards ; but instead of bolting, as I should have done had I been in their place, they stood right at my elbow like plucky men, as they were. What if they had been of the timid sort? They would never have consented to follow the trail of that dangerous beast.

I paced the distance from where we stood to the dead tiger and found it to be just thirty yards. My first was a dead centre shot, striking him exactly in the left eye, scarcely nicking the edge of the lid. I had intended that that bullet should enter his brain, but owing to the narrowness of the brain-cavity it only fractured the left side of the cranium. However, it rendered him quite powerless either to fight or run away, and he would have died very soon from such a terrible wound. In fact, I now think my second shot was really unnecessary. Owing to the position of his head I could not possibly have placed a bullet in his forehead so that it would have reached the brain, but had I been using a regulation "No. 8-bore rifle," throwing a 2-ounce ball, I could have blown the whole top of his head off very neatly (!)-and utterly ruined him as a specimen. My second shot struck one of his neck vertebræ and cut his spinal cord, killing him instantly, a favorite shot with me when I can eatch an animal at rest.

$\mathrm{He}$ was a splendid specimen every way, just in the prime of tiger-hood, fat, sleek, and glossy. Up to that time I could not make myself believe that a tiger can pick up a man in his mouth and run away with him as easily as a terrier does with a rat. But when I measured that great brute, I saw and realized just how it is done. Before touching him with a knife we measured him carefully, twice, and recorded the figures in my note-book. His dimensions were as follows :

Felis tigris.

ANimaluai Hills, September 27, 1877.

Length from tip of nose to end of tail vertebræ ....9 feet $8 \frac{1}{2}$ inches.

Length of tail alone....................... 3 " 6 "

Vertical height at shoulders.................... 3 " 7

Girth.............................. "4

Circumference of neck......................... " " 8 "

Circumference of head around the jaws............ " 3 " 0 "

Circumference of fore-arm................. 1 foot 8 "

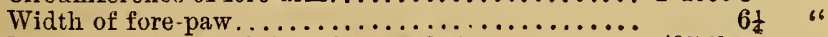

Weight (by standard American scales).......... $495 \mathrm{lbs}$. 
My experience with that specimen will serve as a good illustrar tion of the difficulties I had to contend with in curing skins in that rainy jungle. In a climate that is dry and hot, skins can be cured, sometimes, almost without preservatives; but in the moist and hot tropics, every bit of skin which does not feel the effects of a powerful preservative at the right time will simply decompose before it will cure in the least. When the powdered alum does not reach the epidermis, the latter slips off in "about four days, taking the hair along with it, leaving unsightly bald patches on the skin. Thick skins must be thinned down with the knife, so that the alum will strike through at once to the roots of the hair, and harden the whole skin. For the benefit of the sportsman and the general reader, I am tempted to give brief directions for,skinning a tiger, so that it may be mounted as a first class-museum specimen; for which see the Appendix. We removed the skin of our tiger, applied the preservatives, and hung it over a pole to dry, expecting that such glorious sunny weather as we were then having would allow it to cure in a very few days. That same evening it began to rain, and for the next ten days it was either a steady down-pour or a dreary drizzle. Of course, no skin could dry in such a vapor bath as that, and, worst of all, I was very short of alum.

For a week I played a game with the elements, with that tiger skin for a stake. I hung it out in the air whenever the rain ceased for an hour; I built a fire before it, and came near roasting one leg. I had a wide shed built, near my hut, under which I hung the skin, spread out and stretched so that the air could reach every portion of it freely. I applied to it all the alum I had, both in the dry state and made into a warm bath, but still the skin would not and could not harden in the least, nor get dry so long as I remained there.

Determined not to lose such a specimen we broke up our camp hastily and hurried off half a day's march to a spot that was higher and more open, and where less rain fell. There we found the sun shining, not hotly by any means, and unpacking our tiger skin we spread it out widely in his gracious beams, which saved it at the last moment.

Mr. Theobald sympathized with me very heartily during my troubles with it, and congratulated me upon my final success, informing me as he did so that he had once lost two fine tiger skins under similar circumstances, in spite of all he could do to save them.

I had nearly the same trouble with every large mammal skin I prepared in that rainy jungle, and I realized more than ever that "eternal vigilance is the price of " a collection. 


\section{CHAPTER XV.}

\section{SKELETONIZING AN ELEPHANT.}

Mischievous Elephants. - Chase of a Large Herd. - Death of a Tusker. -Forbidden Ground.-A Secret.-The Mulcer's Oath.-A Change of Base.-Skeletonizing an Elephant in Sixteen Hours. - Cacheing the Bones. - The Traces of our Guilt.-Moral Aspect of the Affair.-The Spotted Deer.-A Pretty Picture.-The Indian Elk or Sambur.-Bad Case of Protective Coloring. -Serenaded by Sambur.-The "Brain-fever bird."-Tree Rats.-The Muntjac._Delicious Venison.-The Neilgherry Goat.-Wild Hogs.

When we returned to Tellicul after our absence while drying the tiger skin, we found all our huts a total wreck. A large herd of elephants had visited the spot and walked through them from one end to the other, tearing them completely to pieces, smashing tables and cots, and even pulling up a few of the posts, and throwing them some distance. All this just for pure mischief, just to be doing something, and to show us what they could do. Many a night in those hills I have heard the trumpeting and squeaking of elephants near our camp, and I would never have been at all surprised to have been awakened by an elephant pulling my hut down over my head. I never went to sleep without Theobald's elephant-gun standing loaded within reach of my hand, and other weapons close by, so that in case any wild beast made us a midnight call we could give him a cordial reception. I also had a hole cut in the end of my hut, at the foot of my cot, so that in case a mischievous elephant should come and knock at my door in the middle of the night, I could get out at the opposite end to receive him in due form.

Three weeks after the death of the tiger, another herd of elephants visited our forest. The moment we found the trail, we set out upon it as fast as we could go, and strained every nerve to come up with the animals before they could get out of our hunting ground. But once more we were doomed to disappointment and aggravation. An hour before sunset, the trackers declared that 
the herd was only a half-hour in advance of us-and the trail crossed the river into the Government Forest, of course! We gave it up that day, but the next morning we took up the trail where we had left it the previous evening, and followed it rather leisurely for some hours, just to see where it would finally lead to. That herd was the largest I ever saw on those hills, containing between forty and fifty elephants, five or six of which were tuskers. In some places it left a trail like the track of a small hurricane, mowing down the tall grass in a swath a hundred feet wide, pulling down and smashing scores of old bamboos in one place, just for the fun of the thing, and, stranger still, we saw several saplings the size of a man's arm or larger which had been half uprooted and borne down to the ground.

The herd had made a wide circuit through a corner of the Government Forest, and just before they quitted it they had done still further mischief. They visited a camp of wood-cutters on the bank of the Toonacadavoo River, where there were four large huts for the accommodation of over fifty men. We found the huts torn and smashed all to pieces, and of the long row of round stones on which the men set their chatties of rice to cook, every stone had been displaced and rolled about by those rascally elephants.

From the huts, the elephants had turned off westward and headed straight for Cochin. In one place we saw where an old tusker had been barking a tree with his tusks, just for amusement, and once where he had thrust them into a bank of earth for a foot or more. Again we came to where he had lain him down to sleep and left a very perfect impression of his right tusk in the moist earth. The trail led us through all sorts of places, and finally crossed the boundary into Cochin. At last, we overhauled the herd as it was feeding along a rather steep, grassy hill-side, which was strewn here and there with rugged rocks, a capital situation. But alas! we were on forbidden territory again, Cochin this time, and once more that fine loomed up before our eyes. Apart from the fine, I had no conscientious scruples about the matter, for when an elephant roams through four territories in one day, to which does he belong more than to the others? I argued the question, gave it up, and decided to kill one of those elephants if possible, take its skeleton for my collection, and if caught, pay the fine and call it square, although financially it might prove a losing game.

We posted ourselves among some large rocks, well in advance of the elephants, and waited for them to feed up toward us. 


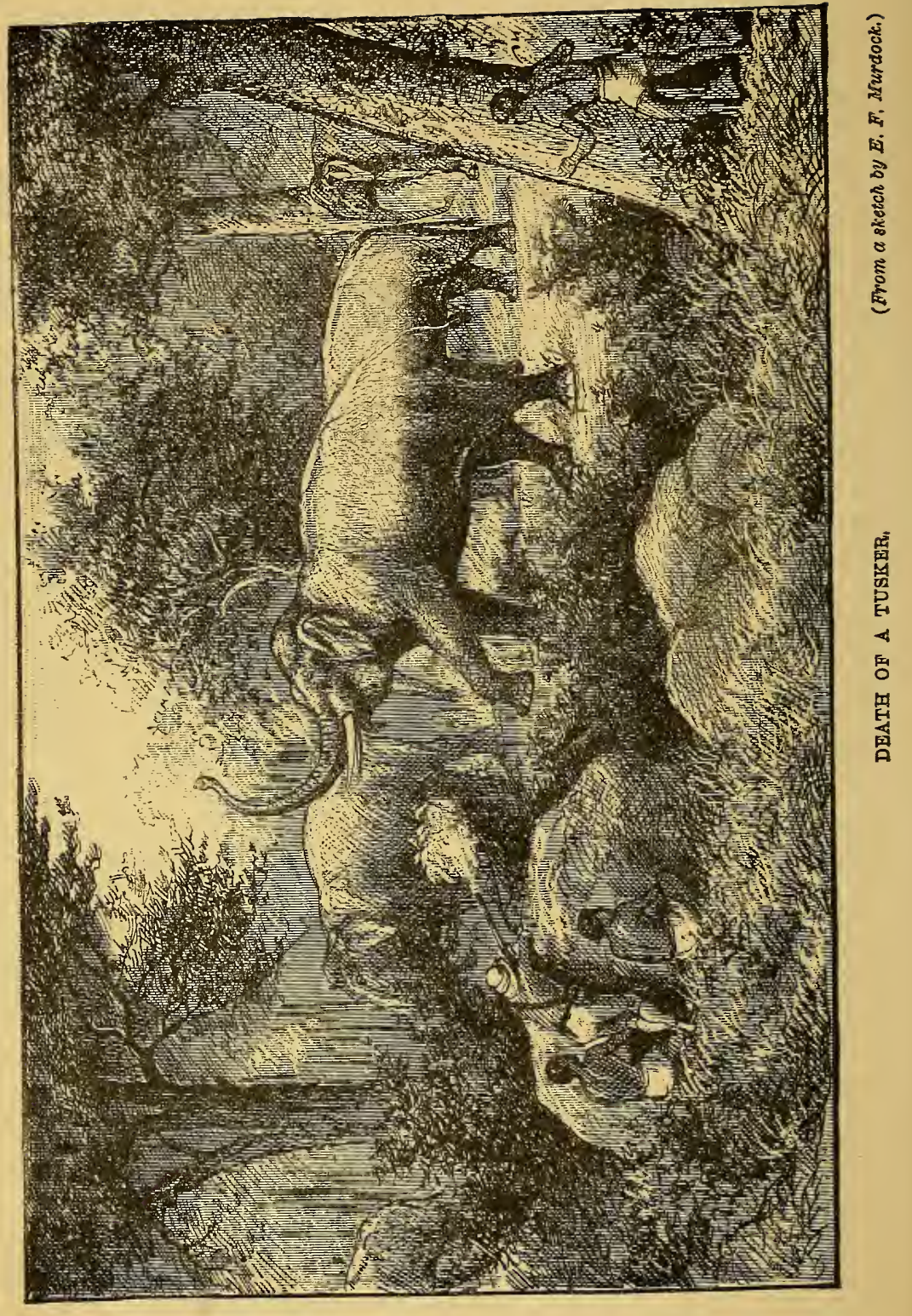


On they came, and we saw there were five tuskers. This time I made my calculations more carefully than before, fired confidently, and my victim sank down in his tracks without a groan, and died without a kick. Being well below our position, he received my spherical zinc bullet high up on the left side of his head, whence it ranged downward, passing through eleven inches of bone and eleven inches of brain, and came out well below his right ear. I regret to say that he was not the largest tusker in the herd, being surpassed by one other which was so surrounded by other elephants that he was practically inaccessible, and therefore the victory was not as great as it might have been.

We returned to camp directly, and ordered all the women and children to start at once for Toonacadavoo. We had a big secret to keep, and preferred to manage it without any of their assistance. Women can keep a secret very closely, but it usually requires a great many of them to accomplish it. As soon as the women had been bundled off, bag and baggage, I told my men, through my cook-interpreter, that no other person besides ourselves must ever hear anything about that dead elephant, for should it get found out we would all get into trouble. They declared the secret should die with them. Then my new servant, Mullen, a private peon lent me by Mr. Theobald, resorted to a little device to play upon the superstitious feelings of the Mulcers.

Mullen was a Mohammedan, and a very shrewd fellow every way. He took my two big guns, laid them upon the ground, one across the other, with the hammers at full cock, and laid my largest hunting-knife-an infant broad-sword, which I never once carried-upon the guns, where they crossed each other. Then he ordered my five Mulcers to walk up on one side of the altar, and told the first man, Channa, to hold up his hands. Channa did so, whereupon the peon administered a sort of double-geared, self-acting oath or invocation, which translated ran about as follows: "Everybody sees that Channa promises before his sawmy (i.e., his favorite god) and these horrible makers-of-dead-animals, that he will never tell any man, woman, or child anything about the dead elephant, and what the 'Merican sahib is about to do with it; and that he (Channa) begs his sawmy to remember, and if he ever does tell about it he prays that his sawmy will send a man to shoot him with one of these guns and stab him with that knife, or one just as large." Channa repeats the oath, steps over the "makers-of-dead-animals," and the ceremony is complete. Each of the others followed in 
turn, while I stood by with a very straight face to lend an air of owlish solemnity to the scene.

Without a moment's delay we broke up our camp and hurried off to the dead elephant, which lay in a wild, unfrequented spot between two ranges of hills. We had a small tent, which we pitched in a lovely little valley, beside a running stream, a quarter of a mile from the elephant. The men cleared a place between three bamboo clumps and piled bamboo branches in the openings, so that a wild animal could not walk over them as they slept without their know. ing of its approach. Shortly before sunset our camp was settled and we were ready for work. I "harangued" the men for a mo. ment, telling them we had hard work ahead of us, and that for the next two or three days I would expect them to work hard, and I would double their wages. Then I served out arrack and tobacco all around, got out the skinning-knives, grindstone, oilstone, lantern, etc., and we lit down upon that carcass like a flock of vultures.

The elephant had fallen upon his side, back down hill fortunately, and we took his dimensions very easily. He was eight feet four inches in vertical height at the shoulders. As he lay there the top of the carcass was just on a level with my chin, and our task was to quarry the entire skeleton out of that great mountain of flesh and blood. We decided that we did not dare to attempt taking the skin, for under the circumstances we would have all we could do to take even the skeleton and get away with it without being seen by any of the Cochin people. Besides, I wanted the skin of a larger animal than that proved to be.

First, we stripped the skin from the upper side of the animal, to have it out of the way, then cut off the two legs which were uppermost, the one at the shoulder and the other at the hip, and set two men at work upon them to cut off the flesh, piece by piece. We found that it required the strength of two men to roll the fore-leg over as it lay upon the ground. From the first we worked very systematically, cutting off the flesh in huge chunks and tumbling it down the hill out of the way. The viscera soon swelled to an enormous size, and when we cut open the abdomen they burst out in a huge, unwieldy mass, that cost us three hours' hard tugging and lifting to detach and move out of the way.

When night came we lighted our lantern, built a large fire near the carcass, and while one man held the lantern and piled dry wood upon the fire to keep it blazing brightly, the rest of us toiled or till midnight, like so many bloody vampires. At last we were quite 
tired out, and having made an excellent beginning, we left off work, went down to the little creek and bathed, after which $I$ again served out arrack all around to the men and finished a quart of Bass' ale on my own account. With our tracking, marching to and fro, and work on the elephant, we had had a hard day of it; but the Mulcers had grown quite plump and vigorous on a two months' diet of game, I had been free from fever for nearly two weeks, and little cared we for any amount of hard work which did not quite kill us.

At sunrise the next morning we were again at our task, and after cutting the flesh from the entire upper side of the body, cutting off the head and as much as possible of the lower legs, we procured levers and, by dint of great exertion and no small amount of engineering, turned the carcass over. After the greater portion of the flesh had been removed, we cut out the sternum in one piece, cut out the ribs one by one, divided the massive spinal column into four sections, and cut each leg in two at ankle and knee. Then all the parts of the skeleton were cleaned neatly and carefully, one by one. The skin of each foot I saved to mount as a footstool, and the tail also was kept as a trophy.

By 4 P.M., after about sixteen hours' hard work, my five Mulcers and I had cut out all the bones of the skeleton, cleaned them neatly, painted them over with strong arsenical soap and tied them up into bundles suitable for carrying: Being anxious to leave that neighborhood as soon as possible, we carried all the bones about three hundred yards and hid them away amongst some large rocks, after which we spent an hour in making that spot look like a dense thicket. We cut green boughs and stuck them up in the heap of bones, and in the clefts of the rocks all around it, making young trees grow up and green branches droop over with a naturalness that was quite artistic. A stranger might have passed within twenty yards of the caché without even suspecting its presence.

But at the scene of action there was about an acre of meat, pieces of skin, blood, brains, and viscera which showed unmistakably that some great animal had been wrecked. That we could not hide, and one of my men, the peon who administered the oath to the Mulcers, proposed that we get several pairs of bison horns and throw them down there, along with a few bones, to mislead any of the Cochin people who might happen to pass that way. It was a good suggestion, but I thought we could risk the matter as it was. Then we "folded our tent like the Arabs and as silently stole away," first obliterating all traces of our camp, and marched boldly down 
to Toonacadavoo-but we persistently refused to be inierviewed on the subject of wild elephants.

The next day I sent the men back with a week's provisions, by the end of which time they had carried off all the bones without being seen by any one, and deposited them in a safe place in the Kulungud forest. I may add in this connection that they were faithful to their oath, at least to a great extent, and I doubt if the people of Cochin have even yet heard of that affair. I suppose I did not do altogether right about that elephant, and many severe moralists will condemn me. When they do, I shall reply with the well-worn formula, "It was all in the interest of Science." Verily, science, like charity, covers a multitude of sins. I hate a scientific thief as much as any one-and the world is full of them-but if any one can steal aught from me, that was not mine yesterday, and may not be mine to-morrow, and which I shall never miss nor ask for, he is welcome to it.

" He that's robbed, not wanting what is stolen, Tell him not of it, aud he is not robbed at all."

I am positive the Rajah of Cochin never missed that tusker from the vast herds which roam through his territories, and, considering the purpose and the circumstances, I think I was justified in taking it.

During the month of September I spent a good share of my time in hunting smaller kinds of game, deer of all kinds in particular. Being still desirous of taking another elephant for its skin, I left my old camp at Tellicul, moved farther up the Teckadee River and camped in a fine open spot called Moochpardi. The hunting ground about this place was, excepting for elephants, all that we could ask, and we endeavored to make the most of it.

The commonest animal in the Animallais, after the black monkey, is the axis deer (Cervus axis), or "spotted deer" of sportsmen. It was an understood thing between my men and me, that we could go out any day and bring in one of these beautiful animals, and we counted it exceedingly hard luck if we ever went out for deer and were obliged to return without one. Had we been so disposed, we could have slaughtered a great many of them, for they were very numerous, but we never shot even one which we did not positively need, either for skin, skeleton, or venison. From first to last we killed about twenty, a very moderate score, considering the number of tempting opportunities we had. I hate to see game 


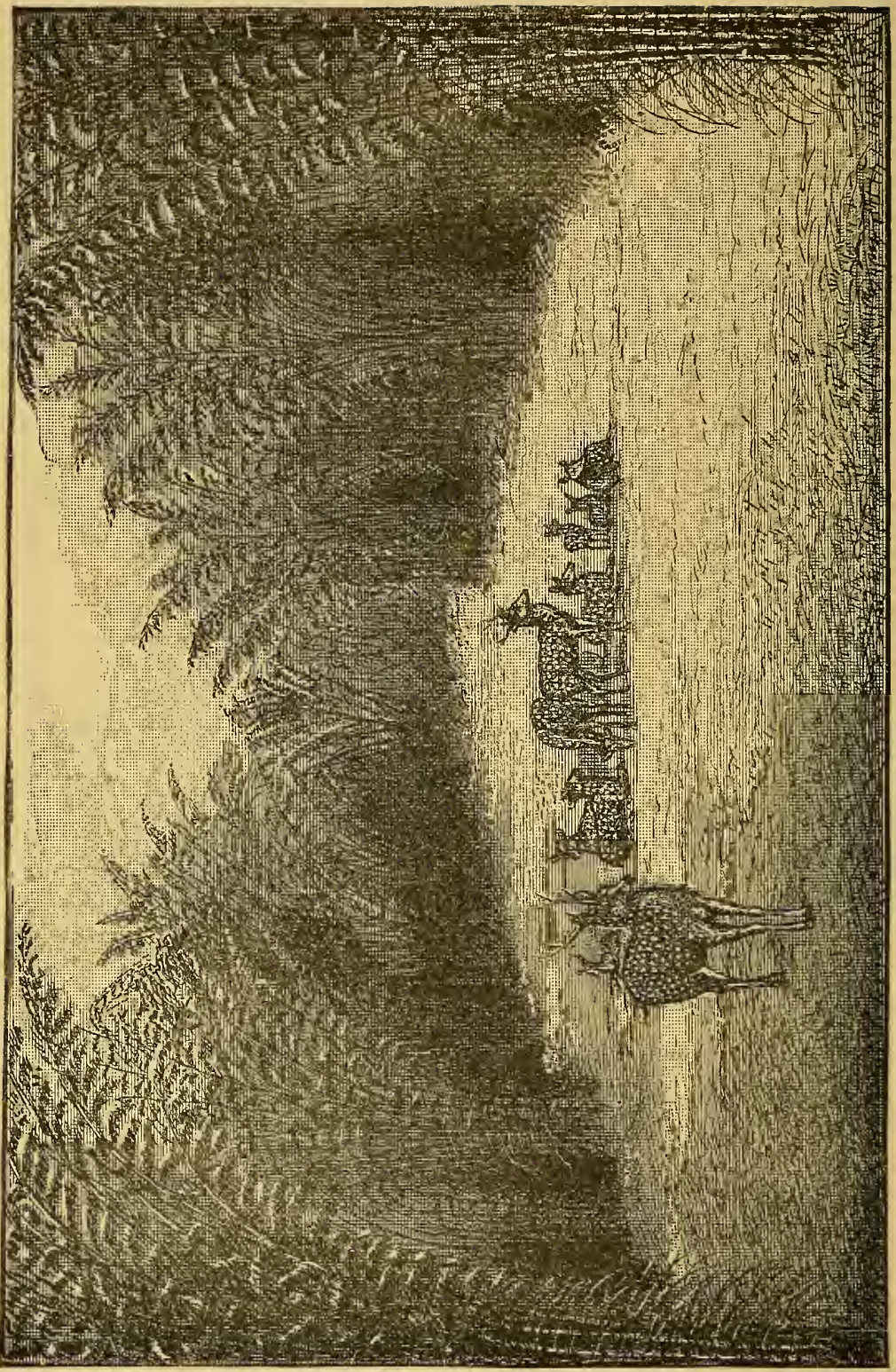


slaughtered to no purpose, and I hate all such game-butchers as those of our Western Territories who have already nearly exterminated the American bison.

All around Moochpardi are numerous grassy glades in the forest, usually of three to five acres in extent, where the ground is low and moist, and the grass is sweetest and tenderest. In these beautiful little pastures, hedged around by the tall, dark bamboo forest, the spotted deer love to feed in the early morning, before the sun gets too hot, and in the late afternoon when the shadows lengthen. We always found them in those places between four and five o'clock in the afternoon, although, to be sure, we used to happen upon them in all kinds of forest, and at all hours of the day. After a few hours' hard work on specimens and a quiet midday snooze in my hut, I would get on my hunting gear, call up Vera, and tell him that we would "go out now." Ten minutes later we would be on the look-out for game. We would go to one glade after another, always coming up to them against the wind, until at last we reached the right one, and our eyes would be gladdened by the sight of a dozen spotted beauties, grazing quietly, or lying at rest upon the green sward.

One particularly beautiful scene of this kind is stamped upon my memory with photographic accuracy. There was a small glade about the size of a city square, quite surrounded by dense bamboo forest, which was a favorite feeding ground for spotted deer. Stealing up to this through the dark jungle, late one bright afternoon, we espied in the centre of the open space a number of spotted forms which were a feast for the eyes of any lover of nature. Creeping up quite close to the edge of the opening, we crouched behind a thick clump of bamboos and gazed in silent admiration upon the lovely picture before us.

Grouped together in a most charming fashion, were about sixty deer of all ages and sizes, from a tiny fawn up to a splendid stag with horns measuring-but I must not anticipate. How lithe, graceful, and beautifully clean they all looked! The slanting rays of the sun shone full against their beautifully spotted sides, bringing out the white spots in striking contrast against the bright fawncolored ground. Some were leisurely cropping the short grass, giving an occasional glance into the dark and treacherous forest, and others lay about at their ease, blinking lazily, and patiently grinding away at their cuds, now and then drawing a long breath of contentment. Surely, the axis deer is the most beautiful of all its tribe. 
It seemed a pity to spoil such a pretty picture by shedding blood; but after all, death from bullet, knife, or spear is the most fitting end for any wild animal. Why should I not slay that noble stag in a moment's time and preserve it to be admired by thousands of other men, rather than leave it to be pulled down and torn to bits by a tiger? Without further argument, I sent a Maynard bullet through his shoulders, and he was mine. The next moment the herd dashed away at a great pace, but I managed to get in another shot, which brought down a fine doe.

The dimensions and weight of both specimens are given in the table of measurements, and may be taken as the average size attained by this species. This deer is difficult to approach within fair shooting distance, but a careful hunter can, in nearly every case, stalk a herd successfully in such forest as that upon the Animallais. At the same time they are exceedingly wary, and in brushy ground would be very difficult to kill. A stick breaking under the hunter's foot is quite sufficient to send the herd off flying, and their sight is usually quite as keen as their sense of sound. I have noticed that the buck never leads a herd, as many suppose, but lags along toward the rear, while an old doe leads the van. The flesh is always good eating, and that of young individuals is very fine indeed, fine-grained and sweet, but, like most venison, a little dry. The tongue is of course a choice tit-bit.

The axis is not easily frightened by evidences of civilization, and at times they are guilty of the most barefaced impudence. Once at Moochpardi, a solitary stag came up close to our camp, but on the other side of the river, in broad daylight, and uttered his loud, clear note of defiance. He repeated it so often and so defiantly that I finally went out with my rifle, waded the river, stalked my challenger successfully, and-made a clean miss. But that was not the only time we heard spotted deer calling near our camp.

The sambur, or Indian elk (Rusa aristotelis), is abundant in the Animallais, although not seen so frequently as the axis deer, nor in anything like such numbers. Usually they are found solitary, often two or three are found together, and once I saw seven in one herd. The sambur is the largest animal of the deer tribe in the East Indies, and is in many respects the oriental counterpart of our American elk, or wapiti (Cervus canadensis), although the former is not nearly so large and noble looking an animal as its American congener. The sambur stands about four feet six to ten inches in 
vertical height at the shoulder, the length of head and body is from six to seven feet, and the tail trvelve inches. Its body color varies from dark brown to slaty gray, according to the season and locality, the under parts are pale pinkish yellow, and upon the oldest stags the hair is long upon the throat and neck, forming a bristly mane.

The horns have but three points, a stout, thick brow-antler springing forward directly from the base or burr of the horn, and the beam is bifurcated near its extremity, sometimes the inner and sometimes the outer tine being the longer. The horns of adult stags average thirty-six inches in length, although they often far exceed that size. Mr. Dawson, of Ootacamund, showed me a splendid pair which measured forty-four inches from base to tip.

I cannot call the sambur a handsome animal by any means. Certainly a stag without its horns is the homeliest deer I ever saw, and as one rushed heavily away from me in the forest it always reminded me of a mulley cow. The body is heavy, the hair thin and coarse, and, to judge from the amount of noise made by a running sambur, it struck me as being a heavy-going and rather clumsy animal.

When lying down or standing motionless against a bamboo clump, a sambur is very difficult to see, at least for my eyes. I once afforded my men a ludicrous and aggravating illustration of this fact. I found that the eyes of my Mulcers differed from mine in their being able to pierce through underbrush and make out an object which I could scarcely see at all, even when pointed out. On the other hand, I could detect a moving object, even were the motion ever so slight, just as quickly as any of them, and a little quicker than even Vera, as was several times fairly proven.

One day we were hunting through the bamboo forest for whatever game we could find, when Vera stopped, uttered his low game signal, " tut-tut-tut," and pointed into a low thicket fifty yards away. He said it was a sambur. I looked intently, made up my mind I saw it, and blazed away. The object I fired at did not move. Vera said, "It is there yet, sahib!" and I fired again at what I thought was it. The same result as before. The sambur did not run. I fired two more shots at an imaginary deer, and the men began to laugh at me. I was disgusted with myself, and exclaimed, "Blast my eyes!" with far more fervency than any sailor.

Presently a twig moved, I saw the sambur and my fifth bullet struck it, but not quite fatally. It rushed out of the thicket, ran a 
short distance and stopped behind some bamboos. Vera took me up quite close to it and tried to make me see it. I looked and looked, and he pointed and pointed, saying, "There, sahib! there!" but I couldn't make it out. The men all grinned from ear to ear, and I blasted my eyes more heartily than ever. Finally I sighted a brown object in a thicket fifty yards away, and fired at it through the clump of bamboos near which we were standing. Imagine my feelings when the sambur sprang up from the ground on the other side of the bamboo clump, almost under the muzzle of my rifle, or at least only twenty-five yards away! He had been lying down, and I fired directly over him. As he ran off slowly, I hit him again and brought him down, but this did not atone for my former stupidity.

It was a bad case of protective coloring, which I had noticed many times before. The summer coat of the sambur is precisely of the same dull gray color as the branching, scraggy base of a bamboo clump.

Sambur hunting in the Animallais is a mere question of patient tracking and straight shooting. The game is easy to stalk and easy to shoot. All around Tellikul, sambur were very plentiful, and many a time during the night some daring old buck would come up within fifty or a hundred paces of our camp, and blow one blast after another on his dinner-horn. I know of no sound which the so-called "bark" of this animal so nearly resembles, as a short, strong blast on a deep-toned tin horn. What sounds can be more pleasant to a hunter's ears than such a midnight serenade in the heart of a grand old forest!

There was one serenader, however, who often annoyed me by his outlandish song. It was the hawk-cuckoo (Hierococcyx varius, Vahl.), also called the "brain-fever bird," partly because its cry sounds like " brain-fever," and also because of its fancied tendency to produce that painful malady. This bird would perch quite close to my hut, and begin with a low whistling cry of "hew-ee," but with each repetition it was given louder until it reached the highest pitch of the bird's lungs, about like this :

\section{"hew-ee! hew-EE! HEW-EE ! HEW-EE！HEW-EE!"}

About every five minutes, or less, it would begin at the bottom of the gamut and keep getting louder and louder, until at the last it would end in a shrill shriek, like a steam-whistle, and the exhausted bird would stop to rest. This serenade was a great annoyance to 
me sometimes, especially when I was feverish and inclined to be wakeful.

While I lived at Tellikul, two tree-rats (Mus rufescens) used to come into my hut from the jungle, nearly every night, and gallop over the floor and climb all about the place, rattling papers continually and rummaging around, until I would get so nervous and irritated that for hours I could not sleep. I tried every plan I could think of to kill those two rats, but somehow my schemes all failed. I tried to poison them, smash them in a deadfall, shoot them, blow them up with gunpowder, and even to spear them; but something happened every time so that they escaped. At last, to my great relief, their nightly visits ceased.

When I first came up to the Hills, Mr. Theobald was living in the Deputy Conservator's bungalow, which had a very thick roof made of layers of cocoanut leaves. This thatch literally swarmed with tree-rats, and one or two other species, and at night, after we had retired, they would come down to the floor by dozens, and go galloping and rummaging all about, fighting and squealing until daylight. Several times rats ran over me as I lay in my cot, and once one jumped from a beam and alighted upon my forehead as I lay asleep. At last they annoyed me so much that I had to keep my light burning all night, which kept them away to some extent. Mr. Theobald had got accustomed to them, as I should in time, and it was well he had, for so long as that thatch roof remained upon the house it would be swarming with rats. We tried to poison them, but they were too smart for us. We caught a great many in different kinds of traps, however.

One of the most interesting of all the small deer is the muntjac (Cervulus aureus), which we frequently met in hunting on the Animallais and studied with unusual interest. This curious little animal is found in nearly all the thick forests and jungles of India, from an elevation of nine thousand feet in the Himalayas * to Ceylon, and also throughout the Malay peninsula, Borneo, Sumatra, and Java. The muntjac is really the connecting link between the Cervidce and Moschidce, or musk deer, having the antlers of the former and long upper canines of the latter.

Jerdon $\nmid$ gives the height of the muntjac as 26 to 28 inches, but out of ten adult specimens which I shot in various parts of the East Indies, the largest was only 22 inches in vertical height, with 
length of head and body $35 \frac{1}{2}$ inches. The body color of the animal is a clear, bright reddish bay. The antler's, which are 4 to 5 inches long, are set up on two round pedestals of bone $2 \frac{1}{2}$ inches high, covered with skin and densely hairy. There are two long, black ridges of skin and two corresponding furrows extending down the face, which, together with its curious antlers, give the little animal a very strange appearance. The legs are short, the hindquarters round and heavy, and it can neither run fast nor far. The head is always carried low, which enables the defenceless little creature to creep through tangled jungle faster than its enemies can follow. It has a very peculiar cry, which is really a bark, like the yapping of a small dog. The first time $I$ heard it in the jungle I thought, until told otherwise, it was a dog barking. Twice by its cry alone I have found and shot this " barking deer." Each peculiarity of this strange little animal has caused it to receive a separate name, so that, besides muntjac, it is called "rib-faced deer," "barking deer," "red hog deer," and worst of all, "jungle sheep," from the manner in which it carries its head and neck. The flesh of the muntjac is the finest venison I ever tasted, and in fact, aside from birds, I know no wild meat equal to it. Could it be placed upon the table of an epicure, I am sure it would be counted a great delicacy. The meat is very fine-grained, tender, but seldom fat, and possesses an exquisite game flavor quite peculiar to itself, which is indescribable. The most delicious soup I ever tasted was made from the flesh of a muntjac.

The Neilgherry goat, or "ibex" of sportsmen (Hemitragus hylocrius), inhabits various precipitous places in the Animallais, and is now quite abundant. A sportsman on the Neilgherries does well if he kills one or two in a week, but here I was told of two gentlemen killing six in one day. Once we went after goats to a rocky cliff near Sungam, the elephant camp, six miles from Toonacadavoo, and after a long, laborious climb to the summit, we found one lying on a narrow ledge of rock, half-way down the side of the precipice, and far out of range. We took a good look at him through the glass, and watched him until he finally got up and sauntered out of sight, but we never saw him again. How he ever got down to that narrow ledge on the face of a smooth, perpendicular wall of rock, was more than I could see; nor could I divine why he chose to go in the most dangerous place he could find, unless to escape his enemies. The only specimen of this wild goat I secured was shot for me by Arndee and brought in quite fresh. With so 


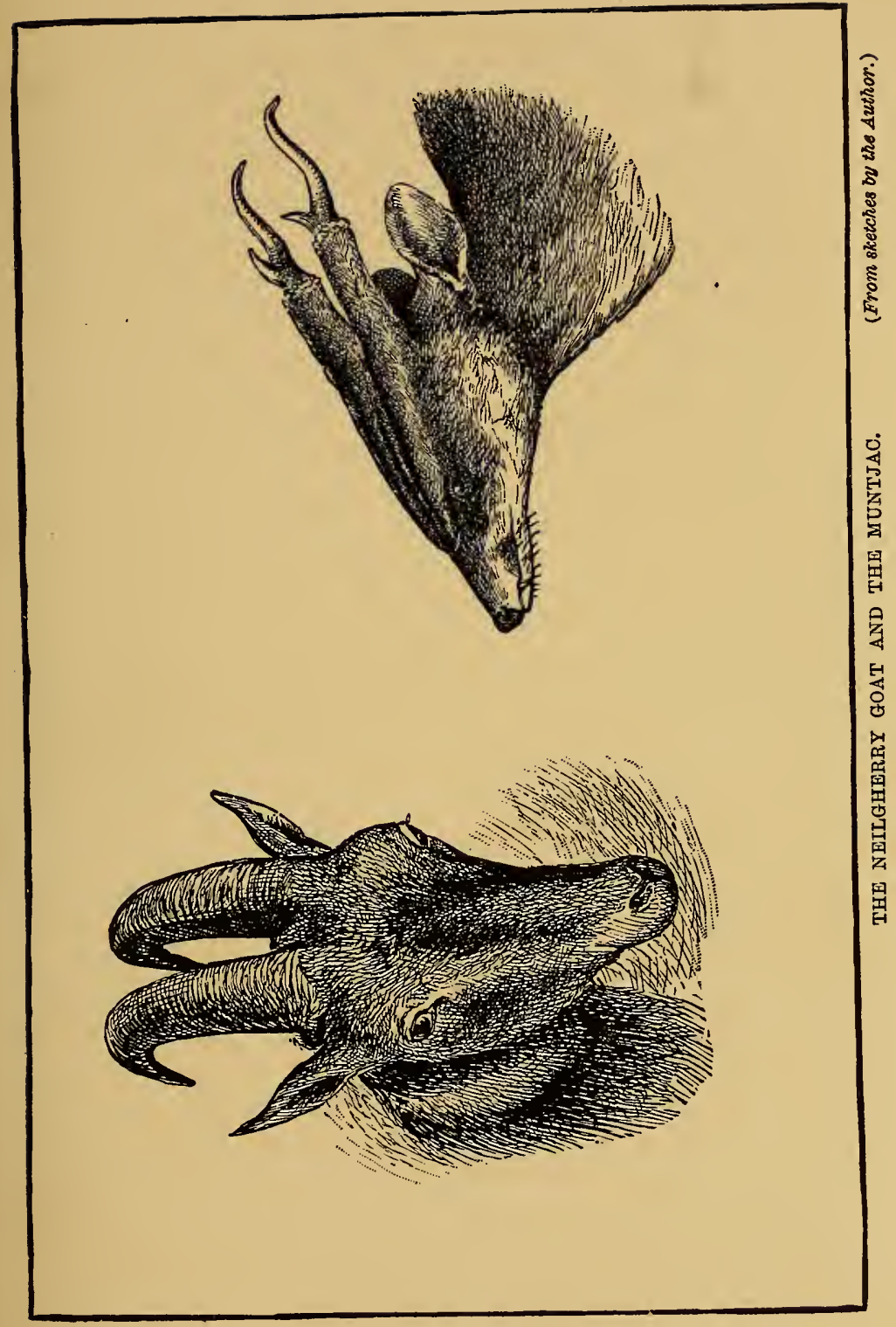



many other interesting animals around me, I was not ambitious to wear my body out, and perhaps break my neck, in trying to get one or two more goats.

In the course of our hunting large game, we occasionally fell in with droves of wild hog, or "pig" (Sus Indicus), but somehow I succeeded in killing only two good specimens. We always started them in brushy forest, where the bushes were so thick it was almost impossible to hit a hog running through them. One day, while we were in camp at Moochpardi, we went out in the afternoon, and in less than an hour brought down a fine doe axis deer and a buck muntjac, which we told Nangen and Corlee to carry home. In returning, Vera and I were alone, walking along a path which led along the edge of a long, open glade with thick, dark jungle on one side. All at at once Vera stopped, knit his brows, focused his keen eyes upon some object among the thick bushes, and the next moment pointed at a large boar standing motionless as a rock behind a tree, with only his head and ears visible. The old fellow thought he was fully screened, but the next instant a rifle bullet went through his ear and into his brain, and we had another fine specimen to add to the day's account. He weighed two hundred and thirty pounds, but Vera and Channa slung him under a pole and trotted home with him in fine style. 


\section{CHAPTER XVI.}

\section{THE SECOND YEAR OF THE MADRAS FAMINE.}

Sickness in the Jungle.-Temporary Absence from the Hills.-A Starving Waif. - The Spectre of Famine.-Famine-stricken Natives.-Cause and Effects of the Famine.-The Relief Camp at Animallai.-A Review of the Hungry.-The Government and the Famine._"Money Doles."-Mortality._"Be ye Warmed and Fed!"-End of the Drought.

Toward the end of September, my supplies of all kinds were quite exhausted, and having a huge pile of skins, rough skeletons and skulls to care for, I determined to go down from the hills for a few weeks, pack up my collection for safe-keeping, and see if a change of air, water, and diet would not benefit my health. I would have quitted the hills then for good, had I not felt in duty bound to bring away the skin of a really large elephant.

During my three months on the Animallais, I had nine separate attacks of fever, and all the time there were from five to ten raw ulcers on each of my ankles, which I had to dress daily with courtplaster and cotton before I could wear my hunting shoes. Many times I had to stuff cotton in my shoes all around my ankles, so that I could make out to walk without severe pain. Those ulcers remained unhealed as long as I stayed in Southern India, and did not get well until I had been some time in Ceylon.

At this time Professor Ward kept writing to me, "Take great care of your health, and run no risk of losing life or limb. If you are attacked by fever, leave that country at once." But I was not going to be beaten by a little fever. What I constantly dreaded was dysentery, for an attack of that would perhaps have forced me to abandon my enterprise. I was told it is almost impossible. for a European to recover from a severe attack of it without taking a long sea-royage, or going to England.

Early in July, Mr. Theobald, who was thoroughly fever-proof, was attacked by it, and in a week he was reduced to a gaunt, colorless, hollow-eyed ghost of his former self. I feared he would never re- 
cover from it without going to England; but he did. To my surprise and admiration he cured himself, with a little advice from another doctor, and that, too, while the Deputy Conservator, who had occupied the Animallai post with him, was on his way to England to get rid of the same disease.

Mr. Theobald used to doctor the natives very successfully, curing their fevers and other ailments, one after another. I never saw a man more universally liked by all the natives who knew him than was he. He was particularly kind and charitable to the Mulcers and Karders, poor wretches to whom a powerful friend in the Government service was a perfect godsend. He treated them like so many children, and they in return would have done and endured anything to serve him.

When the time came for me to leave the hills, I sent for about thirty coolies from Animallai, to carry my collection down to the foot of the ghaut, where some bandies were waiting to take it the remaining ten miles, to Animallai. Theobald gave me his horse to ride, but at the top of the pass I dismounted and gave him in charge of the syce, while I started to make the descent on foot. The weather was simply perfect, and a more glorious afternoon I never saw. From the winding road which leads down the steep mountain side, one catches occasional views of the plain, which stretches out from the base of the mountain, mile after mile, a vast sea of bare, brown earth dotted with green fields, clumps of trees, and red-tiled villages as far as the eye can reach, until in the distance all are blended together. From my cool eyrie, I could easily trace the course of the Animallai River by the fringe of green trees along its banks, and before me, at the end of a long stretch of straight road, lay the village of Animallai. An hour later I was trudging along that dusty highway, with the sun beating down upon me and the perspiration pouring off my face like rain.

Two miles from Animallai there is another village, and as I approached it, my attention was arrested by a little child about four years old, entirely naked, of course, hobbling slowly about in the sandy bed of a dried-up pond. Its feet and legs were swollen with "famine dropsy," as if they had elephantiasis, the ankles being as large as the thighs, and the miserable little thing could step only a few inches at a time. Its sunken cheeks, hollow eyes, and protruding ribs told of starvation, and it was plain to be seen the helpless waif would soon die, unless cared for. I told my boy to take up the child and carry it to the village, or else find some one else to 
do it. He declined to touch it, and it was some time before we found a coolie who was willing to take the wretched little waif in his arms and carry it along, even under promise of liberal pay for his services.

As we stood in the road trying to carry out our intentions, people stopped out of curiosity, and presently there came toward us, from a clump of bushes, a man in the last stage of starvation. $\mathrm{He}$ was entirely nude, except a dirty rag around his loins, and being naturally tall, his gaunt appearance was all the more striking. $\mathrm{He}$ was indeed a living skeleton, literally skin and bone. He was nearly six feet high, but I could have picked him up in my arms and carried him like a child. Every large bone in his body was sharply outlined through his dark, unhealthy-looking skin, and his stomach was shrunken in as though he had been disembowelled. This ghastly apparition, with a stick in one hand and an old earthen chattie in the other, slowly hobbled up on trembling limbs, and stood before me, with WANT written on every feature. As soon as it came close up to me-I say $i t$, because it seemed more like the gaunt spectre of Famine than a living man-it slowly went down upon its knees, then upon its hands, feebly and painfully, and finally pressed its forehead to the dust at my feet and lay there grovelling. Its only word or exclamation was "Saw-mee-ee!" repeated with a despairing moan on the last syllable.

It meant the same as " $\mathrm{Oh}$, lord!" in our language, and was addressed to me personally, as to an idol! The wretched man had been brought so low that he could forsake his idols and cry to a white man for succor. I never felt so utterly mean and helpless.

The above is no fancy picture, nor overdrawn for the sake of effect, but only one out of ten thousand such experiences occurring daily during those fearful times. It was the second year of the famine, and hundreds were dying every day of starvation and famine diseases. Every time I stopped at the bungalow in Animallai, men, women, and children came flocking to the doors with that dismal wail of "Saw-mee-ee," often rising in perfect chorus. They were mostly old men, and women with children, sometimes babes which were nothing but little black skeletons. The old men would pat their hollow stomachs with one claw-like hand, and extend the other, and the women would point to their emaciated children and hold up their bony arms. At first I began to give the people coppers, and sometimes rice, but I soon found it would not do. They came to me in such continually increasing crowds that I was quite 
overwhelmed, and compelled in self-defence to refuse them entirely. Had I obeyed the dictates of my feelings, I would, in a week's time, have been wholly bankrupt. About that time, however, efficient measures for the relief of the famine-stricken people were adopted by the Government.

The child we found wandering, and the starving man who appeared at the same time, we took with us to Animallai, where there was a relief camp. We were told that the parents of the former were both dead, and there was absolutely no one left to care whether it lived or diecl. A coolie carried the child along with me, and the man, being unable to walk, was left to get into one of my bandies when they came along. On reaching the relief camp I gave the child into the charge of the doctor, who placed it in a hospital shed and promised that it should have every attention.

A wide-spread famine of a year's duration, in a country as thickly populated as India, means the death of thousands in spite of all help. But when it extends over two years, as did that of Madras in 187677 , it means the death of millions. In April, 1876, the southwest monsoon failed to bring rain, and none fell until late in the following year. The ground became literally baked, and refused to yield either grass or grain, the wells and tanks dried up, the people consumed all the grain remaining from the previous crop-very little at most-and soon became wholly dependent upon the grain imported from Calcutta, Burmah, and Ceylon, and landed at Madras. The ever-poor agricultural laborers, and equally poor ryots, who are all the slaves of the money-lenders, and the small shop-keepers of every description, were the ones who soonest ate up all they owned and sold everything they could spare for food. In the Madras Presidency and Mysore there are thirty-five million people, of whom about twenty millions were directly under the famine scourge. Think of it. Not a few thousand people in the State of Kansas, or Wisconsin, or the burned districts of Michigan, but more than one-third as many people as there are in the whole Cnited States, to be fed upon imported food for nearly two years, and that, too, at famine prices.

In a comparatively short time, thousands were wholly dependent upon charity, and each succeeding month the number was increased by thousands more. Private charity exhausted itself, and had not the Government taken measures to save life regardless of cost, it would now be easier to count the living than the dead. The treasury of India was opened to supply the starving people with 
food, physicians, and medicines. Relief camps were organized in stricken districts, to which the low-caste people flocked in thousands for food and medical treatment; while thousands more, of higher caste, stayed away and lived upon the "money-doles" which were distributed faithfully and judiciously by the missionaries.

I very frequently visited the relief camp at Animallai, and studied its internal economy with much interest. As it was a type of many such, I will try to describe it as I saw it for the first time. On a stretch of open ground near the river stood a rectangular enclosure, about four hundred feet long and two hundred wide, divided in the middle by a wall, so that the whole formed two hollow squares. Rough pole sheds with roofs of thatch extended all along the sides of the enclosure, and afforded dry sleeping rooms for the people. In one corner of the yard was the kitchen, in which was a long row of huge, earthen cooking-pots, and next to it was the doctor's office. Outside the camp was another shed which served as a hospital.

I passed into the camp in the evening, just at meal-time. One yard was empty, but the other was filled with men, women, and children, squatting upon the ground in three divisions, each subdivided into ranks of ten or twenty. There were about three hundred people present waiting to be fed. At a gate near the upper end of the wall dividing the two yards, stood the huge earthen pots; one containing pepper-water, the other a kind of soup made of gram, and some baskets full of boiled rice pressed into balls. Those for the children were about the size of large pop-corn balls, those for the men and women were three times as large, and weighed two and a half pounds each. In each of the pots was a ladle made of a cocoanut, shell with a piece of bamboo for a handle.

The food was steaming hot, and the people were not only ready but anxious for it. When the word was given, the children rose, approached the gate in single file, and I took my stand beside the jar of pepper-water and prepared to serve it out. The children, most of whom were absolutely naked, came up closely one after another, each carrying a receptacle for his portion of food. Some had earthen chatties, some had joints of bamboo or old tin cans, and others had only shallow pieces of broken crockery or leaky tin. Each received a ladle full of soup, another of pepper-water and a ball of rice, and they all filed through into the other yard. The children, as a rule, looked quite well cared for, and some were quite plump.

Next came the men, and with them we had our hands full. 
They crowded up to the gate like wild beasts, and several times the attendants had to seize them by the hair of their heads and hold them back, to save the pots from being overthrown. Some begged for a double allowance until they were hustled off ; some came up with a bewildered, dreamy air, and would have gone away without any food had we permitted them. Such a review of beggars, such a procession of hollow stomach, protruding ribs, and fleshless arms and thighs I never saw before. Many were very old, wrinkled, and skinny, bent almost double and barely able to hobble along; some had famine dropsy; some were deformed, several limped, many were blind of one eje, but all were desperately hungry.

At last the review of the hungry was over, and in the adjoining enclosure we presently found them all sitting quietly on their hams devouring their food. Twice a day was that same scene enacted, each time decently and in order, and in that camp and village but few people died. But this was only a very small camp in comparison with many others. All were closely inspected, and frequently by the specially appointed Famine officers. The Government quickly responded to calls for more grain, or for medicine, surgical instruments, blankets or additional assistance.

The Vice-regal Government (at Calcutta) did not fully awake to the urgency of the situation in Madras until what seemed to me about the eleventh hour. Then the methods of the Madras Government were found fault with, a large amount of executive talent was exported from the Northern Presidencies for the benefit of Madras, and friction was the result. Toward the close of the famine, a host of civil officers were sent from Bengal at great expense, many coming even from Assam, to do duty in the famine districts. I knew one enterprising officer who travelled by rail from Calcutta to Bombay and thence down to Madras, instead of coming direct by steamer, in order to make a snug little surplus of about four hundred rupees on his mileage allowance.

The difficulty of dealing with a famine in India cannot be fully understood, save by those who are familiar with the character of the people. Natives of high caste would rather die of starvation than go to the relief camps and receive food with the common people. A Brahmin would rather die by inches than partake of food prepared by the hands of the fairest missionary lady in all India. I knew of one case of this kind. A Brahmin lay dying of starvation by the roadside in Bangalore, when a kind-hearted lady living near, passed by and saw him. She had some conjee (rice-soup), pre. 
pared immediately and taken to him, but the dying bigot refused to touch it and expired the next hour.

Instead of allowing all those to starve, who, on account of caste prejudices refused to come to the relief camp for food, the everpatient, long-suffering government officials caused money to be distributed among them, in sums sufficient to purchase daily food. To the missionaries fell the important and arduous work of ascertaining which were the deserving ones, and distributing the funds among them. At the Animallai bungalow I had the pleasure of meeting the Rev. Mr. Hutchison and lady, English missionaries from Coimbatore, who had for months been engaged in going from village to village with their native Christian helpers, and distributing the "money doles" among those whom they found to be deserving of help. If I remember rightly, he distributed about four hundred rupees every day while he was in Animallai. How I envied him the satisfaction he undoubtedly felt in handing out hard cash to those hungry wretches.

It would be impossible to say too much in praise of the energy and activity displayed by the Madras Government in fighting for the lives of the millions under its charge. I do not see how a government could have done more. Month after month a perfect torrent of grain was poured into Madras from seaward, and for months the entire resources of the Madras railway systems were strained to the utmost to carry it into the famine districts fast enough to keep the people from dying by thousands.

But, in spite of all efforts to afford relief, the mortality during the famine was very great. Many died from sheer starvation, and more still from diseases engendered by the long scarcity of food and water. The official report places the number of deaths from the famine in the Madras Presidency and Mysore, at 1,400,000, but the most careful reckoning made by private individuals, who could have no reason to mislead, shows that in reality the number of deaths was over five million. It is highly probable that only a moderate proportion of the deaths that really occurred were officially recorded and reported. The total cost of the famine to the Government was about thirteen million pounds sterling. England contri. buted, by the donations of private individuals, $£ 800,000(\$ 3,840$,000 ). The churches of the United States have spent millions on missionary work in India, but so far as I can ascertain, the Great Republic contributed only $\$ 800$ for the relief of the starving people in Madras. Verily, this is a case of " be ye warmed and fed;" 
for the souls of the perishing Hindoos were liberally cared for, while their bodies were left to shift for themselves. At present there is, in my opinion, nothing which needs so much care, in every respect, as the body of the Hindoo native, and nothing which deserves so little attention as his soul. If he is only out of debt and well fed he is happy, and no amount of Christianity can better his moral condition in the least, for he simply will not be converted (!) unless he can make money by it.

The Madras famine ended in the autumn of 1877 with the return of the monsoon rains, and when I quitted the Coimbatore District in December of that year, the relief camp was deserted, the special famine officers were returning to Bengal, and the ryots were reaping a reasonably good harvest. 


\section{CHAPTER XVII.}

\section{THE POETRY OF FOREST LIFE.-BISON SHOOTING.}

Return to the Hills. -Benighted in the Jungle.-Native Meanness.-Doray. sawmy, the "Gentleman's God."-A Jewel of a Servant -I rospects. Fever again.-Bass' Pale Ale.-Glorious Weather.-Fine Forest.--The Poetry of Life in the Forest.-Our Mode of Hunting. - A Bison Hunt. Death of a Solitary Bull.-A Noble Animal.-Characters and Habits of the Species. - Anotlier Hunt.-Four Bison in Five Shots. - The Bison as an Antagonist. - Mr. Morgan's Encounter with a Wounded Bull.-A Close Shave.-A Typical English Sportsman and his Battery.-How to Preserve a Bison skin for Mounting.

Leaving my collection stored at Palghaut, I went by rail up to Coimbatore, laid in a full stock of provisions and preservatives, and on the 25th of October returned to Animallai village. Arriving there I learned that Mr. Theobald's health was very bad, that he had been granted leave to change posts, and was soon going to leave the Animallais for Nelumboor. Being attacked by fever again myself, I was detained at Animallai until he came down, bag and baggage, and we had our farewell visit there. During this short delay, I collected my old huuting-gang, gave the men an advance of money and rice, and sent them to Moochpardi to erect a good large hut for me. We were certain there would be plenty of elephants around that camp by the time I should return to it.

When I made ready to return to my old hunting-grounds, Mr. Theobald fairly loaded me with favors. He insisted upon lending me a fine young milch cow and calf, which he conld not well take with him, his elephant gun, as before, and quite an array of camp conveniences which I had before done without. On November $3 d$ we were ready, and loading our baggage upon six pack-bullocks, six coolies, and a bandy, we started about noon, which was as early as those wretched natives could be pulled together and shoved off. We tried to start the day previous, but owing to an unusual development of native cussedness, failed utterly. 
After ten miles of slow but terrible jolting behind the meanest pair of bullocks I ever saw, we reached the foot of the Teckadee ghaut, a terribly steep, rocky pass, and began the ascent. For three hour's my boy and I worried with those coolies and bullocks, carrying one pack after another, until we finally reached the top of the pass and started for Moochpardi. Recent rains had made the road very muddy, and the coolies and bullock-drivers grumbled and complained unceasingly. At sunset, five miles of muddy road through thick forest, and a swollen river, lay between us and our camp. The man with the cow and calf, and the coolies with my outfit chest, I allowed to turn off at Teckadee for the night, but the bullocks and their loads were obliged to go on.

As we passed a large camp of timber-cartmen, I tried hard to hire a cart to carry us to Moochpardi, or even a man to show us the way ; but neither could I get for love or money. They would see us get lost in the jungle and perish, too, for that matter, before they would, of their own good will, stir a step to aid us. No one is more cringing, fawning, and servile than the Indian low caste native when he is hungry, and no one is more arrogant, disobliging, and inhuman when he is well-fed and housed. I am not ashamed to say that I hate the "gentle Hindoo," and if you, my reader, ever fall into his power, or have actual need of his good will, you will soon say the same.

And so we had to go on, and trust to luck to find the road. We lit the lantern, and my new servant, acting as an advance guard carried it and one of my guns ahead; after him came the file of bullocks and coolies, while I carried a naked candle shielded by my hat, and marched along as a rear guard. It was a tedious and toilsome tramp through the mud and the black darkness, all the time harassed by the fear of a drenching storm and of missing the road. When we reached the river, we undressed and waded it, the mer. carrying the packs on their heads-how chilly and swift the water was!-and kept on, until at about nine o'clock we dragged wearily into our old camp at Moochpardi.

My old gang was there, and hailed our arrival with delight, while they proudly led me to the fine new bamboo hut they had erected for me, at a total cost of precisely $\$ 2.50$. And then I found once more what a priceless jewel to the jungle traveller is a really good servant. I had a new one whom I had picked up in Coimbatore in this wise : I had determined to discharge the servant I had brought down from the hills, a clumsy, old, gray-haired man not fit for jungle 
life, and while I was waiting an hour at Pothanoor Junction for the train to Coimbatore, I went to the butler, or "head-boy," of the refreshment station, and asked him where I could find a good servant.

"Why sir, you got one servant already. What you want with one more?" "That's none of your business. I want another and a better one. Can you find one for me?" "No, sir!" "Where do you think I can find one?" "I don't know, sir." "Now look here. If you will find me a good 'boy,' that can cook and speak a little English, I will give you a rupee!"

You should have seen him brighten up. Telling me to wait there for him, he ran off and in fifteen minutes returned with a finelouking young man wearing a magnificent black mustache, and rubbing his eyes in a bewildered way. The butler recommended him strongly and offered to be "secruit" (security) for him to the extent of twenty rupees. I looked at the boy keenly, and he at me, asked him a few questions hurriedly, answered a few, and in five minutes we had struck a bargain. The train was nearly due. He dashed off to where he had been sleeping, in five minutes ran back with a moderate sized white bundle; I handed him his ticket and three minutes later we were off.

I saw that the idea of going into the jungle on a hunting spree had stirred him up profoundly, and I knew he was my man. His name was Doraysawmy-meaning "gentleman's god!"-and he was worthy of his name. After my other three Madras servants, he seemed almost worthy of adoration. He was a capital cook, a first-rate tailor in his way, clean, neat, and industrious as any New England housewife. Of my own accord I nearly doubled his wages, and at last paid him at the rate of eighteen rupees per month; but he was worth it. He was a perfect jewel of a boy.

When we got to my new but that night, he showed his good qualities at once. First, he tore the cover off a box, fished out a cork-screw and a cup from the camp chest, and in a moment handed me a brimming cup of Bass' pale ale, the most celestial stuff that ever warmed the midriff of a tired and hungry traveller. In return I gave him a dram of arrack, which helped him also. Then he flew around and undid certain of the packs, made the men build a fire, and in twenty minutes a supper of bacon, eggs, and hot chocolate was ready for me. While I was busy with these, he slung my hammock, and got out my pillow and blanket. I sat and watched him in dumb astonishment; it was so totally unlike any- 
thing I had been accustomed to. Such was Doraysawmy's style, and he kept it up right along.

During the first few days following our return to Moochpardi, which is in the Kulungud forest, I sent my men all over the territory searching for elephant signs. Every year previous to that, there had always been from one to three herds roaming about that territory in October and November, but to the surprise of every one, we found none at all. At first I stayed in camp, husbanding my strength for the grand crisis when it should come, and every day we kept hoping a good herd would pay us a visit. A week after our return I was attacked by hard chills, a high fever and a horrible vomiting, which was repeated again and again, until I felt as limp, exhausted, and dry as though I had been run through a clothes-wringer.

The quinine I took for the fever acted like tartar emetic, and this time I actually threw up my jungle fever, for after the ninth inning (or rather outing), it left me suddenly and did not return in full force for a month.

It is strange how quickly one recovers from such sharp attacks of fever. I always made it a rule to eat heartily right along, no matter whether I felt hungry or not, and at the last I leaned upon Bass' ale and port wine as if they were a pair of crutches. Until iny last two months upon the hills, my habits had always been strictly temperate, never using tobacco in any form, nor drinking any kind of spirits, wine, or beer, or even tea or coffee when at home, where good cold water is procurable. During my former trips to the tropics I was never sick a day, nor took a dose of medicine, but I took to coffee, temporarily. When I was told, on reaching India, that I would have to drink ale, or brandy-and-soda, or eise wine, right along, I said "Never," and for the first six months I stuck to coffee, chocolate, and water. After three months of fever and fasting I tried Bass' pale ale, and found it always created an appetite. After a long, exhausting tramp through mud and rain, a pint of that immortal stuff was equal to a four hours' rest. I strongly recommend it to every "temperance man" whose lot may be cast in the jungles of the East Indies. To me it was a glorious medicine, and whenever I was ready to drop down, it was always ready to pick me up.

While hanging on at Moochpardi, waiting for some elephants to pay us a visit-there were plenty of them across the river in the Government Leased Forest-we decided that we would never have 
a better opportunity to kill a few more bison and prepare their skins; so at them we went.

During the whole month of November we had simply perfect weather, clear, sunny, and rather dry, just warm enough to be comfortable in the shady forest. Then we enjoyed the very poetry of forest life. Every morning we rose early, ate a good hearty breakfast, packed away a bottle of ale and a substantial luncheon of bread and meat into one side of my cartridge-bag, and called up the men. In a few words I informed Doraysawmy what I wanted him to do during the day, and what I myself wanted to do, which last he would interpret to the men, with many injunctions to take good care of the sahib. I always carried either my rifle or a larger gun. Channa always came behind me with another weapon and my large shot-bag; another man carried my rubber blanket and a sharp hatchet, another carried a bundle containing six slinning knives, a whetstone, and a coil of half-inch rope, while very often the fifth man carried another gun. Vera nearly always led the party, but sometimes Channa, while I followed at his heels.

It was Vera's special business to sight the game, but at the same time every other man, save myself, was always on the lookout, and the hindmost men often took pride in calling us back to point out an animal the leading trackers had not noticed. I did not try to keep a sharp lookout, but reserved all my powers for the game when found. I take a little pride in the fact that I always carried a gun, no matter how many miles we tramped in a day. In going through the forest we always went slowly and in perfect silence, no talking save an occasional word in a very low tone, no stickbreaking, every sense keenly on the alert. Whenever any one saw an animal he would instantly utter a hiss or a low, rapid, "tuttut-tut-tut," made by pressing the tongue against the roof of the mouth, and suddenly withdrawing it with a sucking noise, a signal which was never made under any other circumstances, and at which every one would instantly stop and look sharply about him. Often we would get so near our game that no one dared make even that low signal, and then Vera or Channa would quickly grasp me by one arm and point at the animal.

What a romantic life it was to hunt with such men, through those noble teak and bamboo forests, in such fine weather as we had most of the time, knowing that we were liable at any moment to fall in with some large animal, though, whether it would be axis deer, muntjac, bear, boar, sambur, bison, tiger, or elephant, 
we could not possibly tell. There was a great charm in this glorious uncertainty. At noon, we would sit down beside some clear, cold, running stream, put away the lunch and the bottle of ale, and rest for half an hour. We always managed to get back to camp at least an hour before sunset, either with one or two dead animals borne upon a pole, or else a big skin or skeleton, and a few choice pieces of meat. Near our hut was a fine sheet of bare rock, where we cleaned skins, and the clear. running river near by, in which we had our bath when the day's work was done. $\mathrm{Ab}$ me! those were indeed halcyon days, each one of them worth a whole year of every-day life, and I would gladly have them back again, fever and all.

Around Moochpardi, bison were very abundant. The death of our first one there occurred as follows: We were hunting through fine bamboo jungle one morning, hoping to find a fresh bison trail, when, glancing down a long narrow opening through the trees and bamboos, I thought I saw a pair of horns move, down in a ravine fully two hundred yards away. Vera was ahead of me, but had passed along without noticing anything. I called him back and pointed out what I had seen, and directly he declared that it was a bull bison. We stalked down to where we had seen him, in a most picturesque little glen, but he was not there. He had not seen us, and we knew he could not be far away. As we surmised, he was a solitary bull, which was a sort of guarantee that he was a fine animal.

We at once set upon his trail, and in ten minutes came full upon him at the top of a bushy ridge. Vera seized my arm, pointed ahead quickly, and crouched down to be out of the way. Not more than forty paces from us, head proudly up and looking full in our direction, stood the noblest bison I ever saw. In an instant I took a quick aim at his shoulder, well down, and fired with the No. 8-bore.

He wheeled around and tried to dash away, but it was hard work. He fell once, but picked himself up, and went staggering down the slope at a terrible pace. Near the bottom of the hill he stumbled, went down upon his knees, and then pitched forward upon his side, legs in air and kicking furiously. To put a speedy end to his sufferings I fired a bullet from my rifle into his heart as he lay there, and a moment later his earthly troubles were ended.

What a splendid animal he was every way! He had a very handsome head and horns, an intelligent, noble-looking face, and a 
beautiful mild blue eye. Even my men remarked upon the beauty of his head and face. His measurements were as follows :

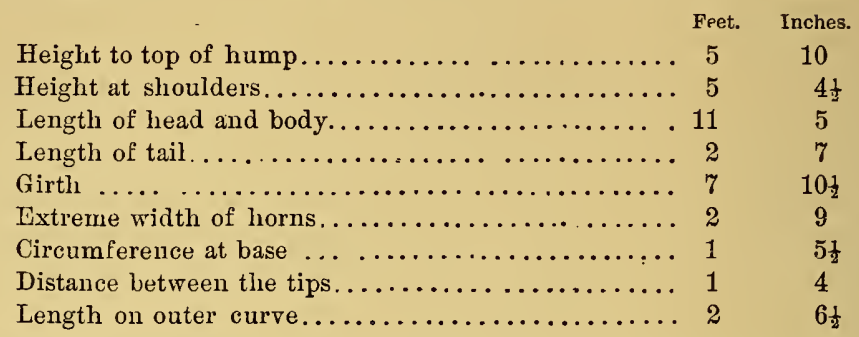

After all, this was not a bison of the very largest size, for the largest bulls are said to measure 6 feet in vertical shoulder height. Somehow, I can never kill an animal so large but that some one else has killed a far larger one. The "Old Shikaree" teils of killing a bison measuring 6 feet 4 inches at the shoulders, and 6 feet 9 inches to the top of the hump; but it is my opinion the "Old Shikaree's" rule slipped back very frequently when he was measuring game.

The Indian bisou (Bos gaurus) is the largest of all the Bovidoe or hollow-horned ruminants, and is in every way a noble animal. It is much larger than its American congener, the buffalo ( $B \circ$ Americanus), but, unlike the latter, it has no mane whatever. The hair is short and thin, and upon the hind quarters of old bulls it is so scanty that the skin is almost bare. Its body color is a dark mahogany brown, deepening to black in old bulls; the forehead and legs below the knees are dirty white, while the inside of the forearms, thighs, and ears, both skin and hair, are of a rich ochre yellow. The iris is pale blue, the end of the nose and the lips dirty white. The hump of the bison is nearly in the middle of the back, from which the dorsal ridge drops abruptly four or five inches to the loins. The legs are very neat and tapering, and the hoof is small, compact, and deer-like, indicating that the bison is intended for a life upon hard ground and among hills and rocks. The foot-print of the large bull mentioned above, measured only 4 inches long by $3 \frac{1}{4}$ wide, a remarkably small foot for so heavy an animal.

Unless they have been thoroughly alarmed, bison are very unsuspicious, and are easily stalked and shot. They usually go in herds of from ten to thirty individuals, sometimes more, and, when feeding, can be approached within easy gun-shot without much 


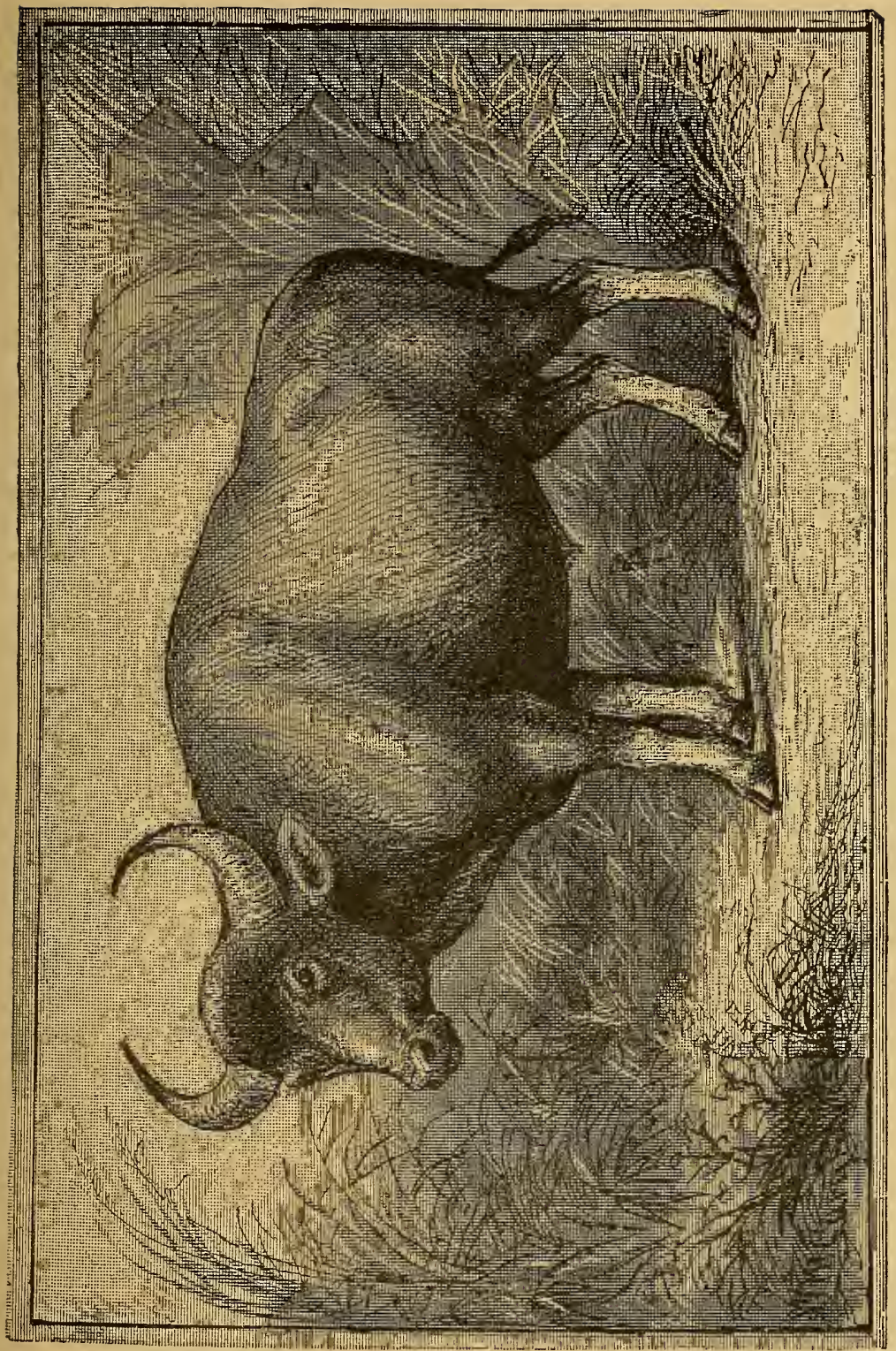

हू. 

difficulty. I never found much "sport" in shooting a bison out of a herd, except in following the trail, for there is so little difficulty and danger connected with it that I felt no more pride in attacking a herd of bison than I would a herd of bullocks. In fact, when in a drove they seemed too much like ordinary cattle. To show what tame sport bison shooting is when once the game is found, I will relate the following :

Two days after the death of the solitary bull mentioned above, we went out and found the trail of a similar individual, but just as we came to the end of his trail we found he had joined a herd of about fifteer others. I stalked up close to the herd, and fired across a little grassy glade at a fine bull, bringing bim down promptly with a shot in the shoulders. Then I fired my remaining barrel at another bull standing among the bamboos, eighty paces distant, but he did not fall. Not feeling very murderously inclined, I leisurely reloaded my gun, the No. 8 muzzle-loader, and for fully three minutes the two bison stood on the opposite side of the glade, watching my movements with the stare of curiosity. When I was ready to fire again the herd sensed the danger and made off, but having one bull I declined to follow.

The next day I shot a large cow, and the day following another, making four bison bagged in five shots. I am sure we could have killed a bison every day for a month or more, had we been so inclined ; but my fixed principle is never to kill a harmless animal which I do not actually need as a specimen, or else to eat.

Judging from my own experience with bison, I consider them very timid and inoffensive animals, except under circumstances of great provocation. From first to last I killed only eight, five bulls and three cows, no one of which made the slightest attempt to charge us. Indeed, in my bison-hunting $I$ never took into account the fact that a bison could charge and make mischief; but at the same time the natives of India regard the bison as a dangerous animal, and many experienced English sportsmen also have a thorough respect for him. I saw one native on the hills, who had been attacked by a bull-bison a few years previous, and so badly mauled that his left arm was almost useless. In Coimbatore I met a young Englishman, Mr. Rhodes Morgan, Deputy Conservator of Forests, who once had a severe taste of a bison's horns, and at my request he kindly furnished me the following account of how it happened :

"It was in June, 1874, when I was inspecting a low range of, 
hills some twenty miles from Coimbatore, that I was going through a forest with a party of Irulars, and suddenly started a young solitary bull bison. After a long, stern chase we came up with him, and saw him standing still and looking at us, eighty yards off. I was armed with a .500 express rifle, and instantly fired at his nose; but, unluckily, he dropped his head as I fired, and the ball, instead of penetrating his brain, passed through his palate and tongue. It evidently severed some large blood-vessel, as the bushes were covered with blood, and we had no difficulty in tracking him. After following him about a mile, we came suddenly upon him, climbing a little, grassy hill some thirty paces above us. The instant he caught sight of me he turned to charge, when I gave him both barrels in the shoulder, which made him gallop madly off into the forest. Tracking him on, I soon saw him standing still and looking at me, some twenty yards off, and instantly gave him another bullet behind the shoulder. He now went crashing down the hill-side and apparently fell, as we heard him kicking, and then he uttered a faint bellow.

"When a bison bellows after being wounded it is almost always a certain sign of death, but in this instance it was not.

"We followed the bull down the side of the hill, where he had evidently rolled, and I was looking about trying to make out where he could have gone, when I suddenly caught sight of his nose not two feet from me! He had backed himself into a dense mass of creepers, and was lying in wait for me! Nothing was visible but his nose, and the instant I saw it, I felt that I was caught.

"In half a second, with a snort like a steam-engine, he sent me flying through the air. I lit on my back, and was immediately struck a blow on my ribs that made them spring inward as the top of a hen-coop would with a heary man sitting on it. I felt that my last hour had come. He struck me with his head again and again, sometimes on my breast, back, and sides, sometimes on my thighs, while sometimes he struck the ground only in his blind fury. The blood was pouring in a stream from his open mouth, and the hot breath from his nostrils sent the blood in sprays all over me.

"I lay quite still, and he presently stopped and looked at me. Imagining that I was dead, he walked slowly away a short distance, and stood there eying me. There was the stump of a huge tree near me, and I thought that if I could only drag myself behind it I would be safe. I began to draw myself along, bit by bit, 
toward it, but in an instant the bull rushed at me again and struck me several fearful blows. I felt now that nothing could save me. He tried to turn me over with his nose, that he might get his horns into me, and getting one horn under ny belt he lifted me up bodi1y. Luckily it was an old belt, and the buckle snapped. He then endeavored to rip me up, so I seized his horn and held on to it with all my strength. In trying to shake himself free he took the whole of the skin off the under side of my right arm with his horn.

"The whole of this time, no fewer than six Irulars had been calmly looking on, and I heard one of them say : 'Dear me! the bison is killing the gentleman!' and another said: 'Send for the shikaree to shoot it.' (The shikaree was two miles away with my tiffin basket!) One of the Irulars now uttered a most diabolical yell. The bull threw up his head, then turned tail and dashed down the hill. Had they only yelled at first, I might have been saved from being pounded almost to a jelly.

"The Irulars all ran forward now to help me to stand up. One of them picked up my rifle, which was lying stamped into the mud and broken by the fall. I was then supported to a large rock, where my first act was to feel myself all over to see if any bones were broken. After lying on the rock for an hour, my shikaree came running up, lamenting. I must have presented a horrible spectacle, for I was one mass of black mud, and smeared all over with blood. The shikaree gave me a drink of water, and, having. washed off the blood and dirt, I felt so much better that I determined to kill that bull if possible.

"An Irular climbed a tree and reported that the bull was standing close by, and that if I could get to a certain large rock I could have a good chance at him. Getting upon the rock, I saw him standing just below me, and immediately let him have both barrels of my No. 12 smooth-bore, but my aim was very unsteady. He then went down the hill, crossed a small stream, and stood again on a bit of level ground. I got up within twenty yards of him, when he charged, and I gave him two more barrels. He now attempted to cross a small nullah, when he fell from weakness, but regaining his feet, he went a little farther, and fell between two rocks, where he got firmly jammed. A bullet through the heart then finished him.

"The next day I was carried into Coimbatore, where I was confined to my bed for a fortnight, my whole body being black and blue." 
I may remark in passing, that Mr. Morgan, who was about such a youngster as myself, in many respects, showed me at his house a really wonderful collection of hunting trophies, all shot and mounted by his own hands. Ranged around his dining-room were about twenty well-mounted heads of bison, among which was the young bull which mauled him so severely, and the walls were literally covered with skulls, antlers, and stuffed heads of sambur, axis deer, muntjac, boar, bison, bear, etc., etc.

In lis parlor were two mounted tiger-heads, two splendid ele. phant tusks, a tiger-skin mat, a cabinet of bird's eggs, and many smaller specimens of great interest. It is truly refreshing to meet a sportsman who is such an industrious saver of trophies, and who, like myself, cannot bear to kill an animal and let it go utterly to waste.

Among other things, Mr. Morgan showed me his "battery," consisting of eight deadly weapons! The largest was a smoothbore, B. L., C. F. gun, No. 4-bore with a barrel $3 \frac{1}{2}$ feet long, carrying twelve drachms of powder and a four-ounce ball. This is the calibre recommended by Sir Samuel Baker, Sanderson, and other noted sportsmen, for elephant shooting! It requires three coolies to carry this gun, turn and turn about on a day's shooting, and $\mathrm{Mr}$. M. fires it from a small tripod-stand he has invented for the purpose. Such a weapon is really a young cannon, and is perhaps such a one as Professor. Ward had in mind when he wrote me at the last to "get a howitzer if you can't bring down elephants with your smaller ordnance."

It is a difficult matter to prepare, in the jungle, a large bison skin so that it can be mounted successfully, and for this reason I will describe how I accomplished the task.

My largest bull was killed about 10 A.M., and, being fully prepared, we measured and skinned him immediately. We removed the skin in the same way as described for the tiger, except that to skin the head, we cut the skin loose from around the base of each horn, then slit the back of the neck and head into a perfect $\mathrm{Y}$, with the long limb extending along the back of the neck, and each of the short ones reaching up to the base of one horn at the back. The head can thus be skinned very easily and lifted out through this hole. We carried the skin home slung under a pole-a heavy load for four men-and after spreading it out on a bit of bare ground we all went at it with our linives, to thin it down. On the back, and sides of the neck, the skin was more than an inch thick, 
which we had to pare down until we could see the roots of the hair. This was a very laborious task, requiring thin-bladed and rery sharp knives.

Late in the afternoon, we rubbed the inside of the skin very thoroughly with arsenical soap, then sprinkled over it about twelve pounds of coarse salt and rubbed it in vigorously with a flat stone. In a short time the salt drew quantities of water out of the skin so that it stood all over in puddles. We then rolled up the skin, let it lie over night, and the next morning thinned it down still more, so that the preservatives could strike the roots of the hair at once. Next we sprinkled powdered alum all over the skin and rubbed it in, using about seven to eight pounds.

After letting the skin lie spread upon the ground for a few hours, fairly pickled in its own moisture, we hung it over a pole in a shady place, spreading it widely with sticks placed cross-wise inside, and the legs were pulled out in various directions and tied fast to stumps. Every night we took it down and put it inside my hut to keep it from the dew and rain. After one very rainy day, two very fine ones, and one that was rather damp, the skin was almost stiff, and quite dry enough to fold up permanently. This skin has since been mounted very successfully at Professor Ward's establishment, and the old bull now stands in the Museum of Comparative Zoology, at Cambridge, Mass. 


\section{CHAPTER XVIII.}

\section{A MEMORABLE ELEPHANT HUNT.}

A Run of Ill-luck. - The Climax. - Strained Relations with an Official. - The Turn of the Tide.-My Last Card. - An Official Favor. -Permission to Kill a Tusker.-More to Sungam.-A Memorable Elephant Hunt.-A Bad Shot.-Dangerous Ground.-A Bold Advance and a Disorderly Retreat.Mulcer Philosophy.-A Long and Tiresome Chase.-Desperate Character of the Jungle.-Luck at Last. - The Attack.-An Anxious Moment.-Victory.-The Dead Tusker.-A Sell on the Mulcers. - Skinning a Nine-anda-half Foot Elephant. - The Modus Operandi.-Camp on the Field of Battle.-Surrounded by Wild Beasts.-Getting up a Scare.-Burning Bamboo. - A Tiger about.-An Accident.-Back to Sungam.-A Mulcer Row.Fever again.-Mutiny in Camp.

DuRrNg the first two weeks I spent at Moochpardi, after my return to the hills, my luck went steadily against me, and I soon found myself in a "sea of troubles." In the first place, we saw there was simply no hope of our finding a wild tusker in the Kulungud forest before the close of the season. My funds had become so nearly exhausted that at last, in spite of economy, I had not ten rupees left, and utter bankruptcy stared me in the face. Mr. Theobald was out of reach, or I could have borrowed. Three months before, I had received from Professor Ward a first bill of exchange for $£ 100$, with the information that the second would follow by the next mail ; but it had failed to turn up, and I was embarrassed. I had written all over India about it, and also home, but it might be weeks longer before I could trace it up, and until I got it, my first of exchange was utterly worthless. My twelfth attack of fever came on and floored me in short order, and for two days I tried my best to throw up my stomach. My ankles were still covered with raw ulcers, six or eight in number, which at times were very painful.

To cap the climax of my difficulties, one day while I lay on my back with fever, I received an official document, bearing the legend "On Her Majesty's Service," from Mr. Gass, officer in temporary charge at Toonacadaroo. The communication politely, but firmly, 
requested me to send him all my men, to work for the Government. He claimed that during my absence from the hills, he had made advances of money and clothing to the Mulcers, and therefore their services properly belonged to the forest department.

Here was a pretty fix. The loss of the men I had trained to assist me meant nothing less than the destruction of all my plans. When told the contents of the letter and the mission of the Govern. ment peon, my men with one accord declared they would not stir a step, and were fairly enraged at the demand. They stoutly asserted they had received no advances from the Government, and no one save myself had any claims upon them. After careful reflection, I made up my mind as to the course I should pursue. It was risky, but I had faith in its success, and acted immediately. I replied to Mr. Gass' letter very politely and respectfully, without expressing any of the indignation I felt, and had all my men except Vera, accompany my communication. But I firmly insisted that the services of the men properly belonged to me, and were only given up that I might avoid even the appearance of doing anything to hinder government work. I also stated that I had made advances of blankets and money to the men, which would therefore be a total loss to me. My gang marched off with the peon, but they privately assured Doraysawmy that after two days, they all intended to run away and come back.

When my men had gone, I began to review my situation, and calculate the chances of ever getting the skin of a big tusker out of the forest in good condition. I noticed that for some time all things had combined against me, and it made me mad. Irepeated to myself my always-encouraging doctrine-the only sure thing about "luck" either good or bad, is, that it is bound to change. A long streak of bad luck always rouses the bull-dog element in my nature, and I feel like fighting it until it gets tired enough to quit. With my fever still burning, and my men all gone but one, I was only able to solemnly declare to Doraysawmy that I would "have an elephant before I left those Hills, or die." A sensible resolution for a sick man!

The very next day my run of bad luck came to an end, and from that moment it steadily improved. While I was taking a bath in the river, my Mulcers suddenly ran down the opposite bank and waded across to me in great glee, with a letter from Mr. Gass, in which he relinquished his claim upon them, and expressed his regret at having proposed to deprive me of their services, under the 
existing circumstances, of which he had not been fully aware. Three days later, a coolie from Animallai brought me the letter from Professor Ward, which contained the truant bill of exchange, and it was at once dispatched to Madras to be cashed. I was now ready to play what was very nearly my last card.

There were no elephants in our forest, but across the river, two miles away in the Government Forest, there were two herds. One day we undertook to drive the smaller herd about a mile and make it cross into our forest, so that we might kill one of the tuskers. The plan was a good one, but I needed sixty men instead of six, and practically it wouldn't work. Then I determined to ask the Madras Government for permission to kill an elephant in the Government Forest. It was truly a forlorn hope, with all the chances against its success. A month previous, young $\mathrm{Mr}$. Wedderburn, a son of the Collector of Coimbatore, had assured me that it would be useless to ask his father for permission to kill an elephant, because he was very much interested in "keddah operations" (elephant catching) and had never granted such a permission to any one, although often asked to do so. I had no letters of introduction, and no personal reputation whatever to recommend me to the favorable notice of the Government authorities. If they granted the request I proposed to make, it would be only from motives of pure charity, and not by reason of any claim I could establish. Without daring to hope my request would be granted, I sat down and wrote the following letter:

\section{CAMP IN THE ANimatlat HiLls.}

November 8, 1877.

To A. Wedderburn, Esq., Collector of Coimbatore District.

DEAR SIR: At last I find myself compelled to address you on the subject of wild elephants. Mr. Douglass * advised me to do so when I first came to these hills, but I have refrained until now, hoping it would not be necessary. Under the present circumstances I am forced to make a virtue of necessity and beg your permission to shoot one or two male elephants in the Government Forest. I feel justified in doing so by the following reasons :

Although I am located in the forest belonging to the Rajah of Kulungud, and have his written permission to kill two elephants in his territory, there are no elephants here now, none have been here for weeks, and the chances are, I will never find a herd in this small forest so full of people. On the contrary, there are two herds in the Government Forest that are likely to remain some time, having already been there some days.

$\mathrm{My}$ being a naturalist and not a sportsman, and working directly in the in.

* Deputy conservator of Forests. 
terests of science, should, I think, give me a claim to consideration that I would not think of asking were I shooting merely for the sport and glory of the thing. I shnot nothing that I do not want as a museum specimen. Professor Ward, whose Natural History Establishment I represent, has tried long and liard to purchase specimens of the Indian elephant, but withont success, and at last I have been sent out here at great expense and trouble, with the elephant as the main object in view. But for the generosity of the Rajah of Kulungud I should have been obliged to make this application to you long ago.

I have come up here again solely for elephants and find none where $I$ expected. The season is rapidly coming to an end, when I shall be obliged to leave these parts, and the chances are that, unless I am permitted to shoot an elephant in the Government Forest as soon as possible, my work is doomed to end in failure. I wish to kill a full-grown tusker, of which I would prepare both skin and skeleton complete.

Hoping that you will consider an exception in my favor justifiable under the circumstances, I remain, dear sir,

Yours obediently and respectfully,

WM. T. HORNADAY.

Everything depended upon this letter. Had I only been a "Dr." or " Professor," or the possessor of any handle to my name, I would have felt less doubtful of the result.

My letter was received by Mr. Wedderburn and forwarded by him, with a favorable indorsement, to his Grace the Duke of Buckingham, Governor of the Madras Presidency. Almost by return mail, it seemed, I received the following official document :

\section{Proceedings of the Madras Government.}

Read the following letter from the District Magistrate of Coimbatore, dated November 10, 1877. No. 248.

Order thereon dated November 14, 187\%. No. 2670.

The Governor in Council sanctions Mr. Wm. T. Hornaday shooting one full-grown tusk elephant in the Animallai Forest.

(Signed) C. G. MASTER.

Secretary to Government.

This was extremely gratifying in more ways than one. Aside from the success of my plans, it gave me great pleasure to know that my arduous labors as a field naturalist were substantially recognized, and that the Government had granted me a great favor solely upon the merits of my case, in spite of the fact that I was a nobody. While I felt really entitled to an elephant, and it was 
no great loss for the Government to give me one, as elephants may never be caught on the Animallais, yet it would have been an easy and natural thing for the Governor and Executive Council to have refused my rather cool request. But the faror was granted, cordially, gracefully, and promptly. And the people of Northern India and Ceylon call this the Benighted Presidency! Then my worst wish for them is, that the same darkness may overtake them soon.

Two days after the above-mentioned order came to hand, we moved our camp to Sungam, a timber depot and elephant camp in the Government Forest, near which were the wild elephants. Learning the general whereabouts of a large herd, we equipped ourselves for the chase with cooked food, knives, blankets, hammock, ropes, etc., and set out to find the trail, determined to bring dowu a tusker before returning. It was a memorable chase, an appropriate ending of my laborious work in those hills, and I am tempted to narrate its chief incidents.

We found the trail where it crossed the road, within a mile of Toonacadavoo, and led straight away into Curran Shola, a wide tract of wild, tangled, and fearfully hilly jungle, which I had never before penetrated. In one place Vera and Channa did some very skilful tracking. This was in a bit of dense jungle where the earth was as bare, smooth, and hard as a base-ball ground, upon which the soft, rubber-like feet of the elephants left scarcely any impression. In this spot, the herd had scattered and fed all around over several acres, and the trackers had great difficulty in finding the direction finally taken by the herd. But they ciphered it out at last and on we went.

In passing through a stretch of fine, lofty, bamboo forest, we came to a place where the elephants had apparently started to make a clearing. On a space of nearly two acres in extent, nearly every bamboo, old and young, had been pulled down and smashed to splinters, and their long, green stems lay twisted, torn, and piled in dire confusion. Whole clumps had been pulled down, a stem at a time, just for fun. The place looked as if a small cyclone had struck it.

About noon we came upon a portion of the herd feeding upon a steep hill-side, and, taking up a position on the opposite slope but quite near by, we rested and watched them. Unfortunately there was no tusker in this lot, nor even a "muckna," or tuskless male. As we sat on the steep hill-side, the elephants fed toward us, but 
below our position, and finally they passed along the bottom of the nullah almost at our feet, within ten yards of us. But we had seen the marks of tusks on several trees as we came along, and we knew there were tuskers in the herd somewhere.

Feeling sure these females would join the rest of the herd, we followed them, and about two miles farther on came upon the entire herd feeding in a dense patch of dead and fallen bamboos, rank weeds, grass, and young bamboo shoots. Curran Shola is full of just such patches, where the fallen bamboos have destroyed the shade and the moisture, and caused the place to grow up with rank grass, thick thorn bushes and trailing vines, the very worst place in the world in which to attack elephants.

We manœurred around the herd until the elephants began to work out of that wretched brush patch into the open jungle which surrounded it, and then by making a very risky stalk I got close up to a splendid old tusker and fired at his temple. A total failure. Fool that I was, I undershot the brain because the elephant was below me. The tusker rushed into the thick patch, several other elephants rushed out of it toward me, then stopped and stood motionless for some seconds. Presently they turned about, went back into the thicket, and began feeding again.

We undertook to follow up the tusker, but it was very nervous work. We could not get along at all save by following the elephant paths, and a charge under such circumstances might easily have been fatal to some of us.

I posted Nangen up in a small tree, whence he could see all over the thicket, and with Vera leading the way and Channa at my heels with a spare gun, we went in. The bushes, grass, and weeds were, in places, nearly twice as high as our heads, and except for the elephant paths we could not see five yards in any direction. We kept a careful eye upon Nangen all the time, and it was well for us that we did so. All at once his arms began to fly about like the sails of a wind-mill, as he violently gesticulated at us and looked unutterable things. Directly we darted back to a place of safety, and the next moment two large elephants walked rapidly across the very spot from whence we first saw Nangen's warning pantomime. Then we concluded not to risk getting amongst twenty-five or thirty elephants in such a place as that was.

After a time the herd quitted that thicket, walked rapidly through the open jungle for a mile, and entered another of the same nature, only much worse. For an hour the elephants went 
feeding up and down in that thorny tangle, crashing over the fallen bamboos, within thirty yards of us sometimes, but I dared not attack them. I supposed then that I was over-cautious, and that an older bunter would have gone at them as they were without delay; but I resolved I would not do it, cowardly or not. I have since found that even the oldest hands sometimes find their elephants in such cover that they dare not venture into it, and my caution was well-timed.

Once I screwed my courage up and ventured into the thicket for about forty paces, alone, but with my gun ready for instant use. Suddenly there rose, out of the thick bushes close before me, the end of a huge trunk with the tip bent forward, scenting the air. In an instant I was discovered, and the elephant gave a perfect bugle call, loud, clear, and thrilling. Directly the elephants went crashing wildly up and down over the fallen bamboos, making a fearful noise; I turned and ran for open ground, and at that moment there came a sharp clap of thunder. For a moment I believe my hair actually stood on end, for it seemed as if bedlam had broken loose; but I soon gained the shelter of a tree, and had a quiet smile at my fright. Shortly after this it began to rain in torrents, and being within about five miles of eamp we went home.

Doraysawmy expressed himself as having been deeply concerned lest I should come to grief under the feet of an elephant, and my safe return took a great weight from his mind. That night he held a solemn council with Vera and Channa, enjoining them to take the greatest care of me. My trackers said to him, so he told me, that "it would not do at all for the sahib to get killed, for if he should, who would give them and their people rice and tobacco, arrack and money, to say nothing of fresh meat?" Yes, they said, they would be very careful of him.

The next morning at daybreak, equipped as before, we set out for the spot where we left the trail the previous evening. The chase that day led through the worst jungle I saw anywhere in India, and over the roughest ground.

Early in the day it took to the side of an immense ridge several miles in extent, half a mile from top to bottom, and everywhere very steep. The ridge was scored all along with deep nullahs, one after another, and the whole slope was a tangled mass of dead bamboo clumps, some fallen bodily and others still standing; rank, green bushes and vines, set with cruel, hook-like thorns, and tall grass everywhere, making the tangled density more complete. 
Ahead of us that ridge-side seemed to stretch out interminably, and of the same desperate character all the way. Of course we could not stir a step through such thick stuff without following in an elephant trail, and in case of a charge we could not have run ten paces, except forward or back.

The dead bamboos lay in piles across our track, and, while the elephants stepped over them with ease, we were obliged to climb and scramble over as best we could. It really seemed that the trail led up hill all the time, and that the jungle was all thorns and briers to scratch and tear us.

About noon we overtook the herd, but in such cover we dared not think of attacking it. For three hours we followed along within hearing of it, hoping it would enter a more open tract somewhere in which we could dare to move about. Once we spent a laborious half-hour in trying to approach the herd from the upper side, but utterly failed. At last I began to feel quite exhausted, and my men also complained of being very tired. Getting fairly desperate, I determined to bring matters to a crisis immediately, no matter what the consequences might be, and then fortune favored us a little. The herd dispersed and began feeding on the side of a ridge which ran down the steep side of the mountain; the cover was more open, and the wind was in our favor.

I soon found three large elephants feeding together on the hillsicle below me, and after watching them a few minutes I saw through the leaves a gleam of white tusks. Bidding all the men stop at the top of the hill, I went at the group alone, and five minutes later was crouching behind a small bush, within twenty feet of the tusker's head. He seemed to be a monster in size, and I thought his tusks were very fine also. He was standing almost broadside to me, but a thick green bough concealed nearly the whole of his head, and prevented my firing. In anxious suspense I crouched behind my little bush, with bated breath and finger on trigger, waiting for the old fellow to move on a single step and pass that branch. But he would not. I fretted and fumed inwardly, and was about to fire through the leaves and risk it, when a joung, half-grown elephant pushed up alongside my tusker, reached out his trunk deliberately, laid hold of that identical green bough and swept it down! Thank you, my young friend!

In an instant I saw I had neither the fair temple nor forehead shot, but just between the two. Aiming about six inches above the eye, my old No. 8 woke the echoes the next moment, which was 
followed by a grand rush on three sides of me. I wheeled around, ran up the hill a few paces to a small tree, and reloaded with all haste. I listened to hear a fall, but if there had been one the noise made by the fleeing herd would have drowned it. Fearing my shot had been a failure, and another laborious trial lay before us, I hurried down the hill again.

Victory! There lay my noble old tusker, stone dead! He hai sunk down in his tracks and died without a struggle or a sound. My zinc bullet had passed entirely through skull and brain, and buried itself ten inches deep in the flesh of the neck. Our dangerous and tiresome chase was ended at last, successfully, and we all rejoiced.

After the manner of griffins generally, I scrambled upon the top of the huge carcass, and opened a bottle of Bass' best in honor of the occasion. Then I called for a certain black bottle in one of the Mulcers' bundles which, as they well knew, had been carried for their especial benefit. There was a general smacking of lips as I produced a cup, drew the cork, and poured out-cocoanut oil ! There was a stare of blank astonishment, a general murmur of disappointment and wrath at Doraysawmy, and the next moment, despite our chagrin, we all burst out laughing at the absurdity of the occurrence. My boy had simply given us a bottle of cocoanut oil instead of the arrack the souls of the Mulcers yearned for.

Our first care was to measure our prize, which we managed to accomplish with fair exactness. His dimensions were as follows :

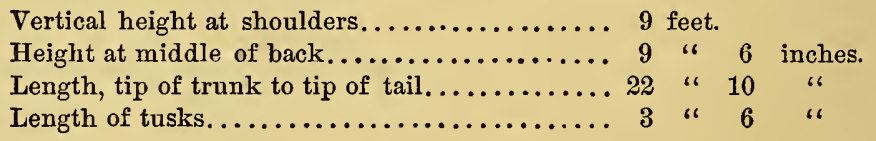

Although our elephant was a large one, his tusks were in reality rather short, but thick in proportion to their length.

It is no light task for six men to skin an elephant weighing four tons or more, in thick jungle, miles from any road, and preserve it, in spite of rain and sun, in a fit state to be transported and successfully mounted afterward. Many of my friends in India, and at home in the Establishment, had expressed the opiuion that such a task could not be successfully accomplished under such circumstances Mr. Theobald was not only doubtful but quite certain that it could not be done. It is a very difficult matter to remove and preserve the skin of a large elephant, even in a menagerie, with all 
• 


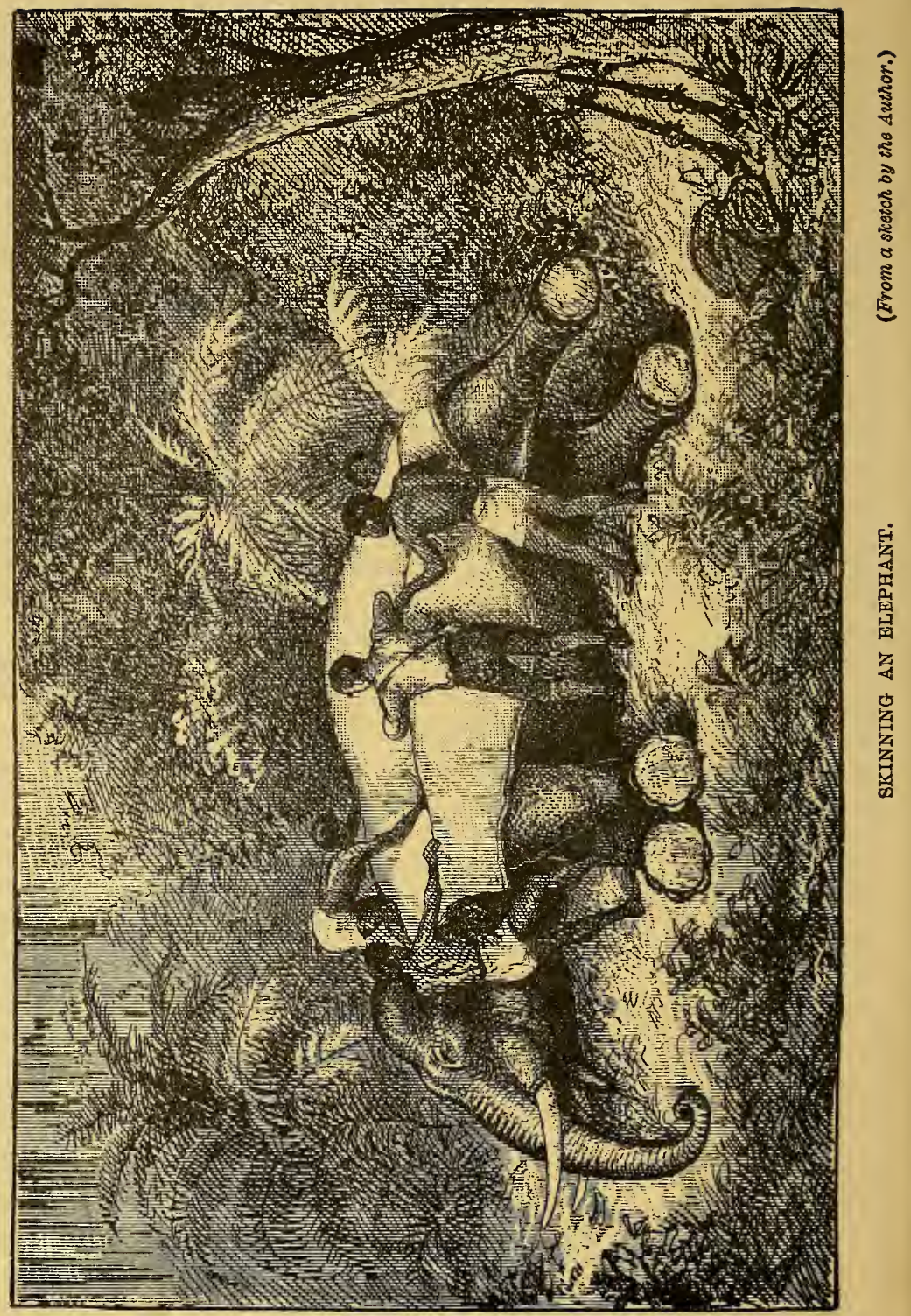


possible assistance and appliances at hand, but it is infinitely more so in a rainy jungle. In fact, Professor Ward and I were about the only persons who believed it possible to accomplish what I had undertaken. For my part, all I asked then was that the fever would keep away from me for about ten days.

After a short rest, in which our previous fatigue was entirely forgotten, we got out our knives and went to work. The elephant lay fairly on his side, and the top of the carcass was just as high as the top of my head;- " a mountain of mummy." I decided that it would be impracticable and unnecessary to remove the skin entire, although we could have done it, had it been desirable. I think it inadvisable to remove and handle an elephant skin entire, even under the most favorable circumstances, and were I called upon to skin an adult elephant in a menagerie, I should proceed precisely as we did then. We decided to cut the skin in three pieces, in such a way that when mounted none of the seams would show, and to this end we slit it open straight along the under side of the animal, straight along the middle of the back, and cut off the head, as the third piece, just at the crease in the neck. Dividing the skin along the middle of the back was terrible work, it being fully an inch and a half in thickness and indescribably tough. Then I congratulated myself upon having thin-bladed knives of the best shear steel, made especially for such work.

Of course each leg was slit from the sole of the foot, straight up the inside, to the opening along the breast and abdomen. When the opening cuts had all been made, we began at the middle of the back and skinned down the side which was uppermost, rolling the heavy skin over as we went along. When we reached the hip and the shoulder, we cut away a few cubic feet of flesh, cut off both the legs, and worked on down to the cut along the abdomen. After getting this half of the skin clear of the animal, we spread it out upon the ground and skinned the two legs without much trouble.

By the time we had accomplished this it was night, so we washed in the stream at the foot of the hill, built a large campfire, slung my hammock, ate our rice, and prepared to be comfortable. We camped just above the carcass, but quite near it, and while the Mulcers sat around the blazing fire, piling on dry bamboos and discussing the events of the day, I lay in my Ashantee hammock, swinging gently to and fro, gazing up at the green leaves dancing in the firelight. To be sure, I glanced occasionally at the huge red and white carcass just below us within the circle of 
light, and in thinking of its fine proportions all the fatigues and dangers of the chase were forgotten, or remembered only with satisfaction and pride. The night was clear and balmy, and the stars came out and peeped down through the leaves to see what we were doing. A light breeze came from the west, setting all the leaves a-whispering, and the bamboos rubbing together with peculiar measured "creechy-crawchy" sounds, like the creakings of a ship's rigging. We were many miles from a human habitation of any kind, in a wholly unfrequented part of the forest, and our only neighbors were the wild beasts of the jungle; but as I rolled myself snugly in my blanket and surveyed the wild scene, I vowed that this was "the jolliest life that ever was led."

Just as we were about to settle down for the night, we were rather startled at hearing a loud, ringing trumpet-note issue from the jungle on our right, and rather near us, too. This did not greatly matter, only we hoped the herd would not come our way just then. But a moment later this call was answered by a similar note from the valley on our left, and then we knew we were just between the two portions of the divided herd, and the elephants were trying to get together again. Neither party was much more than a quarter of a mile from us, apparently, and the Mulcers began to grow uneasy. They built another large fire and piled on dry bamboos until both blazed high; and I concluded I would feel more comfortable if I swung my hammock just between the two.

But the elephants kept trumpeting and answering back across that half-mile of jungle, waking the silent echoes far and wide with their shrill bugle calls, until at last we saw that they were unmistakably approaching each other in a direct line for our camp.

Then we bestirred ourselves. The Mulcers piled a lot of blazing fagots at the foot of a thick clump of dead and dry bamboos which still stood upright close by. The dry branches and stems caught fire directly, and the flames climbed to the very top of the clump, roaring and crackling fiercely, and throwing out a great light all around. Then the Mulcers began to yell like demons, in which noise I also joined my gentle voice, and I am sure that, could my reader have passed that way just then, he would have taken us for a party of imps out on a midnight spree, and trying to frighten all the wild animals out of their senses.

As might be imagined, the elephants gave us a wide berth, but their trumpeting was kept up at intervals all through the night. The Mulcers sat up all night by turns, watching, and keeping up 
the fires. In the small hours of the morning, when all was still, Channa quietly awakened me with the whispered words, "Naree, sahib!" In another moment I heard the low, deep growling of a tiger in the thick jungle near us, the second time I ever heard that sound in the forest. It was repeated at intervals, in the same halfangry, menacing tone in which a cat warns an intruder away from its prey. I felt that there was little danger of the tiger falling foul of us, because in the first place I knew he could not be a man-eater, and it was evident that he had been attracted to the spot by the scent of warm blood and the flesh of the elephant. He evidently recognized the fact that possession is nine points in law, and admitted the superiority of our claims by keeping away; but the next day we found his pugs, and saw where he had made his lair and lain him down to sleep within seventy yards of our camp.

The next morning we went at the carcass almost as soon as it was light enough to see. We first cut out the entrails and vital organs, and with indescribable difficulty dragged the unwieldy mass a short distance down the hill. That done, we cut off a quantity of flesh from the breast and pelvis, then went to work with a series of levers, props, and ropes attached to the two remaining legs, and after about two hours' hard work, we succeeded in rolling the carcass completely over, with the head still on. One member of my gang, Corlee, had stayed at camp playing sick, so there were only five of us to manage that elephant. After rolling the body over, which we considered quite a feat of engineering skill, we soon removed the second half of the skin and partly skinned the legs. That done, we spread out the two sides of the skin, inside uppermost, covered them with green boughs so that the sun should not shine full upon them, and leaving the head as it was, started for Sungam about 2 P.M.

Just as we were starting, a misfortune overtook me. In picking up our traps Vera stepped upon a sharp knife that had been dropped in a pile of green leaves. The Mulcers are always barefooted, and the keen blade made an ugly gash in Vera's foot, severing a small vein which bled profusely. Being provided for all such slight emergencies, I at once took two stitches in the cut, applied court-plaster and cotton, bound it up, and we started for camp, cutting a path through the jungle as we went along. As I feared, the exertion made Vera's wound bleed profusely in spite of all I could do, but he insisted upon going on.

When within about two miles of camp we crossed a small rocky 
stream, and I made Vera bathe his foot in the cold water while 1 cut a pair of forked sticks to serve him as crutches. A native of the East Indies has no more idea of a crutch, and how to use it, than of a quadrant. I was stooping down on a broad, sloping sheet of rock, trimming a stick with my hatchet, with Vera standing above and behind me, when he suddenly fainted from loss of blood, and the first thing $I \mathrm{knew}$, he pitched forward full upon my back, knocking me flat upon the rock and half into the water. It was a lucky fall for him, for had it not been broken by me as it was, he would have pitched head first upon the rocks, and very likely broken his neck or cracked his skull.

We brought him round in due time, and leaving Nangen with him we started on to camp, to send back four men with my hammock slung to a pole to bring him in. I sent after him immediately upon reaching camp, but the men met him half way, walking slowly along, and a good dose of arrack helped him to accomplish the remaining distance. But he was utterly incapacitated for work for an indefinite time, and I lost his valuable services during the remainder of our task.

This was the first of a series of unnecessary and unlooked for misfortunes and difficulties which came upon me during the preparation of that elephant skin and skeleton. That night there was a social scandal and a grand row in the Mulcer camp, not far from our huts. About bed-time, while I was writing in my journal a record of the day's events, the usual murmur of voices in the huts across the river gradually swelled into a loud jangle, which rapidly increased in volume every moment until it became a perfect tempest of angry voices, pitched on their highest key. Very soon it became evident that an unusual commotion was afoot, for the lights suddenly went out, a bamboo hut was torn down, women and children began to scream, and we distinctly heard the sound of men struggling and blows falling upon bare flesh.

Thinking it high time to interfere, I called for Doraysawmy and the elephant doctor, and snatching up a lantern, we ran down the hill toward the Mulcer camp. The place was in total darkness, but the sounds which met our ears plainly indicated that the Mulcers had gotten up a little hades of their own. Our sudden appearance upon the scene, with a loud call for "order" from the doctor, caused most of the Mulcers to fall back, but the principals in the fight paid no attention. We soon pulled them apart, however, and commanded them to keep the peace. The boy Moreeah, 
had been punished most of all, which afforded me no little satisfaction, for he had always been the worst grumbler in my gang, and made me the most trouble. More than once I was tempted to thrash him myself. After considerable trouble the camp was restored to a peace footing, and all hands settled down for the night.

The next morning, while making up the packs, I had a chill, which of course was followed by fever and a splitting headache. Can it be possible, I asked myself, that I am to lose that elephant skin on account of fever? It really did seem possible. Nothing short of my presence and assistance could save it from ruin within the next twenty-four hours. As my fever increased, I began to be discouraged. Doraysawmy finished making up the packs, consisting of the small tent, necessary provisions, and about a hundred pounds of salt and alum. When all was ready for a start I called up the men and told them we were ready, whereupon they sat down upon the ground, and all but Channa refused point blank to go! Here was a pretty situation for a man with the fever upon him! 


\section{CHAPTER XIX.}

\section{END OF THE ANIMALLAI CAMPAIGN.}

Balky Mulcers - Work on the Elephant again.-Wild Beast versus Tramp and Burglar.-My Mulcers go on a Strike.-Playing a Lone Hand.-Bringing the Men to Terms.-A Bloodless but Complete Victory.-Another Tiger about.-Treatment of the Elephant Skin. -The March out to Sungam.The Season.-The Last of my Hunting Gang.-Descent from the Hills in a Storm.-Paradise Lost.-Fever Again.-Good-by to the Animallais.My Collection of Mammals.

The lazy rascals knew there was hard work ahead, and I was soon to leave the hills, and having accumulated a goodly number of rupees in my service they shrank from further exertion. This, too, in the face of the fact that I had doubled the wages of each man on the evening previous! When we started on the hunt I promised the men a present of five rupees each when we had killed an elephant and skinned it, and the men demanded their money then and there, declaring they would not go a step unless I paid it. Knowing full well they would immediately desert me if I complied, I firmly refused their demand, and declared that unless they all went with me, and at once, none of them would ever receive a single anna of the prize money.

They were stubborn as mules, and refused to stir. In the presence of them all, I called up a messenger and told Doraysawmy to order him, in their hearing, to start at once for Animallai village, and bring me ten chucklers (tanners) before night. He understood my game, and started at once, apparently on the errand. Animallai village was twenty miles away, and before a messenger could go and bring help from there, the skin of my elephant would be ruined by decomposition. An uncured elephant skin cannot lie long. in hot weather without spoiling. While Doraysawmy and the elephant doctor were wrangling with the Mulcers, the sun kept climbing higher and higher above the tree tops, and I knew that a few hours more would seal the fate of the skin I had already worked so hard for. 
My little ruse set the men to thinking. Their wives soon found out the situation, and with lame Vera to back them, came across the river to where the men squatted sullenly around the door of my hut, and attacked them with a perfect volley of abuse for their laziness and stupidity in throwing away their claims upon the sahib's rupees.

The combined pressure was more than the men could stand, and Doraysawmy soon announced their willingness to go. By the time they had their packs ready I had passed the turning-point in my fever, but felt miserably ill. Knowing, however, that if I showed how I felt, the men would refuse to go a step, and that I must get to that elephant or lose it, I took a stick to lean upon, and started on ahead at a snail's pace, with my brain throbbing and jumping at every step. I determined to walk as far as possible, and if I gave out entirely, would be carried the rest of the way. The day was clear and fine, I bathed my head in every stream we crossed, rested about twenty times, and finally climbed up the steep hill-side to the scene of the wreck.

By that time I felt much befter, and without the loss of a moment, we got out our knives and went to work. We had a few hours of daylight left, and all worked like beavers. I had Channa and two others cut off the head and skin it carefully, while the rest of us-we were thes seven in all-skinned the feet and cleaned the inside of the entire skin, removing from it a quantity of adherent flesh. Half an hour before sunset we had the entire skin ready for the preservatives. At that time it weighed not less than nine hundred pounds (I believe eleven hundred would be nearer the mark!), being in many places an inch and a quarter in thickness.

With a brush, I washed the skin over on both sides with a strong solution of arsenical soap and water, and then sprinkled salt over it in liberal quantities and rubbed it in vigorously with a flat stone. Both sides were treated in this way, after which we folded it up compactly and let it lie to absorb the preservatives. At sunset the skin was safe.

Then we pitched the little tent, slung my hammock inside, the men made a lair for themselves under a clump of bamboos close by, we ate our suppers and turned in.

During the night we heard elephants trumpeting in the valley below us, reminding me of the distant band-music one often hears in a city on summer evenings. This led me to wonder how many eiephants, tigers, bears, deer, and wild boars were at that moment 
wandering about the dark forest within a mile's radius of our camp. A goodly number, beyond doubt, enough to make my reader shudder, perhaps, at the bare thought of being there. But softly! Wild beasts are far better company than the drunken roughs, the thieves, burglars, incendiaries and murderers who surround you in the city, or the tramps, combining all these disagreeable vocations, who infest the country generally. If I am to choose between tramp and tiger, I will say, give me the tiger every time, for he is far more honest and respectable as a general thing, far less revengeful, and a better member of society every way.

We had saved the skin of our elephant, or were in a fair way to do so at least, but there remained the task of cutting out the bones of the skeleton also. Our animal had been dead three days, and he began to smell like Lazarus in the sepulchre. The carcass had become a perfect ammonia-generator on a large scale and the vapor soon became almost overpowering. It was necessary to cut out the bones very quickly, or advanced decomposition would very soon render it impossible.

$M_{y}$ boy and I were up at daybreak, and after drinking a pint of good strong coffee I called the men. Instead of getting up and preparing to work, they merely sat up and stared at me in a sleepy, stupid way, without offering to obey. Doraysawmy exhorted them briskly to get up and go to work, for the carcass was beginning to smell bad.

The men replied, "How can we work on that stinking thing? It would make our stomachs sick!" Moreover, they declared they had only agreed to work on the skin, and that was done; they did not care to work on that thing for eight annas a day! Then, in my most commanding manner I commanded them to get up and help me. I commanded in splendid style, but they wouldn't obey! They merely gazed at me in sullen silence, stubborn as mules, and after a while lay down to sleep again.

It was a regular strike, from sheer laziness, and was perfectly exasperating. Should I take a stout stick and attempt to thrash them into obedience? If I did, they would of a certainty run away, and that would be a calamity indeed. I thought of a milder and far better plan, although I could not expect any results from it until the next day. An Indian native is proud and insolent so long as his stomach is full, and he has you in his power; but when it is empty, he is your humble servant. I told Doraysawmy to take no further notice of the men in any way, and after sharpening the 
whole set of knives, I rolled up my sleeves, gave my olfactories leave to suspend work for the day, and went at the huge carcass as eagerly as if it had been a plum-pudding. It was high time, for it was almost ready to walk away of its own accord.

It was not Doraysawmy's duty to do work of that kind, and, being my cook, I greatly preferred that he should not; but the faithful fellow could not stand it to see his master work alone. He threw off his jacket, lit his pipe, rolled his sleeves high up and fell to work on the side opposite me. The Mulcers looked on in wonder. We worked like a couple of steam engines, and the flesh rolled off the skeleton in chunks half as large as ourselves. From time to time, I fired up with Bass' ale and port wine, and the longer the fever kept away the harder I worked. The Mulcers lay there within twenty yards of us, wrapped in their cloths, sleeping the sleep of innocence.

By four o'clock we had the entire body and pelvis roughed out, and the worst was over. Then the Mulcers got up, yawned, shook out their cloths and started down to work. We took no notice of them until the first comer picked up a knife, and then I bawled out at the top of my voice,

"Drop that knife!"

He dropped it. He did not understand the words, but the tone and gesture were unmistakable. The Mulcers were astonished.

"But we are going to work!" they said to Doraysawmy.

"The sahib says you shan't touch this elephant," he replied in a savage tone.

"Well, then we will go!"

The boy told me what they said, and in their own language I told them, "Go, you rascals!"

Then said Doraysawmy impressively, "If you Mulcers go off and leave the sahib alome in the jungle, Theobald Sahib will give each one of you six months in jail!"

There was far more truth than poetry in that statement, and the men knew it well. We knew they would not dare to go unless I abused them. Somehow, European sportsmen and Government officers have all natives so thoroughly trained that they have a wholesome fear of the consequences when they are tempted to abandon a white man in the jungle. Usually they will not do it under any circumstances, for I remember that when I wanted the Mudumallay Chetties to leave me alone with a dead bull bison while they went after more men, they refused point blank and 
obliged me to accompany them. The Mulcers feared a day of reck. oning would come, so they did not dare leave me in the lurch.

At night, while my boy was preparing my supper, the men timidly asked him for rice. We always kept the rice in my tent, and served it out every night, with their salt, tobacco, and money. To save trouble, I paid my men their wages every day. Their request was brought to me, and putting on an awful look I said "No !"

Then the men were stricken with penitence and confessed their sins, saying they had been very bad, their heads were all wrong, and they would never be so lazy again. But they got neither rice nor tobacco. As they were squatting around the door of my tent, watching every mouthful I took at supper-time, a happy thought struck me. I told my boy, and he went almost beside himself. He told the Mulcers to "bring the arrack cup," and they said "Oh! the sahib is going to give us arrack!" How they smiled, and smacked their lips! They brought the cup instantly, I took out a bottle of arrack, uncorked it, and poured out a good drink, looked at the men and saw that they eagerly followed my movements, then handed the cup to Doraysawmy. He drank it off, and smacked his lips fervently several times, while I quickly corked the bottle and put it back in the box. A murmur of mingled surprise, disappointment, and remonstrance arose from the group outside, and presently the men went slowly and sadly away to their own fire.

The next morning the Mulcers awoke hungry. They immediately came to me and announced that they would work if I would give them something to eat. I replied, "How can I give you food when you do not work? You must work before you eat my rice!"

Seeing there was no help for it, they took the knives and fell to work upon the half-cleaned elephant bones as though their souls had yearned for that business. I sent Doray and Channa off to Toony for fifty pounds of salt, and all day I stood over the remaining men, scowling fiercely but saying not a word, like a veritable overseer of slave times, grinding their knives at intervals, and watching their movements.

I never saw men more devoted to their work. They could not even spare time to talk to each other, except now and then to speak in a low tone of "conjee" (rice soup), with the reverence accorded to the name of a departed friend. When sunset came I told them to stop work; and after the knives had been cleaned and put away, wood collected for my camp-fire, and water brought from the 
little rivulet, I served out a day's rations of rice and tobacco. They had had forty-eight hours between meals, and never were strikers more effectually cured. From that time until I left the hills, they worked faitbfully, with never a grumble, and when on final settlement, I partly carried out my threat by stopping a rupee out of each mau's prize money, they did not offer a word of complaint, but frankly admitted they had used me very ill.

The next day being my birthday, I took a holiday, and wrote up my journal. The only incident of the day was our hearing a tiger roaring in one of the ravines below us, not more than a quarter of a mile away. I declined to go after him in that thick underbrush, for had I gone in his neighborhood, he would probably have done a little huuting on his own account.

I had the men unroll the elephant skin, and we found it full of water, but beginning to harden quite properly, and after keeping them at work half a day, thinning down the thicker portions with their knives, we freely applied salt and powdered alum together upon both sides, and again folded it up. I found by experiments that the best way to preserve a very thick skin without a bath in which to soak it, is to treat it with salt first and let it lie a day or two before putting on any alum. Salt strikes through a thick hide where dry alum only goes half-way, leaving the other side to decompose. After decomposition has been arrested by salt, then it is best to apply powdered alum to harden the skin and dry it up completely.

After the men got through with their little strike, I had them clean all the elephant's bones very thoroughly, and after soaping them they were tied up into bundles and made ready to carry out. By the time we were ready to break up camp and move to Sungam, a gang of about twenty coolies arrived from Animallai to assist in carrying out our elephant skin and skeleton. Each of the large sections was slung under a couple of stout poles, and eight men were required for each section. Four more men carried the skin of the head, while my Mulcers carried my camp equipage and a few bones of the skeleton. Doraysawmy again showed his estimable qualities in helping me manage the packing up. It was a queer procession that marched down that steep hill and through the forest toward Sungam. This time I brought up the rear, to see that no valuable article was dropped and lost.

When we reached Sungam, the Mulcers had scarcely time to put down their loads before they were set upon by their wives, 
who had heard all about the strike, and they were roundly abused for their laziness and neglect of their families. The men looked thoroughly ashamed, and each took his lecture very meekly. Poor wretches! it was probably the first time in their lives they ever felt fat enough to strike, and they wanted to see how it would feel to defy a white man and refuse to work.

The next day, part of the men went back and brought away all that remained of the skeleton, while I set the remaining ten, who belonged to the chuckler caste-tanners-at work upon the skin to thin it down still more. They all worked upon it three days, in which time they cut off several hundred pounds of the tough fibre. We now kept the skin spread out all the time, and it began to dry rapidly.

Having succeeded in adding to my collection of Indian mammals the skin of a full-sized male elephant in perfect condition, I was ready to leave the hills. It was then the first week in December, and I had had all the hunting I wanted. Mr. Theobald was gone, and so were nearly all the people attached to the Forest Department. We were then in the middle of the northeast monsoon, it rained a great deal, and the forest, being now almost deserted, seemed really gloomy. On the other hand, however, the elephants and bison had come down in great numbers from the higher ranges, and were quite thick all around Sungam and Toonacadavoo, where they were seldom seen earlier in the season. In many localities where, four months previous, I had hunted through grass not more than a foot high, it was then all of five or six feet. It always made me feel uneasy to walk through grass as high as my head, which could conceal a crouching tiger so closely one might almost stumble over it before seeing it. It is only the abundance of game that preserves the defenceless hill-people from being eaten one after another, and I have often wondered that the game-killing tigers do not occasionally strike down a man by mistake. There are plenty of tigers on the Animallais, for we often saw their pugs, but the cover for them is so continuous, and game so plentiful, that regular tiger hunting is out of the question, and perhaps always will be.

As soon as the elephant skin was dry enough to be transported, I sent for three bandies to meet me at the foot of the hills, and three more to cart my collection and camp equipage down. The day we were to start, we loaded the carts and were almost ready for a move, when a terrific rain-storm came up and delayed us for some hours. About noon it cleared up, however, and being very anxious to make a move, we set out. My Mulcers marched with us 
for about five miles, to show their good will, and even in spite of their late waywardness I felt quite sorry to part from them. They were bound to me by the ties which only a hunter can understand, and I shall always have the "man-and-a-brother" feeling for my faithful and courageous companions of the chase. Together we had been in at the death of many a fine animal. They had always shown themselves plucky in the face of danger, and except in two instan. ces, they had always been faithful and obedient. They begged me to come back soon and shoot some more elephants, and loudly lamented that I needed to go away at all. Poor wretches! it will be a long time, I fancy, before they have another such a " continual feast" of bison, deer, pig, and monkey as they grew fat upon during my four months' shooting on those hills. They are too poor to own fire-arms, or even to use them, hence the greater part of the time they hinger for flesh with game all around them.

When our train reached the top of the pass and began to descend the winding, slippery, and dangerous road, heavy clouds swept against the mountain side, enveloping us in their disagreeable mist, which very soon gave way to more serious moisture as the rain began to descend upon us in blinding sheets. Luckily I had packed into one of the bandies the articles which it was absolutely necessary to keep dry, and this load I effectually covered with my tent-cloth and rubber blankets. Of course we were all drenched to the skin, and the rain was very cold. Half-way down the ghaut, one of our bandies took a sudden slide in rounding a sharp curve, and came within two inches of going over a precipice and smashing the whole outfit. The road had become a running stream and progress was very unsafe.

Thus was our Paradise lost. Like the pair that was driven from Eden, we went down the rugged road in storm and darkness, into the cheerless and inhospitable plains. How different from the gloom surrounding our departure was the balmy sunshine of our first ascent, when all nature seemed to smile.

Just at dark we reached Ardivarum, at the foot of the ghaut, thoroughly bedraggled, and chilled to the bone. The other bandies were waiting for us, and we lost no time in transferring our freight to them. Doraysawmy was attacked with a severe chill which made his teeth chatter for two hours. Luckily we found at Ardivarum a fourth bandy, and I struck a bargain with the driver to take my boy and me to Animallai. We put into it our camp-chest and box of clothes, and, leaving the heavily loaded carts 
to follow on, we set out. It was a miserably cold and tedious ride of ten miles, hut we reached our haven at last, and at midnight landed in a good, tight bungalow. We soon put on dry clothes, and after a hot supper we found there was yet something left to live for.

But our ducking cost us dearly, or it did me at least. The next day but one, after my bandies had arrived, everything been safely housed, and the elephant skin folded up permanently, I began to shake and burn. During the next five davs the fever shook me up more violently than ever before. The quinine I took to check it ixcted every time as an emetic, and I cast up accounts about six or seven times daily. My boy became quite alarmed at last, and threatened to take the matter into his own hands, and have me carried forthwith to Coimbatore to be doctored; but I persuaded him to wait a little. I say persuaded, because I had no power to prevent his having me carried anywhere. A famine officer, Mr. Huddleston, stationed in Palachy, heard of my unfortunate predicament and came forthwith to see me. I had previously met him under very pleasant circumstances, and it was with great difficulty that I prevented his carrying me off, nolens volens, to his bungalow, to be doctored and cared for. I persuaded him also to give me a little time, and in a few days my fever began to abate. Mr. Huddleston insisted upon dividing his choicest stores with me, and kept me supplied with the best the country afforded. He, too, had hunted "ravine deer," black buck, and nil-gai around Etawah in the ravines, and had bagged several leopards in the same district. He was a very keen sportsman, and while I was convalescing he used to gallop over on horseback and spend his spare time with me, talking of the chase, which I verily believe helped me more than medicine.

I remained at Animallai until I was able to get about again, and then I gave my collection a final overhauling and packed it up in some large packing-cases which I procured from Coimbatore.*

* I found that my Animallai collection contained the following mammals, skins or skeletons:-2 Elephants (Elephas Indicus); 2 Tigers (Felis tigris); 1 Jungle cat (Felis chares); 1 Tree cat (Paradoxurus musanga) ; 8 Bison (Bos gaurus); 4 Muntjac (Cervulus aureus); 5 Sambur deer (Rusa aristotelis); 14 Spotted deer (Cervus axis); 1 Neilgherry wild goat (Hemitragus hylocrius); 1 Black bear (Ursus labiatus); 2 Wild boar (Sus Indicus); 3 Madras langurs (Semnopithecus leucoprymnus) ; 38 Black langurs (Semnopithecus cucullatus); 1 Madras monkey (Macacus radiatus) ; 1 Flying squirrel (Pteromys petaurista); 5 Malabar squirrels (Sciurus Malabaricus); 22 Flying foxes (Pteropus Ed. voardsii) ; 2 Indian hares (Lepus nigricollis). 
The elephant skin I had carefully folded before drying, so that I was able to pack the whole of it in a box measuring 2 feet 6 inches by 2 feet 6 inches by 2 feet, and the whole weighed only two hundred and ten pounds. I may add here that in 1880 this skin was mounted at Professor Ward's establishment in Rochester, by another taxidermist, Mr. J. F. D. Bailly, and myself, requiring four months' labor, and the old tusker who fell under such romantic circumstances on the Animallai slope now stands, still "monarch of all he surveys," in the Museum of Comparative Zoology, of Harvard University, Cambridge, Mass.

At last the day came for me to leave, bag and baggage, for Madras. Usually, in my wanderings in the tropics, when the time comes for me to turn my back upon a given locality, I am able to do so without a sigh, or a single wish ever to return and have my experiences over again. Very often, I am glad to think that I am leaving a place forever; but not so with the Animallais. When the time came for me to take my last look at the precipitous range which loomed up like a wall all along the south, shrouded in a soft blue vapor, I felt the sad conviction that never again would I carry a rifle into such another hunter's paradise as that. The jungles had treated me kindly in yielding up so much, and from that day until my last I shall always have a longing to fight those battles over again.

By dint of the greatest determination, I managed to hold $\mathrm{my}$ head up long enough to ship my cases of specimens at Coimbatore, and take the train for Madras. I was not able to call on the Collector, Mr. Wedderburn, to express my thanks for his official kindness to me, and to report my success, but was obliged to make my acknowledgments in writing. After enjoying another fever fit at Madras, I shipped my Southern India collection, five wagon-loads of big boxes, for Rochester, via London, on a Peninsula and Oriental steamer, bestowed my blessing and twenty rupees backsheesh upon Doraysawmy, the gentleman's god, and took passage on a steamer bound for Ceylon. 


\section{CHAPTER $\mathrm{XX}$.}

\section{THE INDIAN ELEPHANT.}

Geographical Distribution. - Indian and African Species Compared.-The Cey. lon Elephant. - The Capture of Wild Elephants. - Breeding in Captivity.Gestation of the Elephant.-Duration of Life.—Growth and Height.-Size of Tusks.-Classes of Elephants._Uses.-Table of Values.-Intellectual Capacity and Temper._Elephants at Work in a Timber Forest. - Feeding Elephants.-Cost of Keeping._- "Must," or Temporary Insanity-"Rogue" Elephants.-How an Elephant Kills a Man.-Swimming Power of Elephants.

DURING my stay in Southern India I was so frequently brought in contact with elephants, both tame and wild, that I was able to study them with some care. As a fitting appendix to the record of my experience in the "Elephant Mountains" (Animallais), I will endearor to give a brief sketch of this interesting animal.

According to the classification of most naturalists, there are only two species of elephants now living, the Indian and the African, both of which are very much smaller than their extinct ancestors, the mammoth (Elephas primogenius) of Europe and Asia, and the Elephas ganesa of Northern India. The Indian variety (Elephas Indicus) is found in a wild state in most of the large forest tracts from the Terai, at the foot of the Himalayas, to within a few miles of Cape Comorin, and also throughout Assam, Burmah, and Siam, and almost the entire length of the Malay Peninsula. In Southern India, elephants are most abundant on the Animallai Hills, in the Wainaad Forest, Coorg, and part of Mysore, particularly the Billigarungan Hills. In the north, they are common in the Bhootan Hills, Assam, and the mountains of Chittagong, and in the Territory of Selangore, near the lower end of the Malay Peninsula they are so numerous and mischievous that an elephant hunter is welcomed by the officers of the government and the natives as well. Elephants are also found in Ceylon in great numbers, and in Sumatra and Borneo, of which hereafter. 
The African elephant is still abundant in Africa generally south of the Sahara, except that near the Cape they have been driven back into the interior by the colonial settlements, extending from the Orange River to the Limpopo, and likewise on the west from Senegambia to the mouth of the Niger. On every side their numbers are decreasing with great rapidity, and those that remain are being rapidly crowded toward the heart of Africa. Even there the natives make war upon them, as far as they are able, for the sake of their ivory. Next to the traffic in slaves, ivory-hunting is the most important business carried on in the interior of the continent. Like the gold-hunters of California, those who engage in it penetrate the most remote and dangerous wildernesses, braving the dangers of death from starvation, fever, and poisoned arrows in their adrenturous search for tusks.

In a brief comparison of the two species, the following are the most striking points of difference :

The African elephant is undeniably larger than the Indian. Sir Samuel Baker informs us that both males and females of the former average about one foot taller than the latter, of which not more than one male in a thousand attains a vertical shoulder height of ten feet. The African elephant has a convex forehead, that amounts to a decided hump in the middle of the face, the head is peaked at the top, and the ears are of such enormous size that they meet and overlap each other above the shoulders. The Indian variety has a very broad, concave forehead, and the head has a deep, central furrow lengthwise along the top, by reason of which the crown is surmounted by two large rounded humps. The ears are not quite half the size of those which literally cover the entire neck and fore-shoulders of the African individual, and the species are easily distinguishable by this point alone. There are various anatomical differences which it is unnecessary to state here.

The Ceylon elephant differs from that of India proper in so many points as to necessitate the belief that it is a distinct variety. Hundreds of new species have been founded, and acceptably, upon far slighter differences than we find here. In the first place, while nine out of every ten male Indian elephants have tusks, not one out of every fifty Ceylon elephants possesses them, and Sir Samuel Baker goes so far as to assert that they are present in only one animal out of every three hundred. The Ceylon elephant has twenty pairs of ribs and twenty dorsal vertebræ, against nineteen of each in the Indian species, while the latter possesses one more sacral 
vertebra than the former. The Ceylon elephant is, without doubt, of smaller average size than its congener of the peninsula, and I be lieve it could be proven that the same difference in size exists between these two that is found between the Indian and the African.

Strange to say, the elephant which inhabits Sumatra exactly rosembles that of Ceylon in point of structure, and many eminent naturalists regard this coincidence as strong evidence in support of the theory that the two islands were once connected by a rast continent. It is, however, much easier to account for the presence of the Ceylon elephant in Sumatra by supposing it to have been originally transported from the former island in a domestic state ancl afterward allowed to run wild.

The Indian elephant in a wild state is now an inhabitant of Northeastern Borneo, but it is highly probable that in a few centuries all the records will be lost or obscured which now inform us that more than a hundred years ago the East India Company sent some elephants as a present to the Sultan of Sulu, and he, fearing the huge beasts would devour the whole annual crop of his little island, had them landed on the coast of Borneo, at Cape Unsang, where they were to be cared for by his subjects. It is easy to conjecture how long an indolent Malay would exert himself to feed an utterly useless animal with the appetite of an elephant, and how soon the animals would be turned loose to feed themselves in the jungle ; nor is it difficult to imagine the naturalists of the twentythird century regarding the presence of the Indian elephant in Borneo as proof positive that that great island was once connected with the mainland of Asia and Ceylon by a continent.

Up to this time, the African elephant has never been systematically captured alive and trained to service by the natives, but in Ceylon, India, Burmah, and Siam, elephant-catching has been carried on regularly from time immemorial. About the time of the English occupation, the island of Ceylon contained, almost beyond question, as many wild elephants as the whole of the peninsula of Hindustan, whole districts being completely overrun with them. Great numbers were caught in corrals, sometimes as many as one hundred and sixty head at a single drive, and even as late as the last decade but one, the number exported annually amounted to an average of one hundred and ninety-three. Since the English occupation, thousands have been slaughtered by sportsmen, and thousands more captured and exported, until finally, in 1870, the Colonial authorities decided that the proper limit of destruction 
had been reached, and a fine was imposed upon the shooting of elephants.

In former times, elephants were so numerous in Southern India that the Madras Government paid a rewarcl of $£ 7$ per head for their destruction. Had this law remained in force up to this time, it is quite sure there would now be very few of the animals remaining in the Presidency, and their complete extinction would be but a question of a few years. In 1873 an act was passed to prevent their destruction, and they are now protected in all parts of India and Ceylon.

In Hindustan, elephants have been caught in the Coimbatore District under the direction of the collector, Mr. Wedderburn; in Mysore by Mr. G. P. Sanderson under government authority and support; and in Chittagong, also, an annual catch has been made on government account for many years past. Smaller operations have also been conducted by private individuals (natives) in the same region with official sanction. It is far cheaper, and more expeditious, to catch elephants for service than to breed and rear them, on account of the fact that an elephant is from fifteen to twentynive years in coming to maturity.

The plan pursued in capturing a wild herd is, like the shooting of one's first elephant, very easy to understand, but very difficult to execute. In a tract of forest which is periodically visited by large herds, a spot is selectad with reference to the natural advantages of the ground, such as streams of water, or high banks, and some days or weeks before the elephants are expected, a large force of natives is set to work to build an enclosure. A keddah, as it is termed in India, is constructed by enclosing several acres of forest with a stockade ten to twelve feet high, built of stout posts set close together and strongly braced on the outside, the whole being firmly lashed together with green bark or creepers. At the proper place, usually on an elephant path, a wide gateway is left, and either a heavy gate is made and suspended above the opening, ready to be instantly dropped, or else a number of stout sliding bars are arranged. From each side of the gate, a long guiding wing is built, similar to the stockade itself, the two diverging and extending some distance out into the open forest.

When a wild herd wanders near enough to this huge trap, and on the gate side, an army of native beaters, from three hundred to two thousand men, with tom-toms, rusty firearms, and brazen throats, surround the elephants on three sides, and by judicious 
use of their noises, drive them into the enclosure, after which the gate is instantly closed and secured.

A keddah is never so strongly built but that the larger elephants could break through it anywhere, by a combined and determined rush, and when a herd is caught, the defence of the stockade immediately becomes a matter of great importance. The beaters surround it with firearms, torches, and long poles, and whenever an attack is threatened upon any given point, the men rally there promptly, and frighten the assailant away. Judging from what I have heard, I should think native music (!) would be a most excellent thing to employ in defending a keddah. It is so thoroughly frightful that I think even the most determined elephant would run from it.

When the captives have finally abandoned their frantic efforts to escape, and stand huddled together in a terrified group in the centre of the enclosure, the tame elephants and the noosers are introduced at the gate, and one by one the wild ones are singled out and surrounded. Usually three or four tame elephants completely surround one of the others and hold him in his place, while the noosers slip down, quietly tie his feet together with strong, soft ropes, and before he is fully aware of the situation he is ready to be marched out of the keddah between two of the tame animals. Most wild elephants are completely tamed, and ready for work, within three or four months after capture, and not unfrequently good-tempered animals can be ridden with safety in a few days. It is, however, a matter requiring more time to bring an elephant up to the perfection of training. Sanderson declares that the largest and oldest elephants are frequently the mosi easily tamed, as they are less apprehensive than the younger ones.

There are other ways in which elephants are caught now and then, namely, in pitfalls and by hunting with tame females. The former method is no longer followed except among the most benighted natives, and the latter can succeed only under the most exceptional and favorable circumstances.

It is so much more economical and expeditious to catch wild elephants and train them, than it would be to breed and rear them in captivity, no particular attention is paid to the latter means of keeping up the supply of serviceable animals. Notwithstanding this, elephants are frequently born in captivity, and have been ever since the days of Pliny. On the Animallais, five were born in one year in the stud belonging to the Forest Department, all of 
which lived. Sanderson mentions the birth of eight calves (between September and November) in a herd of fifty-five elephants he captured in Mysore. Even in the United States, under the most unfavorable circumstances for elephants, two have been born very recently in a menagerie, and are still alive.

The period of gestation in the elephant is about twenty-two months. The fœtus at twelve months is almost jet black, the teeth are destitute of the cementing crusta petrosa, and therefore the enamelled plates, called laminæ in the mature molar, are entirely separate from each other, lying one upon the other in the cavity of the jaw. At birth, the baby elephant is from thirty to thirty-six inches high and weighs from one hundred and forty-five to two hundred pounds. All those I have seen, both wild and in captivity, have been of a dark brown color, several shades darker than adult animals, and were usually quite hairy, especially upon the back and head.

The female elephant reaches the age of puberty at fifteen years, but continues to grow for several years after. An elephant may be said to attain its full growth between the ages of eighteen and twenty-four years in captivity, and between twenty-four and thirty in a wild state. Although there is no possible way of verifying the accuracy of this statement so far as the wild elephants are concerned, it certainly stands to reason that those in captivity, by reason of overwork, underfeeding, exposure to the heat of the sun, and irregularities in their treatment, will stop growing much earlier than the wild animals. It is well known that captive elephants stop growing between the ages first mentioned above, and more than this, that elephants reared in captivity seldom reach the extreme limit of size, which is found only in animals captured after their full growth has been attained. It may therefore be made as a general statement, that the elephant acquires his perfection of form, size, and general physique at about the same age as does a welldeveloped white man of the temperate zone.

At sixty years of age the elephant is considered to be in the prime of life. According to Sanderson, experienced natives believe that elephants generally live to about eighty years of age, and but rarely attain an age of one hundred and twenty years; his own opinion, however, is, that under favorable circumstances the animal attains an age of one hundred and fifty years.

As is the case with nearly all large animals, the height of the Indian elephant is usually recorded in exceptional figures, which, 
being far higher than the average adult animal, convey an crroneous impression. Even the best scientific writers are apt to fall into the habit of giving the largest measurements fairly attainable, which therefore brings the average animal far below the standard they set np. I can scarcely recall an instance of having shot a mammal, even out of a score of the same species, which came up to the measurements recorded by Jerdon in his "Mammals of India."

The height of the male Eleyhas Indicus should be recorded as 9 feet 6 inches, vertical measurement, at the shoulder, and the female 8 feet, for these figures represent the height of from eight to twelve individuals to be found in every hundred; in other words, animals which can be seen without searching throughout the length and breadth of India.

The height of the Indian elephant is nearly everywhere recorded as being from 10 to $10 \frac{1}{2}$ feet. The largest animal of the species ever measured by reliable hands was a tusker described by $\mathbf{M r}$. Corse in 1799 as belonging to Asaph-ul-Daula, a former Vizier of Oudh, which really measured 10 feet 6 inches, perpendicularly, at the shoulder. This animal was merely one out of ten thousand, and it would be quite as sensible to measure Chang, and record the height of Chinamen as being seven and a half feet, as to say that the Indian elephant is as tall as the Vizier's giant.

As furnishing the most positive and accurate information on this point, I tako pleasure in quoting the following paragraphs from Mr. G. P. Sanderson's delightful book, "Thirteen Years Among the Wild Beasts of India." In this work the author has given us the freshest, fullest, and most accurate information ever penned concerning the Indian elephant, as well as the most charming story of jungle life $I$ have ever read. On page 55 he writes as follows:

"Out of some hundreds of tame and newly-caught elephants which $I$ have seen in the south of India and in Bengal, also from Burmah and the different parts of India, and of which I have carefully measured all the largest individuals, I have not seen one 10 feet in vertical height at the shoulders. The largest was an elephant in the Madras Commissariat stud at Hoonsoor, which measured 9 feet 10 inches. The next largest are two tuskers belonging to his Highness the Maharajah of Mysore, each 9 feet 8 inches, captured in Mysore some forty years ago and still alive.

"Of females, the largest I have measured, two leggy animals in the stud at Dacca, were respectively 8 feet 5 inches, and 8 feet 3 inches. As illustrating how exceptional this height is in females, 
I may say that out of one hundred and forty elephants captured by me in keddahs in Mysore and Bengal in 1874 and 1876, the tallest females were just 8 feet. The above are vertical measurements at the shoulder. . . . . There is little doubt that there is not an elephant 10 feet at the shoulder in India."

Mr. Corse also makes the following statement:

"During the war with Tippoo Sultan, of the one hundred and fifty elephants under the management of Captain Sandys not one was 10 feet high, and only a few males $9 \frac{1}{2}$ feet high."

The following table, showing the rate of an elephant's growth, has been compiled from sources of undoubted authenticity-chiefly from the two authors quoted above-and is submitted in the belief that the figures are correct.

Table of Growth of a Mate Euephant.

\begin{tabular}{|c|c|c|c|}
\hline \multirow{2}{*}{ Period of Life. } & \multicolumn{2}{|c|}{ Height at Shoulders. } & \multirow{2}{*}{$\begin{array}{c}\text { Weight. } \\
\begin{array}{c}\text { Pounds. } \\
200\end{array}\end{array}$} \\
\hline & $\begin{array}{c}\text { Feet. } \\
2\end{array}$ & $\begin{array}{c}\text { Inches. } \\
11\end{array}$ & \\
\hline When one year old. & 3 & 10 & $\sim 00$ \\
\hline When two years old ... & 4 & 6 & \\
\hline When three years old................. & 5 & 0 & 940 \\
\hline When four years old $\ldots \ldots \ldots \ldots \ldots \ldots \ldots \ldots$ & 5 & 5 & \\
\hline When five years old $\ldots \ldots \ldots \ldots \ldots \ldots \ldots$. & 5 & 10 & \\
\hline 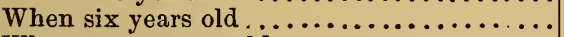 & 6 & $1 \frac{1}{2}$ & 2,725 \\
\hline When seven years old $\ldots \ldots \ldots \ldots \ldots \ldots \ldots$ & 6 & 4 & \\
\hline When eleven years old..$\ldots \ldots \ldots \ldots$. & 7 & 0 & 4,313 \\
\hline When eighteen years old $\ldots \ldots \ldots \ldots \ldots \ldots$ & 8 & 6 & \\
\hline 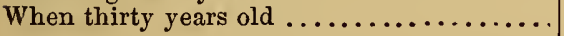 & 9 & 6 & 8,804 \\
\hline
\end{tabular}

As may readily be inferred from the relative size of the species, the African elephant has the larger tusks. The largest tusk taken by Gordon Cumming during his famous hunt for ivory was 10 feet 8 inches long and weighed one hundred and seventy-three pounds. I have never seen a well-authenticated record of a larger single tusk, although Cuvier, on hearsay evidence, mentions a tusk sold in Amsterdam as weighing three hundred pounds. It was very probably a pair. The tusks of the Indian elephant are, in general terms, about half the average length and weight of the African. The largest tusk ever taken in India, so far as can be ascertained, was 8 feet in length and weighed ninety pounds, which may be regarded as one out of ten thousand. The largest taken by Sanderson out of twenty elephants shot, was five feet in length and weighed thirty-seven and one-half pounds, which may justly be considered a 
tusk far above the average size. In a pile of nearly a hundred Indian elephant tusks which I saw in the Custom House at Bombay, not one measured five feet in length, and most of them were under four feet.

In Hindustan, all male elephants have tusks, except about one out of every ten, which, on account of their absence, is called a "muckna." The tips of the tusks project beyond the lip of the maie animal almost as soon as born, and I have even seen them showing very distinctly in a half-grown fœtus. Sanderson asserts, well supported by the best of evidence, that these baby tusks are never shed, notwithstanding the common assertion to the contrary. The female elephants and the mucknas all have miniature tusks, the points of which at first project a few inches beyond the lip, but they are very soon broken short off at the lip, leaving a rough, jagged end which is much used in barking trees, etc.

The natives of India divide elephants into three very distinct castes, or classes, with as much precision as do the most captious breeders of fancy animals, and all local prices are based upon this classification. Commercially, all tame elephants are divided into two classes, those for use, and those for show. For the same reason that every English gentleman of distinction has a long retinue of choice initial letters marching in solemn procession after his name, every Indian prince or nobleman keeps a train of showy elephants to add to his prestige. Lately, however, the elephants, besides being very expensive to keep, have become very high-priced, and the English Government, with commendable forethought, has commenced to distribute initials among the native rajahs and maharajahs to take the place of the animals. I believe that among the more enlightened natives, "C. S. I." is considered equal to three first class tuskers.

All other things being equal, the price paid for an elephant in the Indian market depends almost wholly upon the points of the animal, or, in other words, upon his class. Sanderson says: "Elephants are divided by natives into three castes or breeds, distinguished by their physical conformation; these are termed in Bengal, Koomeriah, Dwasala, and Meerga, which terms may be considered to signify thorough-bred, half-bred, and third-rate.

"Whole herds frequently consist of Dwasalas, but never of Koomeriahs or Meergas alone; these, I have found, occur respectively in the proportion of from ten to fifteen per cent. among ordinary elephants. 


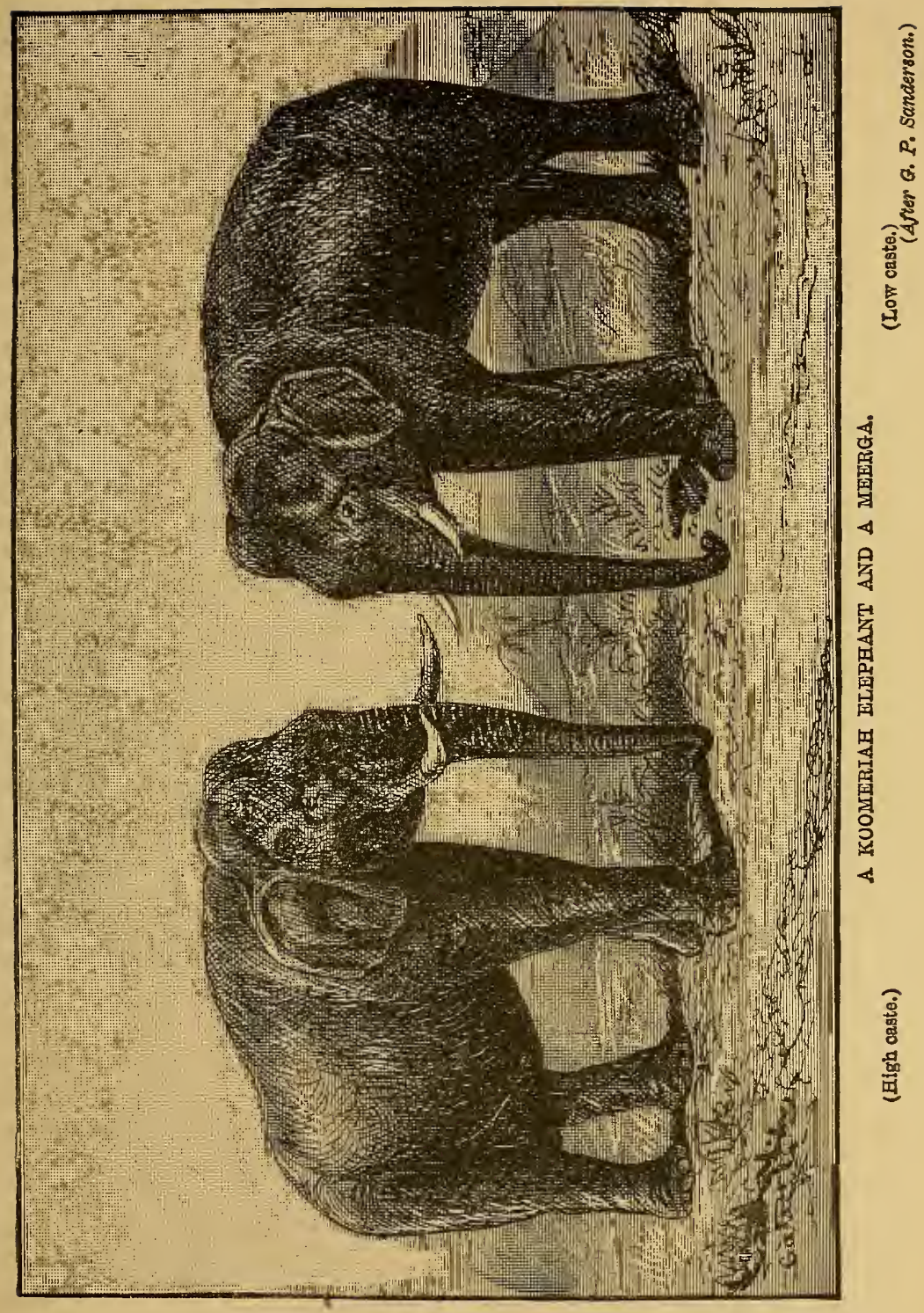



"The Koomeriah, or thorough-bred, takes the first place; he alone can reach extreme excellence, but all the points required for perfection are very rarely found in one individual. He is, among. elephants, what the thorough-bred is among horses, saving that his is a natural, not cultivated superiority. The points of the Koomeriah are ; barrel deep and of great girth ; legs short (especially the hind ones) and colossal, the front pair convex on the front side from the development of muscles; back straight and flat but sloping from shoulder to tail, as an upstanding elephant must be high in front; head and chest massive; neck thick and short ; trunk broad at the base and proportionately heavy throughout; bump between the eyes prominent; cheeks full ; the eye full, bright, and kindly; hind-quarters square and plump; the skin rumpled, thick, inclining to folds at the root of the tail, and soft. If the face, base of trunk, and ears be blotched with cream-colored markings, the animal's value is thereby enhanced. The tail must be long but not touch the ground, and be well feathered.

"The Dwasala class comprises all animals below this standard but which do not present such marked imperfection as to cause them to rank as Meergas, or third-rates; all ordinary elephants (about serenty per cent.) are Dwasalas.

"A pronounced Meerga is the opposite to the Koomeriah. $\mathrm{He}$ is leggy, lank, and weedy, with an arched, sharp-ridged back, difficult to load and liable to galling; his trunk is thin, flabby, and pendulous; his neck long and lean; he falls off behind; and his hide is thin. His head is small, which is a bad point in any elephant; his eye is piggish and restless. His whole appearance is unthrifty and no amount of feeding or care makes him look fat. The Meerga, however, has his uses; from his length of leg and lightness he is generally speedy ; the heavier Koomeriah is usually slow and stately in his paces." *

In Inclia, elephants still form the most imposing feature of every ceremonial procession which involves a display of the "pricle, pomp and circumstance" of a native ruler or prince. Of all created ani. mals, the lordly elephant alone was born to wear splendid trappings of gold cloth surmounted by a magnificent howdah of gold and silver, a perfect diadem in itself, and carry princes upon his back. At such times the king of beasts is fairly crowned, and no monarch in royal purple ever walks with more majestic tread or bears him.

* Wild Beasts of India, p. 84. 
self with more kingly dignity than he. Delhi saw a goodly sight, the like of which will probably never occur again, when it beheld during the Imperial Assemblage of January 1, 1877, a procession of elephants, the finest in all India, splendidly caparisoned and surmounted by magnificent howdahs, in which sat the swarthy princes of a score of native states, bedecked with the most gorgeous colors and glittering with jewels. On such occasions as this the elephant is in his proper sphere.

Aside from the purpose mentioned above, the trained elephant is of great value both to the government and private individuals for dragging timber in forests and piling it at the depots, carrying and drawing pieces of artillery, and also carrying stores on military campaigns, particularly in mountainous regions.

In 1870 the government of Ceylon imposed an export duty of $£ 20$ per head on elephants, which has completely stopped the annual supply of India from that source, and caused a great advance in prices in the Madras and Bengal markets. Since the prices of elephants of the same size and age depend upon their class, it is impossible to state more than their relative values. In the following table I have endeavored to give the ruling prices in India at this date (1882) according to sex and size, indicating the range of prices in each case.

I need hardly say that in the United States, elephants do not figure either in Lord Mayor's processions or timber forests, and are of value to the showman only.

\begin{tabular}{|c|c|c|c|c|c|}
\hline Quality. & $\begin{array}{l}\text { Heigh } \\
\text { shoul }\end{array}$ & & $\begin{array}{r}\text { Value } \\
\text { Indi }\end{array}$ & & $\begin{array}{l}\text { Value in } \\
\text { America.* }\end{array}$ \\
\hline $\begin{array}{l}\text { Baby, during first year } \ldots \ldots \ldots \ldots \\
\text { Female, four years old } \ldots \ldots \ldots \ldots \\
\text { Female, seven years old } \ldots \ldots \ldots \ldots \\
\text { Female, eleven years old } \ldots \ldots \ldots \\
\text { Female, eighteen years old........ } \\
\text { Female, over twenty-five years old. }\end{array}$ & Feet. & \begin{tabular}{rr}
\multicolumn{3}{c}{ Inches. } \\
3 & 0 \\
5 & 6 \\
6 & 4 \\
6 & 10 \\
7 & 8 \\
8 & 3
\end{tabular} & $\begin{array}{l}£ 20 \text { to } \\
25 \text { to } \\
50 \text { to } \\
100 \text { to } \\
150 \text { to } \\
200 \text { to }\end{array}$ & $\begin{array}{r}£ 40 \\
35 \\
75 \\
150 \\
175 \\
275\end{array}$ & $\begin{array}{r}\$ 100,000 \\
2,500 \\
3,000 \\
3,500 \\
4,000 \\
4,500\end{array}$ \\
\hline $\begin{array}{l}\text { Tuskeı, four years old ........... } \\
\text { Tusker, seven years old .......... } \\
\text { Tusker, eleven years old } \ldots \ldots \ldots \\
\text { Tusker, eighteen years old....... } \\
\text { Tusker, over twenty-five years old. } \\
\text { Tusker, highest class............ }\end{array}$ & $9 \frac{1}{2}$ to & $\begin{array}{l}6 \\
4 \\
0 \\
6 \\
4 \\
0\end{array}$ & $\begin{array}{r}50 \text { to } \\
100 \text { to } \\
300 \text { to } \\
600 \text { to } \\
800 \text { to } \\
1,200 \text { to }\end{array}$ & $\begin{array}{r}80 \\
200 \\
500 \\
800 \\
1,200 \\
2,000\end{array}$ & $\begin{array}{r}3,000 \\
3,500 \\
4,000 \\
5,000 \\
7,000 \\
15,000\end{array}$ \\
\hline
\end{tabular}

* Statement furnished by Mr. P. T. Barnum. 
The elephant is the most patient and obedient of all animals, and by far the most intelligent. He has more ability to reason from cause to effect than most other animals of docile temperament, and he is, beyond all question, the most capable of being taught and the most willing to obey after he has been taught. To me it is a matter of surprise that Mr. Sanderson, who has, I presume, more personal knowledge of the animal both tame and wild than any European living, should place so low an estimate upon his mind. He declares that "its sagacity is of a very mediocre description," and also that "its reasoning faculties are far below those of the dog, and possibly other animals."

From this view, which I think is due to the fact that "familiarity breeds contempt," I differ very widely. My acquaintance with tame elephants has created in my mind a respect for their intellectual qualities which I never could have acquired in any other way. A trained dog or horse is such a rarity, even among the thousands of their species, that it is considered a proper object to exhibit at a circus. A horse which will promptly back at the word of command, or a dog which will bark or stand on its hind legs when told to do so, is considered quite accomplished; but in India, any welltrained elephant, at a word or touch from his driver, who sits astride his neck, will "hand up," "kneel," "speak" (trumpet), "salaam" (salute with his trunk), stop, back, lie down, pull down an obstructing branch, gather fodder and "hand up" to his attendant, turn or lift a log, or drag it by taking its clrag-rope between its teeth. He will also protect his attendants or attack a common enemy with fury. I think I am safe in asserting that there are in India to-day, scores of captive elephants who are capable of performing all the services enumerated above. But of course there are many which are not so intelligent.

Contrast this with the performances of our most intelligent breed of dogs, the pointer. Even when taken young and trained under the most favorable circumstances, they are at best capable of being taught only a few things, as to "go on," to "charge," to go in a given direction, and retrieve. The extreme difficulty of teaching a dog anything after he has passed his puppy-hood is so iniversally acknowledged as to have given rise to the familiar proverb, "It is hard to teach an old dog new tricks." What a strong contrast is seen in the wild "koomeriah" elephant, caught when he was about sixty years old (by Mr. Sanderson), who "was easily managed a few days after his capture." Of all animals in the world 
what other would have so quickly learned that mind is superior to matter, that man is master of the dumb brutes, or would have succumbed so gracefully to the inevitable?

While staying at Sungam, the elephant camp and timber depot on the Animallais, I had a fine opportunity to watch the elephants at work and to learn something of their management. Many an hour I spent in the timber yard, quite fascinated by the sight of those giants at work. The first work of the elephant is in the jungle where there are no roads for carts. The teak-trees have been felled and hewn into timbers from 9 to 12 inches square and 15 to 20 feet long, with a handle called a "drag-hole" at one end, through which the drag-rope is passed and made fast. The drag-rope is about two and a half inches in diameter and eighteen feet long, and is made by the Mulcers from the inner bark of a tree called "vaca nar" (Sterculia villosa). These ropes are very strong, unaffected by wetting, but are also quite soft, so that the elephants use them without injuring their lips. One end of the rope is made fast in the drag-hole of the log to be moved, the elephant seizes the free end with his trunk and places it between his huge molars, and with the log almost by his side he bends his head toward it, grips the rope firmly between his teeth, and drags it along. If he is a tusker he puts the rope over his tusk next the log, which gives him considerable leverage. When the rope is about to slip between the teeth, or the jaws begin to tire at a critical moment, $I$ have often seen the elephant wrap his trunk tightly around the rope and pull vigorously with it, apparently to assist his jaws.

This method of working elephants always seemed to me a heathenish and stupid one, and I do not see how it can be characterized in any other way. Instead of walking straight away with the log, as the animal would undoubtedly do in proper harness, the poor beast is obliged to stop every fifty yards to rest his jaws and neck, upon which the whole strain comes. It is entirely unnatural for any animal to draw a load from the head, with its neck bent around sidewise, instead of from the shoulder or the girth.

In turning square timber a tusker puts his tusks under the edge, lifts upward and forward at an angle of forty-five degrees and easily throws it over; but the female or muckna, having no tusks, has to kneel, place the base of the trunk, not the forehead, against the side of the log, and by a downward and forward pressure against the upper edge of the log, push it over. In either case the work is done in less than a minute, if there be no special 
difficulty to orercome. In the Sungam timber depot, all the work of piling and arranging the logs in regular order, at equal distances apart, with the right side uppermost, was performed by elephants, under the direction of their mahouts. A word of command, a silent touch of the hand or knee was enough. There was no loud bawling nor angry swearing at the laborers, such as would have been absolutely necessary had they been Barbadoes or Demerara negroes, nor was there any insulting back-talk or insubordination, such as those abominable scallawags are wont to indulge in. In fact, the elephants worked like intelligent human beings of the better sort.

The elephants of the Forest Department were every night allowed to run loose in the jungle around the camp to feed upon the succulent bamboo shoots and grass, by which they secured their own green fodder, and rendered the services of the usual grass-cutters unnecessary. Every morning they were hunted up and brought in by their mahouts and taken to the stream to bathe. They were made to lie down where the water was deepest and enjoy a full bath and good washing, after which they were ready for breakfast. Another attendant always remained in camp to prepare the cooked food for the herd. The daily allowance of rice for each elephant was one maund, or twenty-four pounds. The entire daily allowance was cooked at once in a huge copper kettle, and when thoroughly boiled, each elephant's share was made up into four or five balls the size of a man's head, and the whole breakfast was laid out on a mat spread near the kettle. The seven or eight elephants then marched up and took their places around the mat facing inward, two on each side, and with the utmost gravity and perfection of " table-manners," stood still to be waited upon in turn. One by one, the cook lifted the balls of rice and placed them carefully in the mouths of the elephants, who always gracefully elevated their trunks while receiving them, and remained quietly until the meal was finished. I often assisted in this interesting performance, and the huge animals never showed me the least incivility.

When a mahout wishes to mount his elephant, he gives a word of command, at which the animal lifts one of his fore-feet and bends it upward, the bare-footed driver steps upon it nimbly, seizes the elephant by the ear and scrambles up the foreleg to his place. On account of my thick-soled shoes, I could not swarm up an elephant's leg in that way, and being without a ladder the elephants always knelt to enable me to reach the riding pad.

Except in forests like the Animallais, where there are no culti- 
vated fields to be trespassed upon, elephants cannot be turned loose at night to browse at will, but must be furnished with a daily supply of green fodder, grass, leaves, sugar-cane, or in lieu of that, dry fodder, in a smaller quantity. The daily government allowance in Bengal is 400 pounds of green fodder, or 240 pounds of dry, while in Madras it is only 250 pounds and 125 pounds respectively for elephants of the same size and internal capacity. Mr. Sanderson has proven, by careful experiments in feeding elephants, that the government allowance in both the Presidencies is wholly insufficient for the actual wants of the animal. He found that during eight consecutive days, eight female elephants consumed a daily average of 650 pounds of green fodder each, and a large tusker consumed 800 pounds of the same food in eighteen hours. In actdition to this the animals had each 18 pounds of grain daily.

The following figures show the cost of keeping an adult female elephant in the Madras Commissariat Department, per month :

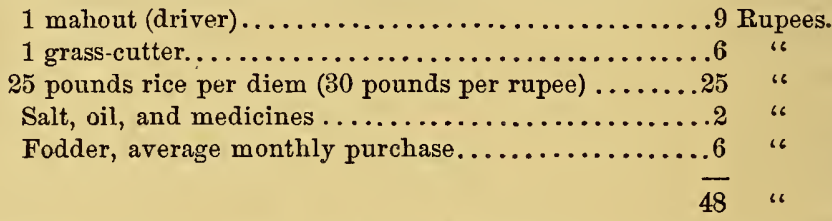

The rupee is equal to about forty-four cents in gold, which would make the cost of keeping an elephant about $\$ 21.12$ per month in our currency.

Male elephants which have passed the age of puberty, twenty years or thereabouts, are subject to fits of "must," or temporary insanity, when they are not sufficiently worked or exercised, and sometimes even when they are. According to all accounts, elephants of advanced age are most subject to these dangerous paroxysms, and the fits vary in duration from four or five weeks to four or five months. They also vary in intensity from dull lethargy in one animal, to the most murderous fury in another. The approach of "must" is indicated by the discharge of a peculiar yellow matter from a small orifice behind the eye, upon the appearance of which the elephant is closely watched, if not chained up altogether.

An elephant in a violent fit of "must" sometimes becomes the incarnation of murderous and destructive deviltry. Many of the so-called "rogue" elephants are, no doubt, old males who from over-eating and lazy habits have been attacked by fits of "must." Sanderson mentions an elephant at Mandla, near Jubbulpore, which 
a few years ago "killed an immense number of people" before its bloody career was ended by two officers.

In Mr. Dawson's fascinating volume, "Neilgherry Sporting Reminiscences," there is a very interesting account from the pen of General Morgan, of the doings of a "must" elephant at Mudumallay (where I did my first bison-shooting), in January, 1870. The elephant went mad, almost killed his mahout, and had inaugurated a perfect reign of terror at the karkhana when General Morgan appeared upon the scene. For fifteen days all work had been stopped, and the station was almost entirely deserted. The vicious brute had smashed down huts, upset carts, broken into the writer's bungalow to get at some sugar (I wish he had caught Ramasawmy!) and every person whom he scented was immediately charged, although strange to say no one was killed. General Morgan was charged almost immediately upon his arrival, but sent a bullet into the animal's forehead above the brain, which caused him to retreat. At another time it required two bullets to stop a more determined charge, upon receiving which the brute fled to the jungle. In the meantime a number of elephants were sent for, and when they came, ten days later, the vicious beast was surrounded and captured without accident. General Morgan's account of the event concludes as follows:

"When he broke loose, I asked the mahout how it happened, as he was nearly killed at the time. He said: 'I was just going to mount, when he knocked me off his foreleg and pressed me down upon the ground across the loins with his tusk (he was a muckna). I exclaimed, "O Rama! (name of the elephant), spare me, have pity on me! How often have I given you jaggery (sugar) and cocoanut! Have I not ever been kind to you? Have I ever defrauded you of your just rights? O Rama! remember I was always good to you and spare me this time!" On which Rama relaxed the awful pressure on my loins and I got up, made him a salaam, and walked away, though I felt as if my back was broken.' Apparently the mahout had treated him fairly, or certainly the elephant had never let him go. The cavadie, or grass-cutter, would have fared differently had he fallen into Rama's hands, for the pain of many a prod from his spear was fresh in Rama's memory, and he no sooner let go the mahout than he took up the scent of the unfortunate cavadie, and hunted him like a dog. The man escaped that day with difficulty. The elephant winded him at a distance of more than two hundred yards, and he was nearly caught, so that finally the cavadie had to abandon the forest, and take refuge across a river ten miles away. 
Occasionally a solitary elephant, in nearly every case a male, takes to tearing down huts, maliciously destroying crops and killing people, by which he speedily earns for himself the title of " a rogue." Judging from what I have heard about such individuals, I believe it could be proven that no elephant becomes a rogue unless he is suffering from some acute ailment, or else a fit of "must." A sportsman once showed me a tusk he had extracted from a famous rogue, the condition of which afforded a ready explanation of the animal's vicious temper. At some late period of his life a heavy ball had been fired into the base of his right tusk, shattering the ivory, splitting the tusk and driving sharp splinters of it into the medullary pulp. The pain must have been excruciating, and yet, like human toothache, it could not kill.

An angry elephant usually kills a mau by treading or kneeling upon his body, and crushing it to a jelly. Occasionally, however, the rictim is subjected to still more terrible torture, as the following passage from Mr. Sanderson's work will show :

"He (the Kakankote rogue) had now returned, evidently not improved in temper, and had marked his arrival by killing a Kurraba, a relative of one of the trackers $I$ had with me on our late expedition. The Kurraba was surprised while digging roots in the jungle, but would probably not have been caught had he been alone. Two youthful aborigines were with him, and it was after putting them up a tree, and attempting to follow, that he was pulled down and torn limb from limb by the elephant. The Kurrabas who found the body, said that the elephant had held the unfortunate man down with one fore-foot, whilst with his trunk he tore legs and arms from their sockets, and jerked them to some distance."

This was the third man killed by the Kakankote rogue, who was himself speedily hunted down and killed by Mr. Sanderson.

One of the strangest features of the elephant is its swimming power. With a colossal body and legs, and with feet almost wholly unadapted to making progress through the water, the elephant swims better than any other terrestrial quadruped. Upon this point, Mr. Sanderson writes as follows :

"A batch of seventy-nine (elephants) that I despatched from Dacca to Barrackpur, near Calcutta, had the Ganges and several of its large tidal branches to cross. In the longest swim they were six hours without touching the bottom; after a rest on a sand-bank, they completed the swim in three more. Not one was lost. I have heard of even more remarkable swims than this." 


\section{$P A R T$ II.-CEYLON.}

\section{CHAPTER XXI.}

\section{COLOMBO.}

Madras to Colombo.-Farewell to Jungle Fever.-The Queen of the Tropies. -The Singhalese.-The Native Shops. - Exorbitant Duty on Methylated Spirits. -An Appeal, and its Result.-Public Opinion.-A Protest.-Legislation for the "Odd Man."-The Sea View Hotel.-Natives as Collectors.-A Morning's Work.-How to Clean and Preserve Echini.-The Gatherings of one Day.-The Fish Market.-The Colombo Museum and its Director.-Native Taxidermists. -Need of European Preparateurs in the East Indies. -An Obliging Firm.

THE next day after leaving Madras, our steamer called at Pondicherry, a little corner of only one hundred and seven square miles, but the largest of the French possessions in India, which all told, amount to only one hundred and eighty six square miles of territory. The city of Pondicherry is a pretty little place, cleaner and whiter than Madras and with the additional advantage over the latter city of having no "harbor works." We lay at anchor in the open sea a mile from shore, and discharged a portion of our cargo into the heavy masulah surf-boats common along the shelterless Coromandel coast.

The following day we called at Negapatam and went through the same programme. The sea was very rough and landing passengers was no joke. It is not an easy matter for any one except an athlete to step from a ship's ladder into a boat which is rising and falling seven feet, three or four times a minute, and if a man is inclined to be clumsy he had best decide before starting whether he prefers to fall on his back or his stomach.

The morning after leaving Negapatam found us on the coast of Ceylon, the pearl of the East Indies. All day we were in sight of 
its shore line of golden yellow sand lying below a bright green fringe of palm-trees, while the forest-clad summits of the mountains loomed up far in the interior. The narrow channel which separates the mainland of India from Ceylon at Paumben is too shallow by about ten feet to allow ocean steamers to pass through, and we were obliged to sail three quarters way around the island to reach Colombo. No one ever had a better opportunity to "scent the spicy perfume of the cinnamon gardens" at long range than did we on that occasion, but a stone image could not have failed more utterly to detect anything of the lind.

For years and years, until the absurdity has become bald with age, has it been asserted as a fact that the spice-laden breezes from Ceylon proclaim the presence of the island to voyagers miles at sea, and some writers have even had the hardihood to assert that they noticed the aroma of the breezes before sighting land. It is time this dear old delusion should be given up.

My first impressions of Colombo were never received. Early in the morning while I was eagerly anticipating the delightful experience of steaming up to the city and landing in Ceylon "at last," my head began to ache, cold waves began to sweep up and down my back, my throat began to fire up and I was soon shivering as though the equator had no existence. By the time we came to anchor it was the fever's innings, and my only thought was to get ashore and find a hotel.

When I landed on the jetty I was balf-blinded with the pain in my head; my brain was dizzy, and I was as sick at the stomach as a drunken man. I looked and acted so much like one that the natives sail, "Look! look! the gentleman is drunk!" and immediately collected around me to see the fun. A native policeman horered obligingly near, to assist me or take me in charge as the case might require, and from his actions I could not tell which thought was uppermost in his mind. But the thought of being in Ceylon braced me up, and I presently crawled to a cool and comfortable hotel, where I went to bed and enjoyed my fever with a certain degree of comfort.

The best physician in Colombo was Dr. White, the Artillery Surgeon, although, by a strange coincidence his house stands with a hospital on one side and a graveyard on the other. I sent for him without delay, and without delay he came, and told me I had best take a trip home (to England), in order to get the fever out of my system. I replied that such a calamity was not to be thought 
of, and he must cure me on the spot. In five minutes he wrote a prescription which proved the death-blow of my fever. It came the next day and took leave of me forever, after having stuck to me faithfully for nearly seven months and floored me sixteen times. The Doctor advised me to keep out of the jungles for a month or two, and remain close by the sea, or upon it if possible for that length of time. I followed his advice to the letter, my fever was effectually stamped out in four weeks, and my former energy returned in full force. The prescription which wrought my salvation I will record here for the benefit of suffering humanity in the East Indies. It is as follows :

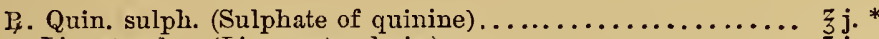

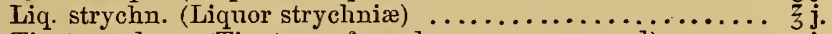

Tinct. card. co. (Tincture of cardamom, compound)........ 3 iv. Acid. sulph. dil. (Dilute sulphuric acid) ............... 3 ij. Aqua (Water in quantity sufficient to make) ...............

M. ft. Mist.

Half a wine-glassful to be taken three times a day.

Colombo is by all odds the most beautiful city I have ever seen in the tropics. Of course, parts of the Pettah, or native quarter, are wholly uninviting, as is the case with nearly every oriental city, and I leave them out of consideration. But take first, if you please, the aristocratic section called the Fort, perched by itself on a little peninsula formed by Colombo Lake and the sea, standing proudly aloof from the Pettah. Here cluster nearly all the Government buildings, the banks, the hotels, all the European shops and the high-class native ones. The streets are beautifully clean and smooth, well shaded by tulip-trees (Thespesia populnea), and at the intersection of the two principal ones there stands a tall, square tower, or campanile, in the top of which is the Colombo light, and directly under it the town clock. From the lower end of the Fort there stretches away toward the south in a clear undulating sweep of a mile and a quarter, the finest esplanade in the world. Why it is stigmatized with such an abominable name as Galle Face, I have been wholly unable to divine, and therefore, suppose that name was given it for some strategic purpose. People will tell you it " faces

* The above is the quantity of quinine called for in the druggist's copy of the original prescription, but the amount (one ounce) is so great as to lead one to believe that one drachm is the quantity intended. In making up the remedy I would advise the substitution of the latter quantity, as the former is palpably a copyist's error.

W. T. H. 
Galle," but it does no such thing; it faces Aden. It is long and rather narrow in places, with the sea on one side and the lake on the other. It is simply an open stretch of gently-rolling, smooth, green lawn, without a sign of a fence, a gravelled foot-path, tree, shrub, or even the inevitable marble statue. There is nothing hackneyed about it. It is as free as the air, and you may walk across it, or gallop over it on horseback to your heart's content.

In the evening toward sunset the wealthy Europeans drive round and round this beautiful Esplanade in their best turnouts, to enjoy the balmy breezes; and the Europeans who are not wealthy walk out, and sit on the benches along the shore. Somehow I always preferred the benches. To me there was a world of quiet enjoyment in sitting there alone, watching the sun as it sank slowly into the sea, the tiny sail-boats of the fishermen gliding by as they sought the harbor; the calm, blue sea, stretching in wide expanse before me, and the surf creeping up the sand at my feet.

The view of Colombo from the clock tower is full of exquisite beauty, particularly when looking south. Along the boundary of the Fort stands a zig-zag row of five long, two-story, many windowed, pale yellow buildings, clean and handsome, which are the military barracks. Immediately beyond them stretches the Esplanade with the Hospital on the left, the Club House fairly trespassing on the green sward farther down, while at the lower end is the Galle Face Hotel, embowered in a beautiful grove of cocoanut trees. Almost in the centre of the city, with the Esplanade for its western shore, lies Slave Lake, a body of water many acres in extent but with such a wonderfully irregular shape, and so many sinuosities of shore-line that one cannot obtain anything like a comprehensive view of it except from a height. Its southern shore curves in and out and all about; but a well-kept carriage-drive winds along its entire length, patiently following all the curves, leading past shady bungalows surrounded by well-kept grounds full of cocoanut-trees, flowering shrubs and beautiful plants found only in the tropics or in hot-houses. No drive can be more delightful than that around the lake about sunset, the time when all hot countries are the most enjoyable.

Beyond the lake, toward the southeast, lie the Cinnamon Gardens, the Museum, wide streets and the airy bungalows of the wealthy European officials and merchants. Let it be remembered that the whole city is embowered in cocoanut-trees, and the ground is nearly everywhere carpeted with green grass. What a striking 


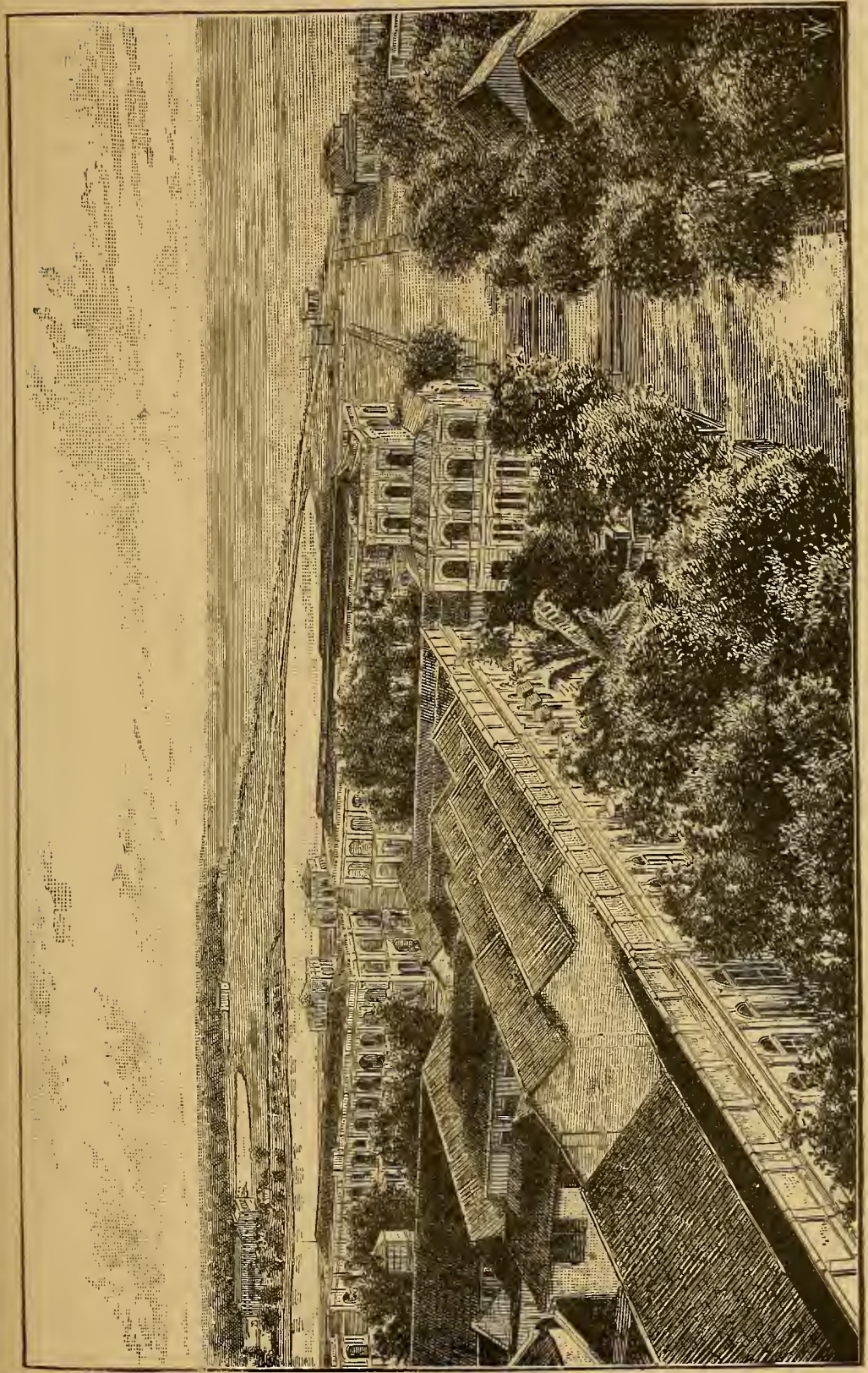

हूँ

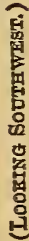

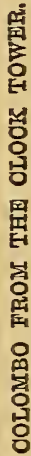



contrast is this genuine luxuriance of vegetation to the parched and barren landscapes of famine-stricken Madras!

East of the Fort lies the native town, extending in a vast semicircle from the edge of the inner harbor around Slave Lake to the seashore below the Galle Face Hotel. The Pettah is well-built but crowded of course, and in the quarter where the principal shops are, the streets are thronged with people and bullock carts. To the north lies the inner harbor, where the small native craft lie in shallow water. From the seaward extremity of the Fort peninsula, a long arm of concrete is being slowly pusbed northward out into the deep water, to increase, by one skilful stroke, both the size of the harbor and the depth of it, by enclosing behind the breakwater a portion of the open sea. Toward the west we look down upon a mass of huge bowlders and masses of rock lying along the beach, against which the surf dashes unceasingly with showers of silvery spray. Beyond these stretch the calm blue waters of the Indian Ocean, dotted with white sails of fishing-boats, until, at the distant horizon, the blue of the sky blends with that of the sea.

A walk through the Fort reminds the traveller that he is in contact with a different class of people and a different language from anything he has met in Hindustan. The language of Southern India (Tamil) is spoken in portions of Northern Ceylon, but the bulk of the native inhabitants are Singhalese, and speak a language known by the same name as that by which they are distinguished.

Here for the first time in our journey eastward we meet with the sarong, which is universally worn by the Malays, and one's first thought is that the fashion was originally borrowed from then.

The average Singhalese gentleman is a curiosity, so far as his "get-up" is concerned. Instead of pantaloons he wears about two yards of cloth, either plain or figured, white or colored, wound tightly around his legs from his waist down to his feet, held either by a belt at the waist or by rolling the edge under.

This primitive petticoat lacks all the good features of the modern garment and possesses not a solitary advantage over trowsers. Unlike the sarong of the Malay, which is worn quite short in comparison, this antiquated "pull back" reaches to the shoes.

Its small circunference destroys all the freedom of the lower limbs so necessary to a man, and compels the wearer to take short mincing steps like a girl. The meanest thing I remember doing in Ceylon was to inveigle two Singhalese gentlemen into climbing: a high picket fence. I climbed it first, to show them how, and for 
the next few minutes was intensely interested in watching their gymnastics. In fairness to them I record the fact that they got over!

Besides the sarong, the gentleman aforesaid wears his hair very lung, combs it straight back, coils it up at the back of his head and catches it with a high tortoise-shell comb. He wears ear-rings also, has at best a very scanty beard, and if he is a beardless boy you will be very apt to think him an uncommonly pretty girl for a native. The men are, as a rule, much better looking than the women, the latter being more masculine in general appearance.

A visit to the native curiosity shops on the Fort is full of interest. With but one exception, they are all kept by Moormen, who are easily distinguished by their bright.red caftans, their shaven heads, and their anxiety to cheat every stranger. The uninitiated traveller should beware of every man in Colombo or Galle who has his head shaved and wears upon it a tall, rimless straw hat, resembling an inverted flower-pot suffering from an overdose of decorative art.

The shops of these worthies contain carved ivory and ebony elephants, ebony canes also elaborately carved, beautiful paper weights made of elephant's teeth sawn into sections and polished; chessmen of carved ivory and sandalwood boxes (from China); tortoise-shell work-boxes, watch-chains, combs, jewel caskets of porcupine quills, ebony wood and ivory; and precious stones of poor quality to the end of the chapter. Even the best of Ceylon native carving is clumsily done, and is not fit to compare with that of the Chinese.

A visit to the business quarter of the Pettah reveals a long row of shops packed closely together, substantially built and well stocked with all the common European articles used in the tropics, and arranged quite in European style. I was surprised at the extensive variety of goods to be found in many of them, and, taken altogether, they were unusually well appointed for native stores. There are no petty bazaars here with impudent Madrasees bawling out at you as you pass quietly along, "You want buy socks?" "What you want?"

The stores of the Chetties who deal in rice are full of grain from floor to ceiling, and it seems a sin that those old fellows should be able to make such piles of money as they do, and not know how to spend it. A fat old Chetty, with his mouth running over with betel juice, a fifty-cent turban on his head, naked to the 
waist, and displaying a breast as hairy as Esau's, whom a stranger would not suspect of being able to buy a hen and chickens, will sit down and sign his name to a check on the Oriental Bank for fifty thousand rupees as calmly as I would. But the similarity would end there, for he would get the money, and I would "get left."

My reception by the Government authorities at Colombo was of a highly characteristic nature, and I am tempted to record it as a fair illustration of the aggravation a traveller is sometimes forced to endure. The incident may serve as a cantion to other naturalists who intend to visit Ceylon.

When Professor Ward and I were in London we looked up the question of alcoholic supplies in the East Indies, and upon being informed that methylated spirits (alcohol charged with methylic acid to render it forever unfit for drinking in any way), by virtue of its character, entered all ports free of duty, the Professor purchased ninety-six gallons of it at $3 \mathrm{~s}$. $2 \mathrm{~d}$. per gallon, or seventy-six cents. Thirty-six gallons were shipped to Colombo, care of Messrs. Lee, Hedges \& Co., to await my arrival, and the remainder was sent to Singapore. I hardly need to say that this spirits was of greater strength than anything procurable in Ceylon, and was to be used in preserving fishes, small reptiles, and crustaceans.

The case of spirits lay in the Custom House until I reached Colombo, when it so happened it was cleared by our agents, at my request of course, while I was off for a few day's shooting.

Imagine my horror to find upon returning that the customs authorities had levied an import duty of six rupees per gallon $(\$ 2.70)$ on the spirits, the same as if it had been good alcohol, and of course Messrs. Lee, Hedges \& Co. had paid it. It amounted to the neat little sum of two hundred and sixteen rupees, or over a hundred dollars, and the case was in my possession.

I mentioned the matter to Mr. Ferguson, editor of the Ceylon Observer with a statement of the circumstances, and he immediately assured me that some one had blundered; that the authorities certainly could not intend to give me so hostile a reception; and that without doubt, a proper representation of the case to the Governor would procure a rebate of the amount charged. Our agents were of the same opinion. Accordingly I went to see the Collector of Customs, Mr. W. D. Halliday, who, when he had heard my statement, gruffly remarked:

"Might write to the Colonial Secretary about it ; that's all the spdvice I can give you ; good day." 
And with a majestic wave of the hand, I was dismissed from the presence of the most bearish and uncivil Englishman I ever saw. I then called upon the acting Colonial Secretary who was very courteous indeed, and after explaining the matter, I left with him a formal petition addressed to the Colonial Secretary, which stated the purpose for which the spirits had been imported, and asked him to sanction a rebate of my rupees. In a week an answer came, saying the Governor was unable to comply with my request.

Mr. Ferguson asked me one day concerning the result, and I showed him a copy of my letter, and the reply to it. His first exclamation was "What a shame!" and he declared he would let the people know just how I had been treated. He did so. The next day there appeared in his paper (the Ceylon Observer) a scathing article headed, "Courtesy to an American Naturalist visiting Ceylon : The Ceylon Government at Fault: Who is to Blame?" from which I must quote the following paragraph :

"So, the Ceylon Government feel it to be their duty in protecting the interests and revenue of the public, to mulct an American naturalist visiting the island in the sum of two hundred and sixteen rupees, for the spirits used in preserving his specimens! Such a thing has surely not happened in the history of the colony before this time. If the Legislature were sitting we should press for an explanation, for the precedent which has been followed, or for the regulation which prevents His Excellency the Governor using his discretion in a remission of duty in a matter where the promotion of science, of international good feeling, of ordinary courtesy and consideration for a stranger and naturalist, so especially called for the step. So far as our experience goes, this is certainly not the plan usually followed by the Indian and Ceylon Governments in the case of scientific visitors, and we heartily regret the blunder-to say the least-which has been committed."

Such was the language of the leading journal in Ceylon. All the other papers, except one, commented upon the matter in the same tone, and it was a satisfaction to me to find unmistakably that the action of the authorities was universally condemned as being utterly stupid and inexcusable. The regulation fixing a high rate of duty upon clear alcohol, according to its strength, is designed to protect the revenue, and to protect the people against the importation of strong alcohol to be used in adulterating liquors, and in manufacturing vile stuff. By no known process can poisonous methylated spirits be rendered fit to use for drinking purposes, or 
even for adulterating liquor, and while alcohol is everywhere heavily taxed, the former passes duty free. It was exceedingly annoying that I should be compelled to pay an import duty of four hundred per cent., and had I only known in time, I would have kept my rupees and left the case of spirits in the Custom House till doomsday. I tried to get the authorities to take it back, return my four hundred per cent. duty, and have the case sold as unclaimed. They "couldn't do it." Would they receive it back, return the duty, and let me ship it to Singapore? "Couldn't do it." I then offered, if they would return my rupees to take the unlucky case of spirits through the Custom House, and bury it in a quiet corner of the back yard where it wouldn't smell bad. Still they " couldn't do it." Could they if I would erect a tombstone over it, and a monument to its memory in the square? No. They "couldn't do it." They had those rupees, and they meant to keep them.

To many men a hundred dollars is a mere trifle, but to a naturalist in the field it means quite a goodly collection of rare and valuable specimens. Unless such a man has a million to back him he cannot go about spending money recklessly from the beginning to the end of the chapter. He always longs to do five times as much as he has means to accomplish, and does not have a dollar to spend unnecessarily. Ten chances to one he spends more money than he has, and is compelled to borrow funds to get home with.

Just here I wish to record the opinion that no country has any business to exact custom-house duties on the scientific apparatus, outfit, or supplies of any kind carried by a travelling naturalist or scientific investigator, either great or small. The expenses of all such persons should be made as light as possible, and both governments and corporations should take pleasure in making exceptions in their favor.* The unavoidable expenses of such travellers are always heavy ; they usually receive small pay for their labors, if, indeed, they receive anything at all ; and their plans always reach to the bottom of their purse. Moreover, the visit of every hard-working naturalist to a foreign country is very apt to result beneficially to the place visited-even though the benefit be small and long delayed. At all events the traveller is certain to leave a good portion

* The C. H. Mallory line of steamships plying between Galveston, Texas, and New York, carry all boxes of Natural History specimens at half rates, and transship them in New York free of charge. Is there any reason why all steamship lines should not do the same? The effect upon our museums would be a tremondous increase in specimens of all kinds. 
of his hard cash behind him, and he takes none of the country's wealth away.

When a collecting naturalist makes a tour through the Indies, either East or West, and visits a number of colonies, it is very discouraging to have to pay from ten to twenty dollars duty on his guns and outfit every two or three months. There is no sense or justice in making such an individual pay duty on articles he is going to use in a place for a few weeks or months and then carry away with him again. A traveller does not visit a colony for the purpose of holding an auction sale of second-hand goods, neither does he give arvay all his effects.

In this case there should be special legislation for the benefit of the traveller and naturalist. "But," said an editor to me in Demerara, "we can't legislate for the odd man." A government with common sense can legislate for the odd man, and some do it. Venezuela can do it and has done it. With all her failings, she is able to teach her enlightened colonial neighbors a lesson which as yet they are too dull to learn. There is a special act which provides that all naturalists visiting Venezuela shall be allowed to import their entire outfit and supplies free of duty, and when we arrived at Ciudad Bolivar, where everything is subject to duty, spirits and firearms in particular, our boxes and barrels were not even opened. We imported a barrel of salt, which under any other circumstances would have been declared contraband and confiscated, and a barrel of spirits which could easily have been used for drinking purposes. The authorities showed us every courtesy during our stay, and we were careful not to abuse our privileges.

Now, mark the contrast! From the Orinoco we returned to Trinidad, where three months previous we had purchased our cask of rum. We returned with it full of fishes, turtles, eels and snakesand the astute custom-house inspector would not allow us to take it to the hotel unless we paid duty on the spirits around the dead animals!

We were obliged to repack the cask, so we did it in the Custom House. Alcoholic specimens are vile-smelling objects at best, and, before we got through we had our revenge. At Demerara, we could not take our guns into the colony for a month's collecting without paying $\$ 8$ duty on them. By a strange coincidence, Sir James Longden, who, as Governor of Ceylon, exacted the outrageous duty on my methylated spirits, was Governor of Britisl Guiana in 1876, at the time of $\mathrm{my}$ visit, when they found it "impossible to legislate for the odd man." 
Although the authorities at Colombo gave me a very hostile re. ception, its aggravating effect was more than counterbalanced by the kind courtesies I received from all the private inclividuals and business firms with which I had anything to do. Indeed, I received favors in Ceylon which, under the same circumstances, I might have sought in vain in most of the States at home.

I took up quarters at the old Sea View Hotel, the smallest in the city kept by Europeans, but it was cosy and comfortable and just the place for me to carry on my work to the best advantage. It occupies the finest hotel site in Colombo, standing; as it does, within a stone's throw of the Flagstaff battery, close to the sea. The elevation is about forty feet, which affords a beautiful bird'seye view, like that from a ship's maintop. Day and night a delicious sea-breeze swept through my sunny little room, and from my window I looked out upon the surf dashing against the rocky reef or tumbling upon the sandy shore farther down; at the fleet of outrigger fishing canoes which sailed by every morning like a vast flock of white-winged gulls, and came scudding back every night laden with their prey; at the movements of the huge ocean steamers as they steamed up from Point de Galle, and away again-all of which formed a delightful panorama full of moving figures, with a vast sheet of calm blue sea for a background. At night I was lulled to sleep by the soft music of the surf breaking gently on the shore and swishing up over the pebbles, and at five o'clock, in the morning I was nearly bounced out of bed by the deafening report of the time-gun, fired, seemingly, just by my ear. The gun might as well have been fired from my window ledge so far as I was concerned, for it was only sixty yards away, at the Flagstaff battery, but, although it used to startle me considerably at first, I became so accustomed to the explosion after a while that it utterly failed to waken me. Such is the force of habit.

As soon as I got fairly over my last touch of jungle fever, I set to work collecting, and from that time forward was busy with specimens from daylight till dark. I rented two rooms upon the ground floor of the hotel, opening upon the paved quadrangle, and there I held high carnival with specimens of all kinds. I had reached a locality where large land animals were not so numerous as in India, but where fishes, reptiles, shells, corals, and marine invertebrates abounded, and to these I turned my attention almost wholly.

In places where natives are numerous and cheap, a collector al. 
ways finds it more profitable to buy whatever small specimens can be caught and brought to him, than to go out and try to make all the captures himself. When the gentlemen of leisure are once well interested, and made to believe they are making money without working for it-for collecting is usually regarded as mere playthey will ransack the country over for whatever is required. The best way to get natives started at collecting is to say nothing about one's wants or intentions, but put on old clothes and go out to some promising spot. When the people see a white man wading after turtles in a muddy pond, or plodding along the sea-shore after shells, star-fishes, or echinoderms, or digging crabs out of the sand, they are struck with the novelty of the thing at once. When they find that the crab-digger has money in his pockets, and will give it for such "trash," they set to work at once and collect whatever will fetch the most money. I have often been amused at the way the West India negroes take hold of such work. A collector may be carrying home a basket of squirming and crawling specimens after a lively day's work in the field, when an astonished darkey breaks in upon his meditations with:

"Oh, boys, lookee dah! Ho! ho! ho! See what dat man got, hey! Say, boss, d'ye want to buy any mo' o' dem air critters?"

"Yes, I do, all I can get," will be the reply.

"Why, lawdy-massy! man, I kin git you 'osts o' dem air. How much you give fo' dem ?"

"I will pay you a fair price."

Off they go, laughing at the absurdity of the thing, but they will be almost sure to bring in something, either good or bad. The news is quickly spread that "a man at the hotel is buying snakes and things," after which he soon has enough to do in buying and caring for what is brought in, and giving directions about what else is wanted.

One morning about sunrise, I dressed for rough work, and, taking with me a coolie and a basket, started for the reef of rocks along the shore in front of the battery. There is nearly always something for the naturalist in such places, often a good deal, and the examination is sure to afford a series of pleasant surprises. On the sheltered side of the rocks we visited, or down in the hollow crevices between the huge bowlders which were piled up along the shore, we found scores of black-spined echini sticking tightly to the rocks, in such situations that the incoming surf submerged them one moment, and, receding the next, left them for the time, almost 
bigh and dry. The little animals clung by means of the converging spines on their under surface, and to get them off it was necessary to work the point of a screw-driver under, and pry at them patiently until the spines were loosened from the rock, and the fragile animals came off without being damaged.

It was impossible to secure large specimens without getting wet in the surf, so it was well we came prepared. There was a strong breeze blowing, and the surf was much higher than usual, which at times made our task somewhat interesting. One moment I would be working away among the bare rocks, and the next the surf would come tearing in between the huge bowlders with a boom and a rush, so that in an instant the water would be boiling and frothing up to my waist. Once or twice I was carried off my feet by the force of the surf, but it would presently recede, and then I could go on with my task until the next roller came in. It was rather lively work, but we secured a basketful of fine large specimens.

In our search for echini, we came upon some very curious little jumping fishes (Salarius alticus) which were hopping about over the rocks, apparently as lively and comfortable out of the water as in. Every time a roller came in, they received a good wetting, but when it receded they were always found clinging to the sides of the rocks, quite high and dry. It was a strange sight to see the little creatures go jumping up the sides of the smooth and slippery rocks, sometimes so steep as to be almost perpendicular. They bend their tails as far as possible toward the left, straighten their bodies suddenly, with the caudal fin stuck to the rock, and jump straight forward from six to eighteen inches at a time. They are four and a half inches long; slender bodied, with a queer little comb or crest on the head, light gray in color, with red eyes. Sometimes one would hop up the side of the rock and perch himself on top, apparently to view the scenery around him. They were so nimble that we had great trouble in catching as many as we needed.

We saw many fine specimens of the handsome painted crab (Graspus strigosus), scrambling over the rocks, and after hard work, caught a few to show the natives, as samples of what we wanted.

Echinoderns, or "sea eggs," as they are sometimes called, are cleaned by cutting away the membrane which closes the mouth and entirely removing the jaws, or "Aristotle's lantern." Then, with a piece of iron wire flattened at the end, all the fleshy matter adhering to the inside of the shell must be scraped loose and drawn out at the mouth opening, after which the inside of the shell should be 
washed thoroughly. When the specimens have been cleaned, they must be immersed for thirty hours in proof spirits, after which they may be put out in a shady place to dry. It is a curious fact that all the echini of Ceylon and Malayana lose their spines unless soaked in spirits before drying, whereas those of the Red Sea, the Mediterranean, and the West Indies can be dried without soaking, and the spines will not fall off.

In a very short time nearly a dozen natives were at work collecting for me and $I$ had my hands full in earing for what they captured and brought in. My instructions from Professor Ward were very simple, but widely comprehensive. "Plunder Ceylon. Rake the island over as with a fine-toothed comb; catch everything you can in three months time, and send me the best of it."

During my first three weeks in Colombo I reaped a rich harvest of fishes, reptiles, crustaceans, and shells, some of which I preserved in spirits while the rest were dried. To give an idea of the richness of Colombo as a collecting ground I will copy from my journal a list of what was brought to me in one day.

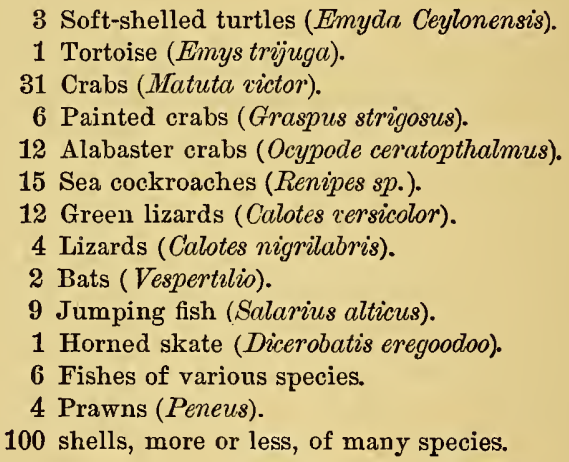

This represents a fair day's work. The next one brought me in snakes of various kinds, frogs, fishes, and invertebrates, making a list quite different from that given above. When the more common species of animals had been gathered in, I used to stimulate my collectors by offering a reward for the first specimen of any desirable kind not already obtained, and in this way my motley crew was induced to search the fields, the sea-shore, and the freshwater ponds high and low. I have never anywhere else had native collectors who were so active and diligent in the field when left to 
themselves as those who worked for me at Colombo. They seemed able to get anything I asked for if it was anywhere to be found.

In due time, I began to visit the fish market every morning when the fish were brought in.

The market itself is a poor affair every way, badly situated, wretchedly appointed, dirty and foul smelling to an uncommon degree. Why the principal fish market of Colombo should be so far beneath comparison with those of Bombay, Calcutta, and Madras I cannot divine. A good building in a suitable locality, would make it one of the finest sights of the Queen City. At present, the market is redeemed from utter unattractiveness only by the magnificent array of fishes, great and small. I believe the fauma of Ceylon comprises a greater variety of both vertebrate and invertebrate forms, than any other locality of twice its area.

At the first opportunity I visited the Government Museum, and was very pleasantly received by the Director, Dr. A. Haly, whom, upon continued acquaintance, I found to be very genial and obliging, and scientifically fitted for the duties of the position he occupies. I quite envied him his beautiful new building; well stocked library of scientific works, his airy office and laboratory, and above all, an island teeming with animal life to draw upon for specimens with which to fill his mahogany and plate-glass cases.

The building is really a beautiful structure, designed by the government architect, and is almost a model of its kind. I was greatly surprised that this, the handsomest modern structure in all the East Indies, cost only $£ 12,000$. It is quite new, and as yet the collections are very small; but a few years will show great change in this respect. I was sorry to see that the institution has not on its staff of workers a man thoroughly skilled in all the latest methods of taxidermy and osteology, with years of working experience to fall back upon in the business of collecting, preserving, and mounting specimens of all kinds.

At the time of my visit, the work of mounting specimens was done by cheap and clumsy natives, who were very poorly fitted for their task. It cut me to the heart to see a deer skeleton mounted, in that humid climate, with iron wire instead of brass, and the skin of a seven-foot shark loaded at the mouth as if it were a cannon. Somehow, all the museum people of the East Indies think that native preparateurs are good enough, and the result is the worst mounted specimens in existence, if I except the fishes in the Mad- 
ras Museum. What else can be expected of a taxidermist who works for a rupee per day?

I take pleasure in acknowledging my obligation to $\mathrm{Dr}$. Haly, for assistance in determining the species of my Ceylon reptiles and crustaceans, and for his valuable service in identifying and naming all the fishes I collected in the island, seventy species in all, except such as were undescribed. I spent many hours in his pleasant company at the museum, assisted by his advice and his books.

After four weeks of busy collecting in Colombo and vicinity, my myrmidons and I had gathered specimens of all the common animals, and it was time to move on. I had calculated my expenses altogether too closely; the remittances I expected from Professor Ward were delayed, and I found myself with insufficient funds for any vigorous work outside of Colombo. I had planned a trip to the Northern Province, but without a loan from some one I would be detained in Colombo, and lose valuable time in waiting for my drafts from headquarters. I was anxious to push on, for I had allowed myself only three months for Ceylon. I brought no letters of introduction to moneyed men, and was a total stranger. But in my perplexity I plucked up courage and stated the circumstances to the firm of Lee, Hedges \& Co.

Mr. Bennett, the manager of the house in Colombo, immediately exclaimed, in the most pleasant manner, "Why, now, I'm glad you have mentioned it, and given us a chance to help you out. We shall be very much pleased to open an account with you. How much money do you need?"

"Well I need about three hundred rupees, but it's too much to take, seeing that I am unable to give you any security."

"That's all right. That's all I want to know." And he gave me a check for the amount, saying, "Now just go ahead up there at Jaffna to suit yourself, and if you need anything more byand-by, or before you get back, just let us know." Had I been doing the firm a favor worth a thousand dollars, its members could not have been more pleasant and cheerful than when thus advancing morey to a stranger without the slightest security beyond his good intentions.

I mention this circumstance to show one of the many bright sides of English character, which is not uniformly so reserved and unapproachable as it is sometimes represented. 


\section{CHAPTER XXII.}

\section{THE NORTHERN PROVINCE.}

Trip to Jafina.-The Paumben Passage._ Jaffna.-Coral Gathering.-The Beauties of Living Coral.-Shallow Waters. - A Harvest of Cartilaginous Fishes. - Rhinobati._Large Rays. - A Handsome Shark. - A Rare and $\mathrm{Cu-}$ rious Fish. - Rhamphobatis ancylostomus Described.-Sea Turtles. -Questionable Value of Native Help. - Start for Mullaitivu. - Jaffna to Point Pedro. - The most Northern Point of Ceylon.-Native Cussedness again.The Slowest Sailing-Craft on Record.

ON February 15th, I embarked with my outfit and a Singhalese servant named Henrique, a necessary evil, on the little colonial steamer Serendib to go to Jaffina, near the northwestern extremity of Ceylon. It was my intention to make a short stay there, and then work my way down the northern coast, toward Trincomalee, until I found good collecting ground. We left Colombo harbor at 5 P.M. and early the next morning, sighted a low-lying strip of sand relieved from utter barrenness by a few green shrubs and Palmyra palms. This was the island of Ramisserama, and we very soon dropped anchor at the mouth of a shallow strait which separates the island from the mainland of India. The Paumben passage-or river, as it is sometimes called by the natives-is a narrow breach a hundred yards wide through a ledge of soft sandstone which extends east and west from the island of Ramisserama to the opposite promontory on the continent of India, east of Ramnad. It is said that at one time the island formed a part of the mainland, and pilgrims passed over it dry shod, but that during many violent storms the sea broke over the chain of rocks at Paumben, and finally a channel was formed which has gradually deepened ever since.

There is only eighteen feet of water at high tide even now, and part of this depth was obtained by dredging. Small as the Seren$d i b$ is, she has to wait for the flood tide in order to pass through. One of the most singular facts in the geographical distribution of 
animals is here forcibly brought to mind. Although the tiger is a good swimmer and has been known to swim Singapore Strait, which is over a mile wide, he has never crossed from the mainland of India into Ceylon, even though the Paumben Passage is not (if I remember rightly) more than a hundred yards in width at its narrowest part. Although Felis tigris is common throughout nearly the whole of Southern Asia, Sumatra, and Java, it has never existed in Ceylon. It certainly was not the width of the strait which hindered its immigration, and the inhabitants of Ceylon have to thank their lucky stars that the two long arms which in reality connect the island and the peninsula, are barren wastes of sand instead of being covered with thick jungle. Had there been sufficient vegetation upon them to afford cover for the tiger, or encourage his migration, there is no doubt that the island would now be infested by these dangerous beasts.

About two o'clock in the afternoon we left Paumben, passed close to Delft Island, and also Middleburg, and at sunset sighted Jaffna. The water was so shallow that our little steamer was obliged to anchor about five miles from the town. The next morning I went ashore with Captain Wellesley in the cutter, and took up quarters in the traveller's bungalow, or rest house, as these valuable institutions are universally called in Ceylon.

Half an hour after landing, I visited the fish-market, a wide open shed down on the beach with the bare ground for a floor. It was not the time of day for fish, and I found only a lot of large and beautifully colored crabs (Lupea sanguinolenta), and about a hundred specimens of the common cuttle-fish (Sepia officinalis), sometimes called the ink fish, which furnishes the sepia water color of commerce, as well as the cuttle-fish bone so indispensable to our canarybirds. The bone in question is the only skeleton the animal possesses, and forms the back of the animal's body, being covered only with a thin skin. The ink with which this cuttle-fish beclouds the water when attacked by an enemy is secreted in a gland near the head, and is discharged with considerable force in time of danger so that the animal is instantly enveloped in a murky cloud. The sepia is very abundant around Jaffna, scores of them being brought in daily; so it seems that the natives not only eat them, but are fond of them. Some of the specimens I obtained were a foot in length.

The morning after my arrival in Jaffna, I hired a small boat, two boatmen and a diver, and made ready for a cruise in search of coral. Before starting, I undertook to tell the men what we were 
going after, but "coral" was to my servant-interpreter a word of unknown meaning. By no possible description could I make the natives understand what I wanted, and finally, as a last resort, I made a little sketch on a piece of paper, when they all exclaimed, "Oh! Koki calli!" The mystery was solved.

We got into our boat and pulled along the eastern side of Mandetivu, a small island to the south of Jaffna, with the expectation of finding coral off its most southern point. It was low water when we started, and the ebbing tide had left bare a wide strip of sand and mud all along the Jaffna shore. For fully five miles around, the sea is very shallow, the depth at low water varying from one foot to six; but it is oftener three feet than otherwise. Small as our boat was we had to follow the channel until clear of the sandbanks, and then we headed south. We saw a number of native fishermen (among them some women also) wading around out in the sea more than a mile from shore, catching crabs, and picking up other edible invertebrates. We overhauled one old woman who was thus cruising about waist deep in water, with a basket slung at her side and a stick in her hand. Her basket contained three fine crabs, two curious little chætodons, and a large sea-anemone (Actinia) which quite resembled a cauliflower with a concave centre. We bought her entire catch for ten cents and went our way. These waders sometimes take cast-nets with them when they go a-wading, with which they catch a good many small fish. The water is so clear that all objects on the bottom are quite discernible, and the crabs, being very slow on foot, are easily caught by hand.

All around Jaffna, the bottom of the sea is of white sand, in some places thickly overgrown with seaweed and in others clean as a floor.

After two hours' pulling at the oars we came to good collecting ground, just off the southeastern shore of Mandetivu. The water was only three to four feet deep, and my old diver got out of the boat to wade around. First we found dozens of holothurians lying scattered about like so many brown sausages, six inches long; so numerous were they, in fact, that one wonders why the natives do not collect and dry them for shipment to China, as is done farther down the coast in the Gulf of Manaar. We could have gathered a hundred without much trouble; but a dozen were sufficient for our wants. It is strange the natives do not eat them, as they do nearly everything else that comes out of the sea.

Next we found some very pretty little star-fishes (Asteria), and 
after drifting over a bed of tall green sea-weed, which swayed in the currents like a field of grain moved by a gentle breeze, we came to a wide tract of clean sand where the coral grew. My diver brought up a piece as a sample and we told him that was what we wanted. Presently he espied something in the water and dived quickly to the bottom. A moment later his feet and legs appeared at the surface, kicking wildly while the rest of his body wrestled with something below, and when he finally righted himself he rose with a huge Madrepora in his hands. One of my boatmen went to his assistance and the specimen was soon safely deposited in the boat. Upon examining it, we found quite a collection of little animals caught amongst the myriad branches of the cluster, of such variety that I took an inventory of the lot. There was 1 squilla, 1 tiny star-fish, 3 tiny crabs of two species, 2 fishes four inches long, 2 yellow and black chrtodons, and 56 tiny fishes about one inch long, gorgeously banded with blue, black, and red. The little fellows had, no doubt, taken refuge among the thickly growing coral branches to escape their natural enemies-the larger fishes.

We presently found quite an extensive grove of coral, where the beautiful branching clusters grew thickly all about over the clean white sea-bottom, in water only five feet deep and clear as crystal. Such a beautiful sight almost made me long to be a merman or a fish, that I might dwell on that clean floor of sand, among the glassy coral groves, the shells and other treasures of the sea.

We loaded our boats with living madrepores of three species, two being of the long-limbed, tree-like variety, and the other, Madrepora cytherea, was of a curious saucer-shaped form, a very large disc hollowed in the centre, and set thickly all over with tiny branches about an inch long. It was grand fun, truly, and downright sorry were we when the boat was piled full and calm possession took the place of eager pursuit.

We landed on the eastern side of Mandetivu, on a raised beach composed almost wholly of fossil coral (Astreopora and Meandrina), which cropped out here and there in large masses. Near the beach we noticed several tons of bleached coral, chiefly madrepores, heaped up in huge piles to be burned into lime. The lime thus obtained becomes, when fully treated, the "chunam" so dear to the palate of every betel-chewing native.

In the fish-market I reaped a rich harvest. Every evening the fishermen bring in their morning's catch and expose it for sale under a shed which stands in the centre of an open space on the 
shore, close to a convenient landing-place for the boats. The men catch the fish and the women sell them. At that time (February) very few scale-fish were caught, not a dozen species all told, and I congratulated myself on having made a good collection at Colombo. Just as I expected, however, from the shallowness of the sea all around, I found that the flat-bodied Chondropterygii (rays and skates) were taken in great variety and abundance. The Jaffna waters seem to be the headquarters for all the species of this order to be found in the Indian Ocean, and I doubt if any other locality in the world of ten times the area can boast as many species as I collected there in one week.

While it is true that none of the specimens I saw could for a moment compare in size with some of the monster rays known to inhabit the vicinity of Madagascar, nor yet the gigantic devil-fish (Manta birostris. Walb.) of our own coast, it is not to be supposed that such fishes could attain such vast dimensions in a locality where they constitute a staple article of food for the people, and are fished for constantly.

On getting home from our trip after coral I set out for the fishmarket, in obedience to my rule to visit such places every day, rain or shine; for no man knoweth what a day's fishing may bring forth. On the way I met an old Tamil woman of most repulsive features and form, carrying on her head a rhinobatus ( $R$. thouini), five feet long, and without a break in its skin. Necessity knows no law, except that the first specimen must always be taken for fear another of the same species is not met, and like a true Dick Turpin I made the old woman stand and deliver. It is always safe to assume that a native will sell anything for money, and in this case the fish was willingly delivered to me, for about double the price paid for it!

I sent this prize back to the rest house and went on to the market where I found a fine large spotted ray (Trygon uarnak) which measured 3 feet 6 inches in width, and 9 feet 6 inches in length including the tail, which alone was 6 feet 7 inches. This specimen I bought for one rupee and carried home in triumph-by proxy. This species is readily distinguished by the black spots of various shapes which thickly cover its entire upper surface on a pale slaty blue ground. The entire under surface is creamy white.

The next day after skinning one of the big fish and skeletonizing the other I visited the market as usual and this time bought two rays of another species (Ettobatis narinari), three more spotted rays 
(T. uarnak), and four butter-fish (Caranx gallus), all of which, excepting the spotted rays, I prepared before I went to bed that night. Lucky it was for me that I knew how to make every stroke count.

The next day after finishing my three remaining specimens I hastened eagerly to the market to see what fresh conquests were in store for me. Another Rhinobatus five feet long, and a splendid specimen of a most beautiful species of shark, the elegant spotted "tiger-shark,"-it should be leopard,--Stegostoma tigrinum.* Its ground color is the bright tawny yellow of the tiger, to be sure, but instead of stripes it is dotted all over with jet-black leopard-like spots. Its form is quite as striking as its colors. Instead of the shapeless flabbiness usually seen in sharks, this one was compactly built, with a very shapely body, having two ridges along the back on each side, and the upper lobe of the tail lengthened for more than two feet. This handsome shark was 6 feet 3 inches in length. In the Colombo market I was one day very much disturbed by finding a piece of skin from one of these creatures which had been cut up and sold. Fortunately for me, fish in Jaffna sell for less than one-third of what they fetch in Colombo, and I was able to buy a great deal without spending much money. The shark cost me only a rupee, and its skin, nicely mounted, may now be seen in the Museum of Comparative Zoology at Cambridge.

At this juncture I was somewhat distracted by the arrival of two boat loads of very fine coral, in which all the species found around Jaffna were well represented. The pale-green madrepores were certainly very beautiful, but the finest specimen was a huge Madrepora cytherea. This superb specimen, nearly three feet in diameter, was exceedingly fragile, and I did not succeed in getting it to Rochester unbroken. I was told that it arrived in about a thousand pieces, but $I$ think the number must have been exaggerated. But at that time I was especially interested in cartilaginous fishes, and for a few days made little account of corals.

My next addition was a round thick-bodied ray, studded all over with very sharp spines (Urogymnus asperrimus), from which it deserves to be known as the spiny ray. After it, came the largest ray of all, 4 feet 3 inches wide, thick-bodied and of a uniform bluish gray color. This was a Trygon sephen, distinguished by having a large fin on the tail near the end. A little later I secured

* Called by the natives, Talei sura, or sea-weed shark. 



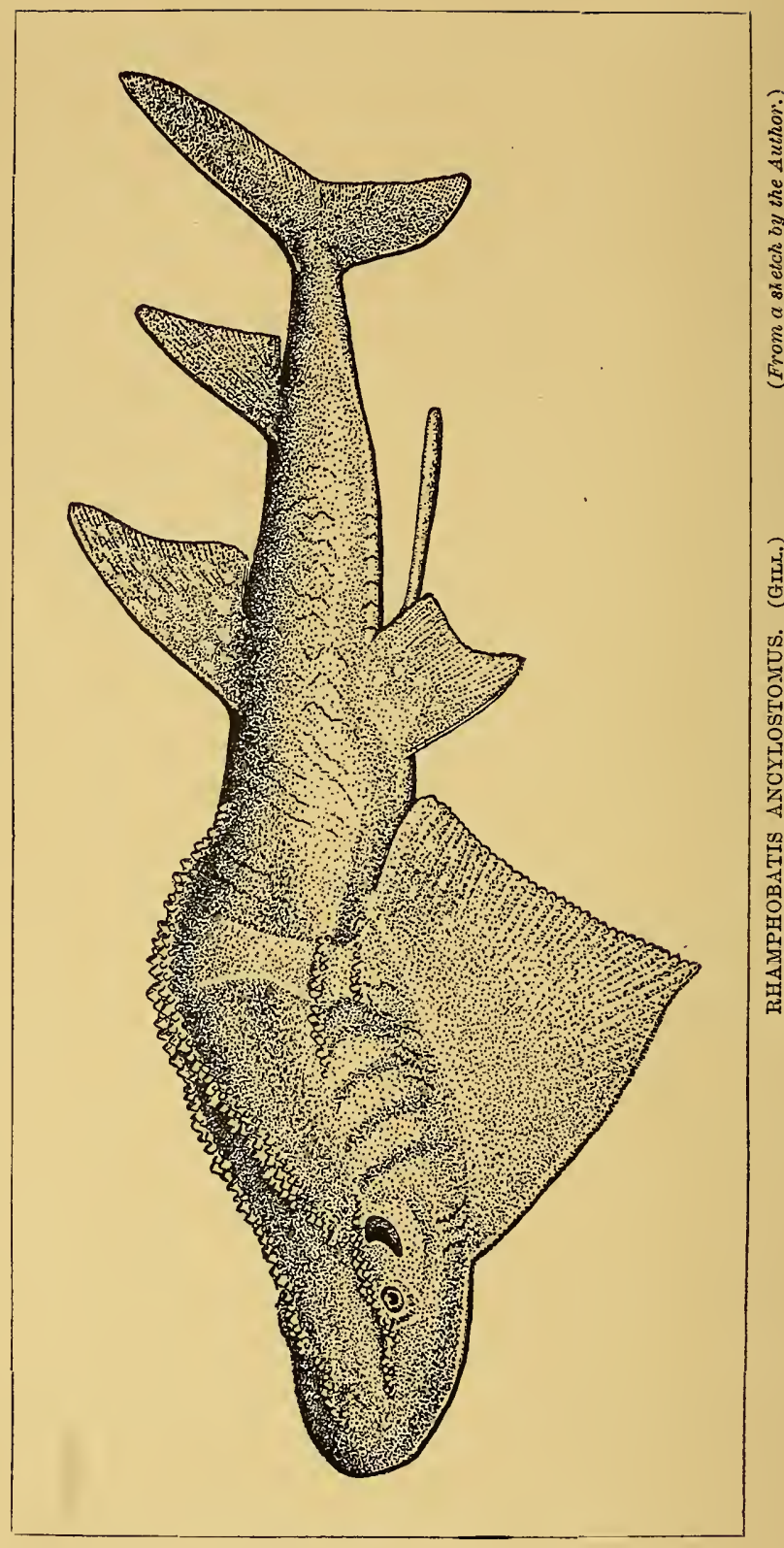


another specimen of this species, but with all my eatches of big fish I did not disdain to gather in such smaller fry as four specimens of Trygon walga, a small shark with black fin tips (Carcharias melanopterus), and four specimens of $C$. acutus. Another small species of Rhinobatus was also rescued from the hands of the spoilers and tenderly cared for.

I was very busy those days, and nights also, for that matter; for I often worked till near midnight. The back yard of the rest house was roomy, shady, and inviting, and in it I planted my table and cut up big fish from morning till night. The poor people came in crowds to get the meat I had to give them, and finally they became such a nuisance I had to forbid their coming inside the yard at all. Still, it was a satisfaction to know that such a quantity of good food was not wasted.

My last catch was the most valuable and important of all. I had collected a goodly number of such specimens as I have already mentioned, and had about ceased to expect anything else particularly new ; though I still made my daily visit to the market.

One evening as I drew near the landing-place, I saw lying on the sandy shore, a large fish of truly remarkable appearance. What could it be? Without evincing any of the lively interest I felt, I strolled forward and looked it over carelessly. I could have shouted with delight, but dared not, for any demonstration of the kind on my part would instantly have sent the price of the fish away above par value. It was a very strange and exceedingly rare shark-like fish, half shark and half ray, known to ichthyologists as Rhamphobatis ancylostomus, and by the natives called "cul uluva."

In length it lacked two inches of seven feet, and its width across the pectoral fins was four feet two inches. The head was flat like that of typical Rinynchobati, but instead of being prolonged into the flat triangular beak so characteristic of $R$. Djeddensis and others, it was abruptly rounded off in front of the pectoral fins. The most striking feature of the animal is the high and angular crest which springs from just behind the head and rises into a rounded hump twelve inches high, studded all along its crest from back to front with a wide band of white tooth-like spines, closely crowded together. Low down on the side there is a much smaller row of the same; another on the head, partly surrounding the eye and gill opening, and a still smaller row directly in front of the eye. These curious rows of clean white teeth-for they certainly are more like shark-teeth than spines-render the animal easily distinguish- 
able, even at quite a distance. The color of the body is blackish gray, but on different parts of the body the shades vary from gray to dull black. The under parts are dirty white, mottled here and there with pink tints. The dorsal fin is marked by a few large, round, white spots.

In the course of removing and preserving the skin, I found 130 small spines from the tails of as many small sting rays, sticking in the head around the mouth and in the muscles around the corners of the mouth. Evidently our ancylostomus had a great liking for ye tender little ray, and sovereign contempt for his many-barbed spine, a single insertion of which would be apt to give a man the lock-jaw on short notice. Apparently they did not cause our sharkray the slightest discomfort, as the number of these trophies showed that he ate all the rays he could catch.

Even the fishermen declared that this fish was very rarely caught, and but for my good luck in buying it from "first hands" - the catcher-I should have been obliged to have paid a good round price for it. The bargain was concluded before the lusty females who act as " middle-men" suspected the danger ; and the way they all set upon that poor fisherman, when they learned he had sold the fish to me for three paltry shillings, and environed him, and howled in his ears in impotent rage, must have made the poor man wish us all at the bottom of the sea.

When I reached Colombo again, my friend Dr. Haly offered me one hundred and fifty rupees for this specimen for the museum, and being in need of hard cash, I reluctantly let it go. I have never seen but one other individual of this species.

On my return from Mullaitivu, in the middle of April, I found cartilaginous fishes had quite gone out of fashion, and in their stead, big sea-turtles were all the rage. I was very glad of such an opportunity to collect some large specimens of the carey (Chelonia virgata), the Indian counterpart of our green turtle (C. mydas). The carey is the largest of the genus Chelonia, good-sized specimens being almost, if not quite, one-third larger than our largest green turtle. The chief difference in form is in the greater convexity of the shell of the former. I secured four very good specimens of the carey, the shell of the largest of which measured underneath 44 by 32 inches. The weight of this specimen I estimated at four hundred pounds, and yet I think it was not so large as one other which I saw in the Calcutta Museum.

The flesh of the carey is considered about on a par with that of 
the shark, and, so I was told, is not eaten by Europeans at all. Nevertheless, I found it very good, tender, and of far better flavor than any of the Jaffna beef I encountered. I was very glad to find the Jaffna market-women do not cut steaks from living turtles in the harrowing manner alluded to by Sir Emerson Tennent in his "Natural History of Ceylon." The animals are killed and afterward cut up in Christian style. They are ridiculously cheap, even to strangers, the price of those I bought ranging from three to ten rupees.

As a fair sample of the eternal cussedness of natives in work like mine, I may cite an incident in the preparation of the large turtle referred to above. I roughed out its skeleton at the market, first sawing out its lower skull, and after putting all the loose bones in the upturned shell, I directed my Singhalese servant, Henrique, to take the bones down to the sea, wash them, and then carry them to the rest house. I charged him particularly not to lose a single bone, but it seemed almost unnecessary, the bones being so large and the skeleton in so few pieces. I went on to the rest house, and after a reasomable delay Henrique put in an appearance with the shell on his head and the bones in it-all that remained at least. The stupid donkey had actually lost both shoulder-girdles! How he accomplished the feat, I never could understand, for the bones were so large and of such awkward shape that neither of them could have been put in a peck measure. I should have thumped the stupid fellow's head against the wall, but somehow I always fail in my duty toward my servants. The bones were never found, and that fine, large skeleton is without them to this day. The above is only a fair instance of the value of natives as assistants. The very next day Henrique further distinguished himself by leaning over the edge of a large box I was packing with corals, holding in his hand a pound can of jam, which he managed to let fall exactly in the centre of a splendid madrepore $I$ had just placed. Of course the cluster was a total wreck.

One of the most pleasant episodes of my very busy fortnight in Jaffua was a call from Mr. Leys, the genial and hospitable manager of the Oriental Bank. He came to tell me there was a deposit in his bank for my benefit in case I should need more funds-thanks to the thoughtfulness of Messrs. Lee, Hedges \& Co., and Mr. Bennett-and to invite me, a total stranger, to dine with him the next evening in company with several other gentlemen. I accepted the invitation, enjoyed a fine dinner, and spent an evening most agree- 
ably with very pleasant company. Among the guests were Mr. Samuel Haughton, an Assistant Gorernment Agent at Mullaitivu, on the north coast, where crocodiles abound and animal life in general is also abundant. On the strength of information obtained from him I determined to go to Mullaitivu at once for a short stay.

The next day I finished packing up everything I had collected in Jaffna, and arranged for its storage until my return, or further orders. I was advised to go to Mullaitivu by sea from Point Pedro, the extreme northern point of Ceylon, twenty-one miles from Jaffna. Accordingly I loaded a bandy with my regular impedimenta, and started it off early in the morning with Henrique as a conductor, while I remained and took the Royal Mail Coach at 4 p.M. The coach was rather crowded. My fellow passengers were "educated natives," rather interesting animals of the "government clerk" type, but they elbowed my ribs, questioned, cross-examined, and talked at me until I was tired and out of patience. For five miles two of them compared notes on the prospects of the petitions they had sent in for certain appointments and promotions. One of them started to read aloud a copy of his, but it covered so many foolscap pages that his friend weakened long before he had finished and abruptly choked him off. The composition stamped the writer as an "amoosin' cuss," and I regret that I cannot produce a copy of it. The petition laid great stress on the writer's two years of service as a scribe in Mullaitivu, and gave a harrowing account of how he was afflicted with fever, and how his wife "was also knocked down."

The country lying between Jaffna and the northern coast is flat and sterile, and not particularly interesting in any way. The rank vegetation and general tropical luxuriance one sees elsewhere in Ceylon is conspicuous by its absence, and on the contrary the country is rather open. What jungle there is, is low and scrubby, and the face of nature had the dry and thirsty look so characteristic of the plains of India in the dry season.

We changed horses every four miles and reached Point Pedro about 8 P.M. The village is small, very prettily situated in an extensive grove of palmyra and cocoa palms, but almost totally barren of food fit for a white man. There is no harbor, but there is here a break in the coral reef which permits boats to land. This fringing reef, composed chiefly of madrepores, lies close along the shore, and I arn told extends for miles without another gap. The coral looks 
very pretty from the shore, and but for my boxes full in Jaffna, I would have been tempted to gather a few clusters.

In half an hour after we reached the rest house, I learned that a small native boat was just ready to set sail for Batticaloa, and would for a consideration land me at Mullaitivu. The captain came and said they had cleared and were ready to start at once. "What, to-night?" "Yes, to-night; we will take you for twenty rupees." I said, "Wait till to-morrow and I will go." "No," said the captain, "if we wait till to-morrow we will charge you thirty rupees." . "All right, then off we go to-night. Boy, pack up the boxes again, and send for a bandy." The boatman was caught. "Sir," said he presently, "we can't go until to-morrow. We haven't cleared sufficiently yet."

"Oh! I thought so! What an honest man you are, to be sure." He thought to swindle me out of ten rupees by way of introduction. So after dining sumptuously off a tough old rooster, and a dish of curry and rice that was like living fire, I went to my blankets on the cot.

The next day, Henrique ransacked the village for eatables, and a long search panned out nothing but two scrawny fowls and a few eggs. No fish, vegetables, fruit, bread, or other meat. Being exceedingly tired from my Jaffna work I was glad to lie nearly all day in my hammock, in delicious, restful idleness.

The boat was to sail at noon, and also at 4 P.м., but the "tyndall" (captain) made the excuse that they had not thoroughly cleared. Then I saw my enemy and knew my work. After getting everything in readiness to start I went for the tyndall and insisted that we should set off. For two hours I made his life a burden to him, and by that time we had got the crew together and were really ready to go. At dark, my luggage was taken aboard and we sailed at once.

The name of the old Tamil tub was Ardi Letchme, and I think she was the clumsiest and slowest craft afloat. She was fairly clean, however, and had a sort of cabin with bunks, in one of which I lay and slept while dozens of big, black cockroaches marched over me in solemn procession. We were four whole days in making that seventy-two miles to Mullaitivu, and at times I thought I should go wild with impatience to get on. The breezes were not very favorable, I admit, but instead of beating up to windward and making some headway, the clumsy old craft just wallowed like a $\log$ in the water. Once the captain brought his vessel to anchor 
for half a day because the winds were contrary! It was on such a craft that I paid first-class steamer rates, and the captain had the withering audacity to ask me to pay for the rice and cocoanuts my servant ate.

I spent the days on deck in the blazing heat, reading and grumbling and wishing for a Whitehead torpedo or a charge of dynamite with which to blow the old tub into the air, captain, crew, cockroaches and all. I would have taken my chances of getting ashore for the sake of the revenge.

But all things earthly end at last, and so did that voyage. We reached Mullaitivu at sunset on March 6th. 


\section{CHAPTER XXIII.}

\section{MULLAITIVU.}

An Unwholesome Village Site.-Dirt and Discomfort.-Crocodile Hunting.Cannibalism and Leprosy among Crocodiles.-Flying Foxes.-A Big Haul.-A Heronry.-Hot Jungle.-Death of Mr. Leys by Sunstroke.Mammals. - A live Manis and its Doings. - On Short Rations. - Exasperating Failure to Receive Supplies. - Tropical Hunger.-A Gloomy Proposition Strangely Refuted.-A Delicious Beverage.-Journal of a Trip into the Interior.-Monkey-shooting.-Character of the Jungle.-Joseph Emerson.-Elephant Skeletons. - Self-buried Frogs. - Two Hundred Monkeys in Four Hours. - Their Fleetness in the Tree-tops. - Deer. -Overland Journey to Jaffna.-Elephant Pass. - Return to Colombo.

Jost half-way between Point Pedro and Trincomalee is the village of Mullaitivu, with the sandy shore and clear blue waters of the Bay of Bengal in front, and a deadly fever-breeding lagoon at the back, a most ill-chosen site truly. As villages go, it is quite a pretentious one, and contains a rest house, a well-appointed hospital, which, thanks to the site of the village, is also well filled, and a court presided over by an European official-an Assistant Government Agent, I believe. I was much disappointed in finding the rest house a very miserable affair, small, barren of furniture, illventilated, and with a floor composed of finely pulverized plaster, three inches deep.

Its one small room was to be my home during my stay there, but the condition of the floor was such that I could not live in the room at all, and was fain to content myself with occupying the verandah, which opened into a nice back yard. Even at this distance I shudder to think of the dirt and discomfort I endured at that place, and but for the pleasure I found in my work it would have been insupportable.

Needing a coolie to accompany me as a game-carrier when I went hunting, and for other purposes as well, I hired a poor deaf fellow, a young man in years and stature, but a timid boy in spirit. 
His wages were nine pence per day, and although he was al. most as deaf as an adder, and knew not a word of English, he understood the sign-language perfectly, and his eagerness to please quite counter-balanced his infirmity. He was a simple-hearted fellow, faithful as a watch-dog, and hung so constantly on my looks and desires, that from the character of his devotion to me he hourly reminded me of one.

From this resemblance I called him Canis. I grew to like the poor fellow very much, and was really sorry to see the last of him when I went away. He asked to be taken with me, but of course that was out of the question.

Mullaitivu is a notorious place for fever, and also a worse disease, as I learned by a visit to the hospital. . The old physician in charge, a very intelligent and well-educated native, showed me a number of cases of a mild form of leprosy, which is the result of a syphilitic venereal disease, from which the doctor solemnly assured me not a single native in that district was free. Some of the cases were fearful to behold, each patient being a living, breathing hell. The disease is, of course, hereditary, which accounts for its universal prevalence.

Although there is absolutely nothing either pleasing or attractive in either the village or the adjacent country, the jungle round about, within easy reach, is good collecting ground. As $\mathrm{Mr}$. Haughton had told me, all the lagoons in the vicinity were inhabited by crocodiles, and to them I turned my attention first. Even the stagnant little fever-breeder within rifle shot of the rest house, at the foot of the Government Agent's compound, has its complement of these scaly scavengers, swimming lazily around and among the lotuses. I shot two specimens almost from under "my own vine and fig-tree."

The next day after my arrival I made an excursion three miles back into the country, to where the road crosses a narrow arm of the lagoon. Although the pool was not more than sixty feet wide, it was quite deep, and literally swarming with crocodiles. The banks were level and perfectly bare, and the only chance for a sure shot was by crawling on hands and knees for seventy-five yards, up to a pile of boards which lay within easy range.

This bit of water, which I called Crocodile Pool, became my regular hunting ground, and for more than a week I visited it daily. At about four o'clock in the afternoon, the crocodiles began to come out to lie on the banks and from that time until nearly sunset was 
the time to gather them. It was my habit to start for the pool at three o'clock, when the sun was blazing hot, taking with me my poor little deaf coolie, Canis familiaris, and also Henrique, if his work allowed, to assist in carrying home the bag. Canis always carried a couple of half-ripe cocoanuts, with which to slake our thirst at the pool, for there it was

\footnotetext{
"Water, water everywhere, Nor any drop to drink."
}

Some days, when the sun was excessively hot and I shot poorly, we got nothing, but on others, when everything went well, we killed and secured all we could care for. Our best day's work was when we shot and got three good specimens, the largest of which was nine feet in length. Altogether I took an even dozen Crocodilus palustris-varying in length from five to nine feet-out of that little pool.

I made the discovery that this species is cannibalistic. On more than one occasion I found their stomachs well filled with flesh which $I$ had cut from the bones of their mates in skeletonizing, and left near the water.

Not only did the loose chunks of meat disappear promptly during the first night of their exposure, but the whole carcasses of the crocodiles I skinned were likewise disposed of. Every morning I would find the ground picked clean, not a vestige either of body, bones, or entrails remaining in sight over night. The flesh (and in some cases the bones also) of twelve crocodiles was thus eaten by the friends and relatives of the deceased.

Two of the crocodiles I shot, specimens seven feet long, were grievously afflicted with a cutaneous disease like leprosy. In one, the whole left side of the head, the neck, and throat were the parts affected, and in the other it was the entire tail. On these parts the epidermis had peeled off entirely, and the skin was covered with huge, scale-like scabs, which, when peeled off, left the diseased skin of an unwholesome bluish color. Both specimens had rumning sores at the points where the sternum and pelvis touched the ground, and both were so emaciated as to be little more than skin and bone. In the stomach of one I found a handful of swamp grass and a lot of small pebbles. Thus were the weak and sickly individuals crowded to the wall in the struggle for existence which was going on in that over-crowded pool. 
I noticed that Crocodilus palustris has one habit which I never observed in other saurians, and which would seem peculiar to this species. They often stand high up on their legs, and walk off like big iguanas, carrying their bodies from six to eight inches above the ground. It is a very novel sight to see an eight-foot crocodile actually stand up and walk, but from the fact that I saw it done by seven or eight individuals, it would seem to be a regular habit with them. The end of the tail always touches the ground, but that member is not dragged by any means. I saw one lean individual run at a very good pace in that position.*

The largest crocodile I shot or saw at Mullaitivu was a fine, tenfoot specimen, which I encountered at very close quarters as it lay in the bushes one hot afternoon, on the banks of the lagoon, north of the village. While hunting quietly along the low, grassy banks, rifle in hand, winding in and out among the bushes, I suddenly espied, just five paces ahead of me, the end of a crocodile's tail projecting past the root of a tree. The rest of the animal was concealed by the foliage. I halted, breathless with fear lest I be discovered and my prize escape, and stood there for several minutes studying the ground. I soon discovered there were two big fellows lying very close together, and both asleep, but ready to awaken at the slightest noise. One twig snapped, or one noisy step, would send them plunging to the bottom of the lagoon. I backed out with great caution and advanced at another opening, until I got a fair view of both the sleeping beauties, as they lay dreaming of big fish, dogs, coolies, and perhaps men. I fired at the largest specimen and he died. It was the nearest I ever came to stumbling over a live crocodile on his native heath.

At the edge of the big lagoon, not far from the Crocodile Pool, I found a heronry in a small grove of low, scrubby trees, which grew out in the mud and water a short distance from the bank. I was attracted to the spot by seeing flying foxes (Pteropus Edwardsii) flying near it, and on a nearer approach I saw a small tree-top hanging full of them. No pear-tree was ever hung more thickly with pears than that little tree with those huge bats, whose wings spread four feet when extended, and whose peculiar fox-like heads have given them the popular name of flying fox. They hung by

* It will be noticed that this strange habit, which seemed almost universa) with individuals of this species, was observed and recorded after the two isolated instances mentioned on page 55 . 



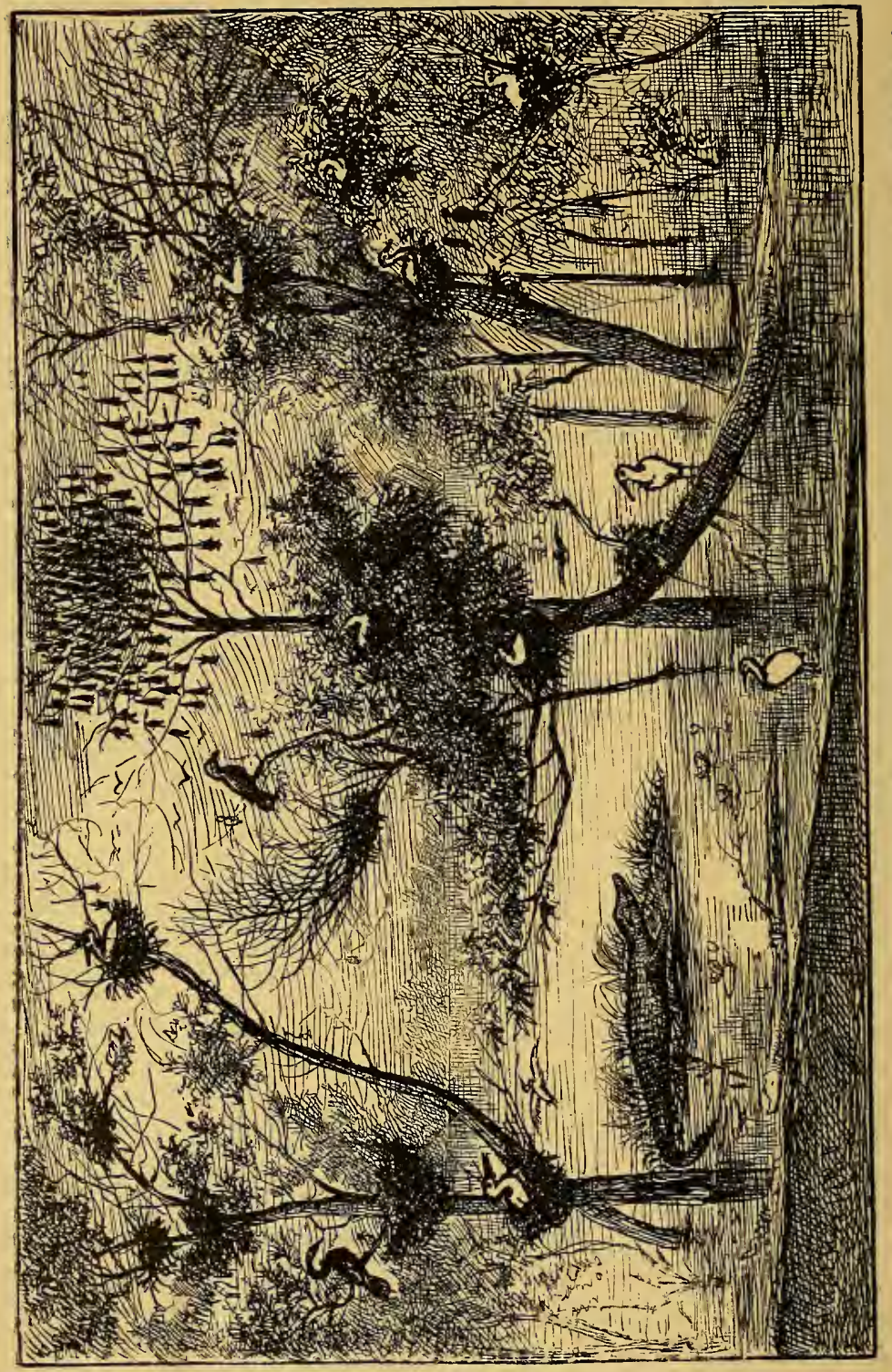

完 
their legs, of course, head downward, looking at a little distance precisely like the pear-shaped nests of our Baltimore oriole, and of about the same size. They actually crowded each other on the limbs, quarrelling, squealing, and occasionally shifting their positions.

I saw that I had a bonanza, for I wanted a hundred specimens of that species, and up to that time had secured only ten. Not having with me the firearms and cartridges I wanted for a regular haul, I left them undisturbed, and returned the next day with my No. 10 double barrel and some very fat cartridges loaded with No. 8 shot. I easily approached within range, and with five shots killed and secured forty-four specimens, in less than a minute. It looked like wholesale murder, but it was not, for I preserved every specimen in the form of either skin or skeleton, and now they are scattered far and wide through the museums of the United States.

Just before I opened fire, a large crocodile lay on a little islet of mud in the middle distance, sunning himself, but he took water in fine style at the first discharge. The birds rose from the trees in a cloud and flapped away, but I knew they would return. After I had disposed of my flying foxes, two days later, I returned for the birds and their eggs. Our first haul was of eggs, and we took home 70 of lesser cormorant (Graculus Javanicus), 9 of darter (Plotus melanogaster), 18 of Herodias garzetta, 4 of large egret $(H$. alba), and 4 of night heron (Nycticorax griseus). I shot several birds of each species, and also killed the crocodile which frequented that incubatory, but the water and mud was so deep and treacherous I was afraid to wade out to where it lay, and left it as a solemn warning to all other crocodiles who might feel inclined to hang about there until the crop of young birds got ripe and fell into the water.

Of course I hunted in every direction around Mullaitivu, and nearly always with good success. Sometimes the bag was an interesting small mammal, and sometimes a large bird or reptile which I had not known to exist there. As a rule, I endeavored to be at home during the hottest part of the day, from ten till three, but more than once I was out all day. I will always remember one particularly roasting, blazing hot day, when I went about five miles above the village, between the great lagoon and the sea-shore, and was out all day hunting through the low, sandy scrub jungle after monkeys, with not a breath of air stirring. My dusky companions from the village complained of the heat more than once, and it really was almost unendurable. The salt perspiration ran 
into my eyes and caused them to smart and inflame painfully. At times we actually gasped for breath. I afterward learned that on that very day my new friend, Mr. Leys, of the Jaffna bank, died of sunstroke while hunting in just such jungle as that, on the other side of the island from me, near Manaar. It "gave me quite a turn," as the English say, when I heard the news and compared the dates.

Not more than a mile from the village, in a bit of the same low, sandy jungle common all along the coast, I saw the bones of two elephants, a cow, and a calf, which the villagers say wandered thither from the interior and perished for the want of water. It may be true.

My reward for the hot day's work mentioned above was two fine monkeys, one, a pretty little rilawa, or bonneted macaque (Macacus pileatus), and the other a big, fat, gray, wanderoo (Semnopithecus leucoprymus), and a black-naped hare (Lepus nigricollis). In my short jungle excursions round the village I shot specimens of jackal (Canis aureus), mungoos (Herpestes griseus), grizzly squirrel (S. macrourus), and jungle striped squirrel (S. tristriatus). I once encountered a large troop of wanderoos within half a mile of the village, two of which were added to my collection.

As usual, I encouraged the natives to hunt and trap quadrupeds for me, and they brought me a number of very desirable specimens, among which was a very pretty little muntjac (Cervulus aureus), two civet cats (Viverra malaccensis), and a live loris (Loris gracitis), a most curious little animal. The most valuable and interesting of all the specimens I obtained at Mullaitivu was a live manis or pengolin (Manis pentadactyla), caught by a native thirtysix miles away. By good luck its captor had heard of me, and that I bought all kinds of animals, and, being an enterprising fellow, he carried it in a bag all that distance to offer me. I gave him a month's wages for the animal, five rupees, and enough coppers additional to enable him to carry home his silver intact. He was quite delighted with his sale, I equally so with my purchase, and we parted with mutual blessings.

My new pet evidently expected fair treatment at our hands, for he soon uncoiled himself and stood up for examination. He was just three feet long, including his tail-which by itself measured seventeen inches-and his weight was eighteen pounds. This tail was a most useful appendage, for it was very broad, measuring five and a half inches across where it joined the body, slightly hol- 
lowed underneath and rounded on the top, its official purpose being to protect the animal's head. In walking he carried his back very highly arched in the middle, and the long, curved claws of his forefeet he bent under his feet until they pointed directly backward, and literally walked on them. His heavy tail barely cleared the ground in walking, and his nose was always carried low, on the lookout for ants. He often stood fully erect on his hind legs, like a kangaroo, when looking about in search of food. Like the knights of old, his armor clanked as he walked along.

Whenever he found a colony of ants he would begin to dig most industriously, and nothing but brick or stone could resist the attacks of those powerful claws. It was great fun to see him attack an ant-hill. After digging a little distance into the hill and exposing the interior, he would thrust his slender, gelatinous tongue for six inches or more into the passage-ways one after another, and draw it out thickly covered with ants. It made my flesh creep to see the vicious little insects upon the animal's tongue and going into its mouth ; but I wished there were enough ant-eaters in the world to exterminate the whole family.

If ever a small animal was especially created to resist the attacks of destroyers, that manis must have been the one. In such plate-armor as he wore he could roll himself up and defy the teeth of the jackal, or leopard, or the fangs of the cobra. Having no teeth at all, and claws fashioned only for digging, he would have fared badly in the jungle without his defensive coat of mail. From the tip of his nose to the tip of his tail, he was covered with broad, flattened, shield-shaped plates of clear, gray horn. These plateswhich were concave underneath and convex above-lay close down upon the skin upon each other, and were arranged in rows with great regularity, beautifully imbricated, and overlapped as perfectly as the slates of a good roof.

My toothless pet was quite peaceable, but not at all affectionate, and when I undertook to cultivate his acquaintance, my advances were received in true English style. Not having any one to introduce me, I undertook to get along without that formality; but it was of no use. He immediately tucked his head down between his four legs, brought his tail under his body and up over his head, and held it there, forming of himself a flattened ball completely covered with scales.

I said to him, "My fine fellow, I really must insist upon know. ing you more intimately ; so here goes." 
I then undertook to uncoil him, but found I could not accom. plish the task alone. I called Henrique to help me, but the tail stuck to the body as if it had been riveted there.

I also called Canis to help, and while I held to the body, the other two braced themselves against me and pulled on the tail with all their strength, to uncoil it. We wrestled with it until we were fairly exhausted, failed utterly, and gave up beaten. Such was the wonderful power in the tail of that small animal.

This led an old Singhalese, from the jungles of the interior, to inform me that the manis sometimes kills elephants in the following manner:

When an elephant troubles a manis, the little animal coils himself around the elephant's trunk, squeezes it so tightly the huge beast cannot breathe, and holds on until the elephant drops dead of suffocation.

It is hardly necessary to say that the above is mere fiction.

From the very first, I had no end of trouble with my scaly pet. During the day he was reasonably quiet, but at night he was very restless, and anxious to go ant-hunting. I could not tie him, for on no part of his body would a rope hold without hurting him, and not for long even then. The first night I had him, I shut him up in the rest house, and in the morning $I$ found him just ready to break through a hole he had dug with his big claws in the six-inch concrete wall. I actually felt a cold chill when I saw how near I had come to losing my rare and valuable specimen.

The following night I put him in a large tin box which had once done duty as the lining of a dry goods box sent from England. I covered the top with boards, piled heavy stones upon them, and went to my hammock feeling sure he could not escape. The box stood in the back yard some distance from where I slept.

About three o'clock in the morning the village dogs suddenly began a furious barking just outside the walls of the compound, and Henrique ran out to see what was the matter. It was the manis. It had found a small rust hole at one corner of the tin prison, and with its powerful claws had worked away until it actually tore a hole in the tin large enough to permit the passage of its body. It was making straight for the jungle, and but for those miserable dogs, who had so often annoyed me by trying to steal my specimens, I would have lost my manis.

The next day it died. Having no chloroform, I drowned it in a clean artificial pool near the village. Very little of it was wasted. 
I preserved dry both the skin and skeleton, the tongue and stomach went into alcohol, and the flesh we ate. Part of it made a delicious stew, rich, sweet, and well-flavored, and part of it we roasted. The latter was dark meat, and although it had a queer flavor, it was tender and very good.

In addition to the discomfort of living in, or rather at, the worst rest house I ever saw, I presently had to contend with a much greater misery than dirt, namely, scarcity of food. I reached Mullaitivu with two weeks' provisions, expecting to stay only that length of time, but in case I should desire to remain longer, I had arranged to have further supplies sent me from Jaffna. I, of course, expected to purchase certain kinds of food in the village, but found nothing whatever for sale save rice-neither fruit, vegetables, fowls, nor meat of any kind. What the people lived on remains a mystery to this day.

At the end of a fortnight, I wrote to a friend in Jaffna, a reverend gentleman who had very kindly offered to do anything in his power to assist me, and asked him to purchase and send me forthwith, by a coolie, certain staple articles of food which I mentioned, and for which I enclosed twenty rupees cash. I counted upon the arrival of the goods before the end of the third week, as surely as my hunger, and until that time I lived on quarter rations. The time expired, but no coolie came. I waited with growing impatience and sharpening appetite day after day, four days longer, and on the fifth sent a letter to my friend, deploring the failure to connect, and expressing the opinion that my letter had never reached him, or else that the coolie sent to me had stolen away with the whole outfit. I begged my friend to send something at once, as I was almost famishing.

After several days, when I was almost ready to return to Jaffna, a letter came from my reverend friend, saying that my letter and the cash enclosed had been received, "but owing to my illness and the difficulty of finding an honest coolie, I have been unable to send you the articles you require." Great Cæsar! Had my clerical friend been eavesdropping then, he certainly would have heard nothing good of himself. He closed by saying that as he was about leaving Jaffna, he had left my rupees with the Superintendent of Police, who would hand them to me on my return. When I returned to Jaffna, he had indeed gone, and the Superintendent of Police had never received from him any cash for me. So I never again saw either my reverend friend or my rupees. 
The loss of the money was a mere trifle, but the outrage upon my inner man I could not condone, and have not to this day. After about twenty meals of plain boiled rice with no accompaniments my appetite succumbs, and my palate refuses it entirely. In a hot climate I believe I could starve easier than eat food which has lost all relish. My hunger was of the kind which called not merely for food of any sort, but palatable, relishable food. In a cold climate, one's hunger is of the ravenous kind that devours whatever comes within reach, and feels satisfied with fulness. In the tropics, I have always found it necessary to have something in reserve to afford the appetite an entire change, even if it be only for a single meal, to break the monotony which would otherwise cause a good article of food to become utterly unpalatable.

When my larder was at its lowest ebb, Mr. Long, the road engineer, whose bungalow was just on the other side of the feverbreeder, kindly sent me a good-sized pumpkin as a present, one. of two he had secured from some distance. It was perfectly delicious, and as long as it lasted I lived high. That pumpkin was an oasis in a desert of rice.

About this time letters came from Professor Ward informing me that, on account of continued hard times, he might be obliged to eall me home soon, even in his next letter. The funds sent me were so meagre that I scarcely dared go on collecting, and at most had not enough to go far. Another letter conveyed the intelligence that a dear friend at home was very ill. Add to the above, the hunger, dirt, and discomfort in which I lived, and the sum of my discouragements was complete. As I lay in my hammock one night, thinking over the gloomy situation and quite unable to sleep, I summed up everything and said to myself, "I could not be any worse off than I am." The thought had not more than taken shape in my mind when a hook snapped, and my hammock went down "bows foremost," giving my lead and shoulders a good bang on the concrete floor. It was such a forcible and instantaneous refutation of my gloomy proposition that, in spite of the stars dancing before my eyes I took the joke and laughed over it.

The water available for drinking purposes at Mullaitivu is so wholly bad that I did not taste it a second time, and during my entire stay drank only water from green cocoanuts.

Fortunately there is a fine grove of cocoa palms a mile above the village, from which I drew my supply of green nuts at the rate of one rupee per dozen. 
To my mind, no other beverage in the world, either natural or artificial-not even champagne at its best-can equal, in refreshing deliciousness, the water of a half-ripe cocoanut fresh from the tree. They are best when there is a goodly deposit of soft meat on the walls of the nut, for at that stage the water has a sharp, sparkling acidity, and a delicate cocoanut flavor, the like of which is unsurpassed by any other liquid I ever tasted. The water is not so good when the nut is perfectly green, and before any meat has been deposited.

It may be only a fancy, but it really seemed to me that the water of the Ceylon cocoanuts have a richer and finer flavor than any others I have tasted. Being a hard drinker, it took five nuts per day to supply my wants; and I am sure no old toper ever enjoyed his dram more than I did those delicious draughts. When inclined to imbibe, cut the hard green husk from around the blossom end of the nut with a sharp hatchet or hunting-knife, until it is whittled down to a point, with the shell of the nut in sight.

On cutting through the shell to make a drinking-hole, $I$ have often seen the water spurt up two feet high, and sometimes into my face. To get the fullest possible enjoyment of the draught it should be taken directly from the nut, nature's own cup. When poured into a drinking vessel its delicate aroma is lost. After this cooling draught, the experienced hand will attack the soft meat on the inside with a spoon without any delay, for it is a delicious morsel.

Being desirous of obtaining some elephant skulls and a lot of odd bones, I learned, after many inquiries, of the death of an elephant the year previous, near a village called Nedunkenni, nineteen miles southwest of Mullaitivu. Making this an excuse for a little collecting trip back from the coast, I hired a covered bullock bandy and set out on the morning of April 2d, accompanied by Henrique, intending to be gone five days. While $I$ am not partial to journalism in books of travel, in this instance I can hardly do better than to copy the daily record of that trip.

"Tuesday, April 2d.-A short distance from Mullaitivu we took the wrong road, and the stupid driver did not discover his mistake until we had travelled four miles upon it. Now four miles out of one's way when the sun is scorching hot is a serious thing, especially when one has to turn back that distance, and is thereby unable to reach the end of the journey that day. I could scarcely keep 
my hands off that driver, and was only able to do so by scolaing like a shrew. The bullocks shared my feeling of disgust, for when we turned to go back they became very refractory, and the poor wretch of a driver actually burst out crying. When the tears began to make furrows in the dust that lay on his dusky cheeks, my anger vanished and I was content to make the best of the situation. At length, we took a short cut through the jungle to reach the other road, and the track we got into was loose sand. By this time the bullocks were almost fagged out and contrary, and for the last halfmile of the short cut Henrique and I had to push with all our strength to keep the cart going. This, at noon, in April, one of the hottest Indian months, in a bed of hot sand, with the sun pouring down upon us and not a breath of air stirring! I thought the conditions for sunstroke were about all there, but neither of us dropped.

"At last we got out, having lost nearly eight miles. Rested a while, then on. Shot a grizzly squirrel (S. macrourus). At nightfall, reached a small village twelve and a half miles from home. Stopped for the night, and quartered under a shed. Bought and shot a chicken, and while Henrique did the cooking act I skinned the squirrel.

"Wednesday, April 3d.-On early in the morning, when the air was balmy and refreshing. At once we started a lot of wanderoo monkeys, of which I killed three of the largest. Also shot three Macacus pileatus, one of which was an old female with a tiny young one clinging to her body. It was alive and unhurt, so I kept it. Farther on shot three more big wanderoos, making six in all, and another grizzly squirrel.

"The jungle which everywhere covers this low, level country between the sea-coast and the mountainous interior, can scarcely be dignified by the name of forest. To my mind, it may be regarded as typical jungle, 'low, dense, very thorny as a rule, barren of grass and difficult to penetrate. Taken all over, it is decidedly low and scrubby, the top of the leafy mass averaging scarcely more than thirty feet in elevation above the ground. There are few trees of good size, and all have a very scraggy appearance, due to the corrugated and irregular growth of their trunks. There is no ground verdure to speak of, and the undergrowth consists of brush with slender, leafless stems. By stooping low and crawling under this growth, one can get along pretty well, but it is very tiresome. In looking under, it is often possible to see for fifty yards around, 
and in this way I saw, to-day, the legs of two deer walking quietly along when I could not see a single hair of their bodies. A monkey or a squirrel is quickly lost to view when running over this thick scrub.

"Reached Nedunkenni about noon, and at once fell to work on the pile of dead monkeys. By sunset I had skinned two of them and skeletonized four, and another had been prepared as a skeleton by Henrique. We quartered in a sort of hut erected for the accommodation of the road engineers, a roof of cocoa palm leaves, mud walls three feet high, and a clean dirt floor.

"Thursday, April 4th.-After I had skeletonized the eighth monkey we went to the burial place of the elephant. Sold. It was, or had been, a baby elephant, a wretchedly small baby at that, and the bones were worthless. The people of the village told us of the remains of another and much larger elephant near a village named Ayladdi, five miles farther on, and we started for it at once, bag and baggage. Reached the village just before nightfall, and for four annas hired a roof under which I slung my hammock and slept in peace and comfort. Noticed in the village two skins of axis deer and one of sambur from animals killed near by.

"Friday, April 5th.-Took three men from the village, and set off very early on foot through the jungle to look for the remains of the elephant. We traversed a lovely path, and once when we emerged into a little open glade I caught sight of a jackal, which was more than he could say of me. He presently opened his mouth and began to pour forth his morning song, but just as he reached the second verse, my bullet went through his liver. He suddenly stopped singing, spun round like a top for a few minutes, snarled, yelped, bit, and scratched, and then quietly lay down, never to get up any more. At noon his skeleton hung on the side of our bandy cover.

"Sold again. The elephant proved to have been a young one, also, but not quite so babyish as the other. The skull alone was perfect and we carried it off, rather disappointed at the net results so far in elephant débris.

"Went back again to Nedunkenni, where we arrived at 3 р.м. Although this is a very small village of not more than a dozen huts, it boasts a free mission-school kept by an old Tamil native-Christian, educated at the Jaffna mission, and there named Joseph Emerson. Joseph was very intelligent and polite, and spoke English with an ease and fluency which quite startled me. But he was wasting his sweetness on the desert air, for his school contained only six pupils. 
He said that a great many would come to him from the neighboring villages, but that the parents were afraid to send their children through the jungle on account of the 'cheetahs' (leopards), bears, and wild elephants. He said there are elephants within two miles of the village now.

"Mr. Emerson told me he had just learned of the remains of another elephant, which he assured me was a very large one, and had died only a year previous, near a village called Padicodooirupu, eight miles to the southeast.

"This jaw-breaking name came very near intimidating me, but after wrestling with it a few minutes $I$ found $I$ could pronounce it from beginning to end without getting lock-jaw, so we came to an about face and started for the place named. Joseph gave me his blessing and a large yellow pumpkin, and having no present in kind to offer, I bestowed upon him two rupees. That pumpkin I would not have bartered for a coat of arms.

"After a hard drive over a rough road we reached Padicodooirupu just at dark. The natives gave me a roof to sleep under where I made myself as comfortable as I could in my hammock. Joseph's pumpkin was sweet and good; and, for the first time in many days, I had a dish of curry and rice that I could eat with relish. As I had nothing else, it was lucky for me that Henrique made it fit to eat. How absurd to think that one's happiness should hinge on a dish of pumpkin curry!

"The people of this village are rather mean, and ill-disposed toward strangers. One man had fever, and I should not greatly mourn if it became an epidemic.

"Saturday, April 6th.-Set off early in the morning with four men from the village, and walked three miles through the jungle to the spot on the sandy bank of the Parayan Ar, where lay all that was left of a once mighty elephant. Bravo! Treasure-trove, or the next thing to it at all events. There lay the entire skeleton excepting the foot-bones and caudal vertebræ, of an old and very large elephant, bleached clean and white. For a wonder the huge skull was absolutely perfect, not even a tooth missing, for which I am under obligations to native shiftlessness. Such teeth as those sell readily for five rupees each, in Colombo and Galle. I sent off at once for reinforcements, and in a short time had nine men on the ground. First we cut a path through the jungle to the road, and then I picked out what bones I wanted, almost the entire lot except the pelvis. We got hoes and dug the sand over in a careful 
search for the small foot-bones, which, for several reasons, I par. ticularly wished to secure.

"In digging for the bones we found several small frogs quite solidly entombed, alive, a foot and a half deep in the solid, sandy earth. We found three species altogether [but I regret to say I never had an opportunity to identify them].

"Although their bodies were greatly distended by the extraordinary quantity of water they contained, they threw up half of it as soon as they were taken from their living tombs, and then became quite active. They had evidently been buried there by their own knowledge and consent during the rains of the northeast monsoon, and, but for our disturbance, would have remained where they were all through the dry and hot season, and until the commencement of the next monsoon. The stream was perfectly dry, and the natives said there was no water for many miles around except in the wells.

"My nine men were heavily loaded with the bones I selected, and at midday, when the sun was flaming hot, we marched out to the bandy, loaded it carefully, and started immediately for Nedunkenni, which we reached a little before sunset and halted for the night.

"Sunday, April 7th.--Rose very early, coffeed in haste, and just as the sun sent his level rays over the top of the jungle, we set out for Mullaitivu. I walked the first six miles and shot three jungle cock and two wanderoo monkeys (S. leucoprymnus).

"These big wanderoos are very numerous all around Nedunkenni for five miles at least, and by going along the road one could easily kill enough in one day to load a cart. This morning I saw more than fifteen big troops of them, each of which contained from ten to fifteen individuals. Usually there are about fifteen in each gang, so that the total number we saw must have been about two hundred. They literally lined the road for seven miles, sometimes in the trees and sometimes on the ground. One troop of very large old fellows we found playing in the road like school-boys, galloping up and down, or chasing each other about with their long tails held up at an angle of forty-five degrees. Their favorite gait is a gallop, unless the branches are too thick to permit it; and they can run almost as fast through the tree-tops as over bare ground. When hotly pursued and thoroughly alarmed, it is marvellous to see them run. They head straight away from their pursuer and gallop madly along the larger branches without a second's pause or hesitation, without a fall or even a misstep, spring boldly from 
one tree-top to the next, and, unless the ground below is very open, they are gone from the hunter's gaze like a flash. Their minds must act like lightning-flashes to enable them to choose the safe and unbroken line of retreat. There is no time to stop and study as to which branch they shall jump upon next, no halting between two opinions, but on they go, the hand and the eye keeping time exactly in the dangerous race. Unless the hunter brings down his specimen before the gang has fairly recovered from its surprise and started off, he may as well give up the chase.

"In these hot jungles the game is afoot in the morning from sunrise till about nine o'clock, and also in the evening just before sunset. Any animal that would go prowling about at midday, instead of lying close in the shade, deserves to be shot. This morning we saw a wild hog trot across the road ahead of us, and a little later a jackal loafing along in a trampish sort of a way. I tried to get within range of him, but he was too knowing for me. We also saw three spotted deer standing quietly in the jungle less than fifty yards from the road, in full view; and six miles from Mullaitivu, we saw three more in the road ahead of us. Had I not killed twenty in the Animallais there would have been a death in each of those families; but having specimens already, and not caring to run the unnecessary risk of being mulcted by the Ceylon Government in the sum of $£ 5$ for shooting a deer without a license, I let the tempting creatures go in peace."

On reaching Mullaitivu I found a fat packet of letters from home, some containing money, some good news, and one the comforting assurance that the expedition to the East Indies should go on as planned. After resting a day, I spent two more in getting my collection into shape, and then engaged two bullock bandys to take me to Jaffna forthwith. The trip was, to me, full of interest, and I again yield to the temptation to drop into journalism.

"April 12th.-Rose early, loaded up with a rush, and after a few any-thing-but-tearful good-byes, we were off. Both bandys were heavily loaded. Of course, I took plenty of cocoanuts (twenty) to drink on the way. As we crossed the two bridges I took a last fond look at my Crocodile Pool, but not a head was above water to shed a tear at our departure. I rode in the front bandy and read 'Hypatia.' At the six-mile post the bandymen begged a halt, for by that time old Sol was getting down to business. For breakfast 
Henrique made a dish of curry and rice which beat my gastro nomic powers completely, and I came near beating him in turn. The trouble was there were too many stones mingled with the rice to call it rice, and not quite enough to call it road-metal. I solemnly promised to fine him two rupees for a repetition of the offence, and he as solemnly promised to reform.

" Jungle just the same as between Nedunkenni and the coast. At dark we halted at a school-house at the fifteenth mile, with the usual thatch-roof and mud walls two feet high, and I hung my hammock under the shelter. The ventilation of the apartment was perfect.

"April 13th.- Rose at 3 A.M. and started; I finished my nap in the bandy as we jogged along. Halted for our midday rest at $\mathrm{Ka}$ raputamooripu, at the twenty-fifth mile, where we struck the Kandy and Jaffna road, sixty miles from the latter place. Halted for the night at the fifty-fifth mile from Jaffna, and I shot a Macacus pileatus.

"April 14th. - On at 3 A.m. as usual, and by breakfast time were at Kokavil, forty-eight and a half miles from Jaffna. This seems to be a favorite halting place for bandys. The road is well littered with straw, and as a result it is a fine feeding ground for the jungle cock (Gallus Stanleyi). I got out and shot five while Henrique was making a cup of coffee, and we had a square meal of their flesh. Halted at noon, at the Veddakkacheri rest house (forty-third mile), in which I shot a very curious bat (Rhinolophus trifoliatus) that was hanging from a rafter.

"The road to-day was a continuous bed of loose sand, and getting on was simply awful. The bullocks toiled through it slowly and painfully with the heavy earts, feet, and wheels sinking in deeply. In order to get along at all we had to lift at the wheels or push behind, while the drivers yelled and belabored the bullocks, and called their mothers and sisters bad names. By what process of reasoning these Tamils are led to suppose it makes a bullock pull better to asperse his mother's reputation, I cannot imagine.

"Over such loose sand the heat is terrific. When I could ride with a clear conscience and 'take it easy,' I sat in the front bandy, sweltering and gasping for breath, bathed in perspiration from head to foot, and covered with dust, which hourly increased in thickness, and formed on me a regular alluvial deposit. As we neared Elephant Pass the jungle gradually grows shorter and thinner, until it altogether disappears. Camped for the night out in the open plain, at a well close to the thirty-sixth mile-post, on the 
edge of the strait. How delicious and refreshing was the bath I took. It was a beautiful moonlight night, cool and balmy-a heaven after the hades of the day.

"April 15th.-Crossed Elephant Pass just at sunrise. It is a shallow strait of salt water, a mile and one-third in width at the narrowest part, where the road crosses, and only two feet in depth at the middle. The bottom is hard gray sand, and to wade through the cool sea-water is a delightful diversion to both man and beast. Strange to say, I saw not a single bird at the Pass on either side.

"There is a fine rest house on the Jaffna side. On getting across, we struck into as fine and smooth a "metal " road as I ever wish to see, and then we rattled along gaily enough. We now came to great groves of cocoa and Palmyra palm-trees, but in the latter I find nothing to admire. The Creator made the Palmyra out of ragged odds and ends of leaves and stems, and never finished the job at that. They look like seedy, weather-beaten, ragged, and unshaved tramps.

"Shot a jungle cock for breakfast, and also killed a wanderoo, but it fell into a pool of water, sank like so much lead, and I declined to go in after it. Breakfasted at the Pallai rest house, twenty-four miles from Jaffna. In the compound I found some very interesting specimens of laterite or 'cabook'-a very curious stone much used for building purposes in Ceylon. When we halted just before dark to rest and eat our curry and rice, the bandymen requested permission to go on to Jaffna, get the bandys unloaded and out of sight before daybreak, to save themselves from being fined for not having ' registered' at Mallaitivu. I said 'go,' and they went. I lay down to sleep, and the next moment, as it seemed to me, Henrique aroused me by saying, 'Sir! sir! This is the rest house, sir.' Sure enough, we were in Jaffna, and it was three o'clock in the morning.

"By the time I had packed up my entire collection, and finished up my work in the Northern Province quite to my satisfaction, the little steamer Serendib touched at Jaffna on her way around the island, and after sending aboard thirteen large cases of specimens, a fifty-gallon cask, and a large crate of turtle skeletons, we took passage to Colombo." 


\section{CHAPTER XXIV.}

\section{KANDY AND POINT DE GALLE.}

The Interior of Ceylon.-A Run up to Kandy.-Native Plows and Plowing.The Mountains.-Kandy.-An Overpraised Town.-Summary of Ceylon Collection.-The Royal Mail Coach.-Governmental Eccentricities. - The Ride to Galle.-Charming Coast Scenery.-A Church Episode.-Bentotte.-Point de Galle.-Neptune's Garden.-Ceylon Gems.-Classification of Dealers.-Study of a Scoundrel, in Black and White.-Diamond cut Diamond.-Farewell to Ceylon.

JUSTICE to the reader and to the subject demands the statement, at this point, that the glories of the island of Ceylon do not lie in that portion of the Northern Province described in the previous chapter. It is the rugged and mountainous interior south of Kandy which contains the picturesque waterfalls, bold precipices, romantic streams, and grand forests full of large game, which constitute what is best worth seeing in this lovely isle. That is the region Sir Samuel Baker has made famous in his two charming books, "Eight Years' Wanderings," and "Rifle and Hound in Ceylon." But for the expense, I would at least have seen Newera Ellia and the hillcountry generally, Adam's Peak, Horton's Plain, the World's End, and the magnificent forests which cover the southern slope of the great plateau. I would have gladly devoted a month to the hillcountry and the adjacent forests in the south, and but for the methylated spirits episode, I could and would have done so; but the Neilgherries and Animallais were behind me and Borneo ahead; so I was partially consoled for being obliged to leave the most interesting half of Ceylon, as an excuse for another visit in the mysterious future.

However, at the last moment I went up to Kandy, as do all wellbehaved travellers who visit the "balmy isle." The distance by rail is seventy-two miles. From Colombo to Rambukana the country is low and covered by a succession of rice-fields or swamps, alternating with jungle-covered knolls, which rise out of the rice-fields like 
islands. In many places the landscape reminds one of the Florida Everglades, with its archipelago of low islets covered with dark green jungle. The rice, or " paddi," grows in soft mud covered by several inches of water, the flow of which, from one little field to another, is regulated by means of small dykes.

It is a strange sight to see all the ryots plowing these fields preparatory to planting the crop. A pair of splay-footed buffaloes are hitched to a wooden plow, which is an exaggerated model of a dog's hind leg; and then they go floundering through soft mud up to their knees, dragging the plow after them, which slips along quite easily and without seriously disturbing the mud in any way, while the driver flounders along at the rear of the procession. The plow does not turn up the earth at all, but merely tickles it a little to put it in good humor for another crop.

From Rambukana it is a steady climb to Kandy, and another engine kindly came to the assistance of the one which brought us from Colombo. The scenery along the line of ascent has a narrow escape from tameness. At one point, called Sensation Rock, where the line is cut in the steep side of a mountain, the view is truly grand. There is a precipice of seven hundred feet for the train to go over if it ever runs off the track at that point; and, below that, another steep descent of more than a thousand feet to where the bright green paddi-fields lie level in the sun, not a hundred feet above the sea.

Some of the hills near the railway are covered with coffee bushes, but those in the distance and also around Kandy were clad with forest. They are neither grand nor beautiful, and in contrast with the Neilgherries they are very tame. But then I doubt if this world can produce another mountain plateau which can match the Neilgherries in beauty and grandeur combined.

Kandy also is very disappointing-as far behind Ootacamund as Madras is behind Colombo. In the pictures it looks pretty enough, but in reality it looks straggling, topsy-turvy, and more or less dirty. There is a lake in the middle of the town, elaborately walled round, but alas! its waters are murky, brownish yellow, and thick with mud. It gives one a bilious feeling to look at it, and, even after a good breakfast, the eye turns from it to the distant hills for comfort.

The lake is of considerable length and a very pleasant drive follows its sinuous margin all the way around. On the hill-sides which rise on either side are the shops and bungalows nestling in 
cocoanut groves, which constitute the only really attractive feature of the town.

The botanical glories of Peradenia gardens I did not have a chance to see-another excuse for a second visit.

Reaching Colombo again, I shipped home my Ceylon collection, which contained the following specimens gathered fresh from the woods and waters in less than four months' time.

\begin{tabular}{|c|c|c|c|c|}
\hline \multicolumn{2}{|c|}{20 species } & Mammals............. & \multicolumn{2}{|l|}{104} \\
\hline 10 & “6 & Birds $\ldots \ldots \ldots \ldots \ldots \ldots \ldots \ldots$ & 20 & “ \\
\hline 8 & “6 & Birds' Eggs . . . . . . . . . . & 153 & "، \\
\hline 27 & "6 & Reptiles........ & 124 & " \\
\hline 68 & “" & 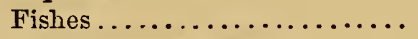 & 180 & “6 \\
\hline 80 & “ & Lepidopterous Insects......... & 155 & “ \\
\hline 18 & "6 & 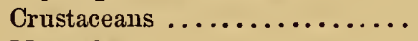 & 181 & “ \\
\hline 120 & “ & Mollusks. ................ & 1,500 & “6 \\
\hline 3 & "6 & Radiates................ & 55 & “ \\
\hline 8 & "، & 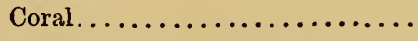 & 44 & 6 \\
\hline
\end{tabular}

In addition to the above the collection included a quantity of such miscellany as elephant skulls, bones, and teeth, specimens of rock, precious stones, woods, minerals and the like, in great variety.

I made no effort to collect birds, for the reason that nearly every other collector makes a specialty of them ; and for insects I had no time.

At the last moment I again found myself embarrassed for hard cash. With all my bills paid, and over a thousand dollars awaiting me in Singapore, as a cable message from Professor Ward informed me, I had not money enough to enable me to leave the island. Much against my will I was obliged to avail myself of the kind offer of Messrs. Lee, Hedges \& Co., accept a loan from them without the ability to offer security, and coolly sail out of their reach.*

The ride from Colombo to Galle in the Royal Mail Coach is one never to be forgotten. Very few of the ocean steamers plying between Europe and the far East touch at Colombo, since Point de Galle has an equally good harbor and lies directly in their track; hence the trips of travellers between the two points by coach.

We made the start at six o'clock in the morning with a light load and very respectable passengers. The only bitter drop in that day's cup of happiness was that, because I was a white man and

* Since my return home, my gratitude to these and similar commercial friends in the East Indies, who aided me in time of need, has caused me to make advances to several parties situated as I was then, not one of whom has ever returned what he borrowed! Such is life! 
couldn't help it, I had to pay twenty rupees for my ride, while an old Singhalese porker, who weighed at least seventy-five pounds more than I, and who had wealth enough to buy up forty men like me, was carried for ten rupees. Anywhere but in Ceylon such a regulation would be too absurd to exist long, but the policy of this remarkable government is to do "as it darn please" in everything. On this impregnable ground it refuses to allow a healthy and wealthy company to build a railway between Galle and Colombo, for fear the seat of commerce in the island would be disturlued and Galle outgrow their intentions. In enlightened countries, such a high-handed attempt to control the natural channel of commerce would be considered remarkable, to say the least, but in Ceylon there is nothing extraordinary about it. All the same, it is a pity there is not some wicked New York reporter on the ground to prowl around for a week or two and find out just what the "divvy" amounts to, when the Colombo rice merchants, shopmen, and hotelkeepers have their quarterly "whack-up" with the government.

Having paid my ten rupees for the ride and ten more for not being black, I climbed up beside my Singhalese Falstaff and was followed by an ayah black enough to satisfy any government, who lrad in charge two sweet little boys - white, too, poor little dearswho were going to Galle to enter school. They occupied the front seat, and nicer children I never saw. It was a real pleasure to have such a long ride with two such rosy, round-faced, blue-eyed little cherubs before one's eyes all the way. Without a moment's delay the driver mounted his box, the bugle sounded, and the horses started off at a gallop. All too quickly we were whirled out of the "fort" and across the beautiful esplanade, which I saw, with regret, for the last time.

Our Royal Coach was rather loose in the joints, and we went, literally, at a rattling pace. The horses were large and rather raw-boned Australian "plugs," well qualified for the work they had to do, and, as we had a fresh pair for every six miles, they were kept either at a very fast trot or a gallop for the whole distance. The road was a dead level, skirting the sea-shore all the way, and beautifully smooth and hard.

Near Panadura, the terminus of the railway which set out for Point de Galle, and would have got there on schedule-time but for the overruling of an all-wise official providence, the road runs along the bank of a lagoon which looks like a large river, and ought to contain countless crocodiles. Not for one moment does 
the shady arenue leave the jungle, save to take us for a short run through the continuous grove of ever-lovely cocoa palms, which stretches along the sandy shore like dark green fringe. I envy the lazy Singhalese whose clean and tidy little huts nestle in the cool cocoanut groves, surrounded by thrifty banana trees that are bowing down with the weight of the green fruit clusters. Looking through the forest of clean white cocoa-trunks, you get glimpses of the sea which make you eager for a better view, until presently an indenture in the coast brings it close to the roadside and opens before you a charming prospect of calm blue water dotted over with tiny white specks which you know must be the sails of the small fishing-boats. We pass two large parties of seine-haulers just in the act of hauling their long seines up to the shore, but we dash by too quickly for detailed investigation. No doubt their nets contain treasures of the deep which we would gladly seize upon, but it is too late now.

By and by we reach Kaltura, at the mouth of the Kalu Ganga, one of the largest rivers of Ceylon. From the bridge it looks more like a lagoon than a river. Kaltura! Aha! This is the place where a wealthy and influential old Singhalese gentleman, a member of the Church of England in good standing, died a few weeks ago, and was refused a Christian burial by the pastor in charge. The refusal was based on the suspicion, or I may say rumor, that in his last moments the old gentleman had renounced his Christian faith and accepted the offices of a native priest. Two sons of the deceased, whose Christianity no one doubts, were greatly distressed by this unfeeling refusal, and the bishop was appealed to by telegraph, and also by letter, for a mandamus, to compel the minister to perform the duty of his office. It was of no avail, and the family was at last obliged to convey the father's remains to Panadura, where they found a minister of more liberal views, who read the burial service in due form. For days the papers of the island were full of articles anent the matter, for and against both parties, and the public mind was wrought up to quite a pitch of excitement. "Fie on ' $t$ ! oh, fie!" As if the reading of the service would have offended God or harmed the minister ; or the entire omission of it for one moment distrubed the peaceful repose of the tired old man. Thus do representative Christians affect an exclusiveness which their Master utterly condemned and bring His cause into contempt. Why not have given the dead man the benefit of the doubt, and bestowed upon his remains the usual ceremony which his sons had 
been taught to consider necessary to the welfare of the soul? After such an exhibition of bigotry and bad temper among the official followers of our meek and lowly Saviour, I thought that, should I die in Ceylon, I would first request the omission of the burial service. I would rather have a single tear shed above my grave than a hollow ceremony performed thereat.

Shortly before noon we halted at the Bentotte rest house for breakfast, a little more than half-way to Galle. The rest house is charmingly situated on a pretty little knoll close to the beach and the mouth of the Bentota Ganga, partly surrounded by a grove of tamarind-trees and cocoa-palms, commanding a fine riew of the cool and refreshing ocean. We breakfasted, chiefly on fish, with the music of the tumbling surf in our ears and a delicious breeze from the ocean fanning our cheeks. Who would not like to spend a whole summer at Bentotte? Thence, onward, the road lay about as close to the beach as it could get and preserve its straightness. I watched that endless strip of yellow sand, mile after mile, but truth compels me to say that I did not see a single living creature upon it, nor even a good shell.

The cocoanut grove along the shore seemed as endless as the shore itself. From Panadura to Galle the road is lined, nearly the whole way, with native huts and bazaars, so that it seems like a ride through a continuous village. To the slow-moving and slowthinking natives our rapid passage must seem like the passage of an express train at home. The Royal Mail Coach has the right of way, and on we go at a gallop, the wet sand flying from the whirling coach-wheels, dashing through one bazaar after another, the bugle blowing every now and then, the children and old women scattering to right and left, and the bullock bandys hastily drawing off to one side to let our coach dash by. We started at six o'clock, changed horses twelve times, halted forty-five minutes at Bentotte, and at 4 P.M. drove across the draw-bridge which spans the moat of the old Dutch fort, dashed up the main street of Point de Galle with a grand flourish, and pulled up in front of the hotel. The coach was wretchedly uncomfortable, but otherwise the ride was all that could be desired.

Galle is a small place, but its natural advantages are immense. Aside from the beautiful harbor with its fringe of cocoa-palns and sandy beach, I was most interested in the wide coral reef which lies along the southern wall of the fort. At low tide, when the sea is calm, one gets from the light-house a beautiful bird's eye view of 
the best portion of Neptune's Garden. At the sight of this lovely grove of pale-green coral (the madrepores are most conspicuous, growing in the crystal sea-water on clean white rocks and sand), I wished that, for a time at least, I could have the power to roam at will over the bottom of the sea. What treasures one could gather, provided one were not gathered first by a shark or octopus.

Galle is a famous place for precious stones, and rascally Moormen who deal in cut-glass imitations. The island produces very fine sapphires, blue, yellow, and white; cat's eyes, moonstones, garnets, "Ceylon ruby" (ruby topaz), star stones, carbuncles, turquoise, and "Ceylon diamonds." The sapphire is the pièce de résistance of the dealer; but, while stones of poor quality are offered by the score, really fine ones are few and far between. Of all the Ceylon gems this is the most successfully imitated in glass, and it is hazardous for the average traveller to buy of any but a responsible dealer.

Pearls may be had by the quart, good ones, too, at from one shilling to twenty shillings each. Gems are equally reasonable in price, and I took the opportunity to select a series of both rough and cut stones of all the kinds for sale in Galle, as so many mineralogical specimens for Professor Ward's private cabinet. Some time previously I had made the acquaintance of as honest a dealer as I ever wish to see, Mahommed Ossen by name (if you care to know), who took pains to supply me with all that I wished at very satisfactory prices. His shop is, or was, very near the Oriental Hotel, and this wholly gratuitous advertisement is inserted solely for the reader's benefit when he visits Galle.

There is one class of dealers to be encountered in Galle, which is a very important factor in the sum of every traveller's happiness, whether he will or no. They are vampires of a mild sort, and feed upon travellers only. The moment your steamer drops anchor in the harbor they swarm on deck and crowd around you, offering the most beautiful gems (of cut glass) you ever saw. They dazzle you with sapphires in all colors, as large as filberts sometimes, topazes, rubies, and pearls, chiefly set in rings, warranted in every case, "good estone, good gole, sar !" If you buy, by all means go to a respectable dealer as soon as possible, and get the gauge of your gullibility. Their best "saffer" rings would be dear at fifteen cents a dozen, for the metal is brass of the poorest kind, and will show its true colors in about a fortnight.

These venders of bogus jewelry are all Moormen, easily distin- 
guished by their shaven heads and inverted flower-pot caps. There are really three varieties of the species, the first of which, respectabilis, is found in well-filled shops, with good wares at reasonable prices.

Another, semi-respectabilis, makes a specialty of tortoise-shell jewelry, both real and imitation, ivory elephants, ebony walkingsticks and elephants, and sandal-wood fans, glove boxes, etc., imported from China. But, it must be admitted, this also drops into bogus jewelry. The other variety, vampirus, makes a specialty of young travellers, and also old ones who have not yet cut their wisdom teeth, who are fooled to the top of their bent; either with bogus gems or worthless stones at a high price.

Both the last-named varieties infest the steamers and hotels, where they will offer the same articles to the same person, time after time, with most annoying pertinacity and impudence. Occasionally enterprising specimens of vampirus have shops and attempt to pass for respectabilis, which they can easily do up to a certain point. While studying up the varieties and values of precious stones, previous to making up my series of specimens, I had an experience with one of these worthies, who "took me in," part way, at least. He came to me at the hotel, presented his card (M. C. Joonoos, 21 Pedlar Street), and politely invited me to visit his shop. It was very near, and after a very little urging I went, really intending to make purchases if I found anything desirable.

When we reached the shop, the quiet retirement of which at once made me think of a bunko establishment, we sat down on opposite sides of a small table, and while the dealer's son was bringing out the stones, I had time to scan the face of my vis-à-vis. Mr. Joonoos was black, but not " comely," his jaws were heavy, his shining black eyes were small and set close together, and his mouth had an ugly droop at the corners. His black beard was thin and straight, and his sharen head was capped by the usual flower-pot of colored straw. The rest of his dress was Singhalese-a loose-fitting coat of white linen cloth, and a petticoat (or sarong) of gayly figured stuff held up by a waist-belt. In upright cases around the walls was an assortment of the fancy articles and "curios" usually purchased by strangers, and in two small show-cases were the "gems."

First we had pearls of all sizes, for the smallest of which Mr. Joonoos asked three rupees each, exactly double the regular price, and urged me to take twenty. I civilly declined pearls, and for the next course we had sapphires, two large blue ones which vampirus set to work in dead earnest to sell, then and there. The largest 
stone was positively the worst of its kind I ever saw, having in its interior, near the apex, a large opaque blur, like a cataract in an eye, which was visible as far as the stone itself. My close examination of this really curious fault misled $\mathrm{Mr}$. Joonoos into thinking I had fallen in love with the gem (!) and he immediately assured me most earnestly that it was "the finest stone in Galle." I was at first amazed at the impudence of the man, but light suddenly dawned upon my mind as to his real character, and I determined to take a hand in the little game. He urged me to buy the stone and I said; "How much?"

"Ten shillings per karet." I examined it more closely and arrested the dealer's encomium by saying, "Weigh it, please, and let's see how much it will cost." He weighed it. Nearly thirteen karets. "About a hundred and thirty shillings," I said, musingly.

"Yes, sir. That's cheap price, sir! Good estone."

"It may be, but I would never give that for it."

Instantly Mr. Joonoos became all eagerness and animation.

"Well, sir, howmuchyougive? Yousayoneprice! How much?"

"Why, there's a flaw in the stone."

"No, sir! That's notaflaw! That's Good estone. Howmuchpougive? You say one price."

"Oh! I've no idea what it's worth."

Mr. Joonoos waxed more and more eager as I seemed to hesitate. He leaned half-way across the table with the sapphire in his hand and eyed me like a rat. He took off his cap like a man laboring hard, and then I saw what an ugly, jail-bird look he had when his head was uncovered. His excitement at having found a victim, and his eagerness to grasp the goodly roll of notes he saw almost within his reach, made the perspiration run off his black scalp in great drops; but the room was cool and comfortable all the while.

I tried to get him to talk of other gems. No, he had set his heart on selling me that particularly worthless stone, with the big milky flaw in it, half as large as the entire stone, and it was exasperating to see his eagerness to foist it upon me at thirteen shilling per karet. Miserable liar that he was, he swore by all the oaths that he knew, again and again, that that was the "finest stone in Galle." At last I could stand it no longer and told him that the stone was worthless and he knew it, and that furthermore I would not give five shillings for it. He was utterly disgusted, and could not conceal his disappointment, but he held his peace and ordered his young hopeful to bring other objects. I must have looked un. 
usually verdant that day, for vampirus evidently took me for an out-and-out greenhorn.

I asked for uncut Ceylon diamonds. Yes, he had some, fifteen shillings per ounce! (Mr. Ossen's price was one shilling per ounce.) I said I thought I would take an ounce, and looking up quickly at his young hopeful standing near the table, I surprised him in the midst of a significant grin, which he instantly sought to extinguish.

"What's that boy grinning for?" I demanded of the dealer.

Mr. Joonoos was greatly annoyed by this unfortunate contretemps, and looked it.

"Oh, he's a little fool; don't you mind, sor; he grins all the time. Go into the other room!" to the boy, with a black scowl.

By that time I had had enough of the little game, and to pay Mr. Joonoos for his efforts in trying to swindle me, I selected about seventy rupees worth of crystals, sapphires, turquoise and emeralds, and had them wrapped up. He thought I was going to pay cash, but he grumbled openly that I took so little. I ought to have taken "for two hundred or three hundred rupees anyhow." He declared he ought to have sold $£ 2,000$ worth in that time. When the goods were wrapped up, I told him to put the parcel aside and keep it until I called again and paid for it. "And when I do," I added, "you will know for sure just how big a fool I am. Ta ta. Try again, Mr. Joonoos."

I left him utterly bewildered at the extent of his failure to make a haul, and never saw him again; but even to this day it enrages me to think how the wily scoundrel spread his net for me. It is humiliating to think I was ever taken for such a flat.

On May 16th, I took passage in the superb steamer Yengtse, of the Messageries Maritimes Company, for Singapore, and Ceylon became to me a memory of the past. Adieu, lovely isle! Good-bye to your sumny sea and groves of coral, your girdle of yellow sand and cocoa-palms, your scrubby jungle, and troops of fat and saucy monkeys. Farewell to your noble forests and mountains, which I did not see, and your humbug cinnamon gardens, which are not worth seeing, nor lying about either. A fond adieu to Colombo and the good friends who live there. Good-bye, too, to official cussedness, to Singhalese laziness, and to Moormen both good and bad.

My thanks are due to the doctor and the climate which cured me effectually of fever, and without any penalty either. Ceylon holds a mortgage on my affections which will never be lifted in this world, I know. Happy Ceylon! 


\section{PART III.-THE MALAY PENINSULA.}

\section{CHAPTER XXV.}

\section{SINGAPORE.}

New Harbor.-A Back-door Entrance.-Mangrove Swamps and Malay Houses.-Street Scenes.-The Sailors' Quarter.-Well-planned City.Chinese Shops and Houses.-Populace.-Social Lifo.-The Curse of the East Indies. - The American Consul.-Two American Travellers. - A Model Millionaire.-The Climate of Singapore.-Market for Live Animals.-A Visit to Mr. Whampoa's Villa._Curios._A Tigerish Orang-Utan._Curiosities in Gardening.

THE twentieth of May found us steaming down the Strait of Malacca, close along the shore of the Malay Peninsula. The strait was almost as smooth as a river, and all day long we sat comfortably under the double awning, enjoying the slowly moving panorama of forest-clad hills and mountains, stretches of level jungle, a river mouth and a Malay village here and there, and pretty green islets rising jauntily out of the water along the shore. The next sunrise saw us threading our way through a bewildering maze of islands, large and small, a perfect archipelago in fact, with only a narrow passage for us at best. Presently we passed a flag-staff upon a hill, and a little later three buoys described a semi-circle to the left around a group of islets, and then we saw far across the water many ships at anchor, and back of them a long line of white buildings two stories high, with a monotonous row of upper windows staring across the water at us. Beyond that lay a background of low, green hills.

This is Singapore, the great central ganglion of the Malay Archipelago and Southeastern Asia, the hub of the Far East. The spokes are steamship lines running in almost every direction, to Bangkok, Saigon, China and Japan, Manilla, Sarawak, Pontianak, Batavia, Sumatra, Ceylon, Calcutta, Rangoon, and Malacca.

We had scarcely exclaimed, "Yonder is Singapore!" when it 
began to pour in literal earnest, anc kept it up during the greater part of that day.

Our steamer, instead of making straight for the town, describes a perfect fish-hook on the chart, leaving Singapore away off to our right and behind us. We enter a little strait which at first we take to be a river, it is so narrow and so completely shut in by green hills and banks of reddish brown shale. But there are large ocean steamers and ships, wharves, dry docks, and coal sheds all along the northern side; so this must be New Harbor.

Having reached the barb of our fish-hook; we tie up at the Borneo Company's wharf, and pull our relaxed energies together for another collecting campaign in a strange locality. I was very loth to quit such a delightful ship as the Yengtse, and actually envied the passengers who were going on to Japan in her. Usually, however, one does not feel so.

This is indeed the end of our voyage, but we are still three miles from the European quarter of the city, so off we go in a rickety bandy with a cart-load of trunks and boxes following slowly after.

Entering Singapore by way of New Harbor is like getting into a house through the scullery window. One's first impressions of the town are associated with coal-dust, mud, stagnant water, and mean buildings, and I found it required quite an effort to shake them off. This back-door entrance is by no means fair to Singapore, for under its baleful influence the traveller is apt to go away (by the next steamer usually) with a low estimate of the city, every way considered.

For the first stage out from New Harbor, the road is built through a muddy and dismal mangrove swamp. Here and there we pass a group of dingy and weather-beaten Malay houses standing on posts over the soft and slimy mud, or perhaps over a thin sheet of murky water. Delightful situation, truly, for the habitations of civilized human beings. Monkeys would choose much better. A Malay prefers to build over water; and, failing that, he builds over the softest mud he can find, usually on the bank of a river or lagoon. His house is quite in keeping with its location. The roof is made of palm leaves, and very often the walls also. The windows are mere slits across the wall near the floor, with clumsy wooden bars across; there is not a speck of paint or whitewash or colored paper visible anywhere, and the whole structure reminds one of an old crow's nest.

Farther on, we emerge from the swarnp and pass a Chinese Joss 
house and cemetery on a hill-side, beyond which we have for a mile, on our right hand, a solid row of Chinese shops and dwellings, and on the other side of the road, a creek flowing mud and slime instead of water. Talk of malaria! It could be cut in that creek, in blocks a foot square, like ice in the Hudson. And the worst of it is that creek stinks-pardon, I mean sticks-by us until we are well into the city itself.

How odd the Chinese shops look with their huge red lanterns, wonderful signs, and flaming inscriptions in black on red paper pasted on the door-posts, lintels, and window-casings. How fat and sleek and hearty-looking are all the Chinese men and women, and how plump and saucy-looking are all their children. I am sure the Chinese are more fleshy, man for man, than any uther people in the world.

Rattling on we go. Here are Chinamen smoking big stems of bamboo, large enough for hitching-posts; here is one having his pig-tail combed and his head shaved as he sits smoking unconcernedly on a bench. We pass four Chinamen with a huge and clumsy coffin upon a cart in which there will soon be a fifth, please heaven. Here is a Malay woman combing her hair in a doorway, and here, ahl old enemies! Here are three shops kept by Tamils, or Klings, as they call them here.

How odd everything looks. The houses are all two stories high, with part of the lower story cut out to give a dry passage way, and the overhanging upper portion supported by húge square pillars of masonry.

Aha! The sailors' quarter, it would seem, if we may judge by the tavern signs. One announces, quite regardless of space, THEMANONTHELOOKOUT,

and displays the portly figure of a Jack tar holding a small Krupp cannon up to his eye, while he squints horribly into the muzzle. Another sign in base imitation of the former proclaims,

THEMANATTHEWHEEL;

and another, the best painted of them all, sets forth, in beautiful letters but homicidal orthography,

THE SILVER ANKER.

Still another proclaims

THE ORIGINAL MADRAS BOB, which is equivalent to the assertion that there are spurious Madras Bobs about, and "all others are base imitations, unless 
stamped by our trade mark, and liable to be prosecuted according to law." Verily human nature seems to be very much the same in Singapore as in Rochester.

The streets are wide, the shops are trim and orderly, and apparently filled to overflowing with their respective wares. What fine times we shall have loafing about these queer streets, and poking our nose into everything that is new!

Just now, however, it is pouring rain, so we rattle on through the Chinese bazaars, across an iron bridge, spanning a sort of inner harbor for lighters and small boats (Singapore River), and, without having passed a single European house or shop, we alight at a hotel just at the foot of Fort-Canning-on-the-hill.

Singapore is certainly the handiest city I ever saw, as well planned and carefully executed as though built entirely by one man. It is like a big desk, full of drawers and pigeon-holes, where everything has its place, and can always be found in it. For instance, around the esplanade you find the European hotels-and bad enough they are, too; around Commercial Square, packed closely together, are all the shipping offices, warehouses, and shops of the European merchants; and along Boat Quay are all the ship chandlers. Near by, you will find a dozen large Chinese medicine shops, a dozen cloth shops, a dozen tin shops, and similar clusters of shops kept by blacksmiths, tailors, and carpenters, others for the sale of fruit, vegetables, grain, "notions," and so on to the end of the chapter. All the washerwomen congregate on a five-acre lawn called Dhobi Green, at one side of which runs a stream of water, and there you will see the white shirts, trowsers, and pajamas of His Excellency, perhaps, hanging in ignominious proximity to and on a level with yours. By some means or other, even the Joss houses, like birds of a feather, have flocked together at one side of the town. Owing to this peculiar grouping of the different trades, one can do more business in less time in Singapore than in any other town in the world.

Architecturally considered, Singapore has little to boast of except solidity and uniformity. With but fer exceptions the buildings are all Chinese, and perfectly innocent of style. It is a twostory town throughout, solidly built of brick, plastered over, and painted a very pale blue or light yellow. There is a remarkable scarcity of the tumble-down, drunk, and disreputable old buildings so essential to the integrity of all other large cities. Some of the Chinese shops and dwellings of the rich merchants are quite elab. 
crately ornamented on the front with fancy tile and brick work, figures of apocryphal dragons and Chinese lions in high relief, and surrounded by beautifully kept gardens of tropical plants and shrubs. All of these impart a tasty and luxuriant air to the streets. The wealthy Chinamen take very kindly to European luxuries of all kinds except in matters of dress. They are lavish in the use of fine furniture, wines, and food, and their turnouts are really dazzling with their fine open carriages, matched horses, elegant harnesses, and liveried servants, though in dress they draw the line at the white stiff hat of English make. Their dress is cool and roomy, made of white silk or linen, and they wear no jewelry whatever.

The population of Singapore (about one hundred thousand) is a sort of omnium gatherum from the various over-crowded countries of Southern Asia generally. The Chinese are by far the most numerous, the most thrifty and enterprising, and the most satisfactory to deal with. The Malays come next, and after them the Tamils from Southern India and Ceylon. The population includes a goodly sprinkling of Portuguese half-castes, a few Javanese, a ferw Siamese, and of Europeans, a mixture of English, Dutch, Germans, French, Swiss, and last but not least, three Americans, our consul and his daughters.

Of the social life of Singapore I know nothing ; but from what I was told, I judge it is not at all different from other British colonies. There are the usual balls and dinner parties, and the usual number of grades in society, each of which knows its station to a line and never ventures beyond it. To an American it seems extremely silly for wholesale merchants and their clerks to hold themselves, socially, above the retail merchants and their clerks, regardless of the amount of business they do, and their moral and intellectual standing. For my part, I have no patience with society's nonsensical standards, in accordance with which a man's business or profession is everything, and he himself is nothing. Thank God for America, where every man stands on his merits, if he has any.

The hotels of Singapore are all bad, and life in them is exceedingly dull. The liquor consumed in them, and the drunken men one sees almost daily, keep the abstemious traveller in a state of perpetual disgust. The extent to which intoxicating liquors of all kinds are drunk in the East Indies is simply appalling. The drinking habit is so universal, that, as a general thing, when you go to call on an acquaintance at his house, or to visit a stranger in com- 
pany with other friends, the greeting is, "What will you have to drink?" If you say you do not drink, or do not wish anything, you are urged most urgently to " take something," until it becomes positively disagreeable; and really the easiest way is to compromise by taking a glass of their beastly lemonade or abominable soda. Furthermore, when your new acquaintances, or old ones either, for that matter, call upon you at your hotel for half an hour's chat, you are expected to order drinks for the crowd, until the crowd is full of whatever it likes best. To omit this feature is to give positive offence in some cases, and even at the best to send your visitors away saying that you are uncivil and not worthy the acquaintance of gentlemen.

Again and again, I have seen men sit down in a hotel and deliberately drink themselves drunk and helpless. At the old Sea-view Hotel in Colombo, there is a room down-stairs kept for the exclusive use of gentlemen who get too intoxicated to leave the premises. Some get foolishly drunk at the dinner-table with their wine; some drunk and quarrelsome; some destructively drunk; others disgracefully, and many helplessly. It was painful to see polished and intelligent young men make free exhibitions of themselves in the public rooms, and become objects of contempt even to the hotel servants. The curse of the East Indies is brandyism. Wrecked livers and stomachs are always charged to the "beastly climate," but in many, many cases the beastly bottle is to blame. Of course no one will be so unthinking as to suppose there are not hosts of good and true men in the East who draw the line at Bass' pale ale or claret, and who never think of touching more fiery intoxicants; there are plenty such, but I fear they are in the minority.

In due time, I called upon our consul, Major Studer, to pay my respects, little thinking that in him I would meet a "fellow-citizen" from my own proud State, Iowa, and be received almost with open arms. Yes, that was my good fortune, and more than that, I had the pleasure of an early introduction to the Major's charming daughter, then Miss Studer, but now a lass no more, a genuine American girl-which is the highest praise I can bestow upon a young lady. It was a great treat to me all around, and their kind hospitality made my stay in Singapore, at the three different times I was there, far more endurable and free from social dulness than would otherwise have been the case.

I think Major Studer is one of the most efficient consuls with whom 
I have yet become acquainted. First, last, and all the time, he is uncompromisingly American, loyal to the backbone, and devoted heart and soul to the interests of the government he represents. In addition to this he has the stamina which such a position requires, and does his duty without the slightest fear of what those around him may say or do. I was not surprised to learn that his official acts have not always met the approbation of those most affected by them, for to my mind no consul can do his duty unflinchingly without making some enemies. From him I learned more of the political history of the Straits Settlements, and the Malay Archipelago, both inside and out, than I could ever have obtained elsewhere.

It was at the Major's, one evening after my return from Borneo, that I met two Americans of the kind one is proud to meet abroad, and pleased to meet at home. Mr. Andrew Carnegie and Mr. Vandevorst ("Vandy") had just then reached the "half-way house" on their pleasure trip around the world, where they stopped for a few days to see the sights. In spite of his Scotch blood, Mr. Carnegie is quite an ideal American, with nothing but praise for his adopted country and all her institutions. More than this, he is what I should call a model millionaire, whom great gain has not rendered insatiably greedy for more, and who industriously coins his money into human happiness instead of reversing the operation, as most of our wealthy men do.

It increases one's estimate of human nature to meet such a man, who, in manner, is as cordial and unassuming as one's best friend, whose human sympathy is his most conspicuous trait, and whose greatest happiness is found in making others happy. While these tardy pages have been in course of preparation, Mr. Carnegie has finished that journey, and made another; and now the public knows him well through the charming pages of "Around the World," and "An American Four-in-Hand in Britain," both of them books of the kind which it warms one's blood to read.

The city of Singapore is situated on an island of the same name, trventy-five miles long by fourteen broad, which is separated from the mainland of the Peninsula by a strait from one-half to threefourths of a mile wide. The island is covered with low hills, the highest of which has an elevation of about five hundred feet. Although Singapore is only seventy miles north of the equator, the temperature is by no means so hot as might at first be supposed. The thermometer seldom rises above eighty-seven degrees in the 
shade, and usually stands at about ten degrees lower than that. There are absolutely no seasons, and nothing to mark the climatic changes which occur elsewhere. It rains nearly every day, copious showers of short duration, quite unlike the all-day down-pour of the monsoons in India. The air is very humid, so that the heat is far less noticeable than would otherwise be the case. One does not swelter as in Calcutta or Madras, although a daily bath is as necessary to comfort as daily bread. Taken altogether, Singapore is really a delightful resting-place for a traveller, full of interesting sights, and pleasant walks and drives. The Raffles Library and Museum, the well-kept Botanic Gardens, the Fort, the markets, the Joss houses, and various bazaars, are all well worth visiting and enjoying. The harbor in front of the town often contains some queer craft, including lumbering Chinese junks and Malay trading proas of thoroughly antique design.

With the exception of shells, star-fishes, and corals, I found nothing on the island that I cared either to collect or buy, and even these were not nearly so abundant as I expected to find them. The Malays assured me it was not the right time of the year for them; but I believed this was only an excuse with them, until I returned from Borneo in December, when they brought me shells and coral, star-fishes, and huge Neptune's cups, literally by the boat load.

Had I been a showman or collector of live animals, I could have gathered quite a harvest of wild beasts in Singapore, at very small cost. I was offered a fine tiger at $\$ 150$; baby orangs at $\$ 20$ to $\$ 30$, a fine pair of proboscis monkeys at $\$ 100$; a pair of full-grown tapirs at the same price; manis and slow lemurs at $\$ 2$; and a rhinoceros at $\$ 250$. These were the asking prices, and it is quite certain that much smaller sums than those named would have purchased the animals in question. The greatest bargain I heard of, was the sale of a full-grown orang-utan (Simia satyrus), four feet two inches in height, to the Hon. H. A. K. Whampoa, for the ridiculous sum of $\$ 65$, or $\$ 35$ less than the price first asked. My desire to see this animal led me to pay a visit to the country seat of his owner, a very wealthy Chinese merchant, quite advanced in years and honors. I went by invitation, and the call was one to be remembered.

On one side of a quiet street in the suburbs, there is a wall enclosing a spacious garden. Passing through an open gate, the posts of which are very high and ornamented with carved figures 
of Chinese dragons, we drove through a well-kept garden, sighted a spacious but unpretentious white honse, and drew up before the massive and finely carved front doors. A gardener, who was trimming a shrub close by, took my card and thrust it through the open carving. Presently the doors opened wide, and I saw Mr. Whampoa coming slowly from the farther end of the wide hall to meet me. He was an old man with a low stoop in his shoulders, a large head, a very thin queue of white hair, small twinkling eyes with a very pleasant expression, perfect manners, and a very kind, unassuming smile. He speaks English as well as I, and has the honor to be Chinese Consul, Turkish Vice-consul, member of the Legislative Council, and the happy possessor of many, many dollars as the result of his labors.

My errand was to see the big orang-utan, but the contents of that lofty hall quite drove the charming creature out of my mind. The first thing that caught my eye was a rounded gray stone about the size of a small coal-scuttle, lying upon the floor as if it were of small account. I scamned it idly, until my glance rested on a spot that had been polished, and I saw that it was jade! Value about three thousand dollars, a present from the owner of a mine for whom Mr. Whampoa had once done some business. We passed through three large, square apartments, which formed a grand saloon, in which were tables for the reception of rare objects of virtu, and the walls and niches were quite filled with "curios." On a table stood a bronze elephant with a pagoda on his back, three feet high, Jipanese work evidently, and exquisitely done. Near it hung a huge Chinese gong, four feet in diameter, on which were two dragons inlaid in gold. Above that, hung a huge-almost colossal-pair of stag-horns, on the massive branches of which were perched stuffed birds of paradise. Bronze storks stood upon the floor, and elsewhere were numerous dragons in bronze, elephant tusks, spears, etc. The furniture was all of ebony, exquisitely carved and lavishly inlaid with mother-of-pearl and ivory. On the walls and cornices were divers and sundry inscriptions in Chinese characters, painted very large and very red. I had hard work to repress the curiosity I felt, and the questions that rose to my lips at every step; but I did not wish to tire the feeble old gentleman, or make him regret my visit, so I held my peace.

Then we went out into the back yard to see the orang. He was a perfect monster in size, compared with all other orangs I had seen in captivity, and as savage as a tiger. My presence seemed 
particularly obnoxious to him, for he scowled and growled at me, made faces, and sprang at me against the wooden bars of his cage in great rage. When I approached him for a nearer view, he thrust his big, hairy arm out from between the bars for about four feet, it seemed to me, and made a grab in my direction, with his huge, black hand. His canine teeth were very large, almost like those of a bear of medium size, and I was very glad he had not an opportunity to try them on my flesh. The brute really acted as if lie recognized in me an enemy to lis race, and foresaw the slaughter to his kind my visit to Borneo afterward caused. Mr. Whampoa had had him about six months. He was fed with leaves, plantains, and pineapples, and seemed in very good condition, but a few months later he died; his skin was stuffed, and is now on exhibition in the Museum.

Besicles the orang, I was shown quite a collection of live animals, including tortoises of three species, argus pheasants, golden and silver pheasants, a gazelle, porcupine, kangaroo, and some beautiful mandarin ducks. I regretted to see that the latter so completely surpass our pretty summer duck (Aix sponsa).

Having viewed the animals, we walked through the gardens, which have been gotten up regardless of expense, and are kept in fine order. One of their most notable features is the abundance of a little shrub, a species of box (Buxus) which has been trained and trimmed into various animal forms. The leaves are small, stiff, and very thickly set, and the branches seem willing and able to assume any form which is desired. It was fashioned into Chinese dragons, elephants, tigers, pigs, rhinoceroses, and even deer with antlers. Every animal was perfectly recognizable at a glance, and the effect was heightened by the addition of large wooden eyes painted somewhat like life. Some of the animals were four or five feet high, while a representation of a Chinese junk, of which there were several, was quite eight feet in length, and very carefully reproduced.

There were flowers after flowers, and shrubs by the score, but what pleased me most was a tank containing an old Demerara friend, the Victoria regia, queen of lilies. Yet a bed of touch-menots took me back like a flash to the terrace flower-beds at college, and further still, to my mother's mounds at our old home, so very, very long ago. Ah, me! The Victoria regia was eclipsed. 


\section{CHAPTER XXVI.}

\section{ON THE SELANGORE SEA-COAST.}

Malacca.-Selangore.-Klang River and Town.-A Kindred Spirit.-Visit to Jerom on the Sea-coast to Collect.-Bamboo Creek.-A Filthy Chinese Village.-A Foul Stream.-Crocodiles. - Catching a Twelve-foot Crocodile with Hook and Line.-The "Alir."-A Harvest of Saurians again.--Crocodiles in the Sea.-Birds.-Shrimp-eating Monkeys.-An Iguana.-The Slowest Race on Record.-Remarkable Fishes. - Catching Periopthalmi.An Adventure in Mud.-Varions Vertebrates.-Centipedes and their Doings.-Doctoring a Ray-stung Fisherman._Malay Character.-Return to Klang.

A WEEK after landing in Singapore, I set off up the coast toward Malacca, in search of good collecting ground. I took with me an intelligent young Portuguese half-caste as assistant and interpreter, my regular jungle outfit, and all the information I could procure regarding that region. Messrs. Katz Brothers, merchants in Singapore, had advised me to visit the newly opened Territory of Selangore, above Malacca, and supplied me with a letter of introduction to Tunku Dia Udin, a Malay noble, living at Klang, the capital, in case I should decide to go there.

Malacca is about ninety miles up the coast from Singapore. It takes four dollars and fourteen hours by steamer to get you there, and after you have reached it you find only a dull and uninteresting, but prettily shaded town. A few hours spent in industrious inquiry convinced me that Malacca was not the place for me, and without a moment's unnecessary delay I changed my programme entirely. The little steamer Telegraph was already getting up steam to go to Selangore and I hastened aboard. In the person of the chief engineer, Mr. J. M. Hood, a Scotchman, of course, I met a " jolly good fellow," who, from first to last, did everything in his power to make my trip to Selangore agreeable. But for his thoughtful kindness from time to time, I would not have fared nearly so well as I did. He was another of those good fellows one meets in knocking about the world, who are so free with their 
favors that it is hopelessly impossible for any but the wealthy traveller to fully requite them.

We left Malacea at 5 P.n. ; and at daybreak the next morning, were in a narrow strait which separates a chain of islands from the mainland of the Malay Peninsula. I thought at first we were in a river; but after steaming smoothly along for a few miles we made a turn toward the mainland, passed a stockade and a white house on a point, showed our colors, and entered the mouth of the River Klang, two hundred miles from Singapore.

Although this is the largest river in Selangore, it is only a hundred and fifty yards wide at the mouth. The water is brown and thick with mud, and looks bilious. The banks are low and swampy, and covered with mangroves and nipa palms growing in the soft mud. Twelve miles from the mouth, the ground suddenly rises high and dry, and we come to Klang, the capital.*

On a stretch of level ground about as large as a race course, on the left bank, are about fifty gray houses covered by roofs of weather-beaten thatch. This is the town. Near the rather insecure wharf stands a good-sized modern building of masonry, painted white, which we know, instinctively, is the publis building of the place, the court-house, treasury, post-office, and the like. Near the river bank, just below the town, we see a smoothly shaven hill, the top of which is encircled with a grassy earthwork and shallow moat, minus water. There is a dusky sentry at the gate and two others on the embankment, so that must be the fort. A short distance back of the fort, at the top of a higher hill, stands a spacious and comfortable modern residence overlooking the town and fort, as if to keep a watchful eye over all. This is the British Residency, and it does not belie its looks.

I went ashore with Mr. Hood and up to the fort, where he introduced me to Mr. H. C. Syers, Superintendent of the police and military force of the Territory, who forthwith gave me a cordial invitation to "put up" with him at his quarters in the fort. Finding there was neither hotel nor boarding house in the town I accepted the offer with a sneaking sense of thankfulness that I was really obliged to do so, for I hate hotel life.

Mr. Syers and I became friends directly, for I greatly admired his strength of character and he was not averse to the companionship of one interested in shooting quite as much as himself.

* The seat of government is now at Quallah Lumpor. 
He was a character fit to do duty as the hero of a vigorous romance, and I found great interest in drawing him out. He was a young Englishman from London, only a little older than I, frank, big-hearted, fearless as a lion-tamer, and tenacious as a bull-dog. $\mathrm{He}$ had been a soldier in the British army, but purchased his discharge in order to enter upon a wider field of usefulness in his present position. No officer could be better fitted by nature to fill a position than he to fill his. He has built up out of very suspicious materials, and solely by his own efforts, the present military force of Selangore, which is now well-armed and equipped, and well-drilled, and his grip upon the law-breaking element is so firm, so severe, and so certain, that outbreaks are now extremely improbable. The vigilance with which murderers are hunted down and executed, has rendered crime of that sort very rare.

From Klang I made one short shooting trip up the river, another down it, and another into the hilly jungle back of the town, all of which were rather barren of results, I thought, and convinced me that I must look elsewhere for good collecting ground. Mr. Syers and I planned a trip into the interior after large game; but just then, the Resident, Captain Douglas, was in Singapore and the execution of the plan had to be deferred till his return. Acting on the information and advice of Mr. Syers, I packed up and hired a Malay boat and crew to take me down the river, and thence up the coast, about fifteen miles, to a little Malay hamlet called Jerom.

We started from Klang with the ebb tide, about two o'clock in the afternoon, passed out at the mouth of the river just at sunset, and, hoisting our sail, to catch the gentle breeze, bore away up the coast. We were soon clear of islands and on the open sea. It was a beautiful moonlight night, of the kind made especially for boating, and I think even the stolid Malays enjoyed it.

We reached Jerom at one o'clock, and all the Malays went ashore while I slept in the boat until morning. I went to sleep with the water patting the side of the boat and tumbling in tiny breakers on the shore in front of the house, but when $I$ awoke in the morning all was still and silent as the grave. The boat lay helpless upon the sand, and the sea had quietly stolen away from the shore, leaving between itself and us a barren bank of mud and sand more than half a mile wide. No wonder it was still. It was well for us we made the shore during the high tide, for otherwise we would have been compelled to wait several hours. 
The only house in the hamlet which could afford me shelter was that of Datu Pudeh, the Malay headman of the place, and having been confided to his care by Mr. Syers, he took me in, and gave me a corner of his front room, in which I hung up my hammock and musquitero without further ceremony. When the tide was in, the house stood almost at the water's edge, rather low upon its posts, with slatted floor, and roof of thatch which had in it several holes large enough to have thrown a dog through. I suppose that, like the man of Arkansaw, when it rained they couldn't fix the roof, and when it did not rain they didn't need to. We had no sooner moved in with our belongings than it began to blow and rain very hard. The bamboo curtains outside were let down over the windows, and the place made as snug as possible, but the wretched old roof leaked like a shower-bath.

A mile above Jerom, a muddy little creek, called Sungei Bulu, runs into the sea between two wide banks of soft mud which are submerged at high tide, and left four feet out of water when the tide is out. A little way up from the mouth is a village of Chinese fishermen who are engaged in catching prawns and making them up into a stinking paste called blachang. Every house in the village is tumble-down, rickety and dirty beyond description, and the village smells even worse than it looks. The Chinamen live more like hogs than human beings; and, for my part, I would rather take up quarters in a respectable pig-sty than in such houses as those are.

At high tide there is no ground visible along the banks of the creek, but, when the ebbing tide empties the murky little stream, the channel flows between sloping banks of soft, slimy, gray mud. I never before encountered mud having such a nasty, putrid smell as that emitted when exposed. It smelled like sulphuretted hydrogen, and was, at times, almost overpowering. If I were making up a hell out of the most disagreeable elements on earth, I would put in it the Sungei Bulu at low tide, as being the most dismal, wholly repulsive and sense-offending stream on the earth. Its water is a kind of mud gruel, seasoned with salt, dead leaves, and rotten wood finely pulverized. One would think that even the meanest living creature would find life unendurable in such a place; but nevertheless the creek is swarming with salt water crocodiles (Crocodilus porosus), all of which deserve to be shot for living in such a vile place.

At low tide they crawl out and lie among the mangroves, wal- 
lowing in the soft, hot mud until the water rises again. I got several specimens by floating quietly down the stream and shooting them before they were aware of our proximity. The largest ones however, were too smart to be taken in that way, and having become convinced of this fact by the failure of several attempts to shoot a well-known individual of large size, I determined to go a-fishing for him.

Acting under the advice of a Chinese fisherman who seemed to know how to catch crocodiles with a hook and line, we got a rattan about forty feet long for a line, and a dry cocoanut to tie at one end as a float. The Chinaman then proceeded to make an "alir," such as the Malays use in Sarawak, by whittling an inch piece of tough green wood ten inches long into a shape something like a crescent, sharp at both ends and with a groove running round the stick at the middle, which was the thickest part, where the line was to be attached.

Some soft but very tough green bark was then procured from the jungle, and braided into a line six feet long, which was at one end fastened firmly round the middle of the alir, and at the other to the long rattan rope. This bark line was supposed to be so soft and tough no crocodile could bite it in two. The bait used was the body of a sting ray caught by one of the fishermen, which was lashed securely to the alir, one end of which was then bent up close to the bark line and tied to it with a bit of string that could be broken by a slight pull. The intention was that the alir should be swallowed point foremost, and when we pulled on the line the upper point would catch in the side of the stomach, break the string and instantly bring the alir crosswise in the crocodile's interior.

The crocodile we wanted to catch was well known by his repeated appearance at the village, within stone's throw of the houses, and he was described as being a perfect monster, with a throat large enough to swallow a large-sized man instantly. The villagers manifested great interest in our effort, and helped us in every possible way.

We took our tackle just far enough above the village to be out of sight, for we wanted our victim to have so good an opportunity that he would not feel bashful. Following the custom of the Malays we found an overhanging branch, quite low down, over the end of which we threw our line so that the bait hung within six inches of the water at high tide, and so adjusted that a very slight 
pull would bring it down. The rattan line we threw into the stream with the cocoanut buoy at the end, and quietly retired to the village to await developments.

At the close of the day the bait still hung there undisturbed, and I walked home to Jerom hoping for better luck on the morrow. The next morning we were there soon after sunrise, and the Chinaman joyfully informed us the bait was gone. We got into a small Malay sampan and paddled up the creek at once to investigate. We found the cocoanut moving slowly through the water against the current and upon laying hold of the line we felt there was big game at the other end. We gave a vigorous pull, and the next instant were almost capsized in mid-stream by a pull we got in return. We then passed the line over the stern of the canoe and while $I$ held it, the rest began to paddle down stream toward the village where we proposed to land our eatch.

Then he showed himself. He rose to the surface apparently to see what was the matter, and, after giving a good look at us, started forward and began to turn as if about to go up stream. Before he had turned half round he fetched up with a violent jerk which must have given one point of the alir a vicious dig into the side of his stomach; for he began to plunge and thrash around with great violence, sending the water circling around him in huge waves. There was also considerable excitement at our end of the line, for the sampan was small, light, very tipsy, and contained three men of good weight. Chinaman, Malay, and Anglo-Saxon, each shouted at the other two in his own language. Had we been eapsized I scarcely know which would have disgusted me most, the ducking in that dirty creek, full of crocodiles, or the loss of my rifle. As soon as we could I tied the weapon fast to the boat so that in the event of a mishap I would not lose it.

After this struggle the crocodile seemed to give up the fight, for he allowed himself to be towed down to the village without further resistance. But as we neared the landing place where we intended to haul him out, he made a final and still more vigorous struggle to get free. He snapped his jaws angrily together in an effort to cut the line, but it was no use, so shutting them together like a vice he plunged first to one side and then the other, striking out with tail and legs, diving deeply one moment and suddenly thrusting his ugly snout far out of water the next.

Another boat came to our assistance at this point and the huge old reptile was dragged shoreward by main force. The men landed 


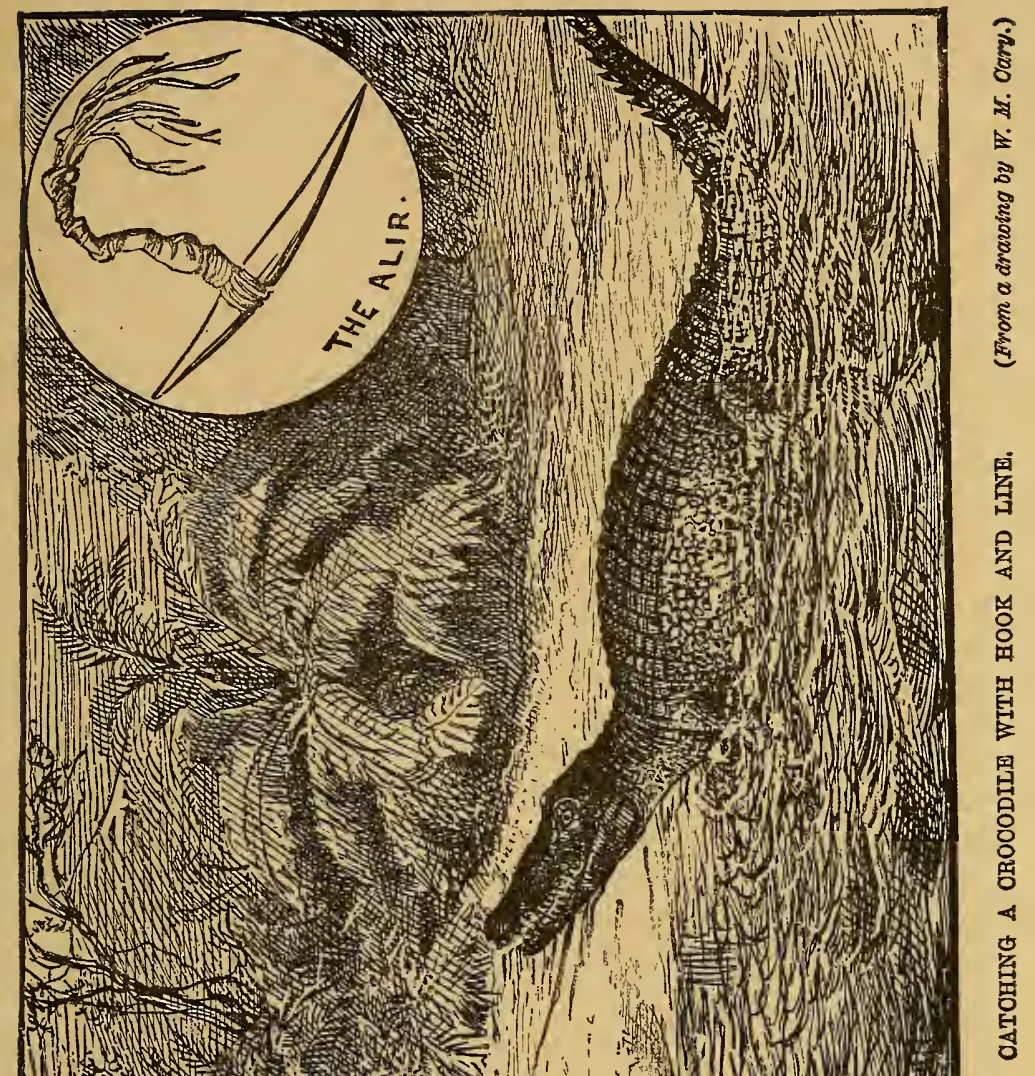



and dragged him close up to the shore without further resistance on his part, whereupon I fired a bullet iuto his neck from the side which cut his spinal marrow so neatly that the vertebra was but very slightly injured. He was the very crocodile we wanted, and his death occasioned no sorrow. He measured exactly twelve feet in length, and his weight was four hundred and fifteen pounds. He was so old, so dingy, dirty, and ugly every way that I concluded to take his skeleton instead of his skin, and spent a day in roughing it out neatly.

Encouraged by this venture, and a satisfactory offer of hard cash, my Chinaman caught for me (on his own hook) two other fine crocodiles, one being eleven feet in length and the other nine, both of which were skinned. I got altogether ten crocodiles out of the Sangei Bulu, which yielded four skins, four skeletons, and one skull.

I was greatly surprised one morning at seeing two crocodiles swimming out in the open sea, directly opposite Jerom, fully a mile from the shore, and three miles from the mouth of the Sungei Bulu. It was a calm, clear day, and I watched them for half an hour with the glass as they floated at the surface of the water, or swam slowly about with their entire length visible the most of the time. One was very large, probably twelve feet in length, and the other was apparently eight feet long. At length they disappeared and we saw them no more. It is not unusual for crocodiles to live in salt water, but I never before saw one out in the open sea.

The mud flats at the mouth of the Sungei Bulu were excellent collecting ground, both when under water and out. Water birds were really numerous when the conditions were favorable for their appearance. Some came to fish in the shallow water and others to pick up a living on the flats when the tide was out. I saw several pelicans (Pelecanus rufescens?) perching on some dead trees near the shore, small white egrets (Herodias garzetta) and a solitary booby (Sula piscator). On a little islet of igneous rock opposite Jerom I saw stone plovers (Esacus recurvirostris), two species of tern (Sterna caspia? and Sternula minuta?), two of ibis, snipes, sand pipers, etc. At low tide many small shrimps were left stranded on the mud, and I often saw troops of small gray monkeys, called krahs (Macacus cynomolgus), wading about in the mud among the mangroves, picking them up. At such times it was easy to shoot them, but difficult to get them afterward.

Once we discovered a fine, large kabra goya or iguana (Hydro- 
saurus salvator), wading about on the mud banks, also looking for food. At my solicitation my young man Francis at once jumped out into the mud and gave chase. He sank alınost to his knees at every step, and the race was certainly the slowest on record. The official time was one hundred yards in twenty minutes; but the kabra goya got beaten, although usually a swift runner; the soft mud so impeded its progress that it was finally overhauled and killed with a stick. Its length was just six feet. We often found small crocodiles lying hidden in the little gullies which the receding water cuts in the mud banks, and shot several as they came charging out toward the deep water.

The most interesting animals we found on the mud flats were some fishes whose actions were really remarkable. Although apparently stranded there, they seemed to feel perfectly at home, and went jumping round over the mud in every direction with the greatest indifference to their sudden change of element. In reality they were feeding upon the tiny crustaceans left on the bank by the receding tide. They were very lively considering the nature of their play-ground, and when I tried to beguile my Malay boatmen into catching some specimens for me, they declared it would be impossible to catch them on account of the deep mud, and the swiftness of the fish. Neither was my young man Francis to be tempted into such a muddy enterprise, and as I make it a rule never to ask a servant or assistant to do anything I would not be willing to do myself, I saw that I would have to lead the attack in person.

The Malays were thunderstruck when I pulled off my shoes and told them to put me ashore. Seeing that I was really going, Francis, like a good boy, did not hesitate to follow, and we stepped out of the sampan into mud and water hip deep.

We will never know the actual depth of the mud on that bank, but we sank into it to our knees at every step, and were fortunate enough to stop sinking at that point. What a circus it must have been for those who looked on! But, in for a penny in for a pound, and, bidding Francis choose the largest fish when possible, we went for them. There were probably a dozen in sight, hopping spas modically about, or lying at rest on the mud, but when we selected the nearest large specimens and made for them, they developed surprising energy and speed, and made straight for their burrows. They progressed by a series of short but rapidly repeated jumps, accomplished by bending the hinder third of the body sharply around to the left, then straightening it very suddenly, and at the 


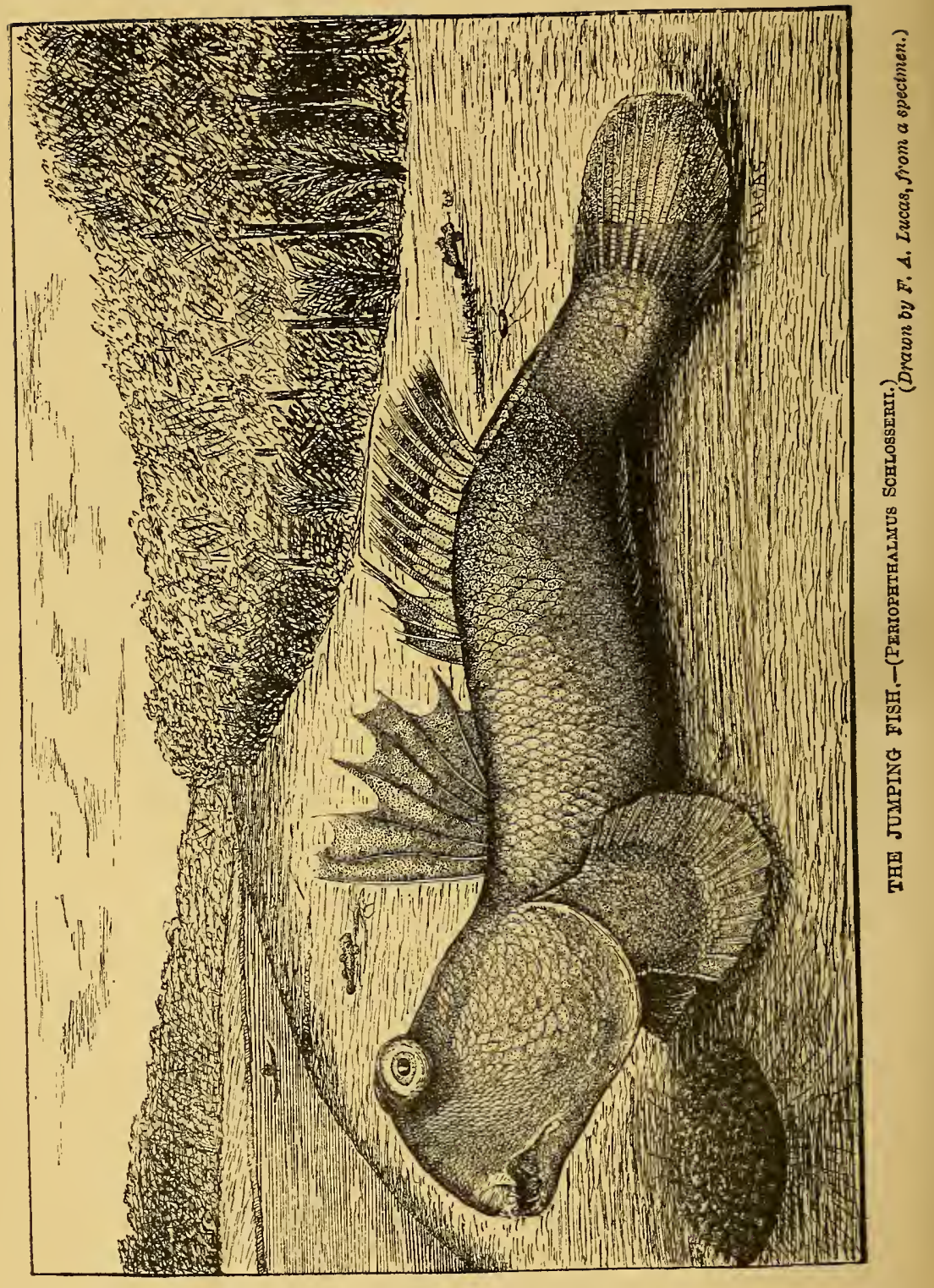


same instant lifting the front half of the body clear of the ground by means of the armlike pectoral fins which act like the front flippers of a sea lion. These fins are almost like arms in their structure and use, the bones being of great length, and thus giving the member great freedom of movement. Owing to the soft and yielding nature of the mud the leaps were short, about six inches being the distance gained each time, but they were so rapid, the mud so very deep and our progress so slow, the fish always succeeded in getting into their holes before we could reach them. Their burrows were simply mud-holes, going straight down to a depth of three to four feet, large enough in diameter to admit a man's arm easily, and, of course, full of water. Although the mud was soft it was not sticky, and we were able to use our hands for spades very effectually. By digging a big hole two feet deep, and standing on one's head in the bottom of it, we were able to reach an arm down two feet farther and seize our fish at the bottom of the burrow. Lucky it was for us that they had no sharp and poisonous spines, like the mud-laff which stung me in Singapore and paralyzed my right hand for some hours.

My first fish was hard to get and hard to hold, but, in the immortal words of "The Shaughraun," "begorra, 'twas worth it."

The species is known scientifically as Periophthalmus schlosserii, (Pallas, Bl. Schn.) a member of the family Gobiidoe, whose expanded ventral fins serve as a foot, the lengthened pectorals as organs of locomotion, while the small gill opening allows the retention of sufficient moisture to sustain the fish for a considerable period on land.

Adult specimens are nine inches long, of a uniform slaty color.

As I remarked before, our living specimens were hard to hold. When I was trying to pass a string through the gills of my first fish, he struggled out of my grasp, and the moment he touched the mud started at his best speed for the water twenty yards distant.

I was horrified at the thought of his getting away, and instantly falling upon my hands and knees I pursued him frantically "on all fours." It must have been a sight fit for the gods, for even my stolid and ever respectful Malays actually shouted with laughter to see the tuan go over the mud like a "buaya" (crocodile). My change of base was successful, however, for I was able to go over the mud instead of through it, and I overhauled my fish in fine style. A few minutes later I saw Francis execute the same brilliant manœuvre for the same cause, and it certainly was a most laugh. able spectacle. 
We got seven fine specimens altogether, one of wlich is figured herewith, and of all the muddy human beings you ever saw-but I will draw the veil.

We were fated to have another adventure in mud which was not down in the programme. We left the mouth of the Sungei Bulu very late one evening with the tide at the ebb, and did not arrive opposite Jerom until after sunset. To my horror, our boat grounded in the mud three-fourths of a mile from shore, and stuck fast, leaving us to chnose between staying in the boat, with the mosquitoes biting vigorously, for five hours, until the tide came in, or wading ashore through that sea of mud. Of course we chose the latter. It is easy to imagine mud knee deep; but it is a different thing to go through it, when one actually sinks to the knee at every step. We had a quarter of a mile of that, floundering along, slowly and painfully, the dim lights on shore seeming farther away every time we looked. At last we emerged from this slough of despond upon firm ground of shells and sand, and the last half of the distance was quickly accomplished; but we were never caught in that way again.

But for a clean sandy shore line, Jerom would be intolerable, for it is entirely surrounded by mud. No prospect could be more dreary than the vast mud-flat left bare all along the shore at low tide. But even the sandy shore is being rapidly eaten away by the sea. The beach is thickly strewn with the trunks of cocoanut trees which have been undermined and overthrown by the waves, and many more are doomed. Back from the beach, for an unknown number of miles, extends a swampy wiiderness inhabited at present only by wild beasts. Mr. Syers once penetrated it a short distance, with a French count as a companion, in search of wild cattle (Bos sondaicus). After proceeding a little over a mile, the Gallic sportsman made his attendants construct a litter and carry him back to Jerom. Mr. Syers proceeded, but found no game, and returned in disgust. Along the banks of the Sungei Bulu I saw where the high grass had been trampled down quite recently by wild elephants.

Besides the specimens of Macacus cynomolgus, the only other mammal species I obtained at Jerom was an otter (Lutra leptonyx), brought in by a Chinaman, who killed it with his parong.

Half a dozen small box-turtles (Cuora Amboinensis) were brought to me, and one large tortoise (Emys trijuga), which was caught near Jerom. The fishermen eatch and eat a good many spinybacked rays (Urogymnus asperrimus) of large size, the dry backs of 
which lay all about Jerom. One was caught during my stay there, but the stupid Chinaman ruined it as a specimen by cutting off the skin of the back, which he brought to me instead of the whole fish I had called for. It was a very large specimen, measuring 2 feet 9 inches across the back, and I exceedingly regretted its destruction.

A collector of insects could have made quite a collection in the house which (partially) sheltered us. On putting on my clothes one morning, I found a fine healthy centipede in my trouserspocket, along with my knife and keys. I took this warning rather carelessly, and paid for it the very next day by putting on my shirt with a four-inch centipede in the shoulder. Feeling something crawling vigorously on my flesh, I reached up and made a grab for it, but unfortunately seized it in such a way that the head was left free, and it instantly bit me. Before I could catch its head it bit again, but it never bit any more. When Francis had helped me out of my shirt, and I loosened my grip on the insect, it looked as if it had been through a clothes wringer. After all, its bite was not so terrible as I had been taught to expect. The sensation was similar to what I would have felt had three or four hot needles been thrust into my shoulder a quarter of an inch or so. I bathed the bite directly with tincture of arnica, my favorite remedy for all such ills, and, after several applications, the pain ceased entirely at the end of about two hours.

Just before I left Jerom one of the Malay fishermen living there was badly hurt by a sting-ray. While reaching down in the water to pull up one of his fishing stakes, he disturbed a large ray, who instantly struck at him and drove the ragged, bony spine on his tail completely through the poor fellow's hand, making a dreadfully ragged and painful wound. Datu Pudeh came for me to doctor him, saying that he was about to die. Catching up my little tin box of medicines I went to the injured man, and found him lying limp and helpless in the arms of his friends, surrounded by a sympathizing crowd, not one of whom knew what to do for him. "Will he die, tuan?" was the universal question. "Certainly not," I replied, with assurance that would have astonished an Abernethy, I dare say. I dreaded lock-jaw, but he hat no symptoms of it then. Calling for cold water I kept a stream running on the man's hand for fifteen minutes, and then steadily bathed the wound with arnica for half an hour. After that I saturated cotton with the same divine stuff, and bound it upon the wound, with the repeated assurance to the patient that he would not die. 
The next day, while I was busy packing up to leare, in walked my patient, so briskly as to take me by surprise, to express his gratitude. He certainly did recover much quicker than I expected. Datu Pudeh begged me to give him some of that wonderful "obat" (medicine) ; and, having used up my supply, I earned his gratitude by sending him some from Klang on my return.

At Jerom I had a very good opportunity to study Malay character, in one phase at least. I had to respect them for their sobriety, their quiet, dignified manner under all circumstances, their entire disinclination to loud-mouthed brawling, and their freedom from all symptoms of the offensive and impertinent curiosity so characteristic of the higher races of men. I was constrained to regret their characteristic indolence, and lack of enterprise, for this national failing, and this alone, has kept the Malays from holding all Malasia securely in their grasp. Procrastination is the evil genius of the Malay, and the exasperation of whoever looks to him for help in time of need.

The people of Jerom treated me well from first to last, but their ways were too slow for me. Somehow they seemed never ready to start, and delay was ever the order of the day. Being totally unused to their deliberate ways, I lost my temper more than once when depending upon them as boatmen and guides. Even when we were ready to return to Klang, and the boat and crew engaged well in advance, neither were ready on the day appointed, nor had a move been made except by ourselves. At last, when we got the boat all ready to load, the Datu declared it had no sail, and we must wait a day, or until one could be procured. After we had given up in despair, the Datu bestirred himself and enabled us to get off with a loss of only two days. And what are two days to a Malay!

Before leaving I gave the Datu's wife a very nice figured sarong, which pleased her mightily, and called forth from her most earnest apologies for their inability to entertain me in better style during my stay. She insisted on cooking a hot dinner for me just before we were to start, to which I finally consented, to please both the lady and myself. There was presently forthcoming a very nice and highly palatable meal of fried bananas, preserves of nutmeg and pomegranate, and a dry short-cake to eat with butter and sugar, made by the Datu's mother-in-law. In one sense it was not much, all told, but in another it was a feast, for it was the very best tho house could offer. 
The mother-in-law and daughter had often peeped through the crack of the door at me, but never had shown themselves until I sent in to the old lady a knife, fork, and spoon as a present, instead of the spoon she had craved as a curiosity ; whereupon she forthwith donned her best sarong and jacket, and came into the room where I was, to thank me for her presents and her daughter's. (Nothing makes a man feel meaner than to give a poor present and see it appreciated far beyond its worth.) But her daughter's face I never saw.

We got off about an hour after dark, spread our huge matting sail, and glided slowly along the shore. Francis spread a bed for us under an extemporized roof, and we slept well. In the middle of the night I was rudely awakened from a dream of bison-hunting by my bedfellow, who sprang to his feet, clawing violently at the back of his neck, and "uttering strange oaths" as well as familiar swear words. He haā been bitten by "an awful big centipede," and advised me, for my own safety, to get up quickly. Being a firm believer in the truth of the saying that "lightning never strikes twice in the same place," I lay still and went to sleep. At noon of the next day we reached Klang again. 


\section{CHAPTER XXVII.}

\section{HUN'TING IN THE INTERIOR OF SELANGORE.}

A Trip to the Interior.-Road to Kwala Lumpor.-The Town._" The Captain Cheena."-A Bonanza in Champague.-Sungei Batu.-A Foolish Feat.-Our Honse. -Feasting on Durians. - A Jacoon House and Family.-Resemblauce to the Dyaks.--An Impromptu Elephant Hunt.-Attack in a Swamp. - Death of a Young Tusker._Plague of Flies._Another Elephant Hunt.-A Close Shave and a Ludicrous Performance.-Discovery and Exploration of Three Fine Caves - Cathedral Cave._Mammals. -Visit to a Tin Mine.-Chinese versus Malays.--Political Condition of Selangore.-Statistics.-Snakes.-Good-by to Klang.-Mr. Robert Campbell, my Good Genius.

ON again reaching Klang I found there Captain Douglas, the British Resident, who, much to my advantage, was kind enough to interest himself in the object of my visit. Through his co-operation Mr. Syers obtained fourteen days' leave of absence for the trip we had planned to take into the interior, and, on the evening of June 27th, we started up the river in Mr. Syers' boat. Four Malays pulled the boat, while we lay down and slept comfortably until we reached Damensara, eighteen miles up, where we tied up till morning. From the Police Station at that point a good carriage road leads east seventeen miles to Kwala Lumpor, the largest town in the territory, in the centre of the mining district.

After our cup of coffee at the police station, I hastily skinned a Macacus nemestrinus (broque monkey), which I bought alive of one of the policemen, and then we started for the other end of the road. Mr. Syers had his two ponies in readiness, and we rode them, leaving our luggage to follow on a cart.

The road lay through very dense, high forest, composed of large and very lofty trees (among which the camphor was often noticed), growing very thickly together, while the ground underneath was ehoked with an undergrowth of thorny palms, rattans and brush so thick it seemed that nothing larger than a cat could get through it. Nowhere was there the smallest opening in 
this dark and damp mass of vegetation, and it made me shudder to think of attempting to go through it. Surely, I thought, we will not attempt to hunt in such forest as that.

Six miles from the river, we came to another police station, Kooboo Ladah, where we halted to wait for the baggage to come up. Two miles farther on we reached the end of the road,* where we found a gang of government coolies waiting to carry our luggage the remainder of the distance. Witbout these men, whose services were thoughtfully supplied by Captain Douglas, we should have been obliged to pay a ruinously exorbitant price for coolie hire, almost as much as our baggage was worth.

For the remainder of the way, we had only a very rongh bridle path through hilly jungle and across many muddy little streams. At the twelfth mile we passed the Sungei Batu police station, very prettily situated in a highly romantic spot.

After passing two or three clearings, we reached the top of a long, steep hill, and, at its foot, Kwala Lumpor lay before us, on the opposite bank of the river Klang, here reduced in size to a narrow but deep creek. A sampan came across to ferry us over, while our ponies swam beside it, and at 5 P.M. we were at our resting place for the night.

All along the river bank, the houses of the Malays stand in a solid row on piles ten feet high, directly over the swift and muddy current. The houses elsewhere throughout the town are walled with mud, and very steeply roofed with attaps (shingles made of nipa-palm leaves), so that a view of the town from any side discloses very little except high, brown roofs slanting steeply up. In the centre of the town is a large market where fruits, vegetables, meats and various abominations of Chinese cookery are sold. The vegetables are sweet potatoes, yams of various kinds, beans, melons, cucumbers, radishes, Chinese cabbage, onions, egg-plant and "lady's fingers." The fruits were the durian, mangosteen, pineapple, banana, and plantain, oranges (of foreign growth), limes, "papayah," and other small kinds not known by English names.

In the centre of the market-place are a lot of gambling-tables, which, a little later in the evening, were crowded with Chinamen earnestly engaged in the noble pastime of "fighting the tiger." The principal streets are lined with Chinese shops, and are uniformly clean and tidily kept. The streets inhabited by the Malays

* This road was completed soon aiter to Kwala Lumpor. 
can be recognized at sight by the accumulation of dirt and malodorous rubbish, and the dilapidated appearance of the houses.

We went straight to the house of the Captain China (pronounced Cheena), the man of importance in the district, who is governor of the Chinese in every sense of the word. His title is Sri Indra Purkasah Wi Jayah Bucktie ("Fair-fighting Chief and Hero"), and his name, Yap Ah Loy, commonly called by Europeans the Captain China. In return for his services to the district in opening new roads and preserving good order, with his own police force, the government allows him a royalty of $\$ 1$ on every bhara (which equals three piculs, or four hundred pounds) of tin exported, and from this source, and also from his eleven tin mines, he is said to be the wealthiest man in the territory. He has in his employ sixteen hundred and twenty-seven men, and entertains at his house, in true European style, every white man who visits Kwala Lumpor. Unfortunately he was absent at that time, but his people received us quite as if he had been there, and made us comfortable with a fine dinner, an abundance of excellent champagne and good beds.

The next morning, while in the largest Chinese store in the place, buying provisions for our stay in the jungle, we struck a bonanza. We found Mumm's champagne for sale at sixty cents a quart, and India pale ale at fifteen cents per pint! How they ever managed to sell either at such ridiculously low prices we could not understand, and, to ease our consciences before victimizing the dealer, we told him he must have made a mistake in marking his goods. No, that was the price, and we could have all we wanted. It would have been flying in the face of a kind Providence to have neglected such an opportunity as comes but once in a lifetime.

Engaging the strongest coolie we could find we loaded him with champagne (at sixty cents per quart!), and marched him ahead of us into the jungle. It was the proudest moment of my life. I may never strike oil, or gold-bearing quartz, or draw a prize in the Louisiana lottery; but I have struck Jules Mumm's best at sixty cents a quart. My only regret is that I did not fill a tub and take a bath in it, for champagne is the only artificial drink I really like.

Having slept and breakfasted at Kwala Lumpor, we saddled our ponies, and prepared to move on six miles farther to Batu. Not having enough government coolies, we had to hire two Chinamen, who charged us $\$ 2.00$ for carrying a sixty-pound box six miles.

We crossed the river again, rode along a bridle-path through 
some dense jungle and one or two clearings, and presently reached Batu, on the Klang River, our journey's end. And right there we did the most foolish thing we could possibly have done, for attempting which we both deserved to have our necks broken. There is a narrow foot-bridge across the river, a single line of planks a foot wide, supported on posts about eight feet high over the bed of the river, and without any railings whatever. Mr. Syers asked if we should ride our ponies over the bridge instead of fording, and I told him to do as he liked, and I would follow. Fool that he was, he started to ride across the bridge, "just for a lark," and, fool that I was, I followed. The least nervousness, or a mis-step on the part of either pony, would have thrown us all over pell-mell, and, considering everything, it is a wonder we got safely over. Not satisfied with this, and to tempt fate still farther, we presently recrossed in the same way. The next day we were amazed at our folly, and ascribed our safety to the Providence which watches over fools and drunken men.

At Batu there are four Malay houses and two Chinese. The headman was absent in Klang, but his wife proved herself a woman capable of meeting an emergency, and forthwith had one of the Malay families vacate their residence, which stood a good distance away from the others in a very pretty grove of durian trees on the high bank of the river. The family moved out, bag and baggage, in twenty minutes, and we moved in with quite as much furniture and general luggage as the dispossessed. The floor was of bamboo slats, tied down to the sleepers, an inch apart, and raised on posts five feet above the ground. The walls were of bark, and the roof of attap. The principal room, in which Mr. Syers and I hung our hammocks, was cool and comfortable, but rather dark from lack of windows. In the other room were quartered our companions, consisting of two Malay policemen, one of them a smart, active young fellow named Yahop-a keen sportsman withal; my boy Francis, Syers' Chinese boy, Cat's Face, cook and servant, and also his Malay horse-keeper, a good servant at all times. The ponies were stabled very comfortably underneath the house.

The jungle all around Batu, although swampy in places, was so open that one could go through it on foot with tolerable ease. Here and there were patches of low and thin forest, broken occasionally with fine grassy glades, such as large animals love to visit for a sight of the sun and sky. But we soon found that beyond this fine ground lay a wide tract of swampy forest, very difficult 
to traverse, and very bad ground on which to attack dangerous game.

The day of our arrival we did nothing; but set out bright and early the following morning with a Malay guide who knew the locality well. We went to look the ground over, and if possible find wild cattle.

For an hour, our guide led us along a muddy path, through very thick jungle, and finally we halted at a place where there were a number of durian trees, and a party of Malays gathering the ripe fruit as fast as it fell. Being an animal of largely frugivorous habits, I have marked that day with a white stone as being the one on which I ate my first durian.

It is said that most Europeans have to learn to like this celebrated fruit. Ye gods! Learn to sip nectar from a blushing maiden's lips, if you must, but if you are fond of fruit at all, you will not need to be taught to eat what is at once the most delicate in substance, and delicious and aromatic in flavor, of all the many good fruits of the tropics.

This remarkable fruit (Durio zibethinus) grows upon a tall forest tree, sixty to eighty feet in height, having a smooth, naked trunk, and otherwise a general resemblance to our hickory. The fruit is very much the same in size and shape as a pineapple, but the entire outside is a bristling array of dark-green, conical spines, three-fourths of an inch high and very sharp. Sometimes, however, the fruit is smaller, and quite round. It is a painful matter to hold a durian except by the stem, and I would about as soon have a six-pound shot fall upon me as one of them. This wholly abominable pod smells even more offensive than it looks, the odor given off being like that of a barrel of onions at its most aggressive stage. Many people are unable to eat durians at all, on this account, but my first one disappeared so suddenly as to greatly astonish and amuse the spectators.

The fruit hangs upon the tree until it ripens and falls of its own accord, and then the husk is pulled open very easily from the blossom end toward the stem, which discloses five longitudinal compartments or cells, in each of which is a row of large chestnutshaped seeds, about five in each shell, each of which is thickly coated with a soft, grayish, pulpy mass, which is the edible portion. In consistency it resembles flour paste, but in flavor it resembles nothing under the sun. There are, indeed, faint suggestions of black walnuts and rich cream, chocolate and sugar, but all these 


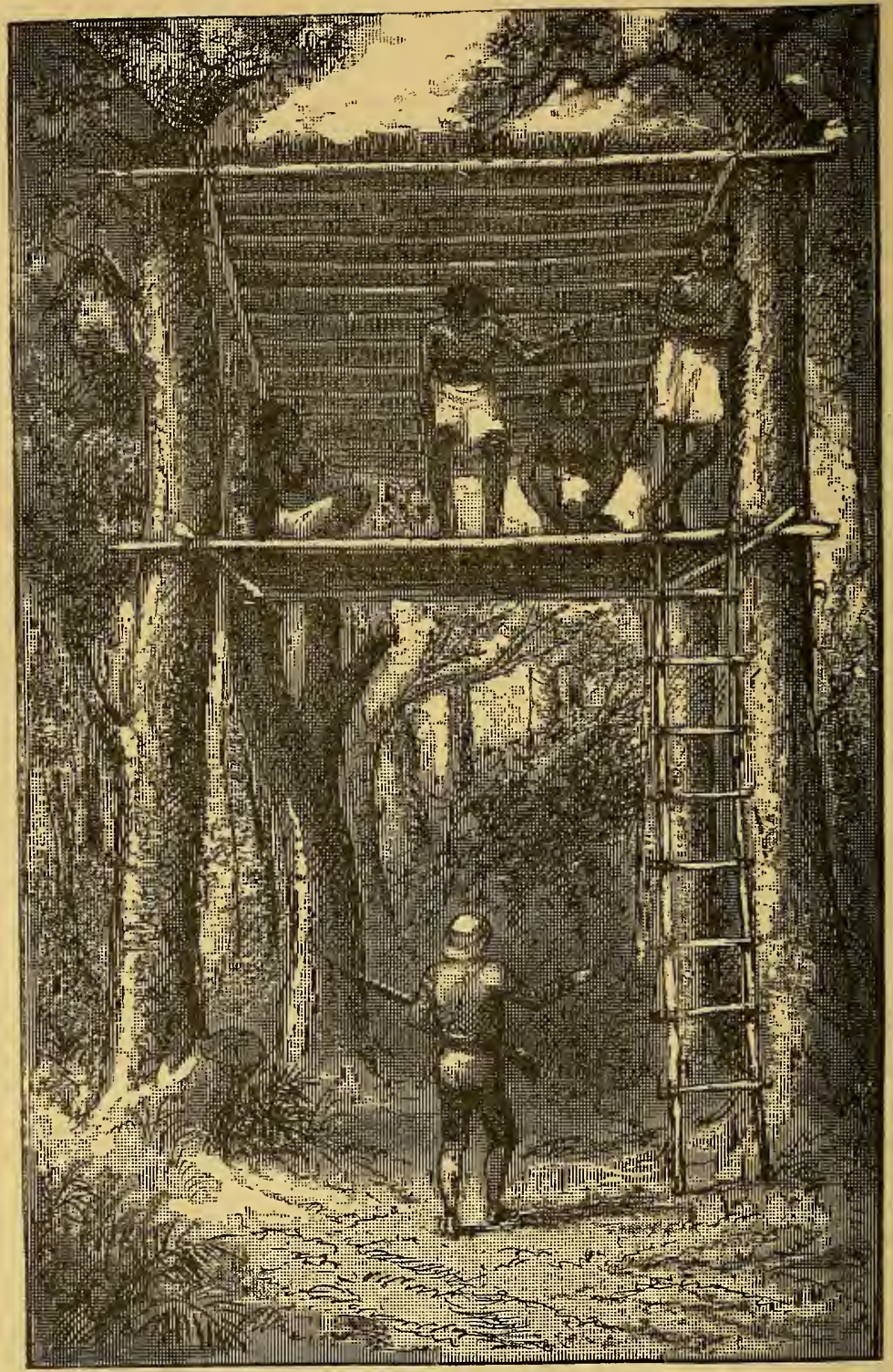

A JACOON HOUSE.

(From Author's sketch.) 
are lost in the flavor peculiar to the fruit itself, indescribable both in delicacy and richness. If there are no durians in heaven it will be the fault of the husk, not the kernel.

The Malays had built a lofty platform of poles to which they could retreat from wild beasts, and also sleep upon at night, and as fast as the durians fell they gathered them. They sold them on the ground, seventeen for a dollar, at which price I invested a dollar forthwith. No Anglo-Indian is half as fond of "brandy-andsoda " as I am of fruit, and I am sure the number of durians exported that week must have fallen off considerably.

While hunting through the forest in search of wild cattle or rhinoceros spoor we came upon the strangest human habitation I ever beheld. It was a Jacoon house, if we may dignify such a structure by that name, and the family was at home. The site had been selected with reference to four small trees, which grew so as to form the four corners of a square about nine feet each way. Twelve feet from the ground four stout saplings had been lashed to the trees to form the foundation of the house, and upon them was lashed the flooring of small green poles. Six feet above it was a roof of green thatch, sloping shed-like from front to back. There were no walls whatever to this remarkable dwelling, which was reached by means of a rude ladder. Upon this platform we found three men, two women, a nursing baby, a miserable little dog, two or three old parongs, some sumpitans and poisoned arrows, and a fire smouldering on a bed of earth at one corner. There were no mats of any kind, and the people slept on the bare poles. The men were naked, with the exception of a dirty loin-cloth, but the women were satisfactorily covered with mantles of dingy cotton cloth.

In physique, physiognomy and habits the Jacoons so closely resemble the forest people (Dyaks) of Borneo as to lead one to believe they have descended, and that, too, by no very long line of ancestry, from some of the numerous sub-tribes now flourishing in that great island. Judging from Mr. Bock's admirable portraits and description of the Poonans, the Jacoons are as much like them as it is possible for two separated tribes to be like each other. The Poonans, like all the Dyaks, have progressed through Borneo from south to north, and it is more likely that the Jacoons are accidental, perhaps involuntary, emigrants from Borneo than that the reverse has been the case.

The Jacoons are a very peaceable, almost timid, people, very ignorant, and wholly averse to living in villages, however small. 
They are nowhere numerous, the total number in Selangore being estimated at only seventy. They subsist wholly upon the fruit and vegetable products of the jungle, and the game they kill with their sumpitans, or blow-guns and poisoned arrows. Some of them are said to be very expert in the use of this singular weapon. The present Rajah Brooke states that he once saw a Jacoon drive an arrow into a single crow-quill at a distance of fifteen yards! We learned accidentally, a few days later, that the Jacoons are very fond of bats, and were stopping at that place in order to capture them in some large caves near by.

They were very accommodating people, and our party held quite an animated conversation with them upon the subject of wild game, as they sat perched aloft and looking down upon us. Fortunately they knew the value of money, and we engaged two of the men to act as our guides when we went in quest of wild cattle, rhinoceros, and other animals. One of them came down forthwith and led us a long tramp through the silent and gloomy forest for the remainder of the day, but we saw nothing worth shooting. Much to our disappointment, the Jacoons said there were, at that time, no rhinocerous in that region, but plenty of elephants.

The next morning about daybreak, as we were dozing comfortably in our hammocks, our sleepy ears were suddenly saluted by a clear, ringing note, like a blast of a hunter's horn, coming from the thick jungle half a mile away. We were instantly galvanized into action.

"Elephants!" we both exclaimed in the same breath, as we sprang out of our hammocks, and into our clothes. Never was a reveille responded to with more alacrity.

We swallowed our coffee, albeit rather hastily, crammed down a substantial breakfast, buckled on our hunting-gear, and mustered the men, who were ready as soon as we were. The Jacoons were not there yet, but no matter; I knew we could track up a herd without them. Leaving orders for the Jacoons to track us up if they came, and overtake us as soon as possible, we hurriedly set out.

To our surprise it took us nearly an hour to find the trail of the herd, and even when we did it was apparently two to three hours old. Evidently we had lost our bearings, to begin with. There was nothing to do but follow up the spoor as we found it, so away we went. Our whole party was there, except Mr. Syers' cook, Cat's Face.

My weapon was a rather ancient Sneider rifle, and Syers was 
armed with a double rifle carrying the same cartridge, good enough for deer, but very light for elephants.

The trail led us through thick forest for a while, but very soon entered a clearer tract and passed through the very grove of durian trees we had visited the day before. Our Malay friends, the durian gatherers, hailed our warlike appearance with delight, and gathered in an excited group around the ruins of their pole platform, which the rascally elephants had torn down with their trunks just before daybreak. They pulled it down as a sort of elephantine joke on the Malays, just to show them they had not built beyond their reach. The Malays, however, regarded it as anything but a joke to be compelled to quit their platform, climb up into the tree-tops and sit there for several hours in a badly scared condition. No wonder they begged us to shoot all the beasts, one by one, which we solemnly promised to do.

Within the next hour, the trail led us up and down through the more open jungle, four times across the river, and for some distance along its pebbly banks. At one time, nearly an hour was lost in trying to carry the trail across a stretch of hard, bare ground, where it got inextricably mixed with a number of other trails made by elephants which had fed about at random. Dispersing, we searched carefully, scrutinizing every broken twig and blade of grass in our effort to find the direction finally taken by the herd. At last we found where our elephants had marched off into the grassy jungle along an old trail for some distance. No wonder we were at fault.

At this juncture up came the Jacoons. "You vagabonds," exclaimed Mr. Syers in Malay, "why didn't you come up an hour ago and save us all this trouble?"

"The white gentlemen walked so fast we thought we would never come up with them," they answered very frankly.

The trail then led straight away for a tract of low, swampy forest, and the character of the jungle changed entirely. Near the edge of the swamp huge, spreading clumps of thorny palms grew in great abundance, and rendered our progress difficult and painful. Strangely enough, however, the farther we got into the swamp the thinner became the undergrowth, until presently it almost entirely disappeared, and in its stead we found uprooted trees, decayed tree-trunks, dead branches, and gnarled surface-roots. The trail had disappeared entirely under a foot of water, save when it crossed a bit of dry ground. We were wading along in water 
half way to our knees, with slow and tiresome progress, when suddenly the old Jacoon ahead of us stopped, and with his parong pointed through the forest.

"There they are, boys!" exclaimed Syers, in an excited whisper.

A hundred yards away across the tangle of fallen trees and dead branches we plainly saw the massive dark-gray forms of nine wild elephants. They were standing in the water, leisurely browsing upon the juicy aquatic plants that grew here and there, and wholly unconscious of our presence. It was a fearful place for an attack, either upon them or by them. Greatly to our amusement our brave Jacoons immediately swarmed up the nearest saplings, and the other members of the party fell back in good order and concealed themselves.

As the reader is possibly aware, I had had trouble with elephants before, but this was my friend Syers' first experience with such colossal game. Like a true sportsman and green hand at elephants, he was for attacking the herd instantly, before it took alarm and ran away, and I had great difficulty in even partially restraining him.

We quickly looked the herd over and saw that the only tusker in it was a rather small one, with short tusks, but fortunately he was the one nearest us. It seemed like an utter impossibility to get near enough for a sure shot through that open swamp; but, selecting our line of attack, and keeping carefully behind the treetrunks as long as possible, we crouched low and stole forward. In spite of our caution, a stick would snap every now and then, and our feet make a noisy disturbance in the water. Mr. Syers, who was eager and excited, took the lead, altogether too rapidly I thought, and I followed, almost upon his heels.

At last we reached a large tree at the foot of which was a bit of bare ground. Syers stepped up on it and cocked both barrels of his rifle. The elephant was in clear view forty yards away, but his hind quarters were toward us and his head was hidden by the root of an upturned tree. Syers threw his rifle up to his cheek with a look that meant business, and was glancing along the barrels for a shot, when I gave him a dig in the ribs and hurriedly whispered :

"Confound it, man, don't fire yet!"

"Why, I can hit him here well enough," he protested, in an excited whisper.

"But you couldn't possibly kill him. We must get up to that root close by his head before we fire." 
I hardly knew whether to be vexed or amused at my good friend's impetuosity, for I felt that as an old elephant hunter of four months' standing (and rumning also!) he should have allowed me to lead the attack. I shall always regard it as a hunter's miracle that we succeeded in approaching that animal when making so much noise and going ahead so precipitately in open cover.

With every nerve strained to highest tension, we crept out recklessly toward the upturned root, crouching almost into the water, and after a few moments of breathless anxiety we reached it and were within twelve paces of our elephant. I was totally surprised at his not seeing, hearing, nor scenting us. He was utterly unconscious of our presence until we both stepped from our cover, aimed quickly at his temple and fired together.

The great beast gave a tremendous start as the bullets crashed into his skull, threw his trunk aloft with a thrilling scream and wheeled toward us.

Before he had time to make a single step forward we aimed for the fatal spot over the eye and fired again. Down sank the ponderous head, the legs gave way, and the huge beast settled down where he stood and rested in the mud, back uppermost, with his feet doubled under him.

We instantly reloaded and came to a "ready," just as the tough old pachyderm began to slightly recover and struggle to regain his feet. Choosing our positions this time, a couple of shots behind the ear penetrated his brain and settled matters. With a convulsive shudder and a deep groan the great creature slowly sank back upon the ground, moved his trunk feebly a few moments, fetched a deep sigh and expired.

Of course all the other elephants had bolted at the first alarm, and were by that time far away. Our followers came running up, grinning from ear to ear at our success, and when they surrounded the fallen giant their exclamations of astonishment were loud and fervent. We could not measure our game, but according to the circumference of his fore foot, and his general appearance, he was about eight feet in height at the shoulders. His back was thickly encrusted all over with a half-inch coating of dried mud, the wise provision of a sagacious animal against the attacks of the swarm of huge gad-flies which buzzed about him. They bit the blood out of us more than once, and annoyed us exceedingly while we were at work on the dead elephant.

In a pouring rain, we cut off his head and took his skull, cervi- 
cal vertebræ, and feet-quite enough of that sort of thing in that pestilential swamp. We carried home all except the skull, which we left to be brought out the next day by a party of Malays.

We reached home thoroughly tired, hungry, and bedraggled, but Jules Mumm and Cat's Face came to our rescue, and as Syers and I sat on the slatted floor and banqueted from the top of our camp chest we ran the chase all over again.

The next day the elephant's skull was carried out of the jungle, and I stayed at home to clean it carefully with knife and scraper, while Mr. Syers went off on an unsuccessful hunt after wild cattle.

The day following that we had another go at elephants. We overtook a herd, and attacked it in thick cover, bareheaded, in a pouring rain which half blinded us. The only tusker in the herd was small and young, and I was for letting him go, but my eager companion insisted that elephants were a nuisance in Selangore, and ought to be killed off for that reason if no other. We fired at the young tusker, but failed to bring him down, and the herd made off very deliberately. They thought our firing was thunder, or at least a part of the storm. I was willing to let them go, but Syers voted to follow them up, so I assented with every appearance of satisfaction. For three mortal hours we went at our best speed along that trail, through mud and water a foot deep, through bog and brake, over fallen trees, and through thickets of thorny palms, until finally, when quite tired out, we came up to the elephants in the densest of cover.

As we were advancing promptly to the attack, across a bit of open ground with the herd on our left, we heard a sudden crashing in the bushes on our right, and in another instant saw a young seven-foot elephant coming full tilt, straight toward us, and not twenty yards away. I thought, "Merciful heavens! The beast is charging us!" and we instantly threw up our guns to fire. I took a quick aim at his forehead, and was in the act of pressing the trigger, when the elephant, then within twenty feet of us, suddenly sheered off at a right angle to his former course, and fairly humped himself to get safely away. He went at a splendid gait, directly away from us.

"All right, my young friend, its a bargain!" thought I, thankfully. "You let me alone and I'll do the same by" _-bang! went Syers' rifle, with an infernal roar just beside my ear, aimed at the fast retreating elephant. Had he shot him in the hind quarter? The animal gave a shrill little scream, humped his back still higher, 
pulled his throttle wide open, and rushed off through the jungle like a runaway locomotive.

I turned to Syers in astonishment.

"What on earth did you shoot for, and where did you hit him?"

"Why, confound it, I thought he was going to run over us, and he scared me so I put a ball through the butt of his ear to pay him off."

I enjoyed a good laugh at my vindictive friend's expense, in which he joined very heartily, for I certainly never saw a more absurd performance in the hunting field. The idea of his firing a ball at that little elephant, who was already doing his best to get away from us, was comical, to say the least, and the joke lasted many a day.

On the way home we made a very interesting discovery, quite by accident. We fell in with an old Malay and some Jacoons, who walked along with us for some distance. As we were going through the forest, a short distance from the foot of a gray limestone cliff about two hundred feet high, covered on the top with forest, we noticed in the air a very curious, pungent odor, like guano, the cause of which we could not divine. Mr. Syers turned to the old Malay, who was familiar with the neighborhood, and inquired :

"What is it that stinks so?"

"Bats' dung, sir."

"Bats' dung! Where is it?"

"In the cave yonder in the rocks, sir."

"Why did you not tell us of it the other time we were here, old simpleton?"

"I didn't know you wanted to know about it, sir," said the old fellow, innocently.

We turned about directly and made for the cliff, under the old man's guidance. The cave was soon reached. We climbed up forty feet or so over a huge pile of angular rocks that had fallen from the face of the cliff, and on going down a sharp incline found ourselves underneath a huge mass of bare limestone rock, leaning at an angle of forty-five degrees against the side of the cliff, forming a cavernous arch, open at both ends and a hundred feet high. It was hung with smooth, dull-gray stalactites, which, when broken off, showed such a clean white limestone formation that it might almost be called marble.

From near the bottom of this curiously formed arch a wide 
opening led into the cave proper. We procured a torch of dry bamboo and entered forthwith. This cave, which it seems is called Gua Belah, or the Double Cave, is about sixty feet wide, a bundred and fifty feet long, to where it terminates in a narrow cleft in the rock, and about forty feet high at the highest point. The ground plan of the cavern is therefore an isosceles triangle. The walls were smooth, of a light-gray color, and without stalactites. The floor was covered to an unknown depth with a layer of loose and dry bat guano, which gave off the odlor we had noticed half a mile away.

The cave was full of bats (Eonycteris spilla) which left their resting places on the walls as we entered, and flew round and round above us in a roaring swarm, at times coming within a foot of our faces. Our footsteps fell noiselessly on the soft and spongy bed of guano, and had we been provided with sticks we could have easily knocked many bats from the walls. There must have been two thousand of them there. In the outer cavern we easily shot a number of specimens as they elung to the rocks high above us.

Not far from that cave was another in the same mountain, which we visited on the following day. The mouth was simply a hole in the base of the rocky wall, leading straight into a low, but very extensive, cavern, which must have been an acre and a half in extent. The low roof reminded me of a mine, and the numerous galleries and narrow passages leading off on either side rather heightened the resemblance. In the light of our torches the roof was yellowish-white and very clean looking, generally smooth, and without stalactites. The floor also was bare rock.

We found the mouth of the cave entirely stopped with branches -excepting one opening about a foot square-and were informed that, after thus blocking the mouth, the Jacoons send two or three men insicle to scare the bats out so they can be knocked down by the sticks of those who stand outside at the opening. We tried the same dodge in order to get a few more perfect specimens, and easily secured five by this knock-down process. The scheme is so easy to work, however, and so successful that the Jacoons have almost entirely depopulated the care of its winged inhabitants.

After leaving this cave, which is called "Gua Lada," or Chilli Cave, we were conducted through a mile of very wet jungle to a third cave, called "Gua Lambong," which is really a very fine cavern. At the mouth there is a perfect little vestibule scooped out of the solid rock by the hand of nature for the express accommoda- 
tion of the party who will keep a stand there for the sale of refreshments, photographs, and torches to the tourists who will visit the cave during the next century.

On entering the cave at the yawning black hole, we found ourselves in a grand cathedral, whose floor, walls, and roof were of smooth white limestone rock. Descending for a few yards from the mouth we came to a clear stream of water rippling across the rocky floor and seeking an exit near the mouth. Crossing this, we

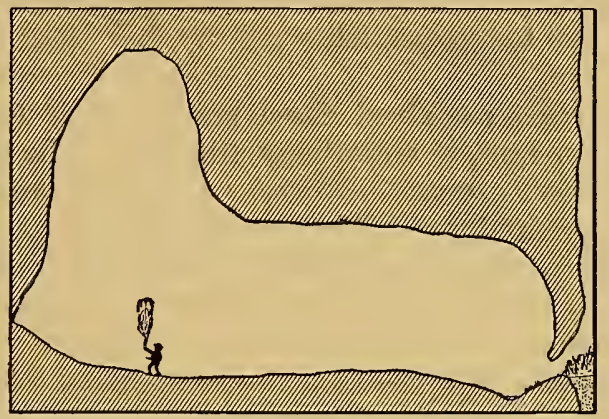

walked forward along a grand gallery, with clean and level floor, perpendicular walls and gothic roof, like the nave of a cathedral, fifty feet wide and sixty feet high. At the farther end of the gallery-which was by our estimate about three hundred feet in length - the roof suddenly rose in a great round dome ninety or a hundred feet in height, completing so perfectly the resemblance of St. Peter's, at Rome, that had I the privilege of naming the cavern I could call it nothing else than Cathedral Cave. The accompanying diagram represents a vertical section, as nearly as could be obtained without measurements.

We stood for some time gazing in silence about us, quite awed by the grandeur of the natural rock-temple we had discovered.

Remembering the Baptistry at Pisa, and, recalling its beautiful echo, I sang out clear and strong,

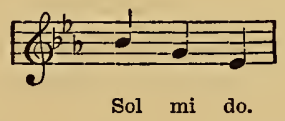

The echo of the three notes mingled directly in a beautiful chord, wonderfully prolonged, like the sound of three voices winging their way upward until they were lost in the distance. The illusion was 
perfect and the effect of the echo highly weird and impressive. It seemed fully a quarter of a minute that the echo reverberated in the top of that rocky dome. As a further experiment, Mr. Syers discharged his rifle, and the report sounded like a deep boom of thunder, prolonged and rolling, echoing in the dome and at the farther end of the long gallery with a long-continued roar.

Under the dome the floor began to rise as we progressed, and sloped up all the rest of the way to where the cavern terminated in a narrow cleft. This portion of the floor was covered with a thick deposit of bat guano, loose and dry, but there were very few bats in the cave.

All these caves are about three miles east of Batu, and nine from Kwala Lumpor, in a northerly direction. The whole hill is a solid mass of white crystalline limestone, and its greatest height is about three hundred feet. Besides catching bats in the caves, the Jacoons say that they often retreat to them for safety at certain seasons when the woods are overrun by wild elephants and other dangerous animals.

We made several other hunting excursions in different directions from Batu, always under good guidance, but, although we often saw the tracks of wild cattle, we were never fortunate enough to fall in with the animals themselves. The inevitable krah monkey (Macacus cynomolgus) was often seen and sometimes shot.

Squirrels were plentiful, and besides two other species (Sciurus ephippium and bicolor) we shot several specimens of the beautiful black and white Sciurus Raffesi.

The Malays and Jacoons brought us many specimens of the pretty little mouse-deer (Tragulus napu and kanchil), several small Feline (Felis marmorata and Bengalensis), and two species of civet cat (Viverra), all of which they caught in traps for our especial benefit. We collected a few bright birds also, and one rhinoceros hornbill.

Having spent a week at Batu with both pleasure and profit, we sent our elephant bones, rock specimens from the caves and other dead weight down to Klang by the river, while we packed up and returned to Kwala Lumpor. On the ride back Mr. Syers' pony went down when at full gallop and gave him a terrible fall, which, but for the protection of his thick pith helmet, mighthave resulted very seriously. It would have sent almost any other man to bed for a week, but my plucky friend insisted on his ability to carry out the programme, and would scarcely let me rub him with my favorite remedy. 
On reaching $K$ wala he took me off four miles south to see a number of tin mines. The road was good all the way, and lay through open uplands of dark alluvial soil. We passed several fine fields of sugar-cane, two of tobacco, and my guide pointed out several coffee bushes hanging full of berries. There were houses and huts of both Malays and Chinese scattered along the road, and the two could always be distinguished at a glance. Those of the Chinese were always in good repair, and surrounded by flourishing and beautifully-kept vegetable gardens of one to two acres in extent. The houses of the Malays were always in bad repair, and their gardens, when they had any, were neglected and weedy. Every Chinaman we met or saw was carrying something, or else at work in his garden. Every Malay was either strolling along empty-handed, or else loafing in the door of his hut. If Selangore were my territory I would give it to the Chinese. Before returning, however, we were astonished beyond measure at seeing two Malays actually at work in a garden, and we stopped and gazed at them in incredulous amazement.

The first tin mine is about four miles from Kwala, situated in the middle of a "flat," near the foot of a range of hills.

The tin is found in the form of dark-colored sand or fine gravel about fifteen feet below the surface, and is reached by simply removing all the over-lying strata of soil, clay, and gravel. The tin lay in a bed, like a vein of coal, about two feet in thickness. The water which runs into the excavation is pumped out by an overshot water-wheel and an endless chain, a very ingenious contrivance which I cannot take time to describe. In the smelting-shed near by the tin is simply melted out and run into ingots of a size and shape convenient to handle.

On reaching Kwala again we found the "Captain Cheena" at home, and be sat us down to a superb dinner, consisting of soup, fish, roast capon, roast duck, green peas, potatoes, cucumbers, pork chops, curry and rice, a monster tart, mangosteens, durians, bananas and champagne. The captain does not speak English, so I lost the benefit of a conversation with him.

The next day we returned to Klang, and after a day's rest I began to get ready to " move on."

We were again entertained at dinner by Captain and Mrs. Douglas at the Residency, and spent a most enjoyable evening. Although the country is perfectly tranquil, the Malays are a trifle uncertain and the Chinese also, as the murder of Europeans not 
long since in Perak, and later at the Dindings, has rendered painfully evident. A body guard of six stalwart policemen from Mr. Syers' force watches over the Residency night and day, so that there is little to fear from foes without. Captain Douglas has entered, heart and soul, into the development of the territory of which he is virtually the governor ; and it is gratifying to see such a promising country in such good hands. Under the control of the shiftless Malays its resources would never have been developed.

It takes the British Government to rule such places and make them habitable for producers, and worth something to the world.

Nominally, the old Sultan of Selangore is still a sultan, and ruler of the country, but actually he is a mere figure-head, living off in a corner at Selangore, and quietly enjoying the royalty of $\$ 2,000$ per month, which is paid him out of the revenues of the country which he is not competent to govern and develop. His son, the heir apparent to the figure-headship, has a much larger harem than his sultanic papa, and also some notions of his own about government, which may result in giving the country a backset if he ever acquires the power to put them in force.

The Territory of Selangore has a coast line of one hundred and twenty miles, and it extends into the interior about fifty miles, where it joins Pahang, another territory of the same political complexion. Its population in $\mathbf{1 8 8 0}$ was fifteen thousand. The chief productions of the country are tin, gutta, rattans, rice, gambier (pepper), and tobacco. The principal industries are tin-mining, gardening, and gambling. The average monthly production of tin is six hundred bharas, or two hundred and forty thousand pounds. The soil of the interior is eertainly very rich, and I should think could be made to produce sugar-cane, tobacco, and perhaps coffee also, with great profit.

As a sort of parting send-off, we were dined the last evening of our stay by Mr. Turney, Treasurer of Selangore and his estimable lady. This is what the Klang people mean by being "civil" to strangers. Healthy civility surely, but the odds are every time in favor of the stranger.

Almost my only disappointment in Selangore was that, from first to last, we found no snakes in the jungle. I fondly hoped to meet a python in his native wilds and see what he would do, or at least an Ophiophagus elaps-snake-eating cobra-but neither did we see. My imagination had pictured the forests of the East Indies as producing a big snake for every square mile, but they are almost as 
scarce as snakes in Ireland. In all my jungle wandering's in the far east I did not encounter a snake four feet long, although I looked for them very hopefully. It was disgusting after all the big snake stories I had heard. The only snake I saw in Selangore was a vicious little viperine affair, eight inches long, which I killed with a prayer-book in Captain Douglas' drawing room at the Residency, while kneeling at prayers one Sunday evening. He came wriggling toward me across the matting, and I took him in. Just before my visit Mr. Syers killed three cobras in his house in the fort, which had taken up quarters under the floor. Fortunately I am not at all nervous, and this discovery did not disturb my slumbers in the least.

On the last day of my stay, an old Malay came into the fort dragging the headless body of a python which measured twelve feet six inches. He was walking through the jungle, and in passing by a hollow tree, the snake thrust its head out of a hole near the bottom. He whipped out his parong and very neatly decapitated the reptile at a single blow. I bought the body and sent him back for the head, which he presently produced, and at the last moment we removed the skin and preserved it for mounting. The jungle had relented and given me a snake after all.

A few months later I saw in Singapore a fine living Ophiophagus elaps, about seren feet long, which Captain Douglas had sent down to the Museum-the third specimen of that species he had secured.

When the time came for me to leave Klang I was in no way thankful to go. My visit had been so pleasant that I was really sorry that I could not stay longer. My collection made a very satisfactory showing for six weeks' work, and Mr. Syers' hearty hospitality had made the place seem like a home. He limself was the most interesting specimen I found in this territory, and as a character study he was "immense." In point of modest reminiscence of "dangers he had passed, and moving accidents by flood and field," he was another Othello, a fit type for the hero of a stalwart romance.

But my time came, and I had to leave his rambling, roomy, and cool bungalow in the fort; the Malay bugler who used to practise the "Dead March in Saul" every morning; the drills and parades; and the jolly friend who entertained me so patiently to the last. At parting, he gave me a Malay kris, and a "pig-tail " which he cut from the head of a Chinese murderer just before hanging him, as souvenirs of the visit. 
Three days later I reached Singapore once more, and prepared to depart for Borneo.

At this point I desire to mention the kindness of Mr. Robert Campbell, now, alas! numbered with the silent majority, who was my good genius all the time I remained within his reach. I was a total stranger to him until a London firm placed a sum of money to my credit with the firm of Messrs. Martin, Dyce \& Co., of which he was the head. When the time came for me to start to Borneo the balance remaining to my credit was not at all sufficient for the trip, and my good friend insisted upon advancing all that I needed. From that time until I started home I spent my funds faster than they came, and every time I became embarrassed Mr. Campbell generously came to my relief. But for his self-forgetful generosity I should more than once have found myself in most unpleasant straits, due, I admit, to my own fault in disregarding Professor Ward's instructions, and going ahead full speed with my work instead of resting and waiting for funds. All thanks to Robert Campbell, and the firm of Martin, Dyce \& Co. Thank heaven that my faith in humanity is so often and so handsomely justified!

But it passes my understanding how any stranger, who under such circumstances is trusted without any security, can be so unspeakably contemptible as to defraud his benefactors, as I have known some to do. 

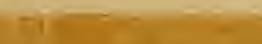


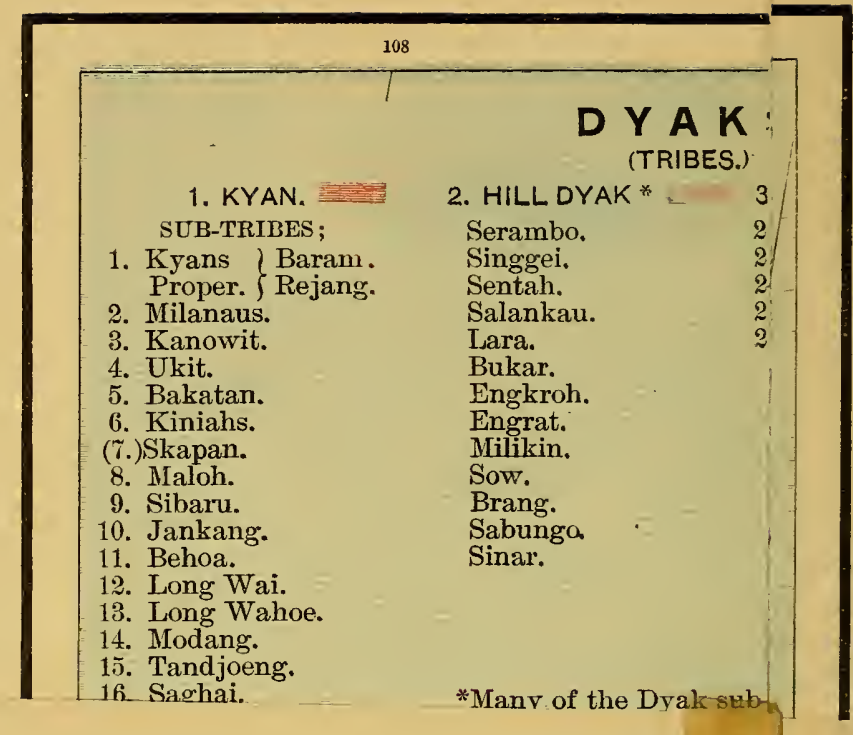




\section{PARTIV.-BORNEO.}

\section{CHAPTER XXVIII.}

\section{SARAWAK, PAST AND PRESENT.}

Geographical Position and Area of Borneo.-Explorations.-From Singapore to Sarawak. - The Finest City in Borneo.-Historical Sketch of Sarawak Territory.-Sir James Brooke.-Anarchy and Oppression.-Cession of the Territory.-Order out of Chaos.-Evolution of a Model Government.-A Wise and Good Rajah.-Justice in Sarawak and the United States.Present Prosperity.-A Lesson for Political Economists.

THREE hundred miles east of Singapore, directly under the equator, lies a vast island clad from centre to circumference with a wonderful and luxuriant growth of unbroken forest, and peopled with the strangest men and beasts to be found in all the East Indies.

Rich in both vegetable and mineral products, teeming with animal life, and filled with both social and scientific problems, Borneo is a most inviting field, interesting alike to the naturalist, the anthropologist, and the student of political economy. In time, also, when its vast agricultural resources are properly developed, it will offer a chance for life, liberty, and happiness to the overcrowded millions of China, Hindostan, and even Europe.

With an area of one hundred and ninety thousand square miles, and a coast line of over three thousand miles, Borneo is the second largest island in the world. When we look at its proportions on a map which compresses the whole of Asia or Australasia into the limits of a single atlas page, we fail to realize its actual immensity. The whole of New England, the Middle States, and Maryland could be set down in the forest which covers Borneo, and still be surrounded by a wide belt of jungle. The length of the island is eight hundred and fifty miles, and its greatest width six hundred and twenty-five. 


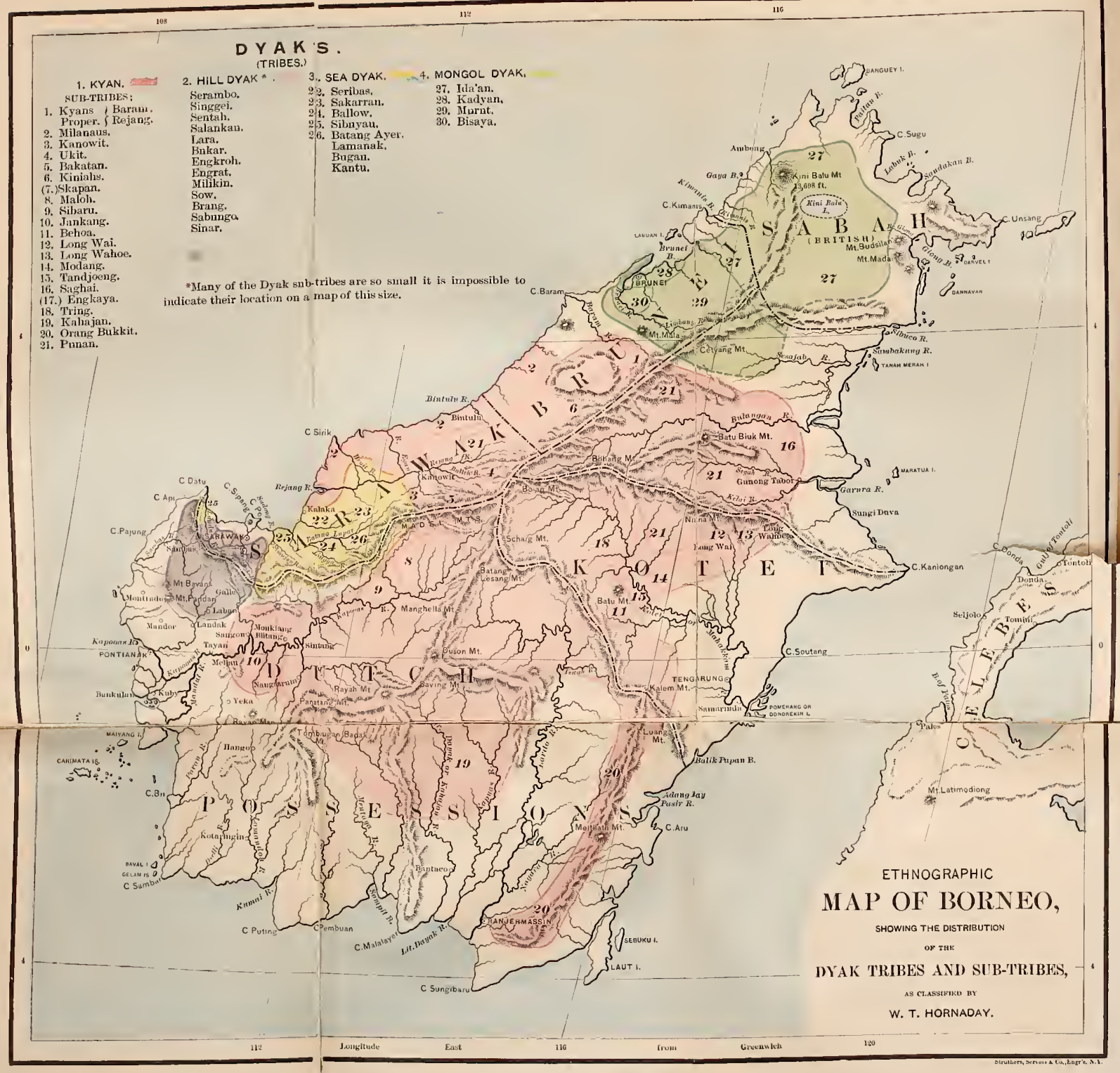


Politically, the island is divided into the Dutch Territory, which embraces the whole southern, central, and western parts of the island, fully one-half its entire area; the Territory of Sarawak on the north coast, ruled by an English rajah ; the sultanate of Brunei, or Borneo Proper, northeast of Sarawak; and beyond that a fine tract of territory, now called Sabah, almost as large as Sarawak, which has had the good fortune to pass from the protection of the sultan of Sulu into the hands of a new mercantile organization called the British North Borneo Company. This territory has the Kimanis River (between Gaya Bay and Labuan Island) for its western boundary, and the Sibuco River on the east coast, for its southern boundary. Its area is between twenty and twenty-five thousand square miles. Its five hundred miles of coast line include a great many finely sheltered bays and harbors, and its interior has not only a number of large rivers, but, also, the highest mountains in Borneo, including Kina Balu. It is extremely gratifying that such a naturally rich and promising country should have fallen into such good hands as those of Sir Rutherford Alcock, and Messrs. Dent, Martin, Read, and Mayne. Success and long life to the British North Borneo Company!

South of Brunei lies Kotei, a large triangular territory, ruled by a Malay sultan, under Dutch protection, but as independent of the Dutch Government as Nicaragua is of the United States, and which should have boundaries and a color of its own on every map. Above Kotei lies another independent territory of similar shape, also under Dutch protection, but about as little known as the Kina Balu country which joins it on the north.

Even in this age of venturesome and persistent travellers, no white man has crossed Borneo from side to side, and its interior remains in great measure a sealed book. No European has ever succeeded in doing more than to ascend one river to near its source, cross a narrow water-shed and descend a contiguous stream to the same coast from which he started. In this way Von Gaffron ascended the Barito and descended the Kapooas, Bock journeyed up the Mahakkam and down the Barito, and Wallace traversed the Sadong and the Sarawak. An energetic Scotchman, prospecting for diamonds, also crossed from the Kapooas River to the Sarawak, St. John thoroughly explored to their sources the Limbang and Baram Rivers on the north coast, and both he and Hugh Low ascended the great mountain of Kina Balu, near the northeastern extremity of the island. 
Nothing could be more arduous and full of risk to life and limb than overland travel in the interior of Borneo, where the travellel is confronted by dense, dark forests and rugged mountains from the beginning to the end of his journey. The interior is practically an uninhabited wilderness, destitute of nearly everything fit for human food, and he who would explore it must carry on his back, through forests and rivers, and over mountains, sufficient food, clothing, and medicines, to last to the end of the journey. The heart of Africa is not nearly so inaccessible as the heart of Borneo. The difficulties of overland travel in the interior are almost beyond belief.

Even in the extreme northeast, accessible from the coast on three sides, there is said to be a great lake and a mountain-peak higher than Kina Balu, never yet visited by a white man, which beckon to the explorer with whispered promises of undiscoverea wonders. From the remote interior of the island come wonderfui stories of a race of men with tails, with descriptions of their form and habits, stories implicitly believed by many intelligent natives. but which even the most skeptical white men are powerless to disprove.

The dense ignorance which prevails in Singapore regarding Borneo is quite phenomenal. Although so near and in regular steam communication with the island, I found it utterly impossible to obtain there any definite information regarding the distribution or abundance of the orang-utan. At last, when on the point of buying a steamer ticket for the Dutch settlement at Pontianak, I was introduced, quite by chance, to the late A. R. Haughton, Esq.-His Highness' resident of the Rejang District, Sarawak-which piece of good fortume led to an immediate and important change in my plans. From this most agreeable and obliging official, who, from his eighteen years of service in the Sarawak Government, was prepared to answer any question regarding Northern Borneo, I learned that the orang-utan had not yet been exterminated in the rajah's territory, and that the valleys of the Sadong and Batang Lupar Rivers abounded in animal life. I forthwith purchased a ticket for Sarawak, and prepared to accompany my new friend, who was returning from leave of absence to England to regain his shattered health.

I often think how differently I might have fared in my visit to Borneo had I not met Mr. Haughton at the critical moment. Thanks to his courtesy and friendly interest, my introduction to 
the island was a very agreeable one ; and I shall always remember that but for him I should have gone further and fared worse, for I learned later that Pontianak would not have been the place for me. Since my return to America, the sad news has reached me that my genial friend has gone forever from the land he helped to govern both wisely and well. In his nineteenth year of service his health failed utterly, and on the voyage home he died on the passage up the Red Sea. The rajah lost a valuable officer and the Dyaks a valuable and trusted friend.

The trim little steamer Rajah Brooke, belonging to the Honorable Borneo Company, makes tri-monthly trips between Singapore and Sarawak (pronounced Sar-ah-wok), carrying to the latter Chinese emigrants, cloth, brass, and ironware, crockery, opium, tobacco, sugar and manufactured sundries, and returning with sago, flour, gutta-percha, dried fish. rattans, edible bird's nests, timber and other jungle products, and also a very considerable quantity of antimony and quicksilver from the mines of the Borneo Company.

On August 7th I embarked myself, a first-class Chinese servant named Ah Kee, a half-caste Portuguese lad named Perara to assist in hunting and preparing specimens, and a complete jungle outfit, with provisions for three months.

At three o'clock we left the Singapore Roads, and, while at our six o'clock dinner, steamed out between Horsburgh Light and Point Romania, the extreme southeastern point of Asia, heading "east-b'-north" for Sarawak. The day following was one of smooth, uneventful sailing o'er a "sultry summer sea," with here and there a pretty green islet in sight, but the cloudless sunrise of the third day out found us running close along the coast of Borneo. Cape Datu lay directly astern, Cape Sipang stood out directly ahead, while all along the south stretched the yellow, sandy beach and evergreen forest of my new land of promise. Borneo at last, the land of apes and monkeys, the home of the orang-utan, the country of the head-hunter, perhaps the sepulchre of the mysterious Missing Link!

Far in the interior there loomed up the rugged masses and isoLated peaks of the Krumbang range, clad with tropical verdure, looking dreamily blue and hazy in the distance. As we proceeded, the view disclosed still more lofty and extensive ranges farther inland, until at last the whole interior seemed to be composed of mountains only, between which and the sea there stretched a wide 
expanse of level forest. A lofty, flat-topped mountain called Peurissen, elevation four thousand four hundred and fifty feet, lying directly south from Cape Sipang, was pointed out as the site which had been selected by the Government of Sarawak for a sanitarium.

The Sarawak River has two main entrances, one called the Santubong, which forms a northwest pass, while the Moritabas is the northeast pass. On the triangular island thus formed, Santubong Peak rises grandly up, like a nearly perfect cone, to a height of two thousand seven hundred and twelve feet, and forms a noble landmark at the river's mouth, visible forty miles at sea.

The Santubong entrance is difficult and dangerous to navigate on account of its sand banks and shoal water, and the Rajah Brooke always acts on the principle that the longest way round is the shortest way to Sarawak. We passed Cape Sipang and presently rounded Po Point, upon which rocky promontory sits a dumpy little light-house. From the flag-staff floats the flag of His Highness, the Rajah of Sarawak, a St. George's cross half black and half red on a yellow field. The face of Po Point is a sinooth cliff of brownish limestone, which shows pale yellow in places where masses of rock have been freshly broken away by round shot from British gunboats and men-of-war. These vessels are in the habit of using the cliff as a target for cannon practice whenever opportunity affords.

At the mouth of the Moritabas entrance, the river is about three hundred yards in width. The west bank rises in a considerable hill, but the eastern shore is a level, alluvial plain of soft mud, scarcely above tide level. At the foot of the hill is the village of Santubong, inhabited by Malay fishermen. The tide is at the ebb as we enter, and the smooth surface of the river is covered with dead leaves and stems of the nipa palm, decayed logs, dry bamboo stems, chunks of wood, sticks, leaves, and trash-in short, a level plain of driftwood floating swiftly out to sea. We wondered which of those logs would be the one to drift far out past Point Po, into the great equatorial current of the East Indies corresponding to our Gulf Stream, and be borne along on the bosom of the Black River, past Japan, until finally cast ashore on one of the Aleutian Islands to serve some islander as firewood, or timber for a new harpoon handle. The river needed skimming, badly, and like most equatorial streams, it needed straining and filtering also, for it was brown and murky with decayed vegetation and vegetable mould.

The banks are covered with low mangroves and nipa palms (Nipa fruticans) growing in the soft mud, the latter sending up 
their tall, feathery leaves so thickly in places as to exclude the inonotonous mangrove entirely. The nipa palm resembles a bunch of cocoanut leaves growing stiffly up, and a cocoanut leaf looks like a huge, uncurled ostrich plume dyed a deep green.

The scenery of the Sarawak River below the capital is decidedly monotonous, and uninteresting except for the distant mountains; but I venture to assert the same may be said of any equatorial river for the first twenty miles up. The banks are of soft mud, the jungle is low and swampy, and the trees are so small and straggling that even the monkeys disdain to inhabit them. We must get farther from the coast to find the grand forests which are fairly alive with wonderful monkeys, and apes, deer, wild "pigs" (fancy a "pig" standing thirty-seven inches high at the shoulders!), civet cats, flying squirrels, hornbills, and argus pheasants. On the way up the Sarawak we saw not a single monkey nor other mammal, and only one or two stray birds.

We followed the tortuous windings of the river for nearly fourteen miles before we came to any signs of civilization; and, for a time, we were in a quandary whether or not to class as such the first Malay houses we saw. The Malay loves water like a duck, and, if possible, he builds his house on piles over a running stream. Failing in that, he builds over stagnant water; and, failing in that, be builds over the softest mud he can find.

He cannot build over the Sarawak River suitably for various reasons, so, leaving thousands of dry acres tenantless, he builds over the soft mud on the river-bank. His boat-house is a pole stuck in the mud, and his wharf is a slimy, slippery, slanting log, reaching down from the top of the bank, across the mud, and into the water indefinitely. If your Malay is really industrious and enterprising, he may even go so far as to cut a few rough notches along the top of his landing-log; but even then it is a difficult and perilous feat for a booted European to make a landing just after the tide has gone out and left a good thick deposit of slippery mud all along the top of the wharf.

As we neared the capital a lofty green peak seemed to rise from just behind the town, but in reality it was several miles beyond. It was Matang Peak, three thousand one hundred and sixty-eight feet in height. We passed a number of Malay houses and straggling villages strung along the banks, passed a flourishing pottery, a warehouse containing a million rattan canes, a number of small boats and a few large ones, came to some airy European 


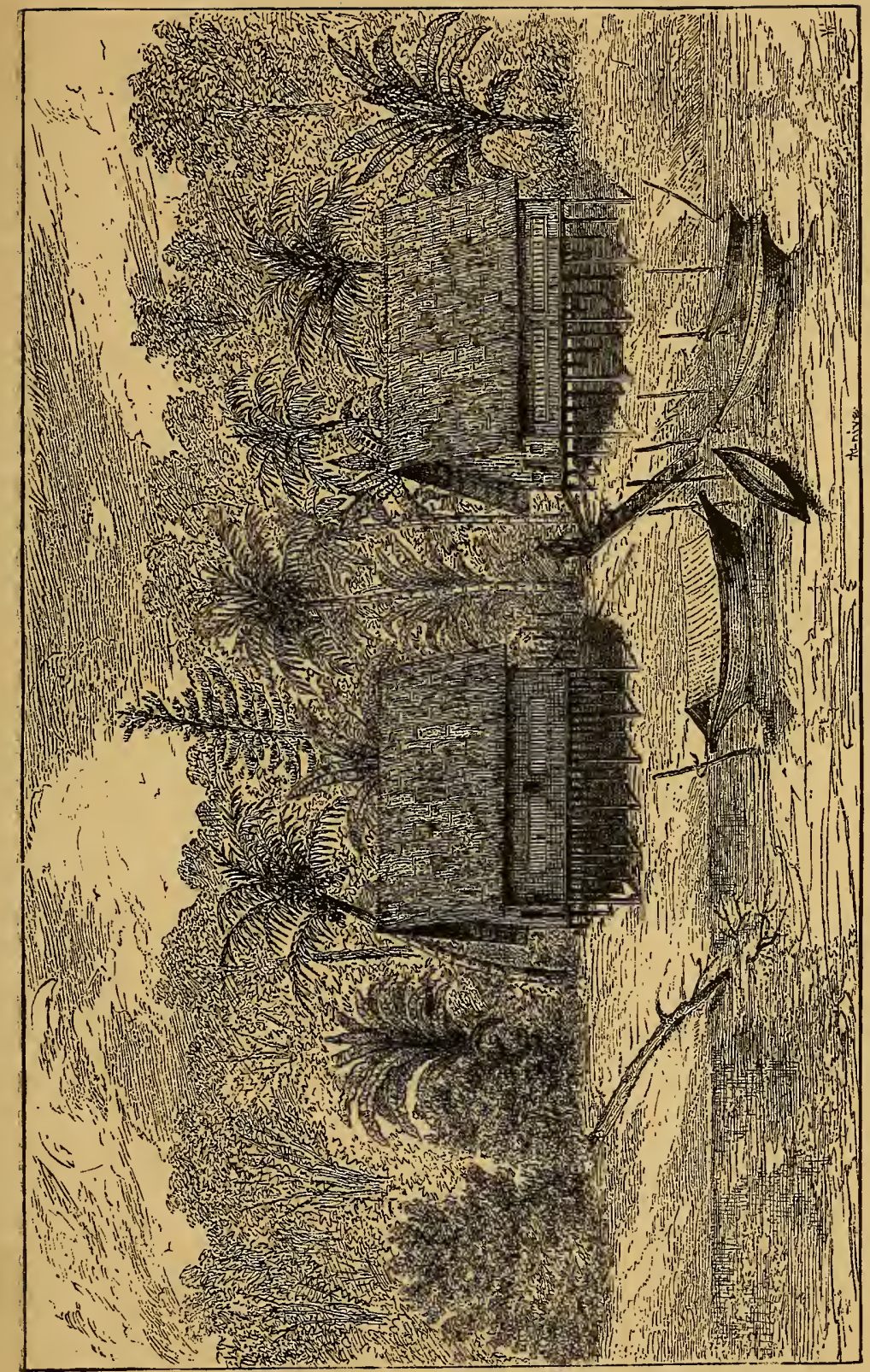

हैं

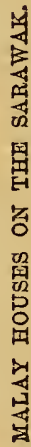



houses, rounded a little promontory and came in sight of the snowwhite walls and battlemented tower of the new prison. We passed the point, the clean white "go-down" (business house) of the Borneo Company, and next to it the long sheds in which the racingboats are housed from one New Year's Day to the next. Wherever an Englishman goes he takes with him all his national institutions, and from Nova Zembla to New Zealand, wherever two or three Englishmen are gathered together, there will they have their annual races and regatta; their club, theatricals, and athletic sports; their Times, Punch, and Bass' pale ale. Forty-six hours from our starting finds us at Sarawak, here known only as Kuching-the Malay for "Cat"-sixteen miles from the sea and four hundred and twenty miles from Singapore.

After the Borneo Company's "go-down" came the Chinese bazaar, a long regular row of two-story Chinese shops built solidly together, designed and executed in the most substantial style of Chinese architecture. On the opposite side of the river, which is here about one hundred and fifty yards wide, is the new fort perched upon a hilltop, a substantial brick structure, rather better calculated to withstand an attack than the flimsy wooden stockade which the Chinese assaulted and carried so easily during their insurrection in 1857.

Just above the fort, at the top of a grassy slope which sweeps up from the riverside and overlooks the town, is the Astana, the residence of His Highness the Rajah, the palace, in fact. It is really three complete houses such as Europeans build in the Straits Settlements, differing from the regular Indian bungalow in being much higher and possessing two stories instead of one. The basement floor contains the dining-room, billiard and store rooms, while the more spacious upper floor, being well above the malarious dampness of the earth, contains the drawing-room, library and sleeping apartments. Along the entire front of the main building runs a cool and roomy verandah, furnished with tables, easy chairs, and newspapers. Long strips of striped black and white matting hang between the pillars which support the roof, and, when let down at full length, they form for the verandah a continuous ventilated screen to protect the interior from the dashing of rain, the glare of the sun and the inquisitive gaze of the passers-by.

An ancient-looking square tower with battlements forms the entrance to the Astana, which, together with the coat of arms over 
the door and the swarthy sentry in the doorway, gives to the edi. fice the air of a feudal castle. But it is a very modest residence for a man who is absolute monarch over such a large territory, and who, were he avariciously disposed, could plunder his subjects sufficiently to enable him to maintain his position in truly regal style.

The river is well filled with craft, including decent schooners of modern type, Malay trading praus, Malay and Dyak "sampans" -every small canoe is a "sampan" in Malayana-Chinese junks, clumsy coasting vessels, a number of large sailing ships, and the steam vessels Aline and Firefly of $\mathrm{H}$. H.'s Navy.

As soon as we touched the wharf, my fellow-passenger was surrounded by a crowd of good-looking young Englishmen, in corded white uniform coats and cork helmets, who welcomed him back with enthusiasm. Meanwhile, I was busy with my two servants, and in a very short time we hired a cart and loaded it with the boxes, bags, and parcels containing our jungle outfit, which included canned provisions, kitchenware, guns, ammunition in great variety, preservatives, tools, alcohol cans, bedding, clothing, and books, and-last but not least-two bags of Spanish dollars.

We took our way up a broad street which leads from the handsome new jail, passed the south side of the bazaar, the courthouse and public offices in the centre of a square, the hospital, the government dispensary, the library, European residences in plenty, and at last came to the hotel of the place, the Rajah's Arms. Just above this hotel, on a pretty knoll, stands the handsome residence and grounds of the Resident of Sarawak proper, an office filled at that time by Mr. William M. Crocker.

In front of the court-house I noticed nearly a dozen extremely long and wide-mouthed brass cannons, all of small calibre, however, but each had a history. Some had been taken from pirates, others from the stockades of rebellious rajals in early days, while others represented fines imposed by the government and paid by native chiefs who had violated the laws. It sounds oddly enough to be told that "Nipah Tuah, of Tatu, has confessed to having murdered a Mukah Dyak, supposing him to be under arms against the government, and had been fined six piculs" (about eight hundred pounds of brass guns)!

A tour of observation through the bazaars and the town is full of interest. One first notices that the streets are scrupulously clean, the drainage good, and that the town has been laid out with European regularity. There is nothing slip-shod or loose-jointed 
about Kuching. The principal business street is that facing the river for about half a mile. The shops, which are kept almost exclusively by Chinese and Klings (Hindoos), are filled with a moderate assortment of European sundries, which include a gaudy array of colored cotton cloti, cheap cutlery, fancy mirrors, tin boxes, combs, glass beads, perfumery, belts, handkerchiefs, Malay caps, tools of many kinds, thread, needles, buttons, brass wire, paddles, spectacles, ammunition, etc. In the provision shops were the usual food staples; and also quantities of alum, blue vitriol, washingsoda, soap, indigo, and various kinds of roots, herbs and seeds "for the healing of nations."

Fruits were abundant, but vegetables were scarce. I noticed quantities of bananas, jak fruit, custard apples, watermelons and dates; also hundreds of fresh turtle eggs from an island near the coast, and poultry in plenty, but in the fish market the supply of fish was very scanty.

Unlike all the other cities and towns in Borneo, Sarawak is high and dry, and quite substantially built. The houses are nearly all of brick, neatly whitewashed, and those of the European residents are nearly always surrounded by spacious ornamental grounds full of trees and flowering shrubs. The houses of the Malays line the river-banks for a considerable distance both above and below the bazaar, but there is not a Dyak residence in the place. They prefer the freedom and seclusion of the jungles.

When we compare the present condition of Sarawak Territory and its people with the state of affairs which existed prior to the year 1841, we are lost in wonder at the mighty changes which have been effected, and admiration for the agencies by which they have been wrought.

In the year 1839, there landed at the town of Sarawak an English gentleman of fortune with a heart full of good-will to men, in shor't, a real nobleman of the highest type our modern civilization is capable of producing. He found the country in a state which must have awakened sympathy in any but a heart of stone. As a study in political economy it is interesting to note the principal features of the condition of Sarawak then and now.

When James Brooke, Esq., arrived from England in his little vessel, the Royalist, he found the territory in an almost indescribable state of anarchy, oppression, and murderous confusion. Forming, as it did at that time, a part of the Kingdom of Borneo proper, and under the dominion of the Malay Sultan of Brunei, Sarawak 
was ruled, or rather misruled, by the Rajah Muda Hassim and his prime minister, Pangeran Makota, the greatest villain who ever wore a sarong. Attached to these worthies and their immediate relations was a swarm of reprobate Malay nobles (?) and lesser followers, representing every degree of worthlessness and profligacy, most of whom lived solely by officially plundering the people, and not a few by covert piracy. The Dyaks were the only producers, and, as such, the Malays considered them their lawful prey. Upon those wretched jungle-dwellers were practised every species of oppression, extortion, and open robbery from the most brutal to the most refined. To prevent any attempt at a combined resistance, the various tribes were encouraged to wage murderous wars with each other, which often led to the utter extermination of whole villages at a single blow. In this way the short-sighted Malays more than once destroyed their own sources of revenue. Head-hunting was the chief business of life with the Dyaks ; and robbery was that of the Malays.

The degree of oppression patiently endured by the poor Dyaks is almost incredible. The Malays, from time immemorial, have regarded them as their natural bondsmen, heathens with no more claims to consideration than oxen, with no inalienable rights even to life. Therefore, in the first place, they were taxed first by the local officers on account of the rajah, and then for the benefit of the officers themselves. The jungle produce collected by the Dyaks was monopolized, i.e., taken at a fixed price by the patingi, who also claimed their mats, boats, fowls, and fruit at his pleasure, and had the power to claim their services at whatever price suited his convenience. When the rajah or the patingi had received all they cared to extort, their relatives and immediate followers claimed the right of forced trade, and gradually this privilege was extended to every Malay in the territory.

To the Dyaks this was a two-edged sword, which was wielded in a very simple manner. The Pangeran Makota, for instance, would send to a Dyak village an invoice of rice, cloth, gongs, iron, or salt at a price from six to eight times their real value, and in payment he would demand, at one-eighth of its value, any produce the Dyaks possessed. The profits from these transactions sometimes reached as high as one thousand five hundred per cent. of the amount invested. If the Dyak declared himself wholly without property, starving, and unable to pay, the reply would be: "Then give me your wife, or your child;" and there was generally sufficient power 
behind the demand to enforce payment in some form. If a whole clan stubbornly refused payment, it would be threatened with an attack from a more powerful hostile clan, and, in one way or another, the Malays managed to keep them in abject poverty. The arch-villain, Makota, used to assert that he liked to get even their cooking-pots from them. Not only were the Dyaks robbed, but in most instances they were compelled to carry to the boats the very plunder which had been taken from them.

If a Malay was ever injured in body or estate, and the injury, however slight, could in any way be attributed to a Dyak, the latter would be fined heavily for " a fault." To seriously injure a Malay, no matter how accidentally, was ruin to the Dyak. Matters finally came to such a pass that the wretched aborigines abstained from growing crops which only brought their oppressors upon them, and, in many instances, were able to live ouly by secreting food in the jungles. Hundreds of women and children were seized and kept as slaves, and scores of Dyak men became slave debtors. Seriff Sahib and his brother, Seriff Muller, two atrocious pirate chieftains, both of whom were incontinently thrashed and utterly crushed by Captain Keppel and Rajah Brooke, were formerly in the habit of sending armed parties to the Dyak settlements to bring down all the young boys and girls they could catch. It is stated, on good authority, that three hundred boys and girls have frequently been captured at one time, and kept as slaves.

The Malay rulers not only permitted indiscriminate head-hunting and sanguinary warfare among the Dyak tribes, but openly connived at it. It is hard to imagine a ruler giving a powerful clan permission to attack and exterminate a weaker one, also his own subjects, but this was often done.

As a consequence, the Dyaks could no longer live in clans, but sought refuge in the mountains or the jungle, a few together ; and one of them pathetically said: "We do not live like men ; we are like monkeys; we are hunted from place to place; we have no houses; and when we light a fire we fear the smoke will draw our enemies upon us."

All these miseries were inflicted upon a people naturally amiable and peaceful, honest, of cheerful disposition, and almost childlike simplicity of manner. The result can be readily imagined. In two years' time, by reason of famine, sword, slavery, forced labor, and sickness, the Dyak population of Sarawak proper was reduced from 14,360 persons to 6,792 , or less than one-half! Some clans 
were reduced from 330 families to 50 ; one of 100 families had lost all its women and children; another had been reduced from 120 families to 2 ; and two tribes had been utterly exterminated, or driven from the territory.

Such was the condition of the people when, on September 24, 1841 , the Territory of Sarawak proper was formally ceded to James Brooke, and he became its "rajah" with the fullest powers. $\mathrm{He}$ was the man for the hour. His first official act was the release and restoration to their families of over a hundred married women and girls who had been confined at the capital for a whole year by the former rajah. Just previous to this formal cession of the territory, there arrived at the capital, Kuching, a hundred war-boats manned by two thousand five hundred blood-thirsty Dyaks, who came to ask permission of Muda Hassim to attack a weaker tribe on the Sambas! But James Brooke was there, and the petition was urged in vain.

For once it really seems that Providence directly espoused the cause of suffering humanity in sending a philanthropic statesman to distressed Sarawak. The diplomatic difficulties he encountered would have hopelessly entangled a smaller mind or crushed a weaker character. It is surprising that he was not assassinated by Makota's followers during his first year of office. But out of rebellion and chaos he brought tranquillity and order. He ruled a superior and an inferior race, masters and slaves, to the complete satisfaction of both. With a judicial wisdom unparalleled in the history of nations, he formulated a code of laws and a system of government which actually dispensed equal justice to all, in practice as well as theory, and which was entirely satisfactory to Mohammedan Malays, and heathen Dyaks.

The present Territory of Sarawak is the fruit of Rajah Brooke's policy, as inaugurated by him and perpetuated by his successor. From a territory of at first only 3,000 square miles, Sarawak has been increased by concessions until its area is now 25,000 square miles. The population of the capital has risen from 1,500 to 21,000 , while that of the whole territory is 225,000 , of which there are of Hill and Sea Dyaks 125,000 ; Kyans, of all clans, 30,000 ; Malays 60,000 , and Chinese 8,000. The government " is able and willing to maintain order and to offer security to life and property." The Dyaks are peaceful, prosperous and happy; head-hunting has been entirely suppressed, and piracy, on the north coast of Borneo at least, is a thing of the past. Even-handed and speedy justice is meted out to every subject so fairly that none can complain. 
Criminal cases are tried by jury, but there are no lawyers in the territory, and no elaborate system of loop-holes known as "legal precedents," whereby error is systematically perpetuated and justice perverted.

The Sarawak murderer is certain to meet his just deserts, and quickly, for the native juror has not jet acquired that degree of civilized intelligence which would enable him to find a verdict of "not guilty" for a wilful and brutal murderer. A short residence in some of our more enlightened States would be a revelation to their simple minds. In Sarawak it is the barbarous custom to hang murderers as soon as their guilt is proven, instead of keeping them in confinement and trying them again and again at great expense, or putting them in prison to be pardoned out on the Connecticut plan. Sarawak has very few laws, but "a heap of justice," which is cheap, speedy, and of prime quality; in all of which she is the opposite of every other civilized country in the world. In Sarawak no innocent man is convicted and no guilty man escapes. To most of my countrymen this statement may sound preposterous and absurd, but to any one who can imsgine a country absolutely without lawyers to shield criminals and thwart justice, or "legal precedents" and " technicalities" to convict the innocent and acquit the guilty, the assertion is, perhaps, not beyond belief.

Sir James Brooke's success was very largely due to the liberality of his views on all political matters. When he framed the primary code of laws for the government of his distracted little country, he pleased the Mohammedan Malays and disarmed the suspicions of their priests by incorporating in it many of the precepts of the Koran. He was extremely tolerant of harmless native prejudice. The dignity and candor of his character, his firmness and courage, and his devotion to justice won the respect, confidence, and even affection of the better class of Malays and all the Dyaks, save those who were professional pirates. The latter soon had good cause to fear him, for, with a large force of Dyaks, aided by Captain Keppel and other officers of the British navy, the pirates all along the north coast were thrashed into peaceful agriculturists, and their depredations stopped forever.

Sarawak is a model of good government. It has already been stated that the people are peaceful and prosperous, and that life is secure in all parts of the country. With a revenue, in 1879, of $\$ 229.302$, the rajah managed to maintain a civil list which included about twenty picked European officers and a host of Malays ; a mili- 
tary force of about two hundred men; fourteen forts with their garrisons ; a number of light-houses; a steam war vessel, the Aline, and two steam launches; to pay pensions; to build two new forts; to operate a coal mine; to pay European passages to and from England; to take $\$ 20,000$ for his own use, and yet have the snug little sum of $\$ 37,673$ remaining from the annual revenue to the credit of the government. What a lesson for the ex-Khedive of Egypt, and others nearer home! 


\section{CHAPTER XXIX.}

\section{FROM SARAWAK TO THE SADONG.}

Hunting near Kuching. - Crocodiles in the Sarawak. - A Dangerous Pest. - War of Extermination.-From Sarawak to the Sadong.-The Simujan Village. -A Hunt for an Orang-utan.-In the Swamp.-On the Mountain. - Valuable Information at Last.

WhiLE I remained a few days at Sarawak to gather information about the orang-utan and other animals before making a start for the jungles, I purchased from a Malay a very good small boat to use as a hunting-boat, and made several excursions up and down the river.

I was surprised at finding proboscis monkeys (Nasalis larvatus) along the west bank of the river, not more than two miles below the town. I fired my rifle at one we found sunning himself at the edge of the jungle, knocked him off his perch in a twinkling, and the next moment we sprang ashore, or at least into two feet of soft mud, and waded landward. We reached the edge of the undergrowth and endeavored to penetrate it, but after a long struggle with the thorny tangle we gave up beaten, and the monkey got away. We found another monkey, the krah (Macacus cynomolgus), quite numerous along the river, but, the mud was so deep and the jungle so thick and thorny that we failed to secure more than one specimen. Had this been my only opportunity we would have secured good specimens of both species regardless of difficulties; but we knew we would have better chances elsewhere.

A few specimens were brought to me at the hotel, among which was a fine female Manis Javanica, here called "tingeling," with a tiny young one clinging to her. The latter was quite a prize, being of a good size to preserve entire in alcohol, while the mother furnished a fine skeleton. Squirrels are abundant along the river, and my new hunter distinguished himself by bringing in half a dozen. Turtles and beetles were brought to me by the Malay small boy, 
and for a few days we did a thriving business. Two professional crocodile hunters brought in a Crocodilus porosus eleven feet long, and delivered it to Mr. Buck, the superintendent of police, for the government reward of thirty-five cents per foot. The reptile was alive, but securely bound, and Mr. Buck kindly placed it at my disposal. Having just taken a goodly number of the same species at Selangore, I decided to take the head only, and a Malay was called to decapitate the animal as it lay. He drew his "parong latok," a very heavy sword with an edge like a razor, and with two terrific blows severed the crocodile's head from its body.

Owing to the fact that the crocodiles which infest all the rivers of Sarawak Territory are voracious man-eaters and destroy several lives annually, the government is waging a war of extermination against the species, and with telling effect. During that year (1878) 266 crocodiles were brought to Kuching for the reward, 153 of which were caught in the Sarawak River and its branches, and 113 in the Samarahan ; 53 were caught by one man, a Malay named Mau, and 48 by another named Bujang, both of whom follow that business exclusively. Nearly all were taken with the "alir," on the same plan as that we pursued in Selangore, described in Chapter XXVI. The largest crocodile taken that year measured 13 feet 10 inches, and of the whole number only two others exceeded 13 feet. Two were between twelve and thirteen feet, ten between eleven and twelve, and eighteen between ten and eleven, while the remaining two hundred and thirty-three were under ten feet, the majority measuring from seven to nine feet. The amount paid out in rewards was $\$ 738.28$.

$\mathrm{Mr}$. Crocker gave me a huge skull of Crocodilus porosus, which was 2 feet 10 inches in length, and must have come from a specimen not less than sixteen feet long. Besides the salt-water crocodile, a true gavial (Tomistoma Schlegellii), is found growing to a great size in the Sarawak River and the Rejang, and perhaps, in nearly all the large rivers of the territory above tidal influence. I procured of Mr. A. Hart Everett, the naturalist, a very large skull of this species from the Upper Sarawak, which measured 3 feet 3 inches in length. This species, however, is much more rare than the other, and I did not succeed in securing a fresh specimen.

The information that I received concerning the orang-utan was to the effect that they inhabit the valleys of the rivers Sadong and Batang Lupar, but not the Sarawak or Samarahan, and are usually seen in the fruit season. But the fruit season had passed months 
before my arrival, the orangs had retired to the depth of the forest, and no one could give me the least information as to where they had gone, or how I could manage to find them. Three or four were killed annually on the Sadong or its tributaries, and I decided to visit that locality in search of others. Mr. Crocker, the resident of Sarawak proper, very kindly offered me the goverument house on the Sadong as a residence and base of operations during my stay in that region, an offer which I was very glad to accept. In addition to this he also offered me a passage in the government schooner Gertrude, then about to make a trip to Sadong for a cargo of coal.

One day about sunset, we dropped down the river with the ebbing tide and, catching a light breeze at the river mouth, stood out to sea. All the next day we moved quietly along, and at sunset stood in and came to anchor at the mouth of the Sadong; to wait for the flowing tide to carry us up. Late that night I was dimly conscious of the fact that something was done about the auchor, and it seemed to me that the very next minute our vessel brought up with a loud "bump" and a violent jerk. "Run aground!" I said to myself, and went on deck to see what the trouble was. It was gray dawn of another day, a mist was slowly rising from the river, and the cocks were crowing loudly among the weather-beaten attap roofs that lined the river banks. We were at anchor in the mouth of the Simujan River, where it enters the Sadong, about twenty miles up. Along the left bank of the stream were about thirty Malay houses, nestling among the cocoanut-trees, forming the Malay kampong, while on the opposite side about half as many dwellings and shops built close up to the edge of the bank made up the Chinese kampong. As is the rule throughout Sarawak, the Chinese own nearly all the shops and do nearly all the trading. What the Malays do for a living I never could imagine.

The government house stands a hundred yards above the confluence of the two rivers, and I was surprised at finding it so wellbuilt, roomy, and comfortable. It was built to accommodate such of the government officers as might have occasion to visit this locality in the discharge of their duties. As usual the house stands on posts six feet high, and the space underneath is quite well adapted to such work as skinning and skeletonizing auimals. It contains two suites of rooms, and a latticed verandah in front of each sleeping apartment, which is a capital place for keeping pet monkeys and orang-utans. 
At the front of the house the steps lead up into a spacious audience-room, from the door of which there is a fine view of several miles directly down the Sadong, here a mighty river half a mile wide. The house is used as a police station by a detachment of half a dozen men, whose duties consist mainly in striking the hours on a deep-toned gong which hangs in the verandah. Ah me! that gong! As I recall its deep mellow "boom," which was always music to my ears, there rise before me pictures of half-naked Dyaks, red-haired orang-utans, dark-green jungle, wet trousers, canned salmon, green peas, and Bass' pale ale.

The grounds in front of the house are tastefully laid out, and quite filled with flowering shrubs and curious plants from the surrounding jungle, all of which seem to thrive without care.

The virgin jungle comes up to within a hundred yards of the house at the back, and the Malay kampong nestles at its edge. Near the house stands the government rice store, where the Dyak revenue (of one dollar's worth of rice per family) is received and stored. The whole establishment was then in charge of Mr. Eng: Quee, the government writer, a Chinese half-caste, to whom I brought, from Mr. Crocker, a letter which proved an open sesame to all the privileges the place afforded. No one could be more obliging than I found $\mathrm{Mr}$. Eng Quee, and he was of infinite service to me.

An hour after we landed, the Malay headman of the village came to pay his respects ; and a little later a party of Dyaks came to be questioned regarding the possibilities of finding orang-utans. In his own country this animal is universally called the "mias," although he is occasionally referred to by the Malays as an "orangutan," which means, literally, jungle-man, from "orang" man, and "utan " jungle.

The English name of the mias is a corruption of the Malay, commonly written as "orang-outang."

None of the Dyaks or Malays could give any definite information as to the abundance of these animals in the Sadong valley, their present whereabouts, or the best ways and means of finding them.

They assured me there were "mias somewhere in the jungle," but they could not tell me where to seek them. They thought I might kill at least one every week, which was quite encouraging, and I thought I would be satisfied with as good luck as that would be. I gave powder and lead to such of the Dyaks and Malays as were willing to hunt orangs for me, and started them out. 
Two miles from the Chinese kampong; on the eastern side of the Simujan, is the goverument coal mine, to which a wooden tramway leads through the swamps, the only railway in all Borneo. With a letter in my pocket to $\mathrm{Mr}$. Walters, the superintendent of the mine, I started to walk up the tramway, and half way to the mine I found the gentleman himself coming to see me. We were friends in five minutes. He entered heartily into my plans, and gave me much valuable information and advice. Our acquaintance throughout was a most pleasant one, and I never wearied of his sketches of jungle life. But on the subject of orang-utan hunting he confessed himself at fault. He had seen many orangs and killed several, but for several months he had not even heard of any in that vicinity.

Two days later he hurriedly sent word to me that a mias had just been seen in the jungle about two miles above the mine. In less than an hour we were at the mine, and, accompanied by $\mathbf{M r}$. Walters and several Dyaks and Malays, we set out under considerable excitement to find the animal. We followed a rugged forest path until we reached the spot, but the mias was nowhere to be seen. We divided our party and hunted about until nightfall, but found nothing save a fresh mias' nest, and so returned in disappointment.

The next day we determined to try the experiment of hunting through the forest at random. Early in the morning there arrived a Dyak named Dundang, who has the reputation of being a very successful hunter. He was a fine specimen, though too muscular to be considered a typical Dyak. His entire costume consisted of a yard-wide strip of bark-cloth wound around his loins and passed between his thighs with the ends falling down apron-wise in front. His head-gear was a strip of faded pink calico wound around his head and partly confining his long jet-black locks. He was accompanied by another Dyak, and, with them to guide us, Perera and I set out for a tramp.

No sooner had we fairly turned our backs on the coolie quarters at the mines than we were in the jungle. We had decided to try the swamp forest first, and if that yielded us nothing we would take to the low mountain which rises out of it like an island. We plunged into the swamp and for several hours waded through its miry mazes, but saw no animals save one monkey and a few small birds and insects for which we cared nothing.

The trees were rather low, as a rule, but grew very thickly to- 
gether, so that their tops formed a compact mass of green foliage which shut out every ray of sunlight from the ground below. Instead of tangled and spreading brushwood, the undergrowth consisted of saplings, with the stems of rattans, rope-like creepers and lianas hanging from the tree-tops or twining in awkward, angular fashion around their trunks. The ground beneath was little more than a net-work of gnarled roots, rising out of a thick pulp of water and decayed vegetable matter often a foot deep. It was not water; for it was too thick to be called a liquid; it was not mud, for there was scarcely any soil in it; butit was as wet as water and soft as the softest mud. It is this vegetable pulp which, when washed into the rivers of Borneo, is immediately dissolved, and imparts to the streams near the coast their murky brown color.

Almost the entire island of Borneo is quite encircled by a belt of swamp forest such as the above, extending back from the seashore a distance of fifteen to forty miles, where the land rises and asserts itself. Along the coast of Sarawak, particularly between the Sambas and Batang Lupar Rivers, isolated hills and lofty peaks rise abruptly from the level forest here and there-evergreen islands rising out of an evergreen sea. Along the seashore, the jungle is low and scrubby, but it reaches quite down to tide-mark. Where the beach is clean and sandy it is fringed with graceful casuarinas (C. littorea), here called the arrooree tree; but where the shore is of mud, as it is between the Sadong and Batang Lupar, the mangrove forms the boundary of the jungle. A few miles back from the sea the jungle rapidly rises in height and attains its greatest altitude on the hills.

Progress on foot through the swamp is slow and difficult at best, and even the man who prides himself on his ability to follow wherever a native can lead, will find his powers of endurance put to the test when he starts out to follow a naked Dyak through his native swamps. It seems strange that any terrestrial quadruped should voluntarily make its home in these gloomy fastnesses, where there is not even a spot of dry ground large enough for a lair, and yet the sambur deer (Rusa equina), the wild hog, and the tiny Java deer are abundant in this very swamp. I say abundant, because several were taken there during my stay, although on the day of which I am now speaking we saw not one. The only animal we saw was a large monkey with a short tail, called a pigtailed macaque (Macacus nemestrinus), which I shot and skinned.

A day in the swamp, together with two or three shorter excur- 
sions, convinced me that my way to the orang-utan did not lie in that direction. Then we tried the mountain back of the coal mine. We traversed its entire length, hunted over its top and along its sides, over sticks and stones, and across rocky gorges, but not a sign of mias could we discover. After a week spent in such hunting at random, without any success, we gave it up. Once more I began to interview the natives as fast as I could eatch them, Dyaks, Malays, and Chinese as well, as to the present whereabouts of the mias. I elicited no information which I considered valuable until one day two Dyaks arrived from the head-waters of the Simujan River to buy rice at the government store-house. They informed me that they saw two mias as they came down the river, that they often saw them near their village at Padang Lake, and they gave it as their opinion that if I would go up there and hunt for three or four days I might get two or three mias, and perhaps more. "Two or three!" I held my breath in suspense until they brought out their figures, and when they said "two or three "I could have hugged them. Had they said I would find them in " millions, sir, millions!" they would have blasted all my hopes for that river. But the Dyak statement had a ring of truth in it, and I instantly decided to put their advice to the test. I felt so certain it would "pan out" well that I made arrangements to start up the river immediately, and prepared for a prolonged absence. 


\section{CHAPTER XXX.}

\section{AMONG THE ORANG-UTANS.}

Start up the Simujan.-Boat-roofs._Among the Head-hunters.-A Dyak Long. house - Monkeys. - Fire-flies. - A Night on a Tropical River.-Mias' Nests. - Mias, Tuan."-Death of the First Mias - Another Killed.-Screw Pines._" Three Mias in one Day!"-Laborious Work._Swamp Wading. -Padang Lake.-Cordial Reception at a Dyak House.

Just twenty-four hours after our interview with the Dyaks from Padang Lake we started on an expedition up the Simujan, solely on the strength of the information given us by two semi-savages. What if they were lying to me, as so many white, black, yellow, and red men had done before, and sent me on fool's errands? The stock of provisions, ammunition, and preservatives I carried in my boat showed that I fully believed every word told me by those simple-minded children of the jungle.

Mr. Eng Quee had business up the river, and accompanied me in his own boat, with two stout Malays, Blou and Lamudin. My boat was manned by a quiet and obedient little Malay named Dobah, whom I had engaged by the month, Perara, my Portuguese lialf-caste, Ah Kee, my servant and best man, and myself. Both boats were amply roofed with kadjangs, which make a roof at once water-proof, very light, easily adjusted, and so flexible that, when desired, each section can be rolled up and stowed away in the bottom of the boat.

These kadjangs are made of the long, blade-like leaves of the nipa palm, on the same principle as a tile roof. The leaves are each six or seven feet long by two inches wide. They are sewn together with strips of rattan, each alternate leaf overlapping its neighbor on either side, and so on until a section of roof is formed about six and a half feet square. This section is then made to bend in the middle cross-wise, at a sharp angle, so that it can be folded once 
and rolled up, or partly opened and made to stand up, tent-wise, when it forms the very best kind of roof for such a climate.

We started up early in the afternoon with the flood tide, and paddled along at good speed very comfortably. For the first ten or twelve miles the Dyaks have cleared away the jungle on both sides of the river for a hundred yards back, and grow their crops of "paddi" (rice) there. At that time of the year (August) the clearings were all overgrown with rank grass four feet high. About eight miles above Simujan we came to a typical village of the Sea Dyaks, and halted to pay it a visit. It stands on the left bank of the river, quite near the stream, and, from the river, one sees only the end of a house, with its single door and a long, gray, moss-patched roof running far back, in ragged lines of perspective, toward the jungle. The lower part of this structure is almost entirely concealed by the broad-leaved banana-trees which grow closely around it.

The view from the top of the bank discloses, not a collection of houses, but one immense house, one hundred and ninety feet long and thirty feet wide. It stands on a small forest of round posts, five or six inches in diameter, set firmly in the ground, and the floor is ten feet above the ground. At either end is a door, to which there leads up a small tree-trunk, cut on the upper side into notches, which serve as steps. Four rows of posts, the two outer and two middle rows, run up through the floor to the roof, and the rest are cut off at the floor.

What is really the back wall of this long village house leans outward rapidly as it rises from the floor, and is without either door or window. The front is entirely open all the way along, and the floor extends out thirty feet farther on additional posts, forming a convenient open-air platform for drying rice and other jungle produce. The ground underneath the house-it is much more like a house than a village-is damp, wet, littered and dirty, and smells feverish.

We climbed the notched tree-trunk at the end of the house and entered. A delegation of mostly naked men, women, and children met us at the door, with here and there a "Tabet, tuan!" (Good day, sir!) in friendly greeting. Directly two or three women appeared with clean mats, which they spread upou the floor so that a considerable space was covered, and we all sat down. Mr. Eng Quee opened a conversation with the old men, our Malays talked with the young men, and the women and children flocked 
round to have a good look at the "orang-putei" (white man), who repaid their inspection in full, principal and interest.

From the numerous posts which ran up through the house there hung a great many deer antlers, lower jaws of wild boar, parongs, back-baskets (juahs), fish-traps, paddles and spears. Naked children scudded hither and thither over the floor, chasing the fowls, teasing the dogs and playing with the little gibbon, all of which rightfully belonged to the population of the village. As we entered, we found a young woman with a five-foot bamboo pail on her shoulder just starting to the river for water; one man was sitting on the floor making a fish-trap, and another was hewing out a new door with his " biliong," or adze-axe.

We were seated in a long hall, which extended without any division the entire length of the house, and occupied a trifle more than half the entire structure. It was on the open side of the house and faced the open-air platform. Along the other side of the house, likewise extending its entire length from one end to the other, was a row of sixteen rooms, each about twelve feet square, entered by a single door from the middle passage.

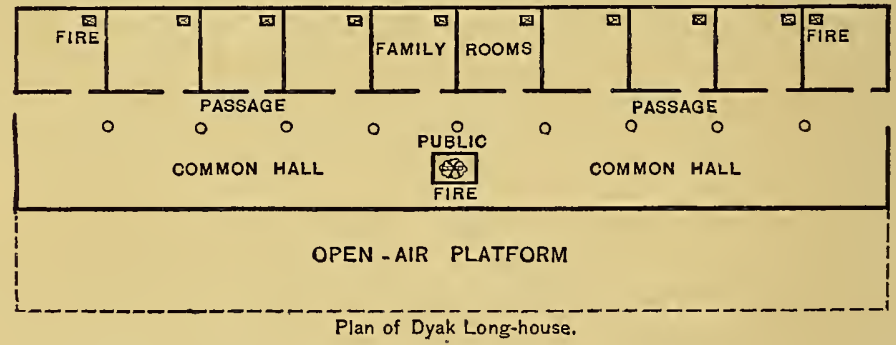

All the timbers of the house were lashed together with rattans, not a nail nor even a wooden pin being used anywhere. Nor were any of the timbers mortised together at any point. The Dyak idea of fastening two objects together is to lash them with green rattan; civilized man believes in nailing, pinning, mortising, or fastening with screws.

The floor was of narrow strips of the nibong palm, an inch and a half wide, lashed to the sleepers about an inch apart, thus giving a floor more open than lattice-work. The wall which divided the rooms from the open hall was of wide boards hewn out with the "biliong," placed upright, and lashed together and to a base-board with rattans. Each door was one wide board with a projecting 


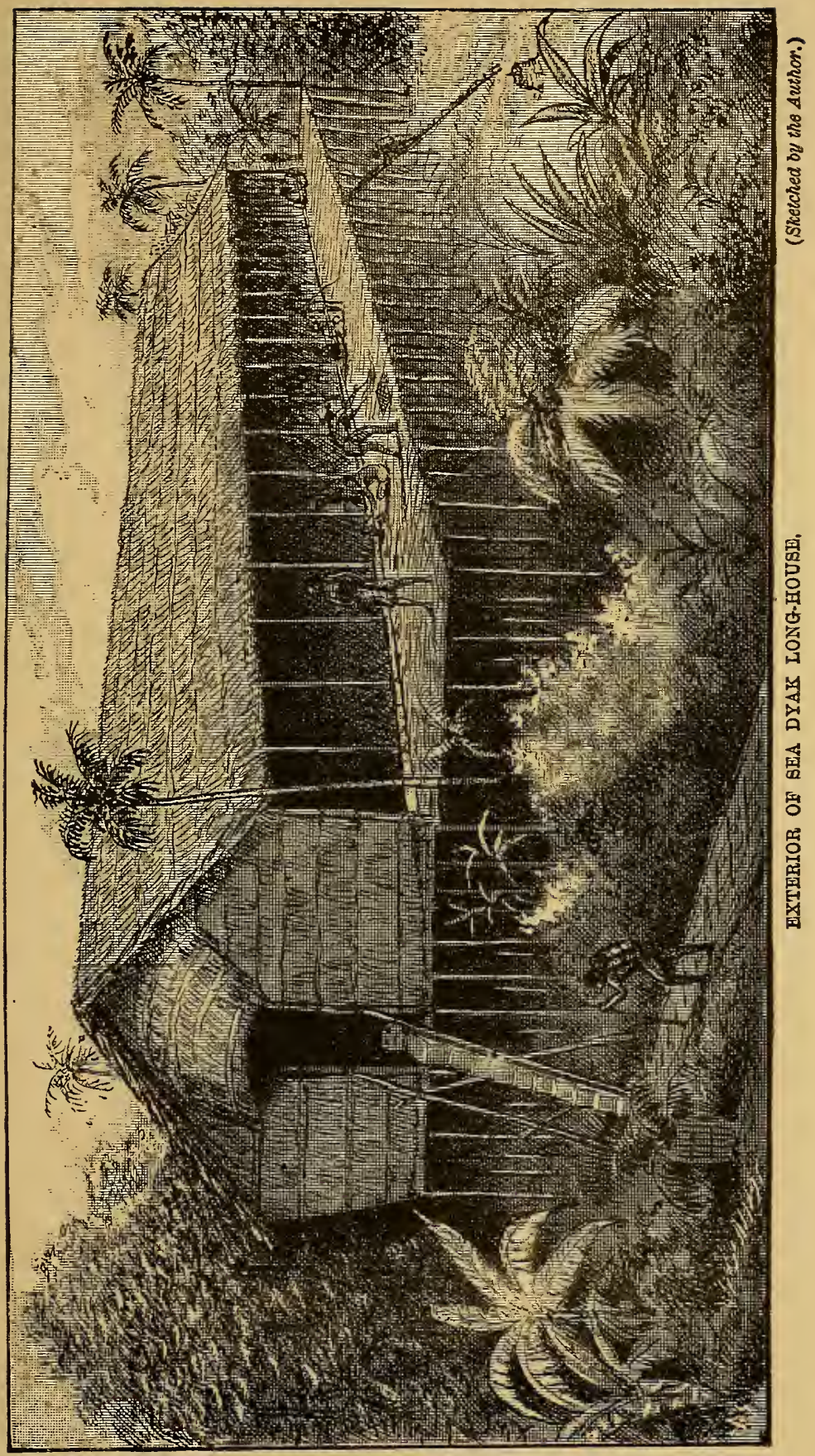





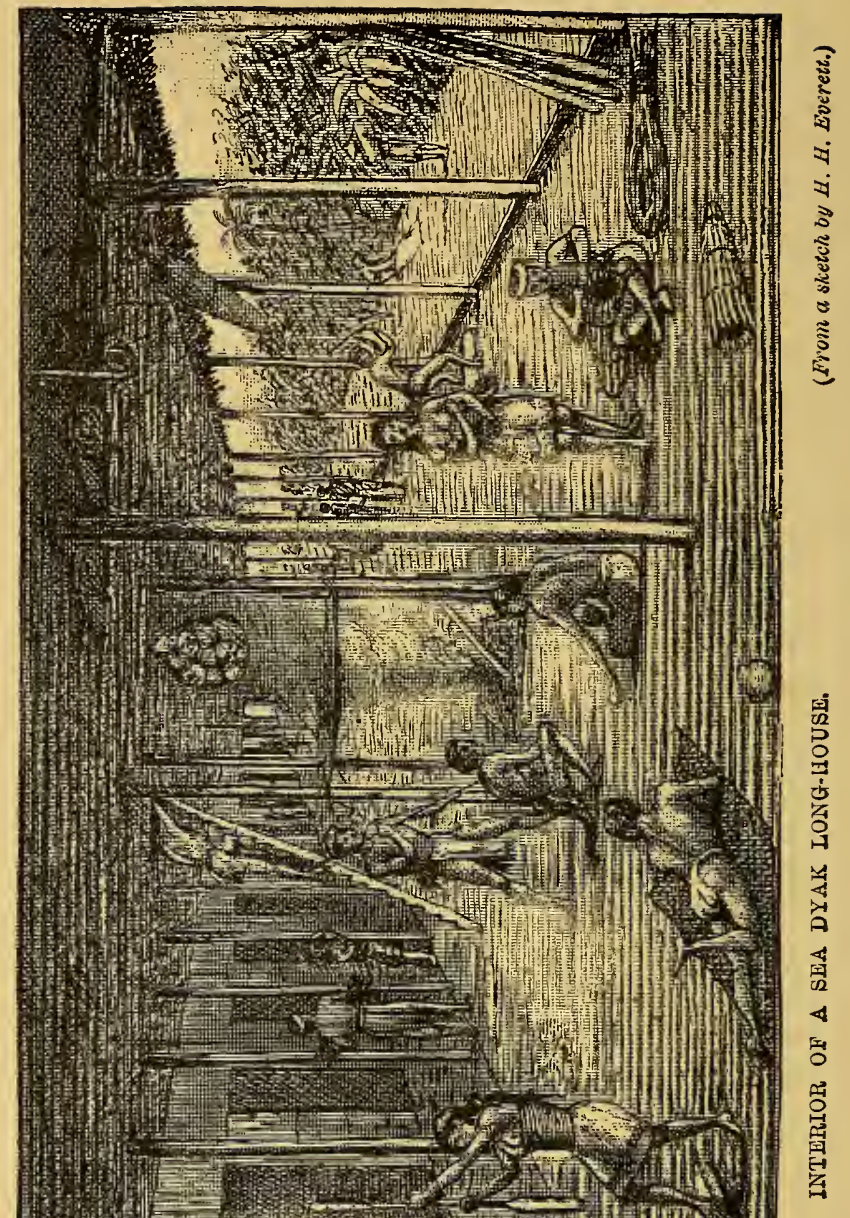

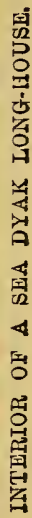

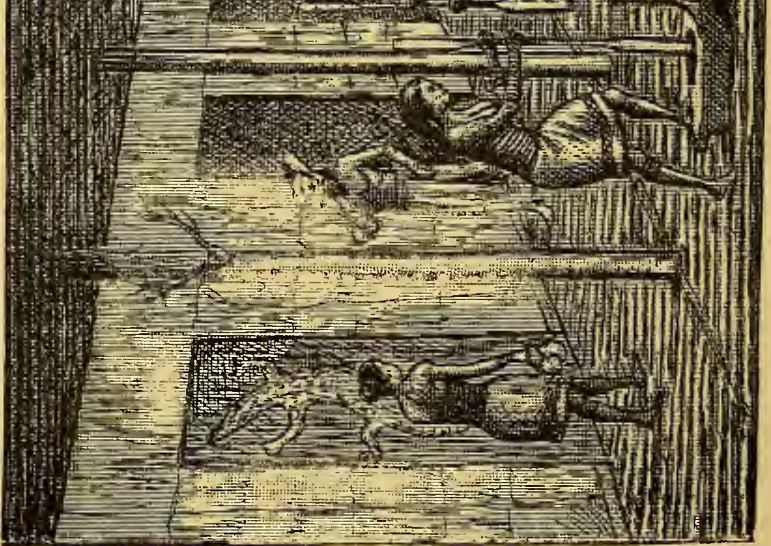


point at the bottom for it to turn upon in lieu of a hinge. On one of the doors nearest us I noticed a figure of a crocodile rudely carved in low relief. The outline was very good but no time had been spent in working out the details.

The side of the house which was enclosed, and also the ends, were macle up of wide slabs of bark lashed to the framework. The roof was of "attap," or large square sections of palm-leaves sewn together and lashed to the rafters in courses, like shingles.

Each room in a Dyak long-house represents a family, or at least a married couple, and a village is taxed according to the number of its "doors." This, then, was "a village of sixteen doors." The young unmarried men and boys slept over the hall in the loft which forms a part of every such habitation, partly for storage and partly for domiciliary purposes.

Each private room has no other door than the one opening from the passage. The floor is generally covered with mats. In a corner of the room next the outer wall is a bed of earth on which the family fire is built. At this corner the roof is so constructed that a portion of it, usually two or three rafters, can be lifted up bodily for about two feet and propped up to admit light and air, and also to allow the smoke to escape in case there should be an excess of it. There are no tables or chairs-indeed no furniture of any kind.

In the centre of the long hall a fire was burning on a bed of earth, and above it hung a bundle of about twenty human heads, or rather skulls, for not a vestige of flesh remained on any of them. Each skull was bound round securely with rattan, evidently to keep the lower jaw in place. All were black and grimy with smoke and soot, and those at the bottom of the bundle, nearest the fire, were quite charred. We were among the head-hunters, and those were trophies which our money could not buy. Thanks to the government of Sir James Brooke, those heads were all old trophies, no doubt collected prior to 1841, by the skinny and toothless old fellows who now totter about the village, and pound their betel in a joint of bamboo because they cannot chew it.

According to all accounts, the Dyaks of Southern Borneo are tame subjects in comparison with the dashing, dare-devil tribes of the north. A man may travel the whole length of the Mahakkam or the Barito and visit the villages of the most warlike tribes without being able to set eyes on more than one skull. Here in the Sadong we find a score in the first village of Sea Dyaks we set foot 
in, and we afterward saw a beautiful collection of forty-two skulls in the first village of Hill Dyaks we visited on the upper Sarawak.

As I had abundant opportunity later on to study the Dyaks themselves, I will not attempt here a description of the inhabitants of this village. At the termination of our call two of the women came and offered me half a dozen fresh eggs, which I accepted, and gave them in return what their souls longed for-tobacco. As we returned to the boat, all the women and children of the house trooped along after us, respectful and well-behaved to the last, to see us off-and to modestly request a little more tobacco. I duly stood treat all round with leaves from the bundles I had laid in store for this purpose, and we parted on good terms.

Just before sunset we passed the last Dyak village and clearing, and came to where the large trees and dense undergrowth clothed the banks to the water's edge and even beyond. Then we began to see monkeys by the score, and as evening approached their numbers seemed to increase as they began to perch in the branches that overhung the river, and settle themselves for the night. Sometimes as many as five or six would be seen sociably huddled together on a single bough, and often one small tree-top contained from fifteen to twenty of the little animals. They were all of one species, Macacus cynomolgus, the commonest in Borneo, if not of the neighboring islands as well, and by the natives it is called the krah. They are about the color of a gray squirrel, and three times as large. I think $I$ never elsewhere saw so many monkeys in the same length of time. I counted them as we paddled along until in a few minutes I ran the number up into the eighties, and was obliged to give up the attempt. They showed not the slightest fear of us, and I could easily have killed a great many. As it was, I shot two, which was all I cared to preserve just then.

Just as darkness set in we came to a large band of proboscis monkeys (Nasalis larvatus), and, although we could only distinguish their moving forms for a moment now and then, their pectliar nasal cry told us what they were.

Fifteen minutes after sunset the last gleam of twilight faded out, and darkness closed over the forest. The river had narrowed rapidly, and was then not over forty yards wide. On either side a wall of green leaves rose from the surface of the stream, and the banks were quite hidden behind the leafy screen.

Just here we were treated to the most glorious exhibition of fire-flies I ever beheld. 'They congregated on certain trees in hun- 
dreds-if not, even thousands, in some instances, and resting quietly on the leaves kept up an incessant and rapid scintillation, each insect flashing about a hundred and twenty times per minute. For three or four miles we passed in about every hundred yards a treetop literally filled with brilliant flashes of white light, which, in the darkness, shone with novel and beautiful effect.

It gives one quite a feeling of awe to paddle along a narrow river between two dark walls of forest in thick darkness. At such times the most garrulous boatmen are quiet, the traveller's mind is filled with romantic thoughts, and the only sounds which break the sombre stillness are the measured dip of the paddles, the swish of the eddies they make, the chirp of the tree-frogs and the occasional twitter of a night-bird.

Haring made several miles after sunset, we tied up to some bushes, ate a frugal dinner, and lay down in our boats to sleep. The mosquitoes were troublesome to the men who had no netting, but being provided with adequate protection I fared better. But my boat leaked from being overloaded, and I slept in water the greater part of the night.

At break of day we were off again, and soon passed the mouth of the southern branch of the Simujan. A few miles farther on we halted at a small bit of cleared ground, built a fire over the water on a pole platform which we covered with mud, and cooked breakfast. Before starting again we cleared the deck for action on Mr. Eng Quee's boat, and made ready for aggressive warfare on the monkey tribe. The kadjangs were rolled up, the supports taken down and stored away below. This "sampan" of Eng Quee's was the best shooting-boat I ever used, and, outside of Borneo, I shall never see its like again. It was a simple dug-out, about fifteen feet long by three and a half feet broad in the middle, pointed at both ends, and just deep enough to be steady. Just below the edge it was completely decked over with strips of nibong palm, and on this, amidships, I placed my ammunition-box for a seat, arranged rifle and double gun, cartridges and field-glass within easy reach. Leaving my boat to follow we again set out.

We were now some distance above tidal influence, and the river had narrower to twenty yards, but it was still very deep and flowed swiftly. The water was much cleaner than below, and was indeed moderately clear. The banks on both sides were entirely submerged for an unknown distance back from the stream, miles perhaps, but the forest was composed almost entirely of trees. The 
nipa palm had been replaced by the screw pine, rasow etam of the Malays (Pandanus candelabrum), which formed a fringe along both sides of the river. They grew in water eight to ten feet deep and very thickly together, so that no boat could reach the shore without a great effort to get through them. The stems were from two to three inches in diameter and thickly studded with short spines. Owing to the depth at which they grew, it was sometimes possible to push them aside and drive a boat through them, when they grew rather thinly, but usually it was necessary to cut a passage in order to reach the shore. I mention them thus particularly because they afterwards caused us great trouble.

We saw no proboscis monkeys that morning, nor any others. The men had to work hard at the paddles to make headway against the rapid current. Early in the day we passed several abandoned orang-utan nests, which aroused expectations of something better, and presently we passed a green nest. From that moment four pairs of eyes sharply scrutinized every dark object or moving twig in the tree-tops as we paddled slowly and silently along. Every doubtful object was instantly pointed out and examined by the " tuan" with the field-glass.

We had just sighted another very green and fresh-looking nest, when there was an excited whisper of,

"Mias, tuan! mias! mias!" and a long arm in front of me pointed it out.

"There he is, sir! there he is !" (in Malay, of course). The light sampan fairly flew along until we came nearly opposite the tree containing our intended victim, but he had recognized the approaching danger and hidden himself in a thick clump of leafy branches. Presently we saw a big hairy arm clasping the trunk of the tree about fifty feet from the ground, but that was all. The boat was stopped directly, and as we could do no better I stood up and sent a bullet through the arm that was exposed, to stir the old fellow up. It startled him, for with an angry growl, he immediately showed himself and started to climb away. As soon as we saw his body I fired again, which caused him to stop short for a moment. Then the two Malays put forth all their strength and drove the boat as far as possible into the thick fringe of screw pines. They stood very thickly together, but their stems yielded a good decul, and by frantic pulling, pushing aside, and chopping we forced a passage through for several yards. At last we came to a dead stop; there was not a speck of land in sight, but the boat could go no farther. 
, 


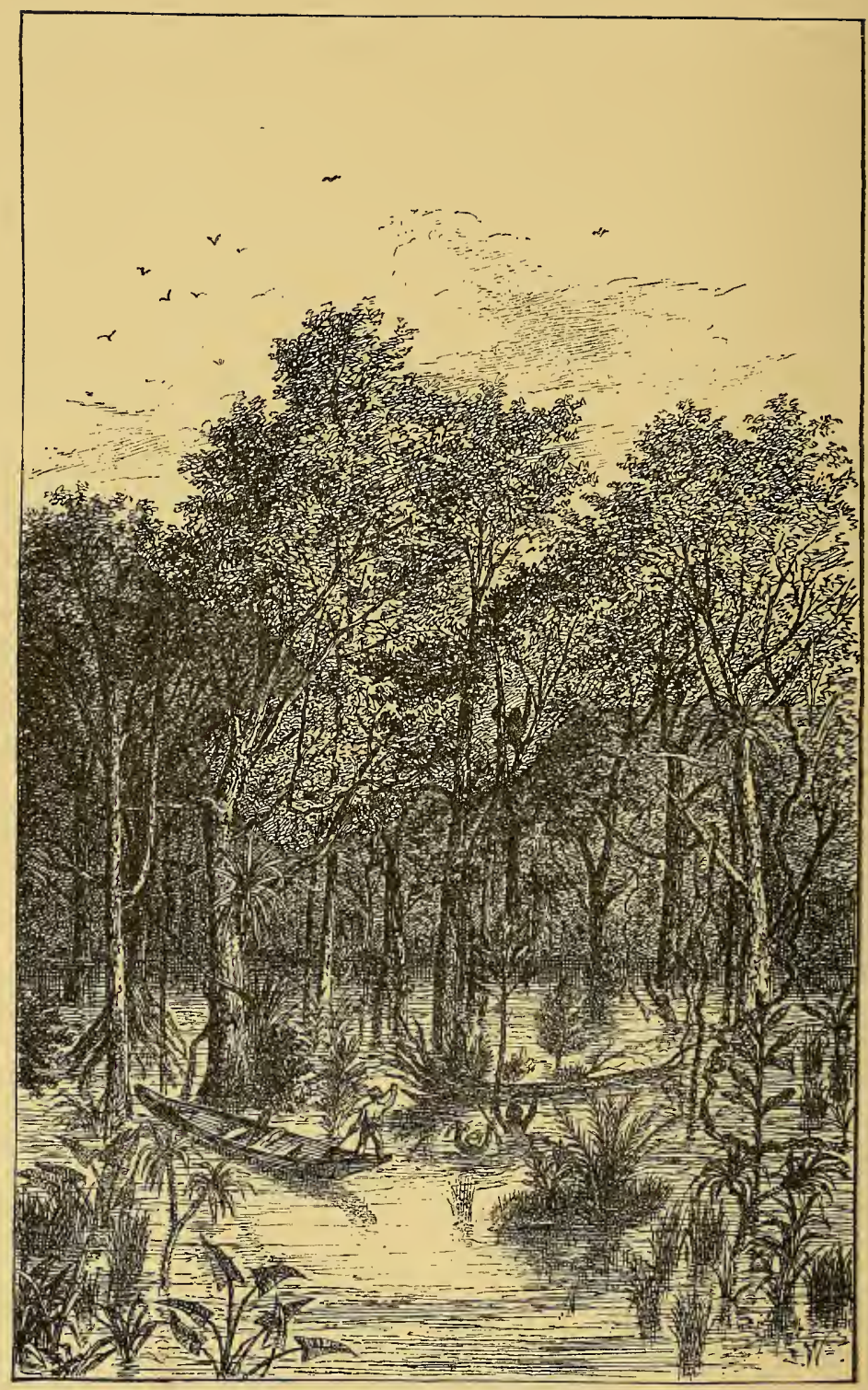

WADING AFTER A WOUNDED ORANG-UTAN.

(From Author's sketch.) 
We were near the large trees by this time, so two of the Malays seized their parongs and slid down into the water while I quickly followed with my rifle and a pocket full of cartridges. Fortunate it was for me in my wading after orangs that my rifle was a breechloader and that Maynard cartridges are water-proof.

We went quite under water, at first, but after swimming a few yards, were able to touch bottom. We waded up to our necks in water until it got shallower, the Malays pushing ahead as fast as possible to keep the mias in sight, until presently they stood still, waist deep in the water, and pointed upward. I soon saw the mias, a fine large one, swinging himself slowly from one tree to another, evidently disabled. I immediately fired for his breast, whereupon he struggled violently for a moment, then made off in frantic haste, climbing along a straight horizontal branch by the aid of his hands alone, swinging along as a gymnast swings underneath a tight rope. He reached fully five feet at every stretch.

Presently he stopped short and let go with one hand, which dropped heavily at his side and came below his knee. For three minutes he hung there facing us, holding by one hand only. How huge and hairy he looked, outlined against the sky! Presently his hand slipped, his hold gave way entirely and, with outstretched arms and legs, he came crashing heavily down through the branches and fell into the water near us with a tremendous splash. He struggled up and turned savagely to bay, grasping the trunk of a sapling to hold himself erect. The Malays rushed at him with their parongs, and one gave him a fierce slash in the neck while I was shouting to them to desist. They were as yet wholly untrained, and would have ruined the skin in a moment. The old mias flung his long arms about, gasped and struggled violently, then quietly settled down in the water, and in another moment was dead. Then we towed him along back to the boat, lifted him in with considerable difficulty and began to examine our prize.

Truly, he was a prize. His back was as broad and his chest as deep as a prize fighter's, while his huge hands and feet seemed made with but one end in view-to grasp and hold on. His arms were remarkably long and sinewy, but his legs were disproportionately short and thick. His body was large and heavy, with a chest both broad and full; his eyes were villanously small and his canine teeth were as large as those of a small bear. His arms and legs were covered with long, coarse, brick-red hair, which grew also on his abdomen and sides, but the skin which covered his breast hung 
in a loose, baggy fold. The face was bare except for a thin growth of hair on the jaws and chin, which, in pictures of the orang utan is usually magnified to a luxuriant beard. His skin was of a shiny brownish-black color, darkest on the face and throat.

We transferred the body of our dead mias to the other boat and proceeded up the river as before. Nests were now quite numerous in the trees along the banks, but we saw none even fifty yards back from the shore. The Dyaks and Malays both assert that the orangs are subject to fever, and resort to the open margins of rivers and lakes for the benefit of the cooling breezes which blow there.

The nest of the orang-utan is simply a lot of small green boughs and twigs broken off by the animal, and piled loosely in the fork of a tree, or the top of a sapling. The pile is usually about three feet in diameter, and on this the orang-utan lies on his back, and sleeps.

A few miles from the scene of our first capture we came to a very fresh green nest, and Eng Quee remarked:

"Now there must be a mias very near that."

The next moment we saw the movement of a heavy body in a tree just beyond, and he added :

"There he is, sir! There's the mias!"

We paddled quickly up and directly saw the mias climbing rapidly away. I fired immediately, and the next moment the boat was driven with full force into the screw pines. We tugged frantically at the stems to force a passage, but were soon brought to a standstill. Holding my rifle above my head, I slid into the water, and this time found it only up to my shoulders. The Malays followed me closely in our wading-match, and in a few minutes we found the mias in a tree-top, disabled, as I had expected. This time my bullet went through his head, whereupon he settled back quietly across two large branches which grew close together, and remained there, dead, with forty feet of bare tree-trunk between him and us. I offered half a dollar to any one who would climb up and throw the mias down, which offer was accepted by one of the Malays. After a hard struggle up the smooth trunk, he reached the animal and sent it tumbling into the water below. Two mias in one day was far better luck than we had dared hope for.

The river narrowed rapidly as we proceeded, and at length there remained only a passage between the screw pines, which formed a barrier thirty yards wide on either side between us and the shore. In two places we found the channel choked with a wide drift of dead pine stems, completely bridging the river, and barring our 
progress. With great labor we cut through one drift and cut a passage around the other wide enough for our boats.

Just before reaching Little Padang Lake, we came to a spot where about forty acres of jungle had been killed-by fire, the Malays said, although I hardly see how it could have beeu burned. The trees stood in the water leafless, dead, and bare, save for a green epiphyte here and there on their branches. Acres of dead screw pines reared their leafless stems aloft, and the prospect was dreary enough. Winding in and out, and turning a great many times, we came to Little Padang Lake, and found it a perfect jungle of Pandanus. Threading our way through that, we came to forest again, and a little farther on entered Padang Lake, also a labyrinth of screw pines. As we were crossing a bit of open water, one of the Malays chanced to look back and immediately exclaimed, in an excited whisper: "Mias, tuan! mias! mias!"

Sure enough, there we espied a mias fast asleep in a little tree close to which we had passed. He lay on his back in the main fork of the tree, holding on by the large limbs.

We paddled up very quietly to within fifty yards, when he discovered us and started up. I fired at him, and, as the boat crashed into the pines, took another shot. The pines were very thick, and there was no shore anywhere. We were obliged to take to the water or lose the animal, so overboard we went, and kept our heads above water by holding to the spiny stems which pricked our hands painfully. After a while we touched a bottom of mud, and were able to wade, though the water was up to our necks. It was slow work. Our feet often got caught in vines, and roots, and sometimes we came against submerged pine-stems waist high, while up to our chins in water. Had the mias not have been hit hard, he would have escaped, for, in spite of our eagerness, our progress was slow and painful. After forty yards of wading we came up with him, and found him badly hurt, and visibly weakening. Not wishing to prolong his sufferings, I sent a bullet through his head, which smashed his skull all to pieces, and tumbled him like a log into the water. Lamudin took him in tow, and we toiled back to the boat.

Three orang-utans in one day! The men hurrahed loud and long ; and I believe I must have indulged in a little shout on my own account.

When you remember, my reader, that it was for the orang-utan that I had made an expensive visit to Borneo, and up to that day 
had been in great doubt as to its whereabouts and abundance, you can perhaps forgive a little honest enthusiasm over the results of our first day's work.

A narrow and tortuous channel led for about a mile through a wide tract of pines, from which we finally emerged on the open lake. It was a shallow body of clear water, about five miles long by two miles at the widest part. The whole western half of the lake is filled with Pandanus, which also chokes it at its southern extremity. On the east they are happily absent, and the water is open quite up to the edge of the forest.

About two miles from the outlet of the lake, up the western side, is a conical mountain, called Gunong Popook, about nine hundred feet high, the end of a chain of low mountains extending westward from the lake.

It was nearly sunset when we reached the open waters of the lake and made for a Dyak house at the foot of Gunong Popook. We landed and walked fifty yards over "batangs" (saplings), passed some huge bowlders of reddish porphyry and just beyond them came to a small Dyak village, or long-house. We climbed the ladder and were greeted very cordially by a pleasant-faced young man, named Hakka, his wife Noonsong, and another woman who spread clean mats for us to sit upon. The betel box was brought out, and we all sat down for a chat. We asked if we might be allowed to stay there that night and perhaps a little longer. Of course we could stay there! Why not? Any stranger was welcome to stay; and who ever heard of a Dyak refusing shelter to a white man and the best the village afforded? They would be glad if we would honor them with a visit two months long.

Very true; a Dyak was never known to refuse hospitality to a friend, and aid when needed, in which my simple-minded savage without any religion whatever is about five thousand per cent. better than the canting, hypocritical Hindoo, who would prefer to have you sleep out in the rain rather than have your presence desecrate his mud sanctuary or even his verandah. The Dyak is the man for me.

We were informed that the whole of the open hall was at our disposal, and in a very short time we had taken formal possession. Our three dead orangs we hung high up in the trees near the house to get them beyond the reach of the lean and hungry dogs; or rather animated dog-skeletons, which roamed about. The Dyaks were really glad to see us, for to them our visit was quite an event, 
and had we owned the house we could scarcely have felt more at home. I gave the men and women tobacco-boxes and lookingglasses, and to the children about fifty coppers apiece, all of which were received with childish enthusiasm.

After a long confab by lantern and torch-light, I hung my hammock and musquitero, for the mosquitoes were quite troublesome, and Eng Quee rigged up his curtain in a corner close by. The other members of our party sought soft places on the floor, and being thoronghly tired with our long day's work, we were soon beyond the realms of thought or care. 


\section{CHAPTER XXXI.}

\section{DOINGS IN THE ORANG-UTAN COUNTRY.}

Preparation of Orang Skins and Skeletons.-Return down the Simujan.Three Orangs Killed.-A Troublesome Infant.-Accessions from Native Hunters. - Seven Orangs in One Day.-Miscellaneous Gatherings. - A Battle-scarred Hero. - The Bore in the Sadong.--Another Trip up the Simujan.-Doctoring an Injured Hunter.-The Dyak at his Worst.-Death of a Huge Orang, "the Rajah."-Dimensions.-A Rival Specimen.--Two Captives.

The day following our arrival at the Popook village was a busy one. We had three mias to skin and also to skeletonize, for all the great apes (gorilla, chimpanzee, and orang-utan) are so rare and valuable that the entire skeleton of each specimen is carefully dissected out, and makes a complete specimen by itself, quite as valuable as the skin.

Near the house was a low platform of poles upon which the Dyaks spread their paddy to dry, and being vacant at that time, we converted it into a very serviceable work-table. We erected the kadjangs over it to protect us from both sun and rain, and, calling all the members of our party, gathered round the festive board for a picnic with the three dead mias. After each specimen had been carefully measured and one sketch made we sharpened the knives and went to work.

The forenoon was very hot and the afternoon very rainy; but we kept dry under the kadjangs and worked steadily on. It was a great bother to skin the fingers without mutilating them. Foreseeing that all my companions would very probably assist on similar occasions in the future, I took pains to teach them the modus operandi, and was pleased to find how intelligently and skilfully they took hold of the work in hand. It was well that I did so; for not very long after that our resources were taxed to the utmost.

My method of preserving the skins and skeletons was very simple, and I am happy to say proved entirely satisfactory. After re- 
moving and carefully cleaning the skins, we first treated them with a liberal application of arsenical soap dissolved in a little water, and then rubbed on all the powdered alum that would stick to the skin. A pole was passed through the arms, and the skins were then hung up to dry, the head and legs being distended with a little loose straw or dry grass, and the skin of the body slightly distended by short sticks placed crosswise.

In the hot, moist, bath-room air of Borneo a slin must dry immediately or it spoils. If it is hung up loosely, or in folds so that the air cannot reach both sides of the entire surface, the hair will drop off all portions that do not dry quickly. I have ventured to state the above facts for the reason that the ignorance of them, simple as they are, has entailed the loss of many a fine skin of orang, chimpanzee, and gorilla.

Orang skeletons, like all others, are prepared, in a rough state, by carefully denuding them of flesh with a knife, but leaving the bones of the various members attached to each other by their ligaments, anointing them with thin arsenical soap, then tying each skeleton in a compact bundle and allowing it to dry in the shade.

Being fully convinced that our best plan for hunting orangs lay in making trips up and down the Simujan River we decided to return forthwith to Sadong, hunting on the way down. On the following morning we loaded our boats and took leave of the hospitable Dyaks. They were loud and long in their invitations to us to come again and stop a long time, promising to do all they could to help us find animals. Having comforted them with the assurance that they would soon see us again, we embarked and set off.

Soon after entering the river, we started several troops of proboscis monkeys, but being just then in quest of grander game, we let them go, promising to call and pay our respects a little later. A little farther down we surprised an orang in the act of taking a drink. He had climbed down within reach of the water and hung at the foot of a stout sapling, dipping one hand into the water, then holding it over his mouth and sucking the water off as it dripped from the knuckles of his closed fingers. He was so busily engaged that I got a good look at him with the glass before he saw us. He was near the open water and I easily brought him down with my rifle, after which we paddled our boat in to where he fell and secured him without even getting out.

Three miles farther on I espied a baby orang up in a tree-top, lianging to the small limbs with out-stretched arms and legs, look- 
ing like a big, red spider. It gazed down at us in stupid, childish wonder, and I was just aiming for it, when Mr. Eng Quee called my attention to the mother of the infant, who was concealed in the top of the same tree. As soon as I fired at her, she climbed with all haste up to her little one, which quickly clasped her round the body, holding on by grasping her hair, and, with the little one clinging to her, the mother started to climb rapidly away.

Fortunately, we were able to get the boat in amongst the trees without much trouble, and all immediately went overboard. We had scarcely done so when a third orang, a young male about two years old, was discovered looking down from a nest overhead, which he immediately left and started to follow the old mother. As he went swinging along underneath a limb, with his body well drawn up I gave him a shot which dropped him instantly, and then we turned our attention to the female. She was resting on a couple of branches, badly wounded, with her baby still clinging to her body in great fright. Seeing that she was not likely to die for some minutes I gave her another shot to promptly end her suffering, and then she came crashing down through the top of the small trees and fell into the water, which was waist deep.

We sprang to secure the baby, but it was under water fully a minute before we found it, quite unable to swim and very nearly drowned. We managed to resuscitate it, however, then the other two were lifted into the boat and we drew out into the stream.

As soon as the baby recovered the use of all its faculties, it seemed possessed of a little devil. It was only about six months old or eight at the most, and weighed about eleven pounds, but it had the temper of a tiger. It made such persistent efforts to pull my hands up to its mouth in order to bite them that I was obliged to tie its elbows together behind its back, pinion its feet also and make it fast by a cord to the side of the boat, so that it could not reach me with its teeth. This, of course, increased its rage.

It was restless as an eel, and gave me endless trouble. Once when I was not watching, it rolled over and before I was aware of the movement seized the calf of my leg between its teeth with a perfectly fiendish expression and bit me very severely. But for my thick woollen stockings and cotton hunting trousers underneath, I think the little wretch would have bitten out a piece of my flesh. I gave him a sounding slap on the side of his head, which caused him to let me go ; but for many days after I carried a large black and blue mark in memory of him. 


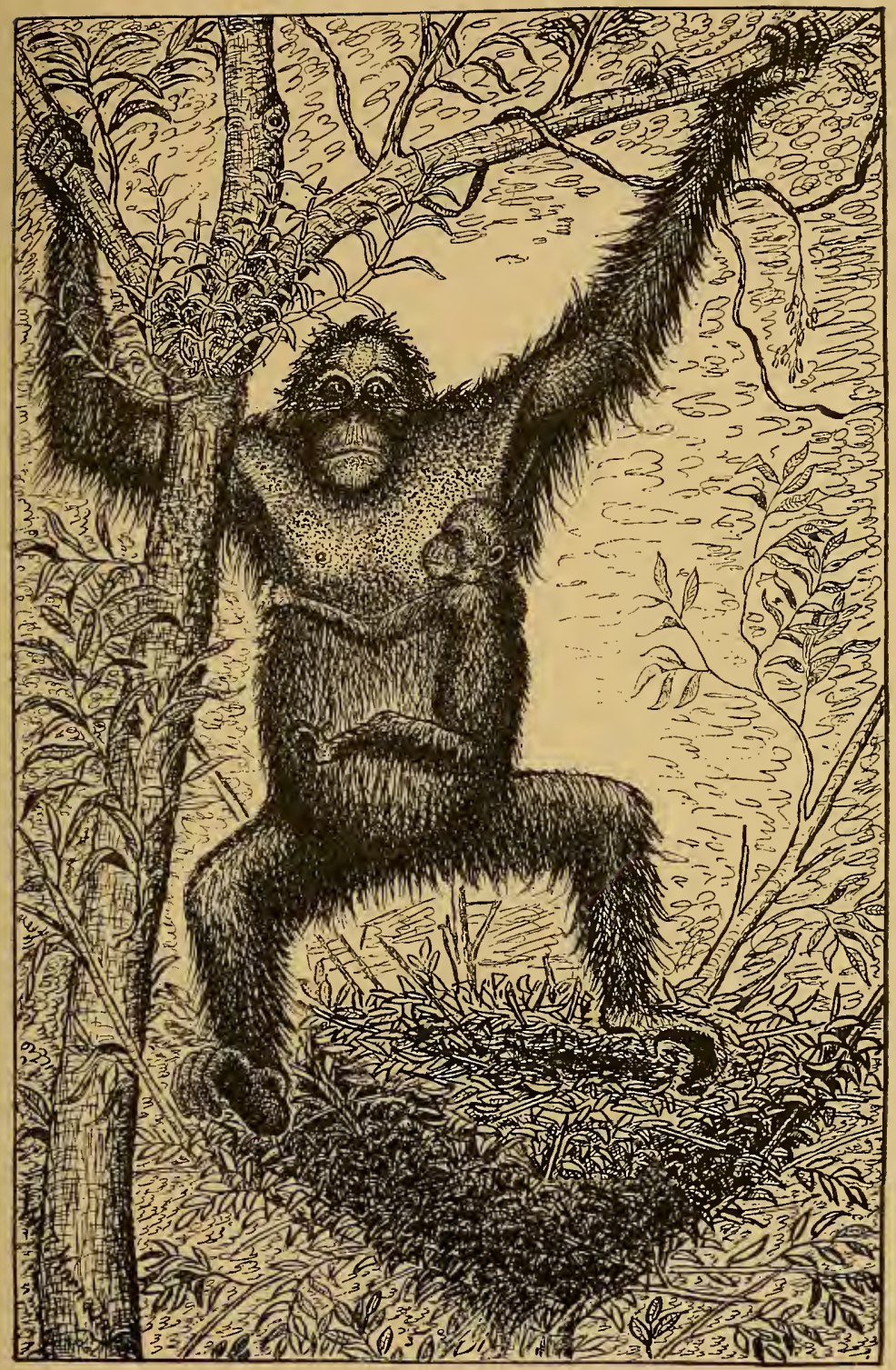

FEMALE ORANG-UTAN, INFANT AND NEST.

(From the group in the U.S. National Afuseum mounted by the Author.) 

Once it tumbled overboard, and I let it get a good ducking before rescuing it.

A heavy rain came on during the afternoon but we set up our kadjangs and kept quite dry. As soon as it ceased, we took to our paddles and went down swiftly with the current, reaching Simujan at sunset, wet, tired, and hungry, but very happy in the possession of seven orangs taken in two days' hunting.

At the back of the government house, there was a wide open space, between the two bath rooms, where the roof projected over the hard ground, which made a capital open-air dissecting-room.

Mr. Eng Quee-placed a table for me and there I skinned orangs and received deputations of natives who came bringing specimens, or wanting gunpowder. The ground under the house was hard, dry and clean, and my motley crew of assistants retired under the floor with their work. Mr. Eng Quee quite enjoyed the novelty of orang-skinning, and quickly became an expert hand at the business. Ah Kee, Perara and the three Malays, worked slowly and required constant supervision, but they learned rapidly.

Early the next morning after our return, came an old Chinaman to whom I had given gunpowder a week previous, escorting two other Chinamen, who carried on a pole the dead body of a good-sized orang, which he had shot the day before. I received it with open arms, paid for it, measured it, and was proceeding to remove the skin, when there arose a loud shout from those around me, and the next moment, three naked Dyaks staggered up, also bearing on a pole another dead mias. This was a fine, large "mias chappin," with the intensely black skin and the remarkable expanded cheeks, or cheek callosities, so characteristic of Simia Wurmbii. This was larger than any of the specimens I had taken thus far. The Dyaks said they were out the night before trying to noose a deer, and found this mias swinging himself from one tree to another, when a branch suddenly broke and let him fall to the ground. They attacked him at once with their spears and killed him. There were fifteen spear wounds in his chest, but I sewed them up carefully and entered the old fellow as No. 8. The men facetiously remarked that we had about enough mias to last through the remainder of that day.

About noon there arose another and louder shout from the men under the house, which increased to a perfect yell as a party of Malays came around the corner with another mias, the largest of all, alive, swinging underneath a pole which had been passed be- 
tween his hands and feet after they were tied together. This was a very old male, " mias rombi " (Simia satyrus), without the expanded cheeks. He was much emaciated, and the Malays said he had jungle fever, which really seemed to be the case. The Malays shot him in the ankle, and, being too weak to climb fast, he fell an easy prey and was taken alive.

Had he been unhurt I would gladly have kept him alive, but I am averse to prolonging the sufferings of hopelessly wounded animals under any pretext, or keeping any animal in painful and barbarous captivity. So I quickly thrust the point of my knife into the occiput of the half-dead animal, pierced his medulla oblongata, and, with a hoarse growl, he instantly expired. This specimen measured four feet four inches in height from head to heel, and eight feet between the tips of his fingers with the arms extended.

Two hours later, the little baby orang relieved me of all anxiety on its account by dying. Blou dryly remarked that it had found dying was getting fashionable with the mias and it wanted to go with the rest. This made seven dead orangs, big and little, to skin and skeletonize in one day! I had adult specimens of both species, male and female, and two young ones; and, by a happy coincidence, the Chinese, Dyaks and Malays had almost made a dead heat in the race after specimens.

There are many good people who are at a loss to understand how a naturalist "can bear to skin and cut up dead animals," no matter how rare and interesting they are. Many wonder how he can have "an appetite to eat," and cry out in holy horror at sight of the raw flesh under his knife. Well, tastes differ, that's all. As for myself, I would not have exchanged the pleasures of that day, when we had those seven orangs to dissect, for a box at the opera the whole season through.

It is a pity that men who "don't see how you can do it" could not have been there on that memorable occasion. When we finished, there was a small mountain of orang flesh, a long row of ghastly, grinning skeletons, and big, red-haired skins enough to have carpeted a good-sized room. I forgot to eat, and did not think of sleeping till after midnight. It was the most valuable day's work I ever did, for the specimens we preserved were worth, unmounted, not less than eight hundred dollars.

It was fortunate that we had such excellent facilities for drying skins as the open space at the back of the house afforded. I applied the preservatives myself to every skin and skeleton, and 
watched them daily to see that they cured properly. The necessity for this constant care of them kept me at Simujan several days, during which time the natives hunted diligently, and brought me many fine specimens both dead and alive. This is the list of one day's gatherings, exclusive of insects :

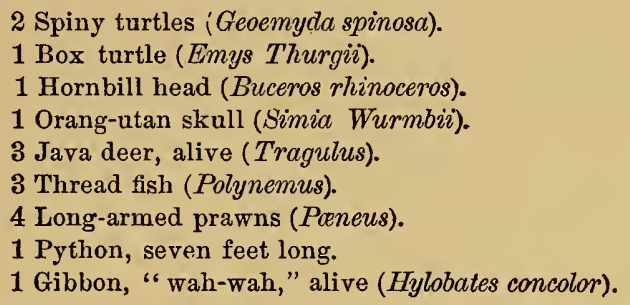

A few days after our great orang-utan day, a Dyak brought in another specimen, which in some respects was a remarkable one. It was a male mias chappin, with cheek callosities ten inches across, and it was evidently a dwarf, though of adult age. Its height was only three feet ten and one-fourth inches, and extent of arms six feet nine inches. The hair on his arms and legs was extremely long, that on his shoulders measuring twelve to fourteen inches in length, which was the longest $I$ have ever seen in an orang.

He bore the scars of many a hard-fought battle. A piece had been bitten out of his upper lip, and the lower lip also had been bitten through ; both middle fingers were off at the second joint, leaving mere stumps; the third right toe had disappeared from the same cause; the fourth left toe and both the great toes had been bitten off at the end ; one finger was quite stiff and misshapen from a bite, and, to crown all, he was actually hump-backed, caused, as I found on dissecting, by some violent injury, possibly a fall. $\mathrm{He}$ had evidently been a regular prize-fighter in his day, a first-class desperado. One of his canine teeth had entirely disappeared, shattered in some bloody fracas, perhaps. I warrant his enemies had good cause to remember him, for he was in prime fighting condition. But, alas! for him, his fighting days are over, and he now peacefully sits on the branch of a tree in the American Museum of Natural History, quietly eating a wax durian.

On the last day of August we made ready for another trip up the Simujan to Padang Lake. The boats were ready at two o'clock, but the tide was still at the ebb, a strong current was setting down the river, and we waited for the flow. Moreover, a great bore was 
expected to come up the river when the tide turned, and we were anxious to see it. Two miles down the Sadong we saw a ragged brown fringe, reaching across the broad river, and rapidly coming nearer. As it swung, like a long arm, around the point a mile below, we plainly heard it roaring like a distant waterfall. On it came, like a tidal wave, a great wall of surf, rolling and curling over at the top, backed by a rushing plain of water nine feet thick. It seemed like a thing of life and purpose, powerful, irresistible. I watched it every moment with the glass until it reached the mouth of the Simujan, where our boats lay. There were no boats on the Sadong, except two little sampans, manned by daring Malays, both of which were upset by the bore, but the occupants clung to their boats, and presently got ashore.

The height of the bore, as nearly as I could determine, was between nine and ten feet, and it travelled upward at the rate of about twelve miles an hour. At a distance of half a mile, the sound it made was like the roar of surf on a stormy beach. As the advancing wave struck the sharp point of land at the confluence of the two rivers, with a truly surf-like roar and thunder, a great volume of water came sweeping up the Simujan, filling the little ditches and catching up the boats that lay stranded high and dry on the muddy banks. In less than half a minute the little river rose eight feet, while, in the Sadong, we saw the great brown billows rolling past the mouth of our snug harbor, and chasing each other up the river in pursuit of the advancing torrent. Our light sampans swung round with the rushing current, the word was given, and we sped swiftly up the river with the advancing tide.

A short distance up we met a sampan containing two Dyaks who were bringing me two more mias, one dead and one alive. The latter was a two-year-old youngster, tied to a stout stick, with its hands above its head and its feet drawn well down and pinioned also.

It bit viciously at everything, and made strenuous efforts to seize any one who came near it. I would as soon have trusted a finger in a steel-trap as between those vicious jaws.

At last, despairing of getting a chance at any of us, the raging little wretch seized one of the fingers of its dead companion and bit it to the bone.

Both orangs were found on a tree near the Dyaks' village, and, having no fire-arms, they promptly chopped down the tree. The old one was killed with spears and parongs, and so badly cut to 
pieces that its skin was almost worthless. But I sent them on to Simujan, where I had left Perara to receive and take care of whatever specimens might arrive in my absence.

The Dyaks said that when the tree fell, a limb struck one of their companions and dislocated his hip, and they begged us to stop at the village and give him "obat" (medicine). An hour later we came to the village where our enterprising Dyaks lived, and, taking my box of medicines, I went ashore to see what I could do.

The house was of good size, containing about fifteen doors, and we were conducted to a room at the farther end where the injured man lay. He was not half so badly off as had been reported-a native rarely is for that matter. He lay on the floor with his injured leg lying in a swing, bared to the hip, and smeared all over with turmeric, which gave the limb an appearance of ghastly mortification.

I soon found that the hip had not been dislocated, and that the injury was only a very painful bruise. I bathed the limb with arnica and bound on a cloth saturated with the same, not so much for the effect it would have upon the injured limb as upon the mind of the sufferer.

Of course the inhabitants of the village crowded into the room and around the door to see what was going on-and such a crowd! Some had that repulsive skin disease called ichthyosis, which causes the epidermis to crack and loosen somewhat, and roll up in thousands of minute rolls, giving the otherwise dark brown body a grayish appearance, Others had large ulcerous sores on their arms and legs, which had been smeared over with turmeric and betel juice. Some had sore eyes, others had tetter and ringworm, and I think that of all the women who surrounded us in that room, about four out of every five were afflicted with visible ailments. It was the most unwholesome and afflicted crowd of Dyaks I ever saw, very different indeed from nearly all those I had seen elsewhere and saw subsequently.

Those who were not afflicted with cutaneous diseases were mostly old women and men, toothless and gray, with the skin hanging on their bare bodies in countless folds and wrinkles. Add to the above, tangled masses of jet-black hair, general nakedness, plenty of dirt, a little colored rattan and plenty of brass wire ornaments, and you have the most prominent features of the crowd which surrounded us. The house stood rather low on its posts, and the ground underneath was in a terribly filthy state, which, in a great 
measure, accounted for the ill-health of the occupants. My only wonder is that they did not die off altogether in a single year. In this village, be it remembered, we saw the Dyak at his worst, and we gladly left it behind.

Just before dark we passed the last Dyak village and kept on paddling for some time longer, until high water, in fact, when we tied up to the bushes for our evening meal, and, in spite of mosquitoes, slept soundly in the boats until morning.

About ten o'clock the next day we killed another good-sized orang, and at noon occurred the grand episode of our experience in Borneo, the death of the "Rajah," the largest orang of all.

We had just met a Malay sampan coming down the river, and, in answer to our inquiries, the occupants said they had seen no mias. Half a mile higher up we heard a deep guttural growl or roar, coming from the jungle back from the river, we thought, which put us on the alert. Presently Blou, who was steering my boat, whispered, "Mias! mias, tuan!" and struggled frantically to stop the boat. The paddlers backed water directly, although we saw nothing until the boat had backed several yards. Then we espied the knee of a large orang, who was lying on a branch about twenty feet above the water and only twenty yards from us. His body was entirely hidden by the green foliage, so I stood up in the boat and fired at his leg to rouse him.

"The Turk awoke." He started up instantly, growling hoarsely with pain and anger, and started to swing away. His reach was surprising in its length. Fortunately the water was deep, there were no screw pines to hinder our progress, and in a moment our sampan was directly under the old fellow, who then climbed high to escape us. It was a huge mias chappin, long-haired, big and burly. He growled savagely at us, and one of my men kept saying in large capitals,

"Chappin! chapPIN! Mtas chappin! fiRe, Sir! fire! fire!-That's mias chappin, big, BIG!!!"

The men were all greatly excited, but I knew that the old fellow was ours and waited for a good shot. In a moment the opportunity came, and I fired twice in quick succession at the orang's breast. He stopped short, luung for a moment by his hands, then his hold gave way and he came tearing down, snapping off a large dead branch as he fell, and landed broadside in the water, which went flying all over us. He fell within ten feet of our boat, and we secured him without getting out. 



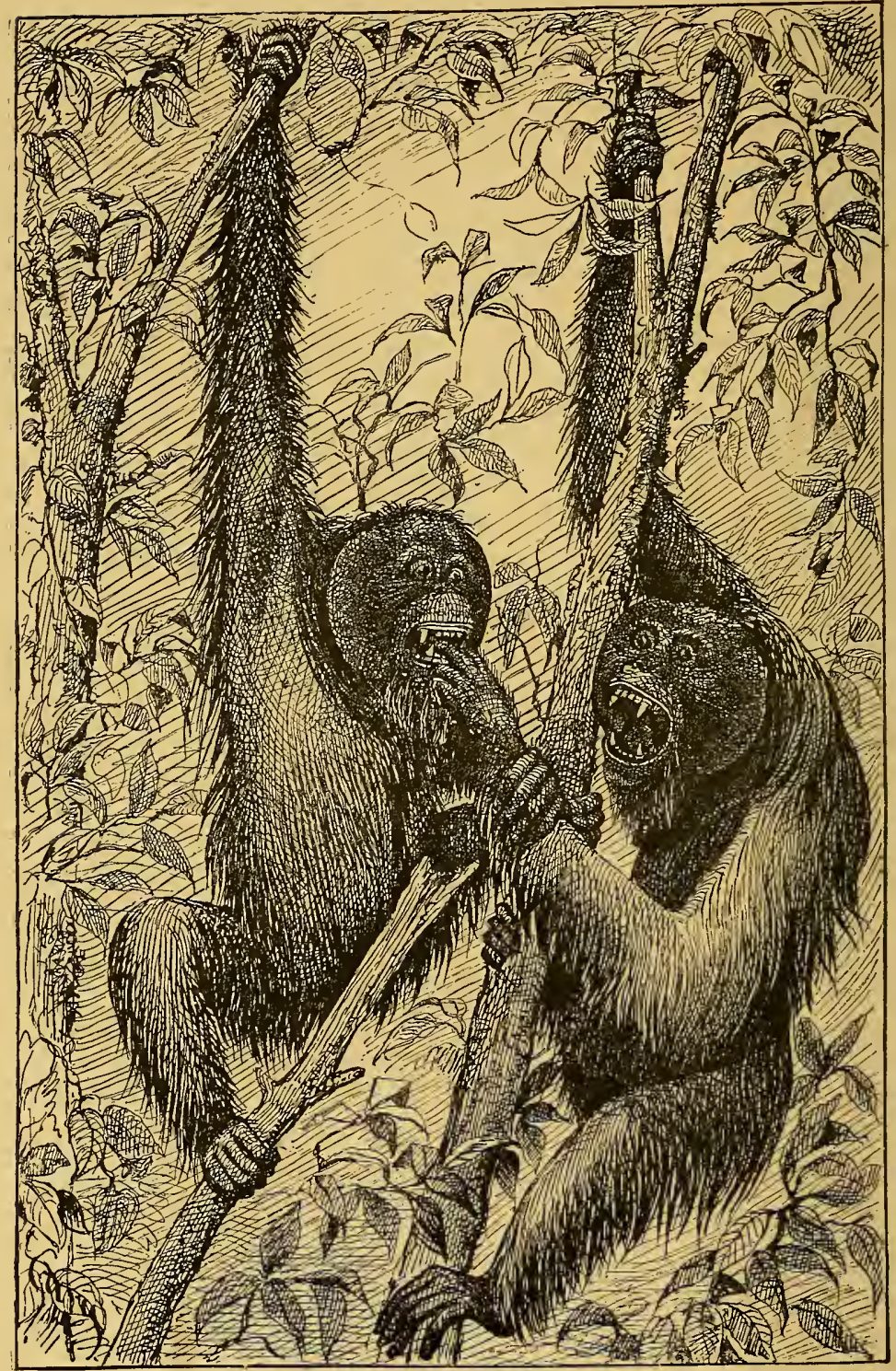

A FIGHT IN THE TREE-TOPS.

(Drawn from the group in the U. S. National 3 useum mounted by the Author.) 
As we seized the arms and pulled the massive head up to the surface of the water, the monster gave a great gasp, and looked reproachfully at us out of his half-closed eyes. I can never forget the strange and even awful sensation with which I regarded the face of the dying animal. There was nothing in it in the least suggestive of anything human, but I felt as if I had shot some grim and terrible gnome or river-god, a satyr indeed!

"Ahdo! Ahdo!" exclaimed Lamudin in Malay, "the Rajah of all the mias!"

We were all filled with wonder at the huge beast before us. He was a perfect giant in size, larger than any the natives had ever seen before, and the largest ever shot by a naturalist. His head, body, and limbs were simply immense, and his weight could not have been much, if any, less than one hundred and ninety pounds.

To give an idea of his size and proportions, I append his measurements, together with those taken of a man of average weight and stature.

\begin{tabular}{|c|c|c|c|c|}
\hline \multirow{9}{*}{ 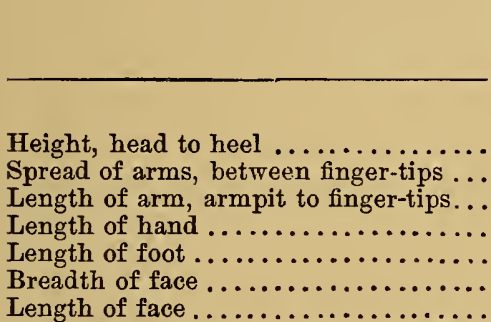 } & \multicolumn{2}{|c|}{$\begin{array}{l}\text { The Orang. } \\
\text { (Male.) }\end{array}$} & \multicolumn{2}{|c|}{$\begin{array}{l}\text { Medium-sized Man } \\
\text { (Anglo-Saxon.) }\end{array}$} \\
\hline & Feet. & Inches. & Feet. & Inches. \\
\hline & 4 & $5 \frac{1}{2}$ & 5 & 8 \\
\hline & 7 & $10 \frac{8}{4}$ & 5 & $7 \frac{1}{2}$ \\
\hline & 3 & $3^{2}$ & 2 & 5 \\
\hline & & $10 \frac{8}{4}$ & & $7 \frac{1}{2}$ \\
\hline & & $12 \frac{1}{2}$ & & 10 \\
\hline & & 13 & & $5 \frac{1}{2}$ \\
\hline & & $11 \frac{1}{2}$ & & $8 \frac{1}{2}$ \\
\hline Circumference of head, behind ears... & 2 & $7 \frac{3}{2}$ & 1 & 10. \\
\hline Circumference of neck ............ & 2 & $3 \frac{8}{4}$ & 1 & 3 \\
\hline Circumference of chest..$\ldots \ldots \ldots \ldots$. & 3 & $5 \frac{1}{2}$ & 3 & $2 \frac{1}{2}$ \\
\hline Circumference of waist ............ & 4 & 2 & 2 & $10 \frac{2}{3}$ \\
\hline Circumference of $\operatorname{arm} \ldots \ldots \ldots \ldots \ldots$ & & $12 \frac{1}{2}$ & & $11 \frac{1}{2}$ \\
\hline Circumference of forearm . . . . . . . & 1 & 2 & & $10 \frac{8}{7}$ \\
\hline Circumference of thigh ............. & & 7 & 1 & 9 \\
\hline Circumference of calf............ & & $11_{*}$ & & $2 \frac{1}{4}$ \\
\hline Weight (estimated) .............. & 185 & ounds. & 160 & ounds. \\
\hline
\end{tabular}

In another chapter will be found a somewhat extended description of both species of the orang, and therefore I will not offer here any information concerning the external characteristics of the animal referred to above. He has since found a place, with several of his nearest relatives, in a huge glass case in the National Museum at Washington, where he is engaged in a sanguinary "Fight in the 
Tree-Tops." In our illustration of that group, under the above title, the figure on the left is that of the "Rajah."

Late in the afternoon we arrived at the Popook village, where we stopped on our previous trip, and took up quarters as before. We remained one day to prepare our specimens, and one more in order to visit a large Dyak village, two miles above the north end of the lake, and on the day following returned again to Simujan. On the way down we took four mias, two old females and two yougg males, and overtook my old Chinese orang hunter in a sampan with two Dyaks and two dead mias, the latter for me, of course. One of the mias was a very large and fine one, although rather sparely built, and my mind was filled with gloomy forebodings that he was equal to the Rajah in height. When we reached Simujan I measured him forthwith, and my worst fears were realized. The animal was actually half an inch taller than the Rajah, and his height was therefore 4 feet 6 inches.

This was indeed a sad blow to us all, and cast quite a gloom over our spirits. Up to that moment the Rajah had been the tallest orang that ever fell into the hands of a naturalist, and I would fain have had him remain so. The old Chinaman had used me very badly, and I was shocked to observe that he did not feel the slightest contrition.

But, after all, the specimen I shot was considerably larger than the other, and surpassed it in every thing except height and length of arm. The Rajah outmeasured him in every other respect, had a broader face, longer and thicker hair, and a far more massive build generally. But for that disgusting half inch my specimen would have been entirely satisfactory.

During my absence Perara had received three other orangs, which made twenty-one in all. I had scarcely paid the old celestial for his specimens when a party of Dyaks arrived with two live ones. I recognized the larger as the one we met on our way up, and he was, if possible, more savage than ever. Even when I cut his bonds he tried hard to bite me, and when he was free, with the exception of a cord round his neck, the company very promptly and respectfully made way for him. I tied him by a long line in the unused bath-room, and he climbed up to the rafters, where he hung, sullenly refusing food, and even knocking the bananas out of my hand when I offered them.

The other live orang was a little fellow, a baby about six months old, of very different disposition from the other two. $\mathrm{He}$ 
was quite peaceable, not even once attempting to bite, but whined softly when I approached him, and rolled up his big brown eyes "ppealingly. His petition was not to be refused. I cut the bark that bound his hands and feet, and placed a pile of soft straw in the verandah for him, into the middle of which he immediately crawled and curled himself up. Thus began a great friendsbip between ape and man.

As a pet, the larger orang was not exactly a success. Day and night he clung to the rafters of the bath-room, as high up as he could get, sullenly refusing all food and repelling my most friendly advances. In the middle of the second night after I got him we were awakened by hearing something strike with a terrific "bang" on the bath-room floor, and, on going in, we found him lying where he had fallen, stone dead. 


\section{CHAPTER XXXII.}

\section{COLLECTING AROUND SIMUJAN.}

Native Hunters. - Two Orangs Killed at Simujan.-Nest-making by an Orang. -A Harvest of Mammals. - A Deputation of Dyaks from the Sibnyan.An Inviting Invitation. - The Rise and Progress of the Baby Orang.-An Interesting Pet.-Humanlike Habits and Emotions.-A Tuba-fishing Picnic.-Third Journey up the Simujan.-Snake Curry.-A Voyage in the Dark.

I GAVE gunpowder ("obat," or gun-medicine!) quite liberally to all the natives who requested it, Dyaks, Malays, and Chinese, and in every possible way encouraged them to hunt animals for me. I found them very diligent and businesslike, and not in the least tricky or dishonest, as were the natives of India and Ceylon, whom I had occasion to employ in the same way. It was a great pleasure to deal with the Simujan people, for they were so frank and honest.

Only one of my hunters was ever guilty of a breach of trust, and that was a young Chinaman of our village, who shot a wild boar in the jungle, a mile from the kampong, and cut it up without giving me a chance to skin it. Getting word of it I went over, confiscated the head, and read the young celestial a lecture that he remembered afterward to our mutual advantage.

After getting back from my second trip up the Simujan I determined to remain some weeks at the village, and, with the aid of my native hunters, give that locality a thorough overhauling.

Early one fine morning we heard the report of firearms coming from the jungle on the right bank of the Sadong, not more than a mile below the village. It continued for about an hour, during which time about twenty-five shots were fired, when it ceased, and a Malay came with a sampan after me. I got my rifle and returned with him, and, on wading three hundred yards into the forest, we found a large party of Dyaks and Malays with a dead mias on the ground and a live one "treed" in the top of a lofty tree. They 
were unable to hit it with their weapons, and no wonder. They were all old flint-lock muskets, and while the Malays aspired to leaden bullets, the poor Dyaks used chunks of iron, made by cutting round iron rods or bolts into pieces an inch long. I now understood why the Dyaks had never asked me for percussion caps.

I got there just in time to see the orang build a large nest for himself. He took up a position in a fork which was well screened by the foliage, and began to break off small branches and pile them loosely in the crotch. There was no attempt at weaving, nor even regularity in anything. He reached out his long, hairy arm, snapped off the leafy branches with a practised hand, and laid them down with the broken ends sticking out. He presently got on the pile with his feet, and standing there to weight it down be turned slowly, breaking branches all the while, and laying them across the pile in front of him, until he had built quite a large nest. When he had finished, he laid down upon it, and was so effectually screened from us that I could not dislodge him, and after two or three shots I told the natives they would have to cut the tree.

Three or four Dyaks were provided with biliongs, and after hastily lashing together a few poles, to serve as a platform to enable them to get at the trunk above the spur roots, they mounted it and began chopping.

The rapidity with which those insignificant little axes ate into the tree was wonderful. In an incredibly short time-less than half an hour-the tree fell, the orang revealed himself and was promptly killed. After we got home I devoted the remainder of the day to sketching the larger of the two orangs, a fine mias chappin, in different positions. With considerable difficulty we hauled him into the top of a tree that stood near the house, put him in a lifelike attitude, with his hands and feet grasping the branches and lashed him there, after which I made a careful sketch of him from the ground.

My native hunters brought me many fine specimens of mammals, a few large birds, many reptiles and a few fishes. The most successful of all my collectors was a fine Dyak named Dundang, already spoken of, who shot four orangs, several rhinoceros hornbills, two or three proboscis monkeys, a wild hog, and quite a number of small mammals. One of the orangs he brought me had the hair on its back quite blackened and singed, as if it had been killed at close range. Upon being questioned, he said he wounded the mias, but could not bring it down, and having fired all his charges but 
one, he climbed into the tree containing the orang, put the muzzle of his gun so near the animal's body that he could not fail to hit, and fired.

The Malays are quite expert in catching deer. Besides noosing a fine sambur buck (Rusa equina?) they caught for me Java deer ("plandok"), one after another, until I cried enough. The latter (Tragulus napu) is the smallest of all the deer tribe, being a true pigmy only nine inches high, very trim, graceful and pretty, but, unfortunately, without antlers. The sambur was a much-dwarfed, faded-out, thin-haired representative of his species, in comparison with the noble stags of the Animallais. His antlers were also very insignificant in comparison, but as for that I have seen fully as great variation in the antlers of our Virginia deer in a far smaller area of distribution.

Two specimens of a curious viverrine animal, half cat and half otter, the Cynogale Bennettii, were brought in, several civet cats, a beautiful flying lemur (Galeopithecus volans), and a slow-paced lemur (Nycticebus tardigradus). The Cynogale, for which I believe there is no common name unless we call it the otter cat, is peculiar to Borneo, and only one species is known. Its muzzle is extremely broad at the end (23 inches), but narrows suddenly midway between the end of the nose and the eyes, which gives the head a very strange appearance, totally unlike that of any other quadruped I am acquainted with. The animal is $24 \frac{3}{4}$ inches in length of head and body, and the tail measures 7 inches. It is covered with a rather thick coat of moderately long but fine fur, of a uniform dark-brown color. I shot in the neighborhood several specimens of the common gray monkey (Mracacus cynomolgus), a pig-tailed macaque (M. nemestrinus), here called the "broque" in Malay, from which the outlandish common name of " bruh" has been evolved.

" One day a party of Dyaks arrived from the head of the Sibuyau River, between the Sadong and Batang Lupar, bringing several fragmentary skins of argus pheasant, which had been taken off in native fashion for the wing and tail feathers, and also a live argus. The poor bird had had a hard time of it, and in looking at it I felt guilty of cruelty to animals. In its struggles it had lost half its body feathers, and, worst of all, when it was caught in the noose one of its legs had been dislocated. I lost no time in putting it beyond the reach of further pain.

The Sibuyau people told me that argus pheasants and animals of many kinds I had not yet found were plentiful around their vil- 


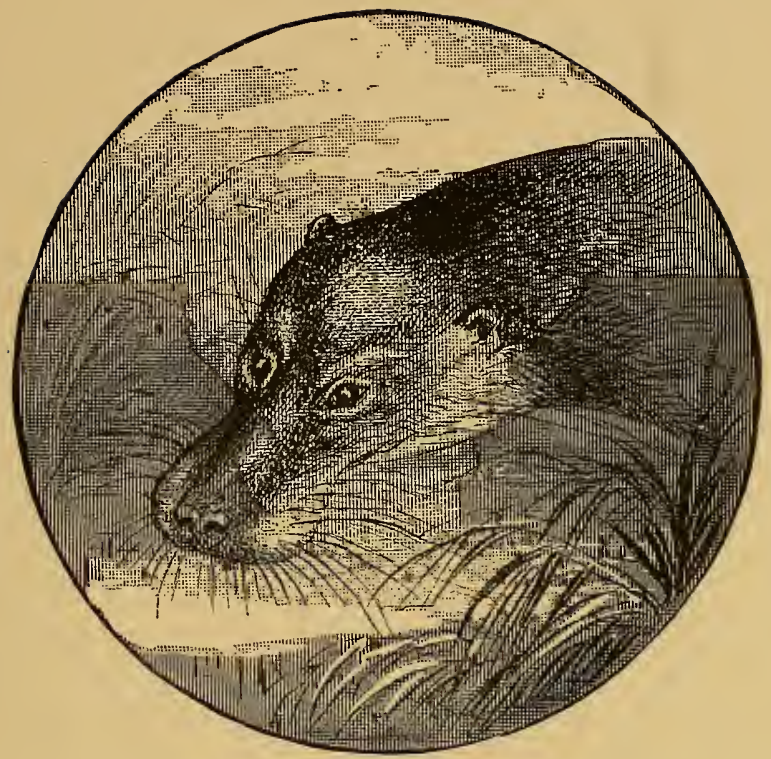

HEAD OF CYNOGALE BENNETTII.

(slietched from life.)

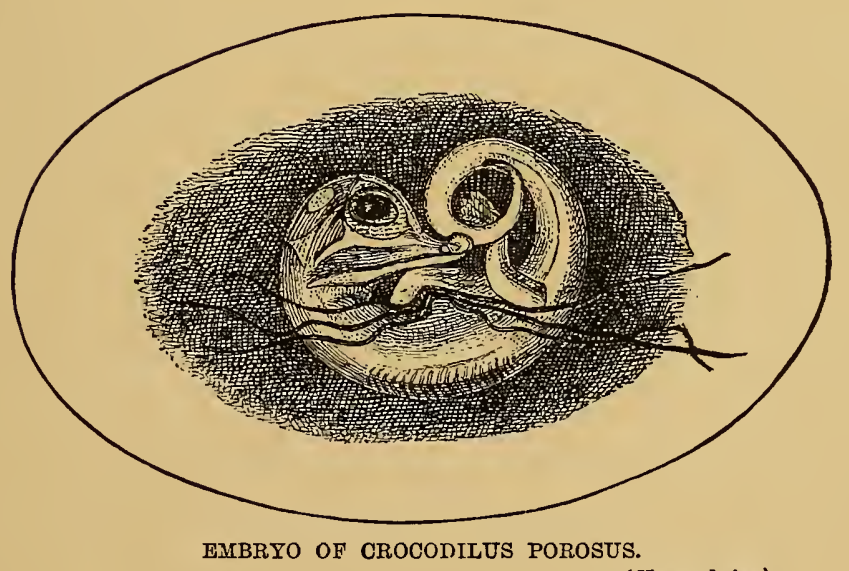

(Natural size.) 



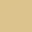

(1)

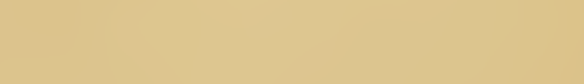

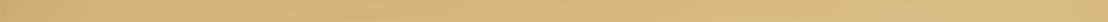




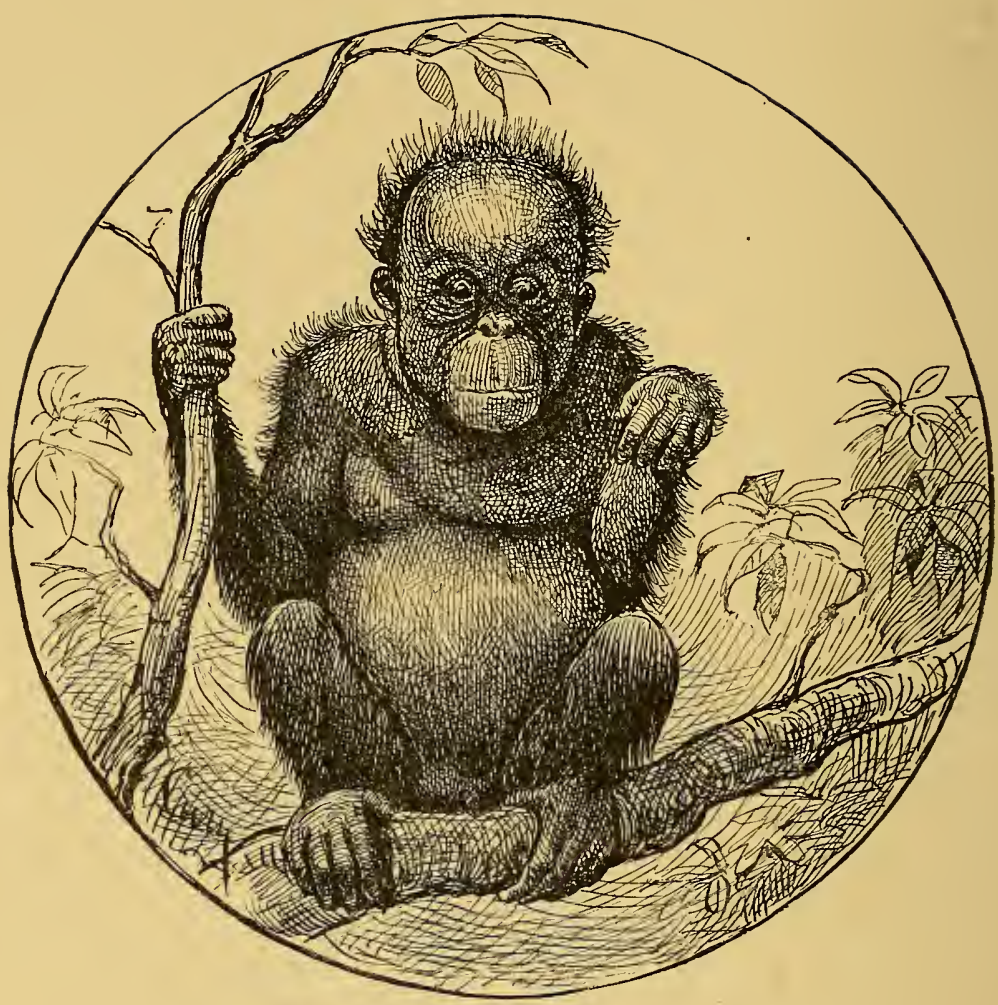

THE "OLd MaN." (Young Orang-utan.)

(From an instantaneous photograph.) 
lage, and gave me a pressing invitation to make them a long visit. I determined to accept it as soon as I had worked up the Sadong region sufficiently, and told them they might expect me in a few weeks.

The baby orang mentioned at the end of the preceding chapter became a striking example of the survival of the fittest. While my first two captives were vicious to the last degree, and died promptly, without repentance, my third pet turned out to be all that heart of man could desire in an orang. He was by no means a thing of beauty, but he certainly was a joy forever.

Judged by our standard of human beauty, he was perhaps as ugly as any healthy child could be and live; but, for all that, his homeliness was interesting; it seemed to conform to a general plan of ugliness, and nothing was lacking to make it perfect. But, judged by the standard of anthropoid beauty, he was as handsome and wholesome a little orang as ever climbed. His eyes were large, bright and full of intelligence, and he had a forehead like a philosopher.

Because of his bald and shiny head, his solemn, wrinkled and melancholy visage, his air of profound gravity and senatorial wisdom, we got to calling him the Old Man, and forgot to give him any Christian name. A thin growth of brick-red hair grew straight up the back of his head and over the crown, making, in certain lights, a perfect halo around his bald, brown pate, reminding one rather forcibly of certain pictures by the old masters.

I measured him, for the first time, on October 15th, in spite of his vigorous opposition, and found that his height was $21 \frac{3}{4}$ inches, extent of arms $34 \frac{1}{2}$ inches, and his weight $10 \frac{1}{2}$ pounds. His body was short and thick, and, like all orangs, his arms were so long and his legs so short that by stooping forward a little, his hands easily touched the ground. In walking, he invariably went on all fours, placing the back of the fingers and ball of the thumb, instead of the palm, upon the ground, and he also turned his toes under. His gait on the ground was very much like that of a man going on crutches with both feet injured alike. On the ground he moved slowly, seeming quite out of his element, but his feats in climbing and his performances on the slack-rope were highly entertaining.

He was fresh from the jungle when brought to me, but I soon convinced him that my intentions were honorable, and slowly gained his confidence. For three or four days he would not allow me to hold him in my arms unless I would let him grasp some firm object 
with at least one hand. The action plainly showed that he feared I would play a trick on him by letting him fall. Presently, however, I hit upon a plan which conquered his suspicion. I made him climb up to my shoulder to get the bananas of which he was very fond, and, after that, a banana held at arm's length above my head would start him to climbing my body as if it were a tree until the tempting bait was reached.

He soon became very fond of being held in my arms, and when I grew tired of holding him, he would grasp the folds of my flannel shirt and hold himself-quite an improvement upon the puny helplessness of human infants.

Next to eating seven bananas at once, his greatest delight was in sitting lazily in my lap while I sat reading, writing, or even eating, sprawling out his legs and arms, catching hold of my book, or my penholder, or pulling at the table-cloth.

Once while holding him in my lap at dinner, he suddenly made a pass at the roast duck which lay before me, and had his teeth in it before I could recover from my surprise. On one occasion when I sat eating, he leisurely climbed up the back of my chair, squatted on the topmost round, leaned lazily forward against me, and rested his chin comfortably on my shoulder. And there he sat all through the meal, watching the performance with the air of a connoisseur.

For a long time he would eat nothing but bananas and sugarcane, and I was at my wits' end to find a way to teach him to eat boiled rice. One day, however, as he was sitting in my lap while I was at dinner, I noticed that his eyes followed the journeys of my spoon with great interest, and it occurred to me that human beings always want what they cannot have. Happy thought! I began to pass each spoonful of rice close to his mouth on its way to mine. He soon began to open his mouth every time he saw the spoon coming, only to be disappointed by seeing it travel on to his next neighbor. From being merely willing to try the rice, he became very anxious when he saw it was denied him, and a little more tantalizing set him to struggling violently for the food he had previously despised. When it was finally given him he ate it with the greatest satisfaction, and thereafter, with the addition of milk, it became his daily food.

He also learned to eat with relish all kinds of cooked meat, vegetables, canned fruit and bread, and to drink tea, coffee, mill and chocolate, in all respects eviucing the tastes of a human being 
-except that he would not touch beer, wine nor spirits. He lived and died a teetotaler.

The Old Man soon grew fat and mischievous, and always did his best to amuse me. Many an absurd childish game we played upon the floor in highly undignified fashion. One of his favorite tricks was to seize my hand suddenly, draw it to his mouth, and make a feint of giving it a terrible bite. But he always knew that he must bite gently, which is more than can be said of any human infant I ever experimented with. Often he would entertain me for half an hour by making the most comically wry faces, for which his broad, india-rubber lips were specially adapted. $\mathrm{He}$ was also a great contortionist, and, having no ligamentum teres, the freedom with which he used his legs was at first quite surprising.

When at Simujan I slept in a tall and wide "four-poster," and the little fellow was always anxious to sleep with me. Whenever I permitted him to do so, his happiness was complete. His farorite position was to lie sprawling upon my chest, affectionately clasping my body with his outstretched arms and legs, with his head on my shoulder and his face close to my neck. Being as clean and wholesome as any human being, and without any odor of tobacco or liquor on his breath, he made a very agreeable bed-fellow until he got into the habit of snoring and sneezing so much as to disturb my slumbers, when it became necessary for him to sleep by himself. Meanwhile, I watched him closely, and did everything I could think of to arouse his mind to action, and stimulate it to act in different directions.

About this time I had another very interesting anthropoid pet, a young gibbon, which I purchased at a Dyak village. Instead of hobbling along like the little orang, which used its arms as if they were crutches, it would stand perfectly erect, partially extend its long, thin arms out sideways to balance himself, and walk across the floor with brisk confidence. When in good health it was quite friendly, and even affectionate, but in spite of my efforts to prolong its life it soon sickened and died.

On September 27th, a bore again came up the river, and on the day following the tide rose to an unusual height, about fourteen feet, covering every speck of land in the kampong, so that the Malays paddled from house to house in their sampans, and Ah Kee had to wade knee deep in water to get my dinner from the cookhouse to the table. It was like a Mississippi freshet, except that it departed as suddenly as it came. 
On October 2d Mr. Eng Quee got up a grand tuba-fishing party, and invited me to make one of it, which I was very glad to do. We rose at midnight and started down the river with the ebb tide. I lay down in the boat and slept until we arrived at the mouth of the Ensengi River, a large creek which empties into the Sadong from the west, about six miles below the village. We found there a number of Malays in sampans, patiently waiting for daybreak, and, after a good deal of time-killing banter, all hands lay down and went to sleep.

At daybreak the little fleet of canoes started up the creek, and, after paddling about two miles, the stream rose above tidal influence, and the banks were thickly fringed with pandanus. The rendezvous was about four miles up.

When all had arrived there were present twenty-three sampans, manned by about sixty Malays. The first thing in order with the Malays was the usual breakfast of boiled rice, which many had brought cold, wrapped in banana leaves, and others cooked on the spot. After that, all fell to work to prepare the tuba, which is the fine, fibrous root of a climbing plant (a species of Menispermum), which possesses a powerful narcotic principle, and is grown for the special purpose of taking fish. It was done up in small, close bundles, the thickness of a man's wrist and six or eight inches long, and was dry and hard.

The bundles were distributed so that each boat received four or five, each man procured a stout little club of green wood, and the pounding began. The game was to reduce the tuba to a pulp, and for an hour sixty clubs beat a lively tattoo on the root bundles as they were held on the edges of the boats. A quantity of water, perhaps twenty gallons, was dipped into each boat, into which the tuba was dipped and wrung out from time to time, until it gradually softened under the pounding process and was reduced to shreds. When water was squeezed out of the tuba it had a white, frothy appearance, like soap-suds.

As fast as the bundles of tuba were reduced to fine shreds, they were chopped up with a parong, and the particles mixed with the water in the boats. When all the root had been thus pounded and chopped up, the Malays procured lumps of clay and dissolved them in the solution until it was made quite murky. Each boat contained about twenty gallons of this narcotic extract.

The stream was about forty feet wide and eight to ten feet deep, the current was swift and the water rather murky. 
We waited until the tide was half out, and then, after selecting a good place, the boats drew close together, the word was given, and with a ringing cheer the extract was quickly dipped up and thrown into the stream. As I looked at the small quantity of tubawater and the volume of water in the creek I must confess to entertaining doubts of the result.

Having performed the act of faith, we began at once to look for fish. The stream absorbed the tuba-water as though it had been so much dirty soap-suds, and not a trace of it was to be seen five minutes after. We drifted slowly down to where there were curves and quiet eddies in the stream, and each man looked for what he considered the most likely place for a fish to rise. Presently we saw two little fellows floating helplessly at the surface, and the man nearest them kindly took them in out of the wet.

Each man had a small dip-net and a "grains" with two or three prongs. The spear-head was set in the end of a bamboo handle so that it would come out when a fish was struck, and of course the spear-head was made fast to the handle by a stout line. Mr. Eng Quee had provided me with a spear, which I was very anxious to use.

Just as our boats reached a wide bend in the stream, a large fish showed its slimy, black back at the surface, just out of our reach. My first thought was that it was a porpoise, it was so large and black. Presently it appeared again and floated for a moment with its back out of water. It was certainly four feet long. Mr. Eng Quee and one of his Malays threw their spears at it but missed. Then I skipped to the bow of my boat, and finding myself within reach of the fish drove my spear into its side. It gave a lunge forward, almost throwing me overboard and upsetting the boat, and then-Oh ! my soul! the line snapped! Down went the huge fish, and we never saw him again. I hoped that some one of the party would see him and take him in, but was disappointed.

Fifteen minutes later, another big fish of the same kind came up, was speared by two Malays, and after a gallant struggle was secured. It was a little over three feet long, scaleless, with a broad, flat head, somewhat like that of a catfish, a thin body, small dorsal fin and the anal fin very broad and long. Its color was blackish-brown, with three light bands along the middle of the side. Altogether nine large specimens of this species (Wallago leerii) were taken during the day.

The tide was still running out when we arrived at the mouth of 
the creek, and many fish were found stranded on the mud along the banks, dead and dying. The Malays waded along at the water's edge, knee deep in mud, to secure those that came ashore, and also others that rose to the surface close to the bank.

Just at the mouth of the creek we found numbers of small fish floating at the surface, of which we easily secured fifteen with our dip-net. All but three were thread fishes, a strange species of Polynemus, which is readily distinguished by the extremely long; white, threadlike filaments, more than twice the length of the whole fish, attached to the pectoral fins. This is, in more respects than one, a very curious fish, as may be seen by an examination of the excellent figure given herewith.

The Malays were desperately fish-hungry, and I could not induce them to sell many of their largest fish, but I consoled myself with the purchase of the smaller ones, and also a very fine large turtle which was caught in a net.

Among the most interesting species taken were Periophthalmus schlosserii, our old friend of the Selangore mud banks, the airbreathing Ophiocephalus, and the celebrated gourami (Osphromenus gourami), a large and fine fish of great economic value, and well known to ichthyologists, especially those engaged in fish culture, from the numerous efforts that have been made, many of them successful, to acclimatize it in various countries from the East Indies to the United States. I found it native to Selangore, where I obtained one very fine specimen. Since there is already an abundance of literature on the gourami, I will add only a reference to the accompanying illustration, which is a reproduction of a figure given by Dr. Theodore N. Gill in his paper on this species, which appeared in the Report of the U. S. Commissioner of Fish and Fisheries in $\mathbf{1 8 7 6 .}$

On the tuba-fishing pic-nic referred to above, I was fortunate in securing a specimen of the very rare and curious little pike-head (Luciocephalus pulcher),* the jaws of which are capable of being protruded far forward, thereby rendering the mouth sub-tubular. The name, Luciocephalus, meaning as it does, "pike-head," is a very apt one, for the head certainly much resembles that of the familiar pike or pickerel of our home waters. The fish, however, is

* For the identification of the fishes I collected in the Sadoug River and its tributaries (35 species), I am under obligations to Dr. Tarleton H. Bean, Curator of Fishes, U. S. National Museum. 


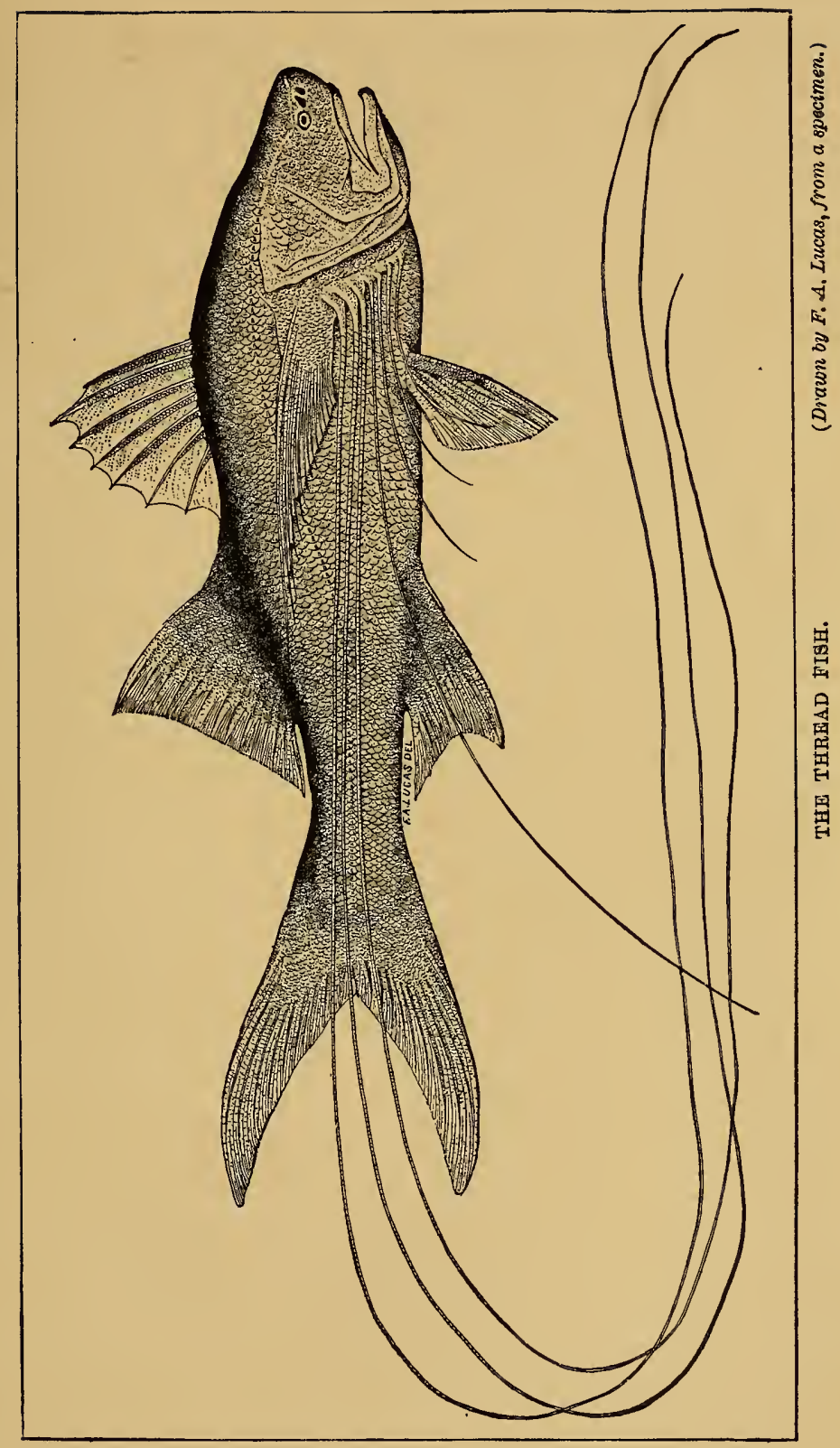





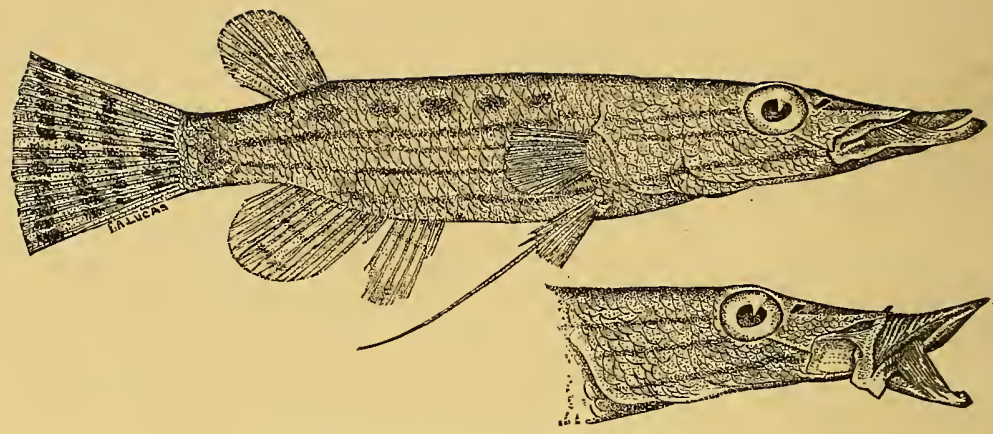

LUCIOCEPHALUS PULCHER. (Page 386.)

(Drawn by $F$. A. Lucas, from a spectmen.)

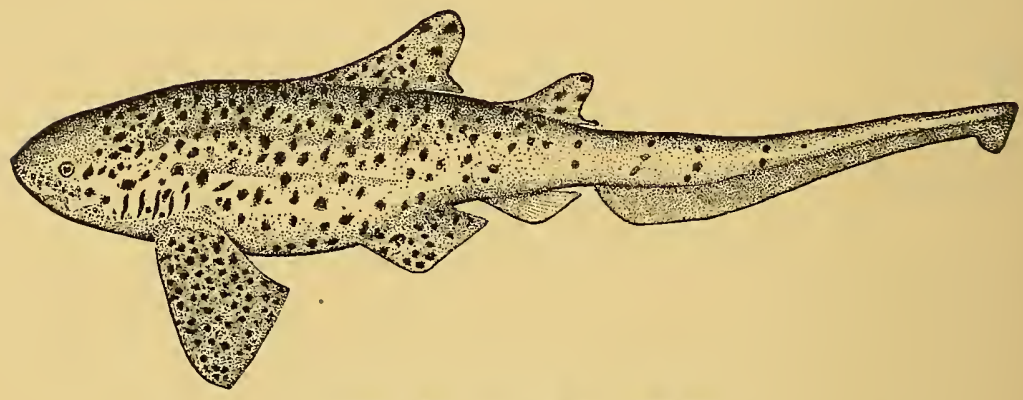

STEGOSTOMA TIGRINUM. (Page 256.)

(From Author's sketch) 
not at all related to the pike, but is nearest akin to the peculiar fishes with labyrinthiform plaryngeals, known as the Anabantids, and comprising, among others, the climbing fish and gourami. Its combination of peculiar characters renders it an object of great interest to naturalists, and by them it is considered to be the representative of a special family, - the Luciocephalids.

The next day my hunters brought me a rhinoceros hornbill, two proboscis monkeys, a live slow-paced lemur (Nycticebus tardigra$d u s$ ) and a brilliant emerald-green tree-snake (Passerita), about six feet long, which was the most beautiful serpent I ever saw. A Dyak boy brought it in his hands, and I received it in mine without any of the revulsion of feeling one ordinarily feels in handling a live snake.

It was a sociable sort of a snake, not in the least nerrous cn account of its captivity, and I kept it alive for some hours, and allowed it to crawl quietly over my table and around the room. I was quite charmed with its splendid color, lithe, beautiful form, and graceful movement. It was a painful matter to both of us when I was at last obliged to consign it to the alchohol ean.

Late in the afternoon of October 4th, I started on my third and last trip to Padang Lake, with the intention of living at the Popook village for two or three weeks. Our starting was delayed by the arrival of a large civet cat, a wild cat, and a wild hog's head, all of which had to be attended to immediately. I took the little baby orang with me, partly because I did not like to risk leaving him, and also because I liked his company.

Darkness overtook us before we had gone far, but it was a clear moonlight night and we expected to make a long pull before tying up. Very soon, however, the sky became overcast with heavy black clouds, making the darkness very intense, and the lightning and thunder foretold an approaching storm. Just before it broke, we came to a tiny Dyak hut, about eight feet square, recently erected at the edge of the bank, and, making fast to the shore, we quickly climbed the ladder and craved shelter. "The man of the house" was at home, with his wife and two children, and we were received with true Dyak cordiality. A dammar torch was burning near the door, and in a corner a small fire was smouldering on a bed of clay. The hut which sheltered us from the pouring rain was of the kind frequently seen along the Sadong and Simujan, a mere temporary erection, built in three days, and occupied only while the owner was planting a crop of paddi and afterward while harvesting it. 
Learning that we were interested in animals, our host exhibited a water-suake about four feet in length, which he had caught in the river that afternoon, and intended to eat. He said it was a clean snake, because it lived on fish. Ah Kee expressed some surprise and incredulity at his intention, whereupon the Dyak immediately proceeded to roast the serpent on the fire and strip off the skin, preparatory to making a snake curry. He said that his people eat large lizards also.

As soon as the rain ceased we proceeded, but before long it began anew, so we tied up at the first Dyak village we came to, and made ourselves comfortable until morning.

The next day was beautifully clear and balmy, of the kind which makes mere existence a delight. We paddled up stream in high spirits, shooting a monkey now and then, halting at noon for a good square meal on a fine bit of dry ground, left so by the greatly lowered waters of the stream. When it came time to eat, my stomach was empty and craved supplies; but it utterly refused Ah Kee's oft-repeated stewed duck, rice, and yams. My appetite called for a new deal, and Ah Kee responded with a tin of "biscuits" (crackers), another of American pressed beef, and a can of delicious cherries, all from San Francisco. How appetizing was that ration of home-grown beef and fruit!

The water in the river was about three feet lower than we had before found it, and dry ground was noticed in several places. Just before sunset we became involved in a chase after a big troop of proboscis monkeys, which consumed considerable time and left us wet, tired, and baffled. Then darkness fell and it began to rain. We were four miles from the Popook village and with a labyrinth of screw pines to go through in the dark, but we were in no condition to remain all night where we were. The two Malays who paddled Eng Quee's boat announced their determination to stay where they were until morning, so I got into my own boat, and told my boys we would go on. The Malays declared it was impossible to go through the screw pines in the dark, but we left them to their own devices and proceeded.

I think I never saw a blacker night. It rained steadily, though not in torrents, and the lightning aided us very effectively. My little Malay man Dobah did the steering. Ah Kee and Perara sat under the kadjangs and paddled, while $I$ sat in the bow, paddling also, and acted as a pilot. How we ever found the entrance to that blind passage through the pines will always be a mystery to me, 



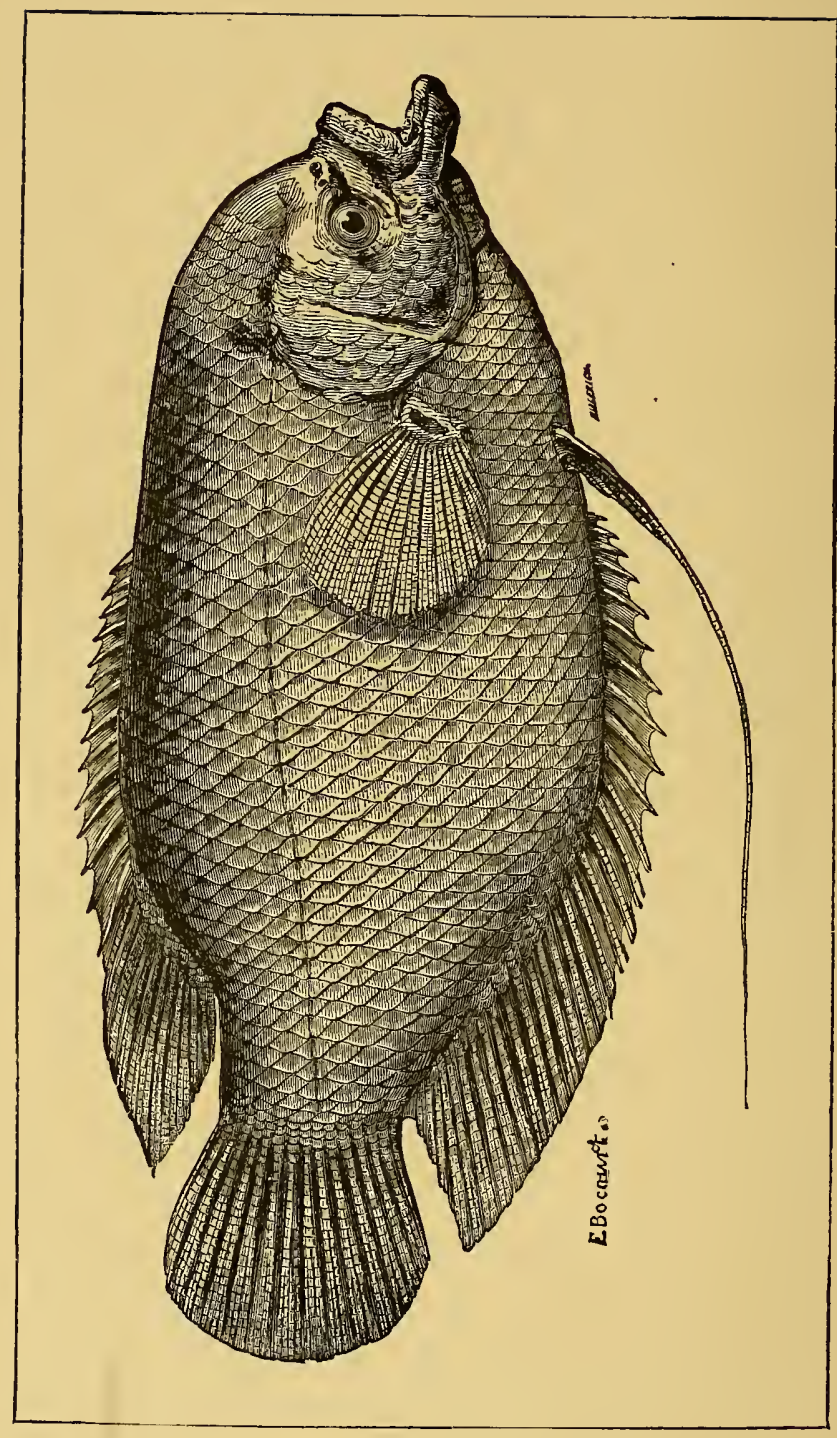

불 
and how we ever got through that narrow, zigzag tunnel in the dark without going astray also passes my comprehension at this time. In many places the channel was so filled with floating Pandanus stems as to be almost impassable, and many times our boatroof was caught by overhanging branches and nearly dragged off. Aided by the lightning flashes, and the slight reflection on the open water, I was able to spy out the passage a few yards at a time and give directions to the steersman.

At last, to our inexpressible relief, we emerged on the open water of the lake, and headed north. By this time the clouds had lifted a little, and we were able to distinguish Gunong Popook. After several trials we found the landing, and a few moments later climbed the ladder of the village. Great was the astonishment of the Dyaks when they saw a white man enter at the door, rifle in hand, with a little red-haired orang-utan clinging to his shirt. There was a large party of visitors in the village, and when we told them from whence we came since nightfall their surprise was profound.

"And who showed you the way?" they demanded.

"The tuan" (mister).

"Ah-doe! Ah-doe! Ah-doe!"

We were wet, cold, and hungry, but all these evils were speedily corrected, and our enjoyment of them was intensified by the thought of Lamudin and his companion in their wet boat on the river, plagued by darkness, rain, mosquitoes and hunger. 


\section{CHAPTER XXXIII.}

\section{COLLECTING AT PADANG IAKE.}

A Hunt on Gunong Popook.-A Lost Hunter.-A Handsome Dyak. - A Reception by Torchlight. - More Orang-utans.-How an Orang Sleeps.-Proboscis Monkeys.-Living rersus Stuffed Specimens. -A Remarkable Nose.Luckless Gibbon-hunting. - Luckless Wild-hog Hunting. - Mud and Thorns.-Picturesque Vegetation._Fresh-water Turtles and Fishes.-Return to the Sadong.

I sPENT a most delightful fortnight with the Dyaks at the Popook village. The weather was continuously fine, the Dyaks were agreeable and interesting, the jungle yielded a good harvest of specimens, and every day there was something new to see and to do.

I presently sent Lamudin and his companion back to Simujan, and with my three other men settled down comfortably to hive and work.

My first experience was a rather ridiculous one for me, and consisted in my getting lost, almost within sight of the village. During the afternoon of the day following our arrival, we heard some wall-wahs (gibbons) crying in the tree-tops, far up the steep side of Gunong Popook, and, hastily catching up my shot-gun, I started for them.

My boy Perara was also hunting on the mountain, and, before I had quite reached my game, he fired twice, close-by, which scared the wah-wahs into silence and out of the neighborhood. I climbed on until I reached the summit of the mountain, which is a perfect cone only a few yards across at the top. Just as I reached the summit, a female sambur deer ran along the steep slope, forty yards below me, in full view. Having only small shot in my gun, it would have been worse than useless to have fired.

Presently, I began to slowly descend. As I was quietly stooping down to examine some shells, another sambur, also a doe, trotted 
up, halted, and stood stock still in full view, not more than twenty yards away. I thought of Balram and how he wished for his sword, and sympathized with him while I thought of my rifle. She impressed me as being the least handsome of all the deer tribe, excepting, perhaps, the female moose. After we had stared at each other a few seconds she trotted off, and a few moments later I saw a stag of the same species, whose antlers were in the velvet. It literally rained sambur because my dish was bottom up.

After wandering about for some time to no purpose, I set out to return to the house. Half way down I shot a black monkey or "bijit" (Semnopithecus femoralis), slung it over my shoulder to carry home, and made for the clearing on the mountainside. After a slow and painful struggle through several acres of thorns $I$ heard a dog bark, saw the edge of the clearing, and knew that I was near the house. At last I reached the edge of the clearing and heaved a sigh of relief, but lo! it wasn't our clearing at all! I had never seen it before, and knew that there was no such spot within a mile of the Popook village. The explanation was not difficult. In coming down the mountain I had made altogether too many degrees of longitude at the top, which brought me out on the west side instead of on the south. It was almost sunset, there was no path leading south from the clearing, and I knew that I could not possibly make my way through that thorny jungle at that time of day without getting lost and benighted.

Seeing smoke at the farther end of the clearing, toward the north, I went toward it, resolved to bivouac in good style, and, if it became necessary, roast my black monkey and sup on it. But I found a path leading away from the clearing, and followed it up rapidly. After walking about a mile, I came to a small Dyak house of four or five doors. Calling out the inhabitants I said to them in Malay, "Give me two men go Popook Dyak house, quick!"

They asked a question or two which I did not quite understand, and therefore answered somewhat at random. They civilly invited me to come in and sit down, and chew betel with them, but with equal civility I declined and urged them to come on. Straightway two of the young men arose, took a fresh chew of the betel, girded up their loins, tied on their parongs and said they were ready. I said we had " better go lake, go boat," and we started for the lake at once.

Both my guides were as fine-looking Dyaks as any I saw in Sarawak Territory. One was a youth about seventeen years old, 
with an intelligent, even handsome face, a beautifully-moulded form, erect carriage, and easy, graceful movement. On the score of good looks and general physique he could discount nine-tenths of all the white boys I ever saw.

The two were dressed alike, in decidedly picturesque costumes. The head-dress was a clean turban of bright scarlet cloth, neatly wound around the head, with a loose end falling over the left ear. The crown of the head was wholly uncovered, and a profusion of jet black locks fell over the top of the turban. The "chawat," or loin-cloth, was also scarlet cloth disposed in ample folds, fringed at both ends, one of which hung down apronlike in front, and the other at the back.

Each of the Dyaks wore behind him, suspended by a cord around the waist, a shield-shaped mat of many colors, which quite covered the body from the loins half way down to the thighs, and was evidently worn to sit upon. One of these protectors was ornamented by a border of cowries sewn on close together all the way round.

Their parong sheaths were each bedecked at the end with a bunch of the most showy wing and tail feathers of the argus pheasant. The persons of my guides were further ornamented by several copper rings worn in each ear, which proclaimed them to be Seribas men, bracelets and armlets of finely-plaited rattan, and leglets of beaded rattan worn just below the knee. Taken altogether they were as handsome savages as one could wish to see.

On reaching the lake, which was about a mile from the house, the Dyaks found two paddles that had been hidden in the grass, dipped the water out of a sunken canoe, and, getting into it, we set off just as it grew dark. As we neared the Popook village we heard people calling for me far up the side of the mountain, but I was not able to make them hear my answering shout. As soon as we reached the village the gong was beaten and several shots fired to call back the four Dyaks and Dobah, who were then far beyond the clearing. I was very well pleased to find that they had turned out so promptly to look for me; going, as they did, naked and barefooted, in the dark, into thick jungle among rocks and thorns. As they were returning, ove of the Dyaks was charged upon by some large animal, presumably a deer, knocked down, considerably bruised and dreadfully scratched, besides receiving a cut on his leg and another on his ear. The suddenness of the assault and its mysterious nature caused great excitement and a volume of loud talk. I served out tobacco to the crowd and dressed the wounds of the injured 
party with arnica and court plaster, which pleased all the Dyaks very much and placed us all on confidential terms.

The natives sat by and looked on with great curiosity while I ate my supper. Afterward they examined my shoes with great interest, and one man succeeded in putting one of them on. They also inspected my feet closely, and a comparison of theirs with mine was the cause of much merriment.

I took advantage of their good humor to ask them about the little metallic plates on some of their front teeth, which looked like gold. I found that each upper incisor and canine tooth was capped by a smooth plate of copper, held in place by a pin driven into a hole in the tooth. The Dyaks showed me how the hole is drilled (with a bow), and one imitated the agony they endure during the operation. He was a good actor, and his facial and bodily contortions and writhings excited roars of laughter.

The next day, while again climbing up the mountain after wahwahs, my Dyak companion discovered an old female orang-utan seated quietly on a branch not more than thirty feet distant. I fired at her, and my bullet killed both her and the baby which she was holding in her arms. Although she was very small, only 3 feet 6 inches in height, she was so old her teeth were worn down to mere stumps, and several had entirely disappeared. Her hair was rather short, on account of which the Dyaks declared her to be a "mias kassar," and therefore different from the other varieties, "rombi" and "chappin."

On the morning of the third day, I took one Dyak and Dobah, and set off in my boat to visit the southern end of the lake. It was delightful weather. There was not a ripple on the surface of the lake, which lay like a polished mirror, reflecting the blue sky and its fleecy clouds, the dark-green mountain and the fringe of forest trees along the banks. Scarcely a bird's song broke the stillness. It was like a landscape in a dream-sunny, silent, balmy and clear. One day in such a spot is worth the toil of half a year to gain it.

Half way down the lake we discovered a fine old orang, lazily finishing his morning nap. His nest, which was nearly three feet across, was not more than fifteen feet above the water, and he lay sprawled out upon it, flat on his back, with the sun at the back of his head, sound asleep. His hairy arms and legs were thrust outward and upward, and his hands (an orang has hands on his legs, if you please) were firmly but mechanically grasping the largest branches while he slept. The back of his head was toward us, and, 
after silently paddling up to within fifteen yards of him, I stood in the boat to observe and afterward to make a rough sketch of him on the inside of an envelope.

While we were watching him, he snored almost continously, " not loud, but deep," until presently the flies bothered him ancl he awoke. With a slow, awkward sweep of his ponderous right arm he drove the flies from his face, and a moment later was wide awake. He was just rising to a sitting posture when my rifle-ball caught him between his shoulders. He sprang up quickly, gave a deep growl, flung limself forward into the tangled mass of green vines and branches which surrounded the nest on three sides, and was instantly lost to view. He went crashing. forward for a few yards and then stopped ; there was a moment's silence, then a heavy fall and a dull splash. Lamudin and Blou went into the water and worked their way in to where the old fellow lay, and presently towed him out.

We went on down to the head of the lake, which, like the western side, is completely filled with screw pines growing in the water. A small creek called Batang Rejang empties into the lake at this point. We entered it and paddled up until it became so obstructed with overhanging branches that further progress was impossible.

On the way back we encountered a large troop of proboscis monkeys, and, by a sudden assault, I succeeded in killing two fine old male specimens. As usual, they were over water, and, being swift climbers and quite shy, were hard to kill. I saw, altogether, during my ramblings in the forests of Borneo, perhaps a hundred and fifty proboscis monkeys; and, without a single exception, all were over water, either river, lake or submerged forest. As long as they are in sight they are very conspicuous objects, choosing the most commanding positions in open tree-tops. Once I saw thirteen in one tree, sitting lazily on the branches, as is their habit, sunning themselves and enjoying the scenery. It was the finest sight I ever saw in which monkeys played a part.

The cry of the "blanda," as the natives call it, is peculiar and unmistakable. Written phonetically it would be "honk," and occasionally "kee-honk," long drawn and deeply resonant, quite like the tone of a bass viol.

As the name would imply, the most striking feature of the proboscis monkey is its nose. In old male specimens this organ reaches its grandest proportions, and is truly enormous in length, breadth and thickness. It hangs from the face like-well, totally unlike any. 



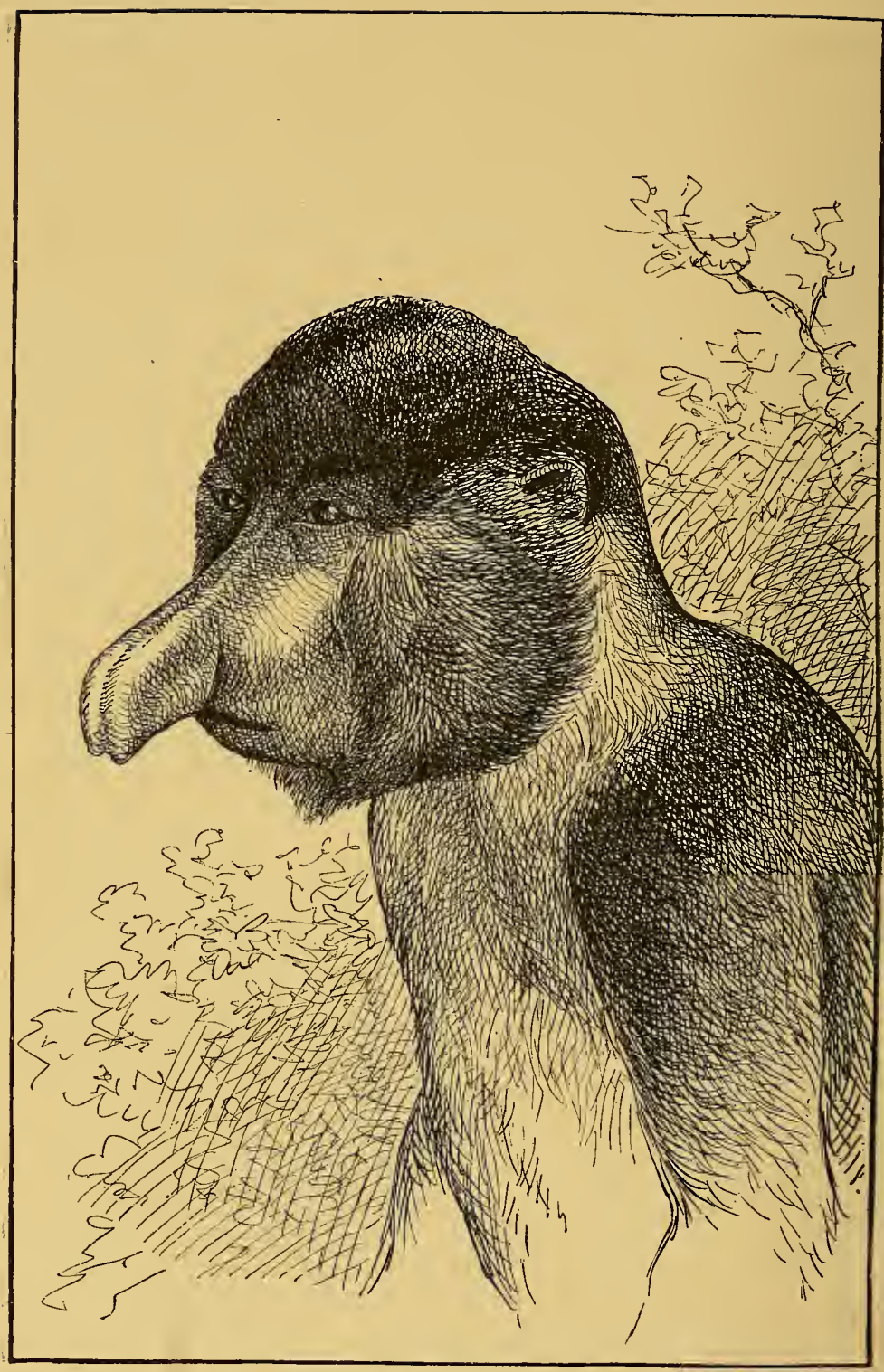

PORTRAIT OF A PROBOSCIS MONKEY.

(From a sketch by the Author.) 
thing else in the world, coming quite below the lowest point of the chin, shaped like a pear except for a furrow down the middle and a contracted septum, which causes the organ to terminate in two points. It is broadest at the middle of the free portion instead of at the base.

Nothing could be more unnatural than the noses of all the stuffed proboscis monkeys I have yet seen in museums. They do not even suggest the natural form or size of the organ. The pictures of the animal sin against nature in the same fashion, and, in order to set Nasalis right before the world and vindicate his nasal character, I fixed my best specimen on a branch in a natural attitude, and drew a picture of him, to scale, a copy of which is submitted in the accompanying engraving.

The proboscis monkey, which, by the way, is found only in Borneo, is a large animal and of striking appearance both in form and color. Its face is cinnamon brown, and its body conspicuously marked with reddish brown and white, the tails of old specimens, being white as snow. Taken altogether, Nasalis larvatus is, to the hunter-naturalist, a very interesting object of pursuit, and were he not partially eclipsed by the orang he would be the most famous quadrumane in the East Indies.

I tried six different times, on as many days, to get a shot at the family of wah-wahs which called to us daily from the summit of Gunong Popook, but the mountain was so steep and the tree-tops so thick that I did not even get a shot. At last I gave it up as a bad job, and determined to reserve my efforts for the Sibuyau, where they were said to be plentiful. Dundang, who followed mo up the Simujan in order to hunt for me, killed one fine large specimen during my stay at the lake, but where he shot it I could not quite understand. He also killed more proboscis monkeys for me, a wild pig, two small orangs, and a few other animals. Black monkeys ( $S$. femoralis) were numerous within two hundred yards of the house, and Perara succeeded in killing several, which was about all he did kill.

Wild hogs were so plentiful in the jungle that the Dyaks had built a pole fence four feet high around three sides of their clearing to protect their crop of rice. Both Mr. Houghton and Eng Quee had assured me they had seen wild pigs which stood thirty-six, and even forty, inches high at the shoulders, their great height being due to the unusual length of their legs, developed in the animal's struggle for existence in low, swampy forest. 
The accounts I had had of the wild pig made me very anxious to secure at least one large specimen. But, although they were so abundant in the jungle about us as to seriously threaten the rice field, I did not even get sight of one in my first week's hunting on Gunong Popook, so I determined to try for them in the swamps. The oldest Dyak in the village, who was therefore an experienced hunter, offered to guide me to the most likely spots, and, with a stout, active lad, named Munkah, to accompany us, early one bright morning we set out.

For several hours we toiled through the swamp, wading through water and thin mud of various depths from ankle to hip, and finally crossed it and came to high ground, at the edge of which we expected to find wild pigs feeding on the fallen fruit of a tree the Dyaks called ejoke. But the pigs were not there. Then we took to the high ground, and for some hours longer we tramped up and down a succession of the steepest of hills, covered with the thorniest kind of jungle. Thorns, did I say? Well, I meant fish-hooks, needles, pins, tacks, and porcupine quills.

Magnificent spreading palms (Livistona sinensis) grew thickly everywhere; very beautiful to the eye their long, slender stems were, but always set with rows of stout and sharp thorns, curved just the wrong way for comfort, and always ready to catch a passing victim. The branches of a worthless climbing rattan (Calamus) were particularly cruel. This species is very abundant, climbing over the underbrush and sending out many long, slender branches which droop like those of the weeping willow. The end of each is leafless for about two feet from the tip, and the slender, supple stem resolves itself into a long row of animated trout-hooks. The way those threadlike stems will reach out to seize a rictim and then hang on, is enough to make one believe them an invention of the devil. One will catch you suddenly by the ear and hold you very still, while another flies back from the man ahead of you and rakes you across the cheek like a fine saw, cutting a neat little gash as it goes. Again, one will spring suddenly and lay hold of your neck with a score of needlelike points, while others fasten themselves in your clothes, or upon your bare hands.

If anathemas could kill, I would take bell and candle and so curse every thorn-bearing plant of the tropics, that beside my anathema the curse of the Catholic Church on Victor-Emmanuel would read like a blessing. In all the vegetable kingdom, there is nothing so useless and wholly objectionable as a thorn, especially the 
accursed fish-hook thorn of the tropics, and if any intelligent reason can be assigned for either its deliberate creation or its evolution, it would be balm to my wounded cuticle. For my part, I consider the thorn one of nature's unmitigated blunders.

Our long tramp was wholly fruitless, for we saw not a single object worth shooting. Fortunately for my collection, my native hunters were more successful, for Dundang sent in a large broque (Macacus nemestrinus) and a baby of the same species; a friendly Dyak brought a large soft-shell turtle which he caught in the lake, and Perara managed to shoot a bijit.

A few days later, Hakka and I made another trial for wild pigs to Gunong Poondah, a low mountain a short distance to the north. We went by boat quite to its foot, up an arm of the lake, and along a narrow creek which led through a bit of lovely forest. The mossy tree-trunks were often covered with beautiful orchids, small ferns, and other parasitical plants, while palms of many species rose out of the water and drooped over the banks. The warm, still air, the subdued light of the forest, and the profusion of picturesque vegetation made up a bit of tropical forest scenery which quite realized my preconceived ideal.

We hunted along the foot of the mountain and stalked carefully up to the ejoke trees, but saw no pigs. Once indeed we started a troop of wah-wahs, but when I was about to fire we heard unmistakably the grunt of a wild pig. Turning reluctantly from the " bird in the hand" we tried to discover the pigs, but failed, and so lost both. The Dyaks fished d: igently in the lake during my stay, and everything caught wis brought to me. The largest fish taken was a very handsome goby (Eleotris marinorata), seventeen inches long ; and the most interesting were three species of climbing perch, Anabas scandens and two others.

After a fortnight's sojourn at the Popook village, I felt satisfied that I had exhausted that locality, and, when Mr. Eng Quee's boat arrived, we loaded up, took leave of our friendly and hospitable hosts -not without regret, on my part, I am bound to say-and returned to Simujan without hap or mishap. 


\section{CHAPTER XXXIV.}

\section{FACTS ABOUT THE ORANG-UTAN.}

Distribution of the Orang-utan.-Its Affinities.-External Appearance.-Remarkable Facial Ornament (?). - Color of Skin.-Hair.-Eyes.-Mode of Fighting.-Pugnacity.-Food.-Unsocial Habits.-Young at Birth.Nesting Habits. - Locomotive Powers. - Inability to Walk or Stand Erect.Height of Adults.-General Measurements.-Two Species Recognized.Characters of Simia Wurmbii and Satyrus.-Individual Peculiarities.

Borneo is truly the land of apes and monkeys. Among its fourteen species, five of which occur nowhere else,* are found the following very interesting forms: the orang-utan (two species), the proboscis monkey, the gibbon, the slow lemur, tarsier, and the flying lemur.

For an island, Borneo is favored with a great variety of very interesting quadrupeds, both large and small, and a far greater number of species peculiar to itself than any of its neighbors of the Archipelago can boast. So far as known at present, it has ninetysix species of mammals, thirty-three of which, or more than onethird, are not found elsewhere. The largest species are the elephant, rhinoceros, tapir, wild cattle, sambur, and wild hog, and the most interesting are the apes and monkeys, insectivores, bats, and porcupines.

The genus Simia occurs in northern Sumatra, but its distribution in Borneo is so much more extensive that we may well say the latter is the home of the orang-utan. It inhabits that wide belt of low, forest-covered swamp forest which lies between the seacoast and the mountain ranges of the interior, extending entirely around the western half of the island. But even this great alluvial plain is inhabited by the orang in certain districts only ; although

* The following are the species peculiar to Borneo: Hylobates concolor, Nasalis larvatus, Semnopithecus rubicundus, Semnopithecus clirysomelas, Semuopithecus frontatus. 
all those portions which are covered by lofty virgin forests seem to present the same features. In the Territory of Sarawak the orang, or "mias," as it is called by the natives, is found along the rivers Batang Lupar and Sadong and their small tributaries, such as the Lingga and Simujan. It does not occur at all along the Sarawak or Samarahan rivers, but farther west it is found, though more rarely, from the river Sambas to the Kapooas, which latter lies directly under the equator. It is also found in Kotei near Samarinda, at the mouth of the Mahakkam, and also on the Tewah River, which flows into the Barito from the east, almost directly under the equator.

Leaving the genus homo out of the question, the orang occupies the third place from the highest in the animal kingdom. The gorilla (Troglodites gorilla) is given the highest place, next in order is the chimpanzee ( $T$. niger), after which comes the orang-utan (Simia Wurmbii and satyrus), followed by the Siamanga syndactyla, the link between the orangs and the gibbons (Hylobates). The orang well deserves the place it occupies. It agrees with the gorilla and chimpanzee in positive size and quality of the brain, but its fore-limbs, as compared with the hind ones, are longer than theirs, while they are also proportionally shorter than those of Siamanga and Hylobates. The heel-bone (calcaneum) is proportionally longer in Simia than in Hylobates, and its thumb is also better developed than that of the gibbons. Among the higher apes, the orang comes nearest to man in the number of ribs (twelve pairs) and form of the cerebral hemispheres, but differs from him in other respects, especially in the limbs, more than do the gorilla and chimpanzee.

The chimpanzee approaches man most closely in the character of its cranium, its dentition, and the proportional size of its arms. The gorilla is more manlike in the proportion of the leg to the body, size of the heel, curvature of the spine, form of pelvis and absolute capacity of the cranium. In its habits the orang resembles the gorilla and chimpanzee, which are not gregarious, while the gibbons are.

The most striking feature of the orang is its great size and general resemblance to man. The chest, arms and hands are especially human in their size and general outline. Since the animal depends mainly upon these members for the means of locomotion they are necessarily of massive proportions. The natural position of the human hand at rest is with the fingers slightly bent, but 
that of the orang is with the fingers tightly closed, and, when measuring our dead specimens, we often found it an absolute impossibility to straighten a single finger without cutting the tendon in the palm of the hand. Thus, when an orang is asleep, the most natural position he can assume is to firmly grasp a branch with each hand.

Male individuals of Simia Wurmbii are distinguished by their wonderful cheek callosities, each side of the face being greatly expanded and flattened into a thick, semi-circular disk extending vertically from the top of the forehead to the angle of the jaw. This remarkable feature is a sexual characteristic, for it is never possessed by the female orangs. So far as I have been able to determine, these facial callosities are purely ornamental, since they are not controlled by voluntary muscles, and are composed merely of tough, white, semi-cartilaginous tissue. In different individuals these callosities vary in width from ten to thirteen and one-half inches.

The skin color of orangs varies according to age, as follows : In infants and all young individuals up to three or four years of age the skin is generally chocolate brown, yellowish on the abdomen and in the palms, while the skin surrounding each eye to the edge of the orbit, and the entire muzzle, or projecting lower portion of the face, is of a more decidedly yellowish or raw-sienna color. Individuals between childhood and middle age vary from dark-yellowish to blackish-brown, the latter color largely predominating. Very often the face and neck is almost or quite black, the palms light-brown and the breast and abdomen mulatto-yellow. In old specimens, especially males of Simia Wurmbii, or the "mias chappin" species, the skin is everywhere a deep, shiny-black, except in the palms, where, from constant wear on rough bark, the cuticle lies in several thick, calloused layers, and is of a dirty gray color.

The hair of orangs varies greatly in color, quantity, quality, and distribution, and has no bearing whatever on the question of species. Speaking generally, it may be described as brick-red, or to be exact, of the color known to painters as Indian-red. It may be said, however, that marked differences in color are found almost entirely on adult male specimens. On all others, it varies but little from pure Indian-red; but on old males it often assumes a faded yellow or raw-sienna color on the arms and legs.

It is always longest on the arms, shoulder-blades, and thighs, 
and shortest on the breast, abdomen, and back. The face and throat are quite bare except for a scanty chin-beard of uncertain length in adult specimens, the longest hairs never exceeding four inches. On the flat cheek callosities of Simia Wurmbii there is a curious growth of very short and uniformly dispersed hairs not more than one-eighth of an inch in length, which lie so closely upon the skin as to escape notice except upon very close inspection.

On the back of the arms and thighs, and on the sides and shoulder-blades of old male orangs, the hair is long, coarse, straight and thick, sometimes reaching a length of from twelve to fifteen inches.

On most individuals of this class, the entire back will be found almost bare from the neck down, having been worn off in the nest. On younger specimens, the hair on the back is thick, and longer than on the abdomen. The back of the hand and the fingers are thinly covered with short stiff hairs. On the forearm the hair grows upward from the wrist to the elbow, where it meets the downward growth on the arm, and the two come together in a point.

The eyes of adults are always very small, with iris of a dark chestnut-brown, and no white visible. The teeth are invariably very much discolored by vegetable acids and juices, and the base of each tooth is always black.

On most of the Wurmbii there seems to be a superabundance of skin on the throat and breast, for it is often found to hang in a great baggy fold. Externally, the orang seems to have no neck at all, the head being set squarely down upon the shoulders. The chest is massive to correspond with the arms and head, but the pelvis is small, and the lower limbs are small, short, and comparatively weak. The orang never sits down as do the gibbons, and therefore has no ischial callosities like the Hylobates.

There is no ligamentum teres in the orang, and the absence of this permits great freedom of movement in the lower limbs. Indeed, the legs seem to possess almost as much freedom of movement as do the arms. I have often seen my little pet orang hang to a rope, with one arm at an angle of fully seventy degrees and, with the greatest comfort imaginable, reach up with his leg at the same angle and grasp the rope with his foot.

Some naturalists attach importance to the facial resemblances of different orangs. I have never seen living specimens of the $\mathrm{Su}$ matran orang, but so far as Bornean species are concerned, I am 
certain that each individual differs as widely from his fellows, and has as many facial peculiarities belonging to himself, as can be found in the individuals of any unmixed race of human beings.

Male orangs are much given to fighting, and often bite off each other's fingers and toes. The upper lip, also, is often found in a mutilated condition from the same cause. I have never heard of their biting off each other's ears, as human roughs do occasionally, but a few hundred years more of evolution may bring their intelligence up to that point. Indeed, may we not confidently predict that this is the next step in intellectual development the orang will take, if he is ever to approach nearer to man.

It is the natural instinct of an orang to seize and bring the offending hand of another to its mouth, instead of moving its own heavy head and body to the object. Thus, in every imaginable way do the powerful and capable limbs and hands serve the inert body and head upon all occasions.

The battered condition of one of my male specimens has already been described (Chapter XXXI.) ; another orang, No. 34, male Wurmbii, had almost lost the edge of his entire upper lip. It had been bitten diagonally across, but still adhered at the left corner, and the wound had evidently healed very quickly, for that triangular piece of upper lip still hung dangling down two inches from the corner of his mouth. He had also lost an entire finger.

No. 36 had lost a piece out of his upper lip, and one of his left toes had been bitten quite off.

During the fruit season, which is from the middle of January to the first of May, the food of the orang is the durian, mangosteen, and rambutan, which are usually found upon the hills. There are also other fruits which ripen at different times, such as the raso and kapayang, but of the former the orangs eat the shoots only. Besides these, they devour the shoots of the Pandanus, and also the leaves of certain trees. During the months of May, June, and July, they retire far into the depths of the forest and are exceedingly difficult to find, but during the season of the heaviest rains, i.e., from August to November, when the forests are quite flooded, they are found in the vicinity of the rivers.

The orang is quite solitary in his habits, the old males always being found alone; nor are two adult females ever found together. On two occasions I found three individuals together, but one was an old female with a nursing infant, and the third was her next oldest offspring, apparently about a year and a half old, who had 
not yet lefi his mother's side to shift for himself. The female orang has but one young at a birth, and from the instance just cited, I infer that it does not leave its mother until nearly two years of age, by which time it is fairly supplanted by a successor.

The size of the young of the orang at birth is quite remarkable, considering the small stature of the adult female. My twentyeighth specimen was a gravid female 30 feet $8 \frac{3}{4}$ inches in height, carrying a fœtus which weighed 7 pounds 3 ounces, and was, of course, fully developed.

The nest of the orang-utan has already been described. He usually selects a small tree, a sapling in fact, and builds his nest in its top, even though his weight causes it to sway alarmingly. $\mathrm{He}$ always builds his nest low down, often within twenty-five feet of the ground, and seldom higher than forty feet. Sometimes it is fully four feet in diameter, but usually not more than three, and quite flat on the top. There is no weaving together of branches, for they are merely piled cross-wise as a natural consequence of their being broken off on different sides of the nest. In short, the orang builds a nest precisely as a man would build one for himself were he obliged to pass a night in a tree-top with neither axe nor knife to cut branches. I have seen in the forest one or two such nests of men where the builder had only his bare hands to work with, and they were just as rudely constructed, of just such materials, and in about the same general position, as the average orang nest.

During one day's travel along the upper Simujan River we counted thirty-six old nests and six which we set down as new or fresh. I have never been able to ascertain to a certainty, but it is my opinion that an orang, after building a nest, sleeps in it several nights in succession, unless he is called upon to leave its neighborhood altogether. Certain it is that whenever a hunter finds a perfectly fresh nest he may with confidence expect to find the builder somewhere near it. An orang never uses a nest after the leaves become withered and dry, no doubt for the reason that the bare branches afford an uncomfortable resting-place. I never saw nor heard of any house-building by orang-utans, though $I$ am led to believe that some individuals may have a habit of covering their bodies with branches for protection against the dashing of the rain-drops during a heavy storm. My little pet orang would invariably cover his head and body with straw or loose clothing the moment it began to rain, even though he was under a roof. 
Even under the most favorable circumstances, orangs are neither graceful nor active in their movements. I think we may justly consider them the most helpless of all the quadrumana. Owing to the great weight of their bodies, and the peculiar structure of their hands, they cannot run nimbly, and never dare to spring from one tree to the next. The smaller monkeys gallop madly along the larger branches, with outspread arms, legs, and tail, leap recklessly from the tree-top, go flying through the air for several yards, and fall sprawling and unhurt upon the side or in the leafy top of the next tree. Not so the orang-utan, with his huge, flabby stomach, fleshy thighs, and massive head. His weight, of one hundred and twenty to one hundred and sixty pounds, compels him to move slowly and circumspectly so that he may not find himself falling heavily to the ground. Owing to the disproportionate shortness of his legs, his progress depends mostly upon his long, sinewy arms, and very often he goes swinging through a treetop by their aid alone. I have frequently seen them swing along beneath the large limbs as a gymnast swings along a tight rope, reaching six feet at a stretch. When passing from one tree to another, be reaches out and gathers in his grasp a number of small branches that he feels sure will sustain his weight then swings himself across.

Upon the ground the orang is a picture of abject helplessness. In his native forests he is very seldom known to descend to the earth, and so far as my experience goes, I have never seen nor heard of a single instance of the kind. True, he climbs down when thirsty until he can reach the water with his hands, but this occurs where there is no dry land to walk upon.

The orang-utan is utterly incapable of standing fully erect without touching the ground with its hands. I have seen many orangs in captivity, but not one of them ever stood erect upon its hind legs for a single instant, and for orangs to be so represented in drawings or museums is contrary to nature.

There has been considerable discussion in regard to the maximum size attained by the orang-utan, and its general measurements. Mr. A. R. Wallace, in his work on the "Malay Archipelago," pp. 72 et seq., makes the following statements :

"I have myself examined the bodies of seventeen freshly-killed orangs. Of this extensive series, sixteen were fully adult, nine being males and seven females. The adult males of the large orangs only varied from 4 feet 1 inch to 4 feet 2 inches in height, measured 
fairly to the heel, so as to give the height of the animal if it stood perfectly erect; the extent of the outstretched arms from 7 feet 2 inches to 7 feet 8 inches; and the width of the face from 10 inches to $13 \frac{1}{2}$ inches. The dimensions of other naturalists closely agree with mine. The largest orang measured by Temminck was four feet high. Of twenty-five specimens collected by Schlegel and Müller, the largest old male was 4 feet 1 inch, and the largest skeleton in the Calcutta Museum was, according to Blyth, 4 feet $1 \frac{1}{2}$ inch; and no specimen has yet reached Europe exceeding these dimensions, although the total number must amount to over a hundred. On the whole, therefore," concludes Mr. Wallace, "I think it will be allowed that up to this time we have not the least reliable evidence of the existence of orangs in Borneo more than 4 feet 2 inches high."

The total number of specimens of the orang-utan of both species, killed by me and my hunters, was forty-three, every one of which I carefully measured while fresh, recording each measurement the moment it was made. I saved the skin of every one of these specimens, and the skeletons of all save three or four of the very youngest ones.

No fewer than seren of my specimens exceeded the maximum height for orangs as given by Mr. Wallace, viz., 4 feet 2 inches, even by the most liberal measurement. My tallest Simia Wurmbii, or "mias chappin," measured 4 feet 6 inches from head to heel, and the next in size 4 feet $5 \frac{1}{2}$ inches. Then a satyrus, or "mias rombi," measured 4 feet $4 \frac{1}{2}$ inches, two other Wurmbii, 4 feet 4 inclies, and 4 feet 3 inches respectively, a satyrus, 4 feet 3 inches, and a Wurmbii, 4 feet $2 \frac{1}{2}$ inches. Only one specimen measured exactly 4 feet 2 inches, and the remaining nine fell below that height. One male specimen, with hair which grew to a length of 12 to 15 inches, in some places, measured only 3 feet $10 \frac{1}{4}$ inches in height. The largest female measured 4 feet, and the smallest adult female 3 feet 6 inches.

These measurements were a great surprise to me, and, feeling that their accuracy might some time be questioned, I made and recorded them with unusual care and exactness. To obtain the height it was my practice to lay the animal upon its back with the legs held straight by an assistant, then loolding the blade of a large knife flat against the top of the head, it was thrust perpendicularly into the table or the earth. Then, while an assistant held the top of the head against the first knife-blade, I pressed another blade firmly 
against the bottom of the heel and thrust it into the earth also. After moving the animal aside a tape line stretched between the inner surfaces of the knife-blades gave the height of the animal. Not a single figure was ever trusted to my memory alone, and my largest orangs were each measured and recorded twice.

From the subjoined table of measurements it will be seen that orangs vary in their proportions in precisely the same way as human beings. Some are short and thick-set; and others are more slenderly built and longer limbed. Specimens Nos. 6 and 9 have short legs and bodies but unusually long arms, while Nos. 43 and 38 are just the reverse. It will also be noticed that the breadth of the facial callosities of Wurmbii bears no relation whatever to the size of the animal. The tallest specimen of the whole series, No. 18, measured only $11_{4}^{1}$ inches across the face, while No. 25, which stood three inches shorter, and was much smaller every way, measured $13 \frac{1}{2}$ inches at the same point.

Measurements of Orang-Utans, Adult Males and Females.

(Given in inches.)

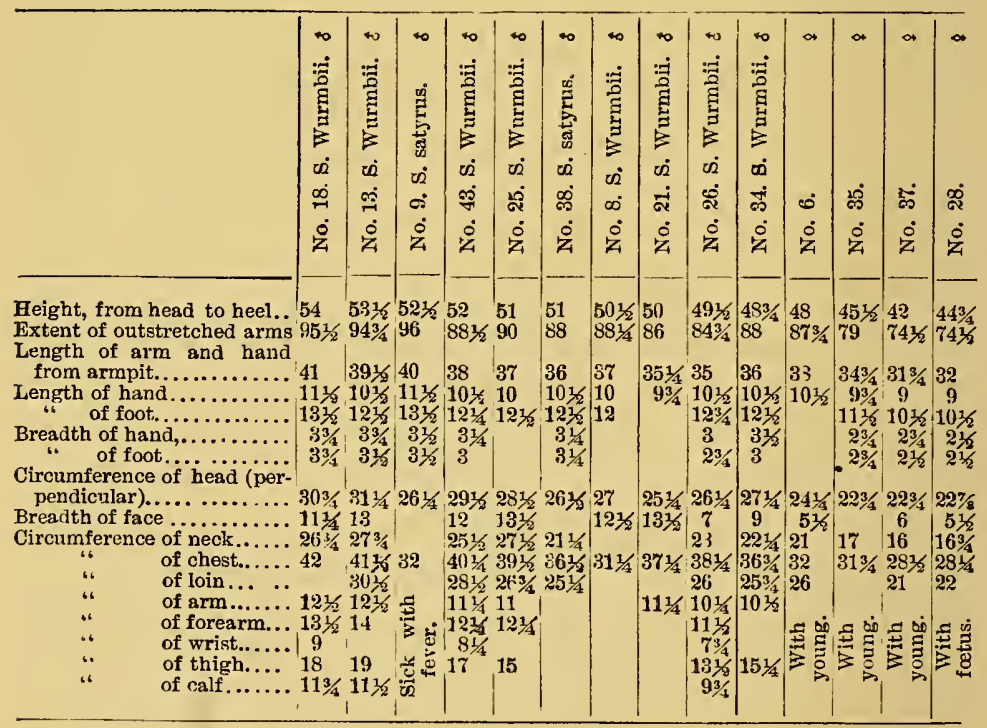

Of the orang-utan there are two clearly defined species, and only two, viz., Simia Wurmbii and S. satyrus. While the points of dif. 
ference between the males of the two species are strongly marked and unmistakable, both externally and anatomically, the females are all very much alike in their external appearance, but readily distinguishable by their skulls.

Male specimens of Wurmbii are distinguished by their remarkable cheek callosities, already described, which are observed in youny as well as old individuals, and also by the joining of the two temporal ridges on the top of the skull to form an elevated sagittal crest, of varying height. In females and young males the temporal ridges subside to the level of the skull either at or before meeting in front of the parietal suture, and are continued backward in a rough line, almost to the lambdoidal crest.

In the skull of the male satyrus the temporal ridges pass backward and slightly converge, but still remain widely separated until they diverge again at the back of the skull and rise to form the lambdoidal crest. The skull of the female shows no continuous elevated ridges, but a rough line instead, which scarcely rises above the level of the skull. No female skull in the collection made by me possesses either the two continuous temporal ridges or the elevated sagittal crest, but the rough lines correspond to the elevated ridges of the males of their respective species in every case, and leave their identity unmistakeable.

Orangs are liable to possess individual peculiarities to a greater extent than perhaps any other of the apes or monkeys. To illustrate : No. 26, Simia Wurmbii, with a very prominent cranial ridge, was utterly destitute of facial callosities or any signs of them, and until dissection, was supposed to be a satyrus. No. 13 had a nail on the hallux of its hinder hands. No. 21 had four molars in each side of its lower jaw, while the other forty-two orangs had only three each. The distance between the temporal ridges of satyrus, and the elevation of the sagittal crest of Wurmbii, varies greatly in different specimens.

We will not say anything about the place the orang has in the long chain of evolution ; but, while abstract argument leads hither and thither, according as this or that writer is most ably gifted for the same, there is still one argument or influence to which every true naturalist is amenable, and which no one will ignore who has studied, from nature, any group of typical forms. Let such an one (if, indeed, one exists to-day) who is prejudiced against the Darwinian views, go to Borneo. Let him there watch from day to day this strangely human form in all its various phases of exist- 
ence. Let him see the orang climb, walk, build its nest, eat, drink, and fight' like a human rough. Let him see the female suckle her young and carry it astride her hip precisely as do the coolie women of Hindostan. Let him witness their human-like emotions of affection, satisfaction, pain, and rage,-let him see ail this, and then he may feel how much more potent has been this lesson than all he has read in pages of abstract ratiocination. 


\section{CHAPTER XXXV.}

\section{A MONTH WITH THE DYAKS.}

Journey to the Sibuyau.-The River.-A Malodorous Village.-Barriers. Proboscis Monkeys and Flying Lemurs.-Head of Canoe Navigation.Swamp-wading.-Our Journey's End.-A Lodge in a Vast Wilderness. Fine Hunting-grounds. - Source of the River.-Hunting Gibbons._Lively Sport.-Gibbons' Remarkable Mode of Progress.-A Mias.-A Successful Hunt.-Affection and Courage of a Male Gibbon.-Helplessness of the Baby Orang in Water.-A Live Tarsier.-More Gibbons Shot.-Argus Pheasants.-Dyak Mode of Șnaring.-A Deadly Pig-trap.-A Shiftless Village.-A Magnificent Bird.-Curious Rodent.-Visit to Lanchang.A Village of Head-hunters.-Trophies of the Chase.-A Fine Dyak Speci. men.

IT was only a bunch of argus pheasant feathers that lured me from Sadong to the Sibuyau, to stay a month with the Dyaks, for better or worse. The promise of wah-wahs, also, had something to do with it, I suppose, even though they are hard to shoot. The Dyaks said their settlement had never been visited by a white man, and in spite of all I could learn from them, the nature of the country remained a profound mystery. But then, the greatest charm of travel is going to places one knows nothing at all about, and. satisfying one's geographical curiosity.

Behold us, then, starting down the Sadong with the turning of the tide, early on the morning of October 28th. At home the trees have taken on their gayest autumn tints, but here the forest is still clad in the same persistent, never-changing, monotonous green it has always worn.

Under the kadjang roof of the old Malay headman's large boat, there sit the "orang putei" (white man), "orang China" (Chinaman), and the "orang utan" or jungle man, my little pet, while three stout Malays furnish the motive-power. Perara and Dobah are coming after us in my own boat. It is a delightful day, quiet, clear, and warm, such as fills a man with a sense of keen enjoyment, provided his digestion is good and his conscience clear. My little 
baby mias seems to enjoy his surroundings as well as the rest of us, for, with true childish instinct, he leans lazily over the edge of the boat and dabbles in the water with his hairy brown hands as it sweeps past the side.

On reaching the sea, we put up our much-mended sail and steered eastward along the coast for a few miles, until, when almost within the mouth of the Batang Lupar, we came about sharply and ran into the mouth of the Sibuyau. A conical mountain rises on the east bank, at the foot of which is a small Malay kampong, and the house of Seriff Hassan, the Port-clearance clerk. We stopped long enough to deliver our papers and hastened on up stream with the flowing tide, to get as far as possible by night-fall.

The Sibuyau is a small stream, not over a hundred yards in width at the mouth, and for a long distance up the banks are prettily fringed with nipa palms. There are a few paddy fields along the banks and the usual accompaniment of flimsy little temporary huts on stilts, reminding one of birds' nests.

About sunset we reached a Dyak village of eight doors standing close to the bank, at which we stopped for the night. It was a miserably dirty and foul-smelling place, or at least the ground underneath the house was giving off an odor like an ancient pig-sty. The Dyaks were almost as dirty as their surroundings, but they were civil, and immediately produced, for us to sit upon, two of the finest mats I ever saw of Dyak manufacture. I tried to buy the smaller one of the two, but they positively refused to sell it. Perhaps their mat-maker was dead.

We had a long confab about the prospect of getting up to the settlement at the head of the river, and were told that the way was long and difficult; that our large boat was too large to go at all ; that they had no boats which could take us; and, furthermore, that they would not go with us under any circumstances. Being unable to see my way out of the difficulty which had suddenly presented itself, I slung my hammock and mosquitero and went to sleep.

In the morning three of the Dyaks agreed to go with me, for a consideration, to help with the large boat; but, when the time came to start, they and two others put their weapons and dogs-I mean dog skeletons-and cooking pots into one of their own canoes, got into it, and paddled off down stream. With a devout wish, expressed in four languages, that they might "go to the devil," we determined to paddle our own canoe, and immediately 
set off. I changed places with Dobah, thus leaving the four Malays and $\mathrm{Ah}$ Kee to manage the large boat.

After a few miles, we passed the limit of the nipa palm, and then the screw pine took its place. As the stream became more narrow the fringe on either side became wider and almost impenetrable in density. About noon, we came to where the channel was blocked by thousands of Pandanus stems, which had drifted together and formed a wide barrier like a "jam" of pine logs. The top of the drift was covered with rank grass, which bound the whole mass together-sometimes strongly enough to walk upon.

During the course of the afternoon we passed eight or ten such barriers; and each one cost a struggle. There was always a passage cut large enongh to accommodate small sampans; but our large boat was heavily laden, and the passage had to be indefinitely enlarged. We were all of two hours in getting her through one drift, which was finally accomplished by cutting a wider passage and then hauling on her from the small boat made fast a few yards in advance, while others lifted on her at the same time. No wonder the Dyaks were chary of trusting their muscles in our keeping for that day.

During the afternoon we saw several troops of proboscis monkeys. They were not so shy as on the Simujan, but sat unconcernedly in the trees, watching us as we went by. As night approached we tied up to the bushes at the edge of a fine bit of open water, fourteen feet deep, and shifted our baggage so that we could lie down. After a most refreshing bath in which all participated, we ate our rice and turned in. Ah Kee and the little mias had a long and violent dispute as to whether they should sleep together, of which question the mias took the affirmative side and finally carried the day.

The large boat leaked badly, and, but for Ah Kee, I think we should have filled and gone down before morning. Being unable to swim he felt a lively interest in keeping the craft afloat, and baled her out five times during the night.

As we proceeded, the next morning, we entered a perfect labyrinth of screw pines, but fortunately there were no more bad drifts and we wound our way along very agreeably. During the forenoon we came upon a troop of proboscis monkeys which contained about thirty-five individuals-the greatest number of that species I ever saw together. I could not resist the temptation to "collect" one of the handsomest specimens of the lot, and the shot started two 
flying lemurs (Galeopithecus variegatus) just out of range. They spread their parachutes to their widest extent, launched boldly out of a tree-top, sailed slowly through the air at an angle of about forty-five degrees, and alighted low kiown on the trunk of a tree about forty feet distant from the one they had quitted. Climbing nimbly up to the top of that tree, they sailed off again, and so on until they were out of sight.

In the afternoon the growth of screw pines ceased abruptly, and we entered a narrower and more tortuous channel which wound in and out among trees and bushes, just wide enough for our boats, but with nothing to spare. After four or five miles of this, the identity of the river was completely lost ; but we followed the channel persistently, and at last found ourselves in a little canal not more than eight feet wide, that came down through the forest as though cut by the hand of man. On either side were solid banks and the trunks of great forest trees beautifully decorated with ferns, orchids and dark-green moss, while the bare stems of creepers, both great and small, hung in many a curve and twist from the branches which met far above our heads. I would like to rave a little over that scenery, and would, but for a constitutional objection to emotional descriptions.

At length our little canal led out of the forest and into an open grassy swamp of considerable width, at the edge of which we arrived at the head of navigation, and a getting-out place for everybody.

There was no house nor village anywhere in sight, but one of our Malays said we could reach one by night-fall, so four of us bundled up our beds, a cooking pot and food for one meal, and set out. Our first half-mile lay across a swamp, through mud and water from one to two feet deep, from which we landed on a bit of dry ground and crossed over to another stretch of morass, worse than the first. The water was from two to five feet deep, but on the top lay a carpet of matted grass which kept us from sinking down out of sight. Once I had the luck to break through and sink down to my waist before the others could fish me out. After a mile of dreadful floundering we came to some fields of growing paddy and emerged upon terra firma once more. We followed a path through a bit of fine, dry open forest, crossed a beautifully clear running brook, our canal again, or rather the Sibuyau River-and two hundred yards further on, came to a small clearing in the middle of which (welcome sight) stood a Dyak village, or long-house of five doors. 
We climbed the notched sapling which served as a ladder at the end of the house, and received the customary Dyak greeting of cheery smiles and pleasant words of welcome, while one of the girls skurried off to fetch the clean mats. We were not sorry to have reached our journey's end, and Ah Kee, never too tired to get up the best meal the larder afforded, set to work, without a moment's delay or waiting to be told, and soon had ready a fine cup of tea with buttered toast accompaniment, and a plate of rice adorned with butter and sugar. Ah Kee was the prince of good servants, and I would that every traveller who knows how to treat a servant could have one like him. He was marked with small-pox and was not what an esthete would call handsome, far from it, but in the jungle, his cheerful and efficient service condoned every physical defect.

The next morning the Dyaks turned out in force and carried up our luggage, of which there were seventeen loads, at thirteen cents per load. We took the three kadjangs which formed our boat-roof and with them made a very cosy room, about twelve feet square, at one end of the long hall.

We bought of the Dyaks enough mats to cover the floor, arranged our boxes to the best advantage to serve as furmiture, and, with a very handy fireplace constructed by $\mathrm{Ah} \mathrm{Kee}$, we were comfortably fixed. One side of the room was entirely open and looked out on the jungle. As soon as we had got fairly settled, all the people of the house came in to pay us a visit. The floor of my room was quite filled with half-naked men, women, and children sitting upon their hams and enjoying the novelty of calling upon a "tuan." The men were fine, healthy-looking fellows, the women were mostly rather ill-favored in personal appearance; and the children were, without exception, very dirty, but all were goodnatured and polite. One little girl had ichthyosis and was exceedingly repulsive, but, happily, she did not belong to our village, and I soon saw the last of her.

Keeping Dobain with me, I paid the other Malays and sent them back to Simujan with the large boat, to return for me at the end of a month. Being comfortably settled in a house which was really very clean and habitable, we immediately began to collect. I set Perara at work shooting and skinning birds, while I devoted my attention to mammals in particular, and everything else in general. I encouraged the Dyaks of the settlement-there were two other villages not far away-to set snares for animals of all kinds, 
and, being at that season without money and very nearly without rice, they bestirred themselves to earn a little money. The people of our village agreed to furnish me with from two to three guides every day for a cash consideration, and they never disappointed me.

There was a fine young man in our house who was not only willing but anxious to accompany me in my hunting trips, and we fraternized at once. With him for a guide and Dobah to carry game, I set out in the afternoon to look over the ground.

On one side of our clearing lay a vast and almost impenetrable tract of swamp-forest, choked with a dense, thorny undergrowth growing in the water. On the other side, however, there rose a succession of hills, neither too high nor too steep for comfort, covered with fine high forest, while what little undergrowth there was was not of the thorny kind. There were many charming little glens and rocky ravines with small streams of clear, cold water dashing down to where three of them came together and formed the source of the Sibuyau River. It gives one a strange sensation to stand at the very source of a river, where it is a feeble brook which one crosses at a single stride. It is a satisfaction to know all about one river, at least, even though it be a small one, from its mouth, where it loses itself in the sea, up to the very springs in the hills from whence the first eupful of water starts down.

I was rejoiced at my good fortune in being led-by blind instinct, I may say - to such a delightful wilderness. It was the finest hunting-ground I saw anywhere in Sarawak. I was sure that such ligh ground and fine open forest must be frequented by correspondingly fine mammals and birds in great numbers, for it seemed to me just the spot an animal would choose for a home-I would have been content to end my days there, had I been a monkey-and the Dyaks assured me my surmise was correct.

In order to place before the reader a pen picture of our daily life in the jungle with the Dyaks, what we did, saw, and thought, I venture to transcribe a portion of my much despised but faithfully kept journal.

"November 1st.-That fine young Dyak accompanies me regularly now as a guide, and with him and my faithful little Malay man, Dobah, I went out hunting for orang-utans and Hylobates. We hunted far and wide over the hills, saw a great number of mias nests, but no mias. But we at last became absorbed in trying to kill a gibbon, and it soon developed into genuine sport, about the 
- . 


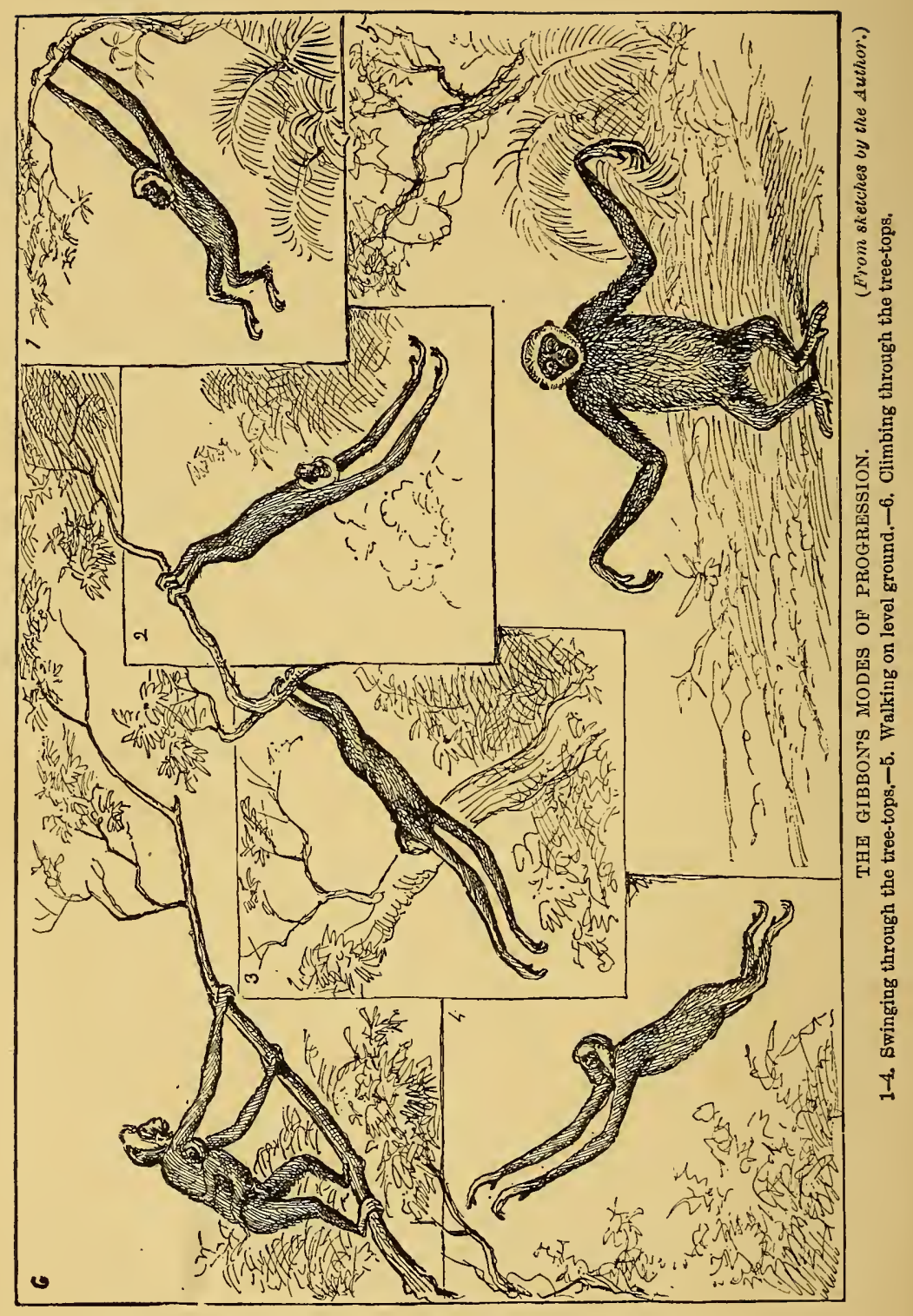


only real 'sport' I have yet had in Borneo, and this is about the character of it.

"You are going along, we will say, at the heels of your Dyak guide, carrying your rifle in the hope of a shot at big game, while the guide carries your double-barrelled gun. All at once you hear a slight vocal sound and a profound rustling in the thick branches at the top of a tall tree, directly over your head.

'. 'Apa ini ?' (What's that?), you ask in a whisper.

"'Wah-wah, tuan!' (gibbons, sir!), says the guide in the same tone.

"You take the double-barrel, loaded with No. 1 shot, and peer anxiously upward to catch sight of the animal. Ah! there he is, on the other side of the tree, and evidently making off. You cannot see his body on account of the leaves, so you steal quickly round and get directly under him to give him a surprise with a charge of shot. But by the time you get around he is apparently no longer there, for you hear a rustling in a tree-top forty yards away, and at last catch a glimpse of his lank, gray body as he swings himself out of sight, without leaving you a second for a shot. Perhaps, though, you blaze away at him, right and left, feel pretty sure you must have stopped him, and watch anxiously while you hurriedly push in fresh cartridges.

"Ha! not dead yet, for there he goes as lively as ever, this time sixty yards away. You see him quite plainly this time, and note with astonishment how rapidly he progresses by swinging himself end over end, holding by his hands while he gives his body a long swing toward another branch. His body becomes horizontal, he grasps the branch with his feet, and, letting go with his hands, swings, head downward and backward, until he comes right side again, lets go with his feet and goes flying through the air to the next branch. He grasps that with his hands, swings the other end of himself forward again, and so on. You see that by this revolutionary method he goes just as well as if he had a head on each end of his body, and that he gets along with astonishing rapidity and directness.

"This will never do. He is about to get away from you, on fair ground. You take your direction, stoop forward, and dart hurriedly along in the direction the gibbon has taken.

"You run a hundred yards at your best speed, and stop, expecting to find him directly over your head. Ha! the branches shake. There he is, fully fifty yards away! Then you get mad, 
drop your hat, grip your gun firmly, draw your head well down between your shoulders, and, with one eye to the front, go tearing through the underbrush like a wild bull, down the hill at full speed and at the imminent risk of breaking your neck. You dart nimbly through every little opening, and choose a practicable route with surprising quickness of eye, as a monkey does when running through tree-tops.

11 "After a hundred and fifty yards, good measure, you stop short, cock your gun, and glare wildly upward to catch sight of your prey as quickly as possible. In three seconds your greedy eyes have scanned every tree-top within gun-shot, and at last you see some branches shaking, a hundred yards away, on the opposite side of a deep ravine! II No use! he has beaten you in a fair race, and goes on swinging gayly from tree to tree, leaving you to sit down panting like a steam-tug, bathed in perspiration, wishing for a drink of water, and puzzled to know whether you ought to laugh or get mad.

"Then you proceed to comfort yourself by calling to mind the fact that the trees are very tall, and it is almost impossible to see a gibbon on account of his gray body harmonizing so well in color with the leaves on which the sun shines; that his hair is fine and elose, and his body and limbs so lean that to shoot at one is almost like shooting at a skeleton; that they never stop running until three or four legs are broken; and finally, that they fly a great deal faster than you ever had an idea they could anyway. IBut, all the same, you pronounce it genuine sport and acknowledge that you have met your match.// And so you draw off to the nearest stream, throw yourself upon the sand, drink about two quarts of clear, cold water, and proceed to repair damages generally.

"So far, I have had five just such experiences as the above with wah-wahs, though the most notable occurred to-day. I had two such chases, felt sure of killing at least one, had three snap shots, and not a single gibbon did I get. They are valuable animals, a skin being worth at least $\$ 20$, to say nothing of the rarity of good ones, and one specimen represents a good day's work-when taken! To hunt them is the most exciting work I have done for some time, violent exercise to be sure, but good to improve one's wind.|| The troop we started this morning had at least ten individuals in it, the most of them full grown and large.

"In the afternoon shot a goat sucker and four black monkeys (Semnopithecus femoralis); saw nothing else except one small gibbon, which I chased, of course,-for practice! 
"Rain at night. Thermometer, 80 degrees F. at 8 P.M.

"November 2d.-The name of my young Dyak guide is Le Tiac. He is just about my height, build, and age, a stout young fellow, and the only difference between us is that he is a Dyak and I am an Anglo-Saxon-which makes all the difference in the world.

"We went out in the morning, far and high on the hills, and saw, at first, only some big rhinoceros horn-bills (Buceros rhinoceros), at which we got no shot. Too many trees for us to see through before they took fight. Heard a troop of wah-wahs crying, stalked up to them with the greatest skill-and did not see even one. Disgusting! Little Dobah was taken with an attack of chills and fever on the way home.

"When we reached the clearing at noon we noticed how hot it was out in the open, whereas in the jungle it was pleasantly cool, damp, and intensely shady. Had we been hunting in the sunshine all the morning, we would have been done up long before the time we returned. The forest is so shady one does not even think of the sun; but in the house we felt the heat. Then we took our deliciously cold bath in the stream near the house, changed clothes, and after a modest breakfast lay down with "Chesterfield's Letters" for a rest. At such times I always lie on the floor near the Old Man, and he takes great delight in teasing me in various ways. He pulls my hair, butts me with his head, sits on my stomach, climbs all over me and wrestles with my bare feet, all in the drollest and most comical way, as only a mias can.

"At 3 P.M. we went out again, without Dobah, and, in about an hour, we saw a mias rombi swinging across a deep ravine. I fired two shots and killed it directly. It fell what seemed a great distance, to the bottom of the ravine, and landed in a very picturesque spot, just beside a clear gurgling stream, that came tumbling down the rocky gorge. This mias, No. 39, female, is not a large one. Le Tiac peeled some strips of bark from a sapling, tied its elbows together behind its back, fixed a broad smooth head-strap, and prepared to carry the animal alone. I proposed to sling it over a pole and help him get away with it, but he preferred to carry it alone; so he backed it and carried it, unassisted, up the steep side of that deep ravine to the top without resting, then down the long ridge and so on home. I can kill ten mias easier than one wah-wah.

"Thermometer : morning, 80 degrees F.; noon, 90 ; night, 82. "November 3d.-A good score to-day. Just after I had fin- 
ished measuring the mias killed jesterday, and was preparing to set out for the usual morning's hunt, a troop of gibbons began whistling-their cry sounds like whistling, and is easily imitatedin the jungle close by, in fact within a hundred yards of the house. Le Tiac and I were after them in less than a minute. It so happened that several paths had been cut through the jungle just where the gibbons were, and, by their help, we were soon close to our pres. We saw one or two of them swinging off in the distance, and at last I cauglit sight of a fine large one, feeding quietly on leaves, within gun-shot. "I fired both barrels to make sure of a kill, and, in a minute or so, as I was walking under the tree to see where my wah-wah |"was, down it came with a heavy "thud" within two feet of me. A little more and it would have fallen on my head.

"To my surprise it was immediately followed by another, a young one this time, which fell flat on its face on the soft earth a yard further off. We picked it up and found it was very much alive, having only a wound in the neck, and Le Tiac held it while I reloaded and looked for others. The little one set up a terrible cry and kept it up steadily, which created a great commotion amongst the other wah-wahs. They were all running away, but on hearing the cries of the little one, two came back and came as near as they dared, but kept so well concealed that I could not get a shot. 'Then we carried the little one about and let it cry while, we ourselves kept very still. It was, perhaps, a mean thing to do; 'but in collecting, necessity knows no law, every wild animal must die some time, and gibbons are too valuable and hard to get for us to let one go through sympathy. Under all other circumstances these animals are exceedingly timid, and flee at the slightest alarm, but this time two of them returned in response to the cries of one of their children in distress. It was a mean thing to do, I know, but when, at last, I got a fair shot at a large wah-wah, of the rescuing party, I disabled him so that he could not get away. He climbed to the topmost branches of the tree be was in, which was about ninety feet high, and I fired at him from below. I was surprised at the shooting it took to collect him. ${ }^{\text {rl }}$

11 " Altogether I fired seven shots with my No. 10 gun, loaded with four drachms of powder and two ounces of No. 1 shot, before he fell, and, to my still greater surprise, I found on examining the body only one bone broken-a tibia. I expected to find the leg and arm-bones mostly smashed to bits. The specimen was a large male, and met its death solely on account of its paternal affection. 
sympathy, and genuine courage in the face of danger. I It measured as follows: length of head and body, 1 foot 7 inches; entire reach of arms and legs, 5 feet 1 inch ; extent of outstretched arms, 5 feet 1 inch; hand, $6 \frac{1}{2} \times 1$ inches; foot, $6 \times 1 \frac{1}{4}$ inches; weight, $10 \frac{1}{4}$ pounds.

"The young specimen was about one-third grown, but its brain being affected and its spine injured by the shock, I killed it immediately for conscience's sake. Late in the evening, when I went down to the creek to bathe, I took the little mias along to see if he could swim. I gave him a perfectly fair chance, for instead of pitching him plump into the water as we do dogs and puppies I waded with him in my arms out to where the water was waist deep, and then poising him on the surface let him go, much against his will. Did he swim? Hardly. He turned beels up in an instant and his old head went down as if it had been filled with lead instead of brains. Instead of striking out vigorously with his arms and legs as other animals do, those useful members simply stuck straight out from his body like four sticks and moved slowly and feebly, first one way and then another, as the old fellow sank to the bottom. I waited a moment to see if he would, in any measure, recover himself, or come to the surface, but he only turned horizontally in the water and remained a foot below the surface, stiff and helpless. I waited until it would have been cruelty to have left him longer, and then, like Pharaoh's daughter, I drew him out. He did not whine or scream, but you should have seen his face. Its expression of injured innocence and disgust at the whole business spoke as plainly as words. But he was soon all right and after wiping him dry I put him down upon the pebbly bank while I went in for my bath. The little rascal began slowly climbing up the bushes, in a listless, indifferent manner, to throw me off my guard. By and by I went out to make him come down, but he was already beyond my reach, and instead of obeying me he gazed down upon me with a superior, patronizing air, and went on climbing higher. Very soon he was twenty feet up, with jungle all around him, and he had evidently made up his mind to go from our gaze like a beautiful dream. It was just sunset, and if not caught within ten minutes ho would be a total loss. I shouted for help and the Dyaks came running down with axes and parongs to chop down trees if necessary. But one of the men espied a slanting tree-trunk, and, by its aid, he climbed nimbly and silently into the top of the tree containing the mias while we below kept the little rascal's attention directed to our- 
selves. He was not aware of this adroit flank movement until he looked up and saw the naked Dyak reaching down from above to grab him. The little fellow was thoroughly terrified by the monstrous apparition, and scrambled down in wild haste, until he landed in my arms, and clung to me for protection. The Dyaks enjoyed a hearty laugh at his expense.

"November 4th.- Had a long, tiresome tramp in the forenoon, over the hills and through the hollows, but saw not a thing worth shooting. Myriads of leeches, however. A Dyak brought me a female argus pheasant in poor plumage. Skeletonized it and ate the flesh for dinner. It was palatable, but neither good nor bad. It had no particular flavor, but was tender, and therefore acceptable.

"Another Dyak brought a flying dragon (Dràco volans), and a beautiful little tarsier (Tarsius spectrum), alive and unhurt. Although it is a monkey, it jumps like a kangaroo, which it is enabled to do by means of its very long hind legs. The peculiar structure of its cervical vertebræ permits great freedom of movement with the head, which it easily turns in a complete circle, starting with the face turned directly backward. It is a very erratic little creature and bit me as severely as it was able when I took it out of its cage. Wishing to make a drawing of it, I placed it on a pole held almost perpendicular, where it hung for half an hour with its face toward me as still as though conscious of the fact that I was taking its picture. The structure of its hands is very peculiar. Each long slender finger terminates in a flat round disk which acts like the sucker of an octopus, and enables the little animal to hold on to a limb by the side pressure of its hands and without grasping, as all the other monkeys do. The eyes are very large, and of a clear liquid brown color, proclaiming the nocturnal habits of the animal.

"Dobah still has fever, Perara is complaining, and would like to have it also in order to escape work. Ah Kee is a jewel, cheerful and companionable. He has just made me a very creditable sleeping suit, pajamas and baju.

"November 5th.-Three argus pheasants and a jungle cock were brought in, all of which I bought and prepared. Having become somewhat acquainted with the inmates of our house, I have commenced to lecture the women on the desirability of bringing their children in contact with clean water at least once a month. They received my lecture as a fine bit of humor on my part, but I think they were ashamed nevertheless.

"November 6th.-Early in the morning we heard another troop 


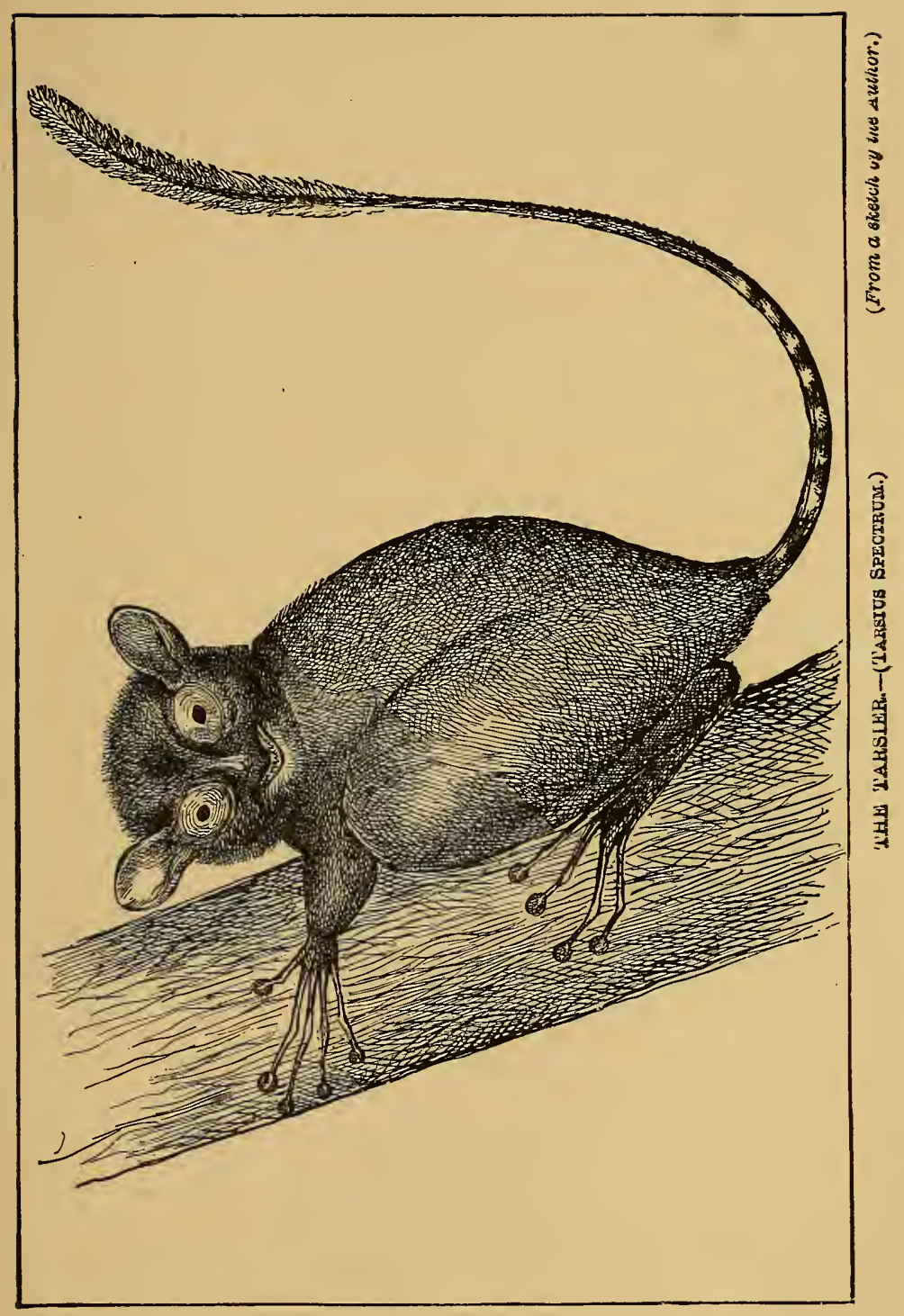



of gibbons whistling in the jungle close by, and in twenty minutes we were under them. Shot a fine old couple, male and female, and a young one belonging to the latter. Allowed two other small ones to get away on account of their tender age.

"November 7th.-Out hunting all the forenoon. Came upon a troop of gibbons, had a fair chance at an old female and let her get away through sheer stupidity ; didn't fire when I had a chance, loping to get a better one. Saw a number of traps set by the Dyaks to catch argus pheasants and small quadrupeds. In this instance a low hedge of green boughs had been built from one ravine to another across a ridge in the most inviting part of the forest. The hedge is a careless affair, about two feet high, but withal so cunningly made that I actually walked into one of the traps without seeing it! At every rod or so a clean gap is left just wide enough for a bird or small mammal to walk through without suspicion, and while in mid-passage he will suddenly be yanked heavenward by a 'twitch-up,' as we boys used to call it.

"The Dyaks make this very effective little engine of destruction by bending down a stout bush close by the gap in the hedge, previously trimming off all the branches, tying a thin strip of soft bark to the end of the bush and making a noose at the other end of the thong. Then a little platform about a foot square is made with small palm-stems, a trigger is set underneath it to hold down the noose and hold up the platform, then the noose is placed upon the latter and opened as wide as the platform will allow.

"When the bird, or small beast steps upon the platform it instantly falls, the thong is freed, the bush springs up, and the noose is jerked tight around the leg of the victim. Of course the bird is jerked high in the air, sometimes dislocating the leg, and is bound to hang there until the traps are visited. The Dyak twitchup is very effective, but the objections to it are that it punishes the victim cruelly before it dies or is found and killed, and also that the noose, in most cases, chafes off the feathers of the thigh and sometimes even the hair and skin from the legs of mammals. In that particular hedge I counted eleven traps, all very neatly constructed. We also saw a machine called a peti, to kill wild pigs, which made me shudder. Three stout, little, two-inch saplings had been selected which grew close beside a jungle path in such a position that when cut off seven feet above ground and tied together at the top they formed a perfect tripod, leaning over the path. A fourth sapling was eut, about five feet of the stem taken, 
and one end firmly lashed in with the other three at the upper end of the tripod. Into the free end of the fourth sapling, which was about two feet above the ground, was firmly fixed a piece of hard, well-seasoned bamboo shaped like a dagger, a foot long and pointing inward. The sapling was sprung out by main force and fastened at the lower end by a string stretched across the path with a trigger attachment. The point is, that when a pig comes tripping gayly along the path on his way to the Dyak's paddy field to see how the crop is getting on, and thinking no guile, snap goes the trigger-spring and he is instantly transfixed by a bayonet of bamboo. How it must hurt! The worst of it is that occasionally an unsuspicious Dyak comes unawares upon one of these infernal machines, gets the sharp bamboo driven through his thigh, and usually dies in consequence.* Two more pheasants were brought in. Perara shot a beautiful Cymbirhynchus, and, in spite of its name, he assured me he killed it with one shot.

"November 8th.-Out all the forenoon with Le Tiac and Dobah, who is well now, thanks to quinine, but saw nothing. On our way home, passed a Dyak house and clearing a mile distant from ours. The house was a small one, four doors, and the dirtiest, most higgledy-piggledy and utterly dejected looking habitation I have seen amongst the Dyaks. The women must read novels to excess ; for the place would do for a picture of the reign of indolence. The way through the clearing to this house was over tree-trunks which sometimes took us fifteen feet from the ground. I am now becoming so accustomed to pole-walking that I look upon a batang as thick as my arm as a very good road. Give us this day our daily bath. How deliciously refreshing is a leisurely dip in the clear, cold water of the shady creek after a five-hours' tramp up hill and down dale !

"One of our Dyaks brought in a superb male argus pheasant (Argus Grayii), which I took supreme pleasure in skinning. What a truly splendid bird! Such delicate richness of coloring is not found in any other bird of my acquaintance. In life, the feathers have a soft, velvety nap, and at the same time a satin-like

* Shortly after the above was written a Kalakah Dyak named Bakir. hunting gutta on the npper Sarawak, was killed by a "peti," or pig-trap of the kind described above. The lance entered his groin and passed quite through his body. To the credit of the Sarawak Government it should be stated that these traps are now prohibited under heavy penalty, and the owner of the one which killed Bakir was promptly fined $\$ 100$, or four years' imprisonment. 
sheen which is not to be found on dry, preserved specimens. The longest wing feathers measured two feet seven inches in length, and the two long tail feathers, three feet two inches. One such bird as this, a creature fit for Paradise, compensates for a thousand petty annoyances. My last lamp chimney broke to-night, of its own accord, which is a calamity indeed, for the lamp is now useless. When my candles are all gone, the evenings will be very long.

"Saturday, November 9th.-Just as I was starting out, a curious porcupine (Atherura fasciculata) was brought in, which had been caught in a pheasant snare. Most unfortunately, the snare had caught three of the legs and so badly chafed and cut the skin as to greatly damage it. It was a very singular animal, twenty-six inches in total length, of which the tail was nine and a half; the body was covered with flattened, gray spines an inch and a half long. I left Perara to remove the skin, with strict injunctions to work carefully ; but when we returned, three hours later, he came to me and plaintively said, 'Can't skin that animal, sir!' Sure enough, the skin was in ruins, the tail off, and also one leg, and the body torn in many places. On examination I found the skin had no more strength than a sheet of wet writing-paper, so we reconsidered the previous motion and took the complete skeleton, but saved the skin for purposes of identification. Being pretty well tired out, I decided to rest during the afternoon, and the clerk of the weather took advantage of our remaining in-doors and sent down a rain.

"November 11th. - Le Tiac brought in two more atheruras, and as Perara declared it was impossible to skin them successfully I went to work and skinned both. Both were injured on the legs by the snare, and it required careful work to make skins of them. Whenever Professor Ward wishes to take the conceit out of one of his young taxidermists I will tell him to have one of these wet-paper skins mounted. If I am not mistaken there will be some barl language used by somebody before these skins are mounted 'in the highest style of the art.'

"I have not seen in this region a snake of any kind until one was brought in to-day. It was only five and a half feet long; head, underparts, and tail a beautiful vermilion; two narrow, white stripes along the back, one along the side, and the intervening space bluish black. Two more flying dragons came in at the same time.

"The women of our village have begun to make the childrer 
wash daily, so every morning they all form a procession and march down to the creek, where they proceed to remove the dirt of the previous day. The first step toward civilization is cleanliness; creeds can come a long ways after. Sent Dobah and Le Tiac to the Sadong to bring me some more Spanish dollars and other useful things. They will return in about six days.

"November 12th.-Now that Le Tiac is away, Gumbong will be my guide, philosopher, and friend in the jungles. He is a good, active fellow, and knows every inch of the forest. To-day we went out northeast, and at last heard wah-wahs calling to us. Killed an old male, female, and a young one.

"In the course of our wandering we came to a small clearing, in the centre of which stood a Dyak village, of ten doors, called Lanchang. We visited it, and found the house is a very roomy one, well built and well kept, roofed with thin boards, and having an extensive platform of poles adjoining the open side for its entire length, level with the floor, evidently intended to accommodate a large crop of paddy. Our arrival was greeted by a chorus of 'ohs' and ' ah-dos' from the old men, old women, and children. All the ablebodied men and women had gone into the jungle to collect gutta, rattans, dammar gum, honey, and, in short, anything which theycould find of any value. One fine young fellow who was just starting out, struck me as being the handsomest Dyak I had ever seen. His name is Ne Siak. $\mathrm{He}$ is about twenty-two years of age, tall for a Dyak, finely formed, with a strong and even handsome face, and erect carriage. Around his middle he wore only the customary bark-cloth chawat, but a scarf of blue cotton-cloth was flung carelessly around his neck from behind, one end of which spread over his left shoulder. A rather faded bandanna was tied turban-wise around his head, with a tuft of hair straying out at the top, while down his neck and upon his shoulders fell a mass of glossy, raven-black hair in the prettiest natural ringlets imaginable. At his side was the usual parong, in its wooden sheath, adorned with a bunch of argus feathers at the lower end, and, slung securely at his back, was a long, cylindrical basket (juah), open at the top, itself a fine specimen of Dyak handiwork. In one hand he carried a stout spear, and the other was free. I looked at him in undisguised admiration, until he stepped nimbly down the ladder at the end of the house and disappeared in the jungle.

"The children were, as usual, very dirty, and some of the women and older girls were but a shade better. Hanging upon the 
posts of the long hall were an unusual number of antlers from the Rusa, and lower jaws of the wild hog. After we had seated ourselves upon the clean mats, we saw hanging directly over our heads a bunch of fifteen human skulls, also trophies of the chase. They were fleshless and bare, often toothless and jawless as well, charred and backened with the smoke of several years. I expressed a desire to buy one, but the people of the house were unwilling to negotiate, at least at a reasonable figure. The standard value of a trophy head in the Sarawak Territory is $\$ 60$, and there are none on the market even at that price." 


\section{CHAPTER XXXVI.}

\section{A MONTH WITH THE DYAKS-Concluded.}

Leeches.-Model Making.-Poor Shooting-Boots.-Bad Ammunition.-A Big Buttress.-Wild Honey.-Human-like Emotions of the Baby Orang.-My Guides go on a Strike.-Flying Gibbons.-Boils and Butterfies. - Bear and Muntjac. -Delicious Venison. -Le Tiac's Omen Bird:-Dyak Shiftlessness in Trade.-Gathering Gutta._Le Tiac Climbs a Tapong Tree.-A Perilous Feat.-Ah Kee gets Lost -A Torch-light Search in the Swamp. - Another Bear.-Return to the Sadong.-The Last Orang.-The Nipa Palm.-A dangerous Squall. - Nesting Habits of the Crocodile.-Farewell to the Sadong.

"November 13тн.-Long before daybreak, we heard wah-wahs whistling off in the jungle in two directions. They are evidently early risers. We went for one company of them as soon as it was light, but, although we expected to find them within two hundred yards of the house, they were more than a mile away, in the swamp. Had three fair shots, failed to bring down anything, and returned crestfallen. Started a civet cat and fired at it-also without result. After coffee at the house, we went out again, but got nothing except about twenty leech-bites. Leeches swarmed where we went to-day, and we were badly bitten. There are two kindsone being the common, short, lead-colored species ; and the other twice as long, with a narrow, yellow stripe along each side of its body. The bite of the latter is most painful.

"Perara shot a yellow-necked hornbill and two other birds, one of which proved to be the celebrated Dyak omen bird (Harpactes rutilus, Vieill), a sub-genus of the trogons, not at all rare on the Sibuyau. The Dyaks at the house noticed it at once, and expressed a desire that we would not kill any more of them, a request to which we readily acceded.

"To-day I selected and bought a number of ethnologicai specimens of the Dyaks, including spears, parongs, biliongs (axes), bark cloth and sundry smaller articles. After considerable encouragement and advice I got Gumbong to work making me a model of a 
Dyak long-house, to be a fac-simile of the real thing. I am to pay him a dollar for it when it is completed. His only objection to making it was a lack of confidence in his ability to make something entirely new and heretofore unseen. But he caught the idea very quickly and went to work at once. Another Dyak has undertaken to make for me a model of a prau (large boat), to be likewise complete in every particular.

"November 14th. - Killed a gibbon in the morning. Perdition seize all English-made foot-gear! My 'superior London-made shooting-boots' (shoes), the best in the market at Singapore, went entirely to pieces to-day, after precisely two-and-a-half months' wear. The soles came off bodily. Would they had been immortal! The hunting-shoes made for me at Rochester lasted me through fourteen months' constant wear in all sorts of wet and dry weather; through muddy swamps and over rocks as well. Now I shall be obliged to wear my Sunday (!) shoes to hunt in, and they, being also of the best English make, will probably last me through the month.

"November 15th. -Shot a half-grown mias. In the afternoon, Perara came running in from the jungle to tell me to come and shoot two mias chappin which he had just seen about a mile from the house. We ran all the way back to the spot, up hill and down, splashing recklessly through mud and water-and of course the mias were both gone. And of course we failed to find them. This is the third time the boys have played that little game on me, and made me nearly drown myself in perspiration.

"November 16th.-A disgusting day's work. Having nearly exhausted my stock of Berdan primers, I loaded all my shells yesterday with Ely's. To-day, in the course of a long jaunt, we found two troops of gibbons, and five cartridges out of nine failed to go off. One fine chance after another resulted in the ghastly metallic 'click' of the hammer, which always chills a hunter's marrow and makes him think unutterable things. In spite of my hard work and good opportunities I killed not even one gibbon, and at last, tired out and disgusted, we started home. But I was doomed to have Tantalus' cup offered me once more. On the way a fine wild hog presented himself at fifty yards and stood still. I quickly drew a bead on his head with my rifle, pulled the trigger-'click,' and away went the hog.

"November 18th.- On going out with Le Tiac and Dobah we found a fine, large porcupine (Hystrix longicauda) caught by a 
hind foot in a twitch-up, and held to its death by a slender bark cord, which one nip of its sharp incisors would easily have severed. Poor, stupid animal. We came upon a large tapang tree which threw out one magnificent buttress fourteen feet long, twelve feet high where it left the tree, and three feet high at the other end. This curious spur-root was a natural plank, two inches in thickness, with perfectly straight sides, covered with thin, smooth bark. I had often heard and read of these buttresses, but not until seeing one did I at all understand what they are like. As I looked at that immense natural slab, hewn out by the hand of nature, I thought of Robinson Crusoe, and how he would have leaped for joy could he have found such ready-grown shelves and tables in his forest. With considerable labor, I climbed into the top of a small tree growing farther down the hill, so as to get a good view of the buttresses, and in that uncomfortable position sketched the foundation of the tree.

"Perara distinguished himself to-day by killing a gibbon, and also a fine flying lemur (Galeopithecus variegatus). These two specimens, our porcupine, and a Cynogale Bennettii, which was brought in by one of our Dyaks, gave us work enough for the afternoon. We ate the flesh of the porcupine, which was good enough, although rather neutral in flavor. As we were obliged to work indoors all the afternoon, it rained half the time. As a general thing, the gnats, moths, mosquitoes, and other insect abominations are so bad at night that it is almost impossible to read or write with any degree of comfort.

"November 19th.-A blank day for me. Perara killed a female orang with my No. 16 gun and No. 1 shot! Of course the animal was roosting low. I am feasting now on wild honey, brought yesterday by a foreign Dyak, who sold me three quarts of nice strained honey for twenty-five cents. My boys protested against the extortion, and declared I need not pay more than fifteen cents, but I would have been ashamed to buy honey for which a Dyak climbed perhaps eighty or ninety feet, at less than eight cents a quart. Were I to climb to the top of a tapang tree for honey it would cost the buyer at least a hundred dollars a quart, if I got any.

"Hot cakes, butter and honey go well together, or at least my baby orang thinks so. Whenever Ah Kee begins to set the table - the box, I mean-for a meal, the Old Man is all animation. He rises instantly from his straw, where he has been lying lazily playing with his toes or making up faces, and gets as near the table as 


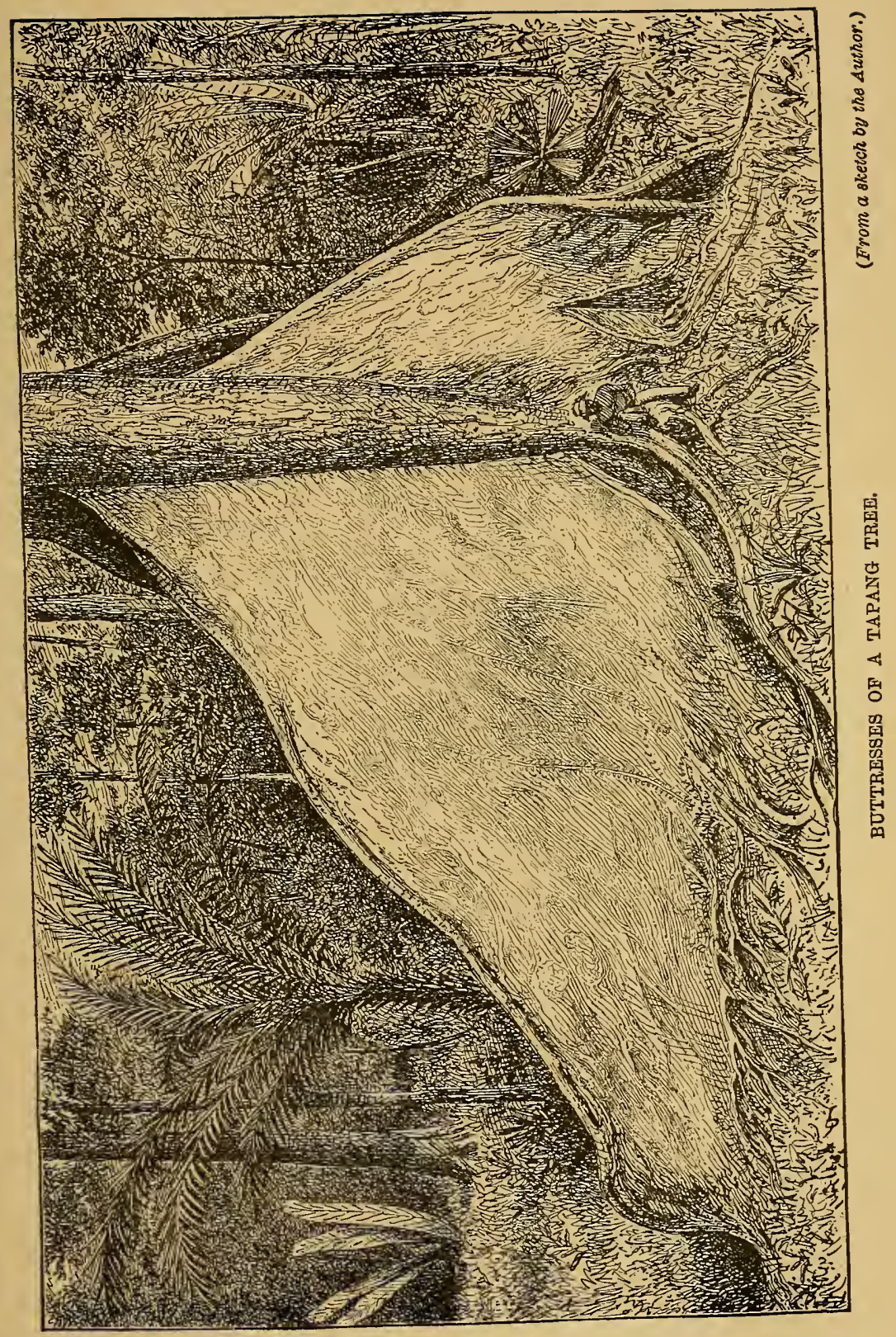



his line will let him go. By standing as nearly erect as he can, stretching his neck to the utmost, he can just see the dishes on the box; and watch for the plates of food. As the crisis approaches, he grows more and more excited, whining, coaxing, and pleading with his eyes for the food which is just beyond his anxious fingers. If I sit down and begin to eat without feeding him, he looks at me reproachfully, his nether lip drops disconsolately, and he whines in an aggrieved tone. If I still refuse to serve him, his whine rises to a shrill, child-like scream, and he throws himself flat upon the floor, kicking and shrieking like a spoiled child. This was the most human action I ever saw in ape or monkey. More than once I attempted to discipline the little brute with a small switch to see if I could make him stop screaming, but, true to the impulses of nature, he only screamed the louder.

"The Old Man evinces a decided liking for me, and also for Ah Kee ; but is shy of strangers. Whenever a dog makes his appearance in our room, or it thunders hard, the little fellow makes straight for me, as fast as he can come, climbs quickly up my legs and nestles in my arms for protection. The Dyaks consider bim unusually bright, even for an orang, and several have travelled miles on purpose to see him.

"November 20th. - Two argus pheasants and a civet cat (Viverra tangalunga) were brought in yesterday, and to-day we prepared their skins. Le Tiac finished making a fiddle for me, and when he delivered it I paid him sixty cents as per agreement. After looking at the money a quarter of an hour, he came to me and said he would rather keep the fiddle, so I gave it back to him, and he returned the money. Foolish fellow. He can make a fiddle any time in a day and a half, but he cannot find a market for another in ten years, I venture to say. But I shall have that fiddle yet, all the same.

"When we arrived here, $\mathrm{Ab}$ Kee assured me there was not a cent of money nor a measure of rice in the house. Since that, they havs earned enough in various ways in my service to enable them to send off twice, to buy rice; but now they are getting stomach-proud, and are prepared to kill the goose that lays the golden eggs. For example: the old man, Gumbong, who has hunted with me during the past week, made up his mind last night that thirty cents per day is not enough wages, and he has therefore struck for fifty. Ah Kee lectured him roundly, and I told him to go to the blazes; but be declared that he would not for less than fifty cents a day. To my 
greater grief, Le Tiac has also struck on the same grounds and there is a coolness between us. He was somewhat surprised when I told him I should not want him any more.

"November 21st.-Leaving the Dyaks to amuse themselves indoors as they saw fit, Dobah and I went out hunting and killed a gibbon with the rifle at rather long range. The way these auimals can swing along is something marvellous. To-day I saw one going down hill through the tree-tops where the forest was rather open, and, for fifty yards, he went as straight as though he had been shot out of a cannon, He flew straight along without an instant's pause or hesitation, always turning end over end. Talk about the 'poetry of motion,' this is poetry set to music. A gibbon seems to progress entirely by the sole act of his will, and without taking the least thought as to the means.

"November 22d.-Two more argus pheasants in the morning, and rain in the afternoon.

"November 23d.-A boil which has been coming on my elbow has at last arrived in full force, and I am quite demoralized. A hammock and a boil do not go well together, especially when the latter is on so salient a point as one's elbow. Spent all last night and to-day in trying to make the thing comfortable. Noticed, very dis. interestedily, a great number of butterflies flitting about the wet ground underneath the house. There were at least a dozen species -all large and brilliantly colored. An entomologist would have a fine time of it among them, and the Dyaks would bring him hundreds at one cent each. To me they are no temptation. It is impossible to collect and care for small objects, like insects, except at the expense of large and important ones, like mammals. It is so far my policy to shun small things, that I do not even pretend to shoot and skin small birds.

"November 24th. - The boil and I are more comfortable. Spent the day reading Maury's 'Physical Geography of the Sea'-one of the most charming books I ever read, deep but clear, like Lake Tahoe. What a pity all writers on scientific subjects have not Maury's wonderful ability to write clearly and to the point.

"November 25th.-When I started out in the morning, with Dobah, Le Tiac repented and offered to go with me on the terms of our old agreement, so we took him. Started out to make some sketches in the jungle, but took my rifle on general principles, though not expecting to use it. After a long and skilfully conducted chase of a troop of gibbons, they finally eluded us altogether. 
As we were toiling disconsolately up a steep hill we heard a sudden rustling and saw the movement of some wild animal in the bushes close to our path. I thought it was a wild pig: An instant later a dark object came shuffling rapidly toward us, growling as it came, and we saw it was a bear. The absurd little beast was actually charging us. When it was within ten paces I gave it a ball exactly between the eyes, which settled it forever. The instant my shot rang out, another and even smaller bear appeared, also above us, and came shuffling down the path, evidently intending to flank us.

"Le Tiac cried out excitedly, 'Bruong, tuan! Bruong!' whereupon the second bear wheeled about and started back up the hill as fast as he could go. Remembering my bear experience in the Animallais, I determined to stay by my first victim and make sure of that one at least. I fired two snap shots, however, at No. 2 ; but he was so much concealed by low bushes that I missed both times and he got away. The one we had was a full-grown female Halarctos Malayanus, but it weighed only 60 pounds,-too small to make our grizzly a square meal! Its total length was 36 inches exclusive of tail (1 inch), and its height at the shoulders was 18 inches. This bear is, I believe, the smallest species known. Its hair is short, very even, smooth, and glossy black everywhere except on the breast, where there is a cream-colored patch shaped like a V. Le Tiac joyfully tied the little beast into a bundle, took it on his back, supported by a strip of bark over his forehead, and we trudged on to make our sketches.

"On reaching the spot where the large argus pheasant was caught in a twitch-up, we all sat down and I began to work. We had sat there very quietly for nearly an hour, when suddenly Dobah exclaimed in a whisper, 'Kejang, tuan!' I looked in the direction he pointed, and, sure enough, down below us, a hundred yards or so, was a pretty little muntjac (Cervulus aureus) walking jauntily along the side of the ravine. I fired and it disappeared. My companions rushed down the hill and found the little animal lying dead behind a log, shot through the heart. It was a beautiful little buck, with perfect horns. After I finished my sketch, Le Tiac backed the bear, Dobah shouldered the muntjac, and we marched home.

"The Dyaks are rather demonstrative. As we approached the house on the open side, the inmates quickly espied us, and we were greeted by a deafening chorus of 'ohs!' and 'ah-doe, ah-does!' as men, women, and children bawled and squealed out their aston. 
ishment and delight. Ah Kee's whole face and head was covered with one vast and all-pervading Chinese smile of delight at our good luck. The secret of all this joy lay in the fact that our game was thoroughly eatable. We gave the Dyaks the flesh of the bear, which they cooked and ate immediately, and kept the muntjac meat for ourselves. Ah Kee boiled down a quantity of it and made the richest and most delicious soup I ever tasted. An epicure who would not gush over the flavor of the muntjac would be unworthy of the name. It certainly surpasses, in exquisite delicacy of ' game' flavor, all the other meats I ever tasted.

"November 26th.-In the jungle during the forenoon, to small purpose, and in the afternoon it rained. Le Tiac started off this morning on a six days' tramp after gutta, but about noon he heard the ery of an omen bird, of the kind called brah-guy, on the right hand, and he was therefore obliged to return and wait two or three days before starting again. He told me that if the bird cries on the right hand or behind one who is starting on a journey, it is a bad sign and he must return at once; but if it cries on the left hand or in front of him he can go on without fear. If he should go on after hearing the bad omen he would have bad luck-either be taken sick, cut his hand or foot, or perhaps the gutta-percha trees would not run any sap when eut. He declared that only once did he venture to go on after hearing the bad omen, and before he returned he accidentally cut his hand with his parong.

"The Dyaks generally attach great importance to the omens or signs which they recognize in the appearance or cry of certain birds, quadrupeds, and insects, in connection with the more important undertakings of their lives. In the Kyan country of the upper Rejang, a large head-hunting expedition of over one thousand warriors, which had just set out on a grand foray, was instantly turned back and broken up by a little kejang (muntjac) which ran across the line of march in front of the expedition. Newly-married couples are sometimes obliged to separate on account of hearing a 'deer cry' within three days after their nuptials, in order to prevent the death of one or the other within a year.* Insects often warn warriors of the presence of their enemies, and again assure them that they may rest securely for the night.

"What a glorious thing it would be for the American farmer's boy if omen birds could be introduced into the United States. $\mathrm{He}$

* St. John. 
would certainly hear one cry on the right hand when starting to the field on a 'show day,' and at least twice a week in the autumn inonths, when the young prairie chickens were flocking around. The lazy school-boy would listen eagerly for them as soon as the strawberries and cherries ripened; and a little later, in melon time, when the days were awfully hot, he would hear an omen bird calling to him from every fence-post on the right as soon as he started off to school. The omen bird would supply a long-felt want, and no true American farmer's boy would be without a flock of them. No other bird would be so safe from harm, or protected with such tender solicitude. Had omen birds been as plentiful as blackbirds on the Iowa prairies, I might have remained a farmer boy much longer than I did; but without them, life on the farm was unendurable.

"A Chinese trader came to the village to-day, to trade rice for gutta-percha, wax, etc. The Dyaks are either very stupid, very lazy and shiftless, or all three together. Instead of taking their gutta down to Kuehing, where they could sell it at 60 cents per cattie ( $1 \frac{1}{3}$ pound), and buy rice at ten to eleven gantongs for a dollar, they loaf around the village until a sharp Chinaman comes along and takes their gutta at $37 \frac{1}{2}$ cents per pound, in exchange for rice at five gantongs to the dollar, and cheats them in the weight of both!

"Ah Kee took his wooden steelyards and showed me how a Chinaman can cheat in weighing an article. By the insertion of a tiny wooden peg beside the string which holds the weight at the place where the end passes through the beam, it is easy to make an article weigh too much or too little, as the weigher chooses. $\mathrm{He}$ assured me most solemnly that Chinese traders nearly always cheat ten per cent. in everything they weigh, when dealing with simple people like the Dyaks.

"November 27th.-Went with Gumbong to see how he collected gutta. A mile from the house he found a gutta tree, about ten inches in diameter, and, after cutting it down, he ringed it neatly all the way along the stem, at intervals of a yard or less. Underneath each ring he put a calabash to catch the milk-white sap which slowly exuded. From this tree and another about the same size, he got about four quarts of sap, which, on being boiled that night for my special benefit, precipitated the gutta at the bottom in a mass like dough. The longer it was boiled, the harder the mass became, and at last it was taken out, placed upon a 
smooth board, kneaded vigorously with the hands, and afterward trodden with the bare feet of the operator. When it got almost too stiff to work, it was flattened out carefully, then rolled up in a wedge-shaped mass, a hole was punched through the thin end to serve as a handle, and it was declared ready for the trader. I have seen the Dyaks roll up a good-sized wad of pounded bark in the centre of these wedges of crude gutta, in order to get even with the traders who cheat in weight, but I have also seen the sharp trader cut every lump of gutta in two before buying it. If he found bark, you may well believe he did not pay for it at the price of gutta. The crude gutta has a mottled, or marbled, light-brown appearance, is heavy and hard, and smooth on the outside.

"November 28 th. - To-day Le Tiac announced his intention of climbing a large tapang tree we saw in the forest a few days ago, and I went along to see it done. His object in climbing was to secure some bees' nests, which we saw hanging to the under side of the largest limb. Some torch-wood was taken along with which to make a smoke to protect the climber from the bees. The tree was a grand specimen of its kind, about five feet in diameter at the base, covered with fine-grained, soft, white bark, straight as a ship's mast and without the smallest limb or knot for fully a hundred and twenty feet up. It towered grandly above its neighbors, and to any one but a Dyak its top was utterly inaccessible. Hanging from the under side of the largest and lowest limb, was a good bees' nest, simply a naked, triangular piece of white comb, but we could not see any bees flying around it.

"A Dyak 'ladder,' by courtesy so called, reached from the ground to the branches, put up the previous year, the Dyaks said, but still strong. It was a very simple contrivance, but one requiring a bold man, utterly destitute of nerves, either to put it up or ascend it. It consisted of seven twenty-foot bamboo poles held almost end to end alongside the trunk by sharp pegs driven into the soft wood about two feet apart, first on one side of the poles and then on the other, to which the bamboo poles were lashed by rattans, and held firmly about eight inches from the tree. These pegs served as the rungs of the ladder. The builder was obliged to let the ends of the poles overlap a few feet in order to build the ladder with safety to himself. Just imagine yourself a hundred feet from the ground, clinging to a shaky lightning-rod and hauling up another section twenty feet long, to put in place and peg fast at the lower end, so that you can climb it and make it fast as you proceed! 
"Le Tiac had few preparations to make. He wore only his chawat, which he adjusted securely, tucking the ends in tightly so that they would not catch on the pegs and trouble him. At his back was securely fastened a juah (back-basket) to receive the comb if it contained honey. His torch was made up securely, and slung from his neck by a cord, so that it would hang down his back lower than his feet. It was then ignited and waved to and fro, until it smoked freely, and he started up. He threw his weight heavily on the first bamboo to test its strength, and also tried the second, more cautiously ; but they held firmly and on he went. It was like climbing a tall factory chimney by the lightning-rod, and a very shaky one at that. It was the most daring feat I ever witnessed, and I regretted that the audience was so small. But the climber did not seem to miss the crowd which his exploit would have attracted in civilized America. He went up, hand and foot, with the most perfect ease and nonchalance, until he had scaled the dizzy height, and seated himself astride the lowest limb to rest a moment and gaze off over the top of the jungle. It actually made my head swim to look at him and imagine myself in his place. Taking his torch in one hand, he held it in readiness and crawled out along the bare limb until he was within reach of the coveted prize. He examined it first on one side and then on the other. 'No honey!' he shouted down as cheerfully as though his climb was a matter of perfect indifference. To our exclamations of disgust, he replied with lofty smiles, and leaving the comb untouched he began to descend, and soon reached the ground without accident.

"I am told that accidents do happen to honey and wax-gatherers now and then, from a fault in the construction of the ladder, but very rarely. Sometimes a number of bees' nests are found on a single branch, and the climber gets so badly stung as to cause him to fall. Where there is any danger on account of the number of bees, two or three Dyaks go up together to make the attack; and, while one gathers the comb, the others protect him from the bees with the smoke of their torches.

"November 28th. -A day of rain, which I spent in the house conversing with the Dyaks, through the interpretation of Ah Kee. They are a very remarkable people morally, and I have conceived a great admiration for them. The more I see of them, the more I see in them worthy of respect. I regret that I cannot spend several years among them and see all kinds of Dyaks under all kinds of circumstances. 
"November 29th. - Last evening, after making my daily entry in this journal, an incident occurred which promised to turn out very seriously. Ah Kee is very fond of hunting, and often takes my gun and goes off hunting by himself. This afternoon, after my dinner was over, he took the big gun and went out. He did not return at the usual time, and, just at sunset, I was standing in the door expecting every moment to see him put in an appearance, when, all at once we heard two reports of his gun coming in quick succession, muffled and faint, and so distant that the sound barely reached our ears. It seemed at least three mises off, and I instantly exclaimed, 'Ah Kee is lost!' I told some of the Dyaks to go at once in the direction of the sound and find him if $\mathrm{p}$ ?ssible. Perara and I began firing our guns, and kept it up at intervals all the time. The Dyaks and Dobah went as far as they could before darkness came on, and $I$ heard them calling and calling, but without an answer. I waited to see if Ah Kee would come nearer, or if the men would find him, and, at last, after it had grown pitch dark, we heard another muffled 'boom!' even fainter and farther away than before, and I saw that if we did not go and find him, he would have to stay all night in the jungle and perhaps longer.

"Now, under certain circumstances, a night in the jungle is no laughing matter. Ah Kee was in the worst swamp in the country, without a parong or knife, or any means of making a fire, perhaps with all his cartridges expended, wet of course, nothing to eat, and tormented by myriads of mosquitoes and leeches, to say nothing of the fear of poisonous snakes or pythons, or of being attacked in the darkness by a bear or a tiger-cat. We knew that even if he heard our firing, he could not possibly come to us in the pitchy darkness of that tangled, thorny jungle, and if left alone, he was iust as apt to go directly away from us as any other way. If not found before to-morrow, he might wander where we could not find him, and, all his cartridges being expended, he would be unable to signal to us. Ah Kee was a faithful fellow-perhaps the best servant I have ever had-and he was devoted heart and soul to my wants and my interests regardless of himself. So I decided, in two seconds, that we must find him at once.

"I called the Dyaks and told them to prepare torches and a good supply of wood, while I put on my hunting gear. Taking my revolver and rifle, with a bag half full of cartridges for each, and a small bottle of gin, we set out. Perara seemed to think it a good joke on Ah Kee, and declared he had often told him not to 
go far away; but I quickly silenced him by saying that there was no possibility of his (Perara's) getting lost, for he seldom went out of hearing of the house, and that if he had had pluck to go a little farther now and then, he might have shot something. We took a torch of wood called 'suloe,' which is full of resin and burns brightly, and, with two extra bundles of it, we set out-three Dyaks, Dobah, and I. The big alarm-gong was brought out and loudly beaten, and, taking our departure by its sound, we went in the direction of Ah Kee's last shot. We were soon half-knee deep in water and ooze, but with the aid of the torch we got on reasonably well. At intervals I fired a shot as we proceeded, and the men kept calling. After going a mile or so we heard a shot far away on our left. We said that must be Ah Kee and we turned that way. After a long time we heard two shots on our right and to the rear. The men all said it was Ah Kee, but I ceclared it came from the house, and was Perara's gun. No, they were sure that it was Ah Kee, while I persisted that it was Perara, so we came to an undecided standstill. They did not want to go on, and so I reluctantly consented to turn back in the direction of the last reports.

"For several hours we wandered about, firing the rifle and calling, but could get no answer, and at last had no idea which way we ourselves were going. If we had only had a comprss we could have gone straight from the house in the direction of Ah Kee's last shot; but alas! my only compass had been lost some weeks before. At length the torch-wood was nearly exhausted and there was simply nothing to do but go back, get more wood, and start again. For the last time we fired the rifle; then shouted: 'Ho! Ah Kee!' until the forest rang for a mile on every side, and as the echoes died away we held our breath to listen. Only the soft twitter of the night birds and the chirping of the tree frogs answered us. The brown half-naked Dyaks looked at me and at each other in hopeless perplexity, but no one had any new plan or thought to suggest. The torch-bearer knocked the ashes from his torch, waved it to and fro until it blazed up again, and then, reluctantly enough, we turned our faces homeward.

"We had gone but a short distance, and I was just planning how we would arouse all the Dyaks in the three villages and offer twenty-five dollars in silver (a fortune to a Dyak) as a reward for finding $\mathrm{Ah}$ Kee, when we were startled by a deep 'boom!' from behind us, which we knew at once was from Ah Kee. Luckily we caught the direction exactly. In less than a minute, two men had 
received hurried directions to hasten to the house for more wood and to come after us with all speed, along the track we would cut through the jungle from the spot where we stood in the direction of the shot. The two Dyaks and I then wheeled about and started through the swamp, slashing our way rapidly along, climbing over fallen logs, tearing through thickets and stumbling through mire, but keeping the direction very carefully. Every hundred yards we would stop and call: 'Ho-o-Ah Kee-ee!' At last we heard a faint, a very faint 'O-o-o-o-ho!'

"'Hurrah, boys! Now we've got him!' and with one joyous, simultaneous yell, which woke the echoes far and wide through the swamp, we settled down to the task of cutting our way to him. The water here was nearly knee-deep, and the palms so dense and thorny that we were forced to cut a passage for every step we advanced. It took us a good half hour to get to him from the time we heard his first answering call. But we kept calling and he answering, so as to keep the right direction, until we were within a few yards, when, cutting through a perfect cheval de frise of palms, whose leaves were twelve feet in length and set with thousands of thorns, we saw a black object wading slowly toward us through the water and the darkness-and Ah Kee was found!

"His wide trousers were rolled about his knees and hung upon him in rags. His 'pig-tail' was wound tightly around his head, his body scratched and bleeding, and, taken altogether, he was a forlorn spectacle. He said he had taken off his clothes, because they caught on all the thorns and hindered him from creeping along. He put on his clothes, took a drink of gin, and as soon as the supply of wood arrived we started home. I was very glad to find him and he was equally glad to be found. He had two cartridges remaining, which he proposed to save to defend himself with, if attacked by any wild animal.

" $\mathrm{He}$ had fired only four times in all, and the others were Perara's marplot shots. Ah Kee heard our firing from the house, and tried, by climbing a tree, to get the direction, but after getting it could not keep it ten minutes. Even when we were firing every five minutes, he went first in one direction then another, then back again, utterly unable to go straight. The forest is so thick that it is almost impossible to judge of direction by sound. Ah Kee got lostin trying first to shoot a wah-wah, and then in following a hornbill as it flew from tree to tree. At last we got to the house amid general rejoicing. And what do you suppose was Ab Kee's first act 
after getting into his dry clothes? He built a fire and made a nice cup of tea for me! That act describes his whole character.

"November 30th.-This morning Gumbong and another Dyak brought in the little bear which escaped us the day we killed the other. It was only about half grown, and they captured it alive. How it did bawl and struggle as it lay on the floor, bound hand and foot. It was a very pretty little specimen, a foot high and twenty-two inches long, with a coat of smooth, fine, inky-black hair. The Dyaks had the good sense to sell him to me, body and soul, for a reasonable price, and his skin was soon added to my collection. Better that, a thousand times, than a life of miserable captivity among the Dyaks.

"True to his engagement of a month previous, Blou arrived today with the large prau and two other Malays to take me back to the Sadong. He also brought a large packet of letters, which I received most gladly. After all, the greatest pleasure of jungle life is getting letters from home. Sent eight loads down to the boats, and Dobah slept there.

"The model Dyak house, prau, and the fiddle Le Tiac made and loved, not wisely but too well, were all delivered to-day, together with more bark-cloth, body ornaments, and musical (!) instruments. The three articles first mentioned were very well made and showed that Dyak mechanical skill is of no mean order when encouraged a little.

"December 1st.-At peep of day, we were up and off, bag and baggage. Of course the Dyaks assisted us in getting away with our plunder. The men went with us to the river, and the women who remained at the house, were loud in their protestations of regret at our departure. They said they would be very lonesome when we were gone. I think each of the women said good-by about fifty times, and as we left the clearing they stood on the ladder and in the door, calling Malay good-bys to 'Tuan,' 'Ah Kee,' and 'Pleira,' one after another as fast as we would answer them, and then begin again. They kept it up until their voices were lost in the jungle behind us, and then a dog at the house set up a dismal howling, as though he, too, were affected by the universal sorrow. It was awful work getting across the grass swamp, and afterward over the wretched 'batangs,' for the remainder of the distance. The batangs were small smooth sapling stems laid end to end over the mud, wet and slippery, so that we occasionally took a sudden slip into the mud and water two feet deep. There 
are plenty of saplings about, and, but for their lack of enterprise, the Dyaks could soon cut enough to lay two or three side by side all along and make a passable road over the mud. But the idea never occurred to them, or if it did, they were too lazy too carry it out.

"Without losing a moment's time, we loaded the boats and started, hoping, by hard paddling, to make the return journey in two days. On the way down I shot my last orang, No. 43-a splendid old male 'chappin,' 4 feet 3 inches in height. He was sitting low down in a tree, comfortably humped up with his chin resting on his hand, facing us, not over thirty yards away, and he did not evince the slightest alarm at our sudden appearance. I shot him very easily, and when he let go, he fell like a bag of meal, sprawling face downward, as mias nearly always fall.

"The nipa palm grows very thickly along the lower Sibuyau, and at low water, when they are not partly submerged, they are very pretty. From fifteen to twenty finely cut leaves grow from each root, of a dense green color, and very graceful. To the native, the nipa is a gift of the gods, apparently designed to supply them with everything in which the jungles are otherwise lacking. From the leaves, the indispensable attap house-roofing is made, cheap, durable, and easily portable, and also kadjangs for boat roofs, so perfectly adapted to the purpose that even the inventive genius of a patent-making American could not produce a better appliance; the roots when burned yield salt, from the spadix toddy is extracted, convertible into vinegar by one process, arrack by another, and sugar and molasses by another.

"Just before reaching the kampong at the mouth of the river, we came to a house where the Malays had lately been making syrup and also sugar. I tasted the former and found it delicious, better than anything of the kind I ever ate, except that made from the sugar maple. It was thick, frothy, and clear, with a peculiar sweetness in which there is a very perceptible flavor of salt. I bought two joints of bamboo full of it, about a gallon, for twenty centscertainly not an exorbitant price-but alas, I had no buckwheat cakes! We reached the village at sunset, and have taken up quarters for the night, in a dismal, empty, and dilapidated hut on shore. Have just finished my supper-by courtesy so-called. My rations to-day consisted solely of one can of salmon (one pound) and another of green peas (one-half pound) washed down with muddy river water. This is my birthday, my third since leaving home, 
and I sit here in this gloomy hut, flat on the floor, with $\mathrm{my}$ blanket spread on the rough poles for a mat, and my ammunition-box between my knees for a writing desk, while outside it is pitch dark, the rain is pouring down, and the tide is running swiftly up. The men prefer to sleep in the boat, and I am left alone in my glory. We have had a long, hard day of it, with precious little to eat, and I will abandon this tiresome journal and seek my swinging cradle.

"December 2d.-Up at daylight, and Perara and I made short work of skinning and skeletonizing the mias. With a little help from Dobah we finished it in two hours. Then we tumbled into the boats and set off. The Malays are working by the job, hence their willingness to make good time. In the afternoon, as we were about entering the mouth of the Sadong, a violent squall caught us, and we came very near being swamped. We certainly would have been had not the wind ripped off our kadjangs clean and clear so quickly that we were saved from going over. Luckily we did not have the sail up. For a time it looked as if there would be an amateur swimming match in which all who could swim would participate to see who could get to shore. But we presently found a haven in the mouth of a small creek, which we ran into thankfully enough, but with passengers and cargo thoroughly drenched, and waited until the squall was over. Dined off a pint tin of hare soup, which was short measure and very thin. Reached Simujan at 10 P.M. and found my valuable collection and all other belongings in perfect safety, just as I left them."

The day after my return Lamudin found the nest of a crocodile on the bank of a small creek about four miles below the kampong; and after shooting at the old female and wounding her, he came to let me know. On visiting the spot with him I found the crocodile lying dead beside the nest whither she had crawled, mortally wounded, to watch her charge to the last. Her length was nine and a half feet.

The nest was situated on a clear strip of marshy ground, about fifty yards from the bank of the creek. It was simply a mound of dead grass, grass-roots, and earth, about nine feet in diameter on the ground and three feet high. The ground around the nest was covered with water at high tide, and the mound was thrown up to afford the eggs a resting-place above high water mark. We went to work with our hands to dig open the nest, and 
after removing about eight inches of warm sodden grass and earth in a high state of fermentation we came to the eggs. They had evidently all been deposited at the same time, over the top of the half-built mould, for they were disposed in a single layer. There were fifty-five of them-an unusually large number for a crocodile -and incubation had been in progress about ten days.

I took thirty-two of the eggs, at three cents each, and the remainder were eagerly purchased at the same price by the Malays of the kampong, who ate them, notwithstanding the fact that each egg contained a little embryo crocodile. I was very anxious to hatch a number of the eggs in order to watch the development of the embryo, and vainly offered five dollars for a setting hen or duck to cover the eggs. I tried to hatch the eggs in warm sand, but my going to Sarawak caused the failure of that plan also. I am therefore only able to present a drawing of the embryo as we first found it.

By this time (December 5th), I had eaten up all my provisions, spent all my money and allotted time, and having made a rich and valuable collection of what I most desired, I was ready to move on. After dining for the last time with genial Mr. Walters, I engaged passage for my two men and two mits, my collection and myself in a Chinese trader's boat bound for Kuching. $\mathrm{Mr}$. Eng Quee gave me at parting a number of valuable ethnological specimens which he had surreptitiously gotten together for my benefit.

I left the little kampong with keen regret, and have ever since looked back upon it longingly. The days I spent on the Sadong, the Simujan, at Padang Lake and the Sibuyau seem like a strange, delightful dream of a sojourn in another world, where every face and form and every object, animate and inanimate, was strange and strangely interesting, and with the sweet there mingles no bitter. It was a lotus-eater's life that I led for four delightful months, free from the aggravations which beset all but jungle life.

The deep, mellow boom of the big gong in the veranda of the government house, on which the policemen struck the hours with measured stroke, and its echo, rolling through the surrounding forest like a wave, will always sound in my ears. I love to think that the hours are struck there now just the same. 



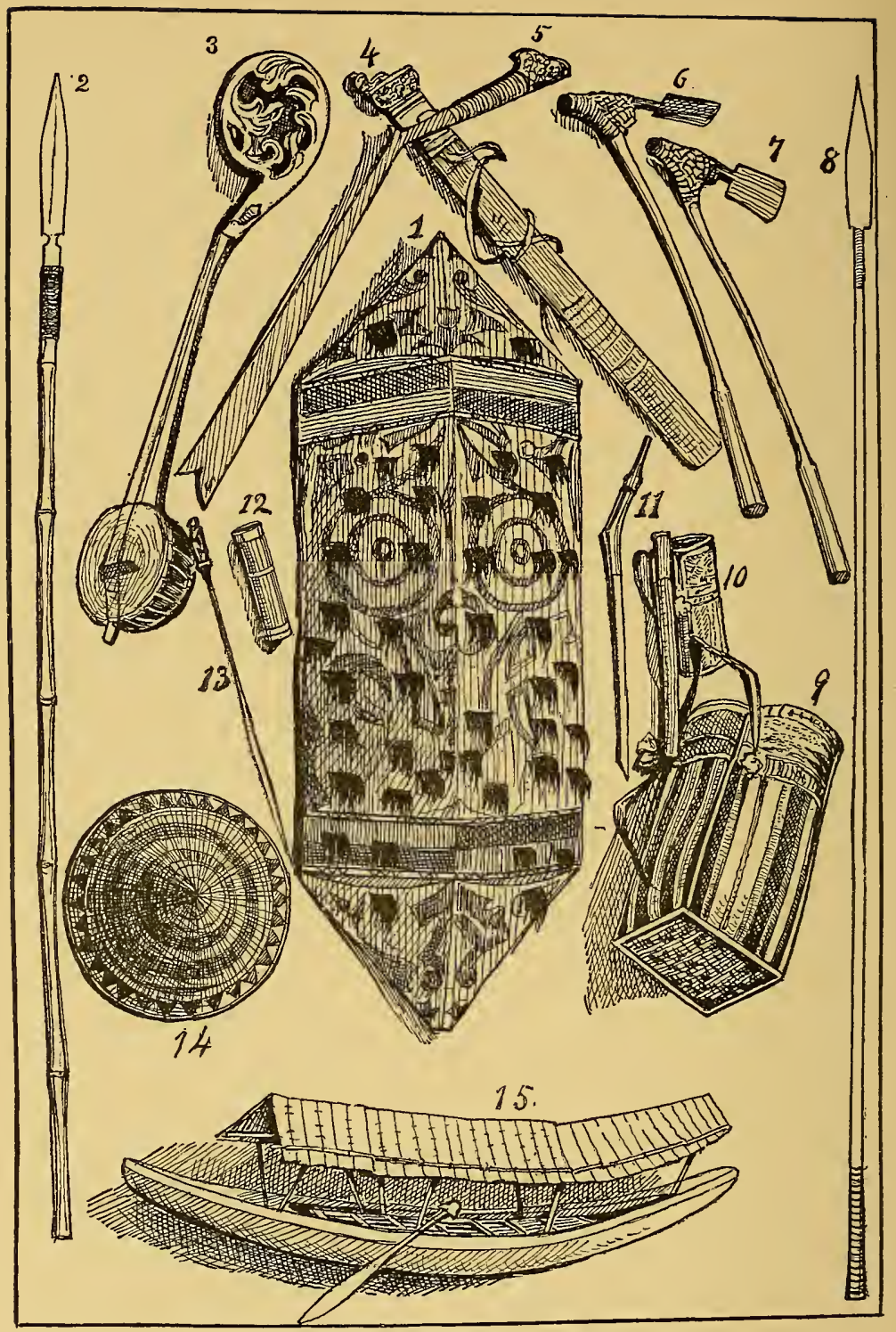

DYAK WEAPONS, UTENSILS, ETC.

(Drawn from specimens collected by the Author.)

1. Kyan war shielđ.

2. Sea Dyak spear.

3. Sea Dyak fiddle.

4. Sheath of Parong latok.

5. Parong latok. (Hill Dyaks.)

6. Biliong, to use as an adze.

7. Biliong, to use as an axe.

8. Sumpitan, used by Poonans.

9. Juah, or back-basket.
10. Sirih basket.

11. Betel knife, to accompany No. 10.

12. Chunam box

13. Sibnyau Dyak measuring-stick. (Used jn setting pig traps.)

14. Sibuyan Dyak hat.

15. Model of Sea Dyak boat, with kadjang roof. 


\section{CHAPTER XXXVII.}

\section{THE ABORIGINES OF BORNEO.}

Civilization an Exterminator of Savage Races.-Stability of the Dyaks.-The Survival of the Fittest. - The Typical Dyak.-Four Great Tribes. - The Kyans. - Their Strength and Distribution.-Tribe Misnamed Milanau.General Characteristics.-Mechanical Skill.-Modes of Warfare.-Aggressiveness.-Cannibalism of certain Sub-tribes.-Tattooing.-Ideas of a Future State-Human Sacrifices.-Houses.-The Hill Dyaks.-Distribution.-Takers of Head Trophies.-Fighting Qualities.-Physique.-Dress and Ornaments. - A Curious Corset. - Weapons. - Houses.-The Pangah.-Social Life.-Strict Morality without Religion.-Prohibition of Consanguineous Marriages.-Marriage Ceremony.-Honesty._Disposal of the Dead. - A Relic of Hindooism.-Ideas of a Supreme Being and Future State.-The Mongol Dyaks. - Remains of Former Chinese Influence.-An Advanced Tribe.-Position.-Physique.-Dress. - Houses. - Skill in Agriculture. - Implements of Husbandry. - Independent but Peaceful.-The Muruts.-Dress and Ornaments.-Houses.-The Kadyans. -Comparative Estimate of the Four Great Dyak Tribes.

SAVAGE tribes deteriorate morally, physically, and numerically, according to the degree in which they are influenced by civilization. Those which yield most readily to the mild blandishments of the missionary, the school-teacher, and the merchant are the first to disappear from the face of the earth. Behind the philanthropical pioneer of Christian civilization, even though he bears in his hands only the Bible and spelling-book, there lurks a host of modern vices and diseases more deadly than the spears and poisoned arrows of the savage. To improve a savage race is to weaken it; to wholly civilize and convert it is to exterminate it altogether. Like the wild beasts of the forest, the children of nature disappear before the grinding progress of civilization.*

* This has proven true in perhaps more than ninety per cent. of all cases in point. Oscasionally, however, a savage tribe is found possessed of suffcient moral strength and tenacity of purpose to withstand th: first great shock of contact with the powerful forces of civilization, and to survive indefinitely thereafter. Such tribes as are thus fitted by nature to absorb the 
To the ethnologist, aboriginal races lose interest in proportion to the extent in which they have adopted modern customs and ideas. If we except the changes in customs necessarily brought about by the suppression of the head-hunting and piracy, it is safe to say that the Dyaks of Borneo are to-day precisely what they were when Europeans first landed. on the island. They have mildly but effectually resisted the best efforts of the missionaries-Protestant, Catholic, and Mohammedan alike-and, being unalterably deroted to jungle life, there exists between them and the white race a gulf which the latter cannot bridge and the former will not. Wise Dyaks ! Neither commerce, education, nor religion can in the least add to their happiness, and so long as they hold their present attitude all those influences combined cannot exterminate them.

By reason of their adherence to all their former traditions, cus. toms, and surroundings, except those mentioned above, and on other accounts as well, the Dyak (by the natives pronounced Dyah) tribes of Borneo are especially interesting. In some respects they are the most remarkable people living, and their condition is well worth study.

As may be inferred from the geographical position of Borneo, the Dyaks are descendants of the Malay race, which has peopled nearly all the islands of the Malay Archipelago with the exception of New Guinea. At present it is impossible for any one to offer more than vague speculations respecting the advent of the aboriginal tribes in Borneo, and than such speculation nothing could be more unprofitable. No one can say whence this vast island was originally peopled, although there are some facts which seem to indicate that the progress of the great Kyan tribe has been from Kotei northwestward. There are well-defined traces of Hindoo influence among the Hill Dyaks in the west, and of Chinese influence in the extreme north; but not a single representative of either race exists in Borneo at the present day, except a few late arrivals. Both the Hindoos and Chinese of past centuries have either been completely exterminated by various influences, or swallowed up by affiliation with the aborigines. The traces of Hindooism are particularly insignificant, consisting mainly of the idea amongst the Hill Dyaks of a Supreme Being of some kind named

virtues of civilization without being weakened by its vices are not exterminated, but are substantially benefited, and go from strength to strength. It is not charged that the evils of civilization go with the missionary and the teacher - far from it-but it is a sad fact that they follow closely after. 
Jowata; the prejudice against killing cattle and deer, and also of eating their flesh ; and a few rude stone images and utensils. It is curious and worthy of note that both these great Oriental races invaded Borneo in the spirit of conquest, but both succumbed to savages of mould superior to their own-a clear case of the survival of the fittest.

Although the aboriginal inhabitants of Borneo are divided into several tribes and scores of sub-tribes or clans, they may, with reasonable exceptions, be described as one body, or sub-race, viz., Dyaks. In general terms, a Dyak may be described as a Bornean semi-savage of Malay extraction, of a yellowish brown complexion, straight, glossy-black hair, smooth face, medium stature, and active, warlike disposition. $\mathrm{He}$ is usually clad in a bark-loin cloth; but sometimes in a war-jacket of skin or padded cloth. He is armed with sword and spear, and possibly the sampitan also; and lives in the jungle in a long-house set high up on posts. He has no definite religious convictions, but respects his wife, and treats both her and his children well. His sustenance is rice, fowls, pigs and fruit grown by himself, and wild animals slain in the forest, supplemented sometimes by the sale of wax, gum, rattans, and gutta collected in the jungle; though these articles are generally exchanged for brass wire, beads, cloth, and other ornaments. $\mathrm{He}$ has no written language, makes no pottery, builds no monuments, carves but little and only in wood, works but little in iron, yet builds fine war-boats. His bearing is independent, dignified, respectful and frank, and he is honest at all times, save in war.

While it is perfectly proper to call every aboriginal inhabitant of Borneo a Dyak (for otherwise it would be necessary to coin a name applicable to all), there are, as has been already intimated, several well-marked tribal divisions, and many sub-tribes or clans, between whom there exist marked ethnological differences, and diversity in language and custom. Before proceeding to a more detailed description of the tribe with which I am best acquainted, it is necessary to a proper understanding of the subject that we take a brief survey of the entire Dyak race, or, to be exact, subrace. .

In my opinion the aboriginal inhabitants of Borneo may best be divided into four great tribes, which should be designated as follows: the Sea Dyaks, Kyans, Hill Dyaks, and Mongol Dyaks.

The Sea Dyaks are distinguished by their brave and warlike 
disposition and love of conquest, their skill in building war-boats and conducting naval operations, which has given to them their name of Orang Laut, or men of the sea; and also the fact that they never tattoo their bodies or limbs. Inasmuch as the people of this tribe may properly be regarded as the true type of the Dyak race they will be described at some length in the next chapter. Something will first be said, however, respecting the other great tribes.

\section{The Kyan Tribe.}

The Kyan tribe is numerically the greatest of the four, and it also covers a much greater extent of territory than any other, embracing fully one-half of the whole island. Its position is central, extending from the mouth of the Segah River and the lower corner of Kotei across the island to the very sea-coast of Sarawak. The accompanying map shows the extent and outline of the territory occupied by this great tribe, and the positions of its various sub-tribes, or clans, so far as known. We have information of at least eighteen sub-tribes-quite definite information respecting some, though extremely meagre concerning the majority at present, but no one can say how many more sub-tribes that have never even been heard of inhabit the unknown interior. The numerical strength of the Kyan tribe is consequently not known; and, while it is quite futile to blindly conjecture the number of its people, we may safely believe from the facts we already have that it exceeds two hundred and fifty thousand.

On the north coast of Borneo the name Kyan is applied only to the people who inhabit the head-waters of the Rejang and the Baram rivers (about fifty villages in all); while the tribe as a whole is named after the Milanaus, an insignificant sub-tribe inhabiting a few miles of sea-coast, a half-civilized offshoot of the true Kyans, who do not practice head-hunting, but according to Rajah Brooke are "exceedingly treacherous." The Milanaus proper are in no sense typical representatives of the sub-tribes usually classed under that narne (and even by Rajah Brooke in his "Ten Years in Sarawak," vol. i., p. 7!); therefore, I have adopted the term Kyan as the name of the whole tribe, for the reason that the sub-tribe commonly known by that name is the largest, the most warlike and enterprising, and in every way most fit to be regarded as the type of the whole people.

Generally speaking, therefore, the Kyan tribe is distinguished 



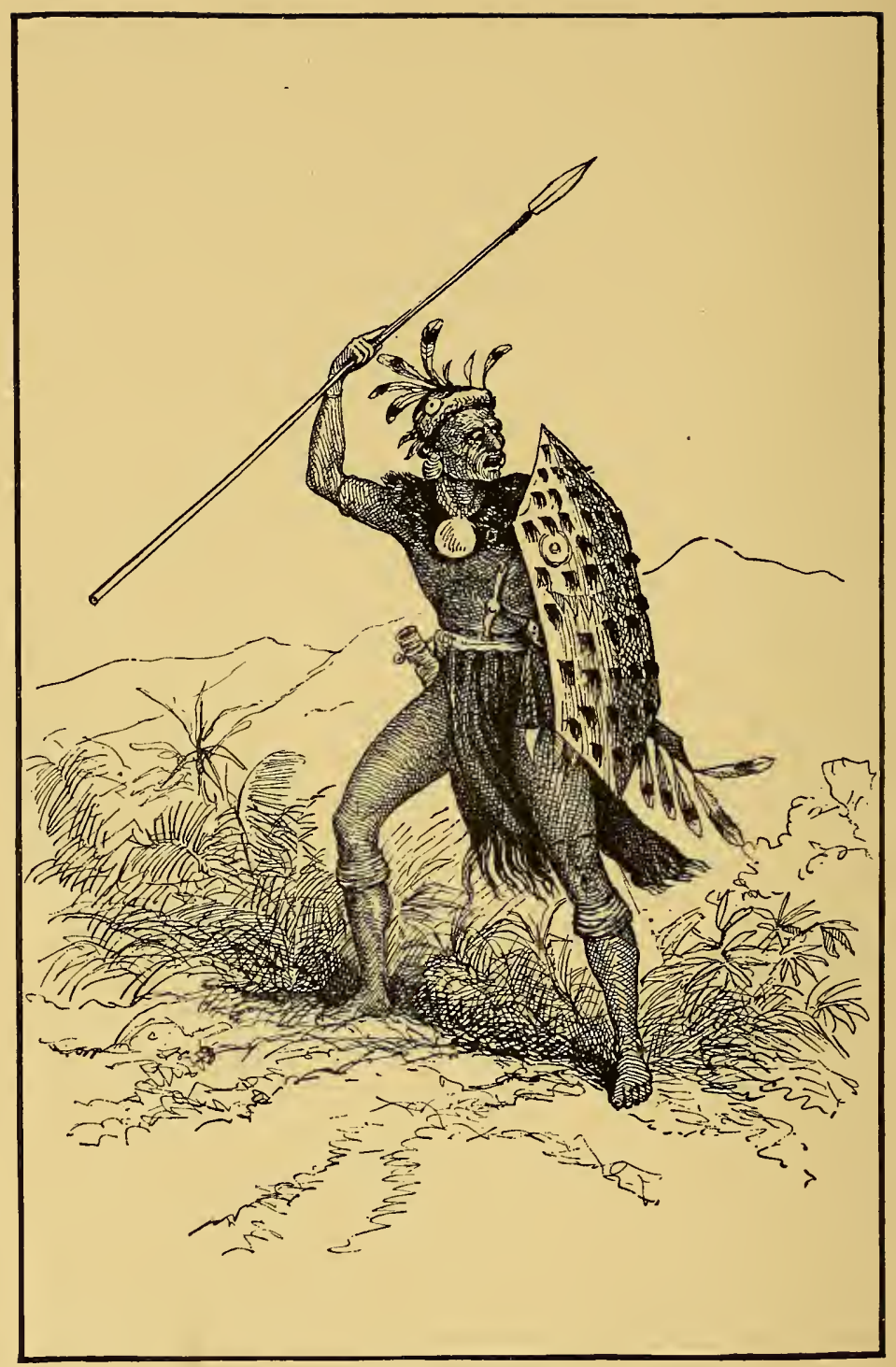

A KIAN WARRIOR.

(From a sketch by H. H. Everetu.) 
by being the farthest removed from civilization and by the practice of sundry barbarous and sometimes cruel customs ; by tattooing; by the use of the sampitan, or blow-pipe, and poisoned arrows ; by wearing sleeveless jackets made of padded cloth or skins of bear, leopard, monkey, or orang-utan; by the burial of their dead, especially of their chiefs, in coffins or vaults raised high on posts; and lastly (and most strangely of all), by their ability to smelt iron ore, and to use both forge and bellows in the manufacture of their weapons, which are of good quality and strangely ornamented. In addition to the above distinguishing characteristics, mention may be made of their war-shields, of hard wood, ornamented on the front with tufts of hair, sometimes dyed in various colors, taken from the heads of slain enemies.

For making forays in great force and suddenly attacking defenceless villages of real or fancied enemies for the purpose of obtaining heads, slaves, and plunder, the Kyans proper and various other sub-tribes have always been famous. They have thus acquired a great reputation for bravery and enterprise in war, but very few facts have been recorded which really justify it. In their head-hunting forays, the Kyans always went in numbers sufficient either to completely overwhelm the attacked or else to insure a retreat, in good order, from the enemy's stockade. Rajal Brooke declares with the disgust natural to the leader of an expedition against an enemy who would not stop to fight, "The Kyan warriors never fought when they could flee."

With the exception of the check which the Kyans proper experienced when they encountered the finest warriors in Borneo, the Sea Dyaks of Sakarran and Seribas, they have steadily driven all other tribes before them in their progress northward from the interior. The Sibuyau Dyaks were forced to migrate bodily from the head-waters of the Batang Lupar and settle nearer the coast, while the poor Bisayas and Muruts have been driven from one settlement to another on the Limbang River, in Borneo proper, until they are greatly weakened and impoverished. The Kyans often destroyed a whole settlement of Muruts at a single blow.

One of the Kyan sub-tribes of Kotei, the Trings, some members of which were interviewed by Mr. Carl Bock, has the reputation of being not only head-hunters, but cannibals, nor did either their chief or priestess deny the charge.* The Bugis kapitan who vis-

* Head-Hunters of Borneo, p. 135. 
ited the Trings at home stated to $\mathrm{Mr}$. Bock that they live "in large houses several hundred feet long, but extremely dirty inside, of a wretched appearance outside," and literally full of skulls taken in head-hunting expeditions.

The Kyans proper have on two occasions been publicly accused of cannibalism, once by some Sibaru Dyaks, of the Kapooas, who declared that the Kyans (their allies) on one occasion ate a Malay who was slain in battle; and once by a Malay noble, named Usup, who declared that in 1855 a few Kyan warriors took portions of the bodies of some executed criminals, which they had helped to eapture when alive, roasted, and ate them. Both these instances are given by Mr. St. Jolnn.* One or two other tribes in the Dutch Territory have also been accused of exhibiting the same bad taste.

The people of the Kyan tribe are the only ones in Borneo with whom the practice of tattooing seems to be universal. Of those who live in the north, the Kyans proper, the Kenowits and Pakatans are known to practise this custom; while of those in the south, Mr. Bock states that all the Dyak sub-tribes in Kotei tattoo, except those in the Long Bleh district. The Tring women and those of the Baram Kyans tattoo their thighs very elaborately, and the women of Long Wai do the same with their feet and hands.

The Kyans come the nearest to having a religious belief, or, rather, system of formulated superstitions, of all the Dyaks. The Baram Kyans believe in a future existence, and their heaven and hell are divided into various compartments for the proper accommodation of all according to the circumstances under which they die. They pay much attention to the carving of wooden images and charms, to all of which more or less meaning is attached ; still their ideas of a Supreme Being and a future state are very vague, and they have no religious rites or outward observances. $t$

The Trings have a well-defined belief in a tribal heaven, and a purgatory of toiling and enduring which must be passed through before the heaven can be reached. Yet the Trings practise cannibalism in war, and offer human sacrifices at the tiwahs (death feasts) which are made upon the return of an expedition. Mr. Perelaer describes such an event, held on the Upper Kahajan River by a Kyan clan (of which the Trings are a branch), at which forty slave debtors were put to death by torture, or by flesh wounds inflicted by the men and boys of the tribe.

* Life in the Forests of the Far East. † St. John, vol. i., p. 110. 
The houses of the Kyans are, in general, very similar to the longhouses of the Sea Dyaks, each of which accommodates a number of families, but very often a number of these long-houses are grouped together in regular village style.

Those of the Baram Kyans are roofed with shingles, and floored with rough boards instead of poles or slats of the nibong palm, such as are usually employed for this purpose.

The Kenowits and Milanaus in the Rejang District formerly built their long-houses on posts, from twenty to twenty-five feet high, or even more, in order that they might better resist the attacks of the hostile Sea Dyaks of the Sakarran and Seribas. Being unable to climb into the houses, their assailants directed their attack against the hard-wood posts, and worked under their shields while trying to chop them in two. Although the inhabitants above rained down stones, beams, spears, and hot water upon the besiegers, Low states that the latter were generally successful.*

The Pakatans and Poonans, wandering tribes who inhabit the unknown interior, build no houses whatever, and are, to that extent, the least advanced of all the East Indian tribes we are acquainted with. Even the open pole platforms of the Jacoons of the Malay Peninsula show a far greater advancement than the simple mat spread upon the damp earth, but one step removed from the wild beasts' lair.

\section{The Hill Draks.}

The Hill Dyaks inhabit the extreme western side of Borneo, their eastern boundary being the Sadong River. As their name implies, they live away from the sea, usually upon the hills and mountains, and are essentially hill-people. Being indisposed to making piratical forays by water in great force, as did the Sea Dyaks in former times, they were usually the victims of their more powerful and rapacious neighbors. Although possessing, perhaps, fully as much courage, man for man, as the Sea Dyaks, they were never so warlike as to make fighting and plundering the chief business of their lives. The Sarawak officers say that they are far more tractable and easily managed than the Sea Dyaks.

Although they formerly took the heads of enemies slain in battle and preserved the cleaned skulls in their head-houses, they deny that they ever had that mania for head-collecting which at one time 
affected the Sea Dyaks. While it is true that the customs of some of the clans required that, in order to be eligible for marriage, a young warrior should be the possessor of a head taken by himself, in most of the clans of this tribe the taking of a head was not a preliminary necessary to marriage. The Hill Dyaks also claim that it has always been contrary to their customs to take the heads of white men or Malays unless slain in battle, or even of strangers from other tribes who were visiting their country.

But notwithstanding their natural ability and present peaceful habits, the Hill Dyaks have been, in their day, warriors of no mean kind. In 1840 Sir James Brooke states * that the Sentah clan embraced about one thousand warriors, and their head-house contained about one thousand heads. In the pangah, or head-house, of the village of Peninjau, on Serambo mountain, I counted fortytwo skulls, or very nearly one for every two fighting men in the village, and $\mathrm{Mr}$. O. H. St. John informed me that there were quite as many in the other two villages of that mountain, Serambo and Bombok.

I did not see many Hill Dyaks, and altogether, representatives of but three clans-the Serambo, Sentah, and Sow. They were so similar in both physique and physiognomy as to render it quite impossible for a stranger to detect any other than purely individual differences between them. They were, I should say, more strongly built than the Sea Dyaks, and a little shorter in stature also, all being decidedly below medium height-five feet, six inches. As a rule both the men and women were well made and muscular, their forms denoting activity and strength in an equal degree. All have that independent and dignified bearing so characteristic of both the Hill and Sea Dyaks, which, resting on a clear conscience and a foundation of good principles, goes far to make the Dyak the equal of the European.

Most of the men wore cloth jackets in addition to the bark-cloth chawat, and a head-dress of either one or the other of the materials just mentioned. The women wore only the bedang, or half-petticoat, reaching from hip to knee, but their waists were encircled by hoops of No. 6 brass wire, which lay, one upon another, from the hips upward, in an unbroken coil half way up their plump breasts, which were conspicuous above the upper coil. In the village of Peninjau, on Serambo mountain, I saw a really good-looking girl,

* Mundy's Narrative. 
who wore a remarkable waist ornament, totally unlike anything I lad before seen or heard of. It was neither more nor less than a tightly-fitting cylinder, or corset, composed entirely of brass wire of large size. One wire hoop was fitted around her waist at the hips, and another half way up her breast, between which were fastened, perpendicularly, brass wires of the same size and equal length, set as closely together as possible without overlaying. This curious girdle of brass was ten inches in width, and, unlike the corset of modern civilization, had no provision for the breasts, which strayed out in a most lawless manner over the top. The girdle fitted so tightly and with such rigidity that I was impelled to ask my companion, Mr. O. H. St. John, how it was removed at the approach of that interesting period in womanhood to which every Dyak woman looks forward with eager interest. He stated that when pregnancy rendered the removal of the corset imperative the old women of the village would tie the girl's hands together, pull them above her head to the utmost stretch of her arms, make them fast to a beam, and then work the girdle off over her head.

In addition to this brass-wire corset, this same young woman wore on each arm about fifteen nicely polished brass rings, or bracelets, which, altogether, reached from her wrist nearly to her elbow, like a long, close-fittting cuff of brass wire. Her entire outfit of wire was quite clean and highly polished, and in sharp contrast with her dark skin, the general effect was quite pleasing.

The Hill Dyak women sometimes wear a loosely-fitting jacket of bright cloth, but are usually seen without it. The ormaments of the men are armlets of plaited rattan, necklaces of beads, and sometimes, as I was told, of leopard's teeth, although I saw none of the latter. Neither men nor women ever tattoo in the least, and their skin is of a yellowish-brown color.

The weapons of the men consist solely of the spear and parong latok, the latter being a heavy sword of the toughest steel, very thick at the back, and with an edge like a razor, gotten up for the express purpose of splitting a head open, or cutting it off altogether, at a single blow. For a European, it is an awkward weapon to use, the hilt being very small and set on the blade at an obtuse angle, in order to give greater force to the swing of the weapon. The parong latok in my possession measures as follows: length of blade, 21 inches; breadth at widest part, 2 inches; thickness at back, $\frac{1}{8}$ inch at the point to $\frac{3}{8}$ at the hilt ; length of hilt, $8 \frac{1}{2}$ inches ; weight, $2 \frac{1}{4} \mathrm{lbs}$. The sheath is of wood, stained dark red, and is 
fastened to the body by a cord made of blue cotton cloth. This weapon and its sheath are figured in the group of weapons and utensils given elsewhere, Nos. 5 and 4 respectively.

The villages of the Hill Dyaks are composed of a number of houses of good size, elevated on posts of course, and each inhabited by several families, instead of the one continuous structure, or longhouse, peculiar to the Sea Dyaks. The departure from the typical long-house is rendered necessary by the fact that their villages are usually on mountains or hills where the surface is too rugged and broken to accommodate one continuous structure several hundred feet long by forty or fifty wide. Each Hill Dyak village contains a pangah, or head-house, a circular structure with a steep and high conical roof. That at Peninjau was about fifty feet in diameter, with a fireplace in the centre, and a broad bench running all the way around the room next to the wall, directly above which the skulls which had been taken by the community had been suspended in a row. Here and there a square section was eut in the roof and fixed so as to be pushed out at the bottom and propped open to admit light and air. The pangah is the purgatory to which the boys of the village are sent to lodge from the time they arrive at puberty until they marry. All strangers are lodged in it, and councils are held there also.

I do not know much of the social life of the Hill Dyaks except what was told me by Mr. St. John and the late A. R. Haughton, Esq. ; but I consider their testimony of higher value than even the personal observations of a stranger and brief sojourner, and therefore I give it unhesitatingly.

The people of this tribe are morally the most highly developed of any in the island of Borneo, if not in the whole archipelago, which, in view of the extent of the influence Hindooism formerly exerted over them, is all the more surprising. Although they are, as a tribe, wholly without religion or any of its restraining influences, their moral principles would put to the blush the children of Israel in their best days. It is claimed that adultery is an uncommon crime (except in the case of the people of Peninjau and Serambo) among them, and there are several large villages in which the oldest men do not remember a single offence of the kind. Under no circumstances does a Dyal woman attempt to produce an abortion, the common and unpreventable crime of civilization in its highest state. But one wife is allowed, except in rare instances, where a chief is permitted two. 
The customs of the Dyaks absolutely prohibit consanguineous marriages, even the marriage of cousins constituting a rank offence, for which the offenders are hearily fined, and socially disgraced as well. Marriages could be contracted in this country or in Europe with honor and éclat which would not be permitted for a moment among the aborigines of Borneo in their native jungle. I have already alluded to the custom of banishing the unmarried men and boys of the village to the pangah for the protection of the families.

And yet the marriage ceremony is devoid of any solemn vows and protestations, certainly destitute of even a spark of religious sentiment, and so simple and absurd as to seem little more than child's play. Indeed, it is so little thought of that it might almost be said a couple may go through with almost any ceremony they please so long as their intention is made public. In some villages a fowl is shaken a certain number of times over the heads of the pair to be wed; in others the bride and groom each take a fowl, pass it in front of them seven times, then cut the throats of both, cook them and eat them. Sometimes a marriage is celebrated by an exchange of bracelets in public; and again by the contracting parties eating a meal of rice, honey and salt together. Like honest people, it is the intention of the other that each participant in a marriage relies upon; and the ceremony merely serves to mark publicly the beginning of their marital relation.

Marriage usually takes place when a girl reaches the age of sixteen, and she is always allowed to engineer her own matrimonial schemes, and choose her partner without let or hindrance. Divorce is not uncommon, but scandal, lying, and wholesale vituperation are not resorted to to accomplish it. If a pair does not live happily together, by reason of laziness on the part of one, or bad temper on the part of the other, the dissatisfied party leaves the other, and, after a fine is paid over by the dissatisfied party to the original offender, both are free and at liberty to marry again. Separations to which both are opposed sometimes take place soon after the marriage, in obedience to certain recognized signs, such as the barking of a deer, which foretells the death of one of the parties if they do not separate. In all his social relations the Dyak is a philosopher, free from gnawing jealousy and yearning for seclusive and perpetual possession. If one wife leaves him he girds up his loins literally and coolly seeks another and a better one. Although he greatly enjoys his wife's society and co- 
operation in his pursuits on the farm, if she leaves him he does not allow her absence to disturb his serenity. The loss of his children affects him much more, for they are his hope and trust.

To the other virtues of the Dyak must be added that of strict honesty and profound respect for the rights of property. Whether they steal from each other I cannot say ; I suppose they do sometimes, although it must be very seldom. It is positively asserted, however, that they never pilfer from Europeans, nor even Malays and Chinese, from whom they would have a right to.take something in remembrance of past oppression and extortion in the one case, and sharp practice with false weights and measures in the other.

Strangely enough, some of the Hill Dyaks burn their dead, a custom which they have clearly adopted from the Hindoos who flourished in Western Borneo several centuries ago. I believe all the people of this tribe in Sarawak Territory practise cremation excepting those who live on the Sadong. The Sadong River Dyaks bury their dead, and bury with them various articles belonging to the deceased, especially his betel box with fresh sirih leaves (black pepper), some old clothes of no value, and perhaps his spear. His land is then divided equally among his children, without discrimination for or against either sex.

The Hill Dyaks have no written language, and no social laws save the customs and traditions which have been handed down from their ancestors; and it must be admitted that these are surprisingly well adapted to their condition and necessities. Chieftainships are hereditary, but their chiefs rule only by the consent of the governed and without the power to oppress.

The Hill Dyaks have dim ideas regarding a future state and a Supreme Spirit named Tupa or Jowata, both Hindoo names. They believe the good Dyaks go to a place under the earth, called Sabyan, where they are happy, and that the bad go to another place, also called Sabyan, where they are not happy. A ferv believe that sometimes their ancestors take the form of deer after death, for which reason, like the Hindoos from whom the idea was probably derived, they will neither kill deer nor eat of their flesh.

Some believe that certain of their warriors become "woodspirits," or wood-devils (antus), after death, and remain on earth to plague such of their survivors as have offended or injured them. They have no religious ceremonies or observances whatever, nor any conception of a God who controls the destinies of men for good or ill. In these people we see morality divorced from any 
form of religion, a state of things which we are often told is impossible. In this condition they are happy and prosperous, which, after all, is the great end of human existence.

\section{The Mongol Dyaks.}

The Mongol Dyaks, whom I regard as the fourth division of the Dyak tribes, are composed of the Ida'ans, or Dusuns, who inhabit the northeastern portion of the island; the Kadyans, who inhabit the hills in the vicinity of Brunei, the capital of Borneo proper; and the Muruts and Bisayas, who are the sole inhabitants of a long strip of territory lying between the country of the Baram Kyans on the south and the Ida'ans on the north, and stretching from near the coast of Borneo proper perhaps three-fourths of the distance across the island. While it is certain that future explorations of the interior of Sabah will add to the above several clans now wholly unknown to us, it will be noticed that the Bajus and Lanuns of the north coast are excluded from the Mongol Dyak tribe. The former are Sea Gipsies, of mixed breed, and no particular nationality, while the Lanuns, formerly the most famous pirates in the East Indies, came to the north coast of Borneo from Mindanau, one of the most southern islands of the Philippine group.

For the most definite and reliable information attainable concerning these sub-tribes we are indebted to Mr. Spencer St. John's admirable work, "Life in the Forests of the Far East," from which the following facts are drawn.

The Ida'ans are the farthest advanced toward civilization of all the aboriginal sub-tribes in Borneo, and from the fact that the language of the other three sub-tribes is nearly identical with theirs, and that they have all been greatly influenced by contact with the Chinese in former years, which influence still affects them, I consider it both convenient and desirable to group them together under the title of Mongol Dyaks. The Ida'ans, who number about forty thousand souls, and constitute perhaps more than four-fifths of the proposed tribal group, certainly differ very strikingly in many respects from the other Dyak tribes; while the three subtribes which we associate with the Ida'ans, certainly resemble them more than they do any others.

The Muruts and Bisayas are, in many respects, similar to the Sea Dyaks, and it is highly probable that they once belonged to that tribe; but, by the onward march of the warlike and aggres- 
sive Kyans, they became separated from the main body, ever since which time, even down to the present day, their implacable enemies have steadily driven them northward step by step, until finally, perhaps even as early as the end of the present century, their northern boundary will reach the country of the Ida'ans, and the three sub-tribes will become more closely related than now.

The Ida'ans (or Dusuns), according to St. John,* are essentially the same in appearance as the Dyak of Sarawak, the Kyan, the Murut and Bisaya. Some of the men tattoo slightly, but in an entirely different fashion from the Kyans. They are clear-skinned and have good-tempered countenances. The women, although not good-looking, are not ugly. All the girls and young women wear a piece of cloth to conceal their bosoms : their petticoats also are longer than usual, and the young girls (of Ginambur) had the front of the head shaved like Chinese girls. Near the sea-coast, the men wear jackets and trousers, but as the traveller advances into the interior, the amount of clothing gradually lessens; cloth garments being seen on a few only at the foot of Kina Balu, beyond which the people are said to wear nothing but bark-cloth.

The houses of the Ida'ans on the Tampasuk River, Mr. St. John declares to be the best he ever saw among the Bornean aborigines. Some were "boarded with finely-worked planks;" the doors were strong and excellently made ; and the flooring of bamboos beaten out, which in one house at least was very neat and free from all dirt. While some have adopted the Chinese custom of a separate house for each family, others occupy the usual long-house so common among the Sea Dyaks, with the open hall and a separate room for each family.

The Ida'ans are essentially agriculturists, in which pursuit they are so far advanced as to use the plough, which is very simple and made entirely of wood, and also an equally rude harrow. They raise rice, sweet potatoes, yams, maize, sugar-cane, tobacco, and cotton. "Simple as this agriculture is," says St. John, "it is superior to anything that exists to the southward of Brunei, and it would be curious if we could investigate the causes that have rendered this small portion of Borneo, between the capital and Malludu Bay, so superior in agriculture to the rest. I think it is obviously a remnant of Chinese civilization." . . . "The Ida'ans also use a species of sledge made of bamboos and drawn by buffaloes to

* Vol. i., p. 379 et seq. 
take their heavy goods to market. The gardens on the Tarawan are well kept and neatly fenced in."

"None of the Ida'ans pay any tribute to any one, and no one dares to oppress them. Each village is a separate government, and almost each house independent. They have no established chiefs, but follow the counsels of the old men to whom they are related. They have no regular wars . . . and their feuds are but petty quarrels. Although every man goes armed, perfect security exists, as was proven by the troops of girls working in the fields without protection."

The only case of pilfering from a white man by a Dyak occurred to Mr. St. John, when among the Ida'ans, which may also be set down as due to the results of Chinese influence and example in former times.

The Muruts and Bisayas are numerically weakened and greatly impoverished by reason of the oft-repeated and usually successful attacks made upon them by the Kyans of Baram. They are steadily driven from one locality to another, and live in constant fear of further raids, for, be it remembered, they are far beyond the beneficent influence of Rajah Brooke's government.

"Orang Murut" means literally "mountain man," and those visited by St. John, who live in the mountain above the source of the Limbang River, he thus describes :

The men wear bear-skin jackets, and head-dresses of bark ornamented with cowries. Heavy necklaces of beads are worn by the men as well as the women, with many rings of lead worn in the rim of the ear. Some young girls have petticoats composed entirely of beads on a ground work of cloth or bark. The girls of this tribe also twist a couple of fathoms of brass wire in circles around their necks, which rise from the shoulders to the chin like a small hoop-skirt.

The Limbang Muruts live in long houses, one of which contained fifty doors, and the long hall was closed in and filled with fireplaces.

The Kadyans, who are few in number and live only about Brunei, are the only clan of the aborigines who have taken kindly to the haunts of civilization and choose to dwell near the city, and many even within it. Although like the Ida'ans, they learned their agriculture from the Chinese during the present century, the influence of the Malays has been sufficient to convert them nearly all to Mohammedanism. 
Before turning our attention to the Sea Dyaks, the various tribes may be placed before the reader in a summarized form in the following manner, to show their comparative rank as viewed from different standpoints :

\section{Morally.}

1st. Hill Dyaks

2d. Sea Dyaks

3d. Mongol Dyaks

4th. Kyans
Mentally.

Sea Dyaks Hill Dyaks

Kyans

Mongol Dyaks
Physically.

Sea Dyaks

Kyans

Hill Dyaks

Mongol Dyaks 



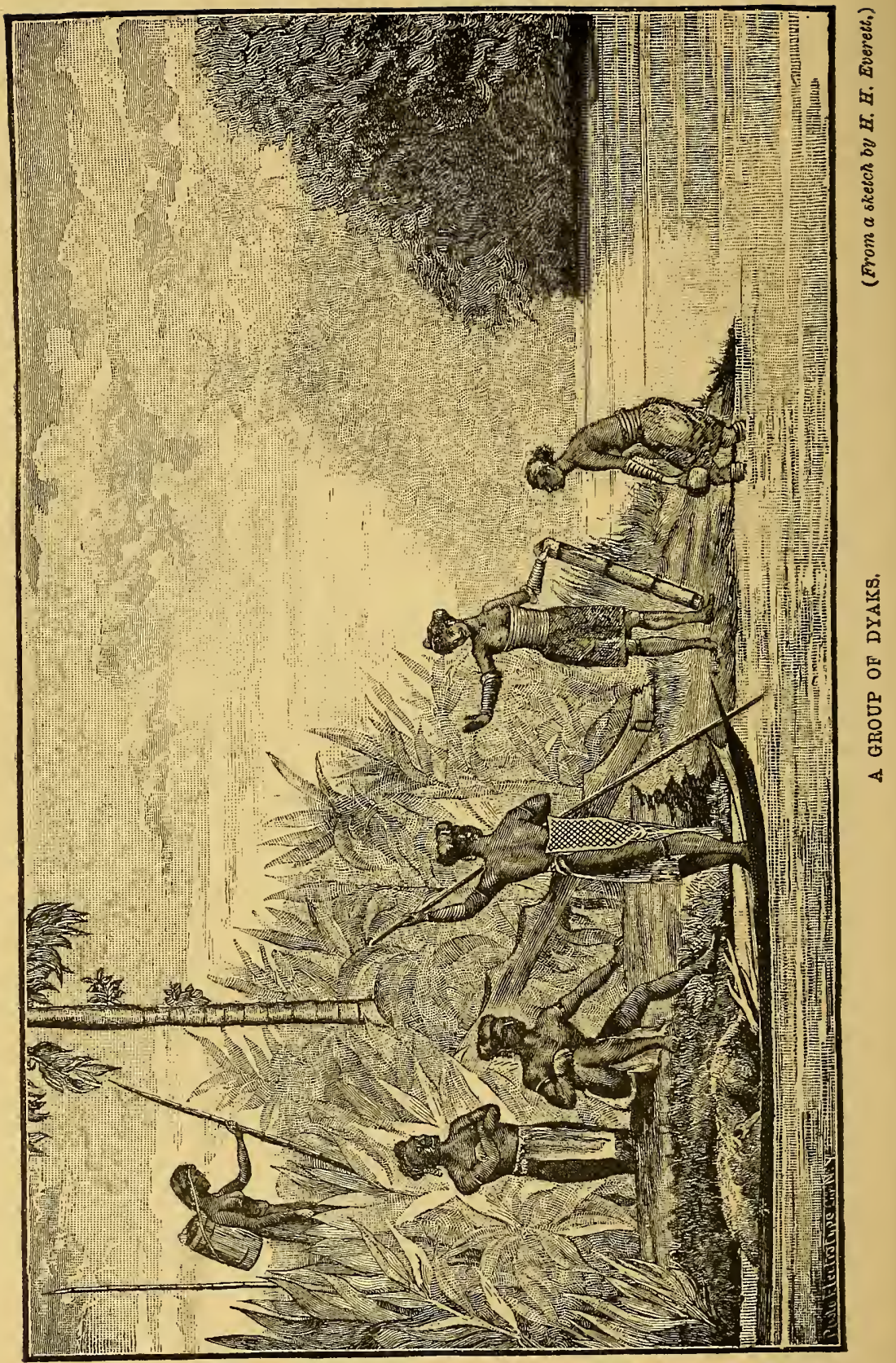




\section{CHAPTER XXXVIII.}

THE SEA DYAKS.

Habitat. - Number. —Sub-tribes. - Their Physique._Sea Dyak Women.-Their Dress and Ornaments.-The Men.-Their Weapons. - War Boats.-Fighting Qualities.-Head-taking and Head-hunting.-A Mania for Murder. - Houses and House-life of the Sea Dyaks. - Communal Harmony.Daily Occupations. - Amusements. - Music-making. - Feasts. -Gentlemanly Drunkenness. - High Social Position of Women.-The Doctrine of Fair Play.-Strict Observance of th. Rights of Property.-A Race of DebtPayers.-Morality without Religion.-Infrequency of Crime.-Dyak Diseases.-Mode of Burial. - The Future of the Race.-Can Christianity Benefit the Dyaks?

Tue tribe of Sea Dyaks has always been celebrated for the bravery and enterprise of its warriors, their independence and resistance of oppression in all forms, and their success in maintaining both offensive and defensive sub-tribal alliances. In Sarawak they occupy all the territory between the Sadong and Rejang Rivers and all the tributaries of the latter up to the Kanowit River which is the boundary of the Kyan country. The largest and most powerful clans reside on the Batang Lupar and its tributaries, and the Seribas. The main body of one large clan, the Sibuyau, inhabits the Lundu River and its tributaries in the western extremity of Sarawak, where they emigrated from the Sibuyau River to escape the aggressions of the people of Sakarran and Seribas. Southward, the clans of this tribe extend to the Kapooas River in the Dutch Territory and beyond it to limits not yet clearly defined.

In Sarawak there are seven sub-tribes of Sea Dyaks, viz. : the Seribas, Sakarran, Ballow, Sibuyau, Undup, Batang Ayer, and Lamanak. The Sarawak Government estimates the total population at ninety thousand (1879).

The Sakarran and Seribas clans are the largest, and also the richest in gold and silver ornaments, jars, gongs, brass guns, and such other goods as help to constitute Dyak wealth.

In physique, the Sea Dyaks, like the Hill Dyaks, are below 
medium stature, the tallest Sibuyau man that I saw being barely five feet four and a half inches while the majority were under five feet three. The men are well proportioned but sparely built, and not, as a rule, what would be called muscular. Their form denotes activity, speed, and endurance, rather than great strength ; precisely the qualities most required by a denizen of the jungle. While this is true of the men in general, it is by no means uncommon to meet thick-set and muscular individuals ; almost the first Dyak I saw, Dundang, was a fleshy native Hercules. Their. movements are easy and graceful, their carriage always erect; and in manner they are independent and dignified, though naturally polite and respectful. They have neither the insolence of the African, the fawning obsequiousness of the Hindoo nor the hypocritical formality of the Anglo-Saxon. The Dyak, in spite of his occasional dirt, is my beau ideal of a man in more respects than one, but nothing commends him to me more strongly than his simple honesty and manly independence.

The color of a typical Sea Dyak is dark-brown with a strong tinge of yellow ; his hair is jet-black and falls in graceful, flowing locks upon his shoulders instead of being perfectly straight and characterless like that of the Malays. His costume consists of the chawat, a piece of cotton or bark-cloth about five feet long wound tightly around the waist and drawn between the legs with one end hanging down apron-wise in front and the other behind. He also wears a sort of turban of red cotton cloth, or perhaps a bandanna or bark-cloth, or he may wear nothing at all on his head. As has already been mentioned, some of the Sibuyaus wear a small coffinshaped mat depending behind from the chawat, and reaching from the small of the back half way down the thigh, evidently to be used as a seat. I have been told that many of the Sea Dyak men wear sleeveless jackets of red cotton cloth padded with cotton, when going to war, but the few I saw worn in the piping times of peace were very common-looking garments of dingy white, or coarse brown cloth, the latter of native manufacture.

The Sea Dyak women, or at least those of the Sibuyau tribe, are much highter in color than the men, the yellow tint predominating. As a rule they are not handsome, but I saw among them a few who were decidedly good-looking, if not even pretty. I particularly remember two girls that I saw in Dundang's village, near Simujan, one of whom was his sister. Both were exceedingly comely girls, whose good features, and plump, well-moulded figures would do 


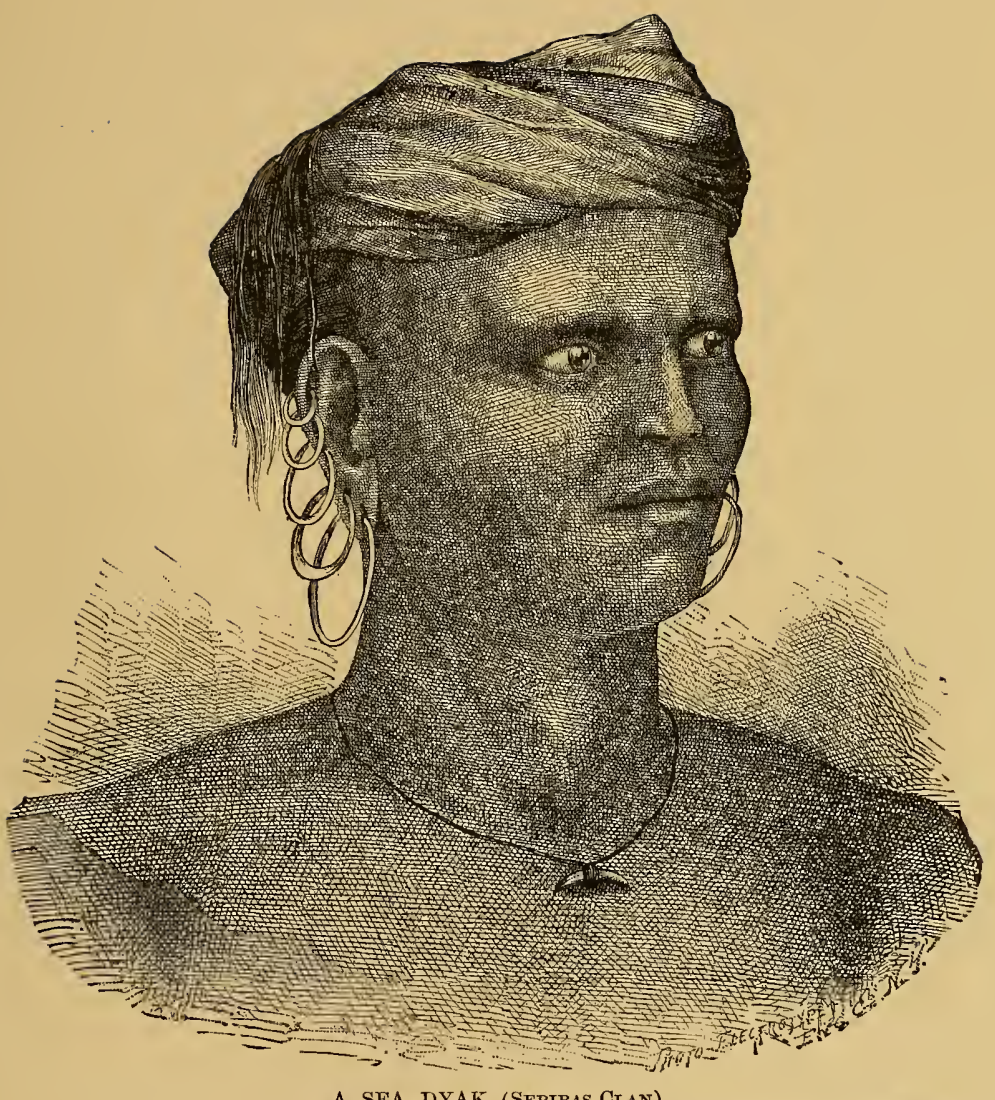

A SEA DYAK (SERIBAS ClaN).

(From a portrait sketch by H. H. Everett.) 




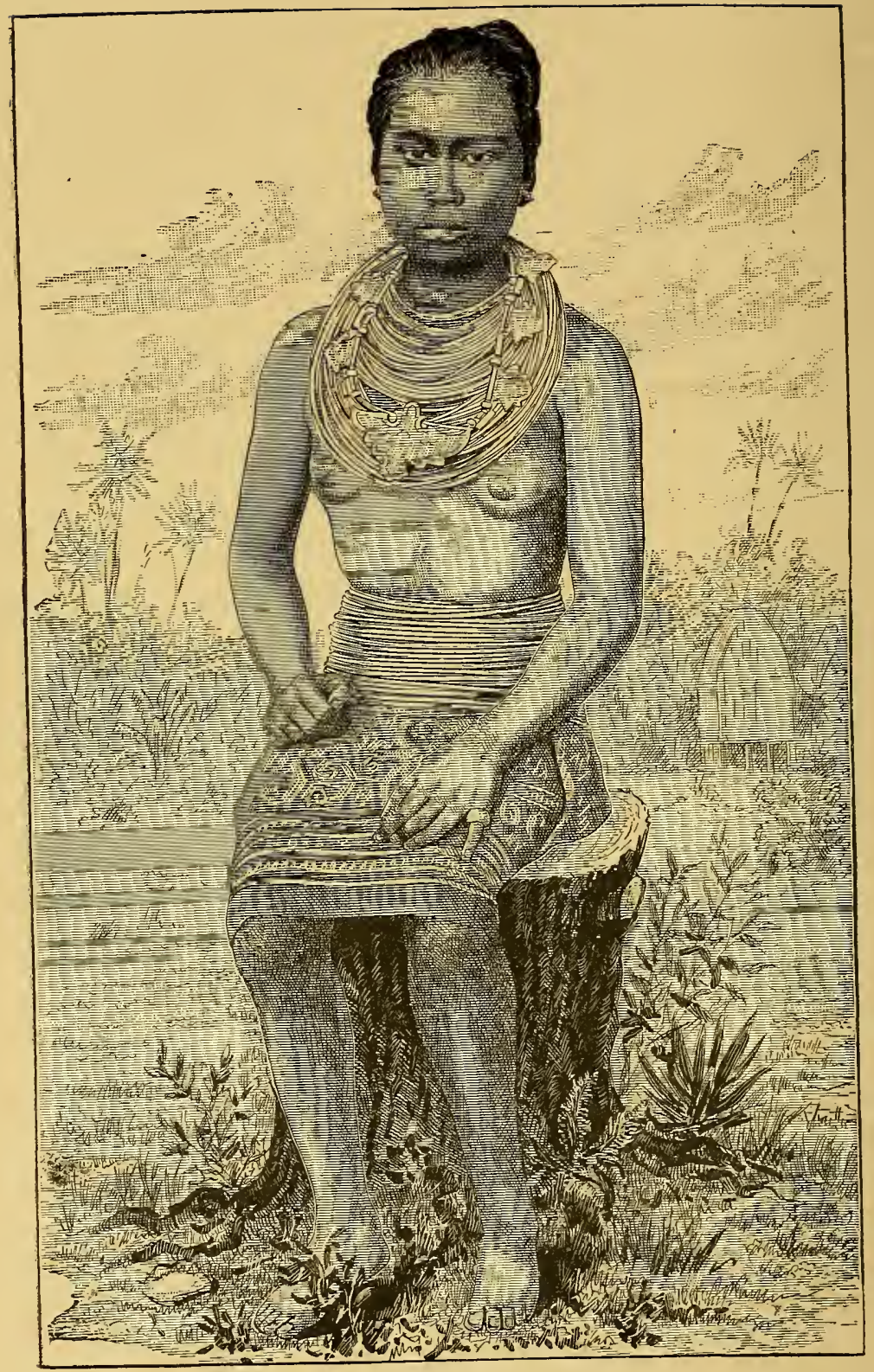

A SHA DYAK BELLE.

(From a photograph.) 
no discredit to a Venus de Medici. As a rule I fear I do not appreciate the beauties of dark-skinned women, and I never yet sav one who would justify even a mild form of emotional description, to say nothing of the stereotyped raving in which the English language is often pumped dry of adjectives with which to convey a faint idea of a beautiful creature. For once, however, I was glad that the Dyak women are partial to "full dress," and I looked at those two forest belles with undisguised but respectful admiration. I remember another young woman, in a foul-smelling village near Padang Lake, whose face was precisely like that of Raphael's Sistine Madonna, except that it was brownish yellow. Her extremely pensive and half sad expression fastened my attention instantly. She had a pretty oval face of a very different outline from the typical Dyak woman, and her whole expression was strangely peculiar for a native. I imagine it was caused by love-sickness.

But the Sea Dyak women in general are by no means bad-look ing. Their faces are bright, intelligent, and interesting, and I dare say others would call many of them pretty. As a rule they are handsomer than the men. Some that I saw were so clear-skinned and light as to be really a dark yellow, but sufficiently warmed with brown to make it healthy-looking, and far from disagreeable. Their eyes are always jet-black and sparkling, and their hair, which is abundant, well-kept, and drawn straight back without parting, is likewise glossy and black as a raven's wing. Their teeth, alas! are also black from chewing betel, which likewise reddens their lips for the time being. Their busts, which are always exposed, are generally plump and well-formed until old age mars all such beauty and leaves the skin hanging from the shrunken sides in hundreds of wrinkles and folds. The girls marry at sixteen and are old women at thirty.

Orclinarily a Dyak woman's sole article of wearing apparel is the bedang, or petticoat fastened at the waist by being tucked over and under a belt of rattans dyed black, and falls within about three inches of the knee. This garment is usually of native cotton cloth, and sometimes very prettily figured. The women living around Padang Lake, and a few on the Simujan, have jackets of red or brown cotton cloth with sleeves, which they always wear when at work in the fields; also wide conical hats, of Malay pattern, made very pretty with fine rattan splints dyed in various colors. Both hat and jacket are always worn when they go visiting, or trading down the river to Simujan. The picture which I remember most 
vividly in connection with my last trip down the Simujan, was Noonsong sitting in the stern of Hakka's prau, paddling and steering for him, clad in a jacket of turkey red, and a gorgeous Malay hat, similar to the one she made for me, her long black hair streaming down her back, the water flying from her paddle and the rain pouring down upon us all.

The ornaments of the Sea Dyak women consist of many coils of thick brass wire, sometimes loose and sometimes fitting tightly, occasionally brass spiral, worn round the waist when they are rich enough to afford it, and coils of split rattan, dyed dark red or black when the brass is beyond their purchase. Loose rings and coils of the same material are sometimes hung around the neck also, and half cover the breast. Beads I never saw worn on the neck. They also wear coils of brass wire, or else large hollow bracelets of silver, on their arms from the wrist upward, when they can afford it. Mr. Haughton informed me that ornaments of gold and silver were quite common among the people of Sakarran and Seribas, the result of their piratical habits in former times. The only ornaments I saw worn on the lower limbs, were leglets of rattan and sometimes brass wire, worn immediately below the knee, varying in number from one to five. Some of the women wore a large ornament like a silver rosette on the lobe of each ear, beaten hollow on the inside and held by being riveted through the flesh. I was told that these are made of gold when the wearer's husband is rich enough to afford it.

The men of Sibuyau wore very neatly-made armlets and leglets of braided rattan, some extremely narrow and others half an inch wide. The men of Sakarran and Seribas wear a number of brass or copper rings of different sizes in the rim of each ear one above another, the largest below, the smallest at the top, and often three or four together, two or three inches in diameter, in the lobe of the ear. With the men of these two clans, this custom is so universal that they are everywhere recognized by it. In former times the Hill Dyaks used to say, "Beware of the men with many rings in their ears ; they are always bad men." I have never seen a specimen of the head-dress worn by the Sea Dyaks when on the war-path, but Mr. Haughton described it to me as a three-inch-wide band of cloth or bark-cloth with cowries sewn upon it, worn tightly around the head from which there stand up from six to a dozen of the wide, black-banded tail feathers of the rhinoceros hornbill.

The weapons of the Sea Dyaks are really insignificant in com. 
parison with the warlike, and once piratical propensities of the people. Their arms are neither numerous in kind nor elaborate in design, and it is surprising that such redoubtable warriors have not developed weapons of better fashion, more elaborate ornamentation, and greater variety. In the matter of both weapons and shields of all kinds, the Kyans far surpass both the Hill and the Sea Dyaks. The arms of the latter consist ordinarily of a common parong or chopper, in shape, size, and weight closely resembling a farmer's corn-knife. It is not so heavy as the parong latok, nor so long; but in good hands it is enough. Like the latter weapon it is carried in a wooden sheath on the left side. Those to be seen now among the Sea Dyaks are very rough, common-looking instruments, not worth keeping as curiosities, and their sole use now is in the neverending, but wholly bloodless, conflict which the Dyak wages with the jungle.

As before stated, the Sea Dyaks never use the sampitan and poisoned arrows. Their spears are as cheap-looking and destitute of all ornament as their parongs, being simply a piece of steel hammered into a rough-looking blade, $8 \frac{1}{2}$ inches long by $1 \frac{1}{2}$ wide; set into a stout handle of rattan five feet long.

I did not see any genuine war boats, and for a full description of them I must refer the reader to Low's "Sarawak," p. 216. It is there stated that " their war-boats, which are ealled 'bankongs,' are generally of great length, frequently as much as seventy feet. They are built very high abaft, and high forward, . . . from a flat keel, without timbers of any sort, the planks being merely sewn one to the other, or rather tied by rattans, through holes about eighteen inches apart, calked with the soft bark of a tree of the tribe Myrtacece, and payed with a preparation of dammar and oils. . . . . They are sometimes steered with a rudder, but more frequently by paddles, and from the assistance the men paddling them are able to give, they turn as on a pivot." The planks from which these boats are made are all hewn out, Crusoe fashion, with "biliongs," two only being obtained from a large tree and that only with infinite labor, it being very necessary that all the planks should be of the same length as the "bankong." "These boats, according to their size, carry crews of from thirty to ninety men, . . and I should think it probable that no boats in the world could equal them in speed."*

* Written in 1847 . 
Every Sea Dyak prau or large boat above the size of a small sampan, or dug-out canoe, is provided with a tight roof of kadjangs supported upon and lashed to a skeleton frame-work of poles. The hull is decked over from stem to stern with an open frame-work of slats of the nibong palm, or of poles, except that an opening is left amidships, whereby to bale out the craft when it leaks. All the praus, or nearly all, are made on the same plan as the bankongs, of planks sewn together with rattans.

Thanks to the benign influence of Rajah Brooke's government, my knowledge of the Dyaks as warriors was obtained wholly at second hand, chiefly from the writings of Sir James and his successor. From the first, it has been the leading principle of both to maintain peace in Sarawak, peaceably, if possible, but if not, to fight for it. The Sibuyau clan has always been the staunch ally of the government in its efforts to subdue, first the hostile and piratical sea tribes, and lastly the Kyans. The powerful and warlike clans of Sakarran and Seribas maintained a close offensive and defensive alliance, and were openly hostile toward all their neighbors. For many years their power remained unbroken and they successfully made one piratical foray after another against the Sibuyaus, Ballows, Undups, and the Hill Dyaks in general. The latter people, being badly scattered and apparently incapable of forming strong defensive alliances, suffered terribly and thousands of them were killed and beheaded, while thousands more (women and children) were made the life-long slaves of their fierce captors.

But the advent of Sir James Brooke and the forces he was able to enlist in the cause he had espoused, ushered in the dawn of a new era. The pirates of Sakarran and Seribas were attacked again and again by Captain Keppel and the forces of the Dido and Phlegethon, aided by Sir James and his fleet of Dyak warriors, and, after repeated and well-merited thrashings, finally submitted.

This left but one hostile tribe in the territory, the Kyans, which submitted in 1863, since which time Sarawak has been quiet, save now and then when some act of insolence or crime rendered it necessary to discipline some particular chief by means of a small expedition. At present, life and property are as secure in Sarawak as in any country in the world.

The Dyak modes of warfare most preferred are precisely the same as those of the best trained warriors of Europe and America, viz., either to attack in overwhelming force and crush with numbers, or to take the enemy by surprise and therefore at a great 
disadvantage. Dyak fighting was usually done at close quarters; and the courage and dash of the combatants has often excited the admiration of trained European fighting men. In former times the villages were mostly fortified by stockades of thick planks or posts set up high all around them, while some were built on bilian posts from twenty to thirty feet high, to be more safe from attack.

From time immemorial, it has been the custom of Sea Dyaks, Hill Dyaks, and Kyans to cut off the heads of slain enemies and keep the cleaned skulls as trophies. Formerly each warrior kept his own trophies, and, in many clans, a Dyak girl would scorn a suitor who had not taken a head. A warrior's grief at the death of his wife or child could only be assuaged with a fresh head, taken by himself, of course, and the death of a chief often involved a regular head-hunting expedition. When a renowned warrior died it was supposed that he could not rest quietly in his grave until a head had been taken in his name.

After a time, however, the custom of head-hunting incidental to war degenerated into a murderous craze for making collections of human skulls, regardless of the circumstances attending their acquisition. It is charged that the Malays are mainly responsible for this result, on the ground that they encouraged the powerful tribes to attack the weaker ones, for the sake of getting as many heads as possible, while the Malays, who aided and abetted the pirates, took the plunder and slaves as their share of the spoil. The heads were no longer regarded as trophies of individual valor. in the field, but all became the property of the clan as a whole, and the end sought by each was to have its collection of heads surpass those of its neighbors in point of number. Often all the adults of a village, both women and men were swept into the vortex, the children only being spared to keep as slaves.

I think Sir James Brooke showed a greater depth of wisdom in his treatment of the Sarawak natives than any one else who has ever occupied a similar position. For example, instead of preaching and making laws from the very first against all head-taking, and thereby incurring the hostility of the Dyaks, he taught them that a head trophy was an emblem of cowardice unless taken in fair fight; that to cut off the head of a defenceless and inoffensive person was a wicked murder, such as no true warrior could be guilty of without disgrace. This principle once admitted, it was an easy task to teach them the folly and crime of warring for beads alone, and to put a stop to the petty wars altogether. With due consist- 
ency however, when the wild warriors of the jungle gathered by thousands to support the Rajah during the Chinese insurrection in 1857, he gave them permission to cut off the head of every man found wearing a queue. Since that time the heads taken in Sarawak have been few and far between, and the takers have, in nearly every case, been treated as ordinary murderers.

The dwellings of the Sea Dyaks are all constructed on precisely the same plan as the one described in a previous chapter (page 355 ), except that, where a village is very large, a number of smaller long houses are built instead of a single continuous structure of enormous length. I have never seen a house longer than that already described, which was one hundred and ninety feet, but one of the Sibuyau long-houses on the Lundu River is six hundred feet in length and contains rooms for as many as fifty families.

Another house of the same tribe situated on a little creek below Simujan was described by Sir James Brooke as being 257 yards, or 771 feet in length!

Most of the Sibuyau village-houses are raised about eight feet above the ground; but some are twelve; and others again only four or five. Externally, they are all weather-beaten, gray, and wholly unpicturesque-looking structures, but sometimes are very prettily surrounded by banana and cocoanut trees.

Within, they are clean enough, because all the dirt and litter falls of itself through the slatted floor ; but the ground underneath is usually covered with litter, perpetually wet and mouldy from the water thrown down through the floor above and, being the favorite resort of the pigs of the village, often smells horribly. Sometimes. the pigs are kept in a sty underneath the long-house. As a matter of course, the old villages are the most foul smelling, and the European traveller should quarter in a new house whenever possible.

The house in which I spent a fortnight at Padang Lake contained four rooms, and was built in about four weeks by Hakka and another Dyak. All the materials came from the adjoining jungle, except the three hundred and fifty attaps composing the roof, which were made on the Sebangan River, below Simujan, and cost 72 ets. per hundred. The entire house was valued at $\$ 40$.

I believe the Sea Dyaks are the only people in the world whose villages consist of a single structure under one immense roof, the greater portion of which is owned in common. No greater proof of their peaceful domestic and social habits could be desired than 
the fact that from five to fifty families, according to the size of the long-house, can live under one roof without coming to blows.

Fancy twenty Auglo-Saxon women living with their husbands and children in twenty rooms, along one side of a vast open hall which serves as work-room and play-room for all. The amount of quarrelling, slandering, back-biting, child-slapping, and child-fighting which would take place would be fearful to contemplate. And yet among the Dyaks I never saw or heard anything like high words, much less a regular quarrel, between either children or adults. The people with whom I lived at Padang Lake and on the Sibuyau were always light-hearted, and generally even merry. It was truly refreshing to see people so universally happy and contented.

They always rise early in the morning, or at about six o'clock; each family kindles a fire in its own private room, and boils the morning meal of rice or vegetables in an earthen pot or joint of bamboo. If they are lucky enough to have on hand the flesh of any animal, that also is boiled or roasted and forms a portion of the meal. When eating, they squat upon a mat in the centre of the room around the vessels containing the food, and all eat with their fingers. The drinking-water is contained in a five-foot section of bamboo which stands in a corner of the room. After eating, the Dyak takes a drink, rinses his mouth, takes down his parong, juah, and tambuk and prepares to set out. If he intends to go into the jungle to search for gutta, honey, dammar gum, or rattans, or to hunt or snare game, he takes with him also his spear, biliong (axe), and his dogs, if he has any. If his day's work lies in his field he takes with him his wife and older children to help plant or reap the paddi, or clear the ground, as the case may be.

Late in the afternoon he returns, his basket laden either with rice, bananas or other fruit, or such jungle products as he has been able to secure. By the time supper is eaten it is night, and time to light the smoky dammar torches, by the flickering light of which both men and women make mats and baskets, boil gutta, make new paddles or biliong handles, and work busily until bedtime. If there are visitors, work is partly suspended in order that the evening may be spent in giving and receiving the news.

About nine o'clock, the young and unmarried men and strangers climb up the ladder into the loft over the long hall, and, after stretching their limbs upon their mats, lie there singing and chattering until they fall asleep. 
The married couples and their small children and girls retire to their rooms, and spread their mats upon the floor, being usually provided with dingy cotton-cloth curtains as a protection against the mosquitoes. The walls are thin and slight, but I never heard issuing from within them any sounds of curtain-lecturing, bickering; or worse still, wife-beating, such as came to my ears in the hotels at Calcutta, Colombo, and Demerara. I have often wondered what would happen if a Dyak should go to beating his wife and she to screaming. I am sure his neighbors would interfere vigorously.

It is not surprising that the Dyalss generally are fond of amusements, although they have no games of chance or mental skill. The people of Muka have great sport swinging with a long rattan attached to a high derrick and guyed to keep it from swaying to and fro. A ladder is planted a short distance off from which to start, and ten or a dozen men often swing together, the outsiders clinging to the arms and legs of the others.* The children of the Hill Dyaks at S'Impio play with peg-tops precisely as do those of England, spinning them, and throwing one spinning top at another to knock it out of place. $\dagger$ The Ballow Dyaks play prisoner's base and international "tug-of-war" in the most approved style, and the Sakarrans are much given to such athletic sports as wrestling, sham-fighting, jumping, running, and swinging.f The Kennowits are good at dancing in time to music, and entertain the visitor with a "mias dance," "deer dance," regular war dance, all in costume, and, most interesting of all, a well-acted pantomimic representation of the various events in a head-hunting expedition, the start, the journey, the surprise, the fight, head-taking, defeat, retreat, etc. $\S$

Mr. A. R. Wallace describes his attempt to initiate some Dyak children into the mysteries of cat's cradle, but he succeeded so poorly that, out of compassion, the children took the string and showed him the proper way to do it.

The only amusements I saw among the Sibuyaus were of a musical character. The people of Gumbong's village, with whom I lived at the head of the Sibuyau, were decidedly musical, and scarcely an evening passed without a performance of some kind.

* Rajah Brooke, "Ten Years in Sarawak." † Hugh Low, "Sarawak." $\ddagger$ Spenser St. John, "Life in the Forests of the Far East."

$\S$ Frederick Boyle, "Adventures Among the Dyaks." 
Le Tiac was the fiddler of the crowd, but, while his instrument was by long odds the most elaborate and pretentious, the sounds it produced were by no means so pleasing as the clarionet-like notes of the numerous reeds, made like a shepherd's pipe, which the men, women, and children were so fond of playing upon in concert. The women had still another instrument, made of a piece of bamboo like a large organ-reed, the tongue of which was made to vibrate sharply by jerking a string attached to one end. The instrument was held all the while firmly against the teeth and the operator breathed forcibly upon the vibrating tongue of the instrument, thereby producing a few harp-like notes. It was a difficult instrument to play upon, but one evening, during the course of a very merry concert given by several of the women in my apartment, I wrestled with ye Dyak harp until I threw it, and succeeded in playing upon it as well as the others, to their great satisfaction and amusement. After that the greatest difficulty was to keep from laughing while we all played together.

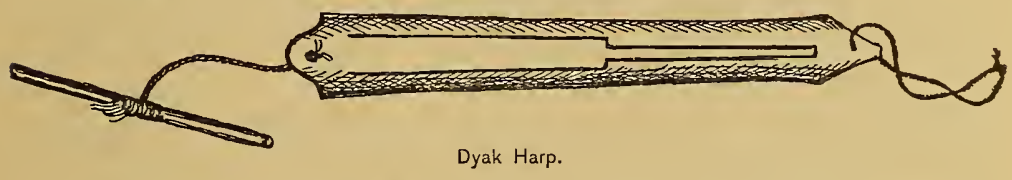

Upon great occasions, such as the gathering of the harvest, the marriage of a person of note in the tribe, or the visit of some European of distinction, the Rajah for instance, the Dyaks gather for a grand feast. Pigs are killed and cooked, rice, fruits, and vegetables are provided and also a liberal supply of tuak, or palm toddy, upon which all the men are expected to get drunk. The company feeds to the fullest possible extent and then the dancing and drinking begin. It is upon these occasions only that the Dyaks drink liquor and get drunk, and after the women take from the men all their weapons to prevent acciclents they go to work deliberately to make their husbands, lovers, and friends of the male sex roaring drunk. A Dyak girl considers it the grandest fun in the world to coax a redoubtable warrior into drinking until he is unable to stand.

I never saw a Dyak feast, nor an intoxicated Dyak, nor even a drop of the tuak which lays the warriors low at their feasts. In this connection, I feel in duty bound to quote Mr. Frederick Boyle's observations and reflections upon a feast in which he participated among the Seribas Dyaks. 
"In England such a scene of drunkenness and uncouth merriment would necessarily be coarse and disgusting to the last degree, but among these savages it is not so. We did not see a single act of impropriety even among the most reckless of the revellers, and the brutality inseparable from a 'heavy wine' at Oxford or Cambridge was utterly absent. We were assured that during the whole festivity decorum would be maintained as strictly as it was in our presence, nor would any Dyak dream of violating the laws of decency and good temper. Whether this be owing to the national character, or the quality of the liquor I cannot judge, inasmuch as it was impossible for us to swallow enough of the latter to decide ; but I am inclined to think that barbarous manhood and savage modesty were the principal causes of public decency. Thus it happened that a scene which, according to all precedent, should have been disgusting, turned out to be pleasantly amusing." *

So it seems the Dyak is a gentleman, even when drunk.

This reminds me to speak of woman's social position among the Sea Dyaks. From the cradle to the grave, she is considered man's equal, except in fighting and hunting. Her opinion is entitled to serious consideration, and her advice is always asked in all matters of importance. In speaking of the women of the Lingga Dyaks, the present Rajah Brooke remarks: "I soon learned that great power and influence is attached to their opinions on matters in general, and that to stand well with them was more than half of any Dyak battle." +

One great secret of the pleasant domestic and social life of the Dyaks lies in the fact that parents think too much of their children to make them marry against their will, or from mercenary motives.

The Sibuyaus believe in strict chastity, both before and after marriage, and lapses from virtue are considered highly shameful. Strangely enough, these simple-minded savages, without written law and wholly without religion, hold that in cases of unchastity, or infidelity to the marriage relation, the man in the case is equally guilty with the woman. Both stand on precisely the same footing toward the remainder of the community, and the disgrace and punishment are shared equally by both participants in the crime.

How very different is this from the improved customs of Christian lands. We say that what is folly in a man becomes crime in

* Adventures among the Dyaks, p. 248.

† Ten Years in Sarawak, I., 129. 
a woman. A man may be as "fast" as he pleases, or, as his means will let him, so long as he preserves the veneering on his character. He may be guilty of open harlotry, or ruin an innocent girl every year or two, and he will still be smilingly welcomed in polite society. He goes his way securely, proudly, is highly spoken of by both men and women, and if he is only rich, is fawned upon as much as ever. How is it with the woman in the case? One single step aside from the path of virtue, one little stumble, and no matter what the temptation or the palliating circumstances, no matter how atrocious the betrayal, she goes down. Into the mire she goes, howled at and spat upon by her sisters, forsaken instantly by the whole world, and literally sent to hell. What is there on earth to-day more deplorably and hopelessly faulty than the social laws of the "highest civilization the world has ever seen?" Even the unlettered savages of the jungle have a better state of society than we.

I have already mentioned the sacredness of the rights of property amongst the Dyaks, but the actual and universal observance of these rights by any class of people in this thievish world is so phenomenal I feel that I have a right to allude to the subject again. In civilized countries, and almost all others except Borneo, every man is not treated precisely as a thief, yet at the same time he who has stealable property is careful not to put temptation in the way of a stranger. Generally speaking; I believe that out of every twenty persons there will always be found one who would steal if he had a chance to get something he very much wanted and could take without detection.

Making debts beyond one's power to pay, is a very popular form of stealing by wholesale, for the encouragement of which we have several thousand laws which furnish ample protection to the perpetrators. Half our bankrupt merchants are ruined by "bad debts," made by people who prefer that method of getting a man's goods to simple burglary.

Once more I assert, with the certainty of being disbelieved, that the Dyaks actually do not steal. I have an account of one who did once steal some gutta from a companion, but he is dead now-hanged, "in the usual manner."

Where else but among the Dyaks will a traveller dare to trust a cart-load of boxes and packages, none of them securely fastened, all filled with scores of trifles, any one of which would be dear to a native's heart, in the centre of a village of fifty strange natives with 
no one to watch for thieves? You can do this among the Dyaks, and lose not one cent's worth. Even the empty tin cans and boxes I threw out of the house were brought to me and shown before they were appropriated. And yet, liad the Dyaks been West Indian negroes, or even like some white men I have known, they would have stolen half my goods in perfect safety to themselves.

I have never heard of a single instance of theft from any European, Malay, or Chinaman, committed by a Sea or Hill Dyak.

Their most wonderful trait, however, is their faithfulness in paying their debts. If the people of the village want goods, a trader will give them his whole cargo, if he can get them to accept it, in exchange for jungle produce to be collected. The day for full settlement is named by the head man, and by that day the debts are all paid. What a glorious country for an honest merchant to start business in!

Like their neighbors of the hills, the Sea Dyaks are without priests and creeds or even the faintest notion of religious observances. Their moral laws are the product of their own evolution, for we see in them no reflection of the religious customs of any of the people who have thus far come in contact with them, either Hindoos, Javanese, Chinese, Malays or Europeans.* Savage nations usually acquire all the vices, and but very few of the virtues, of the civilization which touches them, but so far the Dyaks of Northern Borneo have gone through the fire unscathed. They are yet free from the grovelling idolatry and abominable religious fanaticism of the Hindoos, the sordid avarice of the Chinese, the cleceit, treachery, and licentiousness of the Malays, and the brandy-andsodaism of the Europeans.

The Sea Dyaks believe there is a Supreme Spirit whom they call Battara, and sometimes Jawata (both of which are Hindoo names), and that the dead go to Sabyan, which is below the earth. They revere the memory of a party named Biadum, who was formerly a great chief among them, and at harvest time they make offerings in his memory, quite after our eustom of firing off

* In asserting that the Dyaks have no religion I attach to that word the meaning which is most generally recognized, viz, a system of faith and worship, and obedience to the laws of a Snpreme Being. Although modern anthropologists liave agreed to consider that belief in a Supreme Being of any kind is sufficient to constitute a "religion," it seems to me highly improper to dignify with that wame a ragus, inconsequent notion which bears no fruit whatever, either in worship, obedience, or even love. 
gunpowder on Washington's birthday. Like most ignorant people, they believe in evil spirits who haunt and annoy certain ones among the living, and are superstitious in regard to various omens of good and bad fortune.

Their crimes can be counted on the fingers of owe hand; and instances of their commission are few and far between. It must be remembered that the frenzy for liead collecting, which led to such wholesale murder before the advent of Rajah Brooke, was mainly due to the instigation and encouragement of the reprobate Malays who so nearly ruined the country.

As might be expected, the Dyaks are subject to but few diseases, and those of a simple nature. The most common ailment is called "corrip" (ichthyosis), in which the epidermis of the subject cracks all over the body and the edges roll up into little whitish rolls. The body of a Dyak so affected has a gray appearance, and, although the disease is painless, it is disagreeable to look at and very difficult to cure. Fever and dysentery are both common diseases, and also ophthalmia, which is most prevalent during the time of weeding the paddy fields in September and October, at which season whole tribes are sometimes attacked. If taken in time, it yields to very simple remedies; but many lose their sight from neglecting treatment.

Insanity is very rare, and also natural deformity of person. So far as I could learn, the Dyaks are entirely free from the long list of unmentionable male and female diseases which appear to have been developed by the human race only at its highest stage of civilization and refinement. It is a singular, though melancholy, fact that savages know nothing of venereal diseases, abortion, infanticide, and drunkenness, until they are introduced by the civilized nations of the earth.

Dyak women in confinement are attended only by the old women of the tribe, and, as might be expected from the absence of the health-destroying elothes, food, drink, medicines, and social customs, which make American women weak, they are usually seen going about their regular occupations on the third or fourth day after child-birth.

A favorite Dyak remedy for a cut, bruise, or sprain, is to expectorate a quantity of betel juice upon the part afflicted, which quickly imparts to it a disgusting yellow-jaundice appearance.

Unlike the Hill Dyaks, the people of the Sea tribe always bury their dead. I did not have an opportunity to wituess an in- 
terment or even to see a burial ground, but Mr. Eng Quee told me that the Sibuyaus bury their dead in coffins when they can make them, otherwise without. They put vessels of food beside the grave, and also such of the ornaments of the deceased as are not valuable enough to be carried off by strangers. They formerly buried with their dead many valuable ornaments of gold and silver, but these tempted the low-class Malays to rob the graves, and of late years the custom has been discontinued altogether. The Dyaks select retired spots for burial grounds, never visit them except when really necessary, are averse to taking strangers to see them, and also to talking about their burial customs. They erect no monuments whatever to mark the resting plaçe of their dead, and make their interments very quietly.

Thus ends our brief survey of the Hill and Sea Dyaks, and what does it teach us? In these strange children of nature we see all the cardinal virtues without a ray of religion, morality without ministers, the Christian graces without Christ or gospel. They keep no sabbaths, pray no prayers, build no temples, worship nothing and nobody, and acknowledge no higher tribunal than the bar of public opinion on one hand, and the Sarawak government court on the other.

The Dyak is perhaps the most happy and contented human being under the sun. His wants are few, and his native jungle supplies nearly all of them. Thanks to his state of savagery, he has not developed one-tenth of the disenses which so often make the lives of civilized people a burden. His children do not have scarlet fever, diphtheria, croup, or whooping-cough, nor does he or his wife have consumption, pneumonia, dyspepsia, rheumatism, or gout. But for the rascally Chinaman, who years ago taught him to make toddy from the palm tree, and who even now supplies him with arrack, he might to-day be without the means of getting drunk. As is the case with nearly all savages who drink intoxicating liquors, this vice is the gift of civilization.

In hospitality, human sympatlyy, and charity, the Dyaks are not outranked by any people living, so far as I know, and their morals are as much superior to ours as our intelligence is beyond theirs. If happiness is the goal of human existence, they are much nearer it than we. In this instance, at least, the highest civilization has not evolved the most perfect state of society, and to this extent the fundamental theories of theology, of sociology, and human evolution are utterly at frult. Borneo is no field for the missionary, for 
no religion can give the Dyak aught that will benefit him, or increase the balance of his happiness in the least.

We have seen that there can be, and there is, morality of a high order without any creed, religion, or education whatever. Is it possible that man reaches his highest moral development in a state of savagery? Is it, then, really true that as we increase in civilized intelligence, refinement, and capacity for enjoyment, our capacities and propensities for wickedness and harmful pleasures increase likewise? If this is the case now with mankind, will it always be so? These are serious questions, and I leave them with the reader. 


\section{CHAPTER XXXIX.}

\section{A PLEASURE TRIP UP THE SARAWAK.}

The Firofly.-Mr. A. H. Everett. - The Chinese Gold-washings at Bau. - Caves and Crevices near Paku. - Walk to Tegora.-The Cinnabar Mines of the Borneo Company.-Romantic Boat Ride down the Staat.-Trip to Serambo Mountain. -Dyak Bridges. - Village of Peninjau. - The Rajah's Cottage. Magnificent View.-Retnrn to Kuching.-Farewell to Borneo.- Singapore once more.-End of the Expedition.-Retrospect.-Conclusion.

I RETURNed to Sarawak (Kucling) on the sixth of December, and during the fortnight I spent in packing up my collection and waiting for the steamer, my good friend, Mr. Oliver St. John, Inspector of Public Works, treated me to a glorious trip up the Sarawak River. I say " treated me," for without him as a guide, philosopher, and friend, I should not have gone, and, when I reflect now upon the trouble he took and the miles he walked solely on my account, I feel quite as if I had wronged him.

I had collected until I was tired and sick of specimens, and that trip was made solely for pleasure. Mr. Crocker placed the government steam launch Firefly at our disposal for the trip, and one bright afternoon at two o'clock we started up the river with the turning of the tide. A bend of the stream soon hid the town from our view, and after getting clear of the straggling Malay kampong, we were ready to drink in the successive scenes of the new panorama which began to unroll before us.

Scene first, five miles long-banks low, uncultivated, covered with monotonous mangroves.

Scene second-the banks have risen and asserted themselves; they are clear of old jungle and covered with green paddy fields for a quarter of a mile back from the river, where they meet the forest primeval. Here and there are neat-looking houses, nestling in clumps of banana and cocoanut trees, surrounded by neatly-kept vegetable gardens. From the general look of care and thrift, we are led to hazard the opinion that fields, houses, and gardens belong 
to the Chinese, which proves to be the case. Two or three Chinese shops are passed; Gunong Matang, the mountain so conspicuous from Kuching, also went by us on the right, with a few other peaks of humbler elevation.

Eight miles above Kuching, the mountains of the interior rise prominently into view in long ridges with fleecy white clouds clinging to their densely wooded sides. Though not so very distant, they were of a deep blue color, and, taken altogether, were to the eye a grateful relief from the everlasting green of the level jungle.

We took in the scenery until dark and then reluctantly turned from it to the dinner table. The Firefly is a very comfortable little craft, but her passengers must provicle their own bill of fare and table furniture. We had plenty of soup, but there was not a spoon on board, so we drank it out of our plates and proceeded to dispose of the remainder of the menu with equal facility.

The night was exceedingly dark, and how the steersman managed to keep clear of the banks was more than I could see. About twelve miles up, we came to the confluence of the two branches of the Sarawak River, and took the smaller or western stream, which soon became very narrow, but still remained deep, swift, and murky. About 8 P.s. we reached Busau, twenty-six miles from Kuching, and landed. Here we were at the terminus of the Borneo Company's tram-way system, from which the antimony mined in the vicinity and the quicksilver from Tegora is shipped down the river. Leaving our luggage to be pushed after us on a tram-car, we set ont in the black darkness and walked on the tram-way four miles to Paku. At the police station we turned off and climbed a steep conical hill until we were out of breath, which brought us to the top, upon which was perched a house, to the comforts of which we were hospitably welcomed by Mr. A. Hart Everett, the naturalist.

It was a great treat to meet an accomplished Malasian naturalist on his native heath, a man who knew Borneo by heart, and was, like myself, almost wholly given over to collecting. I plied the poor man with questions until we were both fairly exhausted and obliged to open some bottles of ale. Mr. Everett was on a mission of much more importance to science than the mere collecting of specimens.

Under the patronage and support of the British Museum and the Marquis of Tweeddale, then President of the Zoölogical Society, he had entered upon a thorough and systematic examination of the caves of Borneo, in the hope of finding in the deposits upon their floors fossil remains of the forerunner of the anthropoid apes. It 
was faintly hoped that, even if the cavern deposits did not reveal the missing link, their fossils would at least throw some light upon the point at which the human race diverged from the catarrhine stock. Here was an evolutionist with his war-paint all on, and his weapons in his hand-pick, shovel, and sieve. Imagine the sensations of a Darwinian actually searching for and finding the link between man and the great apes! Another Kohinoor would be a mere glass marble in comparison.

Mr. Everett's methods of search were so thorough and truly searching that not even a bat's tooth escaped the sieves through which the floor deposits of the caves were put. He found the bones. of bats in great abundance, all of living species, however, and one skull of Simia Wurmbii in a fossil state, but, I grieve to say, no traces of extinct animals nor even a prehistoric race of men. I should have stated above that another and equally important object with Mr. Everett was to obtain evidence, if any existed, of the occupation of Borneo by any primitive race anterior to its being peopled by the descendants of the Malays.

Unfortunately for science, Mr. Everett's investigations were soon after brought to an untimely end by the death of the Marquis of Tweedale. In order to reach a new field, Mr. Everett accepted a position with the North Borneo Company and went to the Kina Balu district. It is to be hoped that he may soon find the time and means for a thorough scientific exploration of the terra incognita lying to the south of Kina Balu-a work which no one is better fitted to accomplish than he.

When we started from Kuching I solemnly promised myself not to think "specimen" even once, much less try to collect one, but when Mr. Everett showed me his beautiful specimens of Tupaia, Gymnura, Galeopithecus, Atherura, and ten superb specimens of the most wonderful bat I ever saw (Cheiromelas torquatus), I weakened. When be brought out a huge and quite perfect skull of the Bornean gavial, a species which $I$ had not before encountered (Tomistoma schlegellii), I surrendered unconditionally, and my last dollar was swallowed up in the fearful vortex of "specimens." Crocodiles always were great pets with me.

The dawn of the following day disclosed in every direction a fine view of mountain, hill, and dale-so charming a prospect, that I heartily envied Everett his quarters. The little house was perched exactly upon the summit of the steep cone, open on all sides to the breeze, with not a tree to break the view. 
After coffee, with Mr. Everett accompanying us, we set out and walked four miles northwest to see the Chinese gold-washings at Bau. There was a good path all the way, through the second growth of jungle, and the scenery was highly interesting.

Bau takes its name from a peak close to the washings, from the northern base of which a remarkable pinnacle rises like a gigantic pillar with the top broken off and its precipitous face smooth and bare.

There are two Chinese companies working gold at Bau, and we visited the works of both. Both pursue the same wasteful plan. The gold occurs in very fine particles in a low hill of decomposed porphyry, mixed with a small proportion of blue limestone, manganese, etc. In appearance it resembles yellow clay. A large reservoir affords a good head of water, and, as fast as the hill is dug down, the earth is thrown into the sluices, some of which are nearly a mile long, and washed away. Three or four times a year they turn off the water and wash up the residuum by hand. It is a very wasteful process, and the Chinawomen do a very fair business in washing out the dirt at the lower end of the sluices.

The two gold companies have separate villages and two sets of shops, both well built and neatly kept. It was here that the Chinese insurrection was hatched in 1857, which taught the celestials a fearful lesson, one which it will never be necessary to teach them again. I do not suppose any combination of circumstances could now induce the Chinese to get up another row with the government of Sarawak. Like the people of our Southern States, they now declare that "rebellion must be put down."

As we passed through the village of the Sap Long Moon Kunsi, on our way back, we found a table of refreshments had been prepared for us in a cool veranda. First, last, and all the time, we were helped to tea of the very best quality (so St. John said), strong, bitter, and wholly innocent of either milk or sugar. To me it was about as palatable as soapsuds, but it was nevertheless refreshing to the inner man, and, without consulting my palate in the least, I emptied my tiny cup several times. Besides the tea, we lad sugared peanuts, candied pumpkin, a preserved fig-like fruit from China, and big Chinese gooseberries to eat at the finish in lieu of pickles. Strangely enough, none of our hosts could speak Malay, but a very respectful crowd gathered to see the animals feed. At the next village, the above performance was repeated, except that we sat down to tea and fruit instead of tea and sweet- 
meats. We ate heartily, both by choice and as a matter of courtesy due the company. When hot and thirsty, I can eat a good many mandarin oranges out of politeness to my host.

We reached Everett's quarters about noon, and in the afternoon St. John and I went to see some caves not far away. Half a mile east of Paku is a rocky gorge between two hills, in one of which Ensunal cave is situated. The cavern extends, like a great irregular tunnel, quite through the hill, and is at least four hundred feet from end to end. In some places it is wide and high, like the interior of a cathedral, and in others contracted to a mere passage, so narrow that a man weighing two hundred pounds would not be able to get through. The sides of the cave revealed the fact that the whole hill is full of cracks and fissures. I was surprised at seeing long, slender, rope-like roots of a dark red color coming down from the trees far above, and winding about through the crevices in a most persistent way. In some parts of the cave, water was dripping down in a copious shower, and the soft limestone floor underneath was quite honeycombed with small round holes which the "little drops of water" had drilled. The earth on the bottom of the cave had all been dug up and examined by the indefatigable Chinese in their never-ending search for new deposits of gold.

After leaving the cave, we went on higher up the gorge to some of the remarkable well-like crevices which exist in the hills. They are simply holes running down through the limestone, with ragged, uneven sides, very often of no greater diameter than a common well, three or four feet, and sometimes sixty to seventy feet deep. Sometimes gold is found in the loose dirt at the bottom, and when this is the case they are worked by the Malays. In order to get down one of these holes and up again, the prospector puts sticks across the opening, jamming the ends firmly into the cracks in the sides, thus forming a ladder reaching to the bottom. There is usually a cavern at the bottom of each crevice, and it would seem that the whole hill is a mass of huge rocks, cracked and seamed throughout.

The antimony mine at Bidi was full of water and we did not visit it. With the exception of that one mine, all the rest of the antimony produced is found in surface pockets, many of which have been found, and quickly emptied, along the line of the tramway. The Honorable Borneo Company has a monopoly of all the useful minerals of Sarawak except gold, coal, silver, and diamonds ; and all the antimony found by the natives is purchased by the company at forty to sixty cents per picul, according to its quality. 
On the following morning we rose early and after a good substantial "coffee," Mr. St. John and I set out to walk to Tegora, eleven miles from Paku. There is a good bridle-road and good bridges all the way, and with good company it is a delightful walk. The road is merely a narrow lane through beautiful virgin forest of stately trees and trailing lianas, mossy rocks and acres of pretty ferns.

Presently we came to the Staat River, a small, shady stream, along the south bank of which the road winds for several miles. Far below us, over its bed of clean white pebbles, flowed the river, clear and cool ; at last, when we came to where the road crosses the stream on a high bridge, a deep shady pool in the bend below looked so inviting to our perspiring bodies that I begged St. John to take a swim with me. Boy-like, we "raced" in undressing to see who should take the water first, and in less than five minutes we plunged into the cool, sweet water, where not a ray of the hot sun could reach us, where the water was deep, and, thank heaven! free from crocodiles. How delicious it was, and how loth we were to leave that bath "fit for the gods." It was the first really secure and comfortable swim I had enjoyed since Jackson and I went swimming in the Orinoco, when I stepped upon a small sting-ray with the usual result, and he got nipped by a cariba fish. Verily there is little comfort in swimming in tropical rivers, especially within tidal influence, for they are nearly always dirty, and infested by sharks, sting-rays, crocodiles, and other aquatic vermin.

The last four miles of the road led over a succession of low hills, and the forest scenery grew even more picturesque and charming. At last we reached the village of Pankalan about a mile from Tegora, at which there is a police station and court-room, and also a shop kept by a wealthy Chinaman. We halted at the shop and emptied a quart bottle of champagne, a drink by no means to be despised in the jungle. After we had disposed of a "scratch" breakfast evolved for us by the Chinese shopkeeper's domestics, St. John tarried to hold court, over which he presided as magistrate. Had I but understood the Malay language I would gladly have stayed to watch the proceedings, but having no special interpreter, my presence would have been only a hindrance to the court, so I left, and walked on to Tegora.

On the way to Tegora, where we had been invited to dine and put up for the night, I met Mr. Harvey, a handsome, manly-looking young Englishman, one of the officers in charge of the mines, who 
introduced himself directly and greeted me very cordially. We met again in the evening at the dinner-table, and he proved to be a very jolly and hospitable host.

On reaching the mines, I found $M r$. H. H. Everett, brother of our Paku naturalist, at the furnaces, weighing out bags of cinnabar dust, and close beside him on the ground stood about sixty flasks of mercury ready for shipment to London. A "flask" is a malleable iron bottle with a screw top, which holds seventy-five pounds of mercury.

The cinnabar ore comes out of a very steep, double-peaked hill composed of semi-metamorphic rock, rising to an eievation of about one thousand feet above the sea, and six hundred and fifty feet above the level of the adjacent swamp. Mr. Everett, with the most cheerful resignation and truly guide-like patience, took me into each of the four "levels" that have been mined into the hill, one above another, and gave me all the facts in the case as we proceeded. The lowest level was a new one, and the tunnel had not yet reached the ore. The other three had penetrated quite to the heart of the hill, and on reaching the paying ore it had been mined in every direction, forming a great cavern at the end of each tunnel. The miners are all Chinamen who work out the ore and sell it to the Company according to the assay. The ore was then very poor, and although the rock containad only four per cent. of mercury it was worked as a matter of necessity and at a loss, while all concerned hoped constantly for something better. In one of the levels Mr. Everett showed me a very rich pocket, which had yielded ore almost as heavy as mercury, being ninety per cent. pure metal.

The Tegora mines were opened in 1868. The first ore taken out was stamped, by which process about one-fourth of the metal was lost in the washing. Now itis smelted, and the vapor containing the metal is passed through a flue or shaft about one thousand feet long, which leads off up the steep side of the hill. The mercury is gradually condensed upon the sides of the flue, which after a time is cleaned out by men sent into it. The cleaners often get badly salivated, so much so that they are sometimes utterly helpless from the sores which break out upon different parts of their bodies. We saw two poor fellows who were helpless from salivation; and Mr. Everett himself was also badly off from an overdose of mercury.

The officers of the Borneo Company are very comfortably housed close to the mines, and in the evening at dinner we were 
most hospitably entertained by four of them, Messrs. Everett, Harvey, Gray and, Beecher. Every one was in good spirits, and we had a very merry time until a late hour. An Englishman may be rather rigid and formal on his native isle, but take him in the East Indies, especially in the jungles, and he is certainly the jolliest and best of companions.

On the following day, St. John and I returned to Paku. At Pankalan we took a boat and had a very romantic ride down the Staat, which saved us several miles walking. The river was low and we had to shoot a number of rapids in consequence. The boat was a small one, and at each end stood a Malay with a bamboo pole to guide the frail craft. It was certainly a charming ride. The bed of the stream was sand, pebbles and bowlders, and the banks were shales and limestone. The branches of the trees met far above our heads, giving us a continuous cool shade instead of the glare and heat of the sun, and in a quiet ecstacy of delight we glided smoothly along with the swift current, feasting our eyes upon the beauties of rock and tree, flower, fern, orchid, and mossy bank.

Often when shooting down the rapids at a great rate, with great bowlders lining our narrow way thickly on either hand, or with a wall of rock rising directly before us at the foot of the incline, it seemed as if the next instant our boat would certainly strike and be smashed into kindling wood. But no; just at the right moment, the man in the bow would quickly jam the end of his pole into a crevice or against the rocky wall, give a quick, strong shove, and send us swinging off at a sharp angle down the middle of the channel. The Malays handled the boat as only skilful and practised hands could; and it did not touch a rock even once.

After several miles of this delightful voyaging we came to the getting-out place, and, with a sigh to think the ride was over, reluctantly took to the road and walked the remainder of the way to Paku, which we reached shortly before noon. In the afternoon, while St. John held court, Everett and I strolled out to get some specimens of calc spar, antimony, and limestone, and to talk over all Borneo.

Our last day was to be devoted to an excursion to Serambo Mountain, whither my good friend St. John had invited me, for I should never have dreamed of asking him to do so much hard climbing on my account. We said good-by to Mr. Everett and set out early for the mountain, which rises about two miles east of Paku. There is a good Dyak road, or path, all the way, leading 
over hills, through hollows and across several very interesting Dyak bridges, built across mountain streams, above high water mark, to insure the traveller a crossing in times of flood. Evidently the Hill Dyaks are more averse to floundering through mud and water than their brethren of the Sea tribe.

The low foot-bridges are almost precisely like the hay-racks at which the cattle feed in an Illinois farm-yard. They are very ingenious contrivances, and the idea of their construction might often be copied to good advantage by the settlers of our Western States. They are built by planting two rows of long stakes in the ground slanting in opposite directions, so that a small sapling laid in the fork thus formed will be horizontal, and of the proper height for the footway. Each pair of stakes is lashed together at their point of intersection, and the bridge is further strengthened by perpendicular posts set under the footway. A pole is lashed along the top of each row of stakes to serve as a hand-rail. One of the bridges between Paku and Serambo was about a hundred feet long and nine feet high at the middle.

Sometimes the Dyaks construct very high suspension bridges across streams with high and precipitous banks, by hanging a couple of long bamboo stems with rattans or creepers from the branches of the trees which overhang the chasm. A hand-rail is also constructed, either on one side or both, but even with that, it takes a very steady-headed European to cross without breaking out all over in a cold perspiration. The Dyaks, however, trot across them, carrying heavy loads with the most perfect nonchalance, and the only accidents that occur are by the bamboos becoming rotten and suddenly giving way with a grand crash.

About an hour from Paku we reached the font of the mountain and began to climb up the path which leads to the Rajah's cottage and the three villages of Serambo, Bombok, and Peninjau. It was a hard climb. The whole side of the mountain was strewn, or covered, rather, with boulders and angular masses of rock from the size of a Saratoga trunk to a street car, smooth, mossy, and slippery as ice. I think they must have been covered with soft soap that morning for our especial benefit. We were obliged to proceed with the greatest care and circumspection to aroid coming down with a wreck of muscle and crush of bones. In some places the rocks are so large and piled together in such rugged confusion that the Dyaks have regular ladders and foot-bridges over them, of notched saplings placed end to end with a hand-rail 


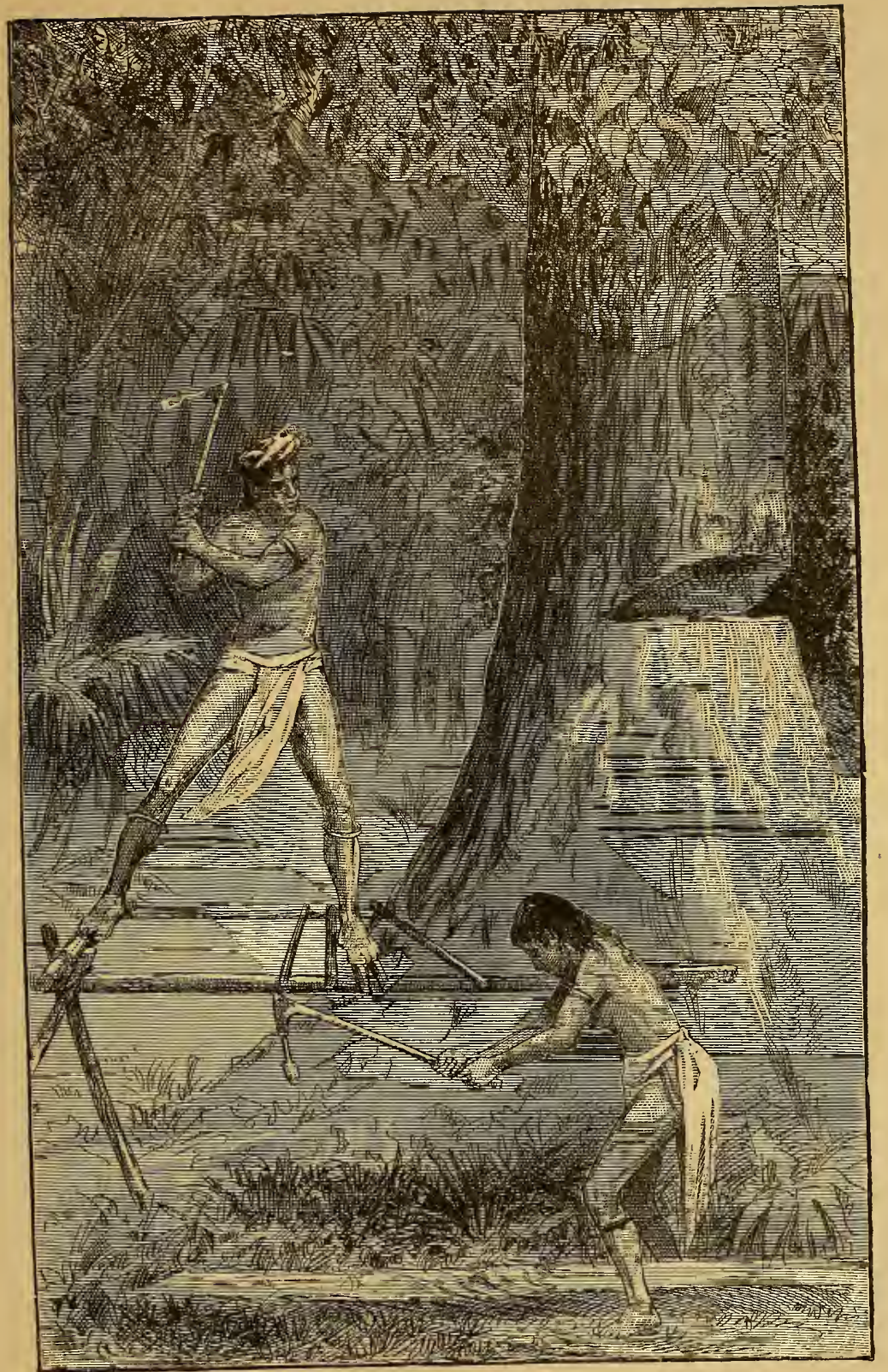

DYAKS USING THE BILIONG, OR AXE-ADZE. (Page 379.)

(From a sketch by $H$. H. Everett.) 

along one side. My journal for that day pantingly declares, "It was hot work to climb such a steep mountain over such a terrible jumble of slippery stones."

Near the top we came to Peninjau, a typical village of the Hill Dyaks. Besides the pangah, or head-house, there were fifteen other houses, each of which contained from three to six rooms and accommodated a total population of about five hundred persons, when the returns were all in. The houses stand just wherever they can find standing-room, with no order or regularity whatever, not a sign of anything like a street nor even a good path anywhere. They were of course built along the side of the mountain, usually with the open side up hill, and all were elevated on posts which were from six to eight feet high on the upper side, where they were the shortest. The rank grass growing all through the village and the uncommon stillness which prevailed, gave the village quite a deserted air, and, sure enough, we found only a few girls and old women in the place, all the rest being away at work on their farms.

As we passed through the village, two young women came out to look at us, who were in their turn inspected with equal curiosity. Their brass waist ornaments were of an entirely different style from any $I$ had before seen, the thick wire being worn up and down from hips to armpits instead of in rings around the waist.

These curious corsets were models of rigidity, and closeness of fit, and being brightly polished, gave the young ladies quite a substantial air. What a magnificent protection they must be against the embraces of a too-powerful lover!

We entered the head-house, which I have already described in a previous chapter.

The heads, or rather skulls, hung in a semi-circle around one side of the room, and there were forty-two of them in all, not counting the skull of a young orang-utan, which probably some enterprising young Dyak, in haste to marry, had, in times past, palmed off upon his unsuspecting lady-love and his brethren, as the head of a fierce young Seribas Dyak.

The collection as a whole was in very good condition, the specimens being moderately clean and not at all smoked. Some had been very carelessly taken, I regret to say, as was shown by the way they had been split open or slashed across with parongs; and from some, large pieces had been hacked out. One I noticed had a deep slash diagonally across the bridge of the nose, which evi- 
dently ended the earthly troubles of the owner in short order None of the skulls were labelled with locality, date, sex, and species as crania always should be, to be valuable.

After leaving the pangah we climbed two hundred feet higher, and at last reached the Rajah's cottage, which has been visited by nearly every European who has thus far set foot in Sarawak. The cottage itself is a sort of summer-house, a veritable "lodge in a vast wilderness," a little house on posts, with three rooms, a veranda extending around three sides, and at that time no furniture except a table and two or three chairs.

But if the cottage is nothing of itself, the location is everything. Back of it is the forest-clad top of Serambo, all about it are flowering shrubs, cocoanut trees, and the tops of the trees which have their roots far below in the steep side of the mountain. Through the cocoanut-grove in front we catch a glimpse of sea and sky, and hasten forward to get beyond the trees. Come with me, quickly, if you would feast your eyes on a most charming view. Fifty yards below the cottage we stand upon a bare rock, the very northernmost point of the summit, nine hundred and fifty feet above the sea, with a clear view to the north, east, and west. It is enchanting. The sun shines brightly, the air is clear, and every object in the vast landscape is defined with unusual clearness of detail.

Almost beneath our feet is a wide semi-circle of ferns, then the feathery tops of the bamboos that grow lower down the steep slope, and beyond that a sloping bank of green tree-tops which finally mingle with the foliage of the plain far below. To the left hand (west), and seemingly very near, rises the Semadjoe mountain range, which forms the boundary between Sarawak and the Dutch Territory, with Bau and Matang still nearer at hand toward the northwest. Everett's house at Paku, far below, looks like a little white martin-box on a tiny mound. Toward the north, seemingly at the foot of Serambo, we can trace the winding course of the western branch of the Sarawak River, brown and murky with the mud of recent rains. Beyond the river stretches a wide level plain covered with green jungle, broken only by a few light patches here and there, either farms or second growth jungle, and a few hills that rise high enough to be recognized as such. Far away in front, at the edge of the sea, rises the fine peak of Santubong, with its head thrust up into a fleecy white cloud. The coast line is clearly defined from the mouth of the Lundu to the Batang Lupar, and 
beyond it the sea stretches out toward the horizon like a sheet of frosted silver.

We can very easily make out the position of Kuching, and trace the windings of the Sarawak for a long distance, but the stream itself is visible in but one or two places. Truly, an enchanting picture in contrast with the monotonous closeness of jungle and river scenery.

Reluctantly enough, we quitted Peninjau, the "look out," and started straight down the mountain, in the direction of Siniwan, at which point the Firefly was to meet us. The descent over those abominably slippery stones was, if anything, more tiresome and difficult than going up. Half way down we met a party of Dyaks coming up. As soon as they heard our voices they quickly dropped their juahs beside the path and bolted into the bushes; but after we had passed out of sight they returned, chattering and laughing, resumed their loads and went on.

Shortly before noon, after a very hot walk to the river, we reached the Firefly, and went down to Kuching in about three hours. For my part, I felt thoroughly tired and foot-sore, and $\mathbf{M r}$. St. John was also quite willing to rest. Our feet were badly blistered, and a large, angry boil on my left arm, which had kept me company all the way, was a companion with whom I would willingly have parted.

Thus ended my jungle life in the East Indies. On December 18th I embarked in the Rajah Brooke for Singapore, serenely happy with the results of my visit to Sarawak. Never has a country used me better or sent me away fuller handed. I have been treated excellently well by both natives and Europeans, have had very few annoyances, $I$ ought to say none at all, and more joys crowded into four months than are counted in many a lifetime. My only regret is that $I$ have not had a score of friends to enjoy it with me. The coast line sinks into the sea behind us, and the hazy blue mountains fade out against the clouds like a dissolving view. Farewell to Borneo!

"Welcome the gleaming sea."

I remained six weeks in Singapore, making up a large collection of corals and shells, for the variety and abundance of which the place is famous. Previous to that time the season had been unfavorable for the successful gathering of marine invertebrates, but now the Malays brought me beautiful shells by the hundred and 
corals by the boat load. Major Studer, our worthy consul, gave me a large room in the lower part of his house, and the use of a cool, shady court, where I bought, assorted, and packed several hundred specimens of coral of twenty-six species, and more shells than I could spare time to catalogue.

My friend Syers sent me a very nice collection of Selangore mammals, skins and skeletons, and snakes in alcohol, all of which he had gathered since my visit there. It is a pity that such an ardent hunter and dead shot with a rifle could not have his lines of duty cast in such a country as Southern India, which, in places, actually teems with noble game. Mr. Syers and I planned an expedition to the Animallais for some future year, with Theobald for a companion in the chase, and when we do actually start on the war-path in that direction some of the big game animals had better get their lives insured against accidents.

My jolly friend Hood, of the Rainbow, put in an appearance during my last days in Singapore, but I felt so down-in-the-mouth at not having sufficient funds left to get me to and through Australia, that I was but sorry company, I know. It was fated that I should not see Australia; for a hunting and collecting trip cannot, like the brook, "go on forever."

Foreseeing that I should have to cross the Pacific in winter, I determined to spare my two baby orangs the miseries of such a voyage, and, after having the Old Man sit for his photograph, I sent them both, under the guardianship of Mr. Vandevorst, to Madras, as a present to my kind friend Theobald. I could not have given him anything that pleased him better. He made a journey of three hundred and fifty miles to meet them; and they receired him with open arms. Both were presented at court before they left Madras, and I hear were very much complimented on their deportment and good looks.

Early in February I turned my face homeward, by way of China and Japan, and reacbed Rochester safe and well, just two years and nine months from the time of my departure. From first to last I had been remarkably prospered, quite as if the prayers and good wishes of my friends had enlisted the services of a special guardian angel to accompany me at every step, in addition to the one I left behind me, whose charming missives of news, hopeful encouragement and unfaltering affection followed me everywhere-one by every mail, without a single break-without which I would have been lonesome indeed. No journey could have been more free 
from accidents, for from first to last I did not meet with so much bodily harm as a cut finger, and returned home with health wholly unimpaired.

Enriched by experiences in foreign lands, wealth which cannot be estimated in dollars and cents, nothing but a desire to have others share with me, through the medium of these pages, the delights of forest and field, river and sea, could have impelled me to the laborious task of writing this narrative in hours which should have been: devoted to rest and recreation. But if a single reader (always excepting the proof-reader) has followed me thus far, and experienced in sympathy a hundredth part of the delight which quickens my blood as I think of the scenes which I have feebly attempted to describe for him, I can say that my labor has not been in vain.

The rifle and knife hang peacefully upon the wall, their labors done. Let me rest my weary pen also. Farewell. 



\section{APPENDIX.}

\section{OUTFit For A COLLECTOR.}

For the benefit of inexperienced collectors, I give below an itemized list of the various articles which constituted my outfit for field-work in collecting and preserving animal specimens of all kinds. I have only to add that my outfit was complete and compact, contained no useless articles, and I found it perfectly adapted to all my wants. Its total cost was about $\$ 270$.

1 Agassiz tank (copper), in wooden box, for alcoholics.

1 chest of black walnut, iron bound, which contained all the articles enumerated below :

1 double B. L. smooth-bore gun, No. 10 , in case.

1 Maynard rifle, cal. 40.

1 " shot-gun, No. 16.

1 Smith \& Wesson revolver, cal. 32.

1 belt and cartridge bag.

40 pounds shot, assorted sizes.

10 pounds Maynard bullets.

1,000 Berdan primers.

12 pounds Orange Ducking powder.

30 pounds arsenical soap.

15 pounds dry arsenic.

1 dozen large skinning knives.

1 dozen small skinning knives.

6 scalpels.

2 claw hatchets.

1 saw.

1 large skin scraper.

1 geological hammer.

1 bull's-eye lantern.

1 A No. 1 field-glass.

1 compass.

2 brushes, for arsenical soap.

1 blow-pipe and set of egg-drills.

1 hydrometer and test-glass.

1 thermometer.

2 pairs hunting-shoes.
2 rubber blankets.

1 double woollen blanket.

1 Ashanti hammock.

3,000 labels, three sizes.

1 tool-box, size 13 by 7 inches, which contained the following:

4 skinning knives.

2 pairs scissors.

1 brain hook.

1 pair long forceps.

1 pair short forceps.

1 pair cutting pliers.

1 pair flat pliers.

2 sets skeleton scrapers.

1 small skin scraper.

1 flat file.

2 three-cornered files.

1 cold chisel.

2 awls.

14 -inch saw (for turtles).

1 tape measure.

12 -foot rule.

1 ivory thimble.

1 oil-stone.

1 spool thread.

2 dozen labels

3 papers glover's needles. 


\section{Recipe for Making Arsenical Soap.}

Ingredients.

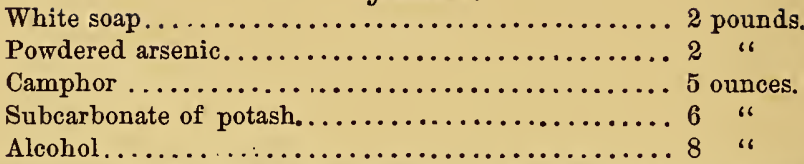

Directions.-Slice the soap and melt it in a small quantity of water over a slow fire, stirring sufficiently to prevent its burning. When melted, add the potash, and stir in the powdered arsenic, after which add the camphor, previously dissolved in the alcohol. When the mass has been boiled down to the consistency of thick molasses, pour it into an earthen jar to cool and harden. Stir it frequently while cooling to prevent the arsenic settling to the bottom. When cold it should be like lard or butter. For use, mix a small quantity with water until it resembles buttermilk, and apply with a common paint brush.

\section{How to Skin a Quadrdped, and Prepare the Skin for Modnting.}

\section{(Subject chosen, a Tiger.)}

First measure the animal carefully and record the dimensions on the spot. Then, as with all land mammals, make a straight clean cut from the throat along the under side of the animal quite to the end of the tail. Slit each leg from the centre of the foot, or the "pad," along the back of the leg to the first joint, or the heel, and stop there. Begiu at the incision along the middle of the body, skin down the sides of the animal as far as possible, then detach the legs at hip and shoulder. Skin each leg down to the very ends of the toes, cut all the flesh and tendons from around the leg-bones as cleanly as possible, but leave the leg-bones attached to the skin at the toes, and to each other by their ligaments. Make a slit along the bottom of each toe so that every morsel of flesh may be removed, and every inch of the skin be laid bare on its inner surface to receive the preservatives. Skin down to the base of each claw.

Detach the head from the body at the first cervical vertebra, and, as you proceed with the head, turn the skin over wrong side out and work gradually down to the end of the nose. When you reach the eye, insert a finger in it from the outside to guide the movements of your knife and prevent your cutting the edges of the eyelid or corners of the eye. The skin on the inner surface of the lips must be cut close along the gums in all cases. After the skin is detached from the skull, the lips must be slit open from the inside until the fold or edge of the lip is reached, and the flesh inside the lip cut away. 'The lip is now unfolded as it were all the way round, and in mounting the animal the place of the flesh will be supplied with clay or putty and the lip folded again as in life; hence the importance of preserving the inner skin of the lips. The roots of the whiskers form a large, thick lump on each side of the nostrils, and these must be slit vertically, so as not to cut off the roots of tiose long, stiff hairs. In most of the Felidne the whiskers are set in rows, so that it is easy to slit the flesh between the rows of root-glands until coming down to the skin itself. Rub the alum well into these gashes when preparing the skin. The cartilage of the ear must be skinned out from the inside by simply turn. ing the ear inside out. 
Carefully scrape all the fat from the inside of the skin and all bits of flesh, and wash off all the blood from both sides, so that the skin shall be thoroughly clean. Now rub the inside of the skin with strong arsenical soap, after which apply powdered alum plentifully to every inch of inner surface. Put on as much alum as the skin will absorb, and on the leg-bones as well as the skin, to make them dry quickly; then hang the skin over a large pole in a shady place where the wind will strike it. Be careful not to stretch the skin unduly. Keep it well spread out, so that the air will reach every part of it freely. Turn the skin about every other day and expose the hair side. In a few days, if the skin has a fair chance, it will begin to get stiff and hard, and then it should be taken down and folded up neatly, hair inside. Leave it in an open place a little longer, and it will become almost as hard as a board, the best condition possible for it. A skin cured in this way can at any time afterward be softened, and either stuffed with gratifying success, or made into a rug of the most desirable kind.

The skull must be cleaned by simply cutting and scraping the flesh cleanly from it with a knife, removing the brain with a bent wire or a piece of hoop iron, rubbing the skull with the arsenical soap, and allowing it to dry. Put a large bunch of tow, cotton, or rags between the teeth and around them, and tie the jaws tightly together to prevent the teeth from getting broken or lost. The skull should in all cases accompany a skin which is to be mounted as a museum specimen, or even as a rug with the head stuffed.

The above directions apply to all carnivorous animals, and, with slight modifications, to all terrestrial mammals except the elephant, rhinoceros, hippopotamus, and a few others. Arsenical soap is the great protective against the attacks of insects, rats, cats, dogs, and other vermin ; and ponodered alum is the best dry preservative for the skins of land quadrupeds, assisted, in certain cases, by salt. Professional collectors should preserve all mammal skins in a bath made of salt and alum dissolved in hot water, voithout drying them at all. I have found that skins so prepared mount so much quicker, easier, and better than if dried, that of late $I$ advise and practise this method exclusively. Casual collectors, such as sportsmen and travellers, will on many accounts find it less trouble to preserve their specimens in a dry state, after the method described above.

\section{- Loss of Life in British India BY Wild Beasts and Serpents.}

Few persons have an adequate conception of the abundance of dangerous animals in India, and the appalling loss of life they occasion. In spite of zealous sportsmen, liberal rewards, poisons, pitfalls, and all other engines of destruction with which the people make war against teeth, claws, and poisonous fangs, the dangerous beasts still hold their own. In the United States, if a man loses his life by a wild animal, forty million people are informed of it in less than a fortnight. The subjoined tables, compiled from official reports and undeniably correct, will show either how little is known generally of what is transpiring in India, or else how little the world cares. With a reasonable allowance of variations, sometimes in one direction and sometimes in another, it may be said that the figures here recorded remain practically the same, year after year. The various governments pay out annually over one hundred thousand rupees in rewards, but instead of bringing about the extermination of 
the species destructive to human life it only serves to prevent their increase beyond a certain point.

Here is a field for the missionaries with a vengeance. I wonder if it has never occurred to them that it would be a good thing to save bodies as well as souls, especially where twenty thousand of the former are destroyed every year by wild beasts and snakes. To my mind, the body of the Hindoo seems more deserving of attention just now than his soul.

Loss of Life and Property by Wild Beasts in British INdia dURING THE YEAR 1878.

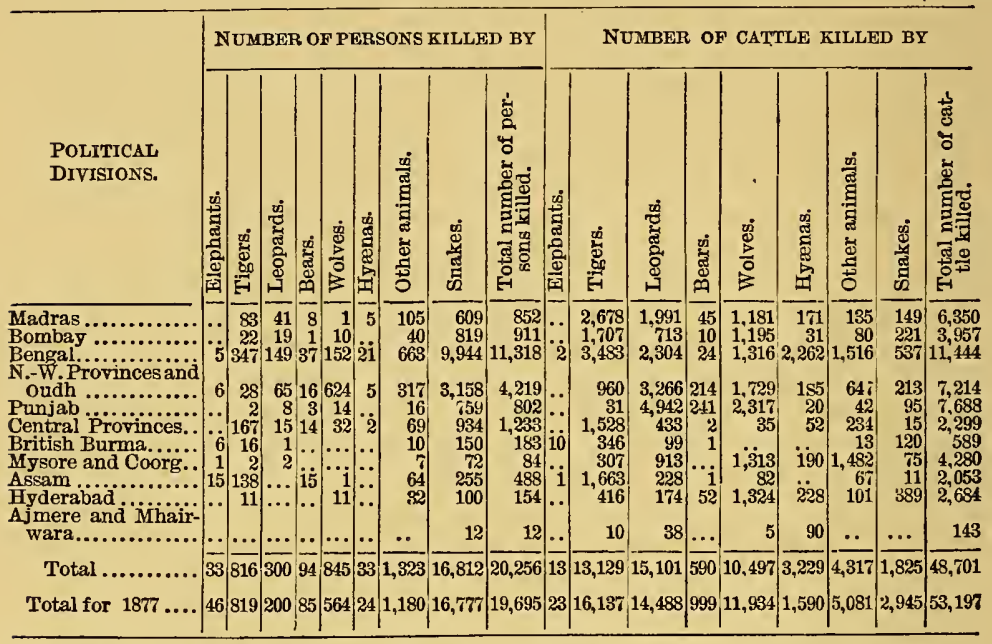

Dangerods animals Destroyed in British India doring the Year 1878.

\begin{tabular}{|c|c|c|c|c|c|c|c|c|c|c|}
\hline . POLITICAL DIVISIONS. & $\begin{array}{l}\text { 总 } \\
\text { 总 } \\
\text { 总 }\end{array}$ & 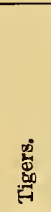 & 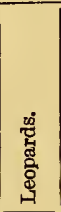 & 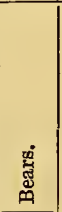 & $\begin{array}{l}\stackrel{\dot{\Phi}}{0} \\
\frac{D}{0}\end{array}$ & 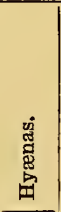 & 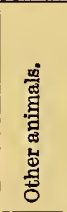 & $\begin{array}{l}\text { 离 } \\
\text { 苐 } \\
\text { 员 }\end{array}$ & 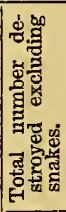 & 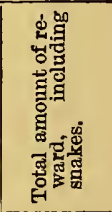 \\
\hline 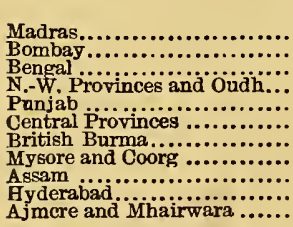 & 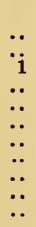 & $\begin{array}{r}185 \\
79 \\
426 \\
87 \\
3 \\
187 \\
80 \\
36 \\
375 \\
32 \\
3\end{array}$ & $\begin{array}{r}613 \\
226 \\
1,0033 \\
427 \\
125 \\
391 \\
65 \\
96 \\
189 \\
54 \\
18 \\
\end{array}$ & $\begin{array}{r}143 \\
34 \\
227 \\
559 \\
45 \\
157 \\
51 \\
1 \\
65 \\
1 \\
1\end{array}$ & $\begin{array}{r}27 \\
156 \\
919 \\
2,589 \\
1,120 \\
219 \\
\cdots \\
\cdots \\
36 \\
\cdots\end{array}$ & \begin{tabular}{r|}
128 \\
1 \\
431 \\
342 \\
4 \\
243 \\
$\cdots$ \\
$\cdots$ \\
$\cdots$ \\
50 \\
2
\end{tabular} & $\begin{array}{r}5,920 \\
445 \\
1,613 \\
491 \\
23 \\
\cdots \ddot{461} \\
1,066 \\
185 \\
\cdots \cdots\end{array}$ & $\begin{array}{r}36,796 \\
24,276 \\
1,697 \\
1,783 \\
410 \\
2,214 \\
691 \\
25 \\
\cdots, 66\end{array}$ & $\begin{array}{r}7,016 \\
941 \\
4,650 \\
4,495 \\
1,320 \\
1,197 \\
6,200 \\
1,200 \\
815 \\
173 \\
23\end{array}$ & 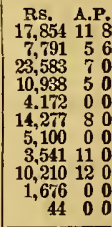 \\
\hline Total ..................... & 1 & 1,493 & 3,237 & 1,283 & 5,067 & 1,202 & 10,204 & 117,958 & 22,487 & 99,189122 \\
\hline Total for $1877 \ldots \ldots \ldots \ldots \ldots$ & 2 & 1,579 & 3,559 & 1,374 & 4,924 & 1,417 & 9,996 & 127,295 & 22,851 & $103,017 \quad 56$ \\
\hline
\end{tabular}




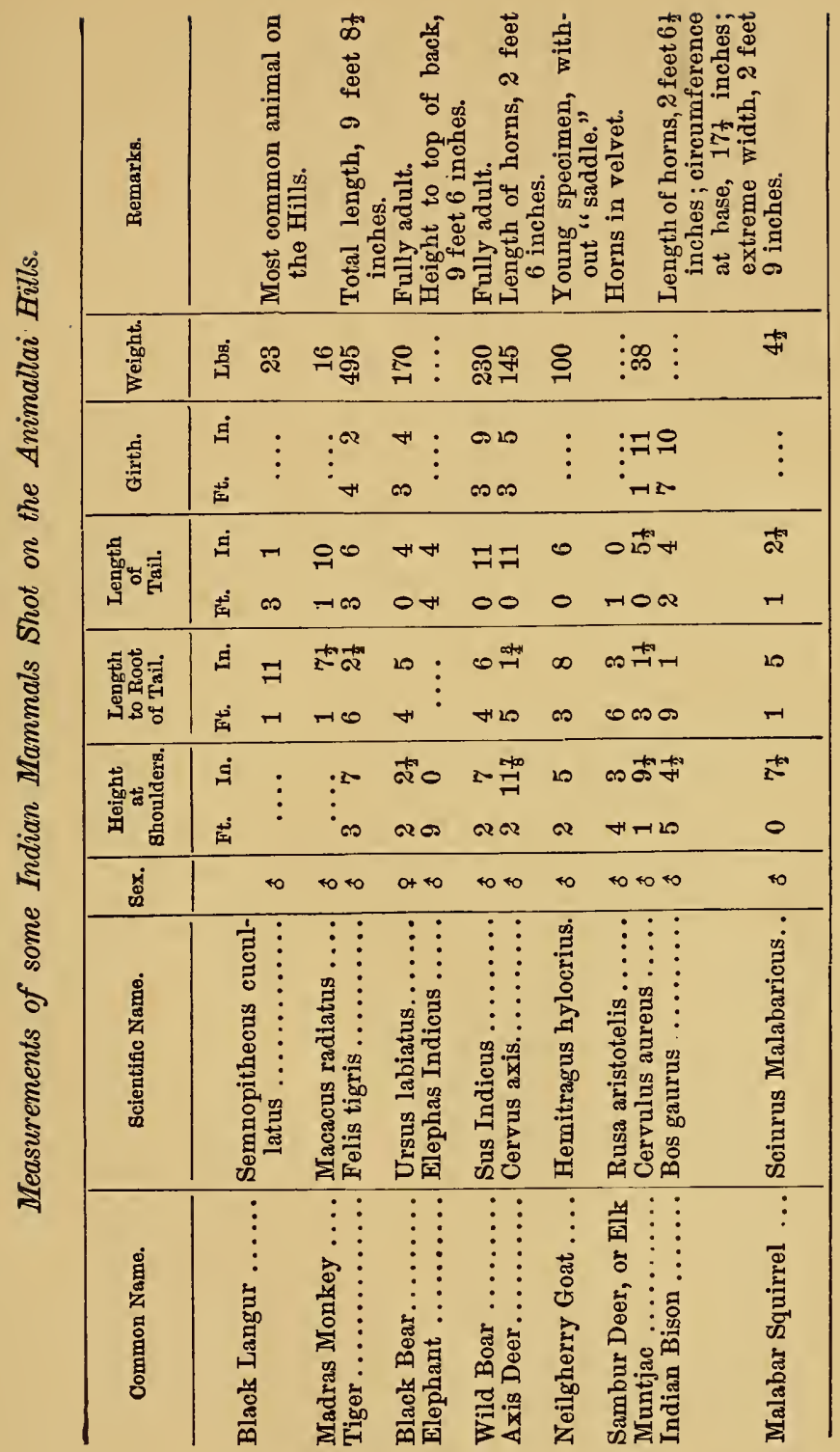





\section{N D E X.}

\section{A}

ACACrA concinna, 128

thorny, 81

Actinia, 253

Aden, 19

Adjutant, entire dog in crop of, 68

"Adventures among the Dyaks," 468

Atobatis narinari, 255

Affection of gibbons for their young, 418

African elephant, 219

tusks of, 225

Ailantus Malabaricus, 128

Aix sponsa, 300

Alabaster, mosque built of, 10, 14

Alcock, Sir Rutherford, 334

Alexandria, 8

Alir, or crocodile hook, 305, 348

Allahabad, 32

Alligator, accident to an, 55

Aline, S. S., 340

Alum, use of, on skins, 44, 193, 213, 367, 493

"American Four-in-Hand in Britain," 297

Amusements of the Dyaks, 468

Anabantids, 387

Animallai Hills, character of forest on, 125

close of work on, 214

cover for game, 155, 214

hunter's paradise, 119

jungle products of, 128

list of mammals collected on, 216

name, derivation of, 119

physical aspect of, 120, 122

seasons on, 125

stormy descent from, 215

tribes on the, 123

Animallai village, 122, 175

relief camp at, 178

Anser Indicus, 34

Antelope bezoartica, 76-80

Antimony in Sarawak, 480

Ardivarum ghaut, 122

Argus grayii, 42:?

Argus pheasant, 380

flesh of, 420

plumage of, $42 \%$
Arnica, tincture, use of, 311

Arsenical noap, use of, $43,165,209,366$, 493

recipe for making, 492

Astana, the, at Sarawak, 339

Asteria, 253

Astreopora, 254

Atherura fasciculata, 423,478

Attap roofs, 315

Axis deer, 139, 166-168

Azadirachta Indica, 81

\section{B}

BAB-EL-MANDEB, Strait of, 19

Baby elephant, and result of fooling around it, 140-141

Baby orang-utan, my, 376

as a bed-fellow, 383

food in captivity, 382

human-like passions, 429

inability to swim, 419

mode of walking, 381

personal appearance, 381

playfulness, 383, 417

presentation of, to Mr. Theobald, 488

social habits, 382

training, 382

Badagas, 99

Bailly, Mr. J. F. D., 217

Baker, Sir Samuel, 281

Ballow Dyaks, games of, 468

Bamboo forest in the Wainaad, 106

forest on the Animallais, 125

huts, 130

huts pulled down by elephants, 198

suspension bridges, Dyak, 484

utensils and furniture, 131

Bambusa arundinacea, 106, 125

Bananas, 315

Banyan tree, 82

Bankongs, 463-464

Baram, Kyans of, $446,448,457$

Kyans good houses of, 449

Baram River, 33t, 446

Barito River, 334

Barking deer, 171, 268

Barriers of Pandanus stems, 411

Bassia latifolia, 146 
Bass' pale ale, 185

Batagur thurgii, 63

Batang Lupar Rivır, 335, 348, 410, 459

Batangs, 439

Bathing at Allahabad, 33 in the Staat River, 481

Bats, 266, 326, 478

Battery, a typical sportsman's, 192

Bau, 317 gold washing at, 479

Beecher, Mr., 483

Bean, Dr. Tarleton H., 386

Beans, 315

Bears, Bornean, 431, 439

Bears, Indian black, adventure with, 144-146

cattle killed by, 494

destroyed, 494

habits and distribution of, 146

persons killed by, 494

Beasts, wild, destruction of, 494 loss of cattle by, 494

loss of human life by, $493-494$

Beauty, lack of, in native women, 461

Bellows, use of, by Kyans, 447

Benares, 83

Benevolence, native, 31

Bennett, Mr. G. M., 250, 259

Bentotte rest house, 286

Betmund, 97

Biadum, 472

Bibos, see Bos

Bidie, Dr. G., 91

Bijit monkey, 391

Biliong, 379

Birds, author's policy in collecting, 2, 430

Bornean, 379, 417, 422, 429

"brain-fever," 170

Dyak mode of snaring, 421

near Mullaitivu, 267

of Selangore, 307,328

omen, 426,432

on the Hoogly, 88

on the Jumna, $34,44,59-62,68$

Bird-nesting, 60-61

Bisayas, 447, 455, 457

Bison, Indian, appearance of the, 188 death of first, 114

dimensions of, 188

easily killed, 189

first hunt for, 109-110

herds of, 189

hunting on the Animallais, 187

Mr. Morgan's adventure with, 189-191 preparing skin of, 192-193

Bison, American, 188

Blachang, 304

Black buck, 76-80

Blackwood, 1:5

Blow-pipe, see Sumpitan,

Boat, model of Dyak, 427

Boats, at Etawah, 37

Dyak, 463-464

Malay, 359

masulab, 80

Boatmen on the Jumna, 46
Boatmen on the Jumna, prayers of, 58

Boating on the Jumna, $33,50,58$ on the Staat, 483

Bock, Mr. Carl, 334, 447

Bombay, market at, 23 nalives, 24

street scenes in, 24-25

Bonneted macaque, 268

Booby, 307

Borassus flabelliformis, 129, 280

Bore in the Sadong, 372, 383

Borneo, area, 333

British North Borneo Company, 334 character of, 333

explorations, 334

forest growth, 352

impenetrability of interior, 335

mammals of, 398

mysteries of the interior, 335

no field for missionaries, 474

political divisions, 334 .

position of, 333

Proper, or Brunei, 334

Borneo Company, of Sarawak, 339, 477, 480,482

British North, 334

Bos Americanus, 183

bubalus, 25

gaurus, 104, 188

Indicus, 25

sondaicus, 310

Box, remarkable training of, 300

Box-turtle, 310

Boycotting of author by an Irish mob, 3

Boyle, Mr. Frederick, 468-469

Brahmin bull, 84

Bridge Jumna, at Allahabad, 32

Bridges, suspension, of the Hill Dyaks, 484

Brass wire ornaments, 450-451, 457, 485

British Museum, 4

accessibility of collections of, 5 catalogues of the, 5

rank of, 5

British North Borneo Company, 334

British rule in India, 91

Broque monkey, 314

Brooke, Rajah Charles, 320, 446, 464

Brooke, Sir James, 341, 350 diplomatic wisdom of, 345,465

Buceros bicornis, 139 rhinoceros, 417

Buffalo, Indian, 25 Toda, 103

Bullock bandy, 120

driving, 121

hackery, 25

Bungalow, Animallai Forest Dep't, 122 dak (or dawk), 35

Mr. Theobald's forest, 124

travellers', at Kulhutty, 106

travellers', at Segor, 106

Burial, Hill Dyak mode of, 454

Kyan, 447

Sibuyau, 474 
Burning of the dead, by the Hill Dyaks, 454

Hindoos, 67

Busau, 477

Butea frondosa, 81

Butter-fish, 256

Butterflies, 430

Buttresses of the tapang-tree, 428

Buxus, 300

\section{C}

Cabbage, Chinese, 315

Cabook, 280

Cairo, old and new, 9-10

Calamus rotang, 128

Calcutta, 86

Calotes nigrilabris, 248

versicolor, 248

Camel, the author rides a, 11

Camp, among wild beasts, 204

at Mooch pardi, 183

at Tellicul, 130-131

of Major Ross, 70

Campbell, Captain E. A., 116

Campbell, Mr. Robert, kindness of, to author, 332

Camphor-trees, 315

Canarium strictum, 128

Canis aureus, 63 pallipes, 76

Cannibalism among certain Kyan clans, $447-448$

Caranx gallus, 256

Carey, 258

Carnegie, Mr. Andrew, 297

Captain Cheena, the, 316, 329

Carcharias acutus, 257

melanopterus, 257

Casarca rutila, 34

Casuarinas, 352

Cathedral Cave, 327

Cat's cradle, game of, known to Dyaks, 468

Caves, discovery of, in Selangore, 325-328 examination of Bornean, 477-478

visit to, near Paku, 480

Centipedes, bite of, 311,313

Cervulus aureus, 171-1;2, 268, 431

Cervus axis, 166-168

Ceylon, between Colombo and Kandy, $237-239$

collection made in, 283

finest portion of, 281

richness of Ceylon fauna, 249

travels in Northern Province of, 251280

elephants in, 219-220

export duty on elephants in, 228

Observer, article in the, 242

Challenger Expedition, collections of, 3

Champagne, cheap, 316

Charge of a dangerous animal, 130

of a female elephant, 141

Cheiromeles torquatus, 478
Chelonia mydas, 258

virgata, 258

Chetties of Colombo, 420

Chimpanzee, 399

Chinese gold companies, 479

hospitality, 316. 329, 479

houses, 275

industry, $3: 9$

influence on the Dyaks. 444, 472, 474

insurrection in Sarawak, 466, 479

merchants of Singapore, 295

settlers on the Sarawak, 476

shops, 293,294

toddy-making taught the Dyaks by the, 474

traders, tricks of, 433

Chittagong, elephant-catching in, 221

Chondropterygii, 255

Christianity without Christ, 474

Church episode in Ceylon, 285

Ciconia alba, 60

Cinchona, government plantations of, 96

Cinnibar mines, at Tegora, 482

Civet cat, 429

Civilization, effect of, on savage races, 443

surpassed by semi-savagery, 474

nnjust discrimination of, against women, $470-471$

Climate, see Weather

Climbing, Dyak mode of, 434

Cloud scene on the Neilgherries, 104

Chypeaster Ghizaensis, 14

Coal mine in Sarawak, 351

Cobra, snake-eating, 330

Cocoanut, groves of, $272,280,285,286$ water of the, 273

Cochin, chasing elephants in, 146 death of a tusker in, 162, 166

Coimbatore, 120,122

Collection, Animallai, 216

Ceylon, 283

of one day at Colombo, 248

of one day at Simujan, 371

Collecting at Colombo, 246-248

birds at Mullaitivu, 267

birds, Bornean, 422, 429

birds in Selangore, 307, 328

kirds on the Jumna, 34, 59-62

ethnological specimens, 426

good ground for, 267,414

shells and coral, 253-254, 256, 487

Collector, outfit for a, 491

Colombo. description of, 237-239

fish-market, 249

harbor. 239

Colonial Secretary of Ceylon, 242

Communal harmony of the Dyaks, 467 . 468

Confinement, Dyak women in, 473

Conjugal felicity of the Dyaks, 468

Coonoor Pass, 95

Consul, United States, at Bombay 22

at Singapore, $296-297$

Conocarpus latifolius, 125

Contentment of the Dyaks, 474

Coolies, high-priced, 315, 316 
Coral, barrier reef of, at Jeddah, 16 barrier reef of, at Point Pedro, 260 barrier reef of, Point de Galle, 278 buildings of fossil coral at Jeddah, 16 collecting at Jaffina, 253-254, 256 collecting at Singapore, 487

Corrip, 473

Cormorant, lesser, 267

Corse, Mr., on height of elephants, 224225

Costume, see Dress, and Ornaments

Country, see Scenery, and Landscape

Court-house in Sarawak, 340

Cremation customs in India, 67 practised by Hill Dyaks, 454

Crevices in limestone hills, 480

Crimes of the Dyaks, 473

Criminal justice in Sarawak, 345

Crocker, Mr. W. M., 340, 349, 476

Crocodile, cannibalistic habits of, 265

catching in Sarawak, 348

catching in Selangore, 305-307

cutaneous disease of, 265

difference between alligator and, 54 eggs of the, 422

hunting at Mullaitivu, 264, 266

hunting in Selangore, 305

hunting on the Jumna, 32, 51-56

hook and line, 305

nest of a Bornean, 421

Crocodiles at sea, 307

man-eating, 348

number of c. killed in Sarawak, 348

sacred, 51

Crocodilians, heads of, 55

Crocodilus

bombifroas, 51

bombifrons, walking of, 55

intermedius, 57

palustris, 265

palustris, attitude in walking, 266

palustris, cannibalistic habits of, 265

palustris, leprosy of, 265

porosus, 304-307, 348

Cucumbers, 315

Cul uluva, 257

Cuora Amboinensis, 310

"Curios," Ceylon, 288

Curran shola, 198, 199

Cuttle fish, 25:

Cymbirhynchus, 422

Cynogale Bennettii, 480, 428

\section{$\mathbf{D}$}

DAR (or dawk) bungalow, 35

Dalbergia latifolia, 125

Damensara, 314

Dances of the Dyaks, 468

Darkness in the forest, 359, 388

Darter, 267

Datu Cape, 336

Datu Pudeh, 311, 312

Dawson, Mr. and Mrs. G. A. R., 117, 169
Debt-making as a safe method of stealing 471

Debt-paying, faithfulness of Dyaks in, 472

Deer, axis, 166-168, 278

rib-faced, or barking, 171-172, 268,431 spotted, 139, 166-168

Dicerobatis eregoodoo, 420

Directions, see Skinning and Skeletoniz. ing

for making arsenical soap, 492

Discases, 120

of the Dyalss, 373, 473

introduced by civilization, 473

of civilization not found among the Dyaks, 474

Divorce among the Dyaks, 453

Doctor, a Neilgherry, 117

the right kind of a, 237

Doctoring a Dyak, 373

a fisherman, 311 .

poor natives, 91,175

Dohrn, Dr. Anton, 7

Domestic life of the Dyaks, $466,468,470$

Doraysawmy, the "Gentleman's God," 181

Douglas, Captain B., 303, 314, 329-330

Draco volans, 420

Drunkenness in the East Indies, 295 of the Dyaks at feasts, 470

Dress of the Chinese merchants, 295 Dyaks, 450, 451, 456, 457, 460, 462

Hindoo women, 24

Karders, 128

Malays, 239

Moormen, 287

Parsees, 24

Singhalese, 239

Todas, 100

Drifts of Pandanus, 411

Duck, mandarin, 300 summer, 300

Dundang, the Dyak hunter, 351, 379, 395

Durian, the, 318 gatherers disturbed by elephants, 321

Durio, zibethinus, 318

Dusuns, see Ida'ans, 455-457

Dutch Possessions in Borneo, 334

Duty on collector's outfits, 243, 244 methylated spirits, 241

outfit at Bombay, 21

Dwasala elephants, 227

Dwellings, see Houses

Dyak, absence of religion in the, $\mathbf{4 4 5}$

accident to a, 373,392

at his worst, 373,422

a typical, 424

belles, 460

cheerful disposition of the, $467-468$

daily life of a, 466

dances, 468

deportment, 355, 358, 393, 413

diseases, 373,473

farms, 355 , 387

head-trophies, see Head-hunting

hospitality, 364, 439 
Dyak, hut at a farm, 387 indolence, 422,440

omen birds, $4: 6,432$

omens in general, 432

pantomime, 393,468

snake eaten by $a, 388$

stature, 459-460

tooth-plates, 393

villages, 355, 373, 410, 434, 448, 449

Dyaks, Hill, see Hill Dyaks

Mongol, see Mongol Dyaks

Dyaks of Borneo, ancestry of, 444

classification, 445

general description of, 445

of Sarawak, character of, 435

decrease of, 343

demonstrative character of, 431,439

former oppression of, $342-343$

present condition of, 344

Dyaks, Sea, vide Sea Dyaks

Dysentery, 120, 174

\section{$\mathbf{E}$}

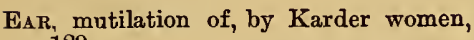
129 ornaments of the Dyaks, 457,462

Echini, collecting, at Colombo, 426 how to clean and preserve, 247

Eggs of the gavial, 45 of the salt-water crocodile, 442 of the scavenger vulture, 61

Egret, 60, 267, 307

Ekka, a ride in an, 69

Eleotris marmorata, 397

Elephant, the Indian, compared with Africar, 219 age of, 223

body, character of, 134

brain, position of, 133

brain, difficulty of hitting, 134

breeding in captivity, 222

castes of, recognized, 226

cost of keeping, 232

death of a tusker, 163, 201, 322

destruction of, 220,221

dimensions of a tusker, 202

doings of a mad, 233

dwasala class of, 227

export duty in Ceylon on, 228

food of a captive, 231

geographical distribution of, 218

gestation, period of, 223

growth, 223-225

height of male and female, 224

hunters hunted by, 147

in Borneo, 220

in Ceylon, 219

in processions, 227

in Selangore, 310,324

in Sumatra, 220

intelligence of, wonderful, 229

koomeriah class, 227

meerga class, 227

mental capacity of, 229

mischievousness of, 161-162, 321
Elephant, the Indian, moral character, 229

"must" in, 232

prices of, in India and America, 228

rogue, character of a, 234

rogue, killed by Mr. Theobald, 124

sagacity in manouvring, 148

sight, dulness of, 137

skinning and preserving skin of, 202 .

$203,205,209,213,214,217$

skull, form and structure of, 133

stealthiness in retreating, 148

swimming power of, 231

table of growth, 225

trumpeting, notes sounded in, 136

tusks of Atrican and Indian, 225

uses of, in India, 226, 228

vulnerable points of, 135

work of in a timber forest, 230

young, 140-141, 223

Elephant, the African, 219

mode of hunting, 133

Elephant catching, 220

keddah operations in, 221

various methods of, 222

Elephant hunting, African method of, 133 character of, 131

failures in, 112, 138, 149, 199

gun for, 137

Indian method of, 133

in Selangore, $320-325$

ludicrous adventure in, 324

success in, 163, 201, 322,

tables turned in, 149

under difficulties, 199-201

Elephant Pass, 280

Elephants, attacking, 138

first herd of wild, 111

law protecting, 126

permit to kill, 127, 197

stampede of, 138

tracking up a herd of, 136

Elephas Indicus, see Elephant, the Indian

primogenius, 218

Elettaria cardamomum, 128

Elevation of the Animallais, 125

of the Neilgherries, 94

of the Wainaad, 106

Emerson, Joseph, 275

Emyda Ceylonensis, 248

Emys trijuga, 248, 310

English institutions, 339

Fing Quee, Mr., 350, 354, 369, 384

Eonycteris spilla, 326

Esacus recurvirostris. 307

Establishment, Ward's Natural Science, $2,193,197,217$

Etawah, 35 population of, 70

Ethnological specimens, 426, 439

Everett, Mr. A. Hart, 477, 478

Everett, Mr. H. H., 482

Evolution, theories of social, at fault, 474

Exaggeration, siuful tendency to, 33

Exterior of Dyak long-house, 355 
FAKIR, 25

Famine, the Madras, 90, 91, 177 deaths during the, 180 end of the, 181 relief measures during the, 178, 180

Farman, Mr., 10, 11

Farnham, Mr., 22

"F'ast" men of civilized society, 471

Feasts, Dyak. 469-470

Feat, a foolish, 317

Felis Bengalensis, 328

chaus, 62, 216

marmorata, 328

Felis tigris, see Tiger

distribution of, 252

migration of, into Ceylon hindered, 252

Ferguson, Mr., of the Ceylon Observer, $24 \%$

Fever, first attack of, 115 on the Animallais, $120,139,150,151$, $174,194,236$

permanent cure of, 237

treatment of, 150

Ficus Indica, 82

religiosa, 82

Fiddle, Dyak, 429, 469

"Fight in the tree-tops," 375

Fighting qualities of the Indian bison, 189

qualities of the orang-ntan, 371

qualities of the saras crane, 60

Fire-arms of Dyaks and Malays, 379

Fire-flies, 359

Fire-fly, the steam launch, 476, 477, 487

Fish, collecting at Jaffna, 255-258

jumping, 308

Sadong River, 385, 387

Selangore, 308

the thread, 386

Fishing with the tuba plant, 384, 386

for crocodiles, 304-307, 348

Fish-market at Bombay, 23

Flowers in Bombay market, 23

Flying dragon, 420

fox, 267

lemur, $380,412,428,478$ squirrel, 114

Food, necessity of appetizing, 272 scarcity of, 150,271

Forced trade, 342

Fort, the, in Colombo, 237 at Sarawak, 339 native shops in, 240

Fossils, Egyptian, from Mokattem Hills, 13

Egyptian, from the Pyramids, 14 search for, in Bornean cave deposits, 477-478

Fraser, Mr., 36

Fruits of Sarawak, 402

Selangore, 315, 317

Frogs, self-buried, 277

Funeral, a Hindoo, 66
GALEOPItheCUS variegatus, 412, 429, 478 volans, 380

Galle, Point de, 286

Galle Face Esplanade, 237

Gallus Stanleyii, 279

Gambling, 315

Games of the Dyaks, 468

Gardening, curiosities of, 300

Gaur, see Indian bison, 188

Gavæus gaurus, see Bos gaurus

Gavial, abundance of, 51,52

Bornean species of, 348,478

colors of, 55

habits of, 46,47

head of, 54

difficulties of $\mathrm{g}$. shooting, 48

geographical distribution of the, 55

native reverence for, 51

not destructive of human life, 56

shooting, $39,41,42,43,46,47,49$

struggle with a wounded, 47

teeth of, $\mathbf{5 7}$

ticklishness of, 56

voice of, 41,56

wariness of, 40

Gavialis Gangeticus, see Gavial

Gaya Bay, 334

Gazella Bennettii, 72

Geese, 75

Geographical distribution of, black bear, Indian, 146

elephant, 218

gavial, $\mathbf{5 5}$

gazelle, 72

orang-utan, 348, 399

sasin antelope, 76

tiger, 154, 252

wild goat, 76

Gertrude, Sarawak schooner, 349

Gharry, 25

Ghee, 37

Gibbon, cry of, 418

difficult to shoot, $395,415,418$

hunting described, $415-416$

incidents in hunting, 413

measurements of, 419

mode of progression, $383,415,430$

money value of, 419

paternal affection of, 418

pet, 383

place in nature, 399

Gill, Dr. Theo. N., 397

Groat, Neilgherry wild, 97, 172

Goby, 397

Gold washing in Sarawak, 479

Gong, at Simujan Government House, 350, 442

Dyak alarm, 437

Groolur tree, 82

Gordon Cumming, largest tusk taken by, 225

mode of elephant-hunting, practised by, 133

Gorilla, 399 
Gourami, the, 386

Government aid during famine, 91,177 , 180

house at Simujan, 349, 369

scientific publications, U. S., 6

Governmental eccentricities in Ceylon, 284

Grace without Gospel, 474

Graculus Javanicus, 267

Grainboats on the Jumna, 58

Graspus strigosus, 247

Gray. Mr., 483

Grus antigone, 59

cinerea, 60

Guardian angel, the author's, 488

Gua Belah, 326

Lada, 326

Lambong, 326

Poondah, 397

Gunong Popook, author lost on, 390

Dyak village at, 361, 366, 390

Günther, Dr., 5

Gutta percha, mode of gathering, 430

Gymnura, 478

Gyps Bengalensis, 34

\section{H}

HALI ZATUS, albicilla, 34

Haly, Dr. A., 250

Harbor, Colombo, 239

Madras destitute of, 89

New, at Singapore, 292

Harp, Dyak, 469

Harvey, Mr., 481, 483

Haughton, M̈r. A. R., 335-336, 395, 452, 462

Haughton, Mr. Samuel, 260, 264

Hawk cuckoo, ery of the, 170

Head-dress of the Sea Dyaks, 462

Head-house of the Hill Dyaks, 450, 452, 485

Head-hunting among the Hill Dyaks, 358, $450,465,485$

among the Kyans, 447

among the Sea Dyaks, 357, 425, 465

among the Trings, 448

suppression of, in Sarawak, 465

trophies, value of, 425

Hemitragus hylocrius, 97, 172

Helarctos Malayanuss, 431; 493

Herodias alba, 60, 267

egrettoides, 88

garzetta, 267,307

Herpestes griseus, 268

Heron, night, 267

Hierococcyx varius, 170

Hill Dyaks, comparison of, with other tribes, 458

consanguineous marriages prohibited by, 453

disposition of the dead, 450

divorce and separation, 453

do not steal, $471-472$

dress and ornaments of, $450-451,485$
Hill Dyaks, games of, 468

habitat of, 449,468

head-house of, 45:3, 485

head-hunting ctustoms of, 450

ideas of a Supreme Being, 444, 454

marriage customs of, $45:-453$

moral principles and practices of, 452 $4 \pi 1,4 \pi 2$

no written language of, 454

physique of, 450

raids upon, by Sea Dyaks, 464

status of, as warriors, 450

villages of, 485

Hindoo influence on the Dyaks, 444, 454, 472

religion, 86

Hindoo, native, character of, 183

condition of, 181

Hog, Bornean wild, 395

Indian, 173, 278

Holothurians, 253

Honey, wild, 428

Dyak mode of procuring, 434

Hood, Mr. J. M., 301, 488

Hoogly River, 87-89

Hornbill, rhinoceros, 379, 417

Horsburgh Light, 336

Hospital for animals, 27

Hospitality, Dyak, 364, 439

Hotel, advantages of a small, 9

Doughty's, 21

Grand New, 9

Rajah's Arms, 340

Sea View, 245, 296

Hotels, drunkenness in, 295-296

House, Jacoon, 319

Malay, at Batu, 317

Malay, at Jerom, 304

model of a Dyak, 426

Houses, of the Baram Kyans, 449

of the Hill Dyaks, 485

of the Ida'ans, 456

of the Malays, 292, 304, 317, 338

of the Milanaus, 448

of the Muruts, 457

of the Pakatans, 449

of the Poonans, 449

of the Sea Dyaks, 355-357, 410, 466

of the Todas, 102

of the Trings, 448

Howdah-shooting, 154

Huddleston, Mr. J. E. L., 216

Human sacrifices, 447

Hunger, tropical, 272, 388

Hunting, axis deer, 166-168

bear, 144

bison, Indian, 109-110, 113, 187, 189

black buck, 80

crocodile, 264-265

elephant, 111, 131, 133, 138, 146, 161, 19

gaur, see Bison

gavial, $46-48$

gazelle, 73-74

gibbon, 395, 415-418

ibex, see Wild Goat

monkey, 107, 115, 143, 274, 347, 394 
Hunting, peacock, 62

sasin antelope, 80

tiger, 154-1506

wild goat, 97,172

wild hog, 396

Hunuman, 84

Hut, Dyak, 387

Moochpardi, my, 183

Tellicul, 130

Toda, 10\%

Hut-building with bamboos, 130, 183

Hutchison, Rev. Mr., 180

Hyænas, cattle killed by, 494

destroyed, 494,

persons killed by, 494

Hydrosaurus salvator, 307

Hystrix longicauda, 427

\section{$\mathbf{I}$}

IBIS, black, 60

Ichthyosis, $373,413,473$

Ida'ans, the, dress of, 456

farthest advanced, 455

houses of the, 456

peaceful habits of, 459

skill of, in agriculture, 456

Infanticide among the Todas, 99, 101

Infant orang-utan, see Baby Orang-utan.

Information, diffioulty in obtaining, 32

Inia, the, 64

Insanity among the Dyaks, 473

Insects, scarcity of, at Etawah, 81

Insurrection, Chinese, in Sarawak, 466 , 479

Interior of Dyak Long-house, 356-357 of Toda hut, 102

Intoxicants among the Dyaks, 469-470, 474

Introduction, letters of, 29

Inuus rhesus, 84

Ivory-hunting in Africa, 219

J ABIRU on the Jumna, 60

Jackal, 63

cry of, $63,275,278$

Jackets worn by Hill Dyak women, 451 Kyans, 447

Muruts, 457

Jacoons, 319

houses of, 319,449

resemblance of, to Poonans, 319

skill in use of sumpitan, 320

Jaffna, 251

shallow waters around, 253

Jeddah, disturbances in, 17 gates of, 18

Jerom, 303

people, 312

quarters at, 304

shore at, 310

Joonoos, Mr. M. C., 288-290
Journey from Colombo to Galle, 2\$4-286

Coimbatore to the Animallais, 122

Jaffna to Point Pedro, 260

Mullaitivu to Jaffna, 278-280

Ootacamund to Mudumallay, 106-107

Jowata, 445

Jungle, character of, in Borneo, 351

character of Malay Peninsula, 314, 317

character of Northern Ceylon, 274

definition of, 10 4

produce, 424

Jungle cat, 62

cock, 279, 280

Jumna River, abundance of gavials in 51

annual rise and fall of, 52

bird life along the, 59,62

boating on, 50

character of, 39,58

coldness of water of, 52

filthiness of, 68

navigation of, 58

porpoises in, 64

ravines along the, 71

turtles, 63

Jury system in Sarawak, 345

Justice in Sarawak, 345

\section{$\mathbf{K}$}

KABRA goya, 307

Kadjang boat roofs, 354

Kadyans, the, 457

Kaltura, 285

Kandy, 282

Kapooas River, 334

Karders, 128

Katz Brothers, 301

Keddah, defence of a, 222 location and construction of, 221 tying wild elephants in the, 222 .

Kenowits, high houses of the, 449 tattooing practised by, 448

Kejang (see Muntjac), 431, 432

Keppel, Sir Henry, 343, 345

Kimanis Rlver, 3334

Kina Balu, Mt., 334, 335

Klang, River, 302, 315

town of, 302

Koomeriah elephant. 227

Kotei, Territory of, 334, 444

Krah monkey, 307, 328, 347, 358

Krumbang Mountains, 336

Kuching (Sarawak), 339

bazaar, 341

public buildings, 340 shipping, 340

Kulhutty bungalow, 106

Kulungud Forest, 127, 185

Rajah of, 127,197

Kurumbers, 109

Kwala Lumpor, 302, 314, 315

Kyan Dyaks, aggressiveness of, 447

Baram, 446, 448, 449, 457

burial customs of, 447 
Kyan Dyaks, cannibalism among some clans of the, $447-448$

comparison of, with other tribes, 458 distinguishing characters of, 446-447 houses of, 449 ideas of a future state held by, 449 progress of, 444 territory of the, 446 warlike habits of the, 447 weapons of the, 447,463

\section{$\mathbf{L}$}

LABOAN Island, 334

Lagenoplastes fluvicola, 61

Landscape, Bornean, from Serambo Mountain, 486

Central Indian, 30

Egyptian, 12

from edge of Neilgherry plateau, 103

in the Ganges delta, 86,88

near Etawah, 35

Neilgherry, 97

on the Animallai Hills, 123

Langur monkey, black, 117, 139 gray, 107

protective instinct in the, 115

Lanuns, the, 455

Laterite, 280

Lee, Hedges \& Co., Messrs, 241

kindness of, to author, $250,259,283$

Leeches, 426

Lee Tiac, 417, 429, 434

Lemur, flying, $380,412,428,478$

slow-paced, 380,398

Leopards, cattle killed by, 494 destroyed in one year, 494 persons killed by, annually, 494

Leptoptilus argala, 68

Lepus nigricollis, 117, 268 ruficaudatus, 76

Leys, Mr., 259 death of, 268

"Life in the Forest of the far East," 455,468

Life, loss of, in India by wild beasts, 493 , 494

Limbang River, 334, 447, 457

Limestone hills of Sarawak, caves in, 480

Livistona sinensis, 396

Lizard, green, 248

Lobocarcinus Paulo-Wurtemburgensis, 13

London, 4

Longden, Sir James, 244

Long-house of Sibuyau Dyaks, 355-357

Long Wai Dyaks, tattooing of, 448

Loris gracilis, 268

Loss of cattle by wild beasts, 494 human life, 493, 494

Lost in the jungle, Ah Kee, 436-438

the author, 112-113, 390

Low, Mr. Hugh, 334, 447, 457

Luciocephalus pulcher, 386

Lundu River, 459

Lupea sanguinolenta, 252

Lutra leptouyx, 310

\section{M}

MACACUS eynomolgus, $307,328,347$

nemestrinus, $314,352,380$

pileatus, $268,274,279$

radiatus, 216

Machan shooting, 154

Macaque, pig-tailed, 352, 397

Madras famine, 90-91

Madras Government, generosity of, to author, 197

famine record of the, 91,180

Madras Bob, "the original, " 298

Madrepora, 254, 287

at Point Pedro, 260

cytherea, 254, 256

Mahakkam River, 334

Makota, Pangeran, 342

Malacca, strait of, 291

town of, 301

Malay character, 312, 329

hospitality, 312

influence on the Dyaks, 343,372

oppression of the Dyaks, 342, 343,

Peninsula, 291

Mammals, collected on the Animallais, list of, 216

collected near Etawah, 34, 35, 63, 64, $70,72,73,74,76,77$

measurements of some Indian, 495

of Borneo, 347, 352, 358, 360, 380, 391, $398,418,420,423,428,429,431,478$

of Ceylon, 266, 268, 274-276, 277, 278, 279 of Selangore, $310,314,320,326,328$

Mandarin duck, 300

Man-eating crocodiles, 398

Mangifera Indica, 81

Mangosteen, 315

Mango tree, 81

Mangroves, 307

Manis Javanica, 347

Manis pentadactyla, 268

flesh of, 271

form and habits of, 268-269

muscular power of tail of, 270

Manta birostris, 255

Market, Bombay grand, 23

Kwala Lumpor, 316

Martin, Dyce \& Co., Messrs., kindness of, to author, 332

Marriage among the Dyaks, 452-453, 461

destitute of religious sentiment, 453

of cousins prohibited, 453

Masulah boats, 89

Matang Peak, 338. 477

Matuta victor, 248

Maynard rifle, accuracy of, 48, 49, 53, 156 tiger killed with a, 158

water-proof quality of, 361

Measurements of Indian mammals, 495 orang-utans, 375,406

Meandrina, 254

Mecca, visit of two Christians to, 18

Meerga elephant, 227

Melons, 315

Menispermum, 384 
Mental capacity of the elephant, 229 scale of the Dyak tribes, 458

Methylated spirits, exorbitant duty on, 241

Mias (see Orang-utan), 350

chappin, 374,375

kassar. 393

rombi, 393,417

Mica, 106

Milanaus, the, 446 high houses of, 449

Mines, antimony, at Bidi, 480

cinnabar, at Tegora, 482

coal, at Simujan, 351

gold, at Bau, 479

tin, at Kwala Lumpor, 329

Missing link, search for traces of, 478

Mob of Irish yahoos beset the author, 3

Model government, a, 345

Models, 426

Mohwa tree, fruit of, eaten by bears, 146

Money doles, 180

Mongol Dyaks, 455-458

Monkey temple at Benares, 83-84

Monkeys, black langur, 117, 139 cry of, 142

flesh of, eaten by Mulcers, 144 mode of hunting, 143 size of, 144

Monkeys, gray langur, 107, 115

krah, 358, 380

near Sarawak, 347

proboscis, see Proboscis Monkey

Selangore, 307, 328

Moochpardi, 166, 167

bison around, 187

return to, 183

Moormen of Point de Galle, 287

Morality of the Dyaks, $452,454,470,471$, 472

Moral equality of men and women, 470 scale of the Dyak tribes, 458

Morgan, General, account of must elephant by, 233

Morgan, Mr. Rhodes, adventure of, with a bison, 189-191

"battery" of, 192

trophies collected by, 192

Moritabas entrance, 337

Mosquitoes, 359, 365

Mud, an adventure in, 310

fish burrows in, 309

Muddimund, 98

Muda Hassim, Rajah, 342-343

Mudumallay. cholera at, 107 disobliging natives at, 107

karkhana, 107, 115, 116

reserved forest, 105

Mugger Peer, 51

Mulcers, camp of, 206

character of the, 127

courage of the, 159

hunting gang of, 127

go on strike, 207-208, 210

Mummies, various, 13,14

Mund of the Todas, 98,108
Mungoos, 268

Muntjac, 171, 268, 431

Murder of Europeans, 329

Muruts, 447, 455

dress and ornaments of, 457

persecution of, by Kyans, 457

Mus rufescens, 171

Museum, Allahabad, 55

American, of Natural History, 371

British, 4

Calcutta, 86

Ceylon Government, 249

Comparative Zoology, of, 193, 217, 256

Derby, at Liverpool, 4

Egyptian Antiquities, at Boulac, 10

Madras Government, 91

Singapore, 298

United States National, 4, 375, 386

University, at Rome, 6

Victoria and Albert, at Bombay, 26

Musical instruments of the Dyaks, 429 , 469, 440

Musnigoorie, 106

Must in elephants, 232-233

Mycteria Australis, 60

Mysore, elephants caught in, 221

N

NAPLES, collecting marine specimens in, 7 zoological station, 7

Nasalis larvatus, 347, 358, 394, 395

National Museum, U. S., 4, 375, 386

Native assistants, 259

hunters, 369, 376, 378, 379

hypocrisy, 108

reverence for crocodiles, 51

reverence for peacocks, 62

Natives of the Etawah district, 64, 66 gifts from, 65

Nedunkenni, 275

Neem, 81

Negapatam, 235

Neilgherry Hills, climate of, 94 physical aspect of, 96 wild animais on, 94,105

Neophron percnopterus, 44, 66 egg and nest of, 60-61

Nest of cliff swallow, 61 crocodile, 441

orang-utan, 360,362, 379, 403

rose-winged paroquet, 62

white scavenger vulture, $60-61$

New Harbor, Singapore, 292

Nile, delta of, 9 valley of, 13

Nil-gai, 74-75

"Nilgiri Sporting Reminiscences," 117, 233

Nipa fruticans, 337

Nipa palm, syrup of, 440

various products of, 440

Nycticebus tardigradus, 380, 387

Nycticorax griseus, 267 


\section{o}

OATH of secrecy, the Mulcers', 163

Objects of the trip, 2

Obscene image at a shrine, 65

Ocypode ceratophthalmus, 248

Old Man, the (see Baby Orang-utan), 381, 417

Omen birds, 426, 432

Omens in general, 432

Ootacamund, 94, 96

Ophiocephalus, 386

Ophiophagus elaps, 330, 331

Ophthalmia among the Dyaks, 473

Orang-utan, attitude of, when sleeping, 393,400

when drinking, 367

eyes of, 401

fierceness of a captive, $300,368,372$, 377

fighting qualities, 371,402

food, 402

food in captivity, 300,382

freedom of lower limbs, 401

fruitless hunting for, $351-353$

general appearance of, $363,399,401$

geographical distribution, 348,399

bair, 400

inability to stand erect, 407

inability to swim, 419

incidents in hunting, 360-363, 375, 393

individual peculiarities, 407

infant (see Baby orang-utan) 367-368, $376,381,383,403,419,428$

largest, the, 375-376

Malay name for the, 350

man compared with an, 375

maximum size attained by, 404-406

measurements, 375,406

mode of progression, 404

nests, 360, 362, 403, 414

" number forty-three," 440

place in nature, 399,407

price of a living, 298

scarcity of, 350

seven specimens in two days, 369

size at birth, 403

skin, 400

skinning and skeletonizing, 366-369, 374

solitary habits, 402

viciousness of newly captured, 368,372 , 377

Whampoa's, Mr., 299

Orchids, 397

Ornaments, personal, of Hill Dyaks, 450451,485

of Muruts, 457

of Sea Dyaks, 462

Osphromenus gourami, 386

Ossen, Mahommed, 287

Ostrich eggs at Aden, 20

Otogyps calvus, 34, 44-45

Otter, 310

Outfit for a collector, 491
$\mathbf{P}$

Padang Lake, 363-364, 39:3-394

Pakatans, 448, 449

Paku, 478

Palæornis torquatus, 62

Palms, cocoa, 272, 280, 285, 286

nipa, 33\%, 440

palmyra, 129,280

Pandanus candelabrum, 360, 363, 364, 402 411

Papayah, 315

Paradoxurus musanga, 70

Parong, common, 46:3

latok, 451

Parsee, author swindled by a, 20

dress and appearance, 24

Passerita, 387

Panadura, 284

Pankalan, 481, 493

Paulaul of the Todas, 100

Paumben Passage, '236, 251-252

Pangah, the $405,452,485$

Peacocks, 62

Peepul tree, 82

Peg tops among the Hill Dyaks, 471, 473

Pelecanus rufescens, $30 \%$

Pengolin, 268-269

Peninjau, village of, 485

Peons, usefulness of, 66

Pera Vera, 156, 186

Perelaer, Mr., 448

Perim Island, 19

Periophthalmus Schlosserii, 308-309, 386

Permit to kill elephants, application for, 196

grant of a, 127, 197

Peti, 421

Dyak killed by a, 422

Petrified forest, excursion to, 10

character of, 12

Pettah, or native quarter of Colombo, 240

Peneus, 248

Penrissen mountains, 337

"Physical Geography of the Sea," 430

Physical scale of the Dyak tribes, 458

Pigs, Dyak traps to kill, 421

wild, in Sarawak, 173, 395

Pike-head, the, 386

Pilfering by a Dyak, solitary case of, 457

Pilot service at Calcutta, 89

Pineapples, 315

Piracy, suppression of, 343, 344

Plandok, 328, 380

Plantain, 315

Platanista Gangetica, 64

Platalea leucorodia, 75

Plotus melanoghaster, 267

Plovers, 307

Point de Galle, 286

native dealers at. 287-288

Poisoned arrows, 447

Polyandry among the Todas, 101

Polynemus, 386

Polypterus, 13

Pompeii, 7 
Pondicherry, 235

Pontianak, 335

Point Pedro, 260

Po Point, 3:37

Population of Sarawak Territory, 344 of Selangore, 330 of Singapore, 295

Porcupines, Bornean, 423, 427

Portax, pictus, 74-75'

Potatoes, sweet, 315

Porpoise of the Jumna, 64 of the Orinoco, 64

Porpoise-shooting, difficulty of, 64

Praus, Dvak, 464

Prawns, 304

Precious stones of Ceylon, 287 imitations of, 287

Prejudice against taking life, 27 against Europeans, 37

Prescription which cured author's jungle fever, 237

Proboscis monkey, habitat, 394

nose of the, 394

peculiar cry, 394

peculiar to Borneo, 398

price of, alive, 298

shyness, 394, 411

wild near Kuching, 347

very large troops of, 411

Protective color of sambur, 170 instinct in monkeys, 115

Provisions for Animallai trip, 120

for boat trip on Jumna, 37

Pterocarpus marsupium, 125

Pteromys petaurista, 114

Pteropus Edwardsii, 216, 266

Punkahs, 87

Python, 87

\section{$\mathbf{P}$}

QUADRUPEDS, directions for skinning, 492

Quee, Mr. Eng., 350, 354, 369, 384

Quicksilver, 482

Quinine, action of, as an emetic, 185 manufacture of, by Madras Gov't, 96 use of, in fever, 150

\section{$\mathbf{R}$}

Railway Journey, from Alexandria to Cairo, 9

Bombay to Allahabad, 30-32

Colombo to Kandy, 281-282

Rhamphobatis ancylostomus, 257-258

Rajah Brooke, see Brooke, Rajah Charles

Rajah Brooke, steamer, 336

Rajah Padang, death of the, 374 size of the, 375

Rajah's Arms Hotel, 340

Ramisserama, 251

Rats, tree, 171

Ravine deer. 172

incidents in hunting, 73-75

Ravines, the Etawah, 71-72
Rays, 255

spiny, 256, 310

Rejang River, 446

Relief camp at Animallai, 178

Religion, absence of, in Hill Dyaks, 454 absence of, in Sea Dyaks, 472

a definition of, not accepted, 472

Remedy, Dyak, 473

Rest House, at Bentotte, 286

at Elephant Pass, 280

at Jaffna, 252

at Mullaitivu, 263

at Pallai, 282

Retrospect, 488-489

Renipes, 248

Rhinobatus djeddensis, 23, 28, 257 thouini, 255

Rhinoceros, price of a live, 298

Rhinolophus trifoliatus, 279

Rhynchops albicollis, 37

Rifle-pits, shooting gavials from, 46

Rilawa monkey, 268, 279

Road, typical "metalled," 69

Rochester, N. Y., return to, 488 start from, 1

Rogue elephants, 234 one killed by Mr. Sanderson, 234 one killed by Mr. Theobald, 124

Romania Point, 386

Rome, art versus nature in, 6

Ross, Col. A. G., 19

Ross, Major J. C., 32, 33, 69

camp establishment of, 70-71

hunting with, $71-76,77-80$

Ross, Mrs. A. G., 19

Ross, Mrs. J. C., 70-71

"Round the World" 297

Royal Mail Coach, 260, 284-286

\section{$\mathbf{S}$}

Sabah, 334, 455

Sabyan, 454,472

Sacred animals, 85

bull, 84

crocodiles, 51

monkeys, 83-84

peacocks, 62

Sadong River, 334, 349

bore in the, 372,383

Sailing vessel, Tamil, 261

Sakarran Dyaks, 447, 449, 462, 464

amusements of the, 468

Salarius alticus, 247

Salvadora Indica, 125

Sambur, 97, 108, 110, 168-170, 216, 380 size and color of the, 169

Sambur hunting, 170, 216

on the Animallais, 168

on the Neilgherries, 97, 103

on the Wynaad, 110

Sampan, the Malay, 359

Sanderson, Mr. G. P., 133

elephant-catching by, 221

largest tusk taken by, 225 
Sanderson, Mr. G. P., on height of elephants, 224

on taming elephants, 222 rogue elephant shot by, 234

Sandpiper, $30 \tau$

Santubong, entrance, 337 Peak, 337

Saras crane, 24

antics of, 59

cry of, 59

fighting qualities of, 60

Sarawak, town of, 339-341

"Sarawak, " Hugh Low's book on, 463, 468

Sarawak Government, 345, 422, 464

Sarawak River, entrances of, 337 Malay houses on, 338

scenery of the. $337,476-477$

trip up the, $476-477$

Sarawak Territory, 334

administration of justice in, 344-345

area of, 344

cession of, 344

commerce of, 336

flag, 337

former condition of, 341-343

forts, 346

military force, 346

present condition of, $344-345,464$

revenue, 345

Sarawak Valley, view of, 486

Sarkidiornis melanonotus, 34, 75

Sasin antelope, 76-80

Savage races, extermination of, 443

Scenery along the coast of Borneo, 336 of the Colombo \& Kandy R. R., 281-282 of the Coonoor Pass, 95 of the Hoogly River, 88 of the Jumna River, 39, 71-72 of the Malacca Strait, 291 of the Sarawak River, 337, 476-477 of the Suez Canal, 15-16

Scenery, beautiful forest, $397,412,481$, 483

between Allahabad and Calcutta, 86

between Bombay and Allahabad, 30-31

between Colombo and Galle, 284-286

from Serambo Mountain, 486

on the Animallais, 123

on the Neilgherries, 97

Sciurus, bicojor, 328

ephippium, 328

macrourus, $26 \mathrm{~S}, 274$

Malabaricus, 107, 216

Raftlesii, 328

tristriatus, 268

Screw pines, 360, 362, 363

Sea Dyaks, as warriors, 447,459 ,

burial customs of, 473-474

color of the, 460

compared with other tribes, 458

daily life, 467

distinguishing characters of, 446

dress and ormaments, 460,462

games, 468

head-dress of, 462
Sea Dyaks, morality of, 470

physique, 459-460

politeness and good behavior, 460, 470

semi-religious notions of, 472

stealing unknown among the, 471-47;

sub-tribes of, 459

territory occupied by, 459

war boats of, 463

weapons of, $462-463$

women of the, $460-462$

Sea Dyak villages, at Gunong Popook 364 , 4ö6

on the Sibuyau, $410,412,422,424$

on the Simujan, 355-357, 373

Sea Gypsies, 455

Sea View Hotel, 245, 296

Search party, 392, 436

Selangore, 301

area of, 330

elephant bunting in, 320-325

police force of, 303

political status of, $329-330$

products of, 315,330

Sultan of, 330

tin mines of, 329

Semnopithecus cucullatus, 117

abundance of, 142

cry of, 142

Semnopithecus femoralis, 391, 395, 416

cucoprymnus, 107, 268

Sepia officinalis, 252

Serambo Mountain, 483

ascent of, 484

descent, 487

view from, 486

villages on, $450,484-485$

Serendib, colonial steamer, 251

Seribas Dyaks, bad reputation of, 462

dress and ornaments, 392, 462

subjugation of, 464

typical specimens of, 391-392

warlike habits of, $447,449,459$

Serpents, cattle killed by, 494

destruction of, 494

persons killed by, 494

Servants, Chinese, 413 coolie, 263

Madrasee, 92, 183-184

native Christian, 22,28

Singhalese, 251, 259

Shark-ray, 257-258

Shavoogan, 149

Shekoabad, 77

Shells, 283, 487

Shields, Kyan, 447, 463

Shipment of collections, from Calcutta, 87 from Colombo, 283

from Madras, 217

from Jaffna, 280

Shoes, hunting, 427

Shops, native in Sarawak, 341

Siamanga syndactyla, 399

Sibaru Dyaks, pervcrted taste of, 448

Sibuco River, $3: 34$

Sibuyau Dyaks, 447, 459, 464

high morality of, 470 
Sibuyau Dyaks, musical instruments of, 468-469

Sibuyau River, 580, 410, 412, 414

Signs in sailors' quarter, 293

Simia sacyrus, 370,399 maximum size of. 405 specific characters of, 407

Simia Wurmbii, 369, 399

cheek eallosities of, 400

maximum size of, 404

skin, 400-401

specific characters of, 407

Simujan River, 349, 359, 362

first journey up, 355-364

second journey, 372-376

third journey, 387-389

Simujan, village of, 349,378

Singapore, approach to, 291-292

architecture, 294

arrangement of, 294

climate, 297-298

corals, 487

drunkenness in, 295

features of interest in, 298

hotels, 295

invertebrates, 298

island of, 297

market for live animals, 298

population, 295

position, 292, 297

sailors' quarter, 293

shells, 487

shops, 293

society, 295

Singhalese natives, 239

Sipang, Cape, 336

Skeletonizing crocodiles, 43

elephants, 164-165, 210-211

orang-ntans, 366-367

seven orangs in one day, 370

Skinning a crocodile, directions for, 44 bison, 192-193

elephant, 203-205, 209

orang-utans, 366-367

quadrupeds, directions for, 492-495

seven orangs in one day, 370

Slave Lake, Colombo, 238

Slavery among the Malays, 343

Snakes, scarcity of, in the Jungles, 329 , 423

Snares, Dyak, for small game, 421

Snipe, 307

Solar topee, 46

Source of the Sibuyau River, 414

Spears, Dyak, 463

Spearing fish in the Sadong, 385

Spiny-ray, 256, 310

Spoonbills, 75

Squall, caught in a, 441

Squirrel, 328

grizzly, 268, 274

Malabar, 10\%, 216

striped, 268

Staat River, 481

romantic ride down the, 483

Stalking large gane, 186
Stegostoma tigrinum, 256

Sterna caspia, 307

Sternula minuta, 307

Sting-ray, fisherman wounded by, 311

St. John, Mr. Oliver H, 450, 451, 452, 476,483

St. John, Mr. Spenser, 334, 434, 448, 455 468

Stork, 60

Street-cars in Bombay, 22, 24

Studer, Major A. G., 296-297, 488

Studer, Miss, 296

Stuffed fishes, 91

Suez canal, 15-16

Sultan of Selangore, 330

of Suln, 334

Sula piscator, 307

Sumpitan used by Jacoons, 320

Poonans and Pakatans, 447

Sunderbunds, 88

Sungam, camp at, 199

Sungei Bulu, 304

birds, 307

Chinese village on, 304

crocodiles in the, 304

Supreme Being, Dyak notions of, 444,448 , 472

Sus Indicus, 173

Suspension bridges of bamboo, 484

Swamps of Borneo, 352, 412, 438

Swimming power of the elephant, 234

Syers, Mr. H. C., 302, 310, 322-325, 328, 331,448

$\mathbf{T}$

\section{TaJ Mehal, 80}

Talei sura, 256

Tamarind tree, 82

Tamil natives in Ceylon, 239

Tapang tree, buttresses of a, 428 Dyak mode of climbing a, 434

Tapir, price of a live, 298

Tarsier, the, 398,420

Tarsius spectrum, 420

Tatties, 87

Tattooing among the Dyaks, 446, 468

Taxidermists, native, 91,249

Teak forests, 125,230

Teckadee ghaut, 183

Tectona grandis, 125

Tegora, 477

cinnabar mines at, 482

Telegraph, steamer, 301

Tellicul, camp at, 130, 131

huts at, destroyed by elephants, 160

Temperature, see Weather

"Ten Years in Sarawak," 446, 468

Terai, the, 154

Tern, 307

Theobald, Mr. A. G. R., 123

kindness of, to author, 123, 182

"Old Man," sent to, 488

permit to shoot elephants secured by, 127

Pconasy rogue elephant shot by, 124 
Theobald, Mr. A. G. R., sickness of, 174, Tuba fishing. 384 182

trophies in bungalow of, 124

Thespesia populnea, 287

"Thirteen Years Among the Wild Beasts of India," 133, 224, 226-227

Thorns, 396

Tiger, death of an immense, 158

difficulty in preserving skin of, 160

dimensions and weight of, 159

not found in Ceylon, 252

prowling near camp, 205

tracking np a large, 157

Tiger hunting, from a maohan, 154 on foot, 155 .

with elephants, 154

Tigers, cattle killed by, 494

cattle-killing, 152

destruction of, annually, 494

game killing, 152

loss of life by, 154, 494

man-eating, 152

on the Animallais, 214

price of, alive, 298

reward for killing, 155

Tiger shark, 256

Tin mines at Kwala Lumpor, 329

Tippecadu, 106

Toda buffalo, 103

Todas, appearance of, 100

census of, 101

dress of, 100

habitations of the, 102

infanticide among the, 100

mund of the, 103

negative character of the, 98,99

phenomenal laziness of, 101

polyandry among the, 101

supposed ancestry of, 102

Tomb of Eve, 17

Tomistoma Schlegellii, 55, 348, 478

Toonacadavoo, forest camp at, 123

Tortoise, 310

Trackers, skilfulness of, 109

Tracking elephants, 136, 198, 321

Traders, tricks of Chinese, 493

Tragulus kanchil, 328

napu, 323,380

Tree cat, 70

Tree climbing perch, 397 snake, 381

tapang, 428, 434

Trees of Northwest Provinces, 81, 82

Tring Dyaks, cannibalistic habits of, 447

buman sacrifices offered by, 448

semi-religious notions of, 448

Trinidad, astuteness of custom-house ofcers at. 244

Trionyx Gangeticus, 63

Troglodites gorilla, 399 niger, 399

Tropical hunger, 272, 388

Trygon sephen, 256

uarnak, 255

wolga, 257

"Tug-of-war" among the Dyaks, 468

Tulip trees, 237

Turney, Mr. C. H. A., 330

Tupaia, 478

Tupa, 454

Tushes of elephants, 219, 225

Turtles, 258

in the Jumna, 63

Tweedale, Marquis of, 477

\section{ULCERS, 174, 194}

Unchastity, penalties for, 470

Urogymnus asperrimus, 256,310

Ursus labiatus, 146

VAMPIRES, 288

Vandevorst, Mr. J. W., 297, 488

Vateria Indica, 128

Vegetables of Sarawak, 341

Selangore, 315

Venereal diseases, 473

Venezuela, courtesy of, to naturalists, 244

Vera, Pera, 186, 205

Vesuvius, 7

Victoria regia, 300

View, (see Landscape, and Scenery) from the Colombo clock tower, 238

from the Neilgherries, 104

from the Sea View Hotel, 245

from the top of Serambo, Mountain, 486

Villages, author's quarters in Dyak, 364 , 410,413

of the Hill Dyaks, 452, 485

of the Kenowits, 449

of the Kyans, 449

of Lanchang, 424

of the Milanaus, 444

of the Sea Dyaks, 355, 357, 410, 466

Viverra, 328

tangalunga, 429

Von Gaffron, Herr, 334

Voyage from Aden to Bombay, 20

Calcutta to Madras, 87-89

Colombo to Jaffna, 251-252

Madras to Colombo, 235-236

Point Pedro to Mullaitivu, 261-262

Port Said to Aden, 15-19

Vulnerable points of arocodile, 40 of elephant, 135

Vulture, king, 34, 44, 45

white scavenger, $44,60,61$

\section{$\mathbf{w}$}

WADING after orang-utans, $361,362,365$

Wah-wah, see Gibbon

Wainaad forest, 105

Wallace, Mr. A. R., 334, 404-405, 468 
Wallago leerii, 385

Walters, Mr. William, 351

Wanderoo monkey, of Ceylon, 268, 274, 277,280

War boats of the Sea Dyaks, 463-464

Ward, Professor Henry A., 2, 18, 32, 174, $192,194,197,203,241,248,272,283$

Ward's Natural Science Establishment, 2,217

Warfare, Dyak modes of, 447, 449, 464

Weapons for a collector, 491 of a typical sportsman, 192 of the Hill Dyaks, 451 of the Sea Dyaks, 463

Weather in Borneo, 417

in Calcutta, 87

in Ceylon, 267

in Madras, 90

in Singapore, 297

on the Animallai Hills, 125, 139, 160, 186,214

on the Jumna River, 50

on the Neilgherry plateau, 94

Wedderburn, Mr. A., 196, 197, 217, 221

Whampoa, Hon. H. A. K., 298-300
White, Dr., cure of fever by, 237

Wife-beating an amusement of civilizas tion, 468

Wild cattle, 310

Wolf, Indian, 76

Wolves, cattle killed by, 494

destroyed, 494

persons killed by, 494

Women, Sea Dyak, chastity of, 470

dress of, 461

form and features of, $460-461$

ornaments of, 462

social position of, 470

Women, ugliness of native, 65

Wood-devils of the Dyaks, 454

$\mathbf{Y}$

YHNGTSE, steamer, 290

$\mathrm{Z}_{\mathrm{BBO}}, 25$ 


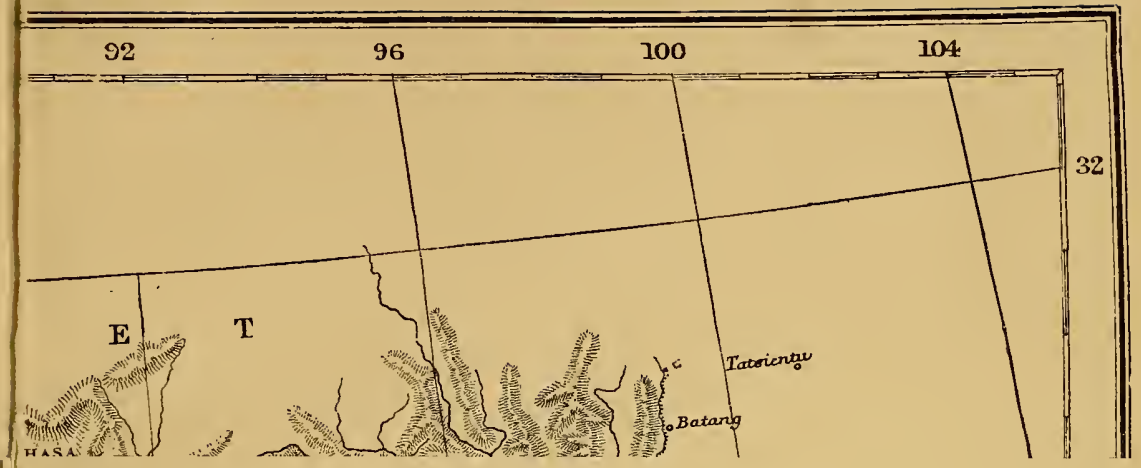





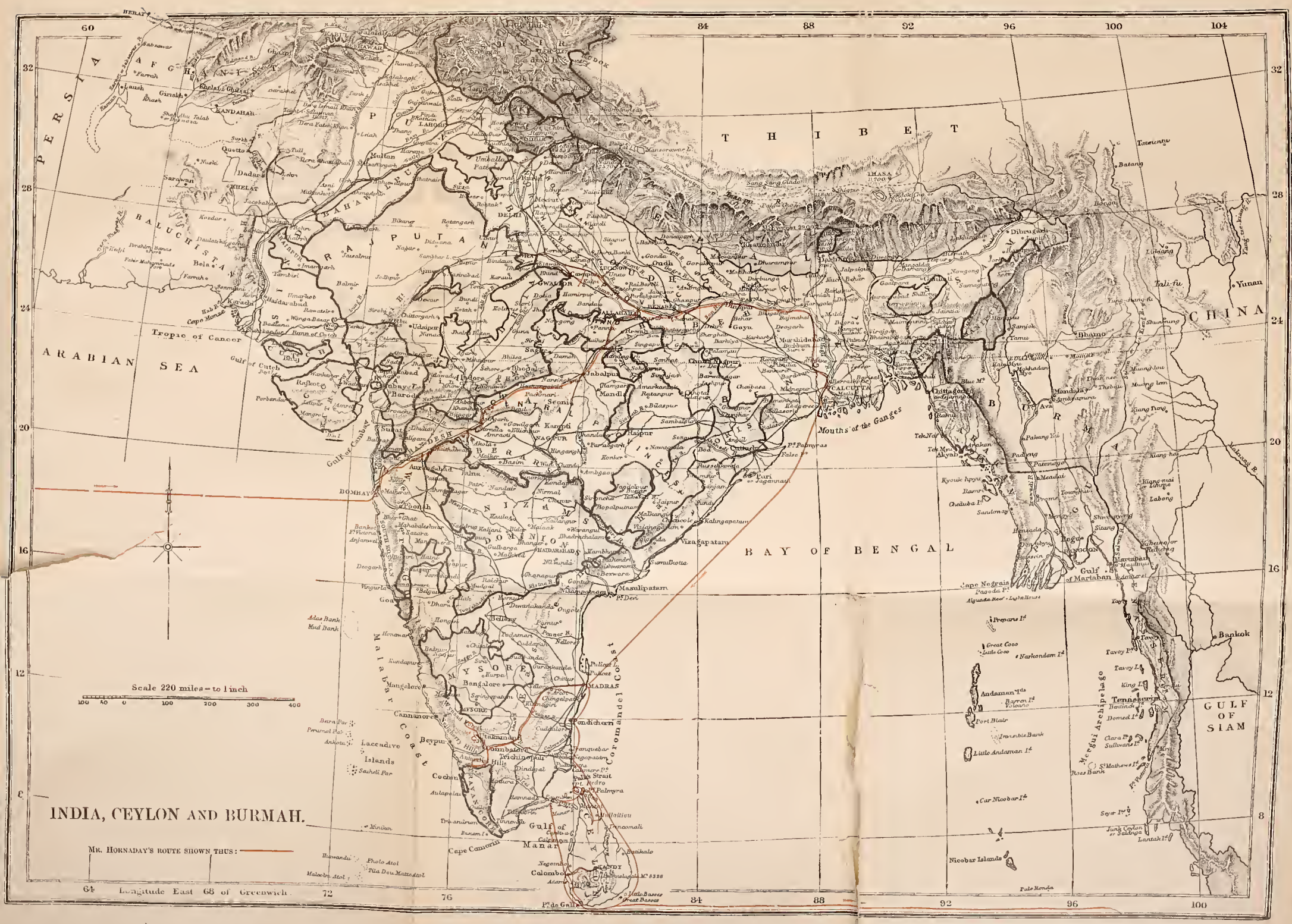


$\frac{1}{F}$ 







LIBRARY OF CONGRESS

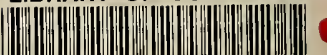

00283451173 